Fall 1991

\title{
1991 Miracle Yearbook
}

\section{Cedarville College}

Follow this and additional works at: https://digitalcommons.cedarville.edu/yearbooks

Part of the Higher Education Commons, Organizational Communication Commons, and the Public Relations and Advertising Commons

\section{Recommended Citation}

Cedarville College, "1991 Miracle Yearbook" (1991). Yearbooks. 41.

https://digitalcommons.cedarville.edu/yearbooks/41

This Book is brought to you for free and open access by DigitalCommons@Cedarville, a service of the Centennial Library. It has been accepted for inclusion in Yearbooks by an authorized administrator of DigitalCommons@Cedarville. For more information, please contact digitalcommons@cedarville.edu. 


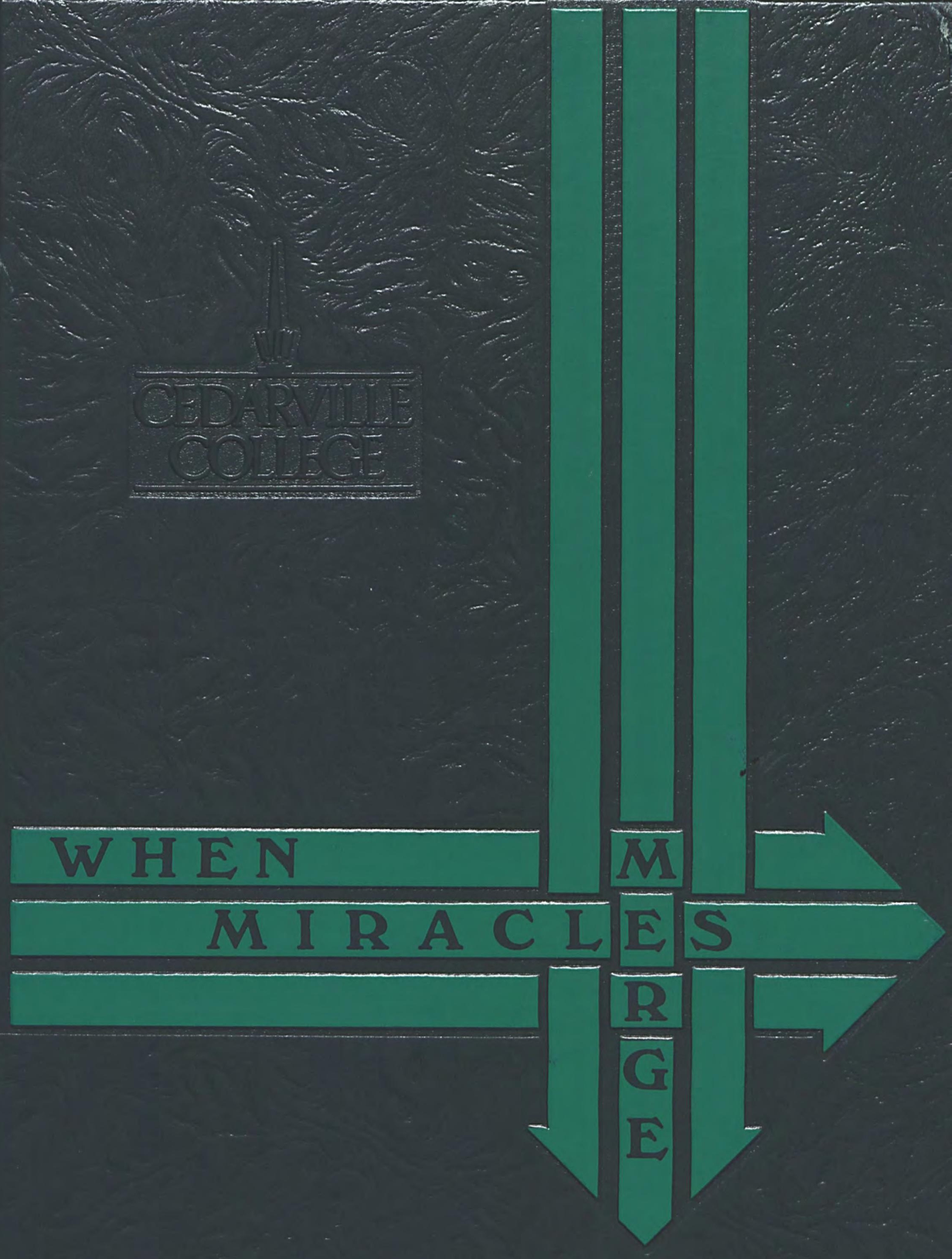






\section{Contents}

Opening

Academics

8

Student Life

50

Ministries

72

Fine Arts

98

Sports

116

Organizations

146

Seniors

164

Closing

210

Index

220

E

$R$

W H $\quad$ E $N$

\section{$\begin{array}{llllllll}M & I & R & A & C & L & E & S\end{array}$}

1991 Miracle

Cedarville College

Cedarville, Ohio 45314

Volume 38 


\section{First There Were Many Miracles ...}

Whether they are from Ohio or Florida, South America or Europe, each person who comes to Cedarville has a background. Every student comes with a testimony of how God has led him or her to repentance. For many the decision to attend Cedarville was easy. For others it was very difficult. But all of the students at Cedarville College can testify to the miracles that finally brought them here.

Even though these miracles may not fit the formal theological definition, the miracles of birth and rebirth, repentence and renewal, parental guidance and the process of maturing are all factors which led students to Cedarville, Ohio.
As students come with different sized suitcases, each of which holding unique contents, they also come with different emotional, mental and spiritual baggage, as God has led each of them down separate paths with unique experiences and challenges.

Two common threads, however, unite all of these very diverse paths. All of them are forged and paved by the 'Lord Jesus Christ. "In all your ways acknowledge $\mathrm{Him}$ and $\mathrm{He}$ will make your paths straight" (Proverbs 3:6). And all of those paths led to one small Ohio town to merge together for a brief four years.
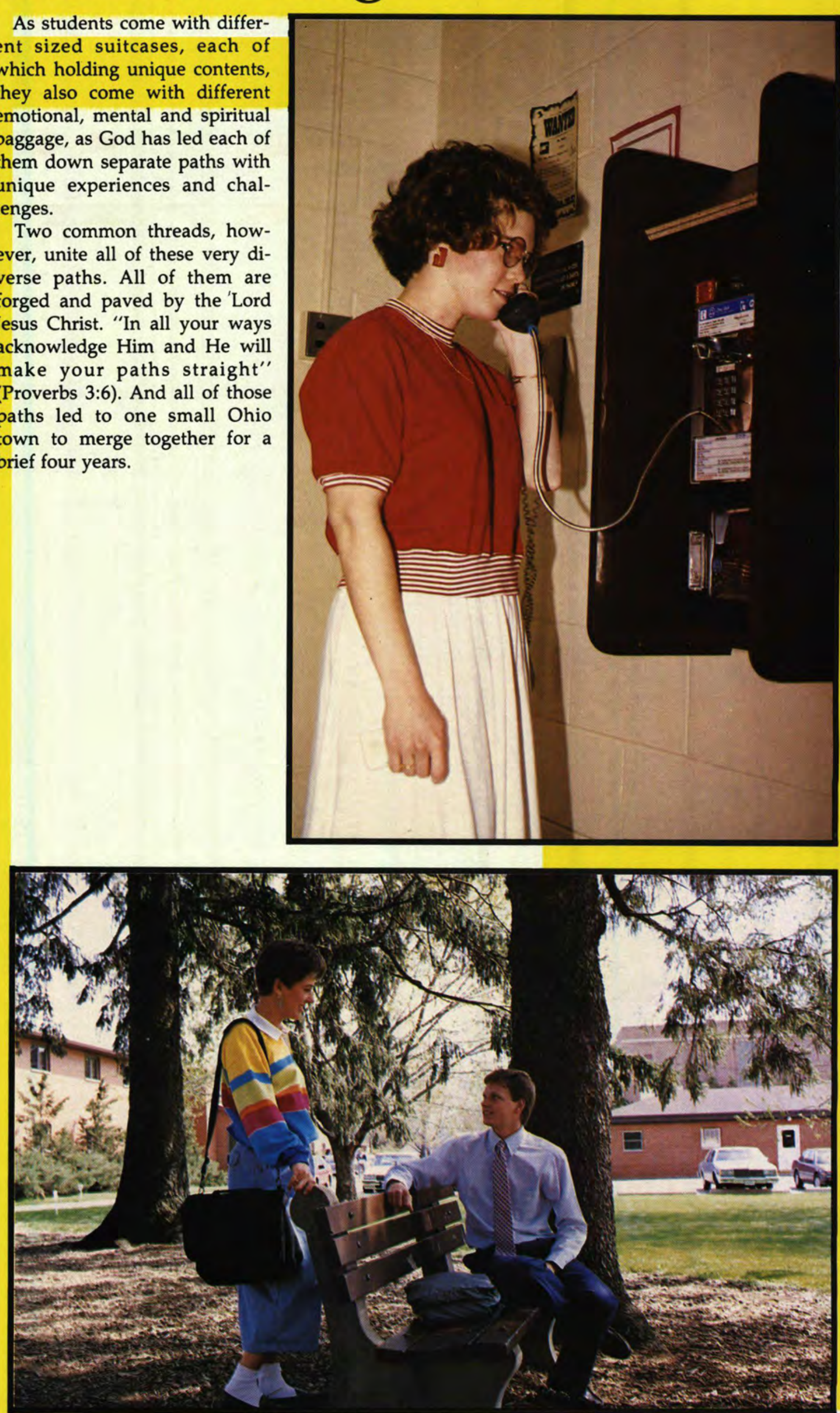

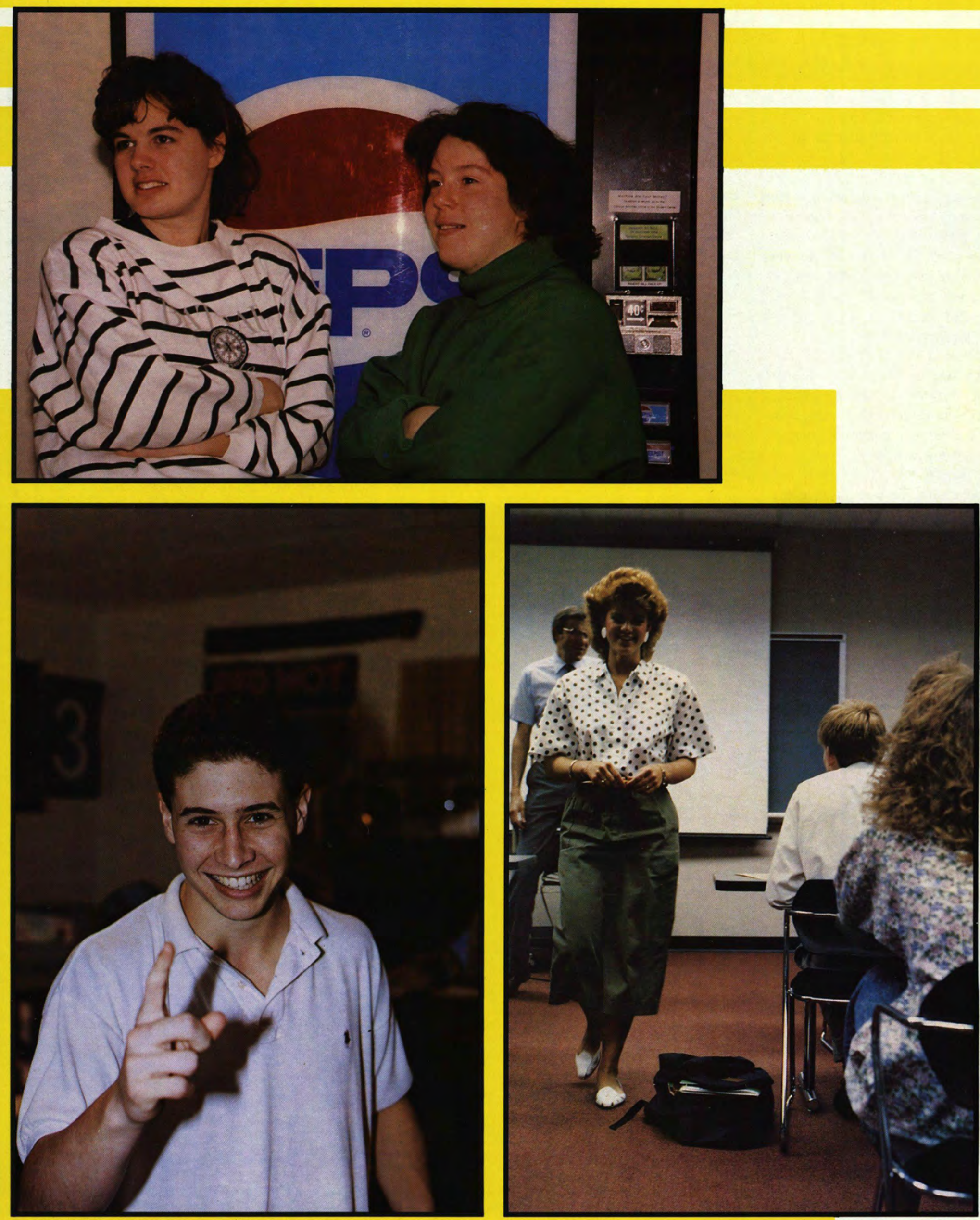

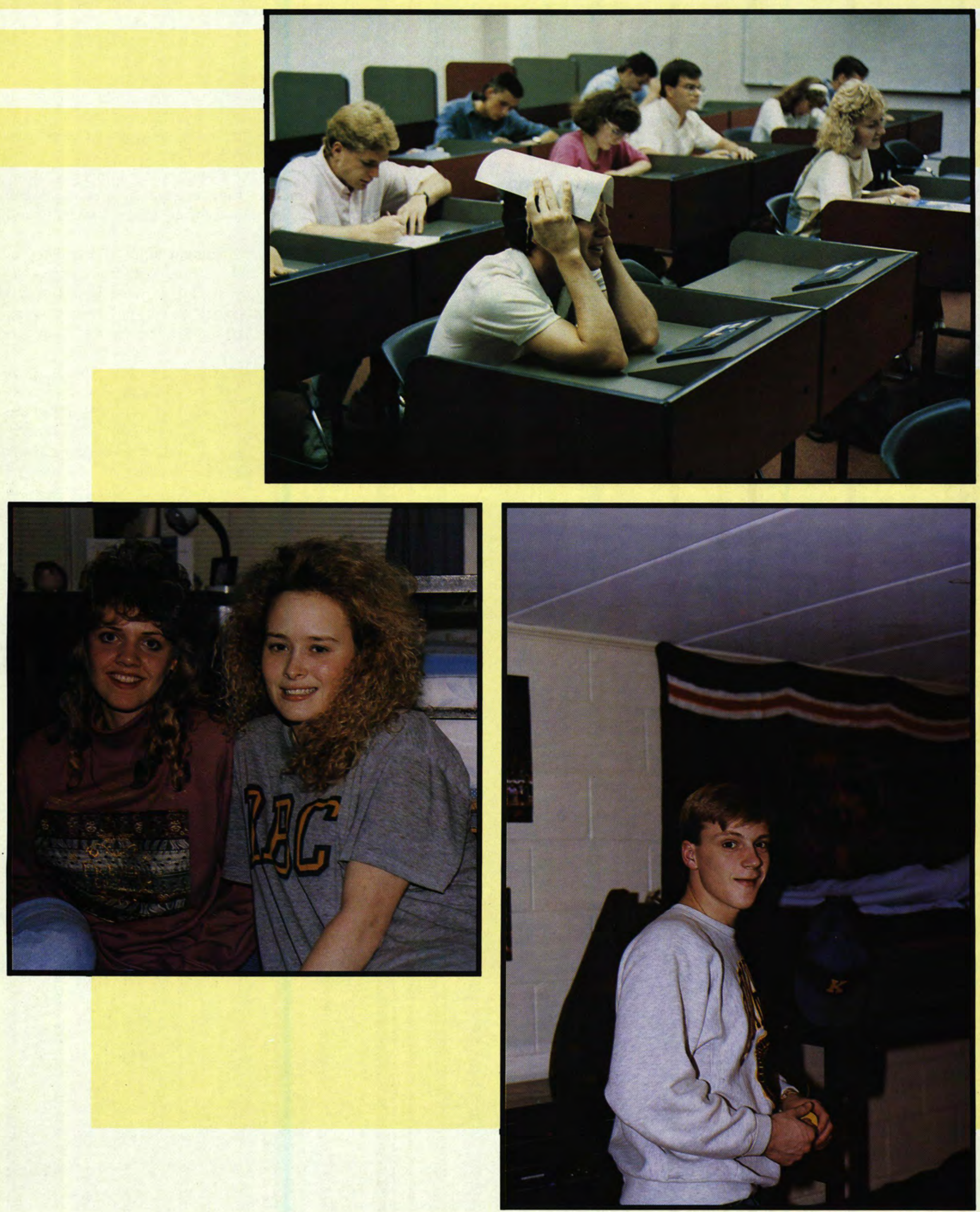


\section{Dedicated to Following God's Leading}

If any faculty member has shown how God can merge a great diversity of experiences in molding one individual for service, it is Dr. Richard Durham. A Professor of New Testament and Greek, Dr. Durham has given his students a living testimony to God's faithfulness and leading.

Dr. Durham has been testimony of patriotism as he served in the U.S. Navy during WWII. He has been a testimony of burden for the lost as he ministered for 18 years in the Philippines, and served as advisor for the FWM, the MK Fellowship, and the MIS Committee at Cedarville. He has also been a testimony of dedication to excellence as he has encouraged his students to do their very best. Now as Dr. Durham retires from full-time teaching, Cedarville College says "farewell," and "thank you."

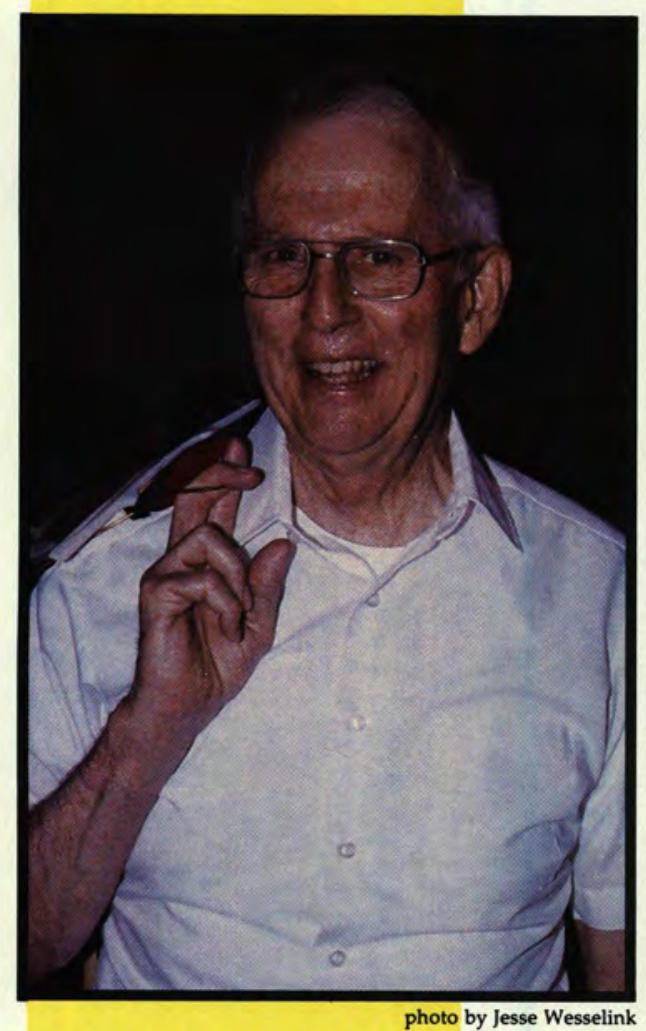

Dr. Durham prepares for his last commencement ceremony as a full-time faculty member.

(Upper right) Dr. Durham poses with his colleagues on the Bible faculty.
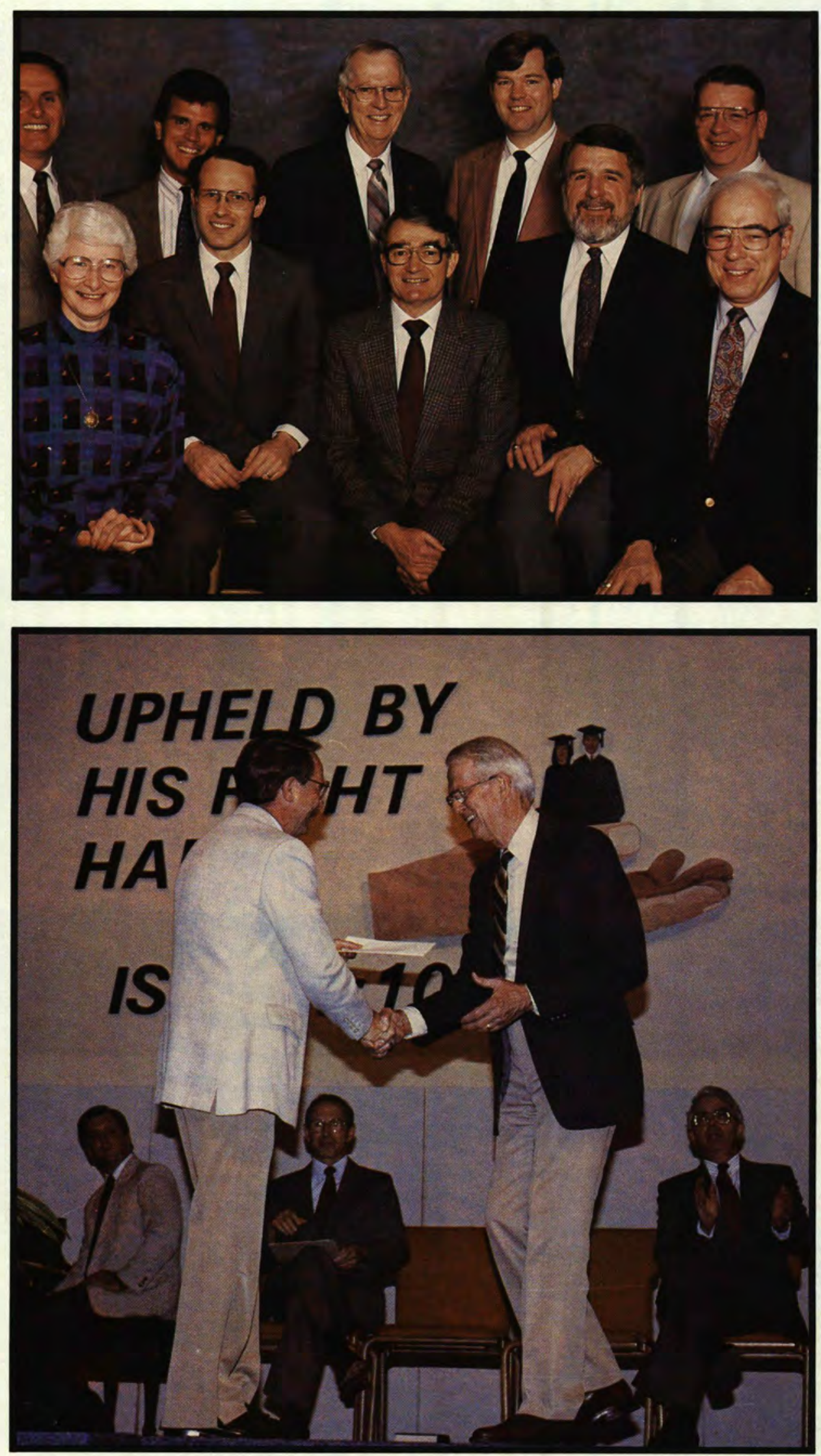

Dr. Durham receives honors from Dr. Dixon for his retirement.

hoto by Jesse Wesselink 

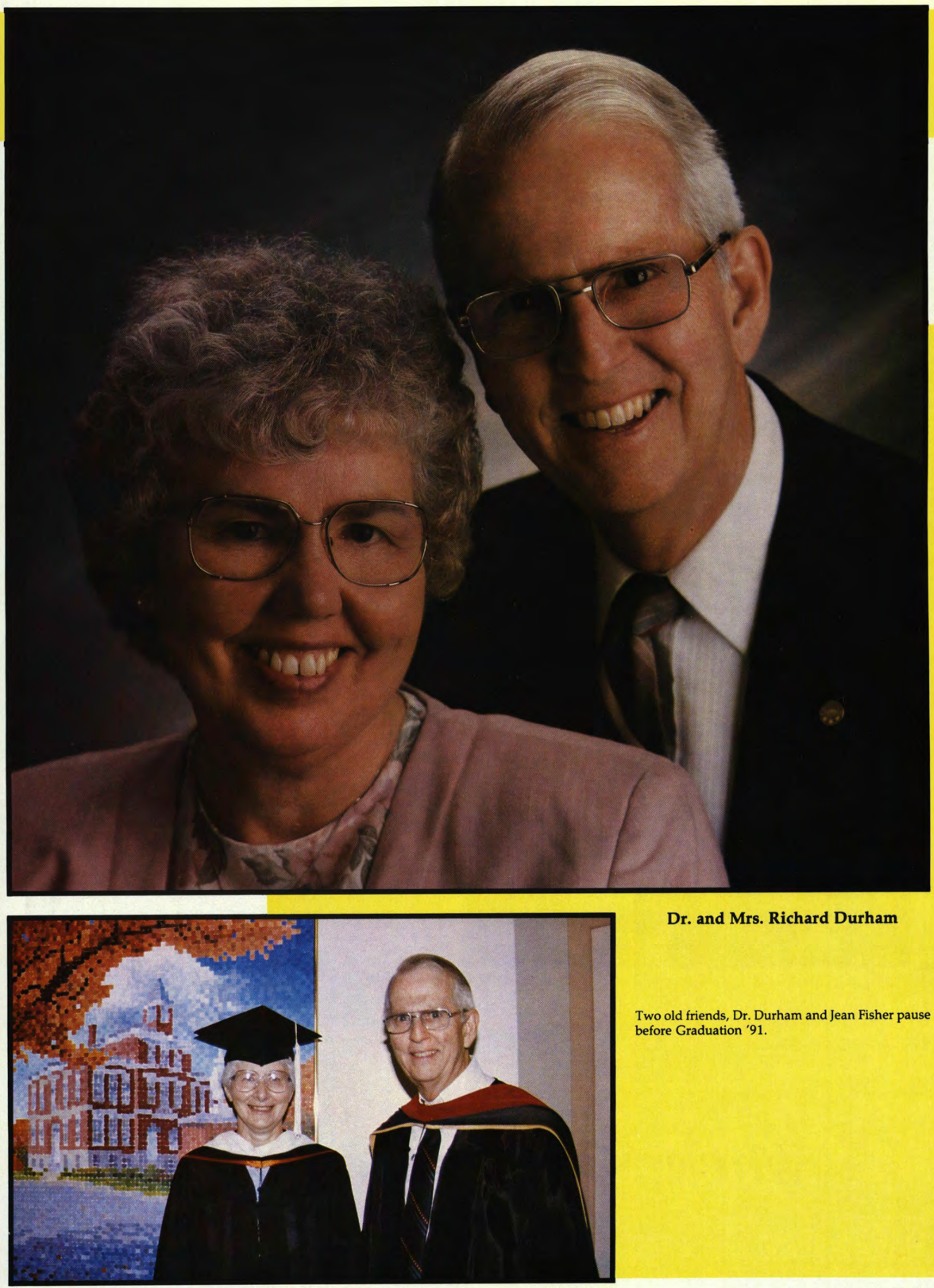

Dr. and Mrs. Richard Durham 
(Top Left) Students enjoy a warm streak of weather while walking between classes.

(Lower Left) Students catch up on a little studying in the College Center lounge between classes.

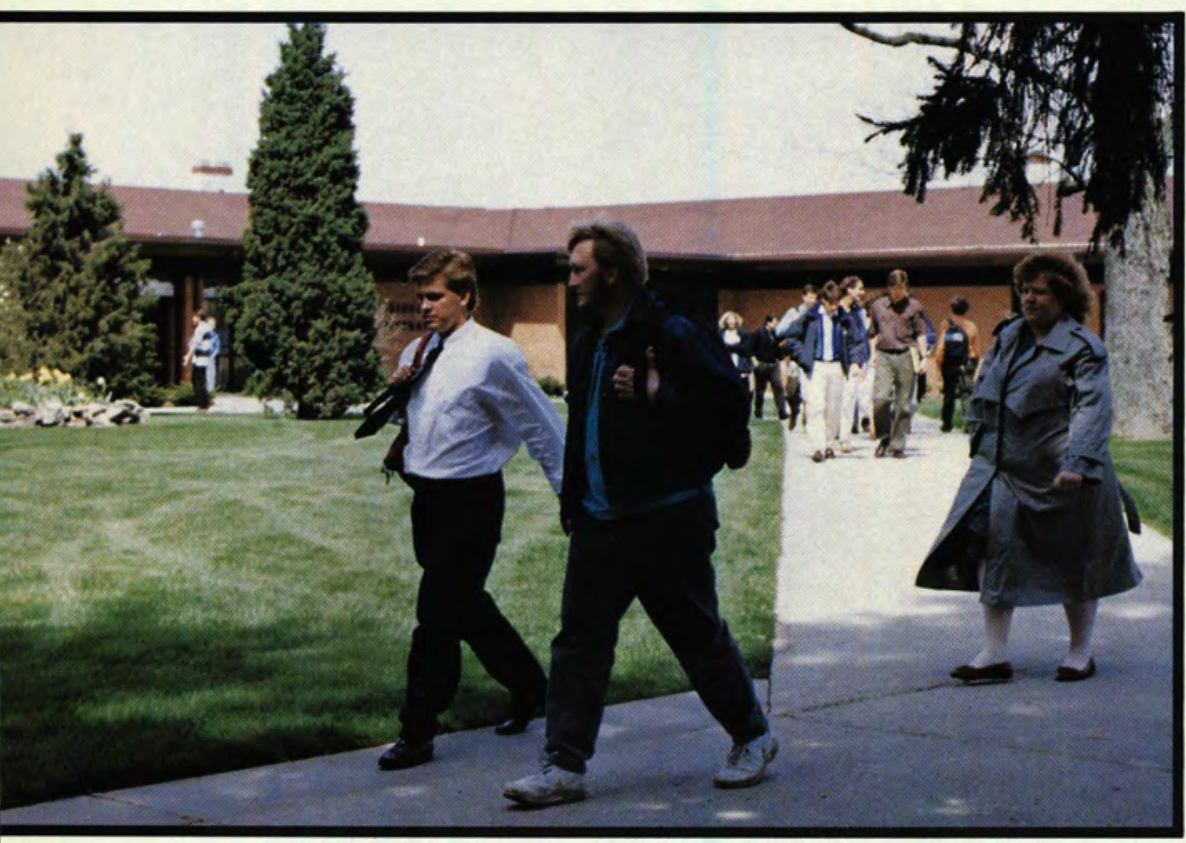

$$
\text { photo by Tania Taylor }
$$
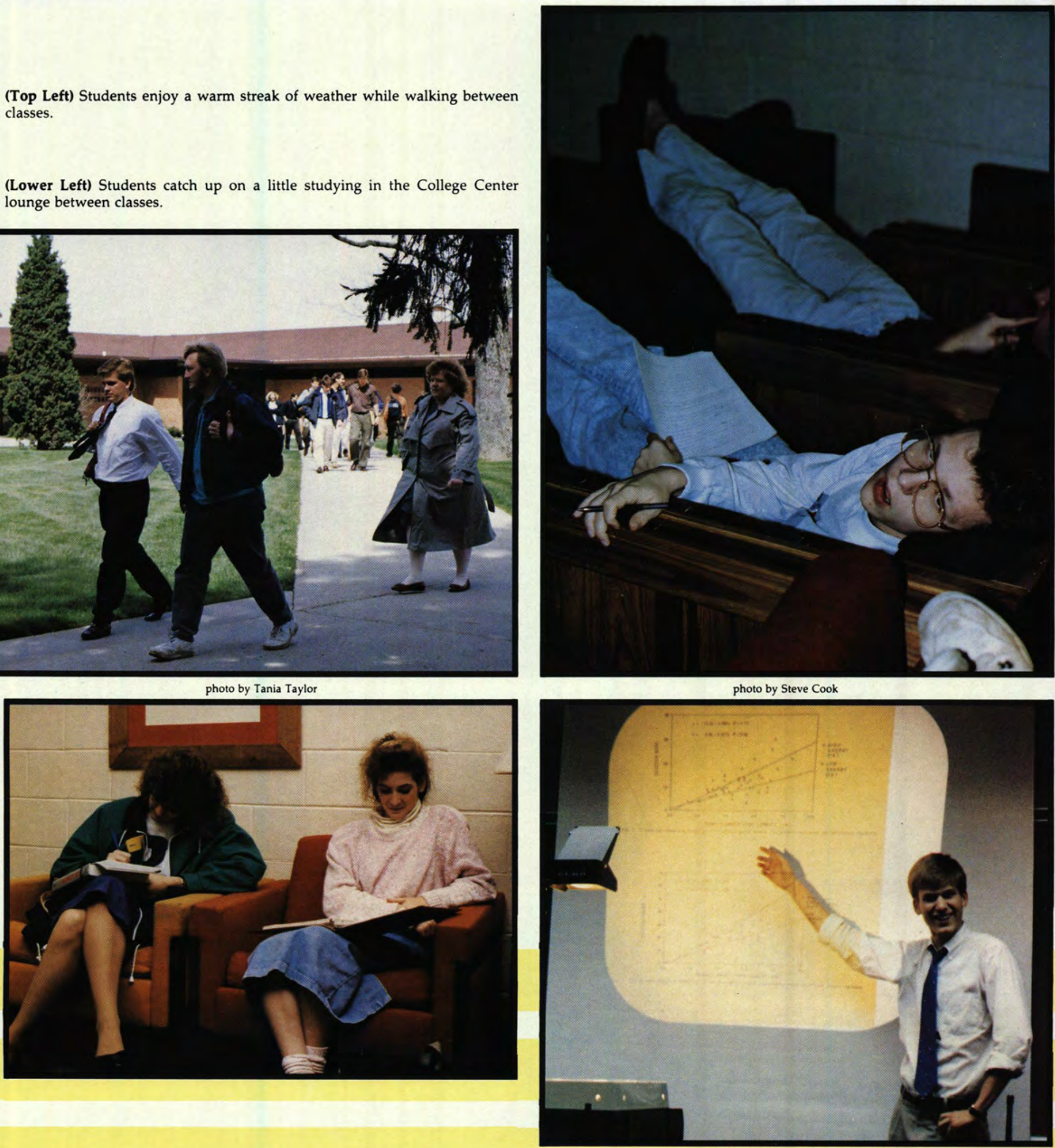

\section{When Miracles Merge. . . Minds are Motivated}




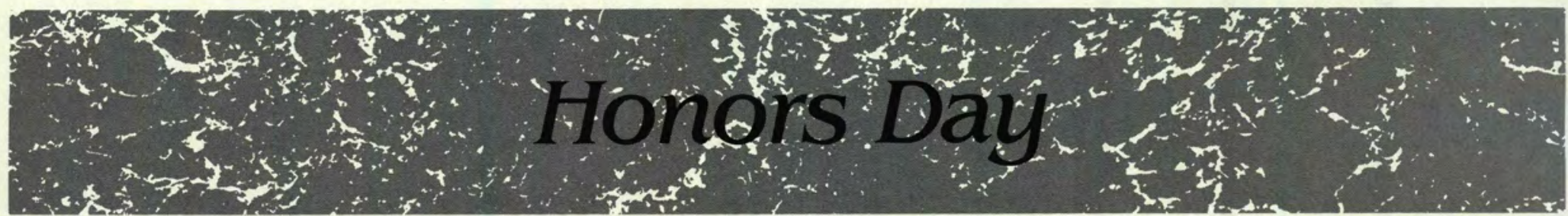

The 27th Annual Academic Honors Chapel was held in the James T. Jeremiah Chapel at the beginning of May. Awards were given according to academic departments and were handed out by the department chairs. Many students were honored with awards for their achievements and for their Christian testimony.

One new award that was given this year in the music department was the Kristi Lynn Walborn Memorial Scholarship Award. This award is given in memory of Kristi Walborn, a former Cedarville student, and is granted to a music major or music education major who has a vocal emphasis.

Recognition was also given to those students who met the requirements for the Dean's Honor List and the Dean's List for Spring and Fall 1990, and Winter quarter 1991.

The last awards given during the Honors Chapel were the Staff and Faculty Members of the Year Awards. The awards were given by Jeff Tague, President of the Student Academic Advisory Board: Staff Member of the Year, David Ormsbee; Faculty Member of the Year, Galen Smith. Both were deserving because of their achievements and involvement with students.

— Lisa Gillett
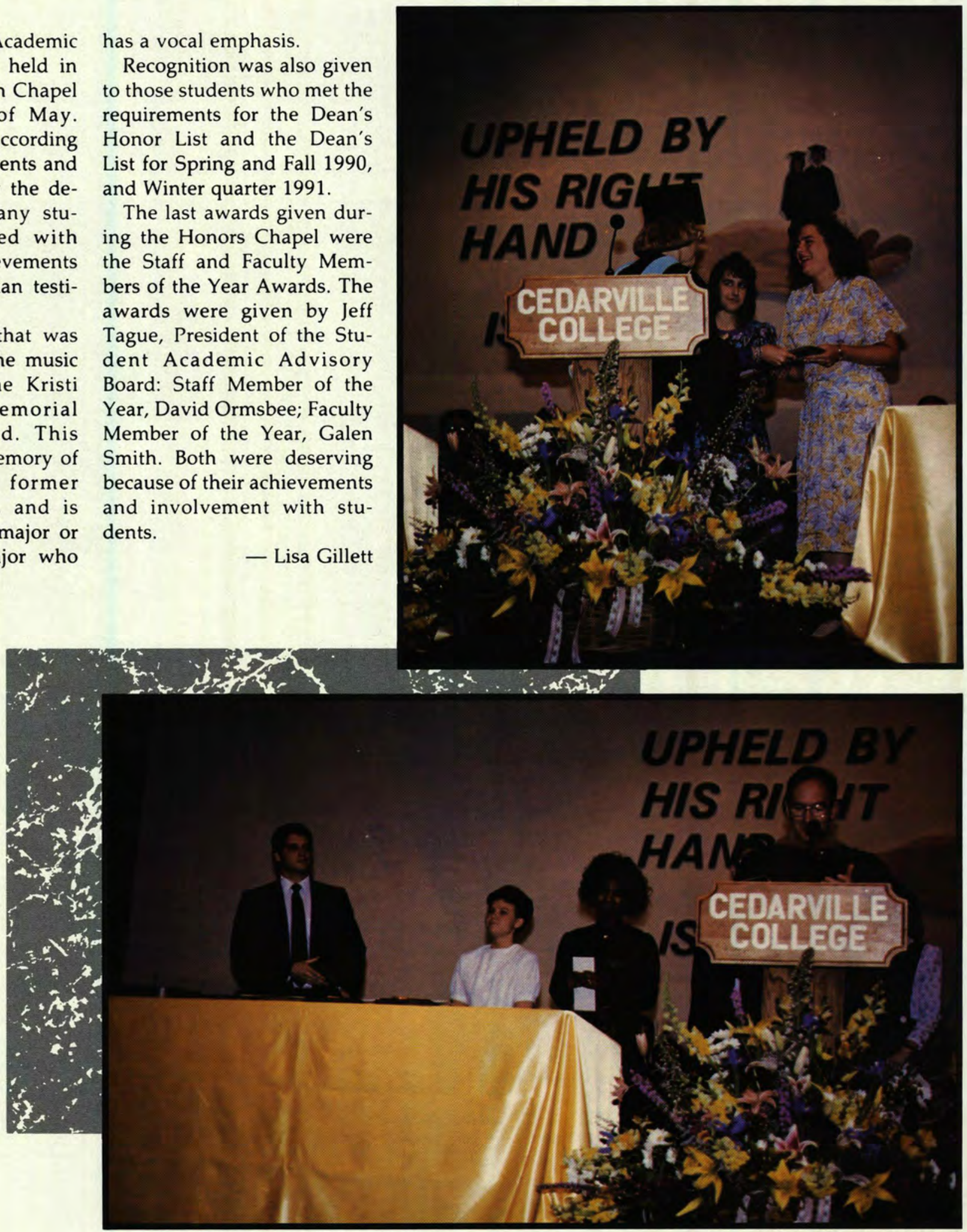

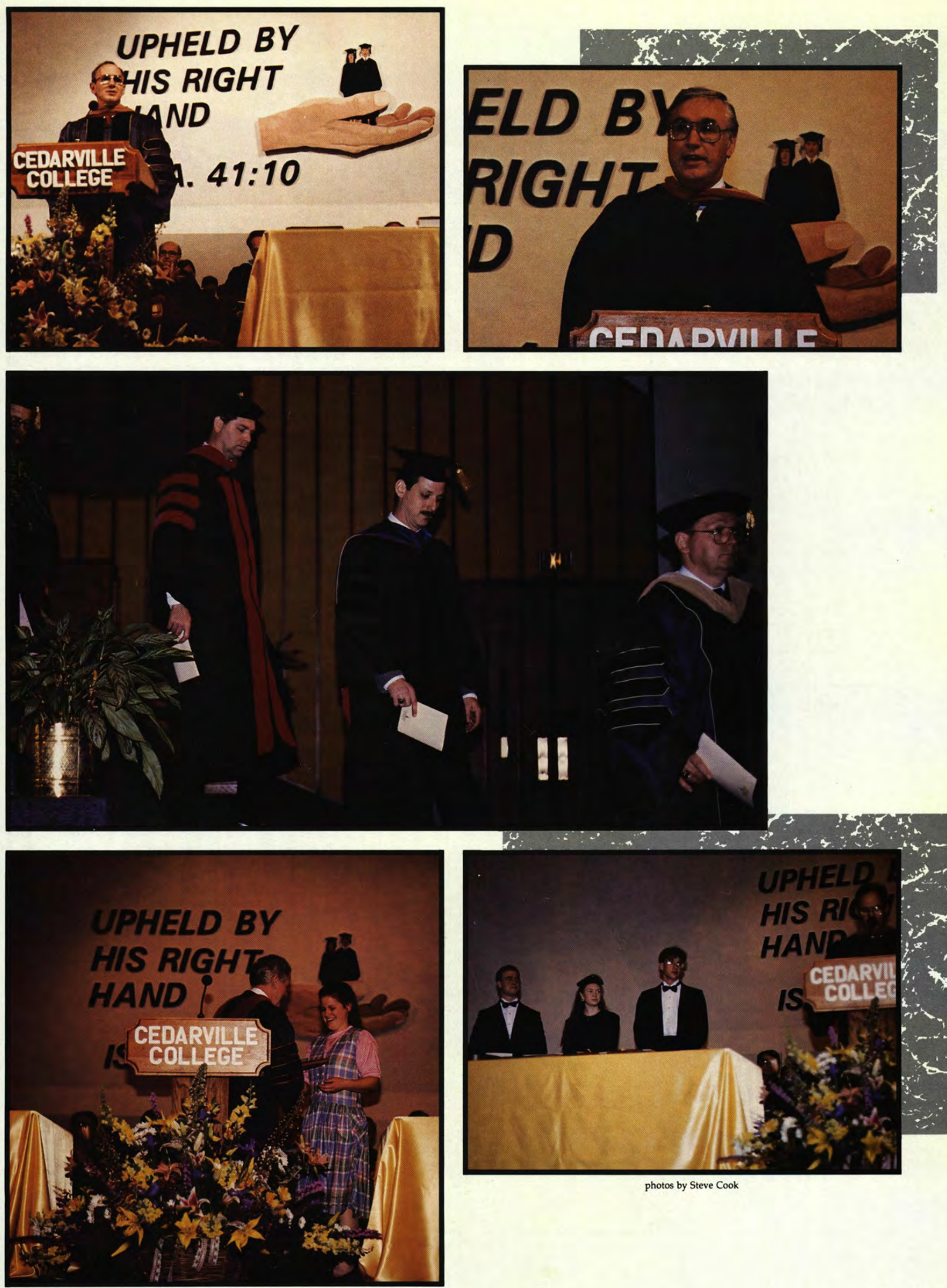

x.

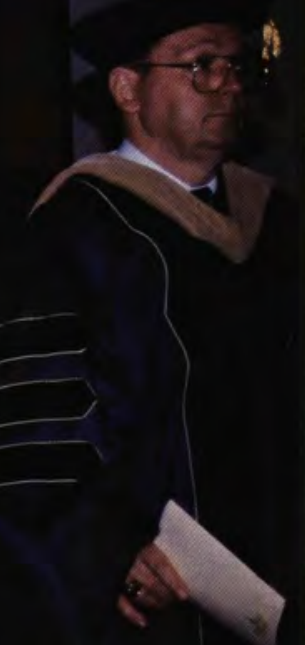

' II

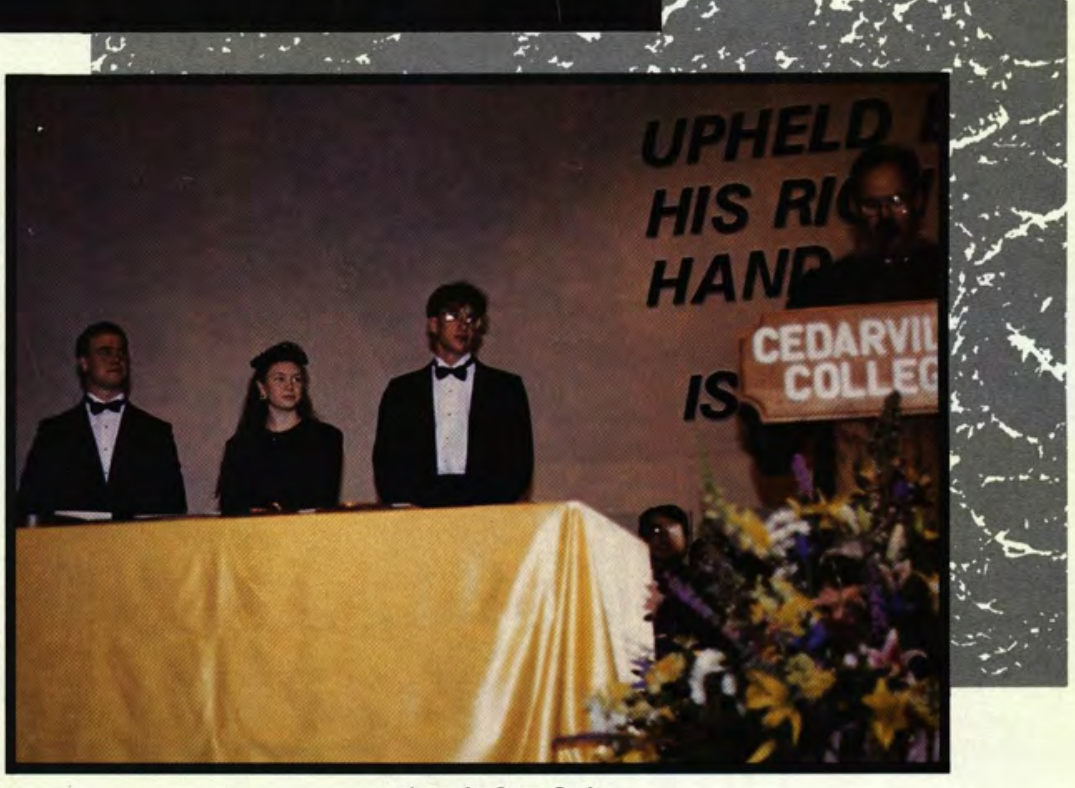

photos by Steve Cook 


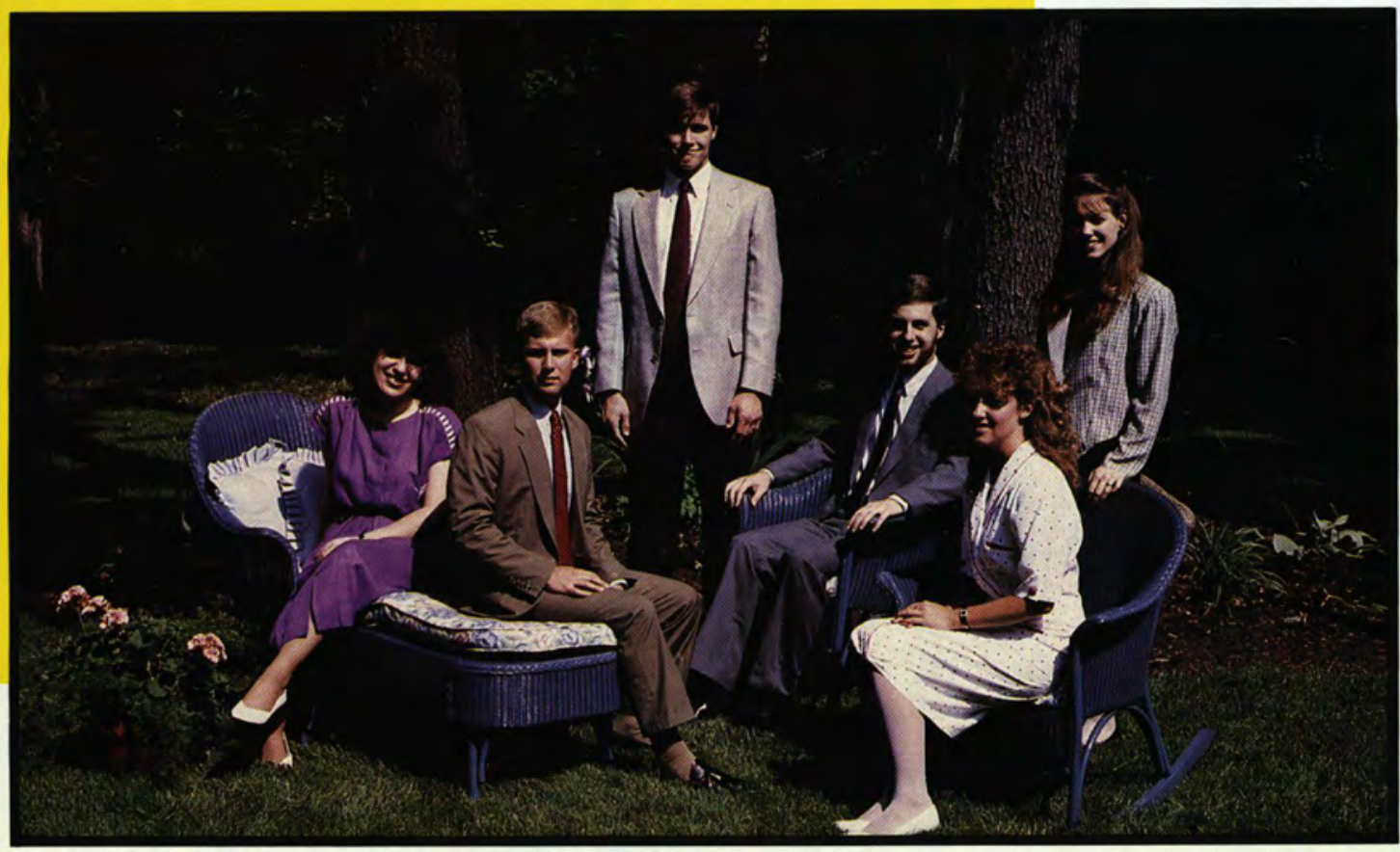

Monica Bolet, Mike Koenig, John Brewer, Kieth Wiederwax, Tricia Niccum, Lind Gagnebin

James Houser, David Kohlmeyer, Debbie Polsdorfer, Lisa Anderson, Kelly Fath

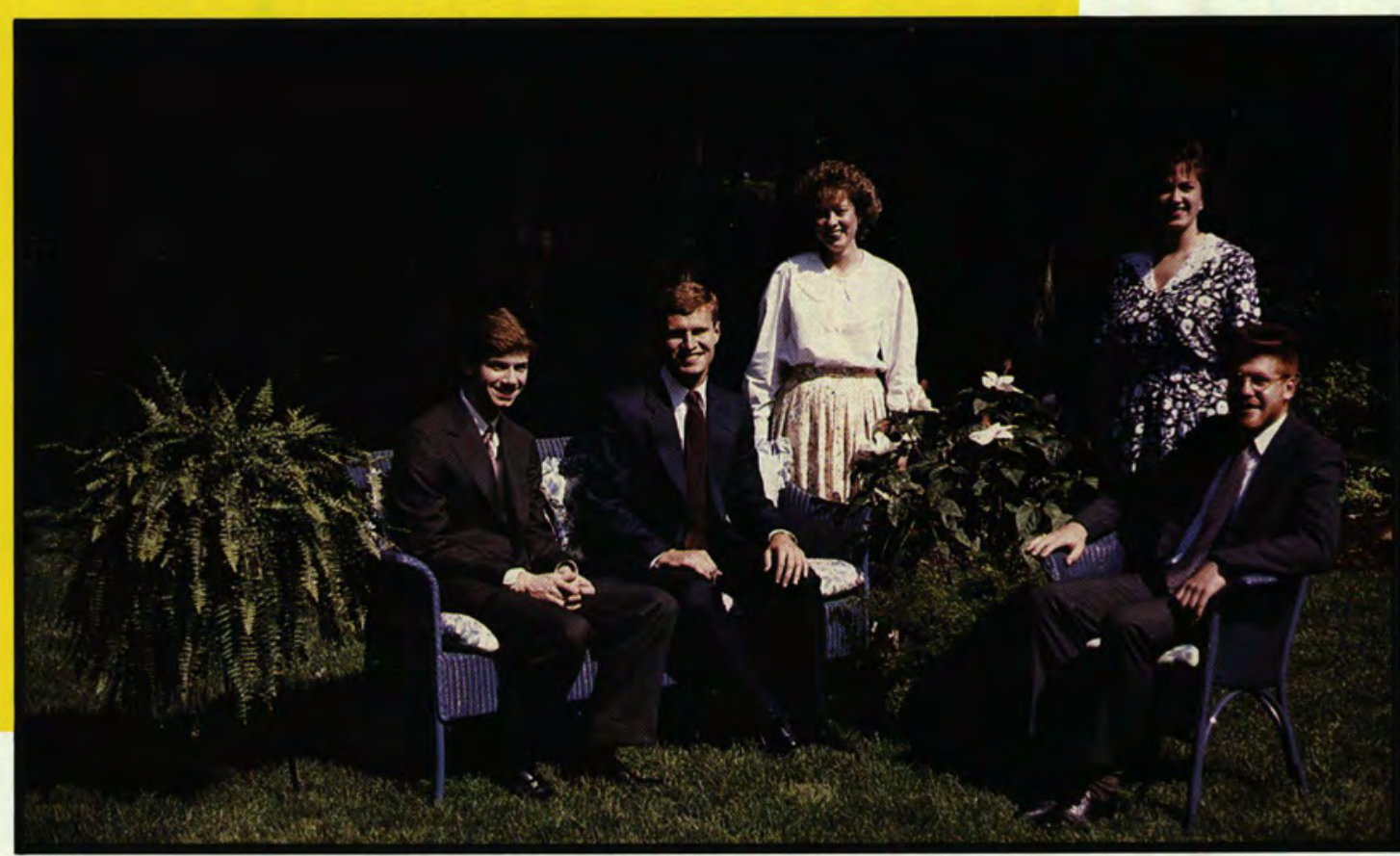

Jill Ernst, Stephen Ross, Ronald Stansbury, Sherry Neal, Christine Michael, Jeffrey Halsted

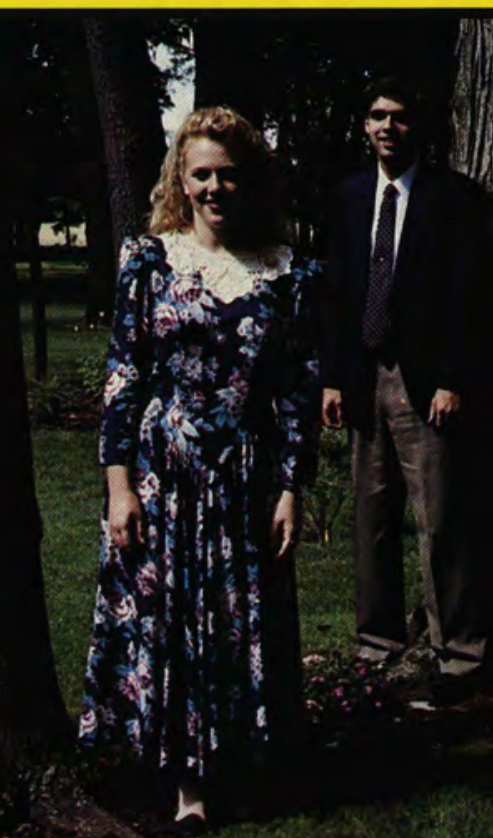

(3) 6) हa

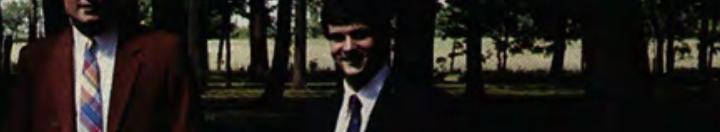

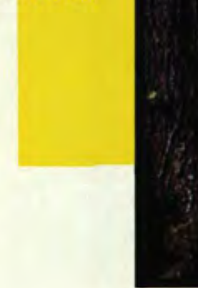




\section{Who's Who}

\section{Among American College Students}

Paul Kitchen, Linda Bean, Todd Bailey, Gwendolyn Cook, Randy Oswald

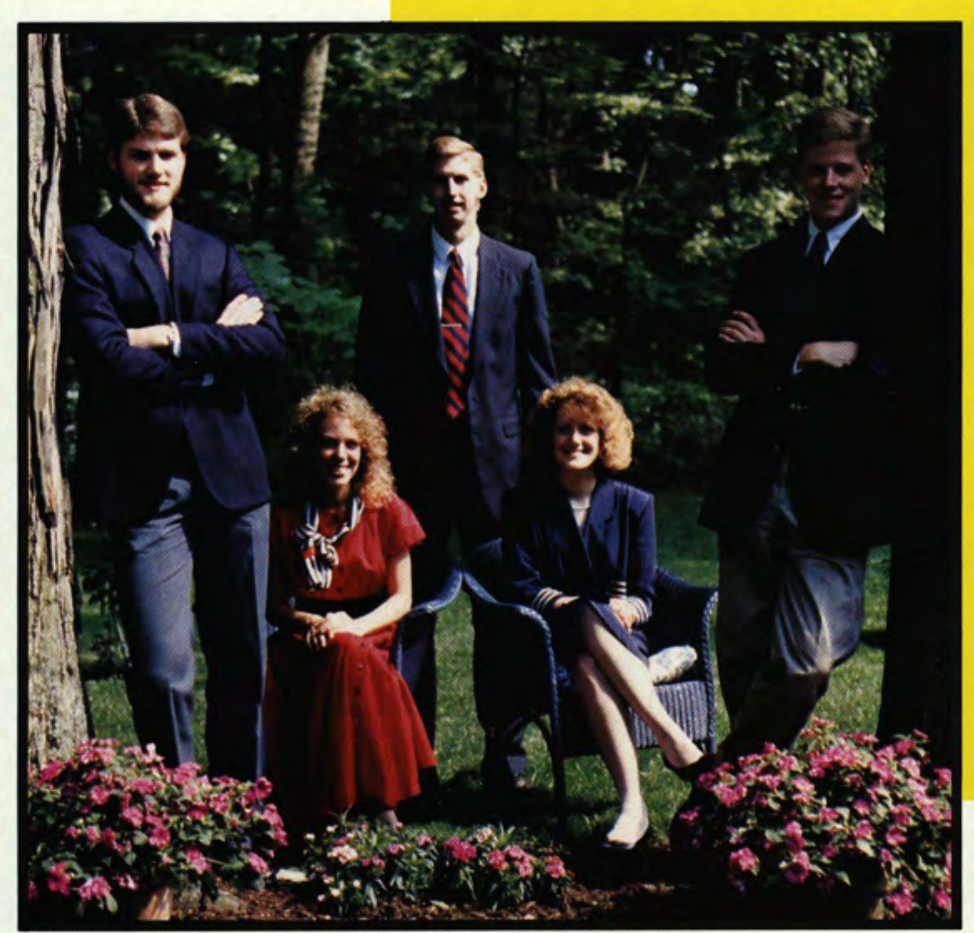

Deborah Donmoyer, Kari Clark, Rodney Latham, Daniel Kain, Linda Thompson, Marcy Sipe

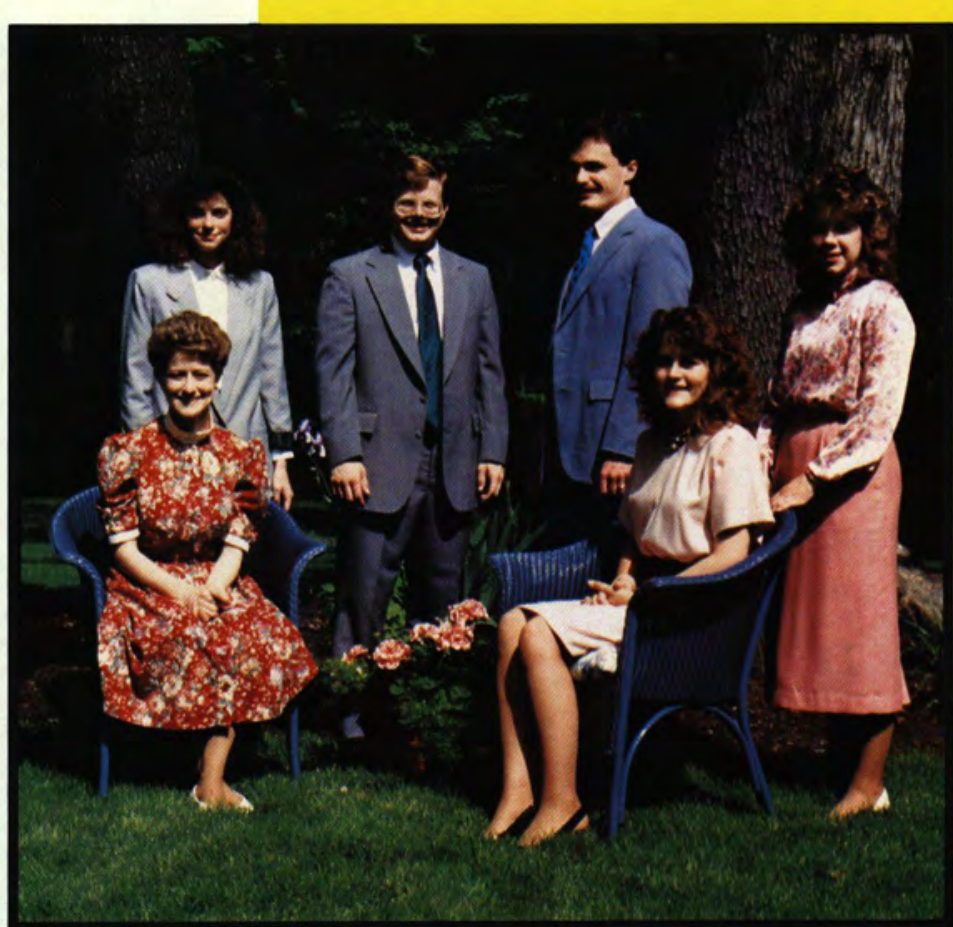

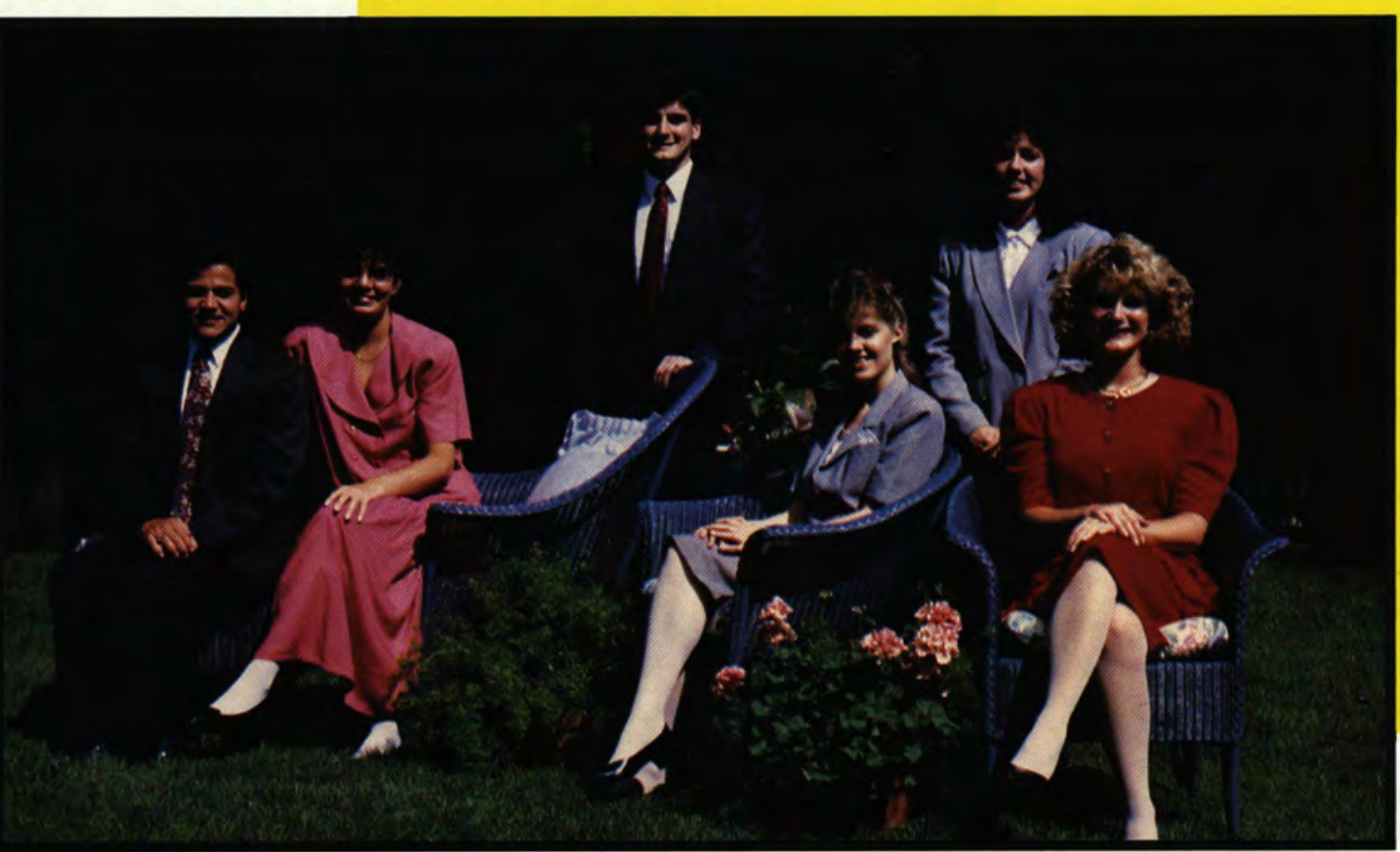

James Breuler, Krista Hill, John Jenks, Beverly Nelson, Carolyn Frisbie, Carrie Quinn

Not Pictured: Wendy Boice, Dwight Davidson, Kathleen Duda, Kellie Kolesar, Jodi Baugh, Jonathan McDugle, Mark Murdoch, Daniel Osterhout, Randolph Schmitke, Jennifer Shade, Lisa Sommerfeld, Cynthia Swanson, Lori Wright 


\section{Administration}

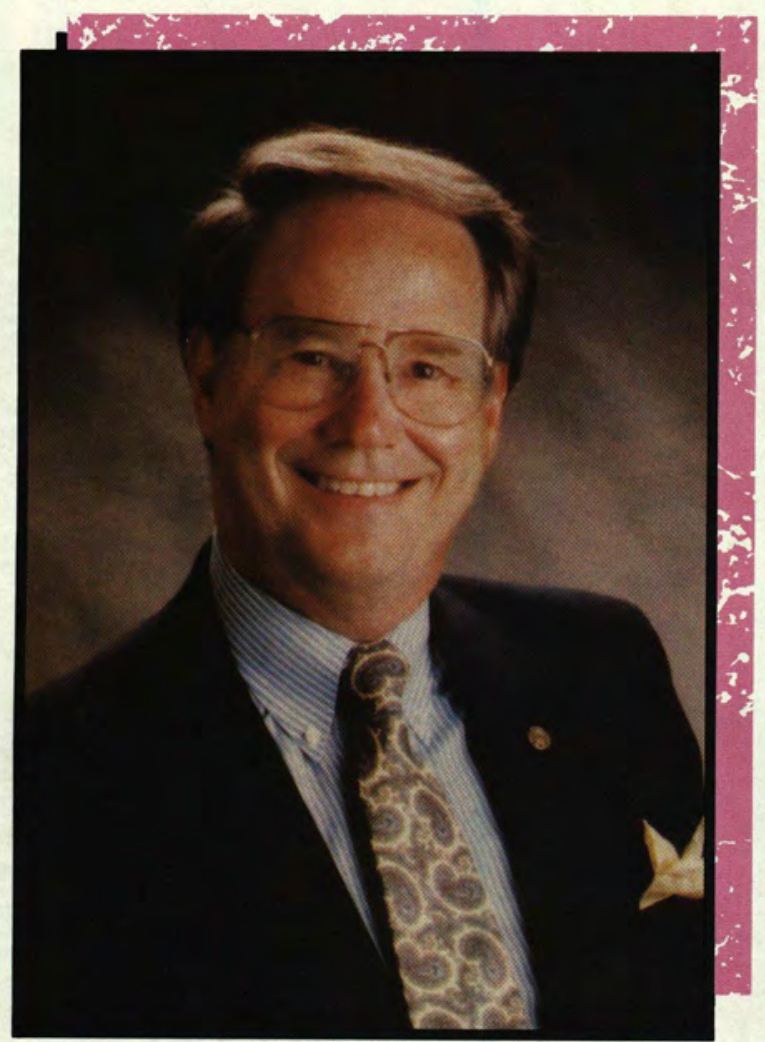

Dr. Paul Dixon

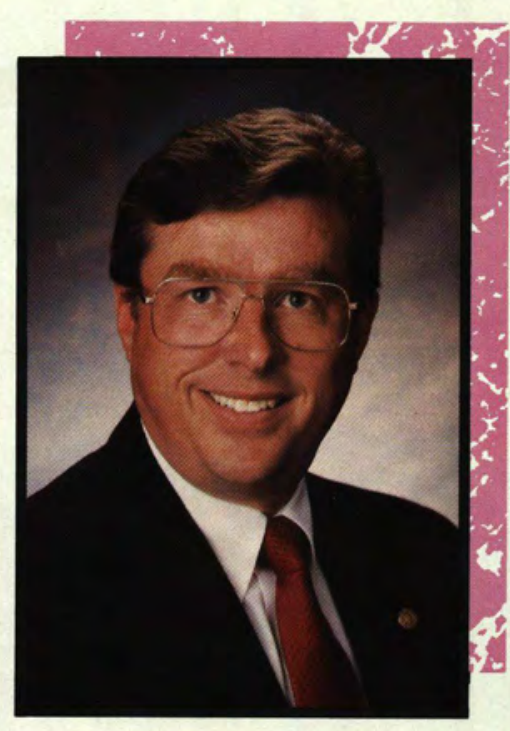

John Anglea Vice President for Business

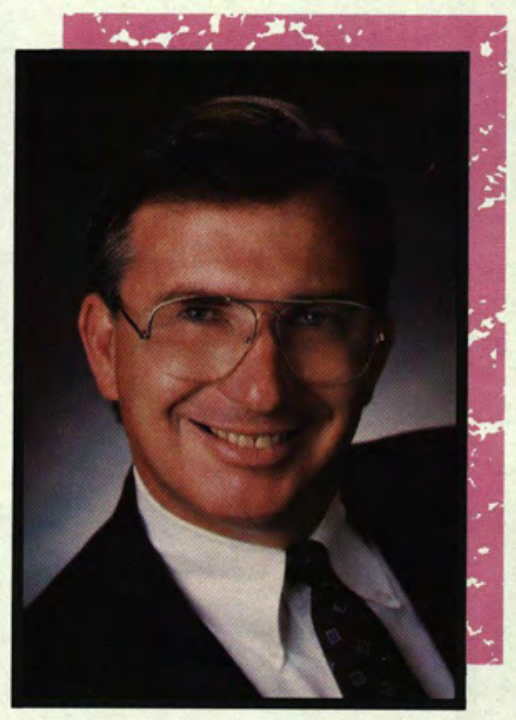

\section{Dr. Martin Clark} Vice President for Development

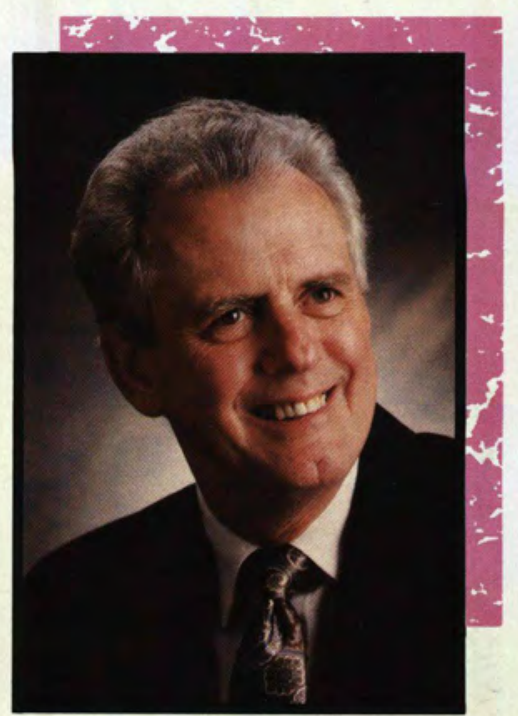

\section{Dr. Harold Green}

Vice President

for Christian Ministries

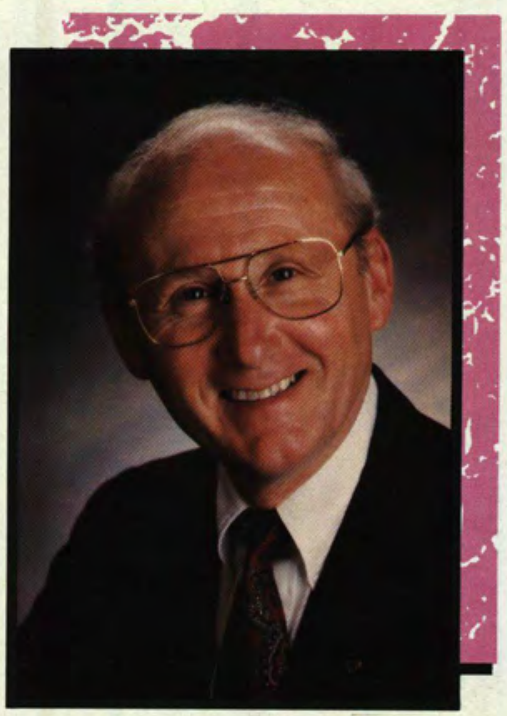

Donald Rickard

Vice President for Student Services

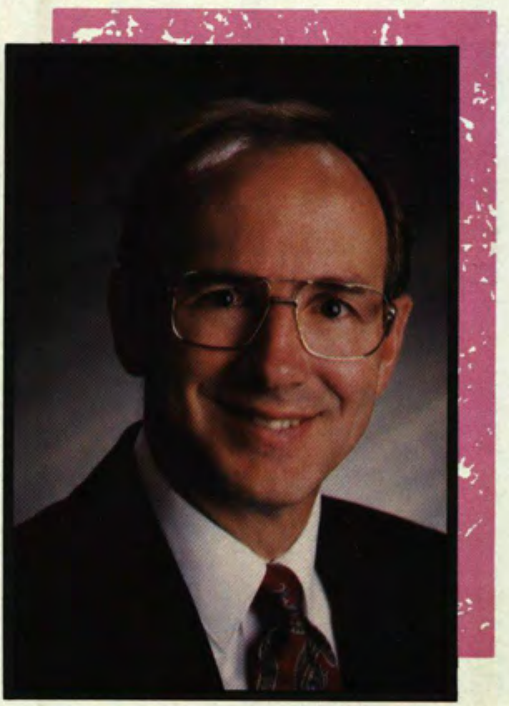

Dr. Duane Wood Academic Vice President 

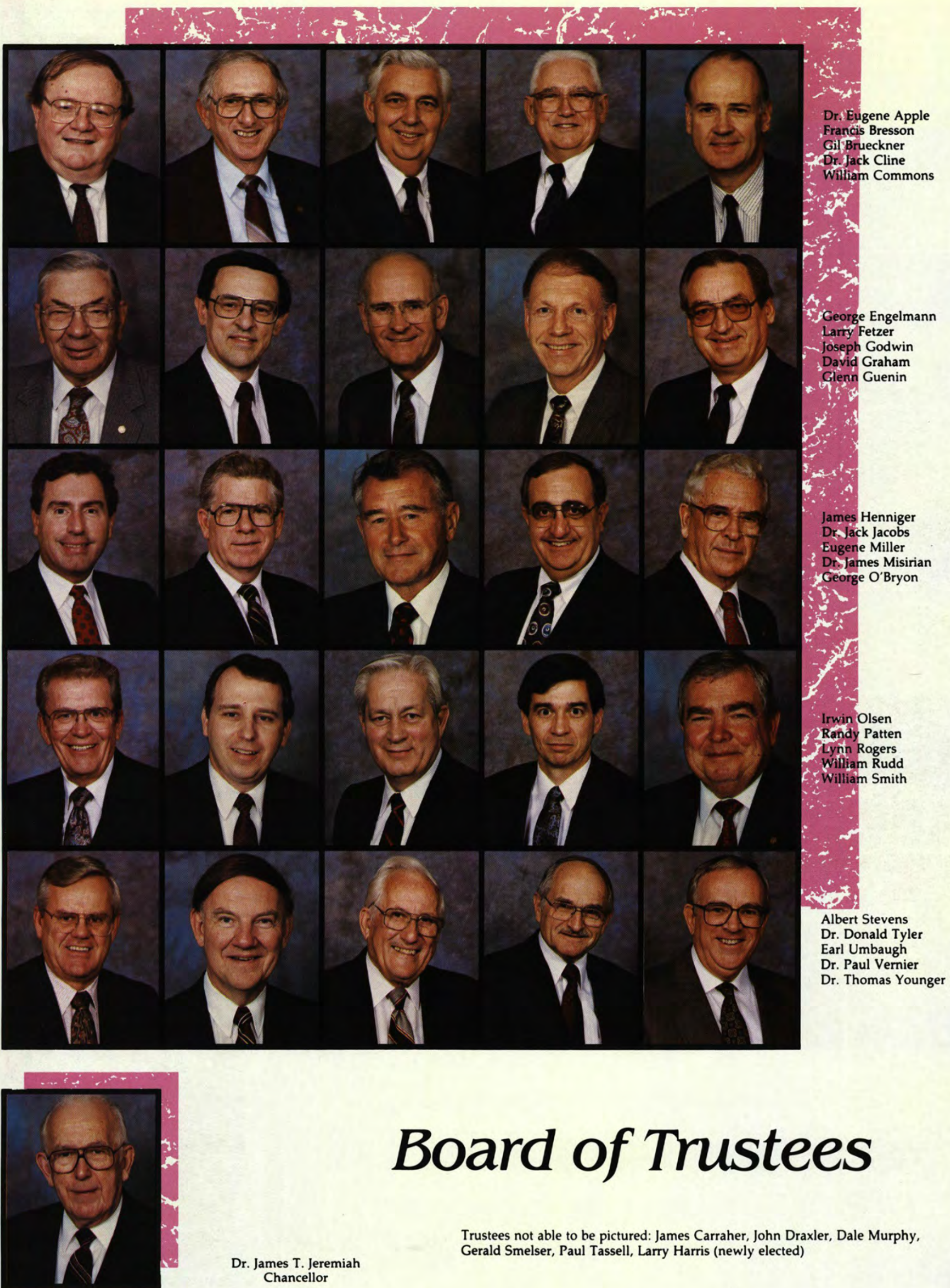

\section{Board of Trustees}

Dr. James T. Jeremiah

Trustees not able to be pictured: James Carraher, John Draxler, Dale Murphy, Gerald Smelser, Paul Tassell, Larry Harris (newly elected)

Chancellor 


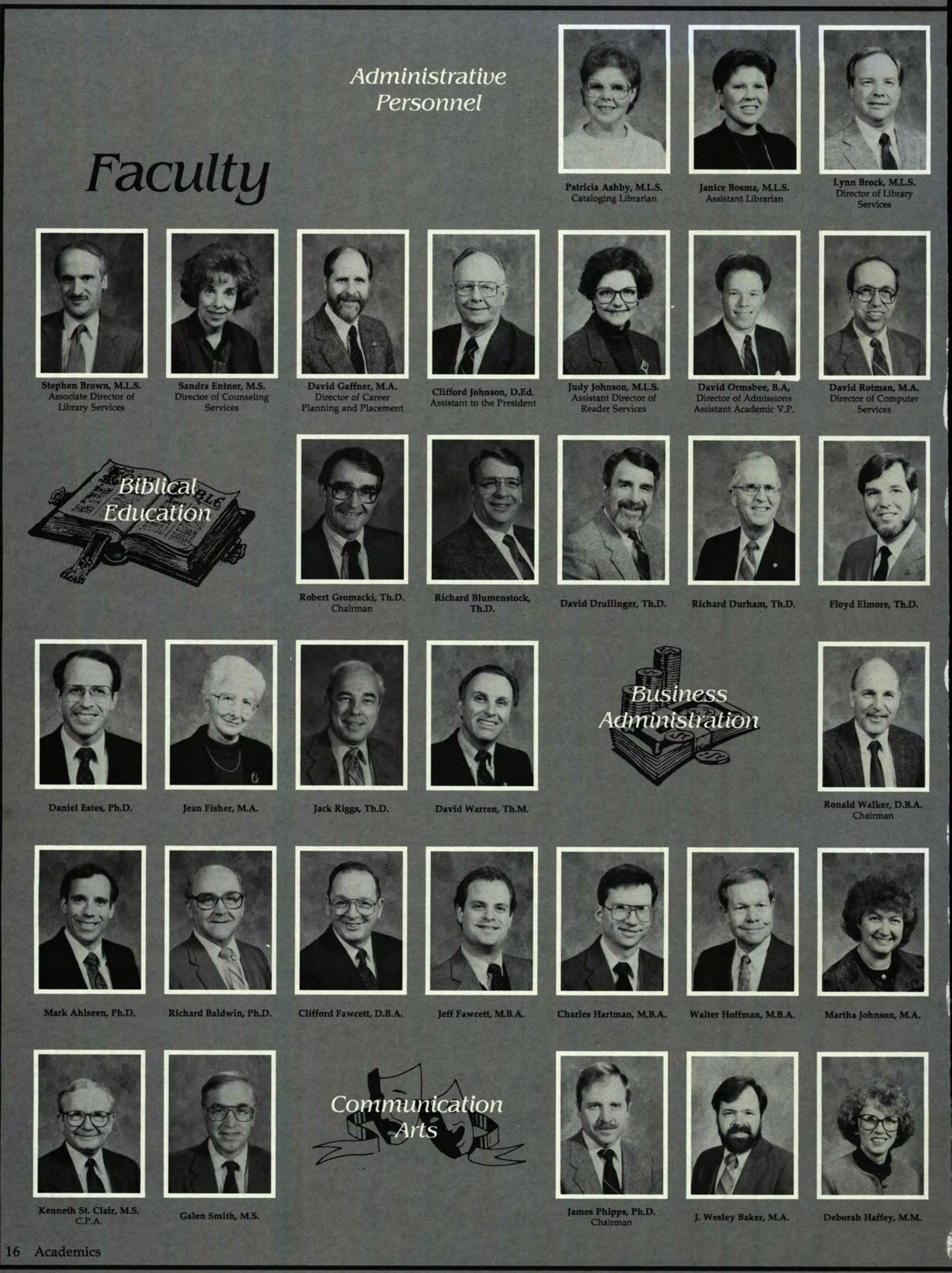



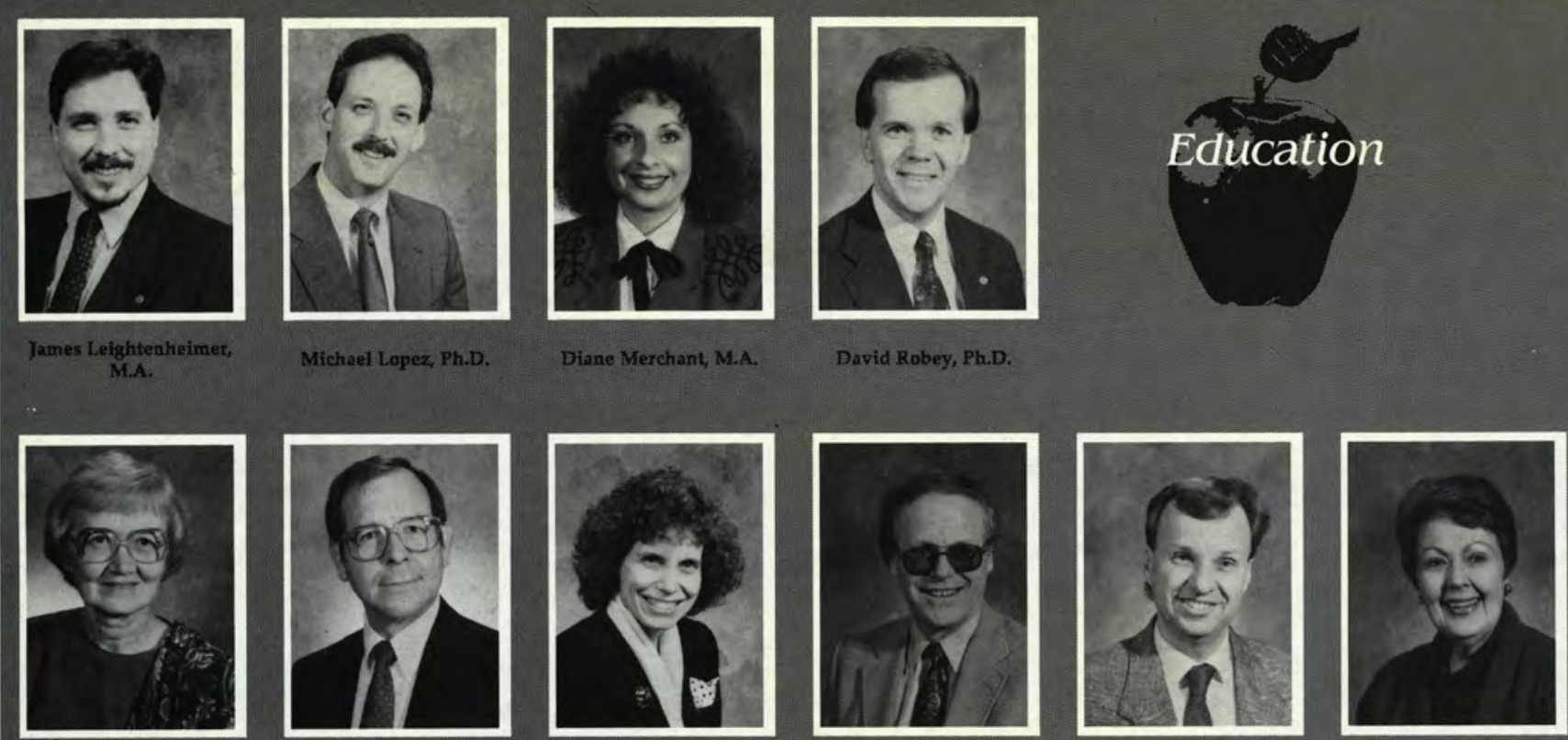

Tim Heaton, M.A.
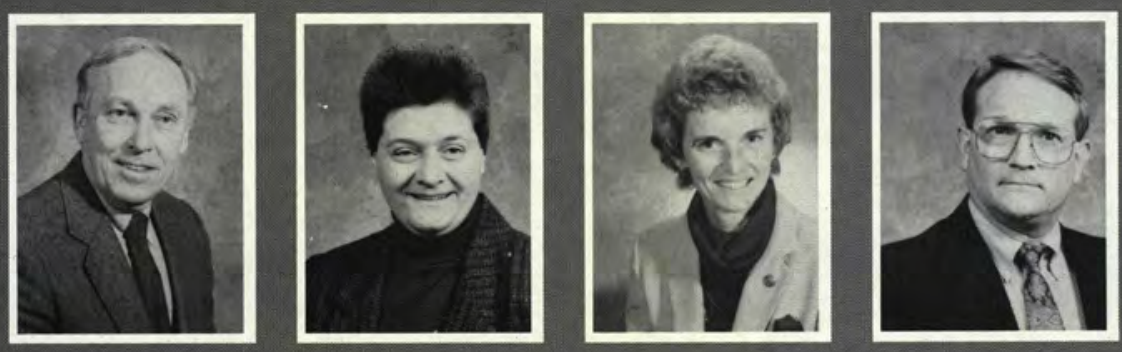

Pamela Deihl, Ph.D.
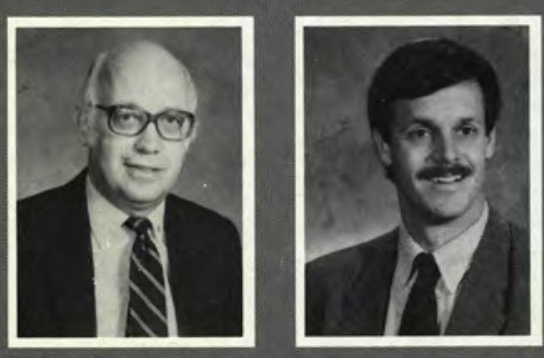

Language and titerature
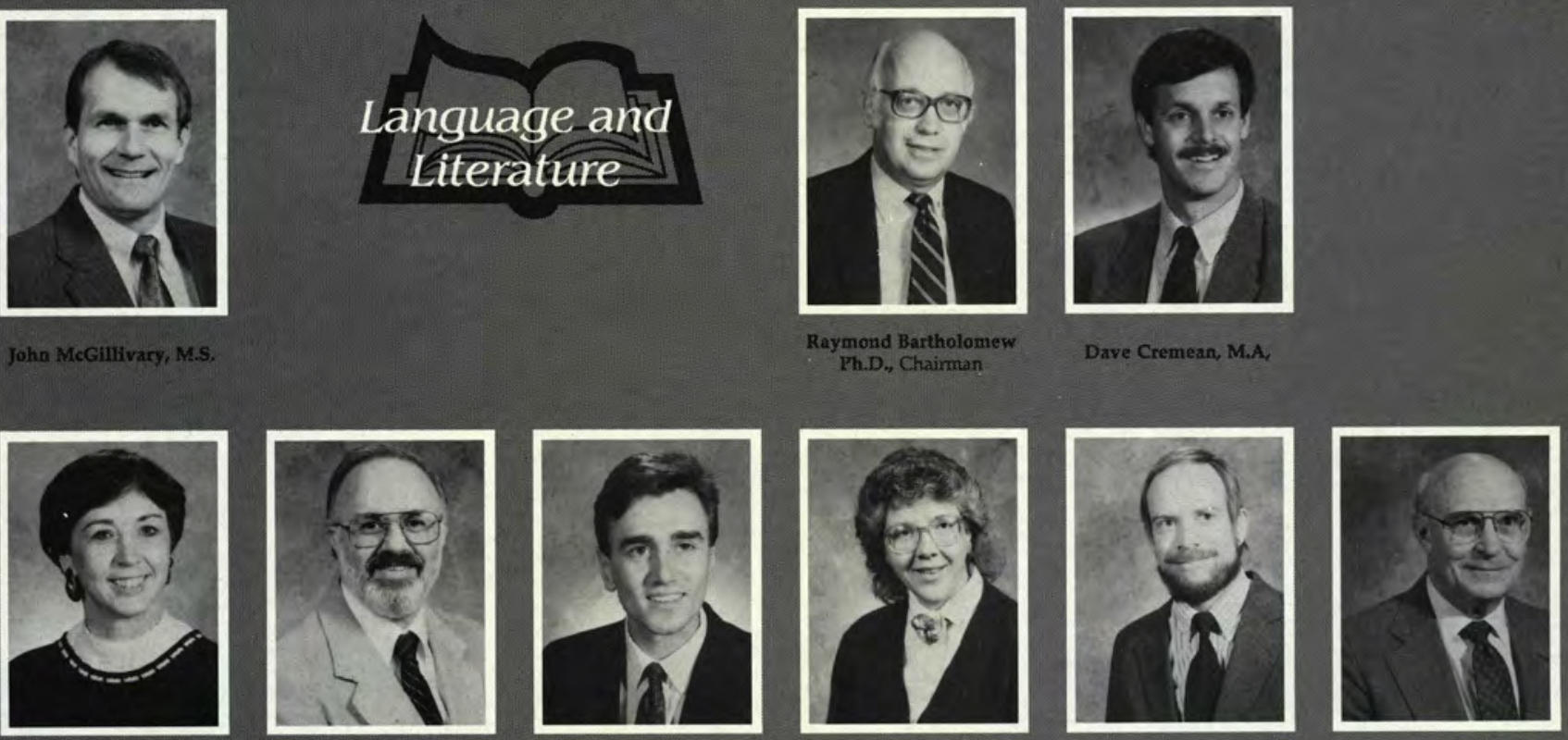

Brian Kennedy, M.A
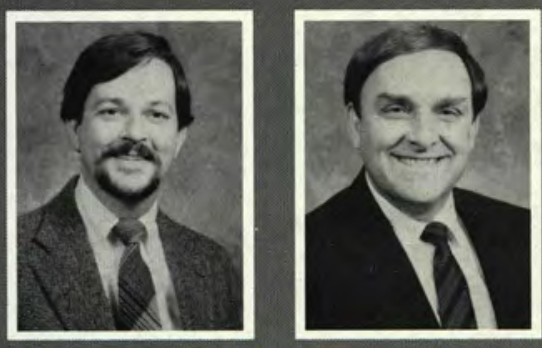

Charles Clevenger
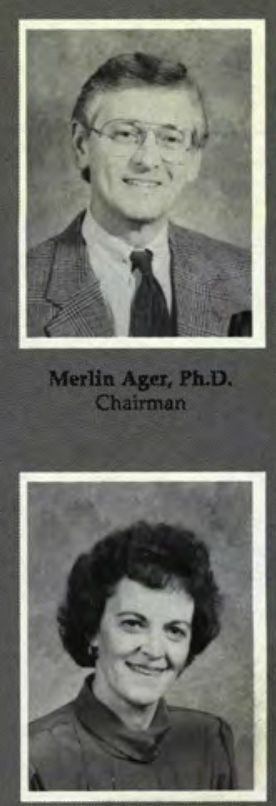

Beverly Monroe, Ph.D.

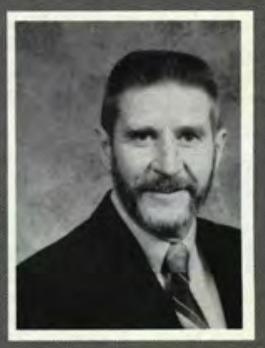

Elvin King M.Ed
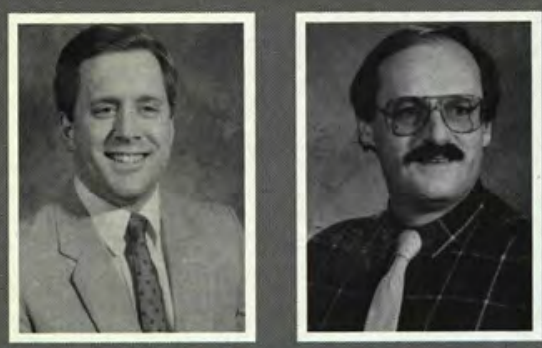

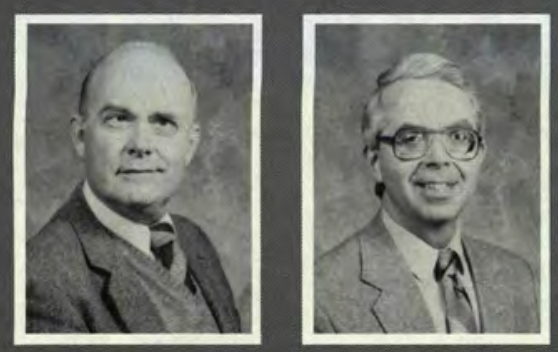

David Matson, Ph.D.
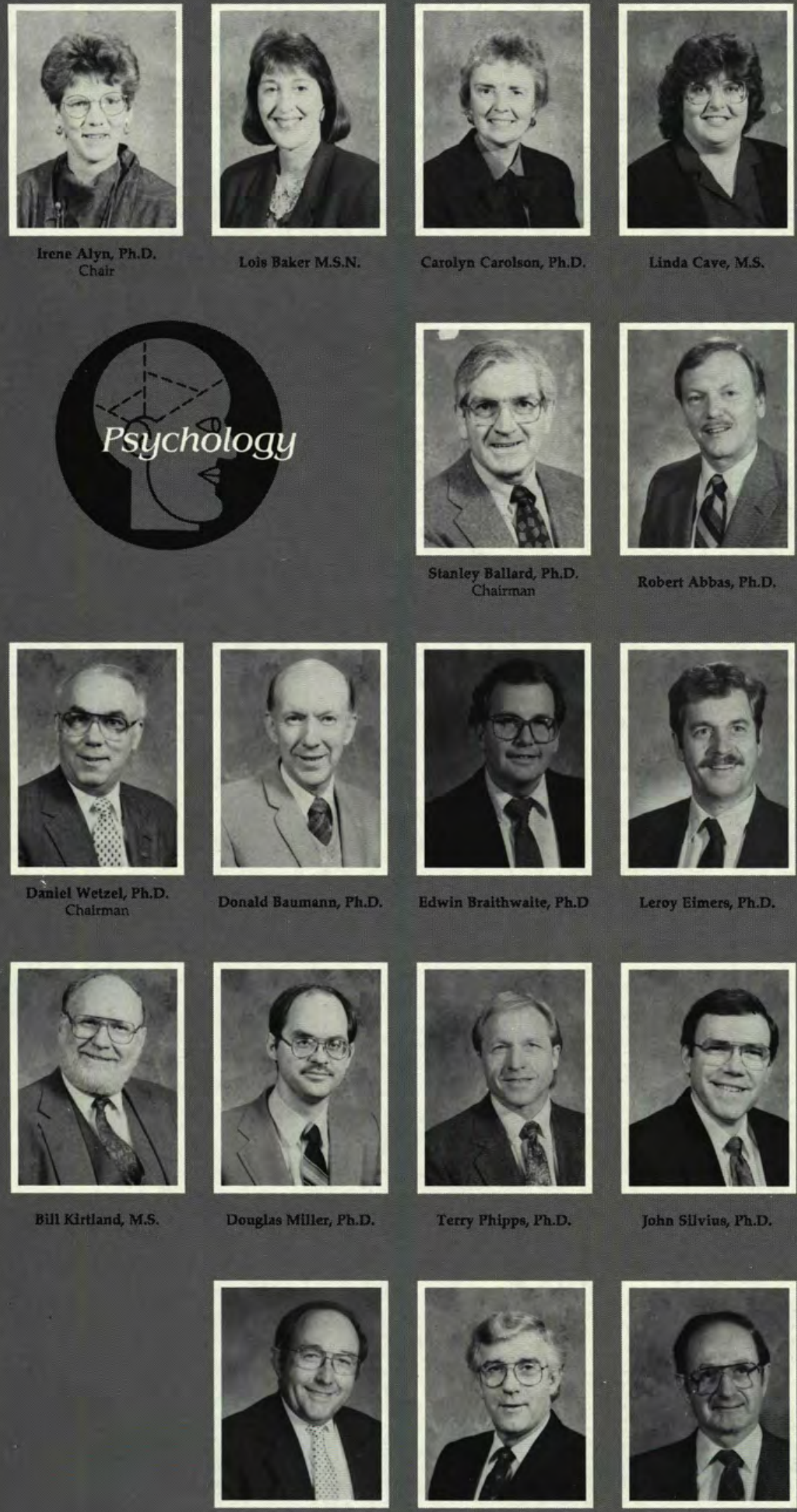
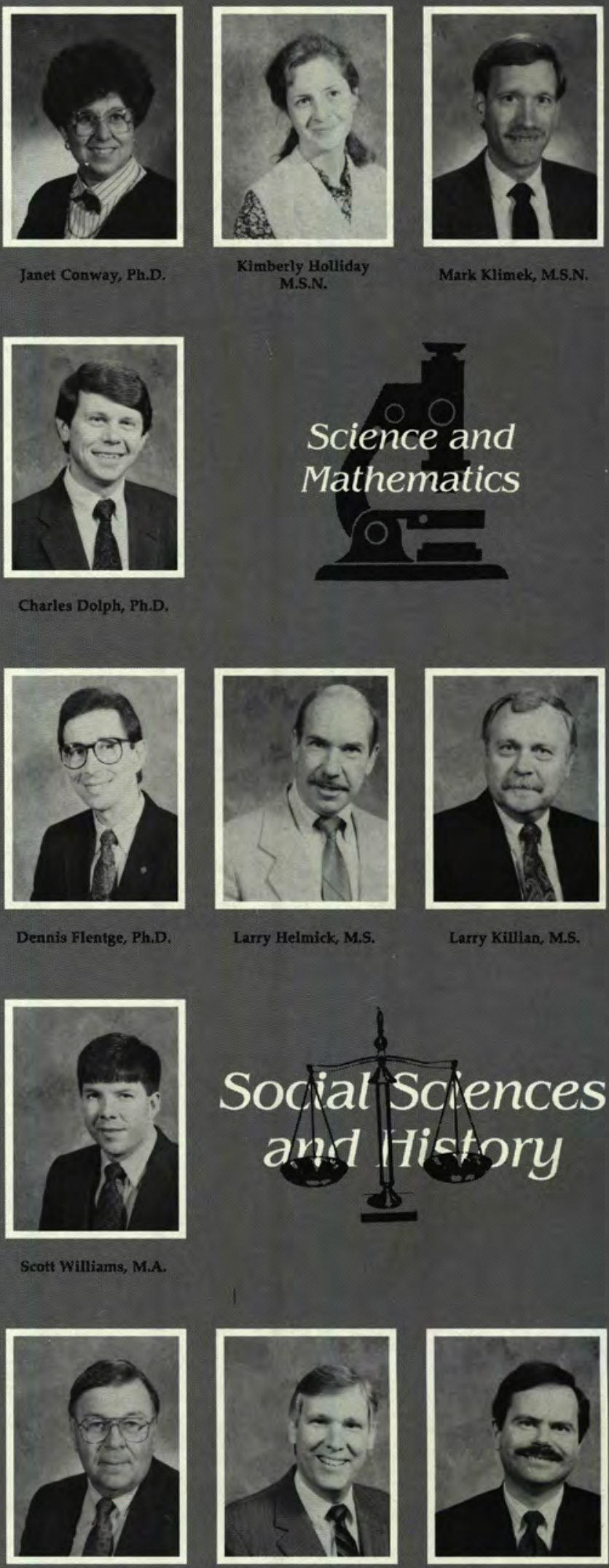

Mimberly Holl
M.S.N.
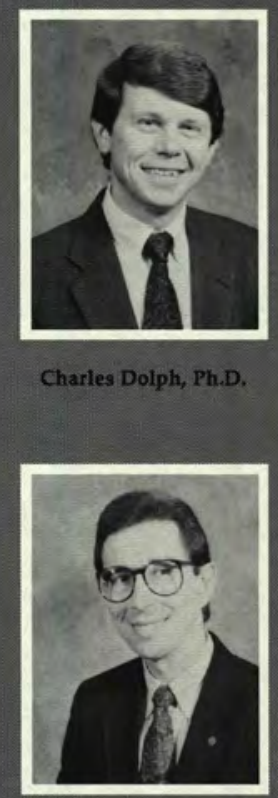

Dennis Flentge, Ph.D.
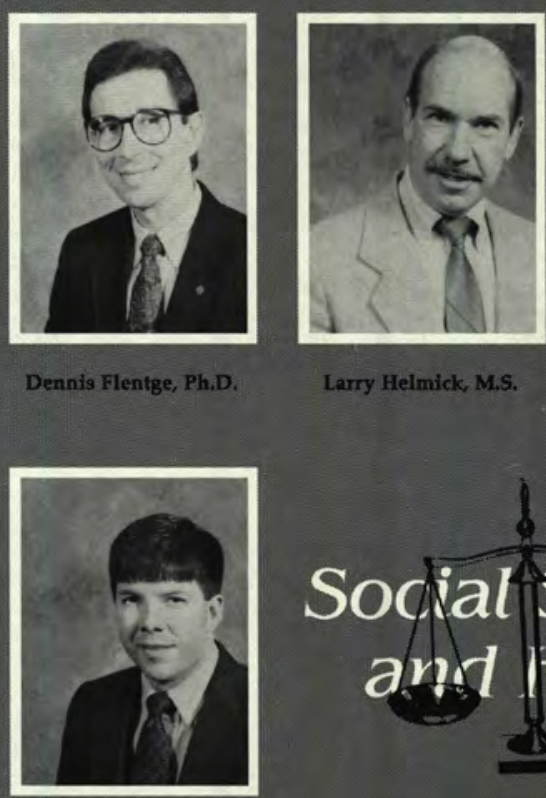

Sodial Scliences

Robert Patr, Ph.D.
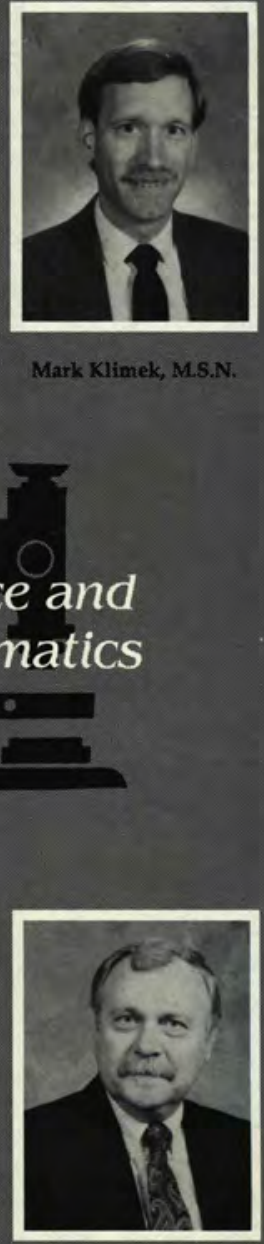

Larry Killian, M.S.

Science and

Mathematics

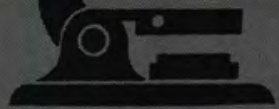
and History 


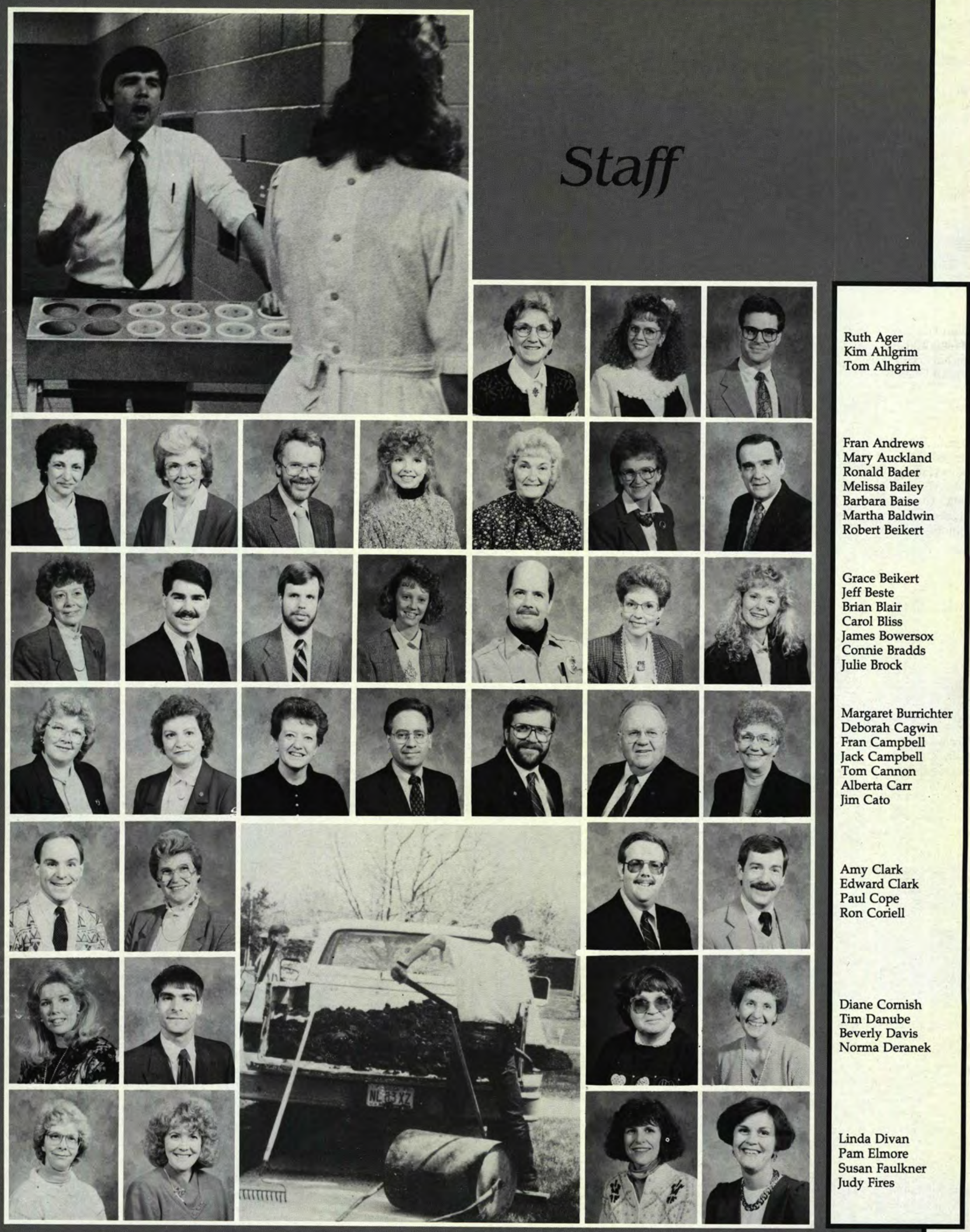


Tim Fisher

Nancy Fissel

Paul Gathany

Al Geist

David Gidley

Dianne Gottwals

Margaret Green

Janice Greenwood

Keith Hague

Marsha Halk

Michael Halk

Shawn Hannay

Donna Harrison

Melinda Howard

Scott Howder

Trish Huber

Leigh Hunt

Shirley Johnson

Timothy Johnson

Murtha Kaercher

Darla Kennedy

Toinette King

Joyce King

Amy Kirtland

Nancy Knauf

Mark Kordic

Gayle Kunz

Greg Kunz

Jill Law

Patricia Lee

Faith Linn

Michelle Longo

Mark Mathews

Wayne Maxie

Cynthia Maxson

Cheryl Miller

Mary Mitchell

George Morris

Buffie Myers

Luann Nicholas

Rose Payne

Doug Phillips
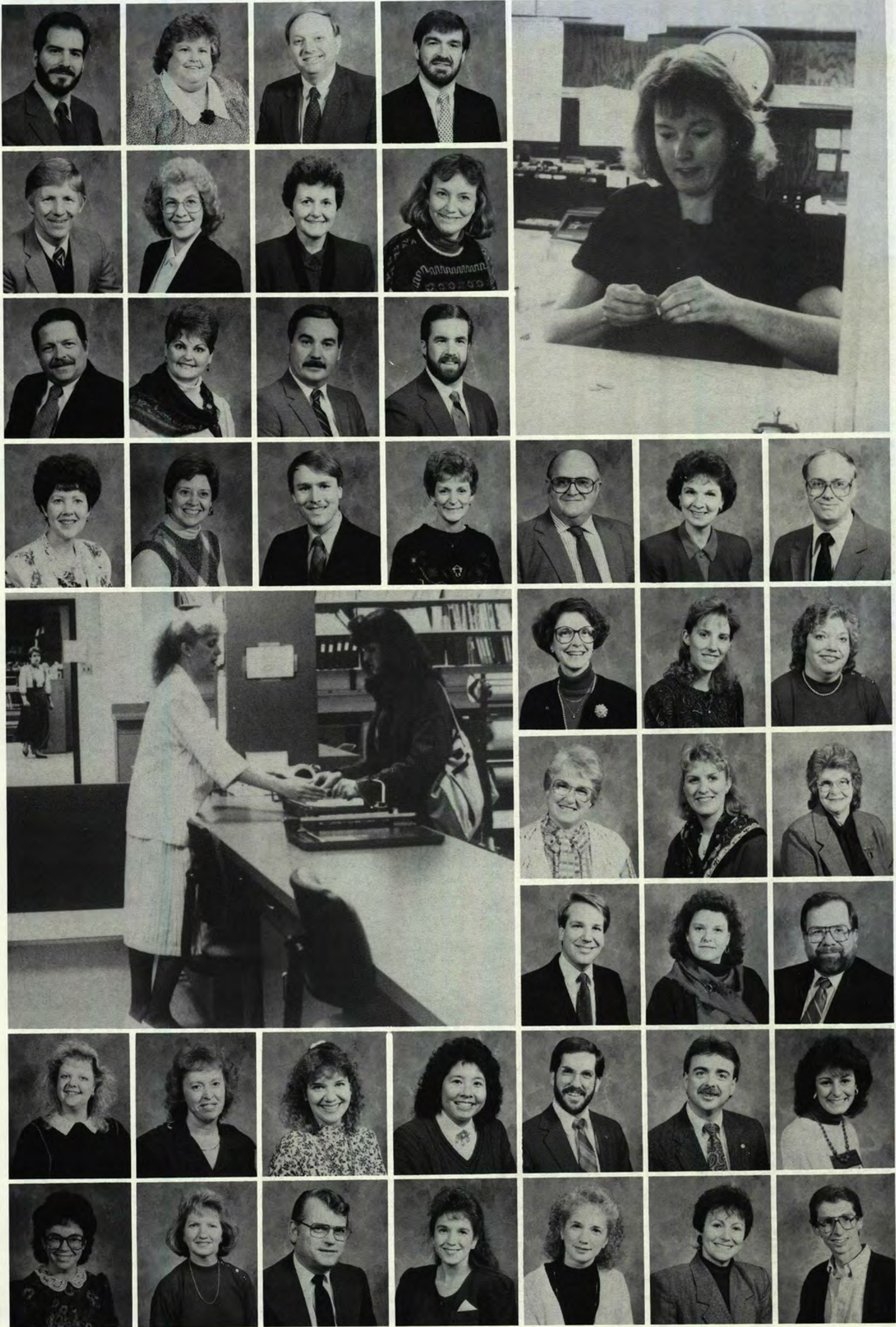


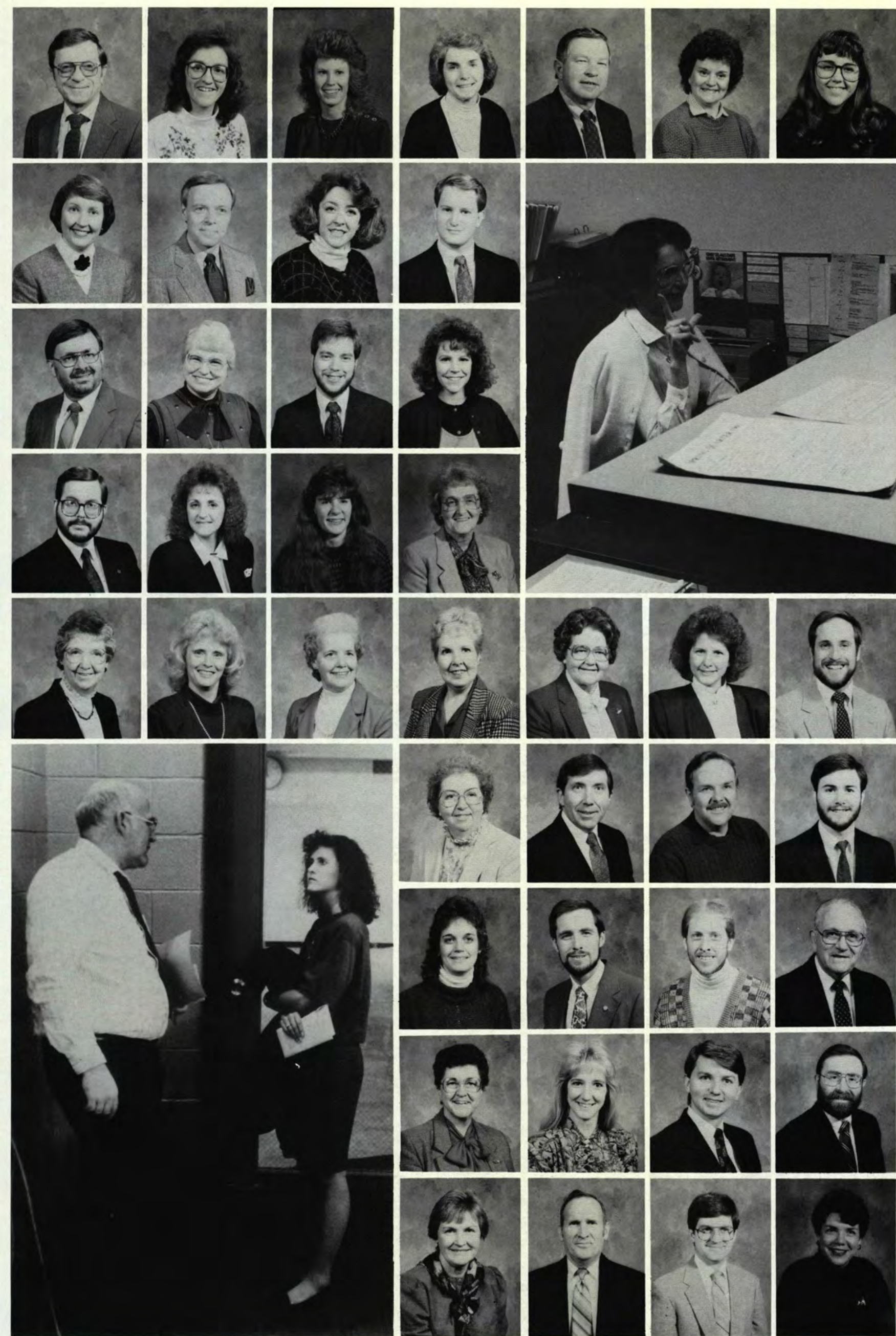

Edmond Phillips

Susan Potter

Nancy Ranger

Joyce Reese

Pete Reese

Beverly Robey

Kimberly Robinson

Lynn Rohm

Robert Rohm

Heidi Rooks

Jeff Sanders

John Skillman

Sylvia Skillman

Ben Smith

Jane Adams Smith

John Smith

Michele Smith

Joan Smoot

Dorothy Spencer

Ida St. Clair

Patty Stutes

Eleanor Taylor

Rae Taylor

Virginia Taylor

Susan Terkelsen

Steven Thompson

Barbara Tucker

Michael Tucker

Cooley Turner

David Ulmer

Bonnie Vickman

Jeff Vickman

Kenneth Vickman

Allan Vine

Kitty Vine

Trudee Wagner

Brandon Waltz

Paul Ware

Phyllis Wetzel

Jay Womack

Mark Womack

Sharon Wood 


\section{Remembering the Past.}

During my twenty-seven years of teaching, thousands of students have walked into my classroom; some have walked into my life. Bryan Armstrong was one of those students. He typified the Cedarville College student during his years here: active in

his social life, diligent in his studies, responsible in his extra-curricular activities, maturing in his walk with God.

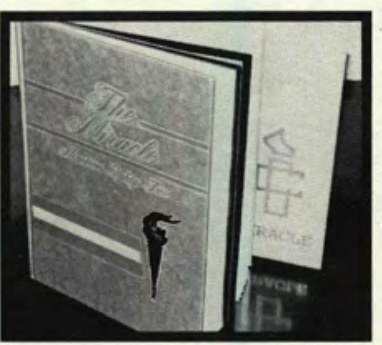

For all of his four years (1979-1983) at Cedarville, he worked on the Miracle staff; for two of those years he was the editor-in-chief. His theme for the 1982 book was "changes." $\mathrm{He}$ wrote in his "Last Writes" on the editor's every event, every lesson, every trial, every joy, and every incident that sticks out clearly in my memory, the

page about how changes had affected his life that year and how in producing the book, God had changed him. In 1983, he ended his editor's "reflections": "To reflect accurately on four years at Cedarville, it is impossible to leave God out of the picture. In

hand of God is evident."

He ended the two volumes with this scripture:

"But he knoweth the way that I take; when he hath tried me, I shall come forth as gold" (Job 23:10).

Now he is forever changed!

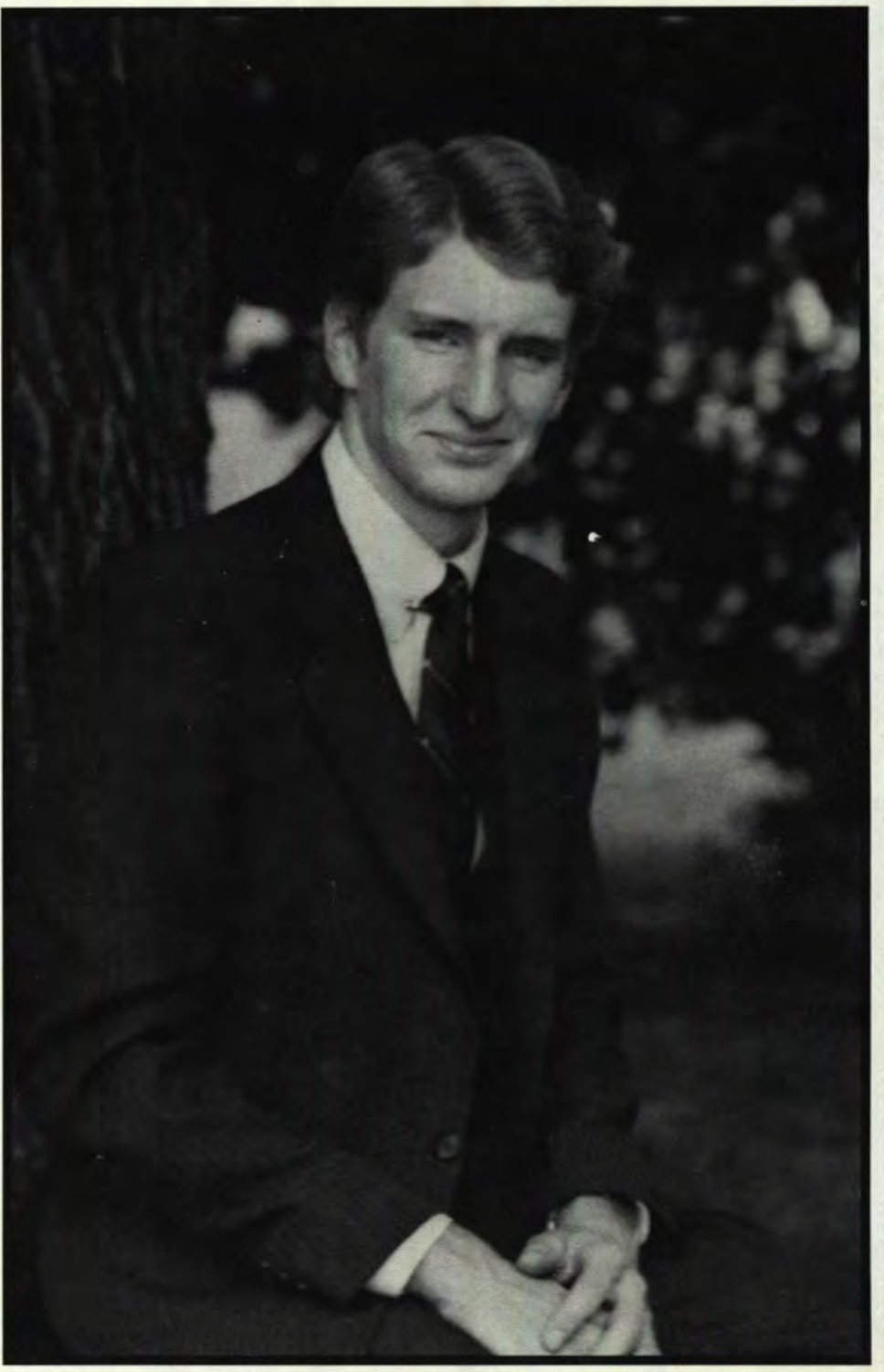

Students provide an outline of the new engineering building for an aerial camera.

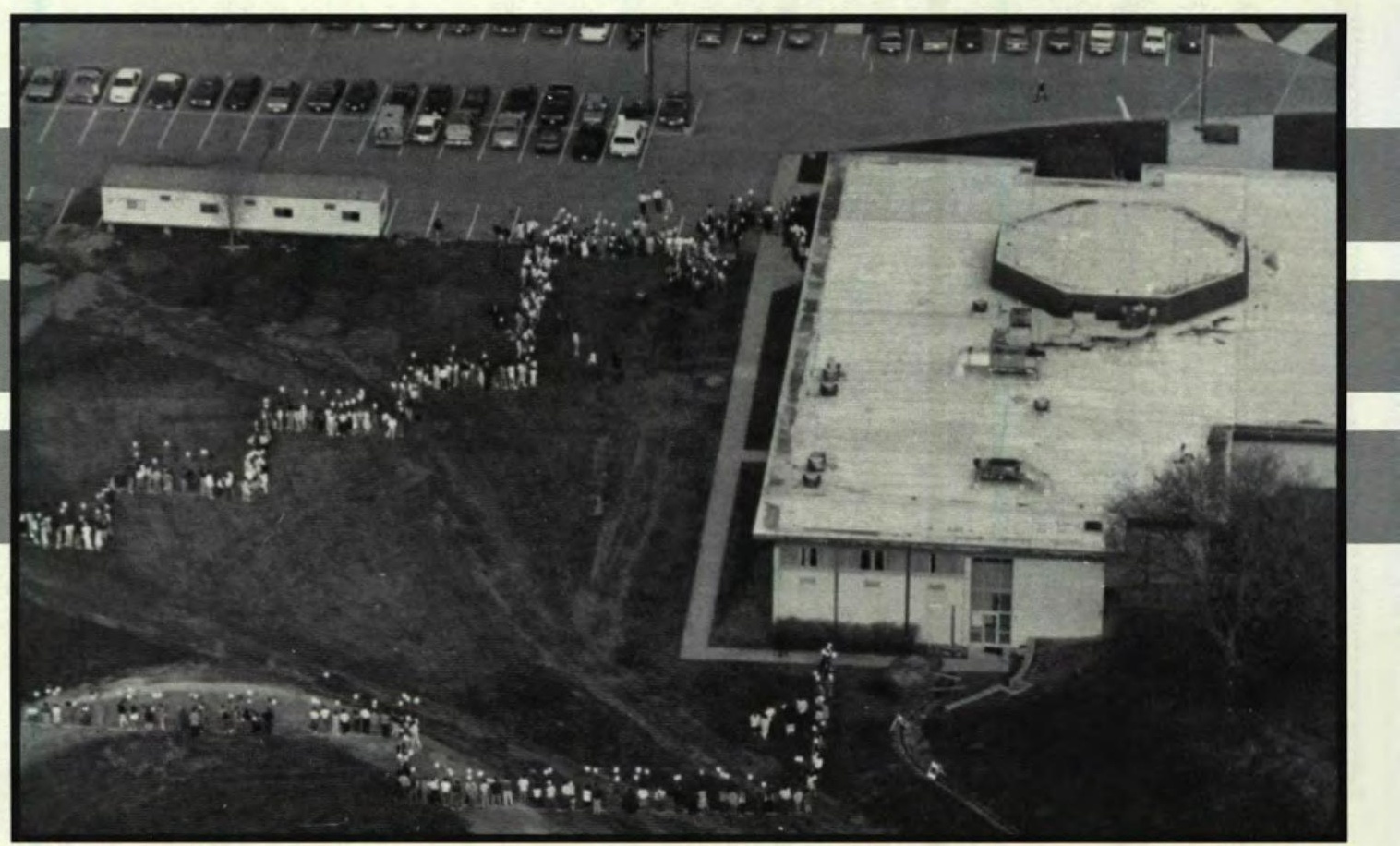

photo by Eric Cochrin 


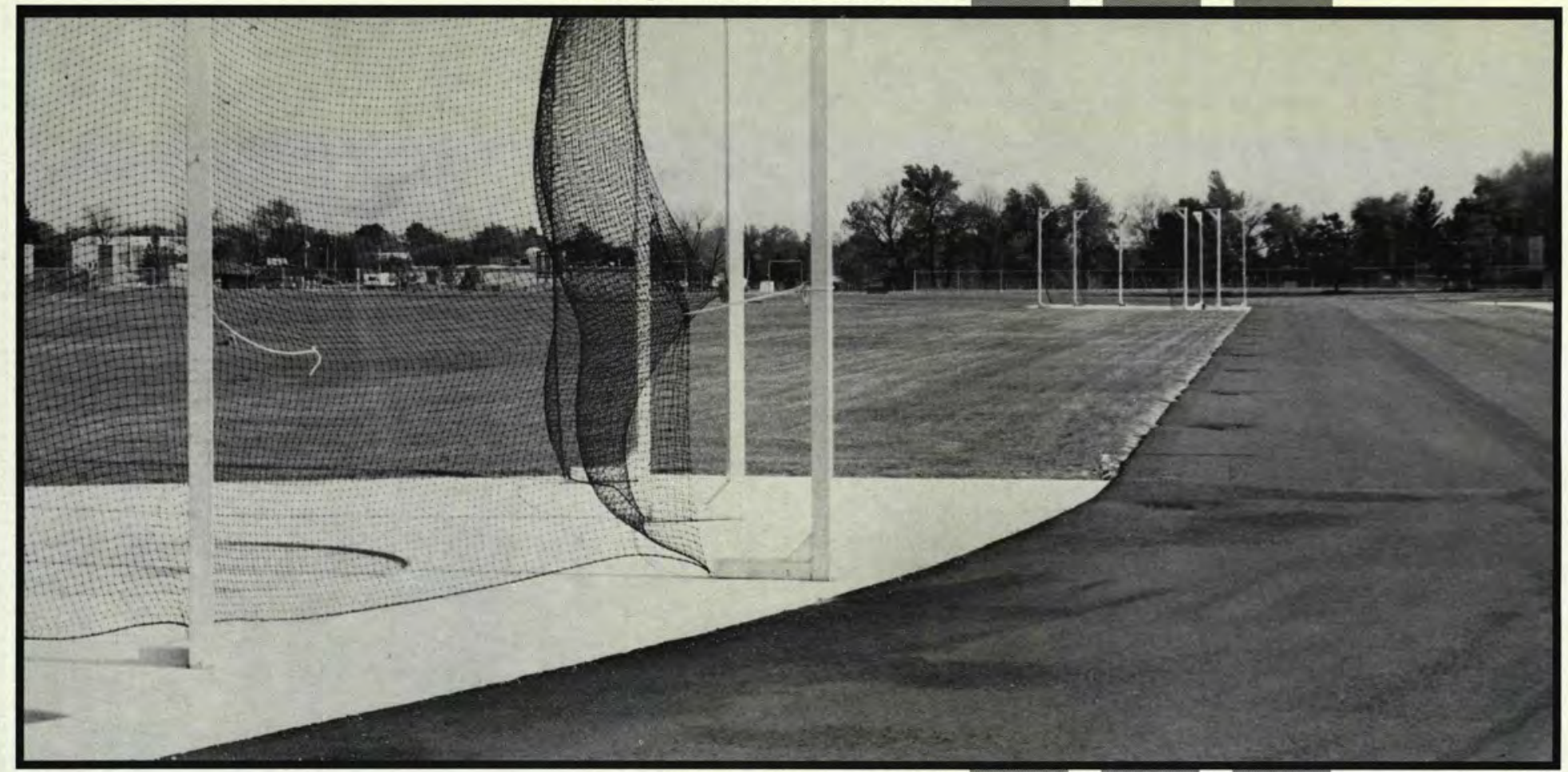

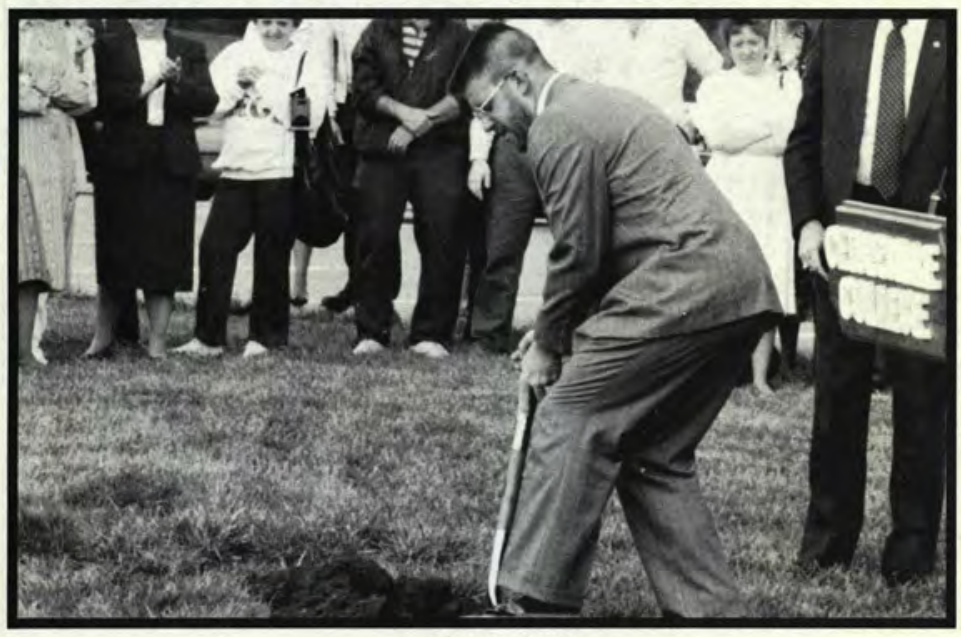

photo by Pat Dixon

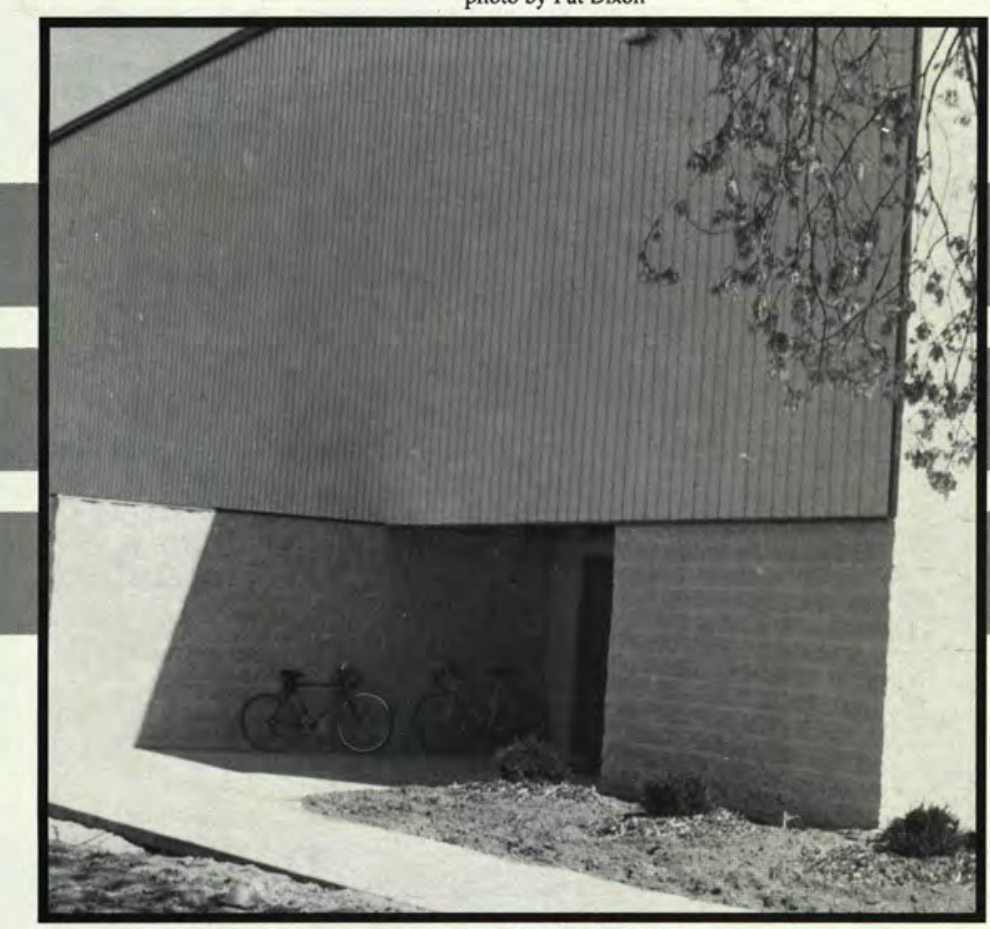

photo by Jesse Wesselink

Kelly Fath helps break ground for the new engineering facility.

Entrance to the new Alford addition.

\section{photo by Jesse Wesselink \\ ... Looking to \\ the Future}

Jack Hammers, Bulldozers, back hoes, hammers, nails, steel. wood and busy workmen were all common sights on campus this year. Cedarville College is showing once again that it truly is looking to the future to accomplish greater things for the Lord than it ever has before. While spiritual accomplishments are very difficult to measure, the vision of the college leadership is clearly demonstrated by all of the activity around campus.

There were three major projects which were undertaken or completed during the 1990-91 school year. The old track was torn up as workmen carefully began construction over the summer on a new track complete with long jump, high jump and shotput areas. The musicians of Cedarville College are elated with the new Fine Arts edition to Alford $\mathrm{Au}$ ditorium, which features a large rehersal room, finally large enough to properly accomodate the many musical groups at Cedarville. And finally, the college broke ground April of 1991 for the new nursing-engineering building, which among other things will house the twoyear old engineering major at Cedarville College. If anything has been impressed on the minds of students, it has been that Cedarville College plans to keep pressing ahead. 
$-2 x+4 x^{2}+y^{2}=$

Wy 258

$3 \quad 2$

$+1$

$c_{i}$

$\therefore$

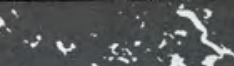

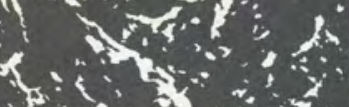
$x^{3}=$

\section{Freshmen}

Abbott, Shawn Alexander, Stephanie

Allen, Anthony

Allen, Denise

Allison, Jason

Andrews, Michael

Apperson, Lori

Armour, Paul

Armstrong, Rebecca

Ashcraft, Eric

Aughinbaugh, David

Awabdy, Nicholas

Baesen, Shelly

Bailey, Tricia

Baise, Travis

Barker, Traci

Barnes, Brian

Barnard, Shannon

Barnitz, Lisa

Baughey, Kristen

Bauman, Lawrence

Beasley, Renee

Beiler, Jeffery

Bell, Andrew

Besosa, Robert

Bickel, Nathan

Biddle, Benjamin Biggers, Kristie

Binning, Eric

Bird, Melissa

Bishop, Aaron

Bishop, Brian

Blenis, Darcey

Blind, Brian

Bockmann, Thomas

Bolger, Brian

Boone, Abigail

Bork, Jenifer

Borkholder, Misty

Bova, Philip

Bretz, Jonathan

Brinkerhoff, Matthew

Broman, Molly

Brooks, John

Brooks, Mary

Brown, Cinnamon

Brown, Daniel

Brown, Melanie

Brundage, Holly

Buckingham, Jeffrey
Barnum, Robert Jr.

Belmont, Kevin

Blake, Robert

Bouchard, Jenae

Bower, Carmen

Breneman, Todd
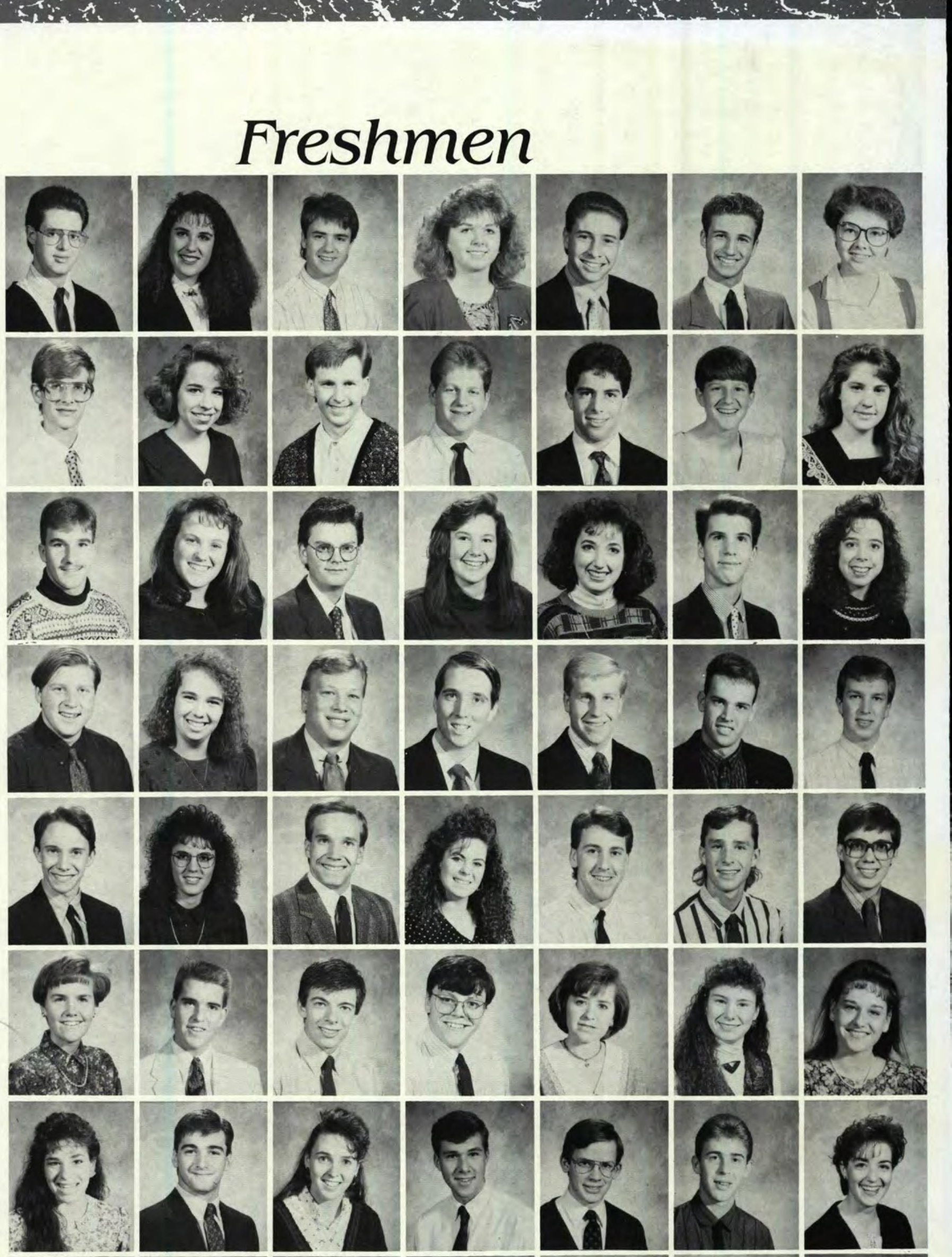

1
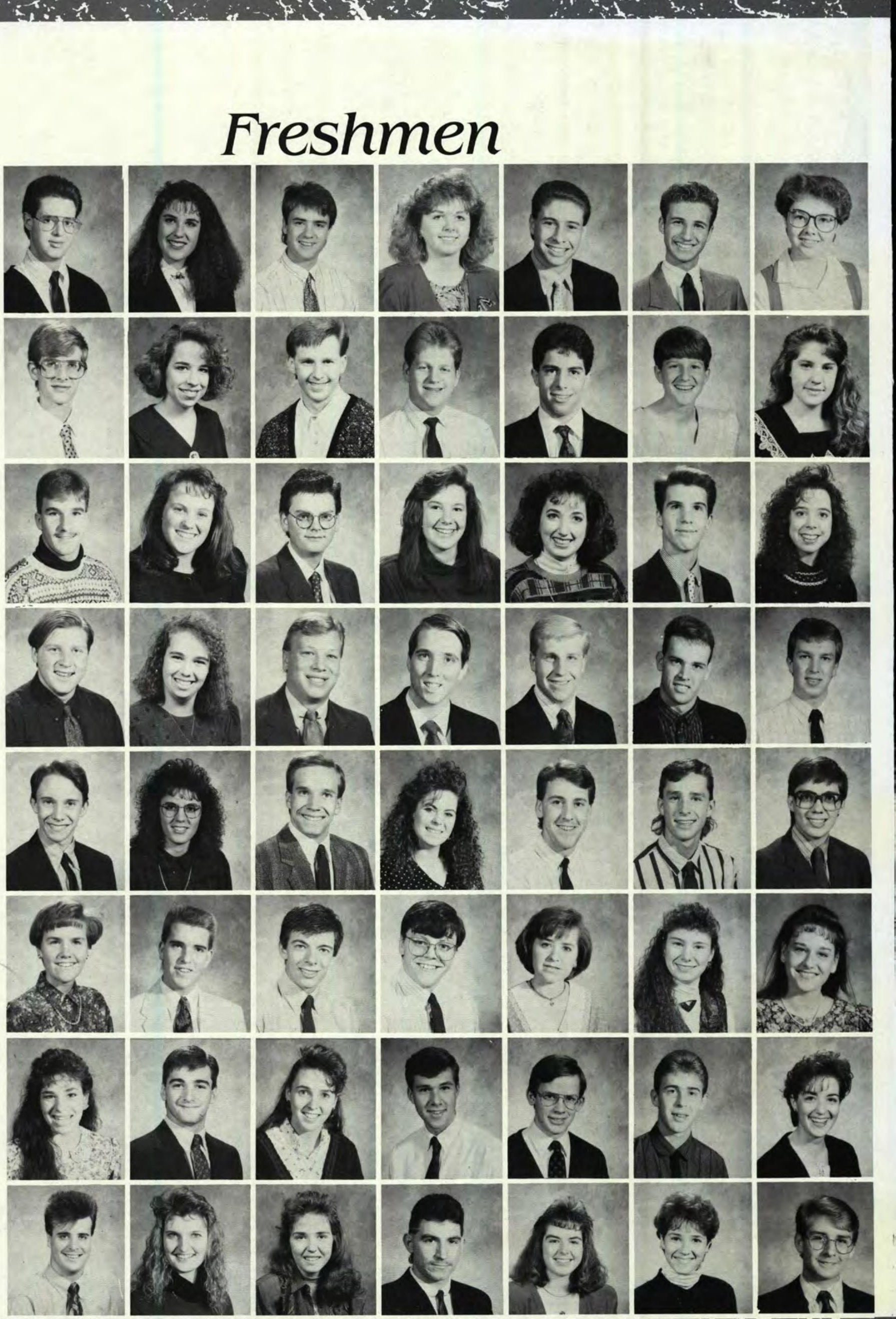

24. Academigs

(5)

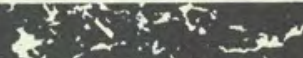




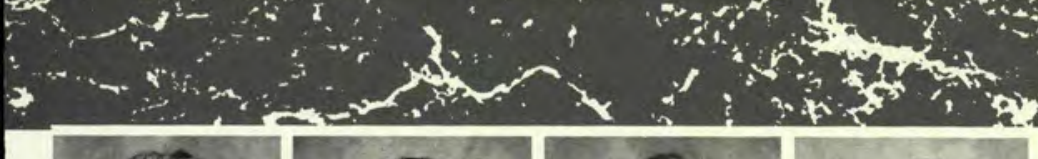

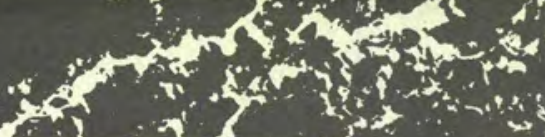
A : (2) 2
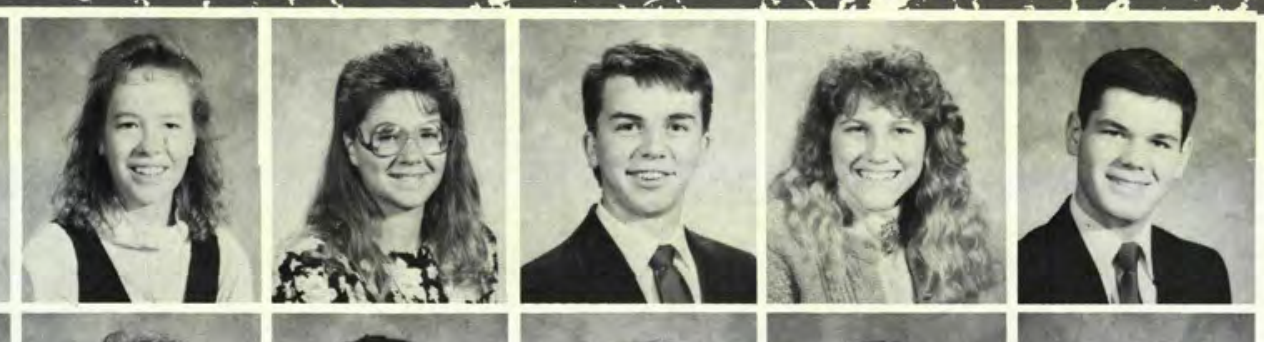

Burke, Rebekah

Burkholder, John

Bush, Sharon

Bush, Shawn

Blyer, Kendra

Calkins, Steven
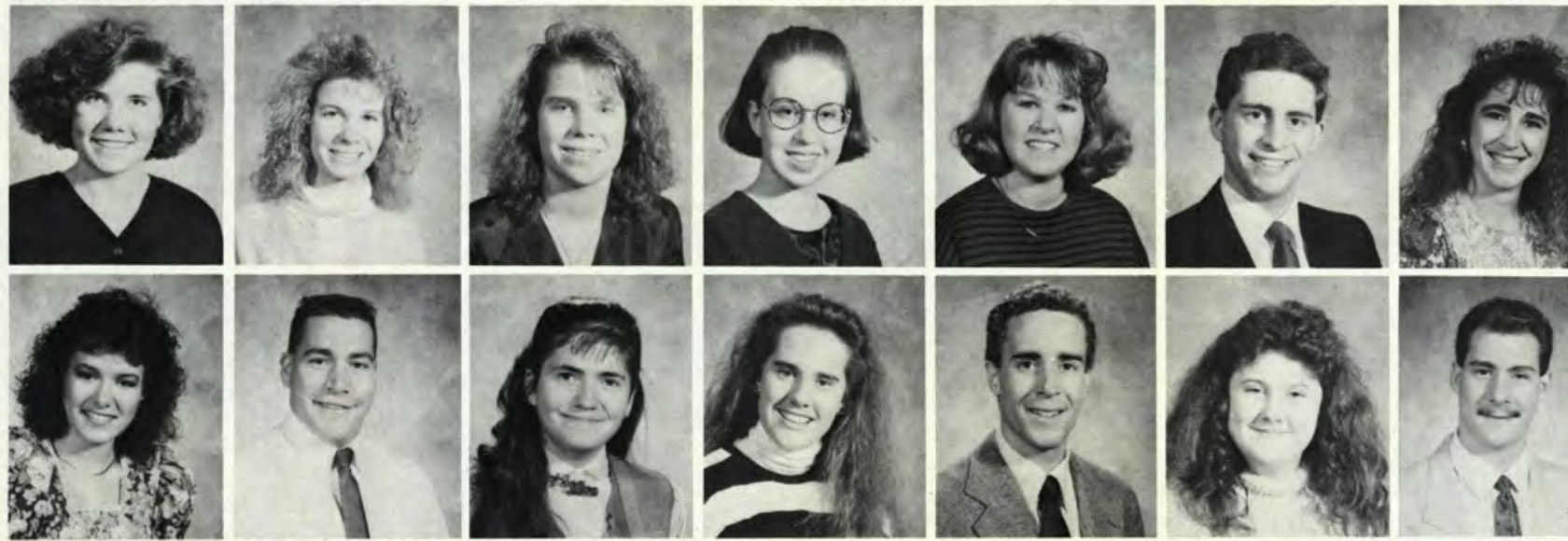

Calvert, Rebecca

Campbell, Julie

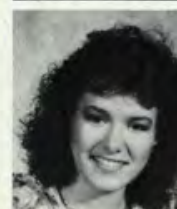

4

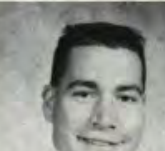

1
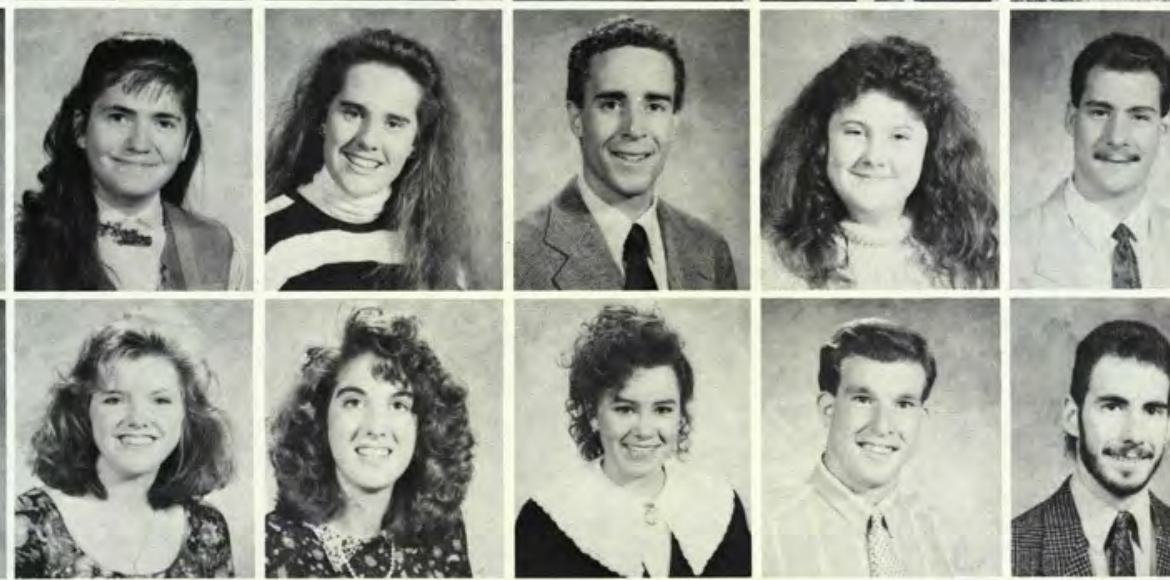

2

है
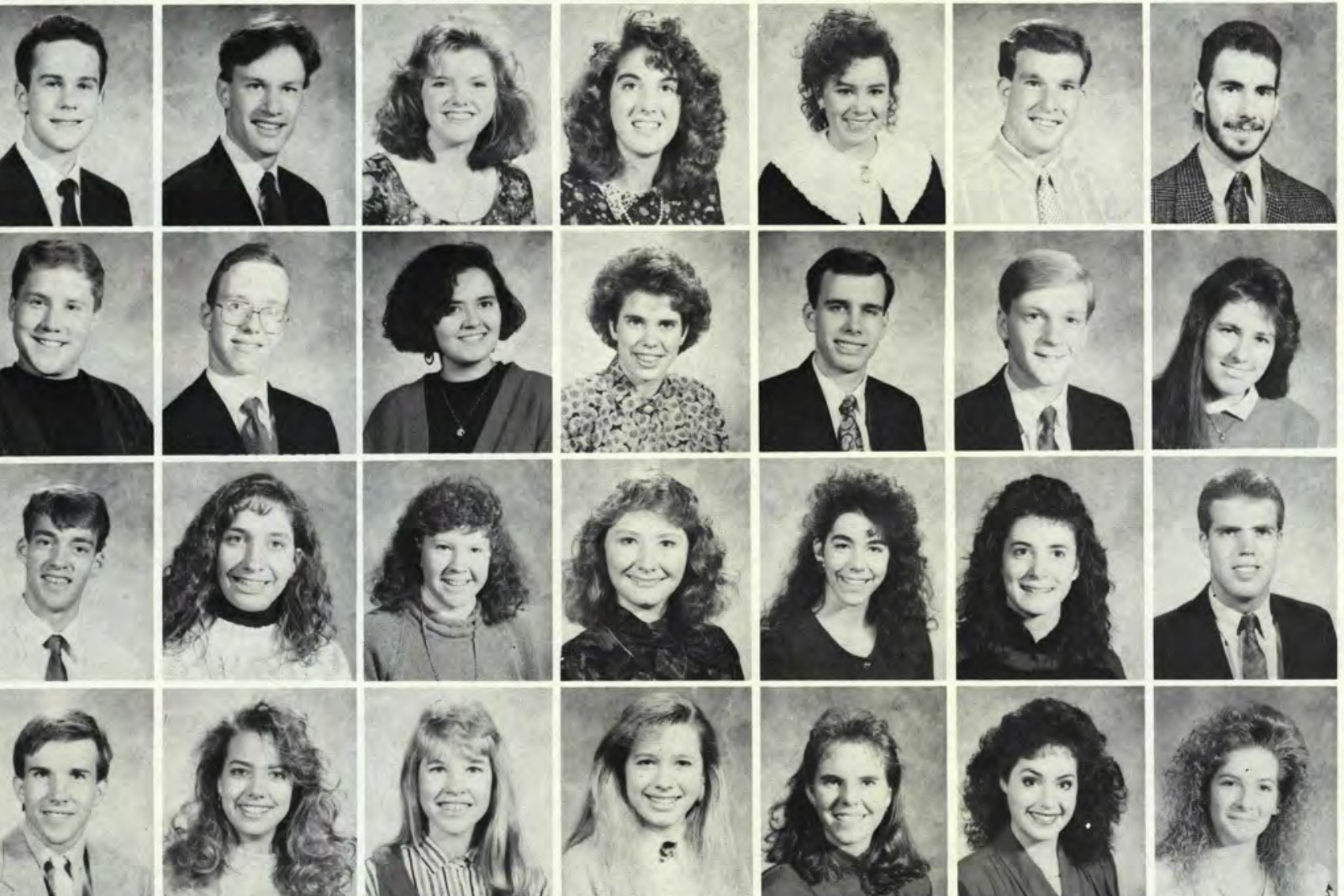

ii)
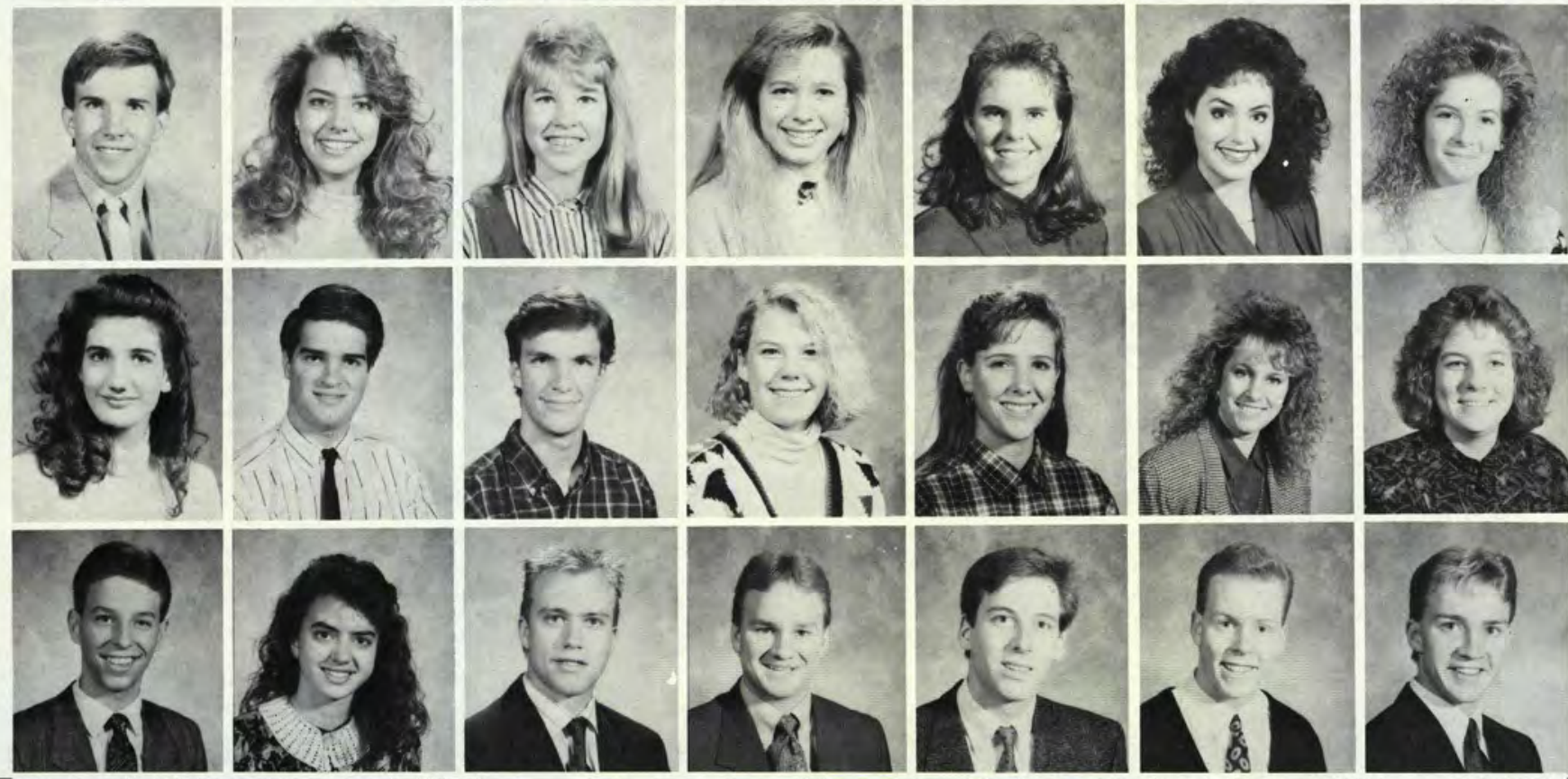

Dobert, Nathan

erty, Carolyn

Duvall, Robert Eckart, Crhistopher Edgerton, James Edington, Harold

Conrad, Robert

Cornett, Jennifer

Courtright, Christina

Cramer, Brian

Crawford, Elizabeth

Crouthamel, Scott Cunningham, Amy

Currall, Gail

Cushman, Kare

Cutler, Matthew

Davidson, David

Davis, Kelly

Dayton, Krista

DeMan, Susan

Denson, Leah

Deshetsky, Kristine Dettwiler, Paul

Dietrich, Kristi

Dillon, Sheila

Doak, Jennifer 


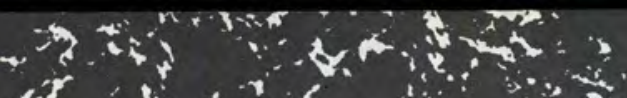

$+x^{2} y+2$

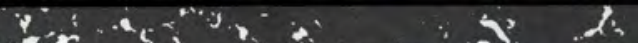

$\because 17$

tr

Edwards, Mary

Eichenlaub, Betsy

Eimers, Renee

Elmore, Nathan

Estenor, Elsa

Erickson, Donald

Ernst, Daniel

Everson, Yolanda

Ewing, Christina

Fales, Elizabeth

Farkus, Andrew

Fidler, Kevin

Fiorello, Peter

Finn, Tami

Fletcher, Derek

Fogle, Kimberly

Foley, Bret

Ford, Debra

Ford, Timothy

Fortner, Jennifer

Francis, Bradley

Freeman, Melissa

Freyhof, Laura

Fulks, Daren

Gannon, Cynthia

Gardner, David

Gardner, Krista

Gavitt, Sherry

ne r s

i)
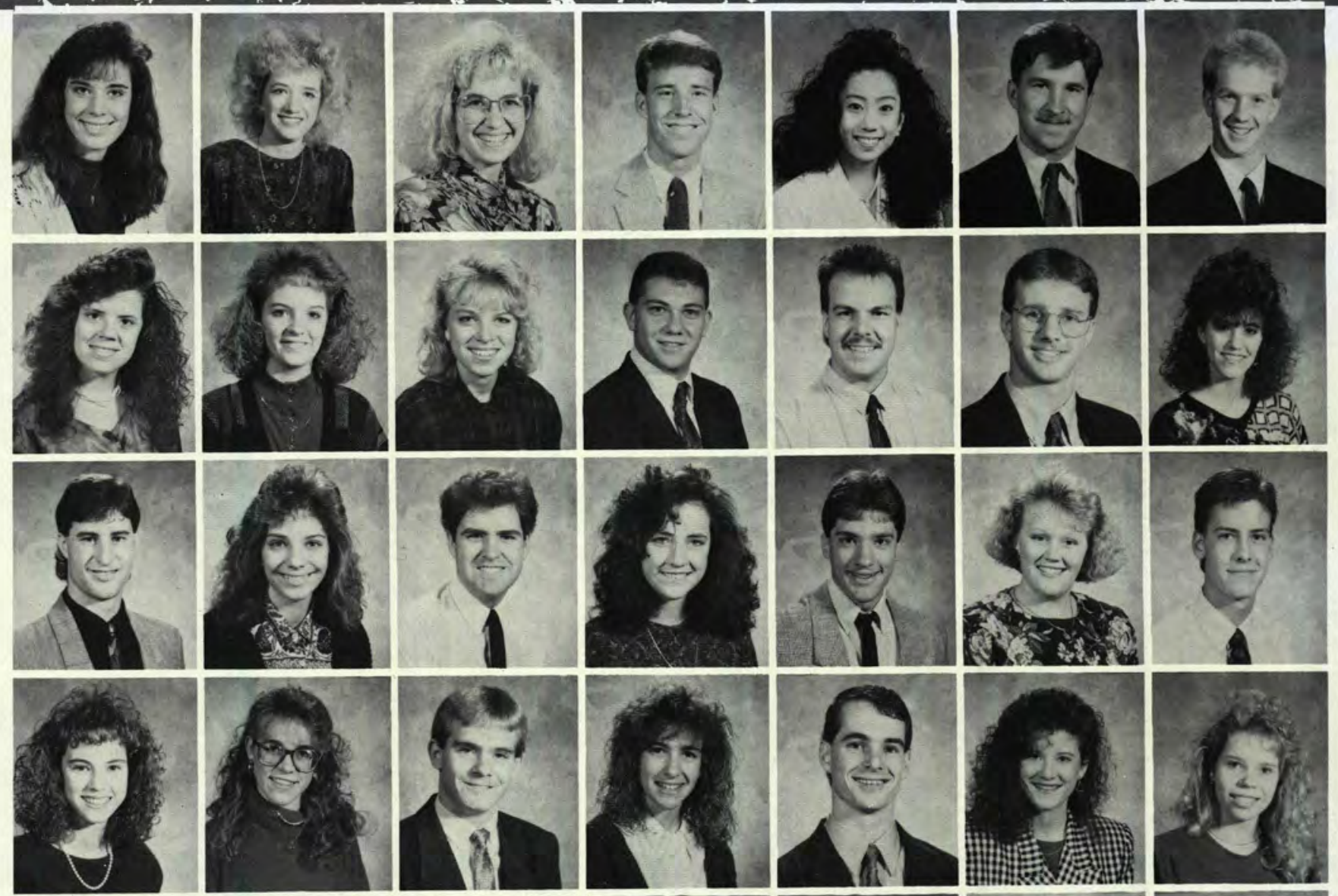

Gerendas Rebecca

Gill, Nathan

Gillam, Rebecca

Godden, Sean

Goding, Matthew

Goldbourn, Kimberly

Good, Brian
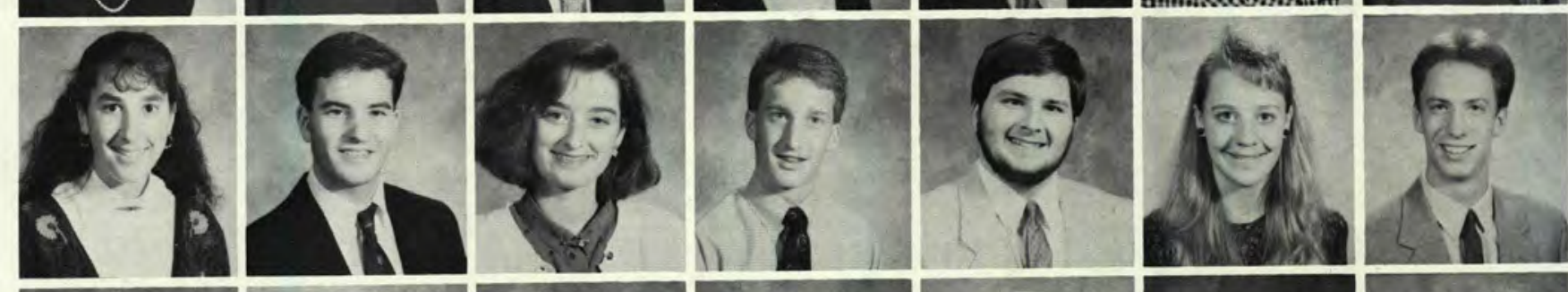

Good, Christopher

Gosser, Dana

Grabbe, Susan

Graham, Robert

Graver, Michael

- Graves, Philip

Grayson, Carrie

Greenly, Jack

Greentree, Annette

Griffith, Samantha

Grinnell, Jeremy

Gritsavage, Reid

Gromko, Eliza

Grove, Cory

Haaksma, Lisa

Hahnenstein, Cathleen

Hahnenstein, Christine

Ham, Jeffrey

Hammock, Darryl

Han, Nathan

Hansen, Paula
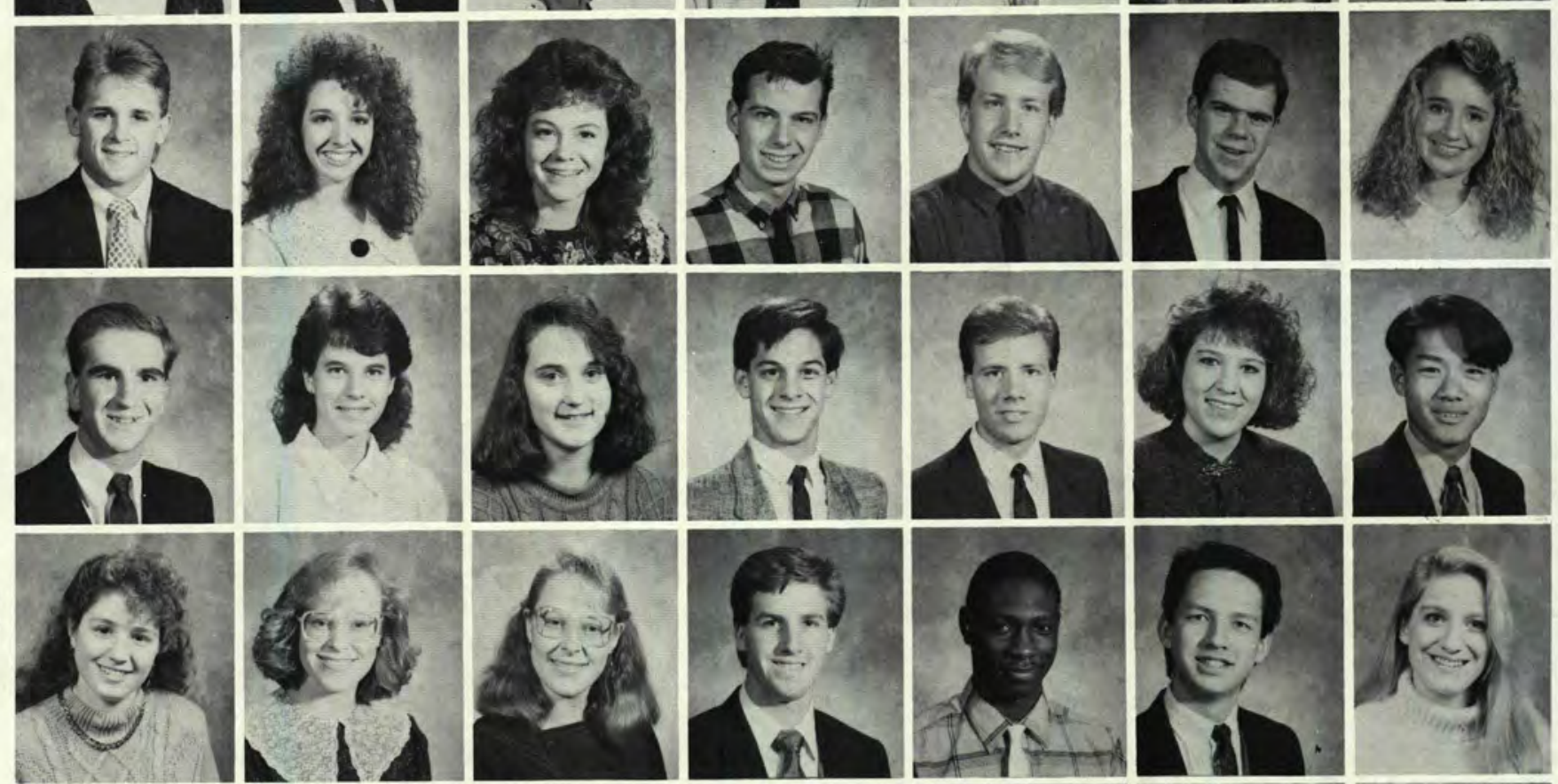

Haseltine, Todd

Harbeson, Amy

Harding, Suzanne

Harju, Aaron

Harkleroad, John

Harmless, Matthew

Harper, Karyn
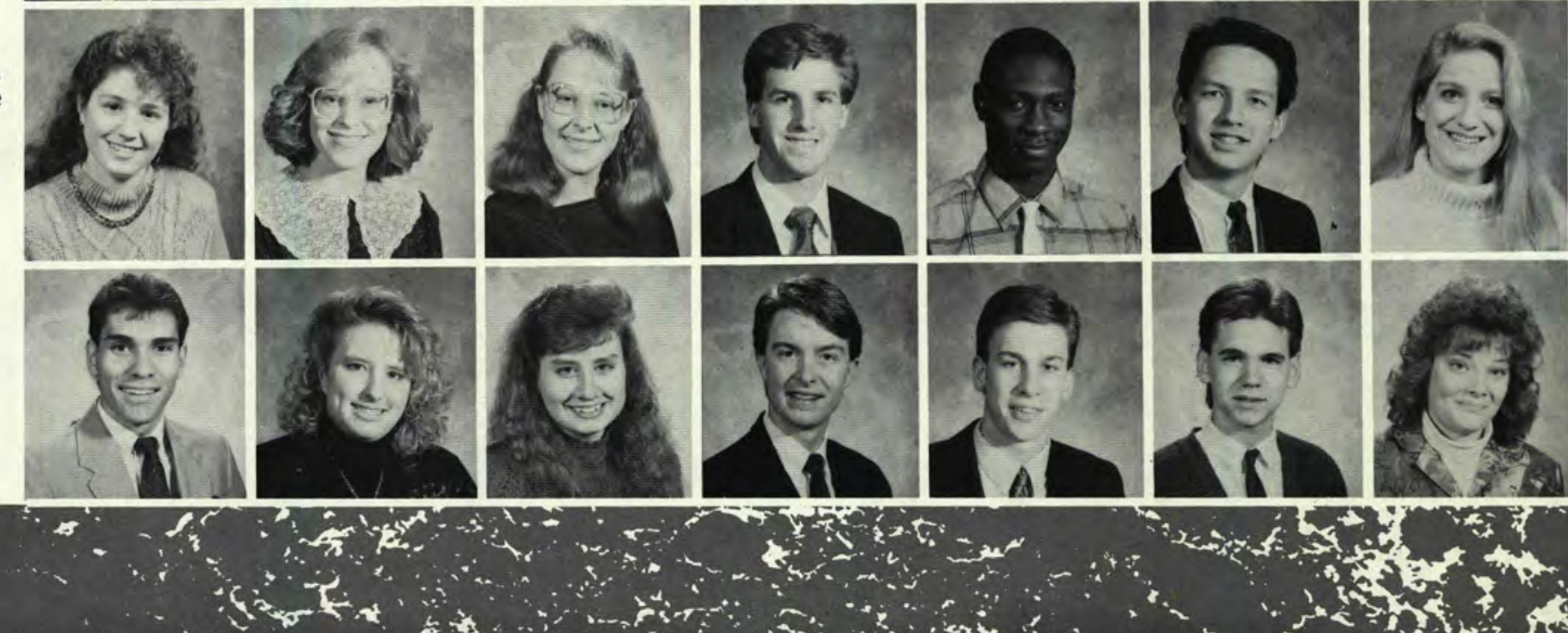


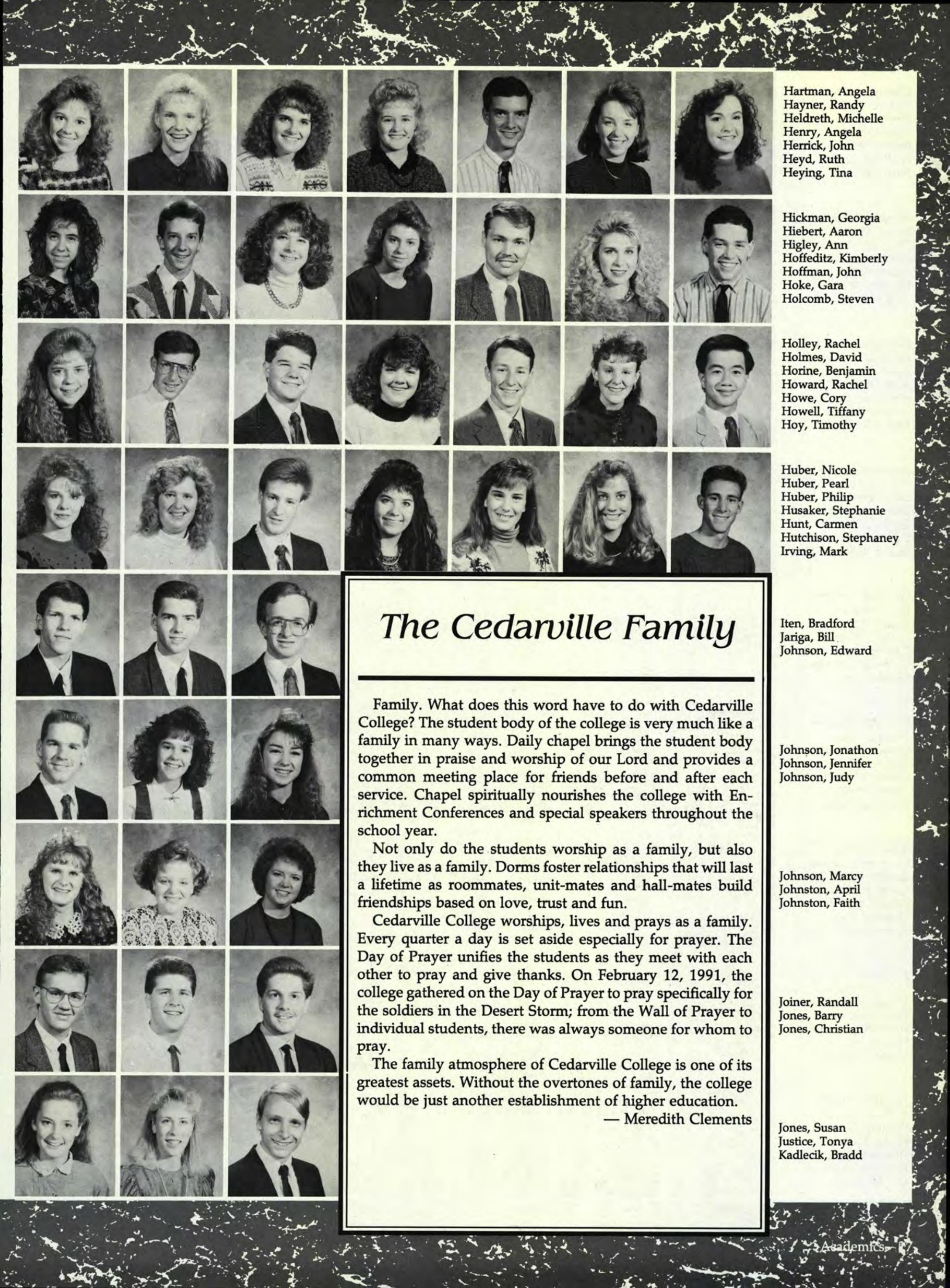




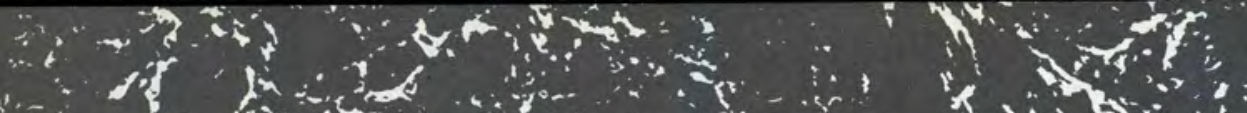

Kalich, Benjamin Karrels, Tom

Kaufman, Devin

Kawarada, Noriko

Keib, Timothy

Keller, Julie

Kenyon, Kerri

Killian, Brenda

King, Teresa

Kirkely, Jacqueline

3. Kohnken, Kimberly

Koonce, Shawn

Krueger, Heidi

Kulin, Alex

Kulp, Stephaine

Kurtz, Jean

Lambert, Jennifer

Landrum, Kristi

Lang, Craig

Lausin, Joseph

LeBlanc, Jay

Lensch, Robin

Leshan, Michael

Lim, Helen

Lindley, Andrea

Lindaberry, Jeffery

Linnehan, Ryan

Locke, Tina

Longfellow, Brian

Lowenhar, Lori

Lucas, Brenda

Lucas, Kelly

Lund, Sena

Lush, Laura

Ludwig, Ramona

Lyons, David

Mach, Julie

Macomber, Carl

Mann, Carrie

Manning, Patricia

Maronn, Denise

Mascari, Jason

McChesney, David

McClish, Michelle

McCormick, Sherrie

McCullough, Sherrie

McComb-Davies,

Beverly

McFadden, Julie

McGillvary, Suzanne

McKinley, Craig

Mee Patrick

Meek, Gregory

Megilligan, Brian

Meeder, Jon

Melvin, Christina

Michael, Lynda

Milentis, Gregory

Miller, Annette

Miller, Brian

Miller, Cindy

Miller, Rhonda

Mills, Robin

Milner, Kristin
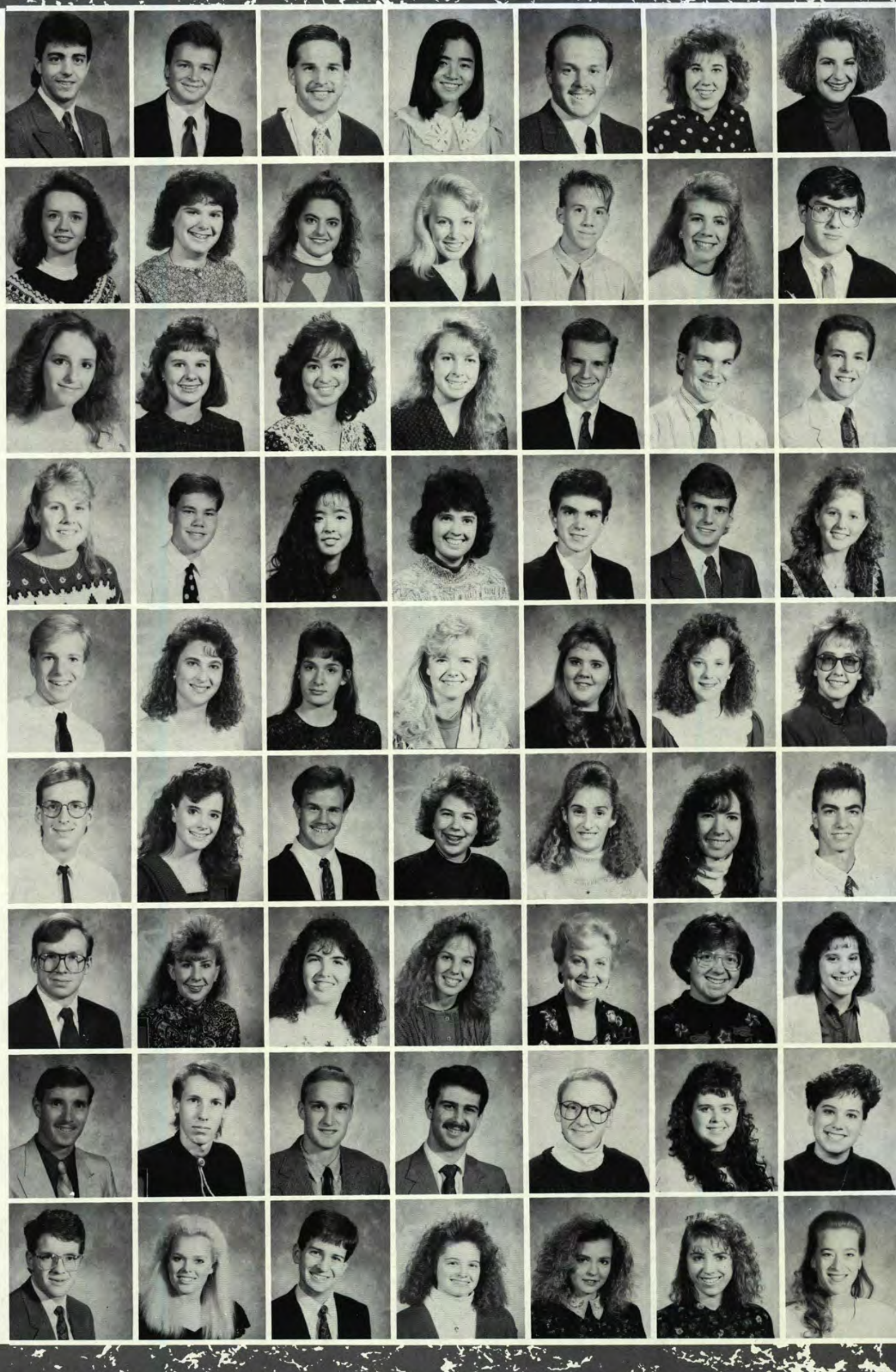

28 Académics

if 
Ross, David

Rotramel, Kevin

Roudabush, Tanja

Rowland, Janet

Rush, Adam

Russel, David

Russel, Randy

Ruth, Scott

Sagraves, Thomas

Sahl, John

Sandy, Scott

Schauer, Matthew

Schlayer, Carol

Schmitke, Roberta

Schryer, Rebecca

Schwingle Gretchen

Seifer, Amy

Seljan Todd

Shaffer, Laura

Shearer, Andrew

Sheen, Fred

Sheldahl, Robin

Shimp, Susan

Shoop, Kevin

Shreve,Matthew

Shumaker, David

Sininger, Heather

Skiles, Jenifer

Slavens, Joseph

Smith, Brock

Smith, Dee

Smith, Michael

Smith, Stacy

Snodgrass, Amber

Snook, Linda

Sorg, Pamela

Southwell, Christina

Souza, Shelly

Stach, Todd

Stackhouse, Sherry

Steininger, Gretchen Stephens, Gail

Stevens, Rebekah
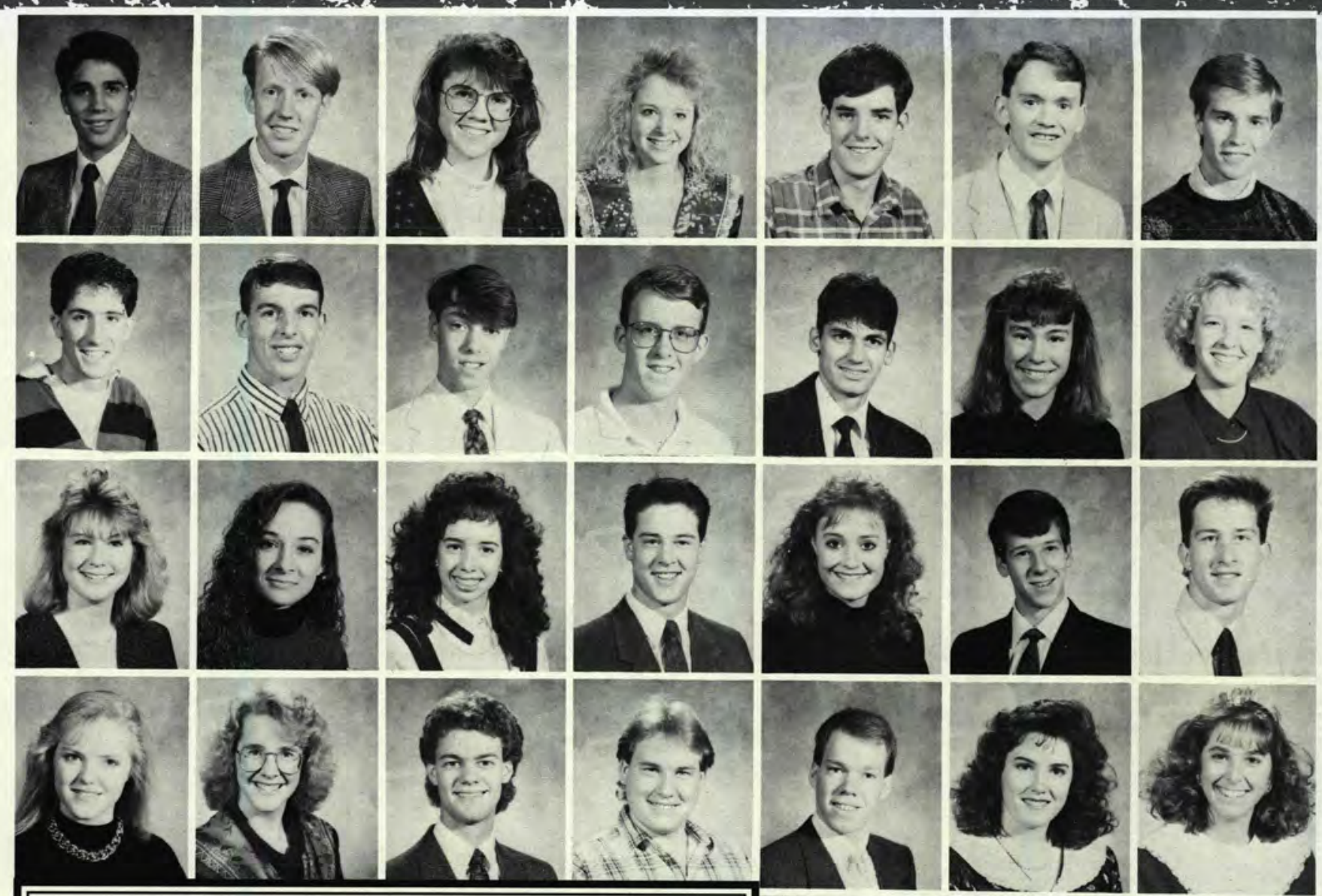

\section{The \\ Bumps \\ Are What \\ We Climb \\ On!}

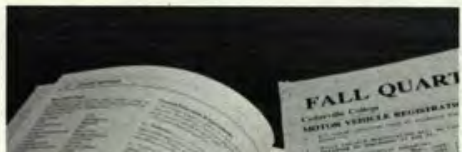

During my freshman year at Cedarville there were many little bumps I had to climb over. One of the bumps, which at the time I thought was a mountain, was registering for classes. At first I thought "Registration won't be that bad." I was wrong! Registration for spring quarter is something I will never forget. I remember being excited when I found those green sheets in my mail box. I started casually thumbing through them and deciding what classes I wanted to take. In all reality I should have left my CRF blank and gone to registration and asked, "What's left?"

My bump of registration was that I registered on the last day of registration and the next to last time period. By the time I actually got to registration, I was a wreck. The night before registration I was ready to throw in the towel, but my dad was there with an encouraging voice saying, "Dear, the bumps are what we climb on." Unfortunately his daughter was skinning her knees on those bumps.

I did make it through registration without any injuries. Even though I did not get the exact classes I wanted, I learned that "The bumps are truly what we climb on."

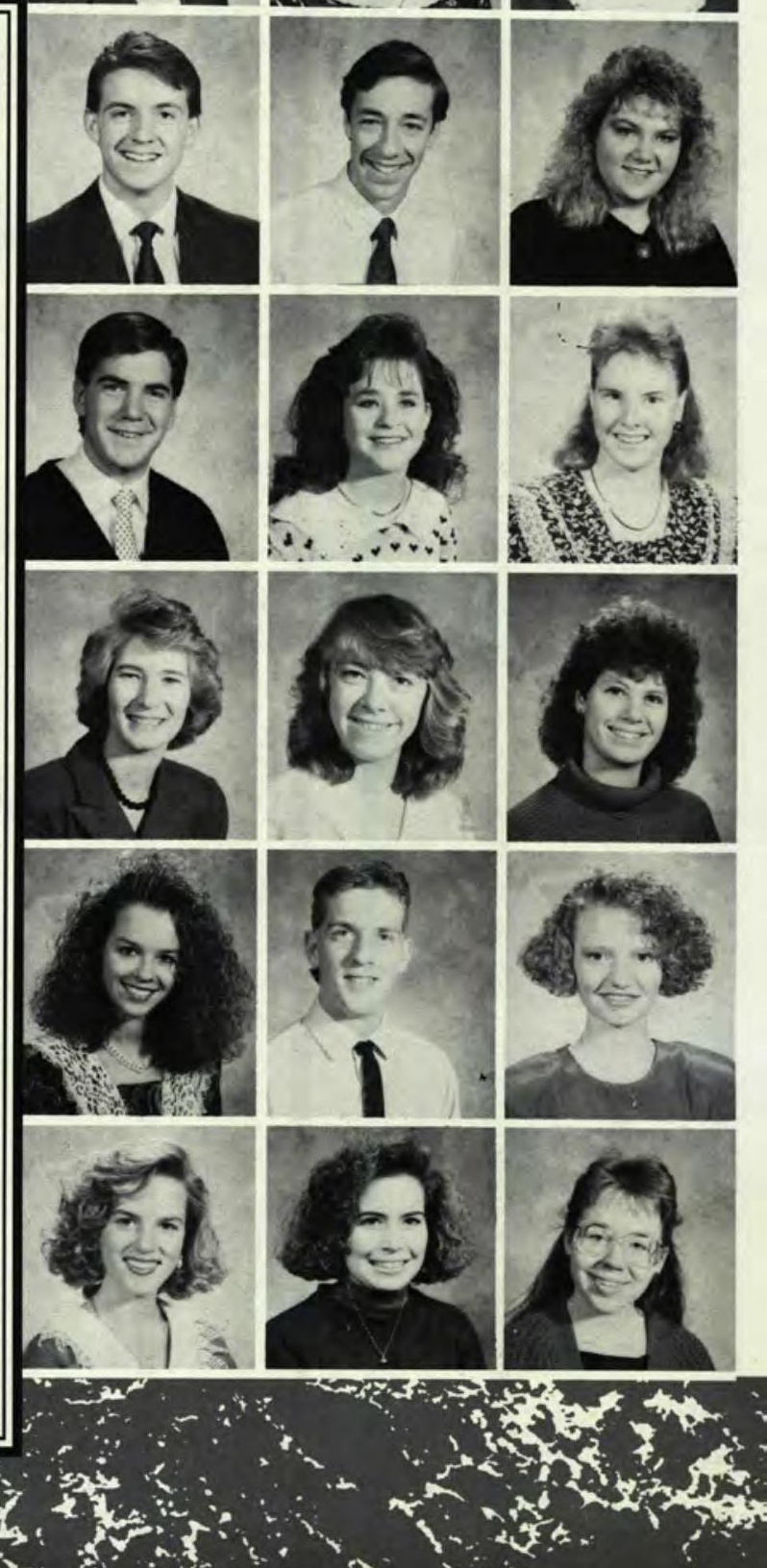




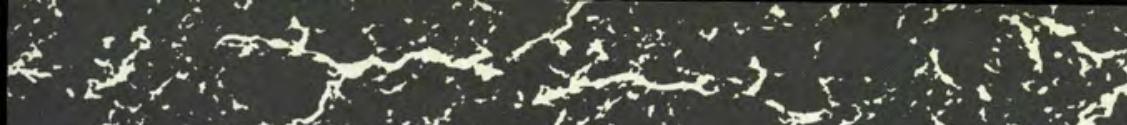

$x^{\prime}=\cos +\infty$ $1=5.5$

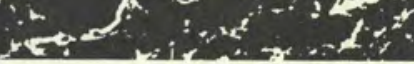

\section{Sophomores}

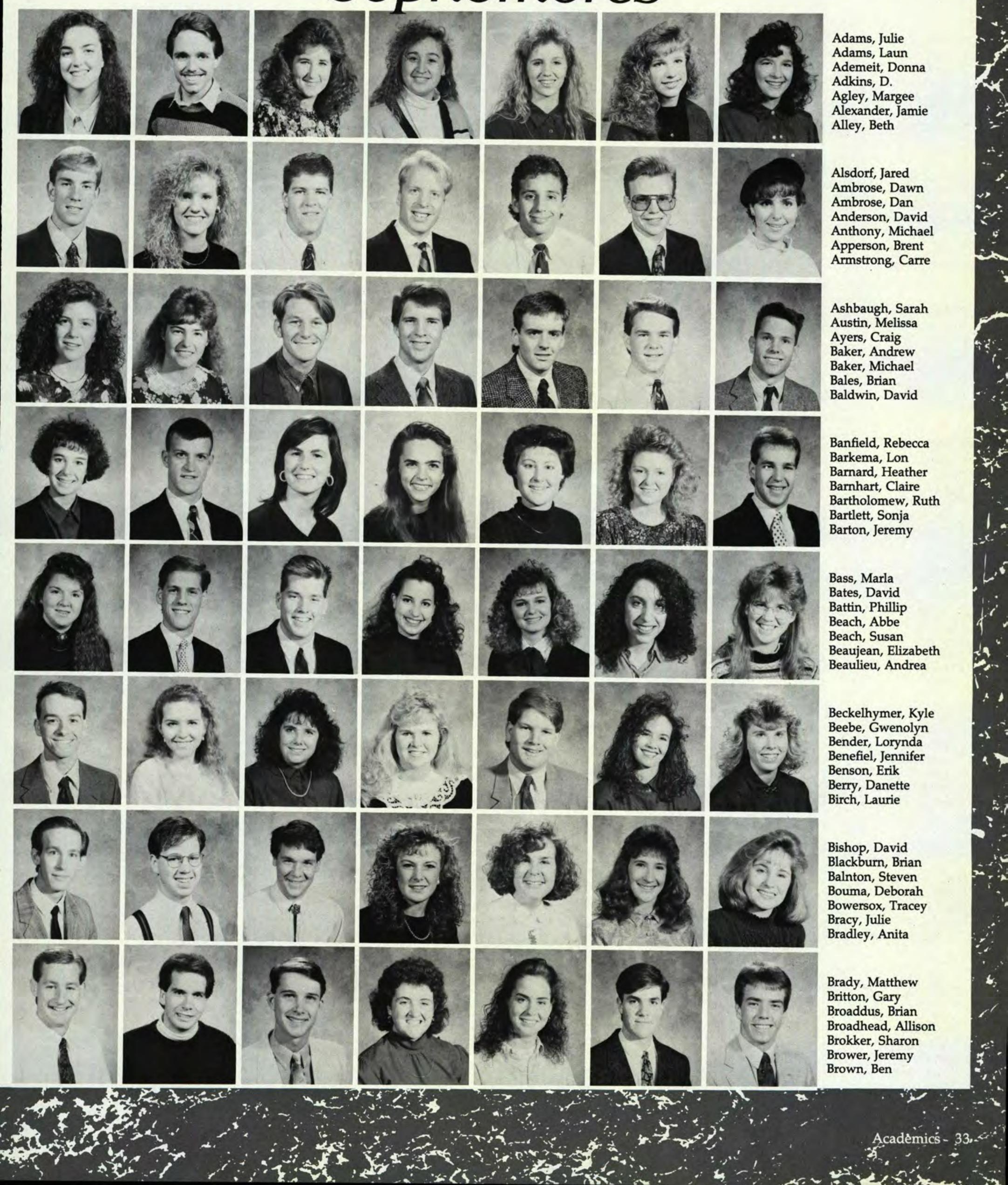




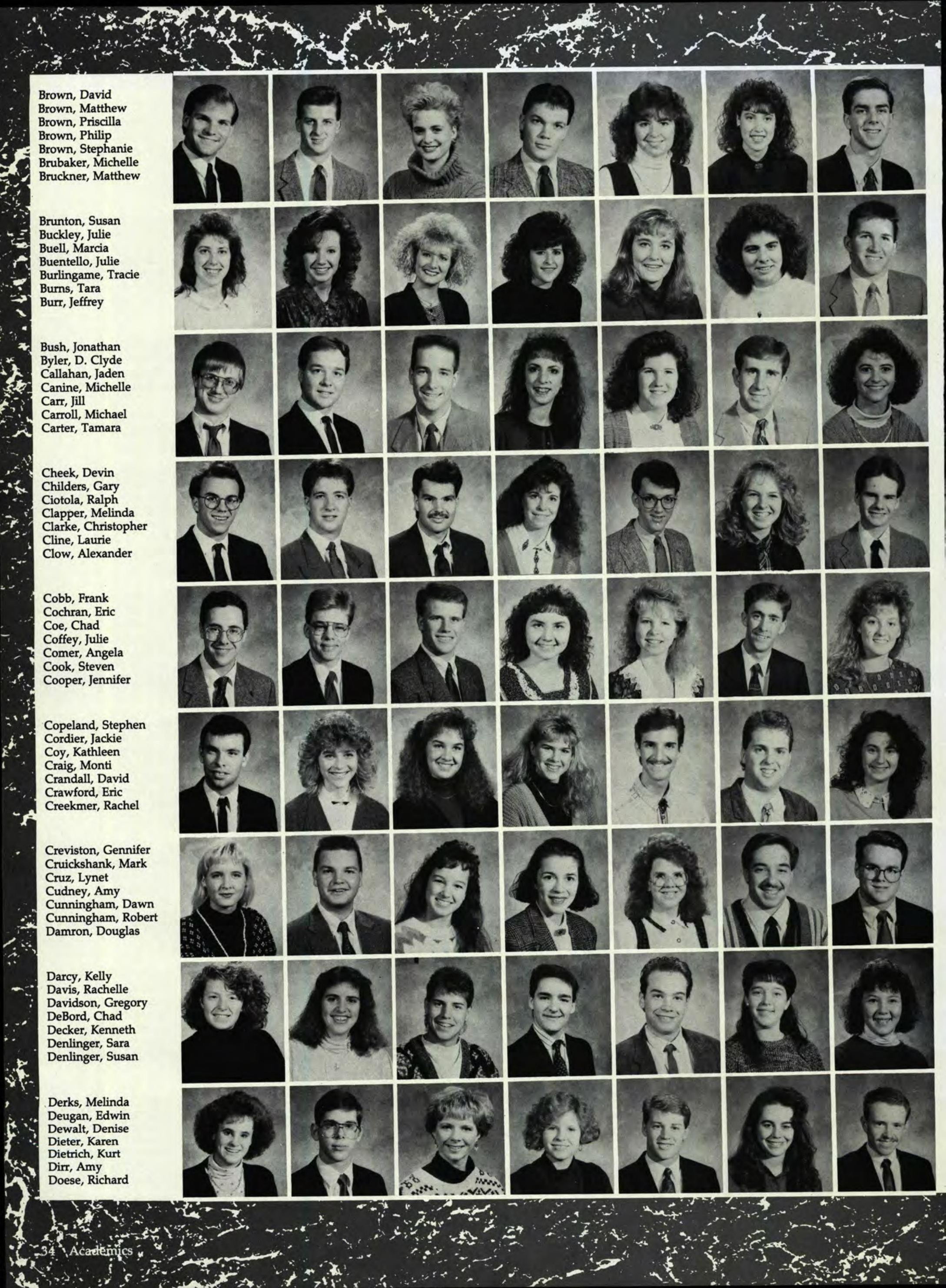




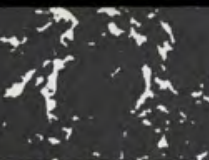

Groninger, Andrea

Guess, Paul

Haberstich, Tamara

Hall, Mitch

Halsted, Tomas

Hamilton, Tod

Harrell, Brian

Harrington, Richard

Hartman, Cheryl

v. Hartman, Kevin

Haselhorst, Jenny

Hauser, Deanne

Hauter, William

Hayden, Roger

Heckart, Joel

Heft, Michael

Hemming, Rosann

Henderson, Gail

Henry, Debra

Henry, Melissa

Herring, Christian

Hess, Beth

Hicks, Paul

Hidalgo, Carlos

Higginbotham, Kim

Hill, John

Hines, Randal

Hoewing, Stephan

Hofert, Nels

Hoffmann, Kenneth

Hoke, Brian

Holden, Steven

Hollaway, Mary

Holsinger, Mark

Hoover, Apryl

Horst, Vonda

Houg, G. Robert

Howard, Patricia

Hubbard, Kimberly

A. Hudson, Julie

Huxtable, Jennifer

Hyten, Jenine

Irish, Kathleen

Irving, Elisabeth

Jacobs, William

Jamieson, Andrew

Jariga, Carol

Jefson, Jill

Johnson, Jeff

Johnson, Kathleen

Johnson, Victoria

Jones, Jason

Jones, Lori

Jones, Tonya

Justice, Susanne

Kaelber, Kari

Kail, Adam

Knauf, Julie

Katz, Andrea

Keefer, Heidi

Keenan, John

Kelly, Kyle

$x^{2}+x^{2}$

Wy:

$+8$

$-4-3$
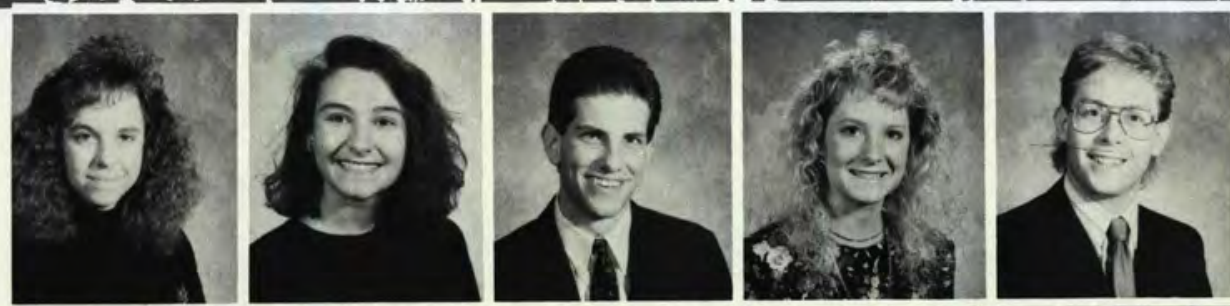

and
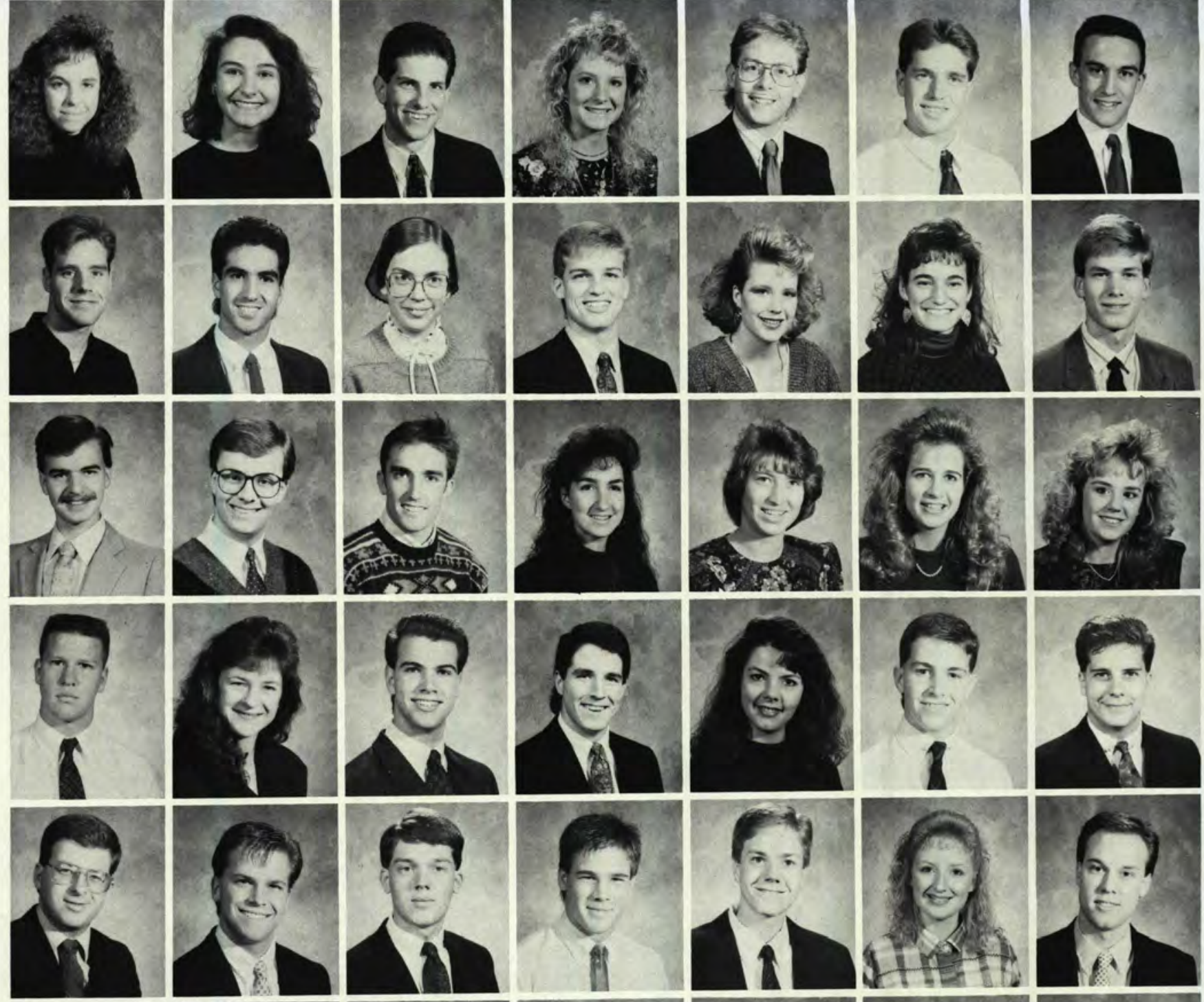

$10-1$
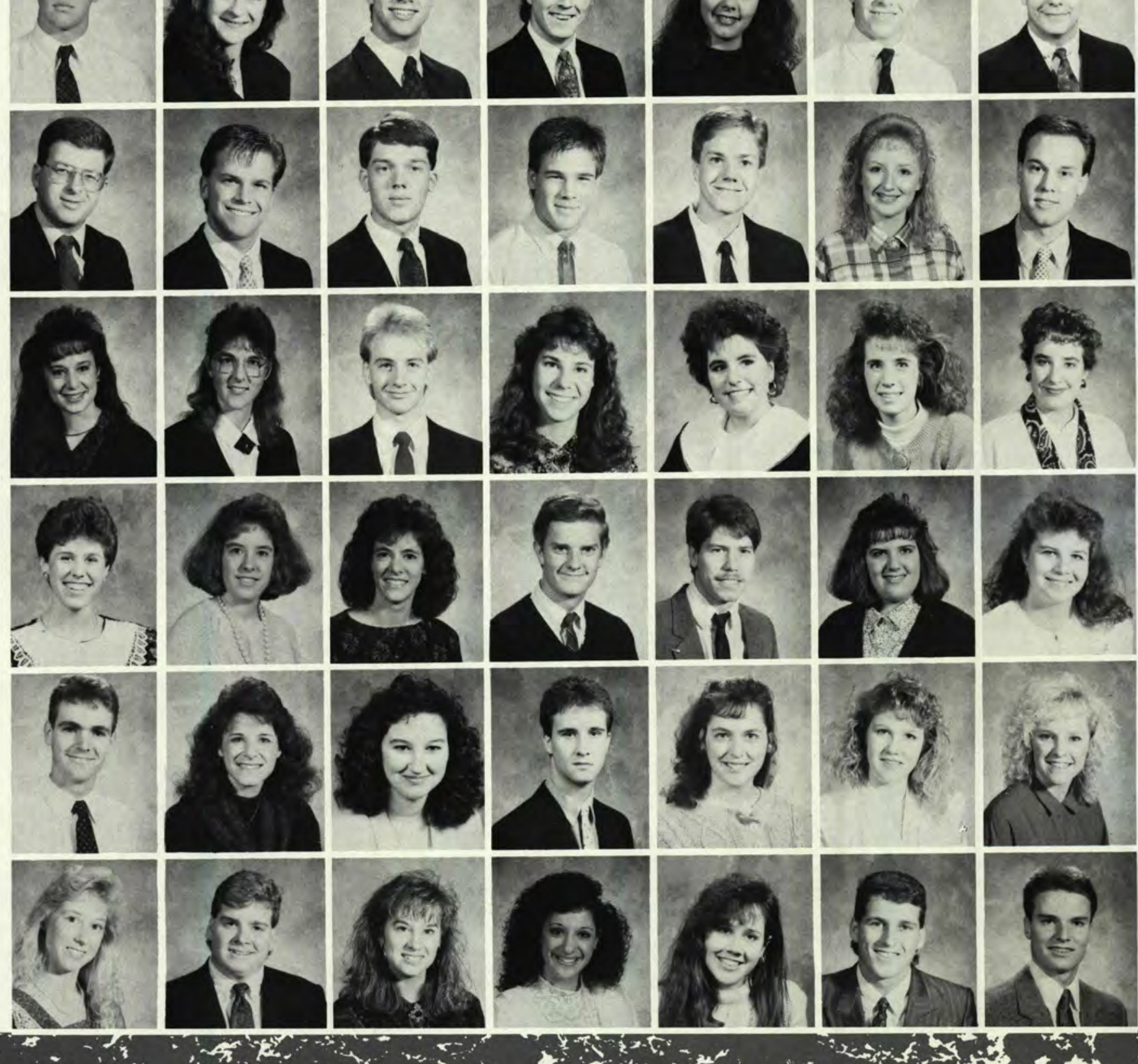

(riont

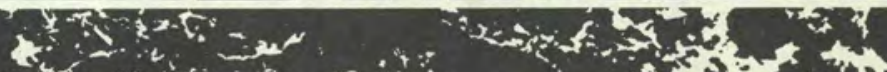

36 Academicg. 


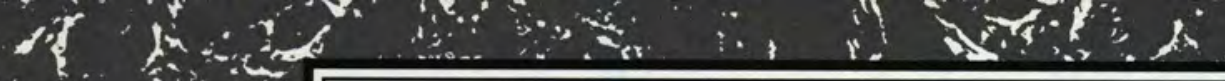

Mitchel, Matthew Montgomery, Bill Moor, Holly

Moore, Bruce

Moore, Mary Ann Moraes, Vivian

Moralles, Jennifer Morgan, Jeffery Morris, Dale

Motl, Christopher Mummey, Julie Murachanian, Kevin

Myles, Melinda Nagel, Shannon Nelson, Michelle

Nettleingham, Brian Neubert, Nancy Noller, Kendal O’Donnell, Erin O'Keefe, Kayley O'Neal, Christine Oligee, Stacy

Oliver, Matthew Olsen, Marsha Otto, Matthias

Overmoyer, Julie Oxford, Heather Padgett, Victoria Paul, Angela

Payne, Janet Pearson, Curt Pearson, Jennifer Pearson, Rob

Peet, Terri

Pereira, John

Perkey, Amy

Petek, Tom Petek, Greg Pfahler, Ruth Pincket, Chris Pinkerton, Cheryl Pletcher, Rosemary Plough, Heidi

Nocturnal

Habits

of the

Student

Species

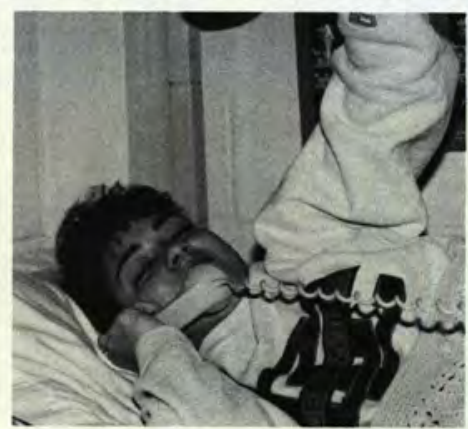

photo by Marsha Olsen

Jennifer Johnson demonstrates one of the favorite evening pastimes.

What happens after hours on the Cedarville College campus? After the library doors are closed, the lights are shut off in the chapel; the CC is locked and the AC is empty? Even after dead air fills the spot of WSRN? What happens? The night life begins!

Popcorn and fast Uno. Pepsi and computer games. Rook and hall ball. And if you are in the right place on the right night, you might even catch the ghost of Pumphin Head Suicide! There are even some students still up at deadly hours of the night who will gladly ask you to abide by Quiet Hour rules, but that happens only in those few elite dorms.

Between Meijers and Young's runs, taken in the wee hours when nothing else is open, engaged guys are laked and engaged girls are on the phone telling everyone about it. In the darkest hours, floating objects mysteriously appear to grace the murky waters of Cedar Lake. Closer to morning the Rock gets another healthy dose of spray paint as an orange glow peeks over the horizon to spread a new day on a slice of Cedarville life.

- Meredith Clements
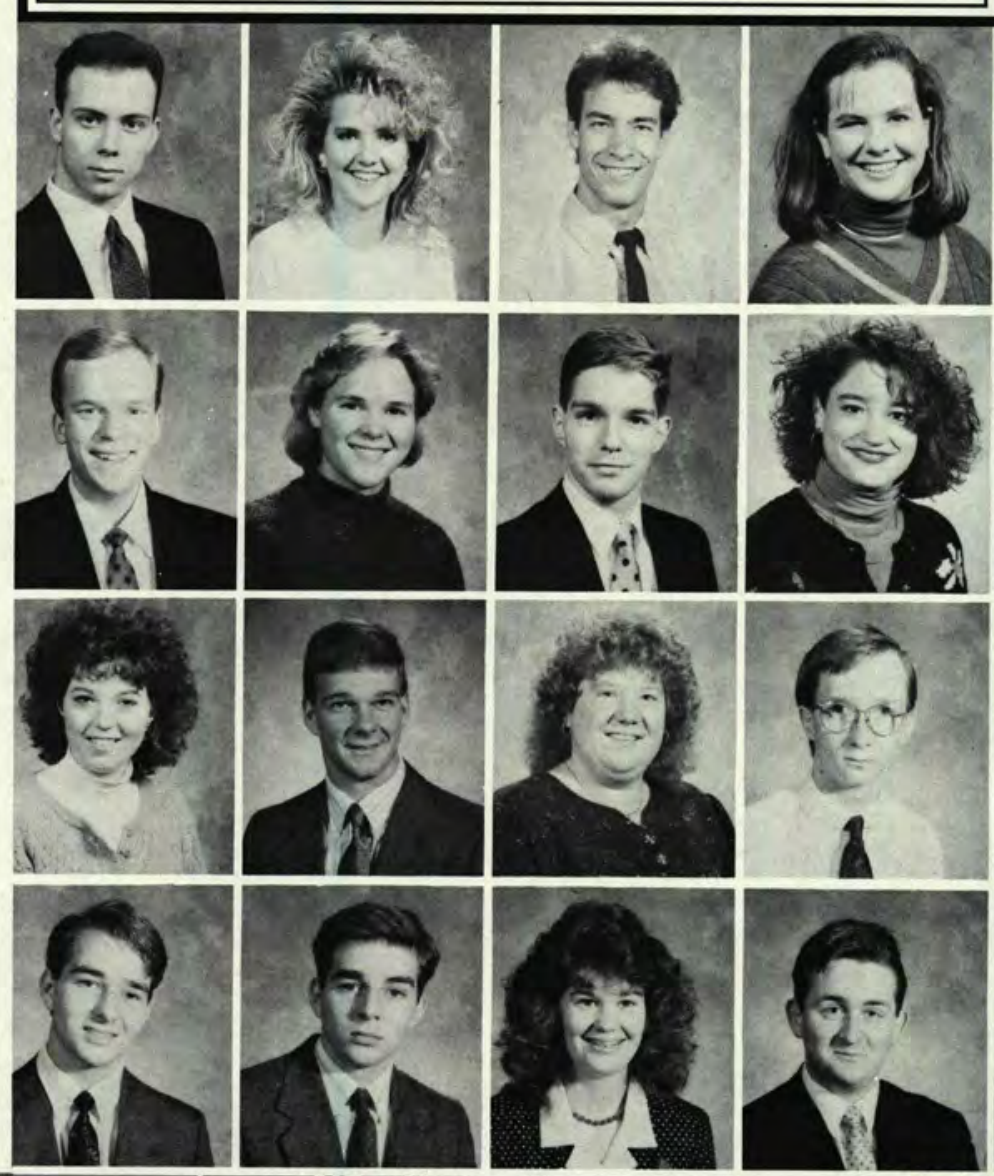
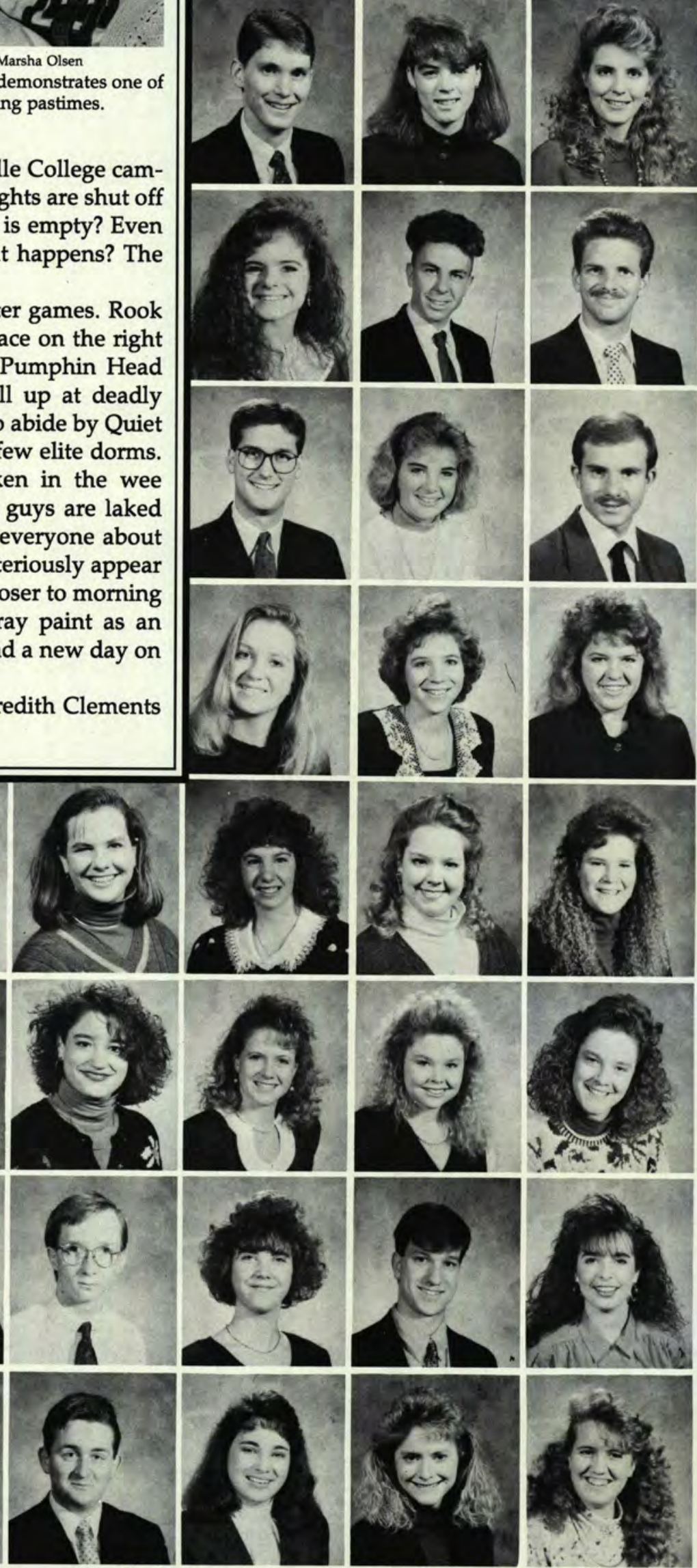

S.

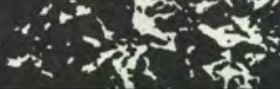




\section{$2+r \cdot e^{4}$}

Sorensen, Eric Souder, Donette Southwell, Randy

Stamper, Cynthia

Stanton, Doug

Starr, Nikki

Stephen, Deana

Stephenson, Martin

Stoll, Lisa

Stonehouse, Hans

Stover, Ryan

Strayer, Shanda

Strong, Luman

Stumbo, Gary

Sutton, Shelly

Swanson, Sharon

Swinehart, Kristal

Tague, Amy

Talyor, Douglas

Talyor, Tania

Tennant, Cindy

Thomas, Joel

Thompson, Dana

Thorsen, Charlie

Tipton, Brett

Titus, Sheryn

Treier, Dan

Tramel, Mary Beth

Uhl, Denise

Ulery, Adam

Unrau, Kerry

Utermahlen, Deborah

Van Eaton, Justin

Vandall, Linda

Vandenburg, Timothy Vanderwest, Ken

Vannest, Steve

Veelman, Bill

Vroegop, Mark

Walker, Bryan

Wall, Melissa

Warnken, Karla

Warnshuis, John

Warren, David

Waters, Cassandra

Weaver, Doris

Weigle, David

White, Angela

White, Shawn

Whitmer, Molly

Whittenburg, Jori

Wilkes, Lisa

Wilks, Christine

Williams, Corinna

Williams, Jon

Wilson, Shannon

Winchip, Stephanie

Winch, Connie

Winfrey, Sandra

Winn, Robert

Winship, Jil

Wolfe, Drue
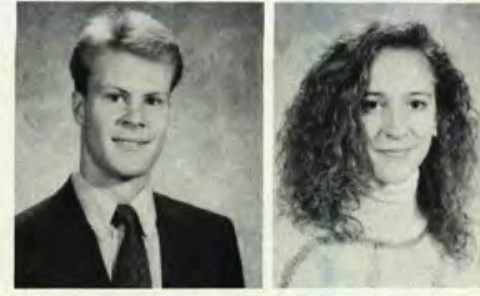

क्षि , सह तो
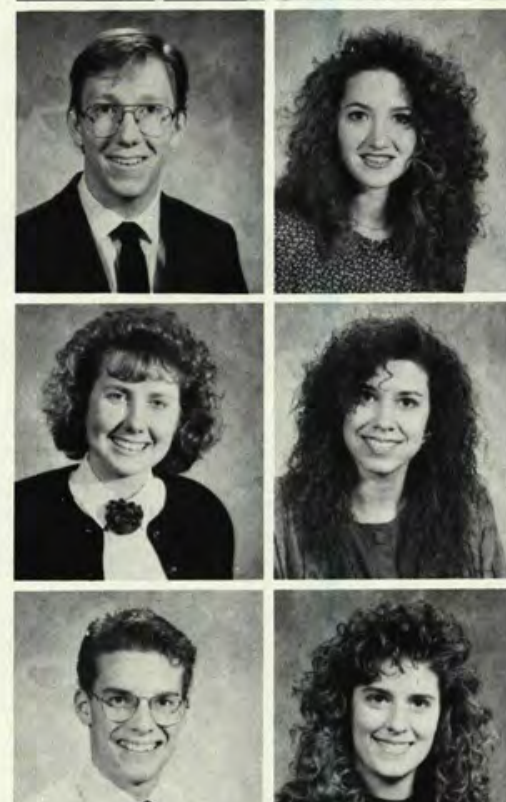

19.
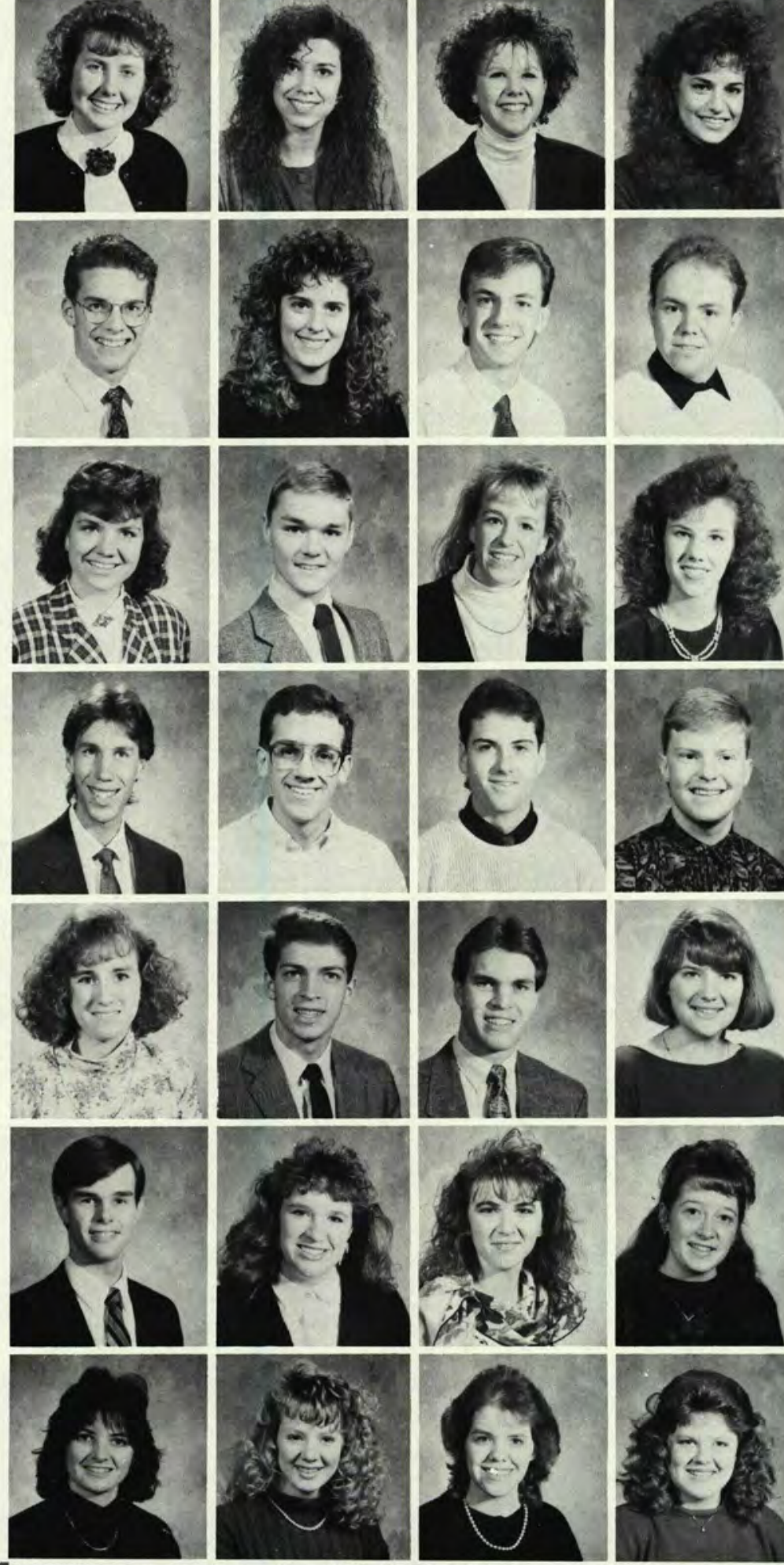

1
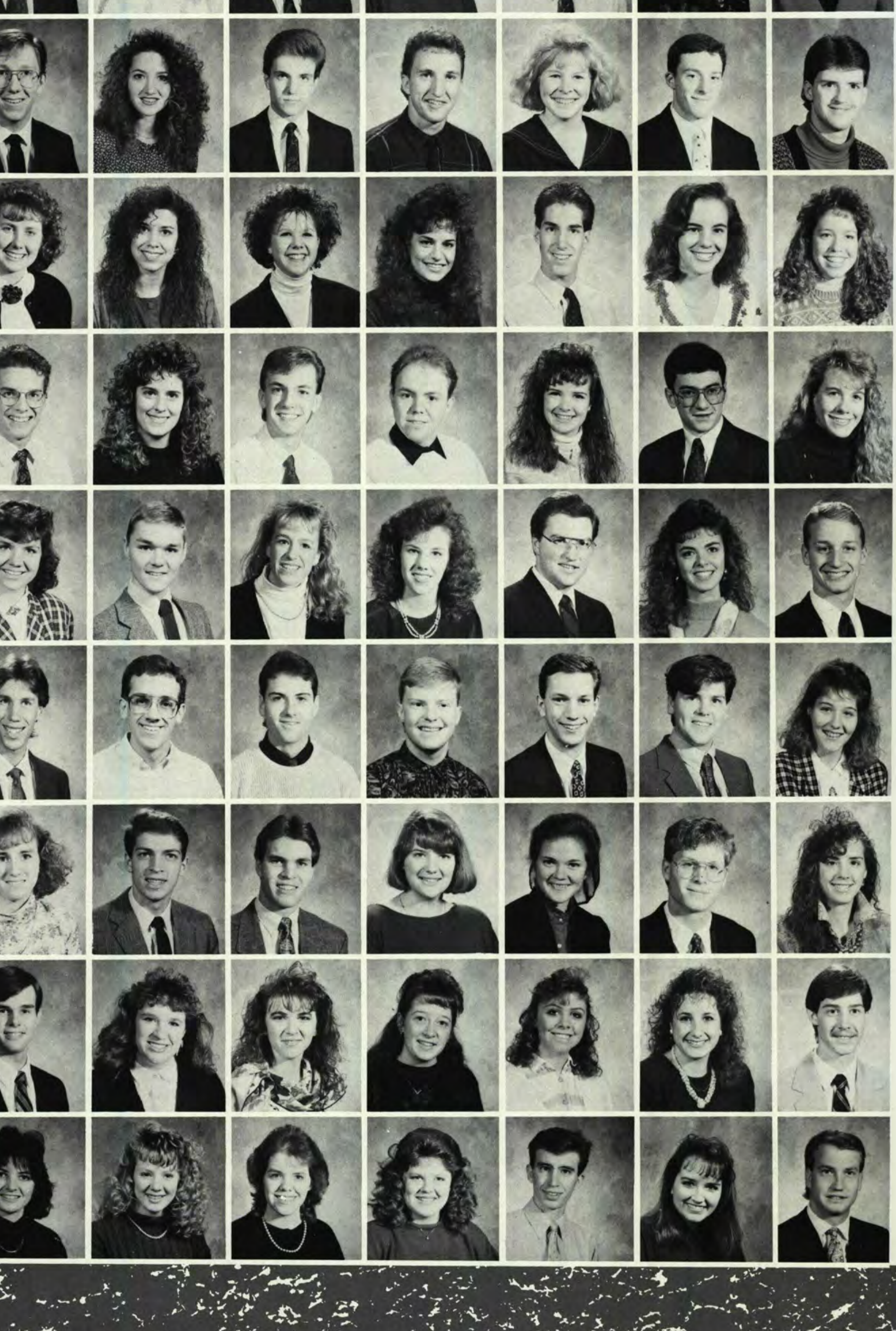

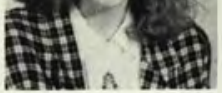
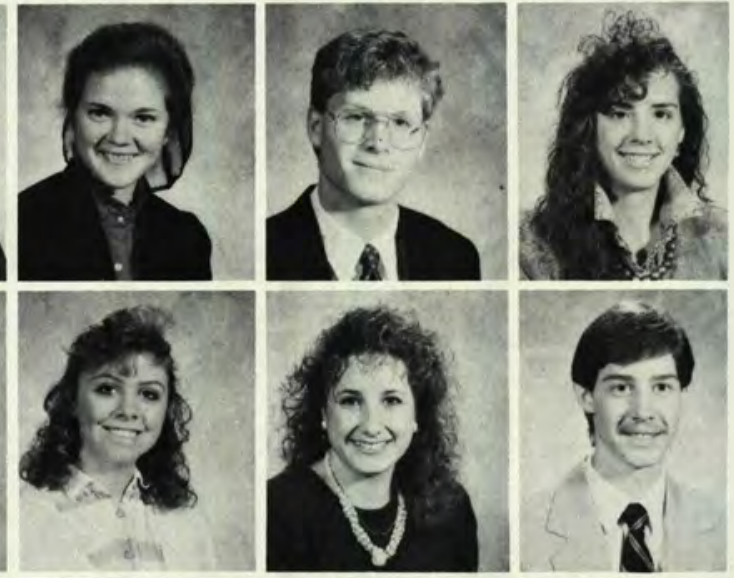

$1<$

8

to $x+2$ 


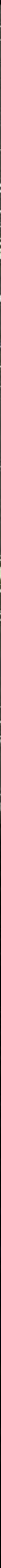




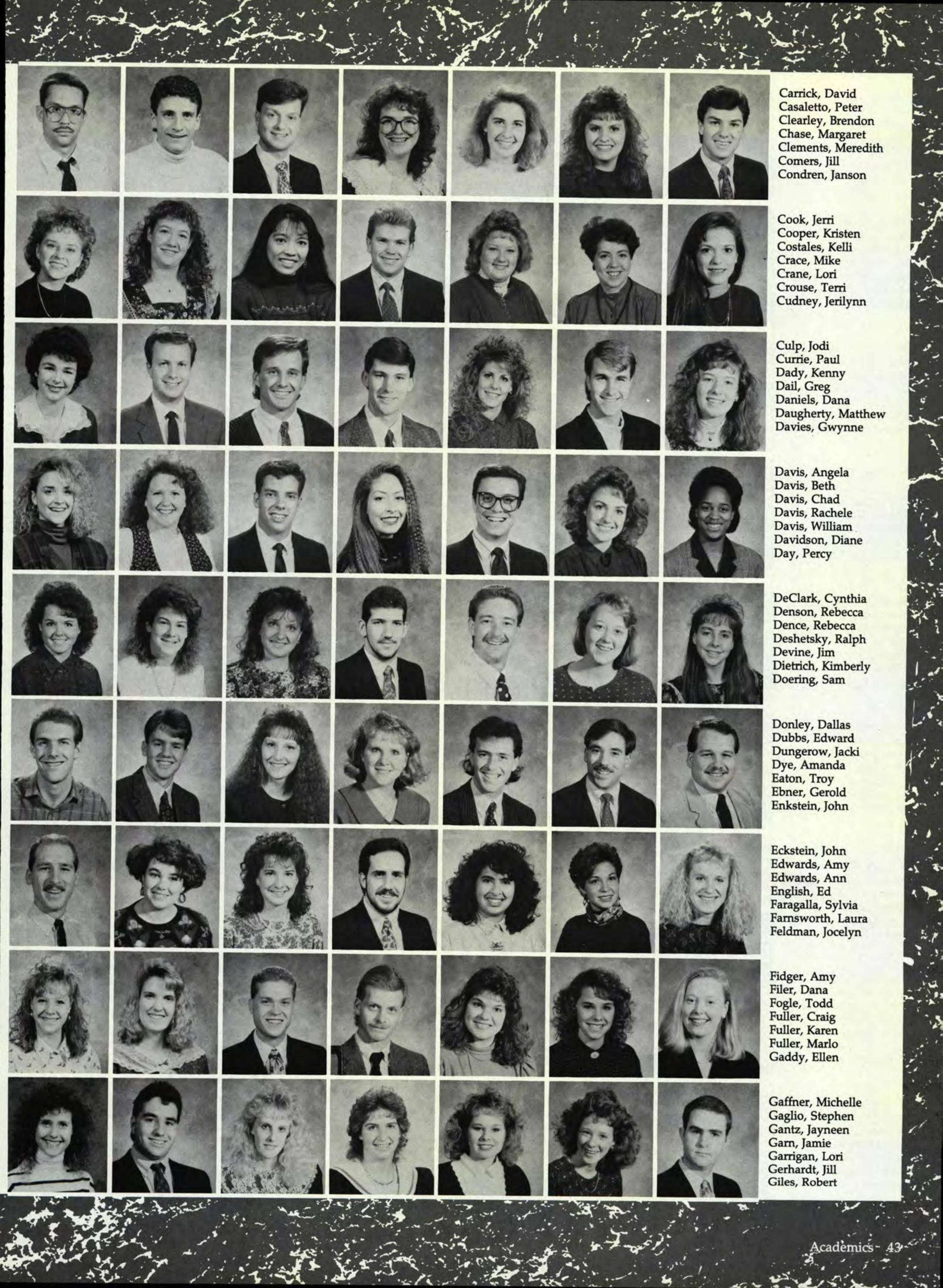


(1)

Gill, Pillip

Gillies, Leigh

Goodwin, George

- Gosman, David

\#. Graham, Allyson

Green, Cinda

Gudeman, Jon

Guider, Donna

Guinther, Brian

Gustafsom, Michael

Guthrie, Heather

Hackenberry, Stephen

Hackney, Lauralyn

Hague, Andrea

Hamilton, Craig

Hamilton, Lori

Hammond, Kevin

Hanks, Jeanne

Hansley, Rich

Hanssen, James

Harbaugh, Kimberly

Harmon, Susan

Harrell, Kelly

Harris, Becky

Harton, Ruth

Harvey, Tammy

Hayes, Eric A.

Hayes, Eric W.

Hazen, Joan

Heim, Karyn

Heinrich, Tim

Henry, David

Heritage, Jennifer

Hibbs, Brian

Hidalgo, Heather

$+1$

Hill, Shannon

Hinman, Kathleen

Hoffeditz, David

Hofheinz, Karl

Hoffman, Beth

Hollander, Laura

Hosner, Kimberly

Hoover, Elaine

Horton, Gerry

House, Kathy

Hughes, Lisa

Hunsberger, Heather

Hurst, Amy

Irwin, Peter

James, Monica

Jamora, Gina

Jensen, Kristen

Jezek, Paul

Jones, Christine

Jones, Diane

Jones, Steve

Jones, Tom

Kaercher, Brandy

Kaiser, Robert

Keiser, Andrew

Kellogg, Heidi

Kelly, Steve

Kimmel, David
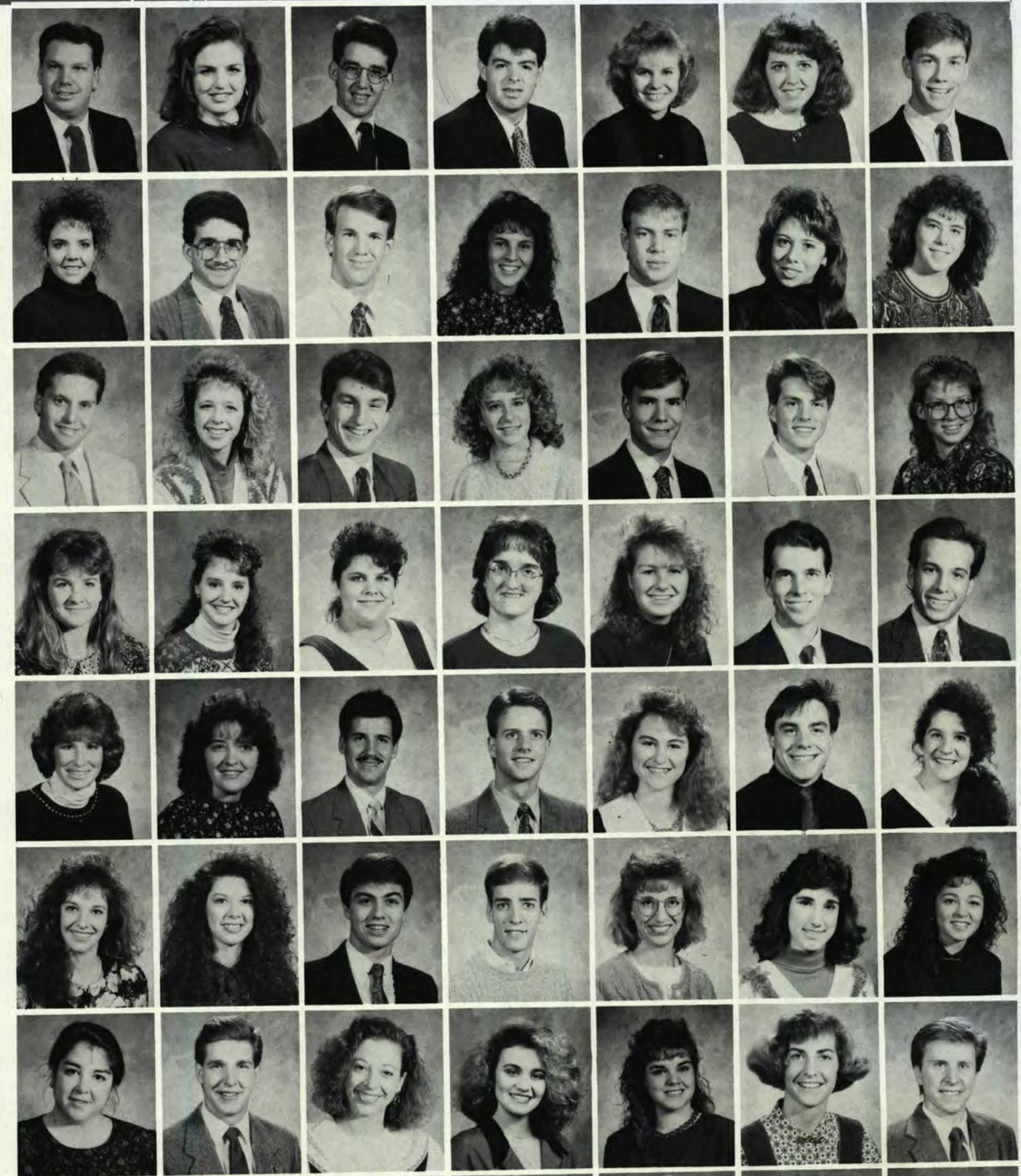



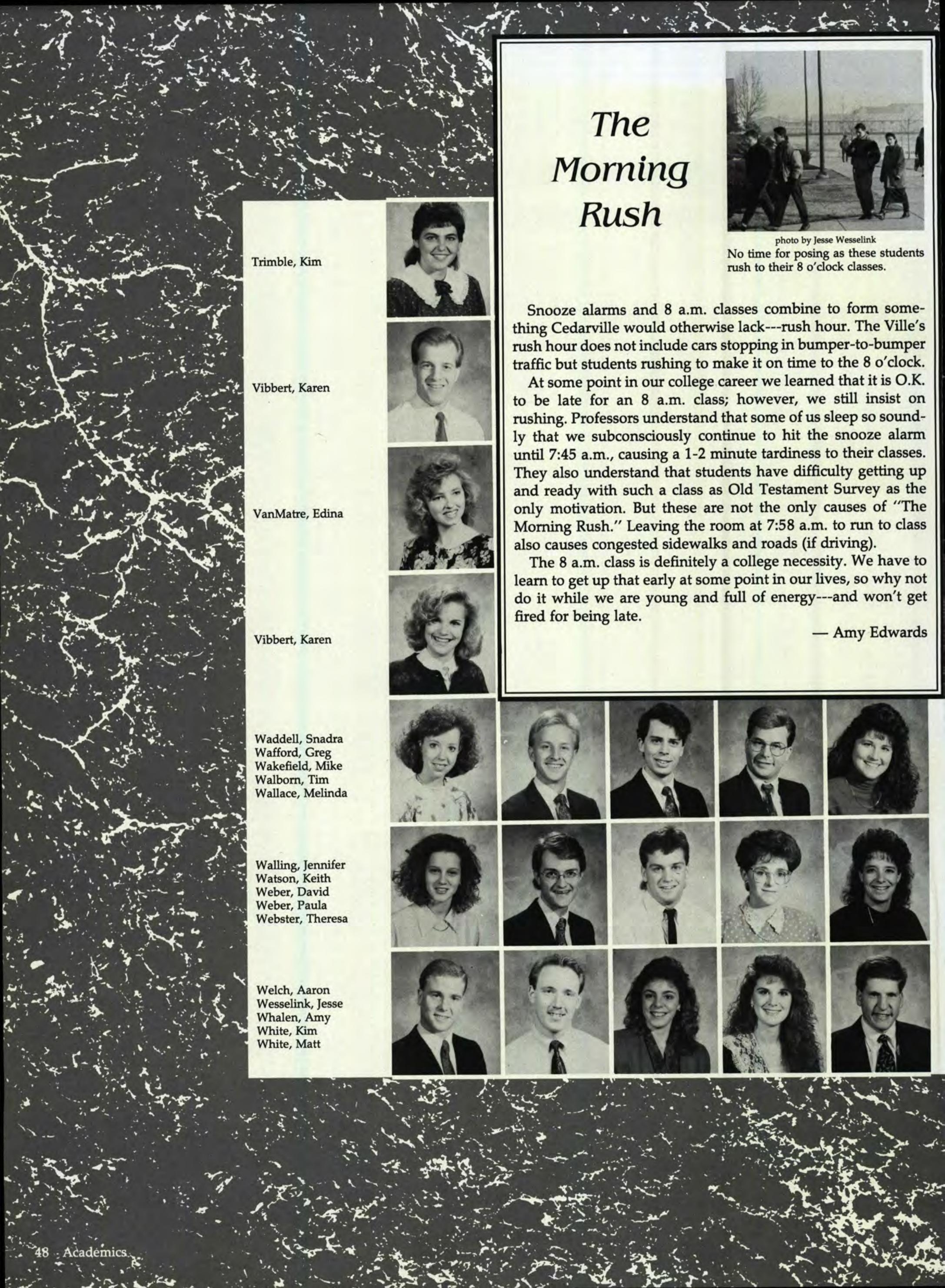




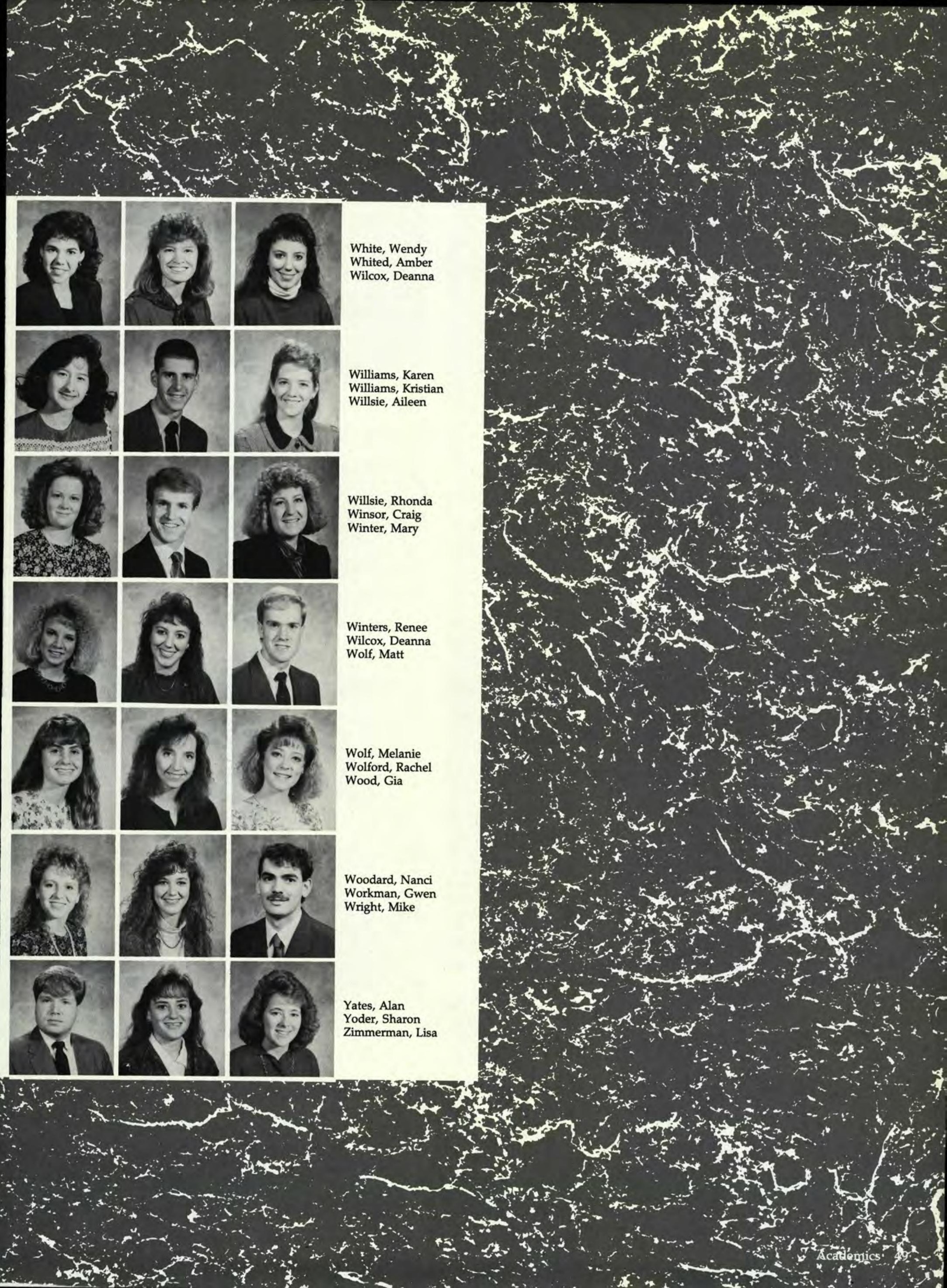


(Right) Brother and sister units making Halloween more fun.

Beth Tales, Marti Day and Brenda Woods display the results of a shaving cream war during cross-country camp.

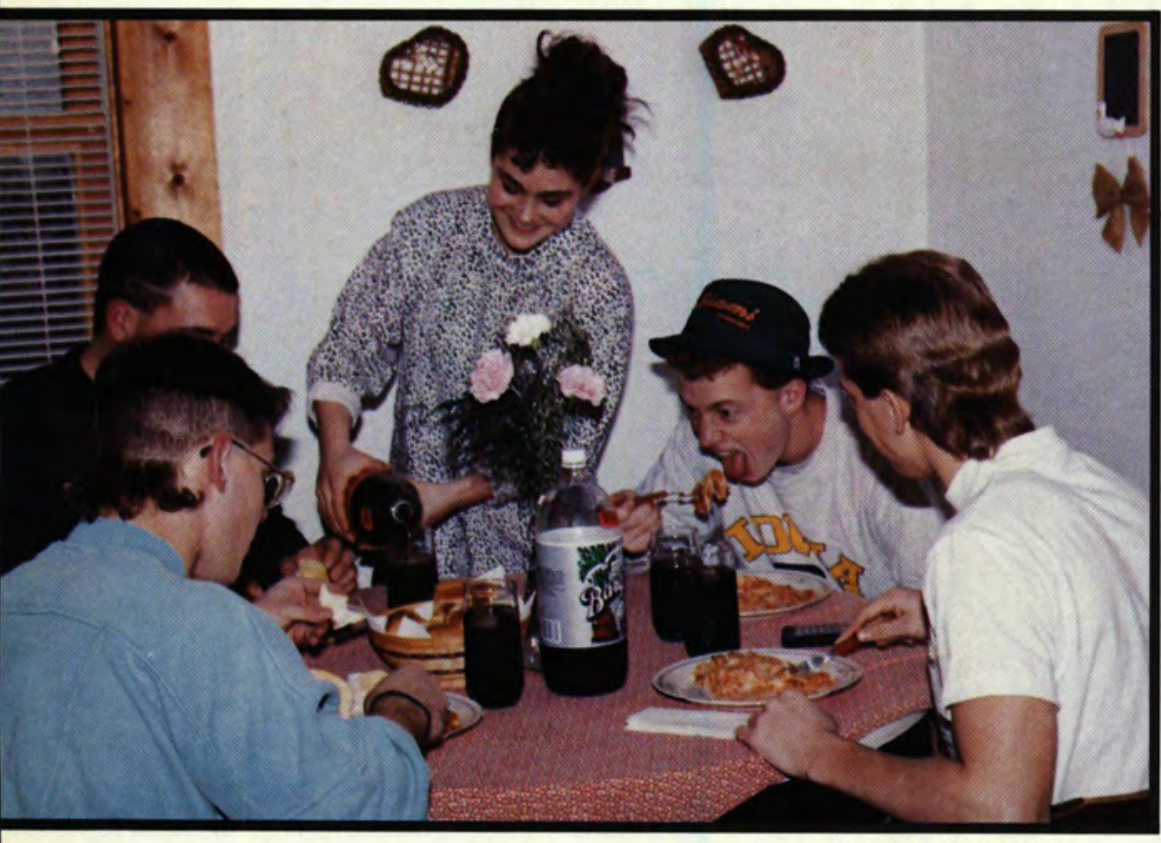

Students enjoy the campus staple.

Bumper Hidalgo displays what can happen after too much studying.

photo by Tania Taylor
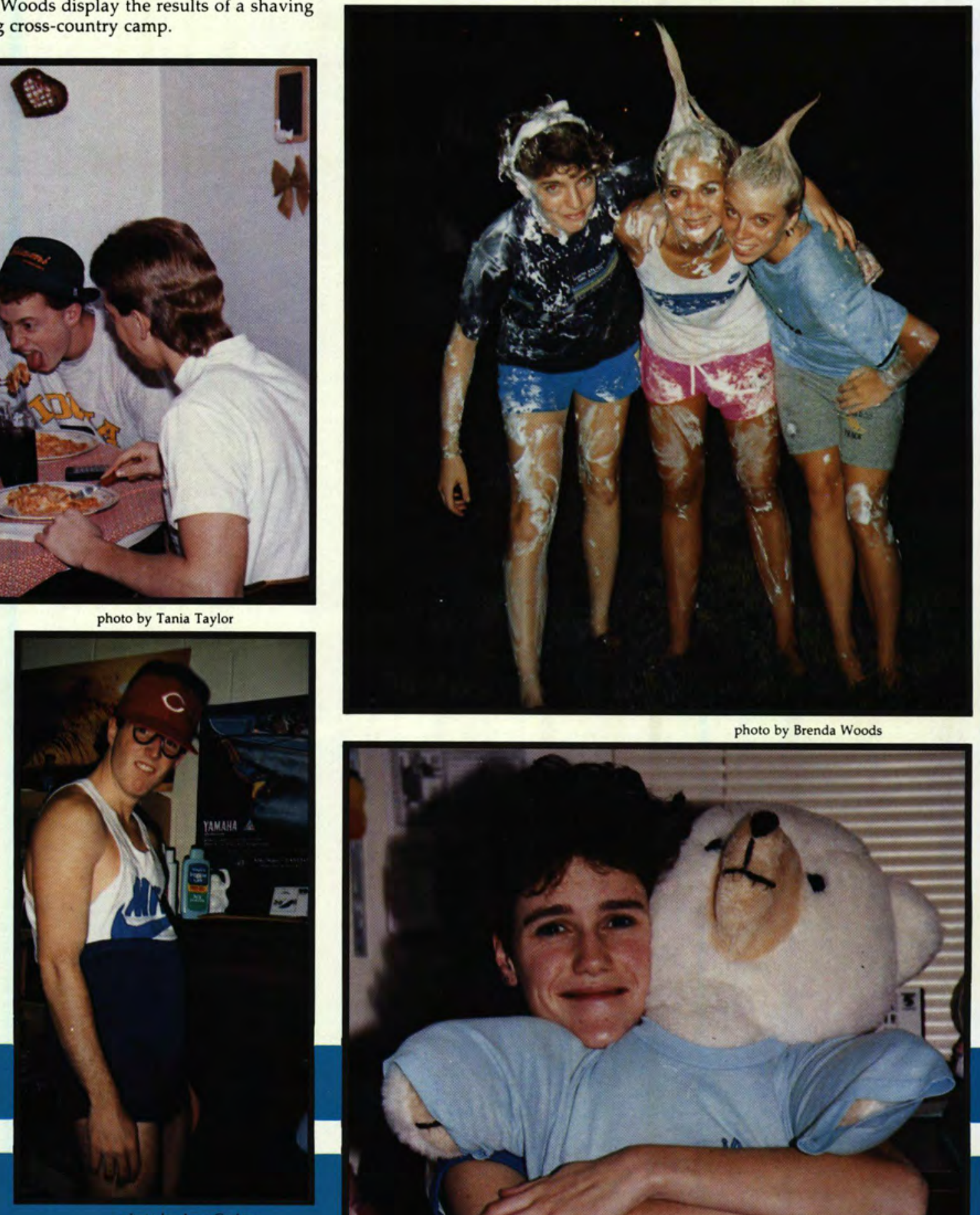

photo by Brenda Woods

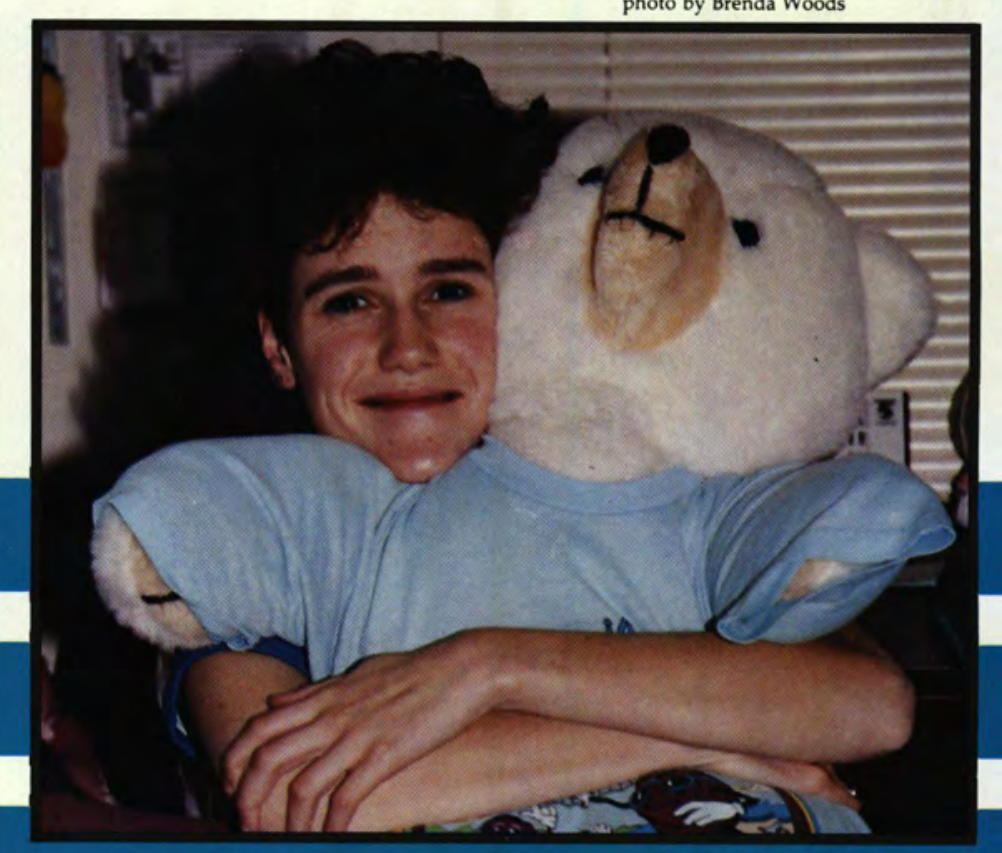

Sometimes students just need a hug

\section{When Miracles Merge. . . Friends are Forever}




\section{Fall Snapshots}
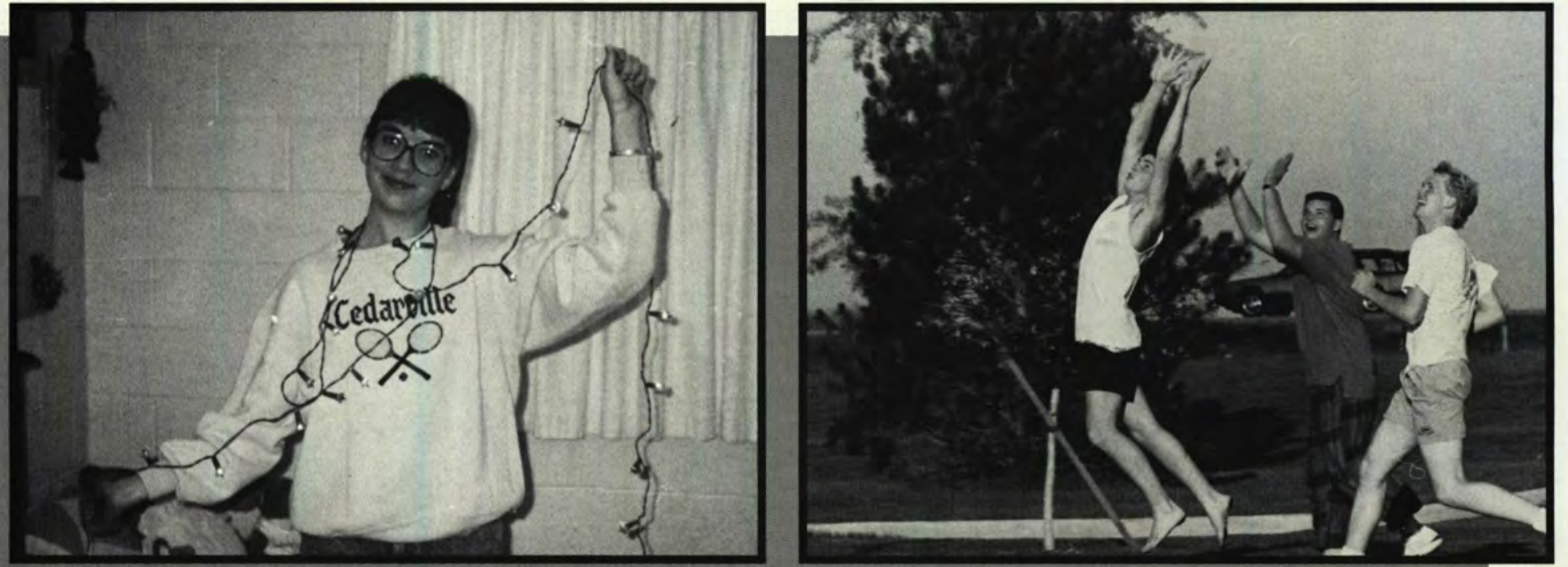

(Upper left) Anticipating Open House, Lori Smith gets set to decorate

(Upper Right) Lowell Olsen, John Hill, and Mark Cruickshank release some tension with a game of A freshman's first hello at Cedarville College.

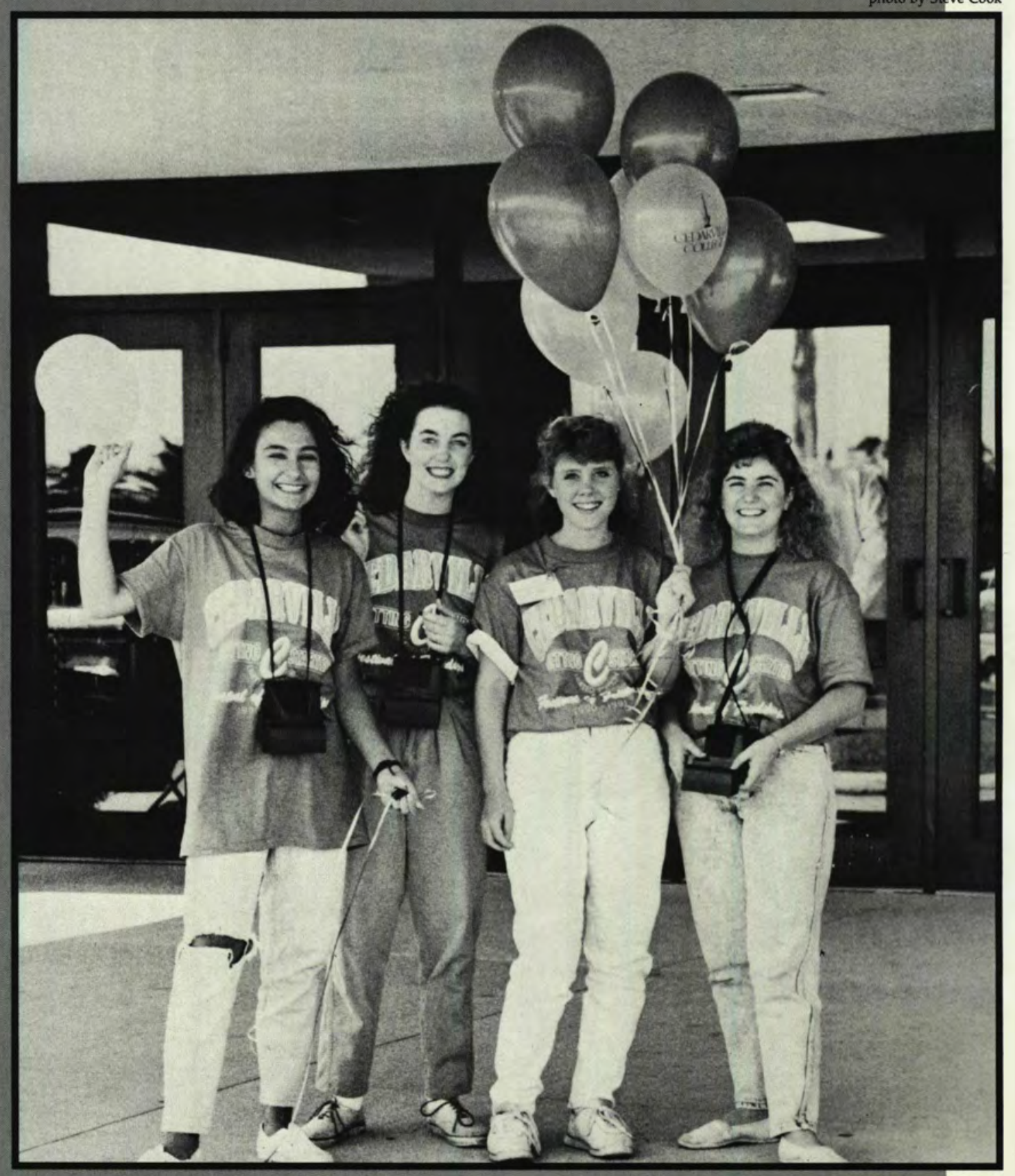




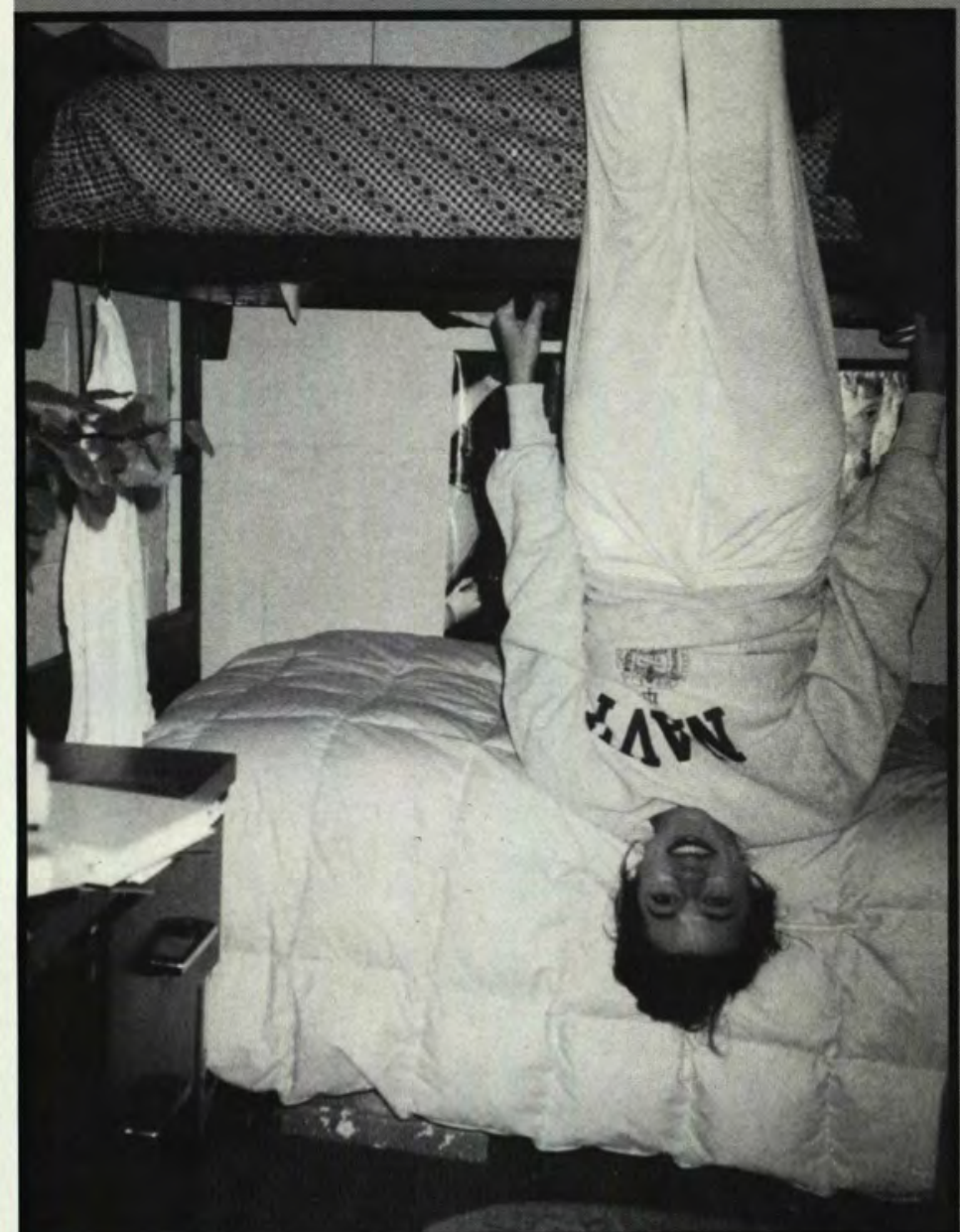

Some creative students take a work break in the back of a stakebed truck.
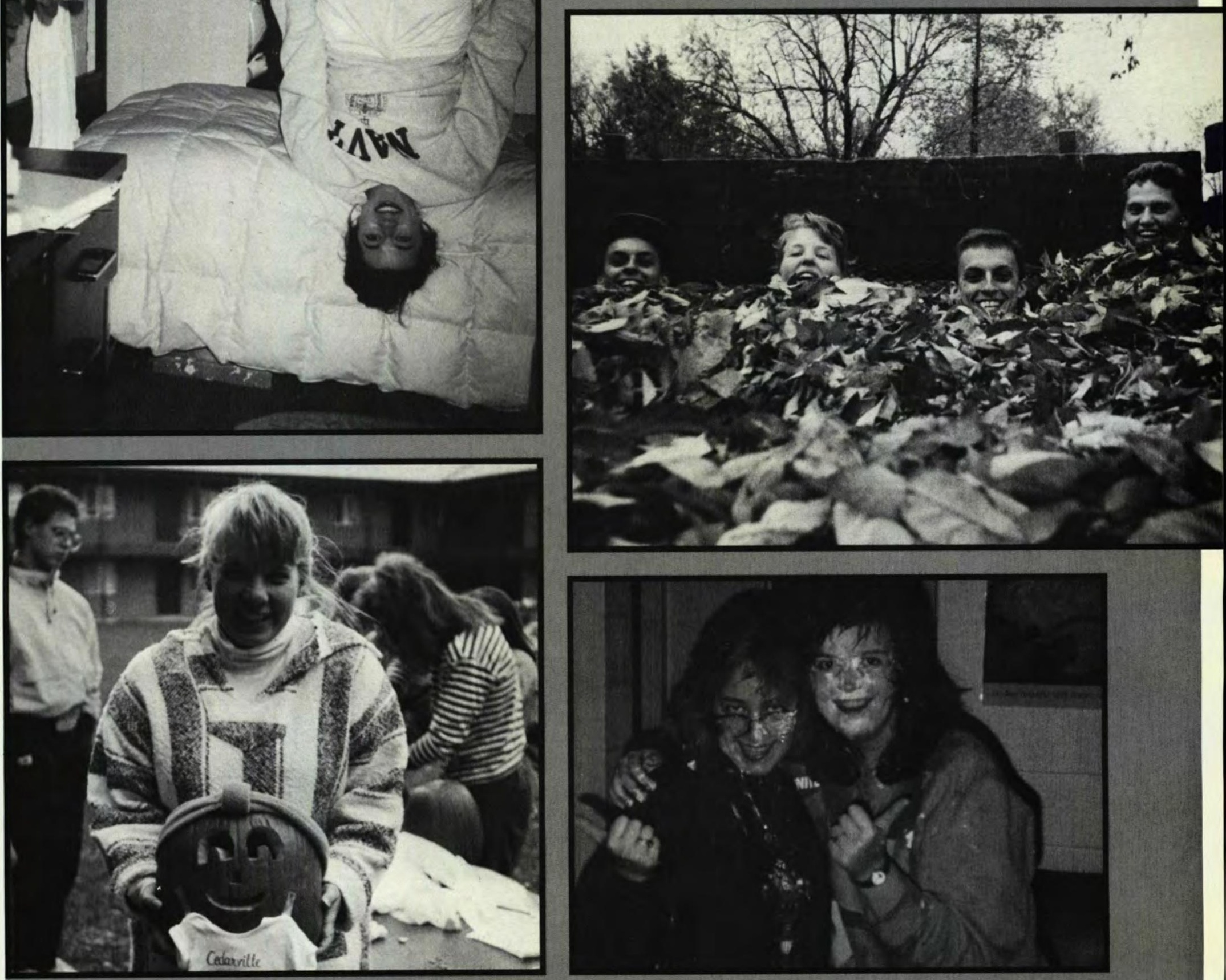

Ginny Stevenson presents her pumpkin pal at the annual Maddox Harvest Party.

Maria Montejo and Mona Ludwig enjoy the rewards of a friendly frosting fight. 


\section{Wright}

Relishes

Royalty

What do the Yellow Jacket soccer team's win over Ohio Dominican 6-0 and Lori Wright have in common? They both represent Homecoming 1990! Lori Wright was crowned Homecoming Queen on Saturday, October 13, at the Royalty Banquet. A nursing major from Columbus, Ohio, Lori's first priority upon graduation is her marriage on June 8 to Larry Nocella. She plans to stay in the Columbus area where she hopes to obtain a position with Riverside Hospital in the critical care unit.

Lori chose Cedarville not only for its outstanding nursing program but also for its strong integration of biblical principles within the program itself. The goals of Cedarville facilitated Lori's choice when she desired high standards and a balance of Christianity and quality.

When asked what she would miss about Cedarville, Lori's immediate response was "Chapel." She believed that chapel was a common bond between the students. Growth is a major part of Cedarville College, and Lori has grown the most through her friends with whom she was brought into contact.

\section{- Meredith Clements}
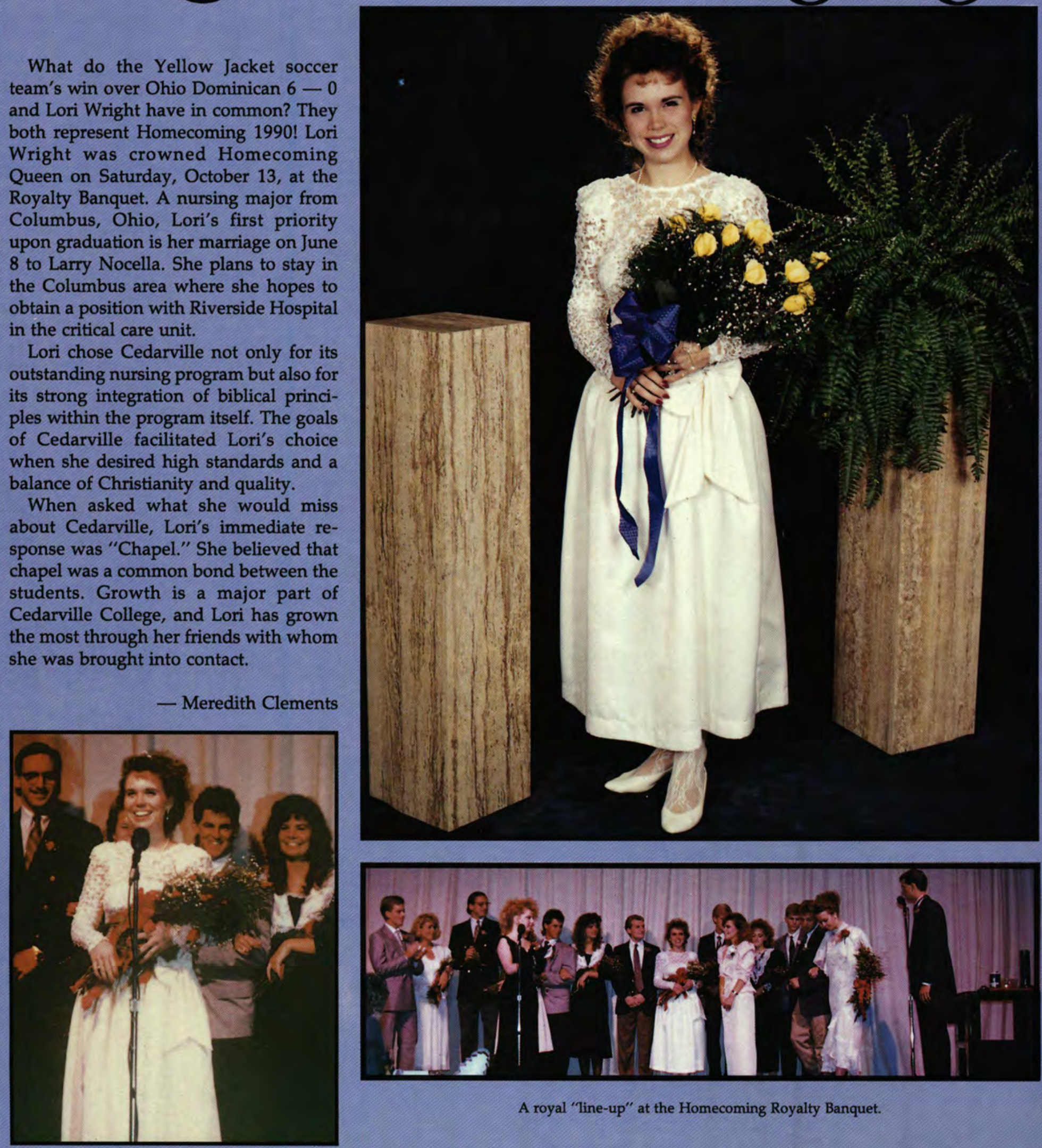

A royal "line-up" at the Homecoming Royalty Banquet.

Lori Wright receives her crown as the 1990-91 Homecoming queen. 


\section{Building UP}

\section{to Fun}

"What if we make a space shuttle zooming into the future?" "What if we use children dressed up as adults?" "What if we throw candy to the spectators?" Several weeks before the Homecoming Parade, usually hidden in an old barn in the middle of cornfield, answers to ques tions such as these are being hastily answered as the sophomore, junior and senior classes design and build their homecoming floats.

The projects begin with many "what if' $s$ " and develop through long hours of

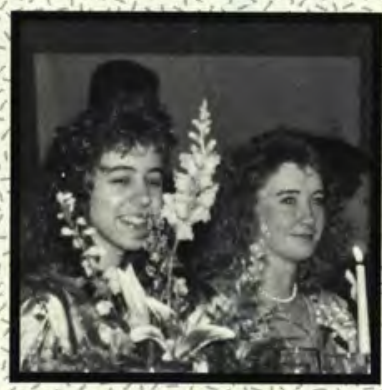

toil, sweat and tears as dedicated students make their way out to the "secret" locations to help make their classes floats the best. Once one finds the secluded location (if one finds

it), let him beware, for no one enters such a den of activity without paying the price of working hard, making prog ress, and having lots of fun along the way. Driving

nails, cutting wood, shaping chicken wire, and spreading paint describe just half of this experience. Making great friendships by letting your hair down" describes the other half.

- Jesse Wesselink

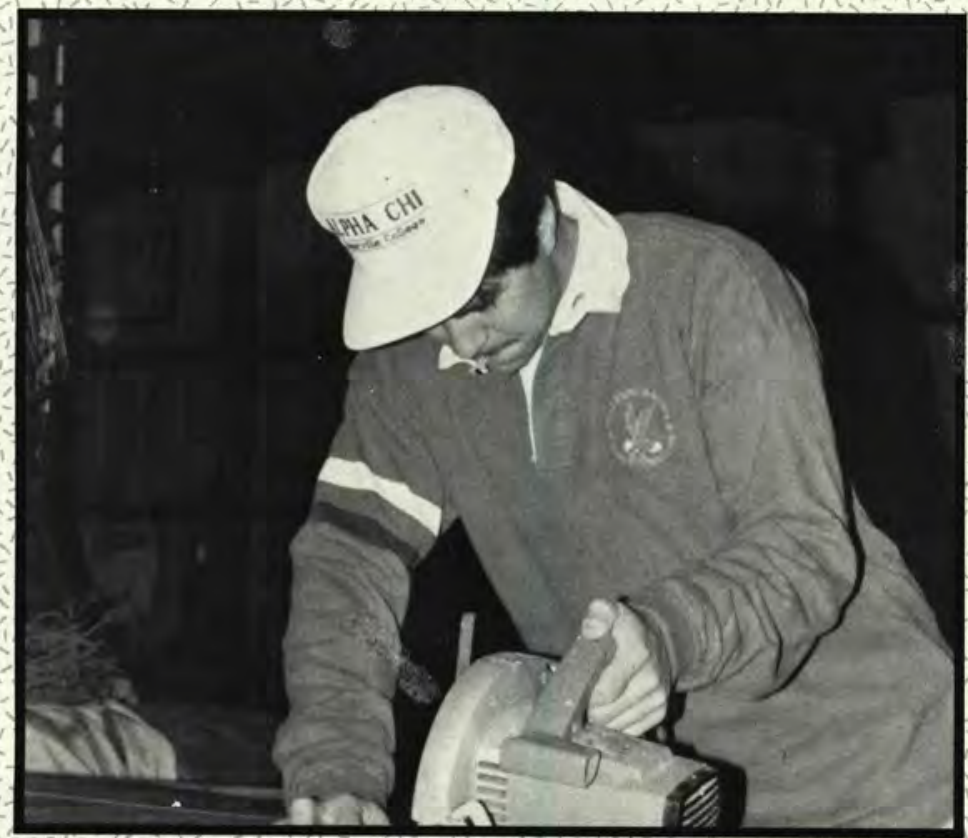

photo by Jesse Wesselink

Mike Feliciano saws his time away for the senior Homecoming float.
Karen Williams and Kelly Harrell pool their efforts to work on a Homecoming float.

Devin Cheek and Beth Erving talk before dinner at the Homecoming Royalty Banquet.

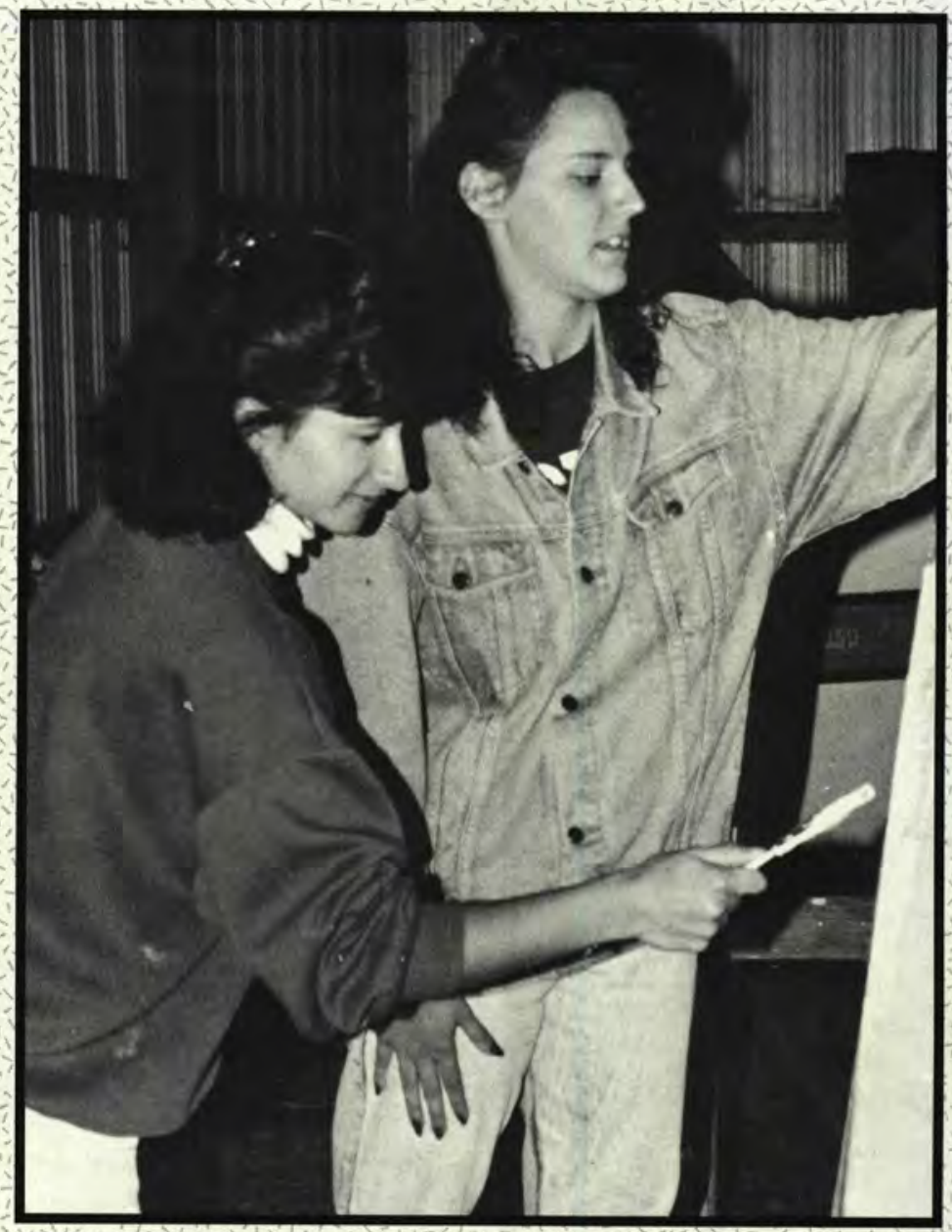

photo by Jesse Wesselink

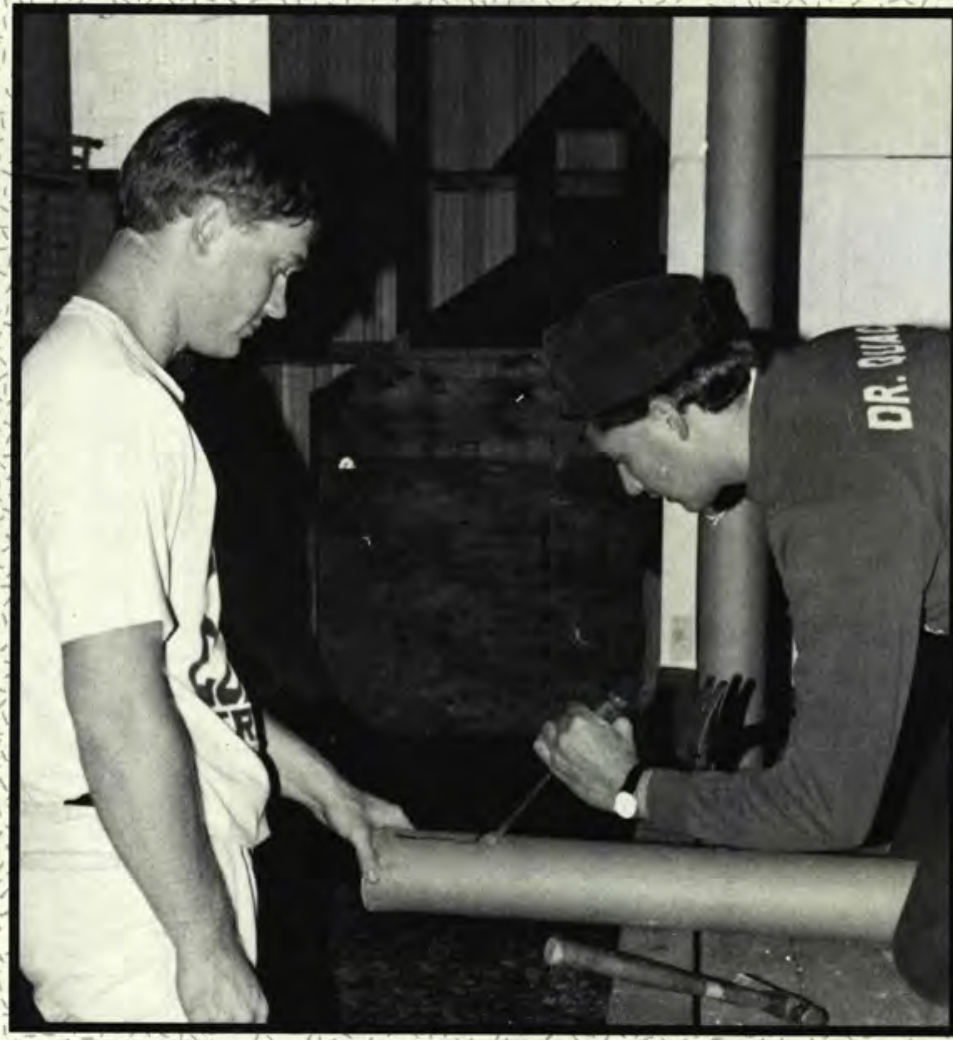

photo by Jesse Wesselink

Matthew Moser and Craig Hamilton diligently work on the junior class float 

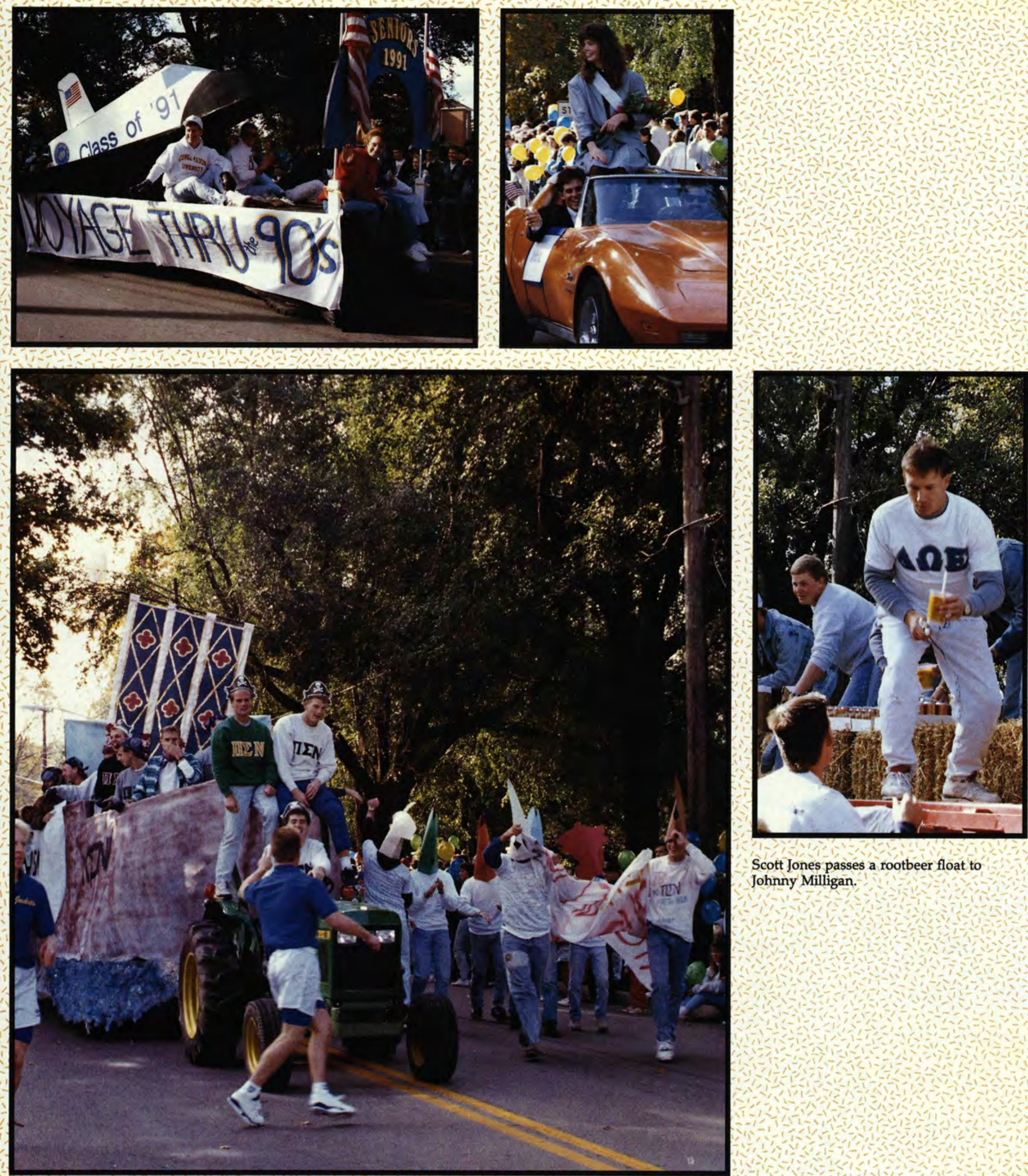

Scott Jones passes a rootbeer float to Johnny Milligan. 
Winter
Snapshots

Hangin' on for fun at Donkey Basketball

photo by Andy Jamieson
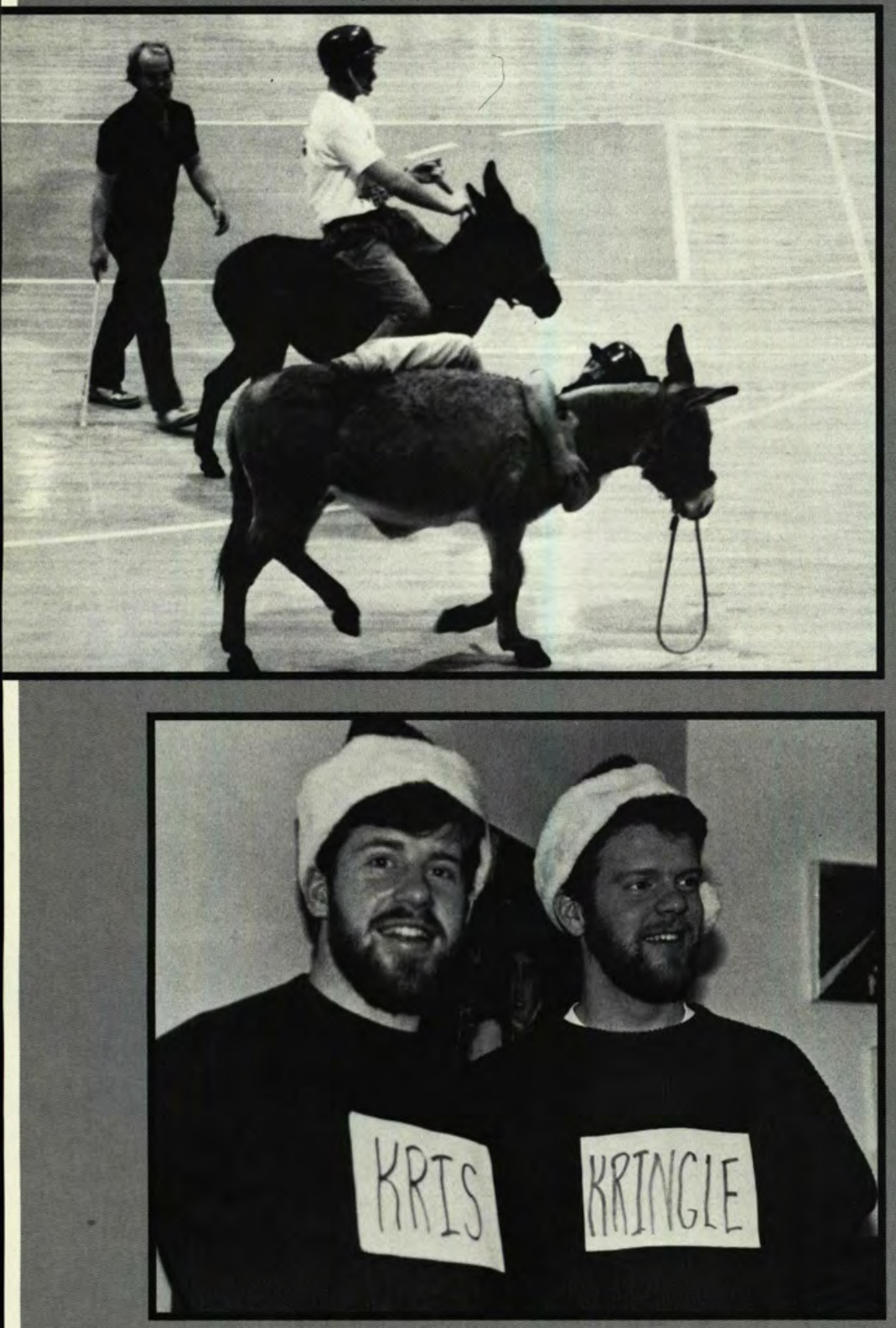

photo by Steve Cook

Kelly Fath and Curtis Carr, alias Kris Kringle, flaunt their beards as they participate in Follicle Follies.
Jon Leonard keeps his eye on the ball as he takes a breath in the A.C.

photo by Gwynne Davies
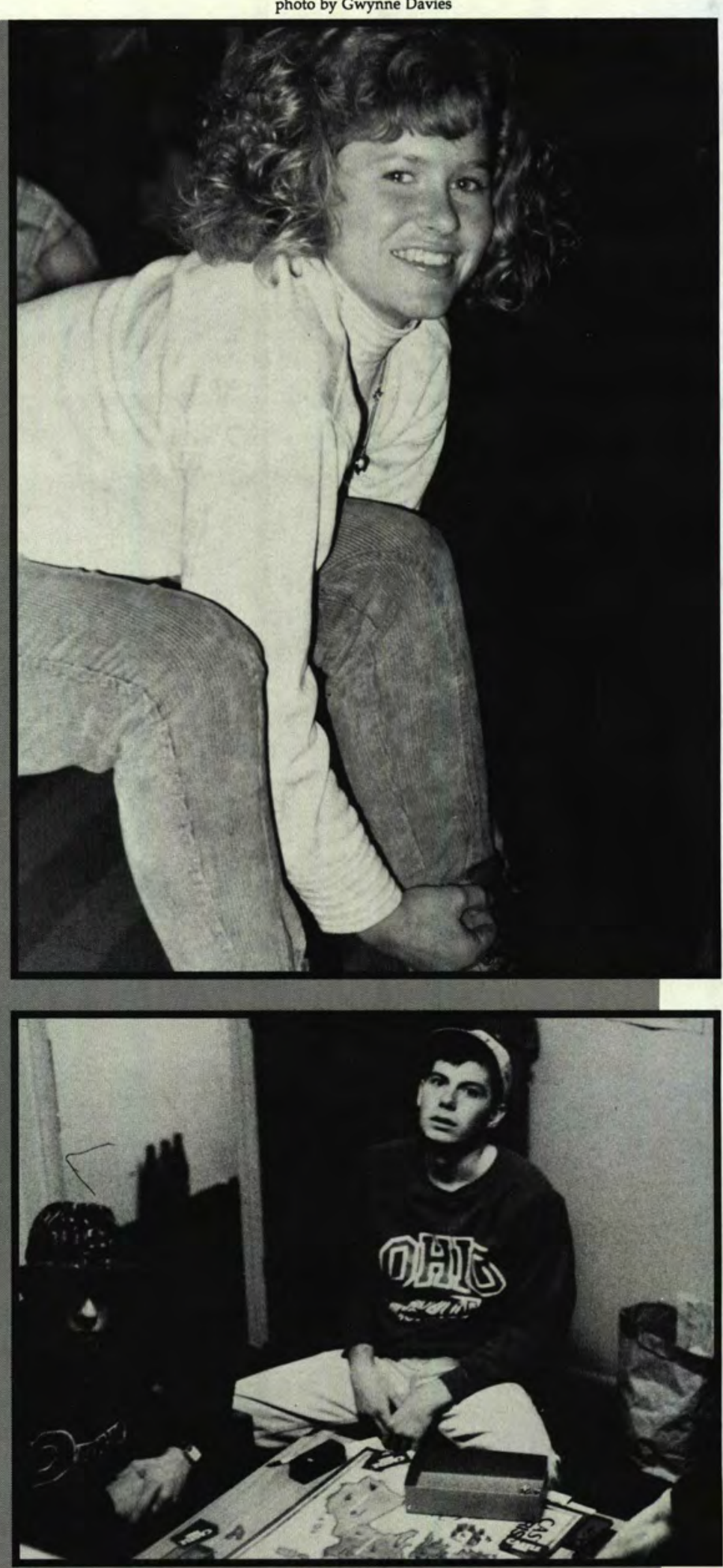

photo by Andy Jamieson 


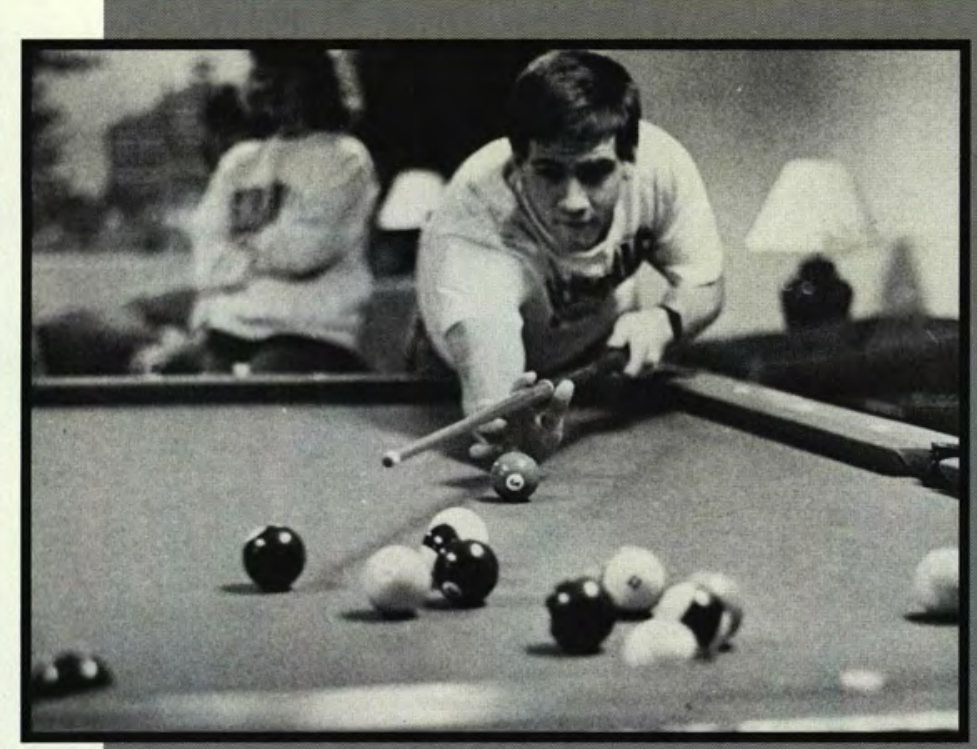

photo by Steve Cook

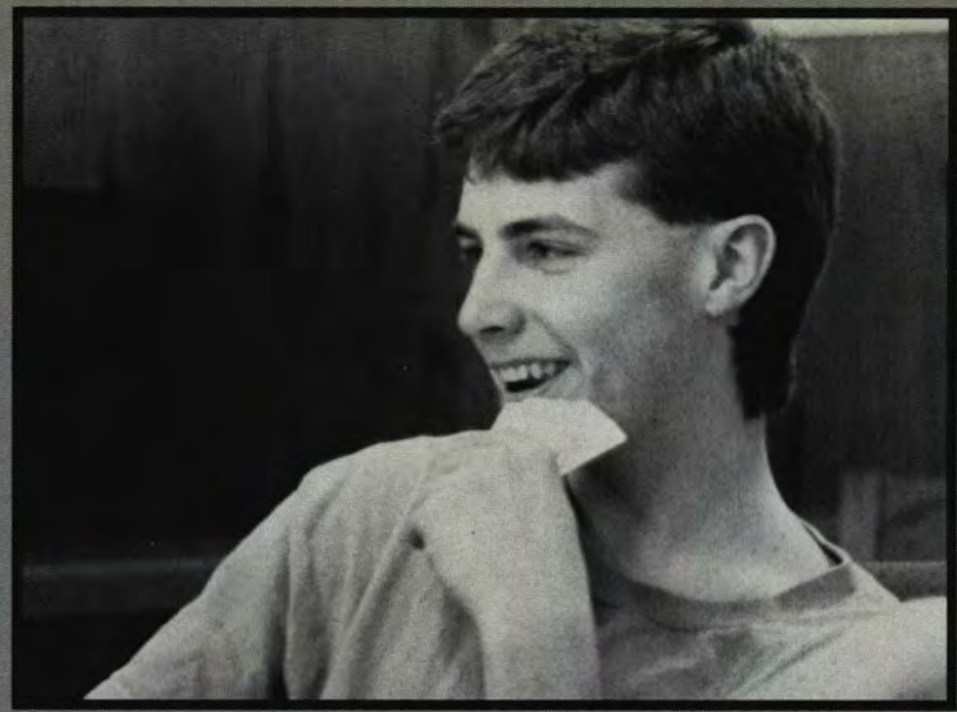

photo by Steve Cook

upper léft John Leonard keeps his eye on the ball as he takes a breath in the A.C.

upper rightJohn Hill enjoys a game of cards.

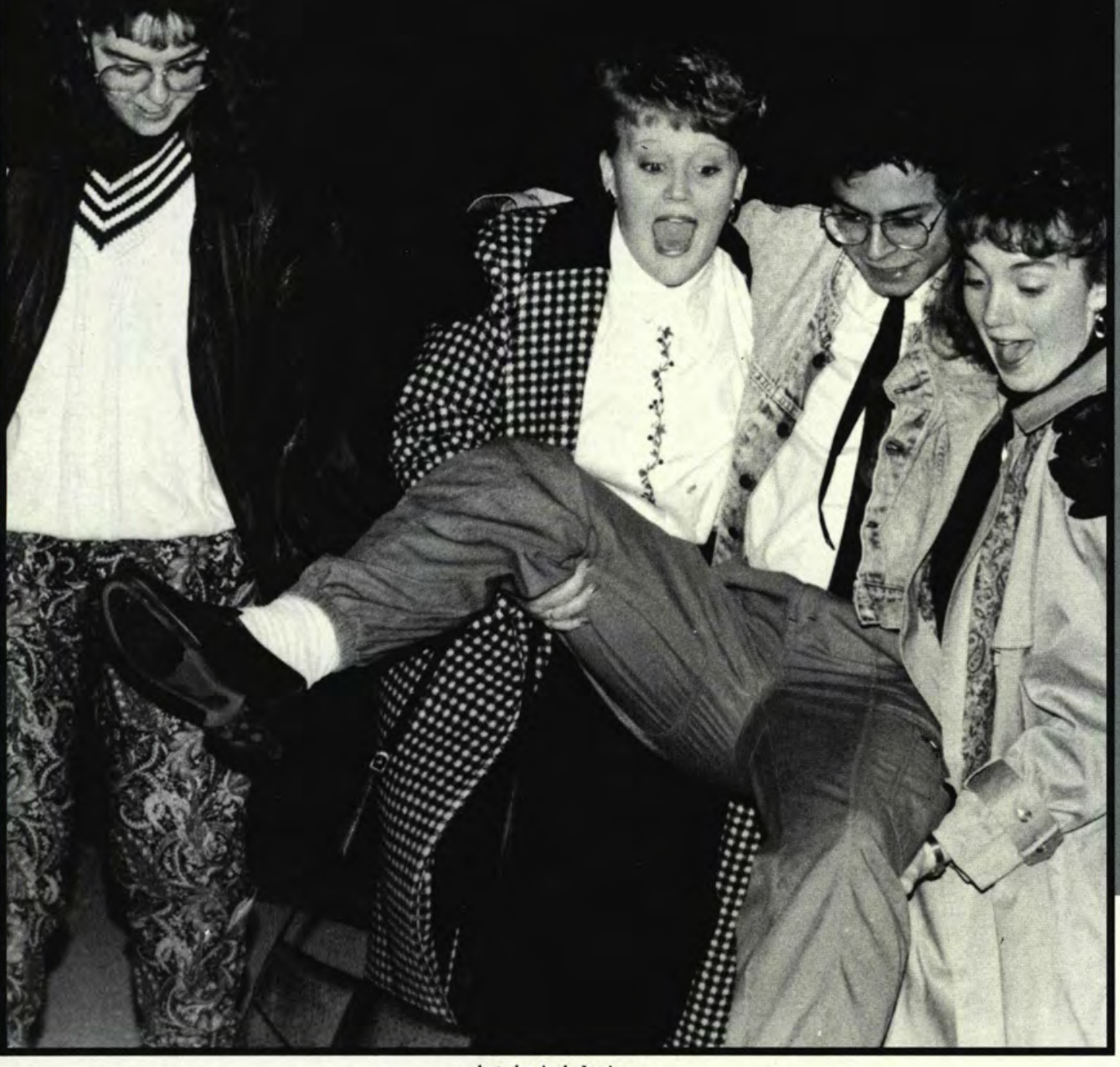




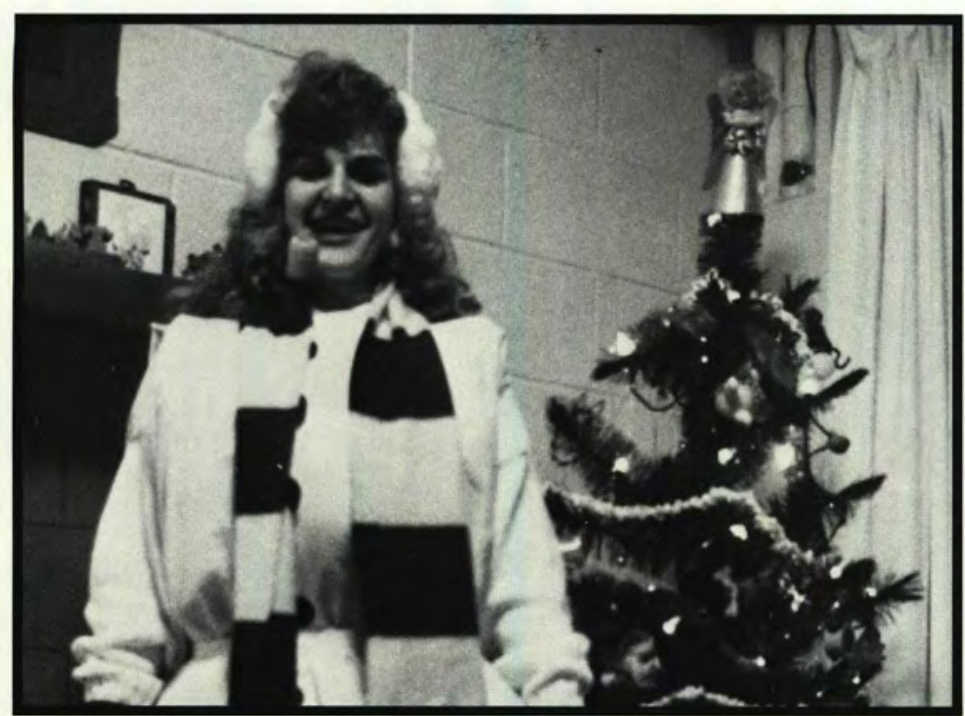

photo by Marsha Olsen

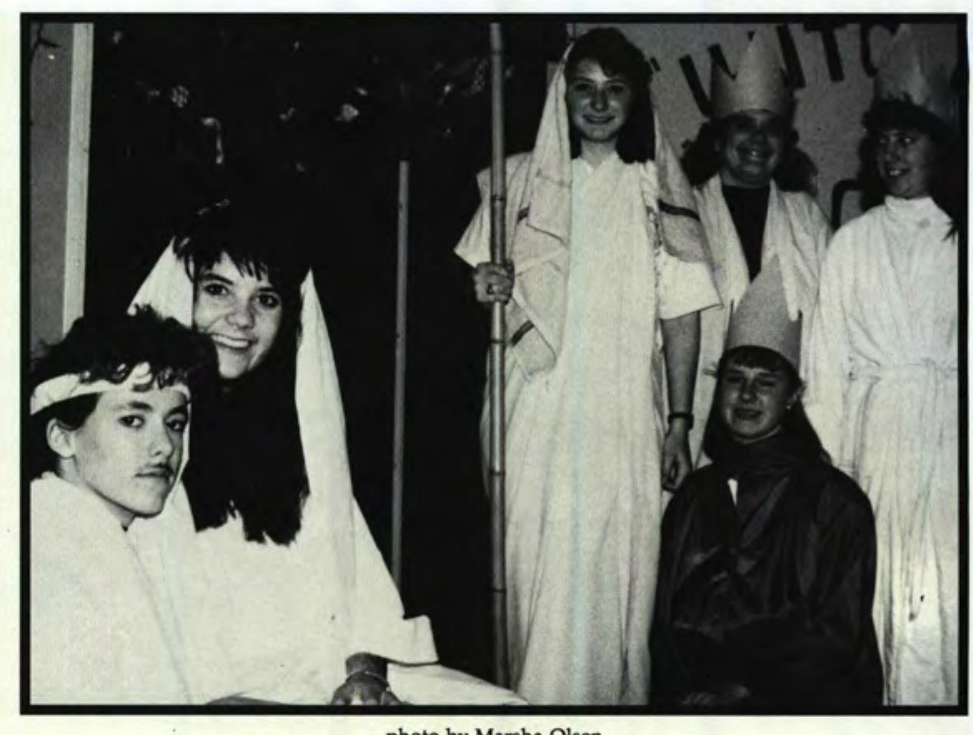

photo by Marsha Olsen

(Upper Left)Lori Bishop mielts visitors' hearts

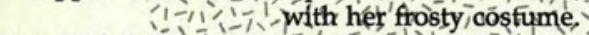
(Upper Right) The women of Màddox 17 display the true-spirit of Christmas:-

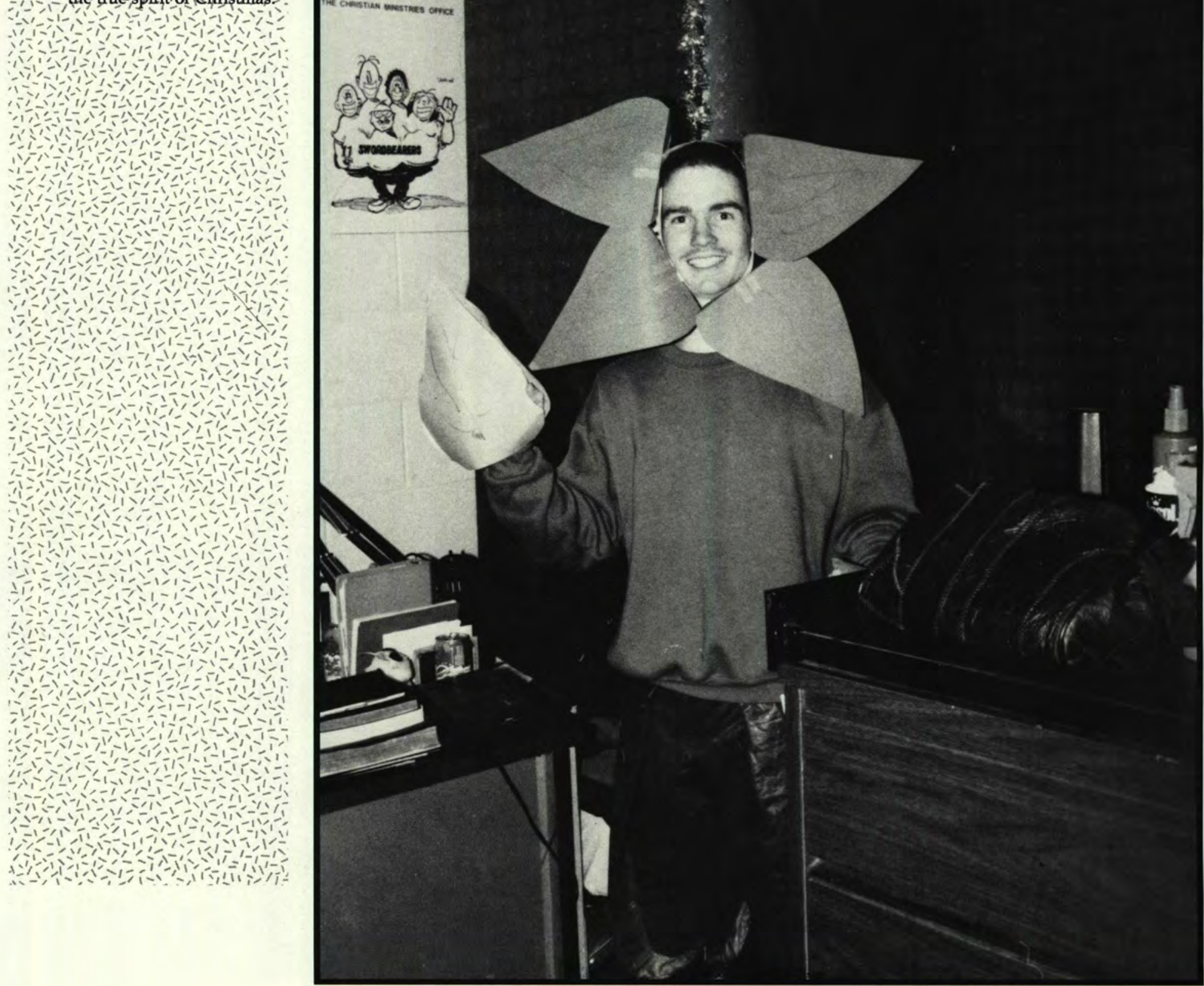

Tom Bonifield brightens the season with his own rendition of the Christmas poinsettia. 

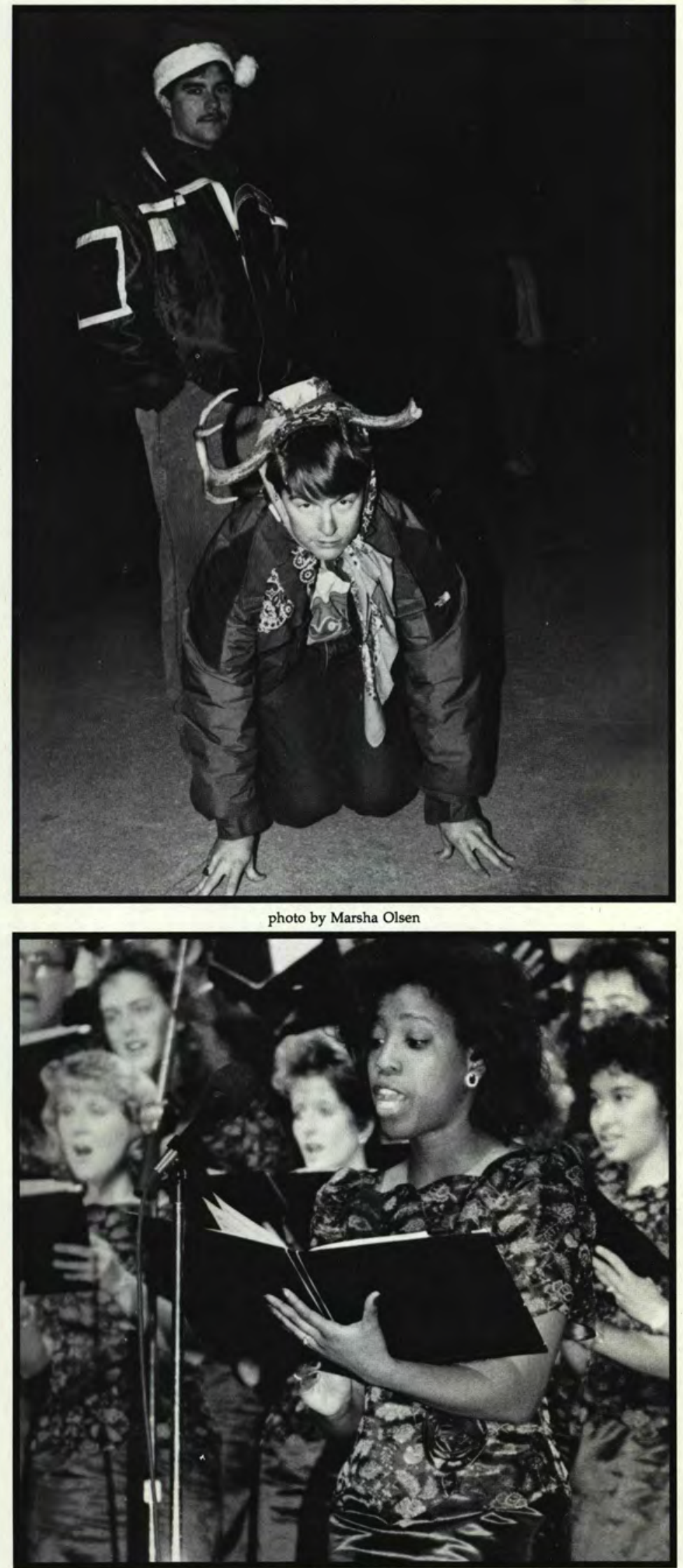

photo by Tania Taylor

Mike Feliciano lands his reindeer in Cedarville for a quick photo.
The air surrounding

Cedarville College was filled with excitement on November 30 and December 3 when the Open House Party exploded all over campus, and coeds bombarded decorated dorm rooms. Students waited in their respective dorms to show off their tinseled rooms glowing with multi-colored lights strung from the walls and hallways. Santa and his elves even made a special appearance in the Carr basement. WSRN provided a musical evening of Christmas favorites for the Open House

Party and once again the campus was submerged in the Christmas spirit. - $M$.

Clements
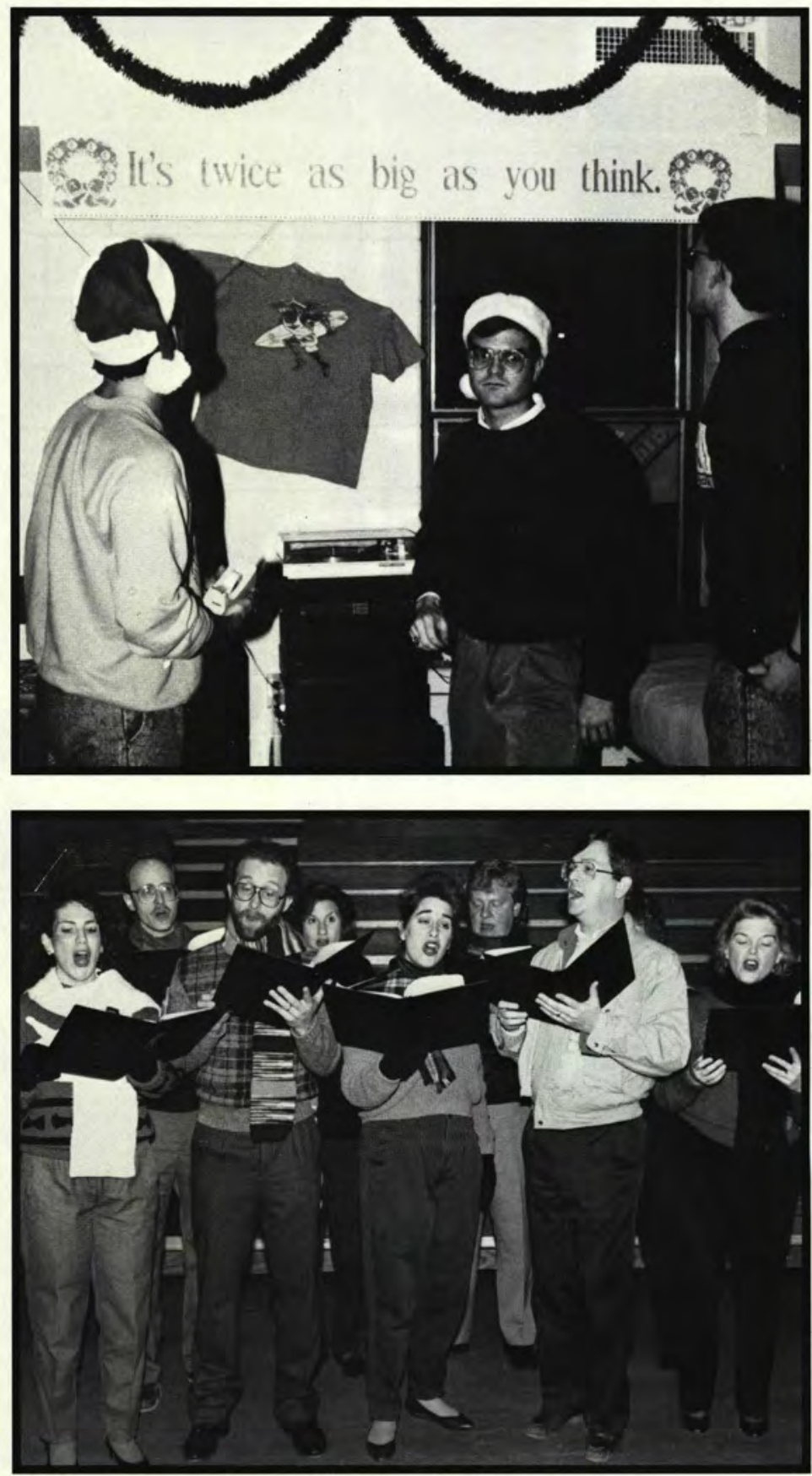

photo by Tania Taylo

Galyn Nook and Chris Clark evaluate their decorations.

Dr. Clevenger leads a group of carolers at the Christmas Festival. 

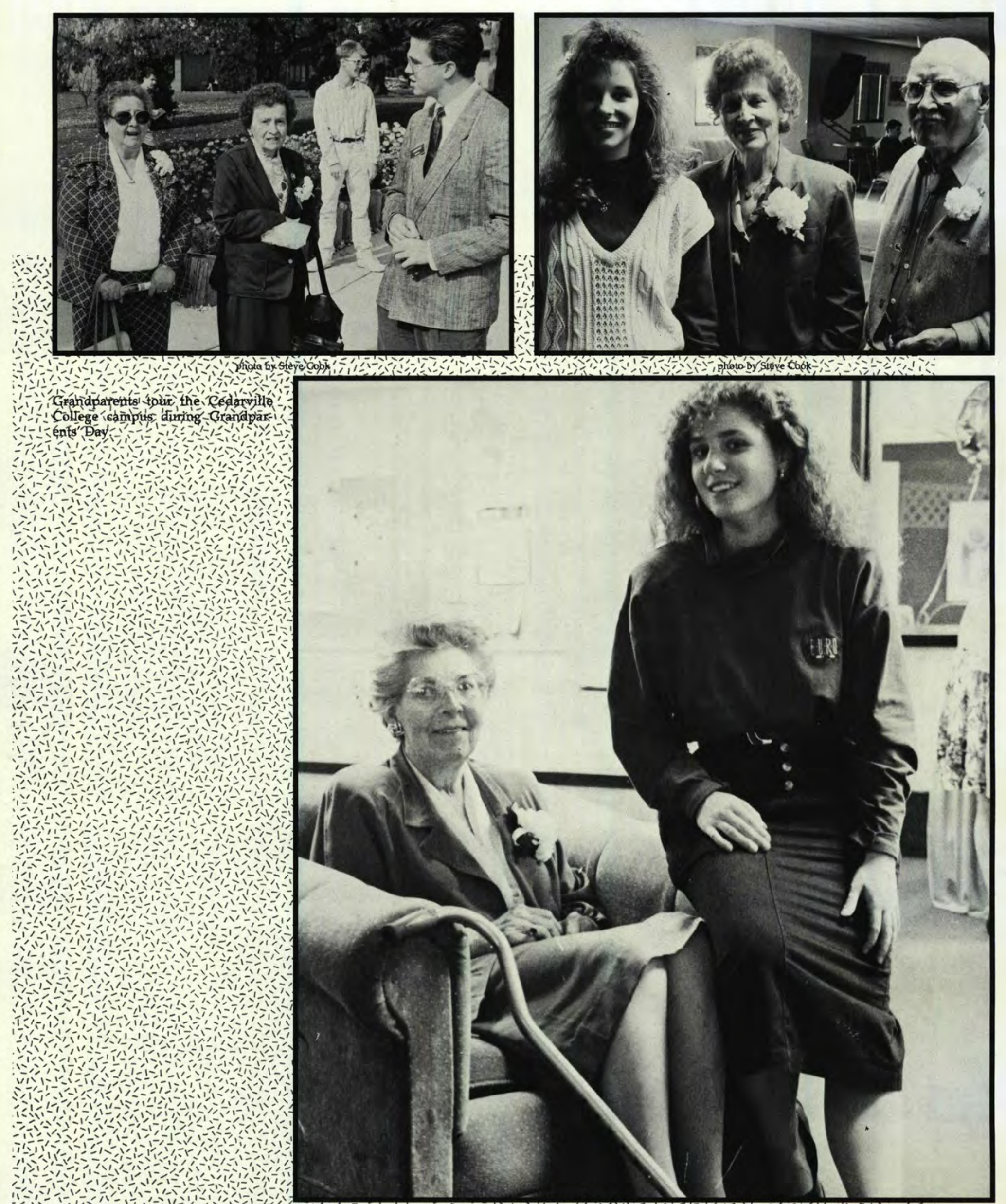


\section{An Umbrella of Prayer In the Desert Storm}

On February 12, 1991, Cedarville College observed the second Day of Prayer of the 1990-91 school year. This day was especially important because of the ongoing war in the Persian Gulf. The Wall of Prayer (the college's momento of the fighting soldiers) was the focus of the day.

The soldiers in the Middle East were given utmost attention as students turned their hearts to God. Dr. Terry Phipps of the science department gave a very moving testimony which related the experiences he had in Vietnam to those now serving in the Middle East. His words helped students to understand the feelings of a soldier at war which in turn encouraged us to be supportive.

The service continued with a taped message from Lorn Reno who currently was serving in Washington D.C. He told students how effectively to pray for the soldiers in the Middle East and the personnel "running" the war. His advice assisted the students as they went to prayer.

In order to pray more effectively for the personnel listed on the Wall of Prayer, names were passed out to each student. Several minutes were spent in prayer as students broke into groups to remember the names they were given.

Continuing in prayer, several students involved in R.O.T.C. prayed aloud for the P.O.W.'s, the M.I.A.'s, and those wounded or killed in action.

In this time of world unrest, it is encouraging to know that God is still in control, and we can turn to him with our needs. The Day of Prayer will always be an integral part of the Cedarville College year.

- Amy Edwards

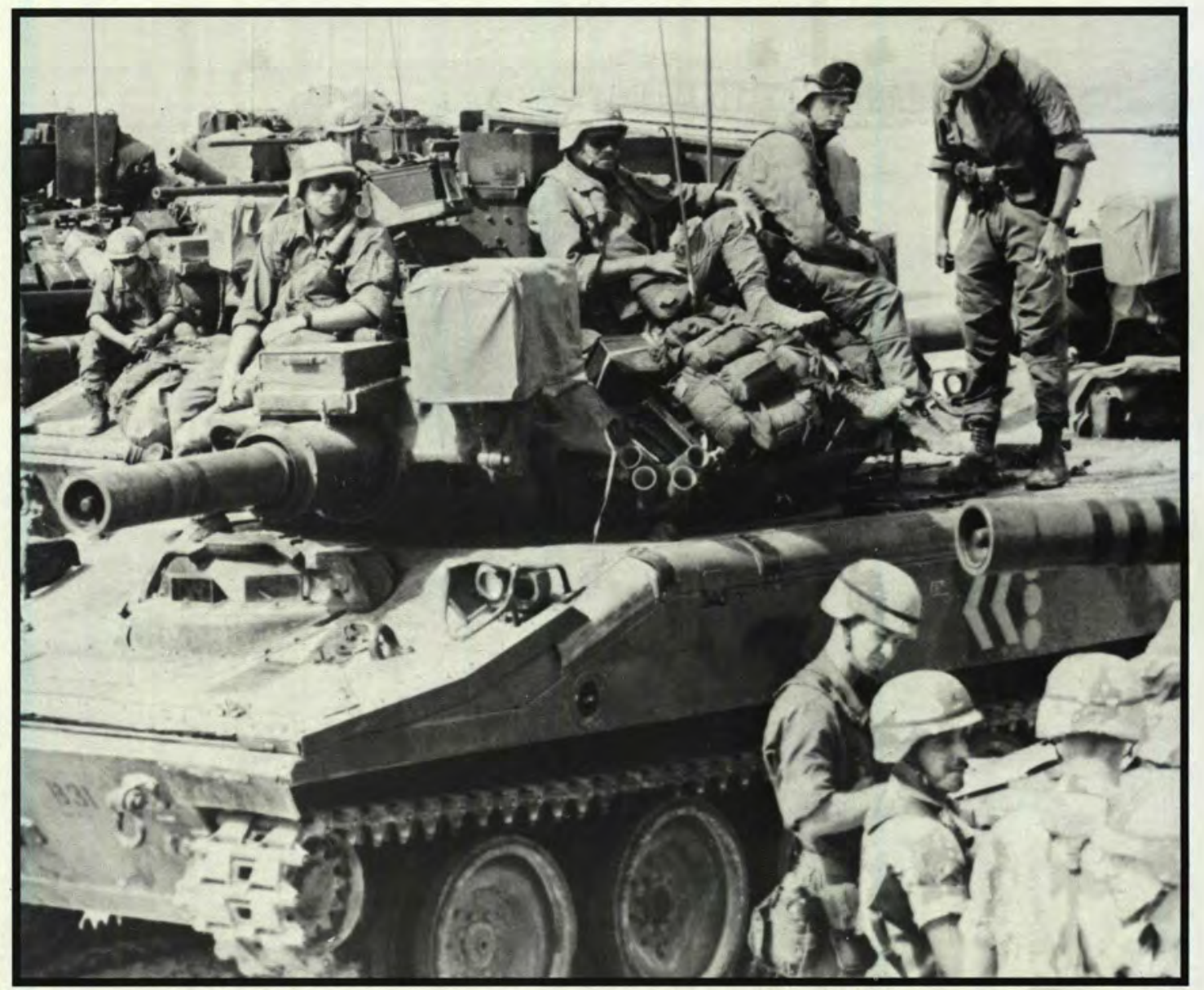

photo by RM Photo Service

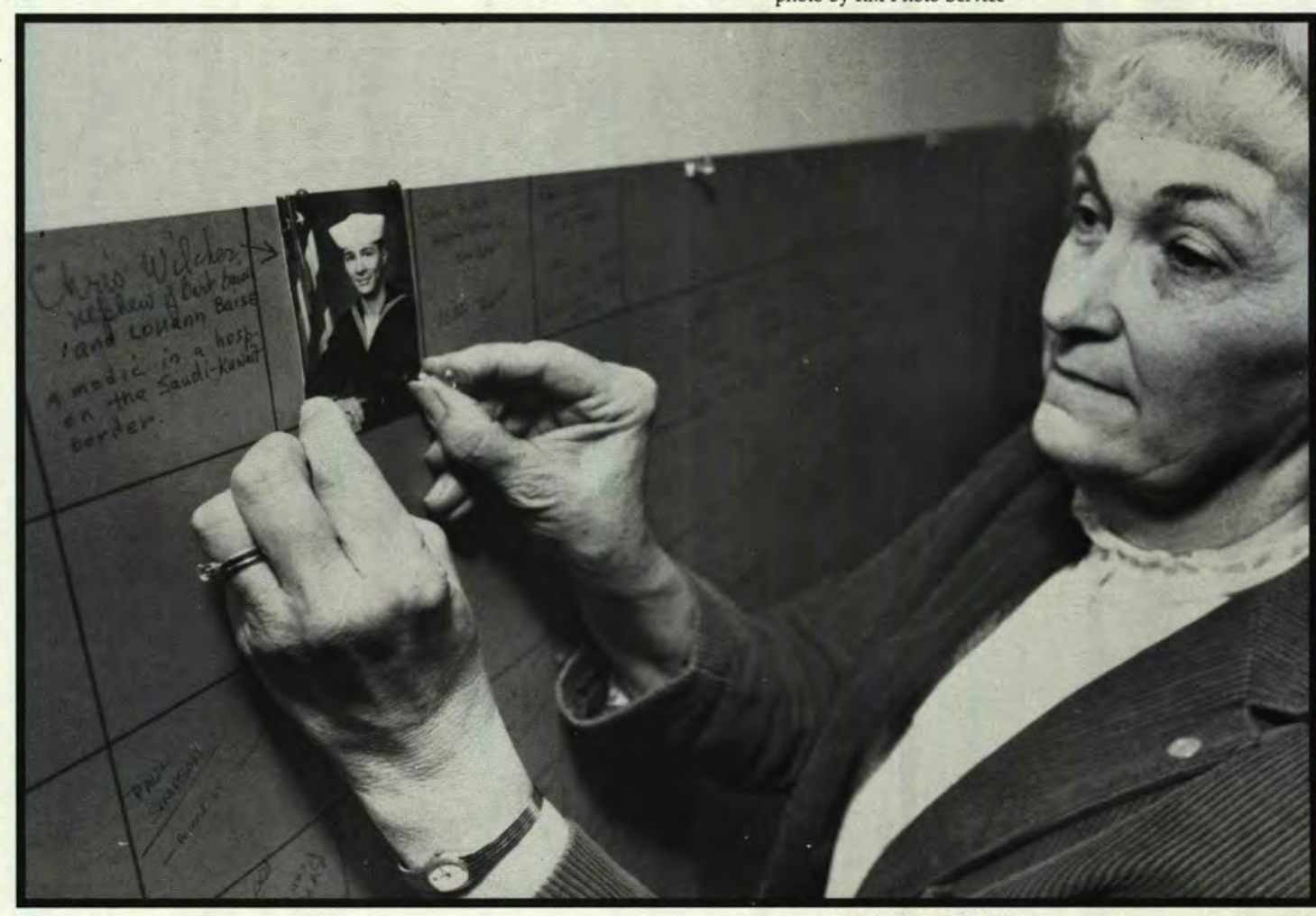

American troops in Saudi Arabia.

Mrs. Baise pins a picture of her nephew on the "Wall of Prayer." 


\section{Spring Snapshots}

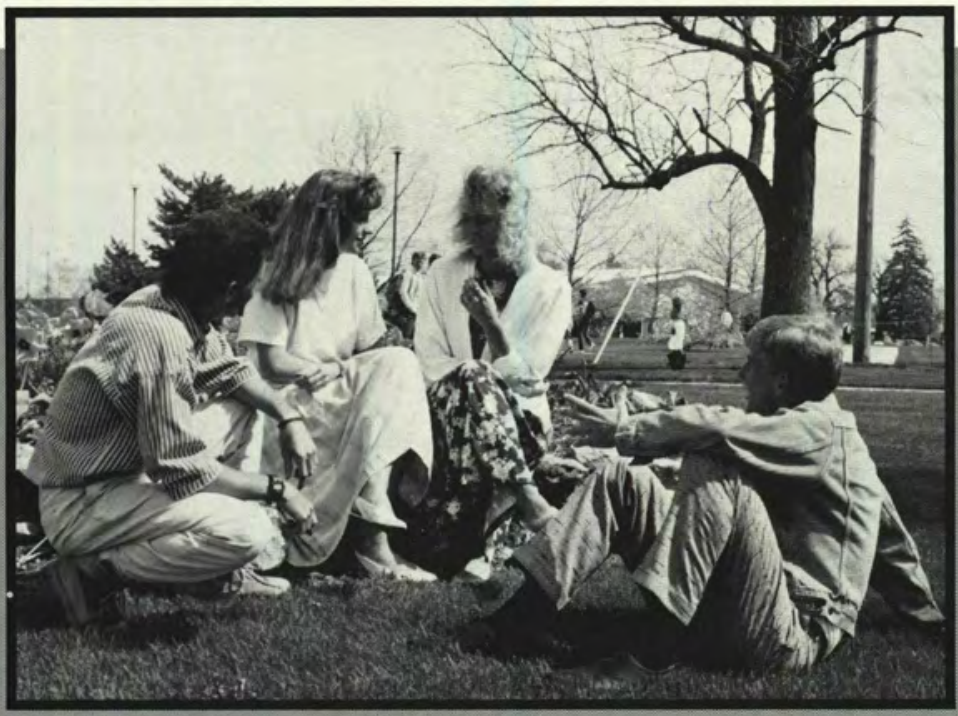

photo by Andy Jamieson

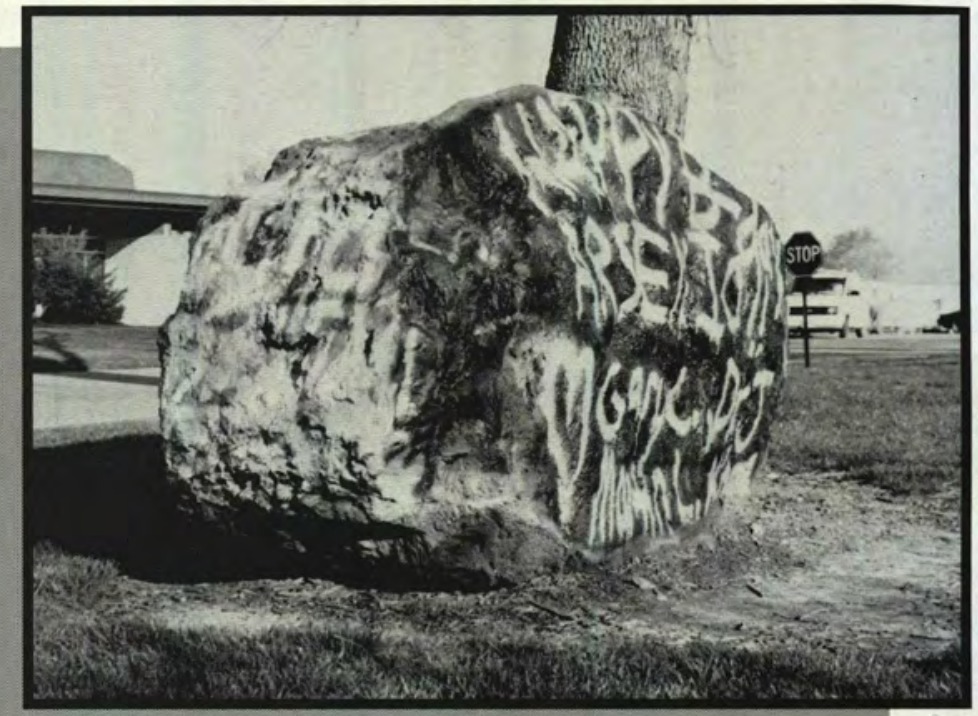

photo by Andy Jamieson

The Cedarville campus provides a great place for a social visit - at least in spring.

A biology class scales to the top during a field trip.

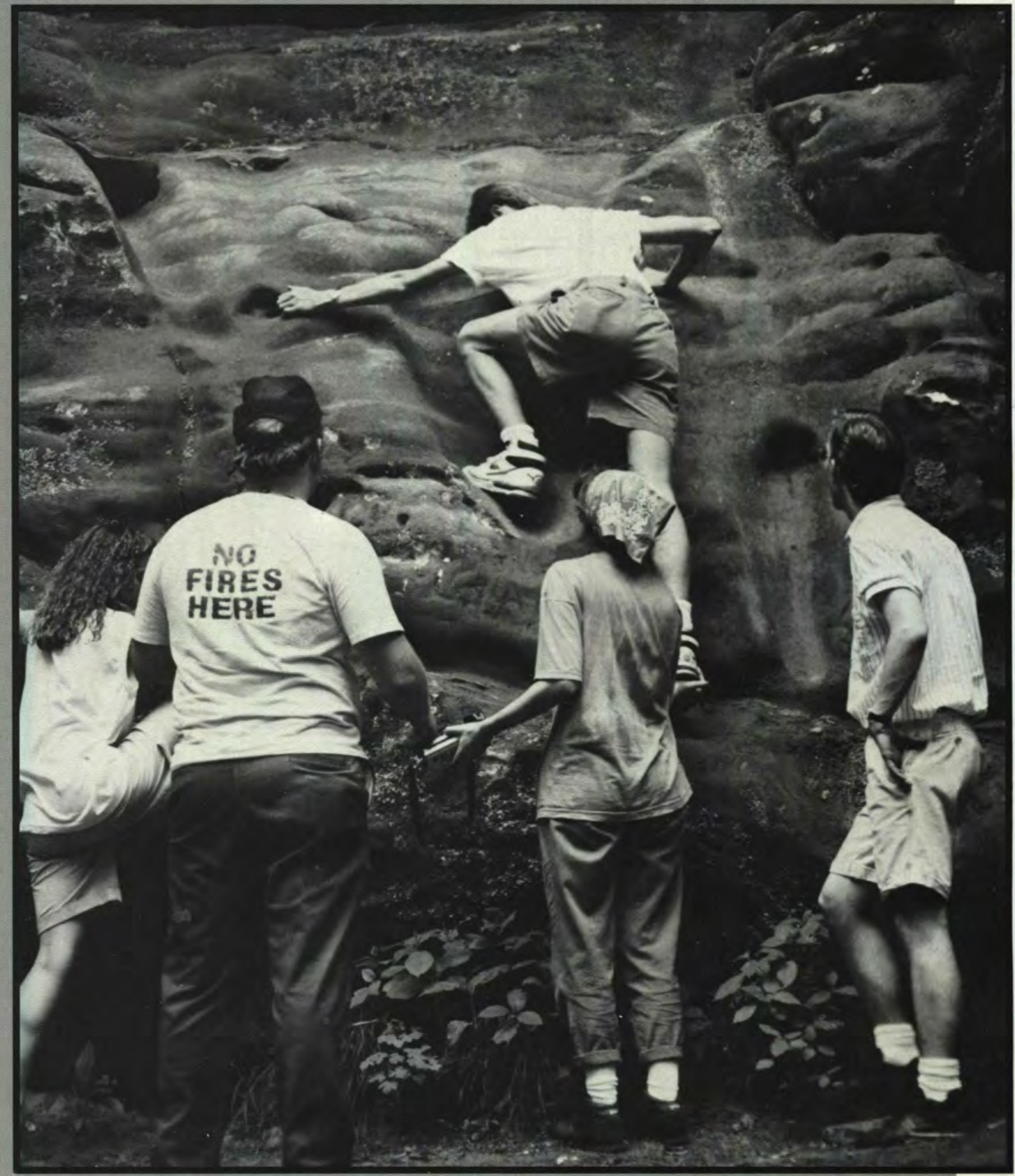


Receiving mail is a major highlight of a student's day.

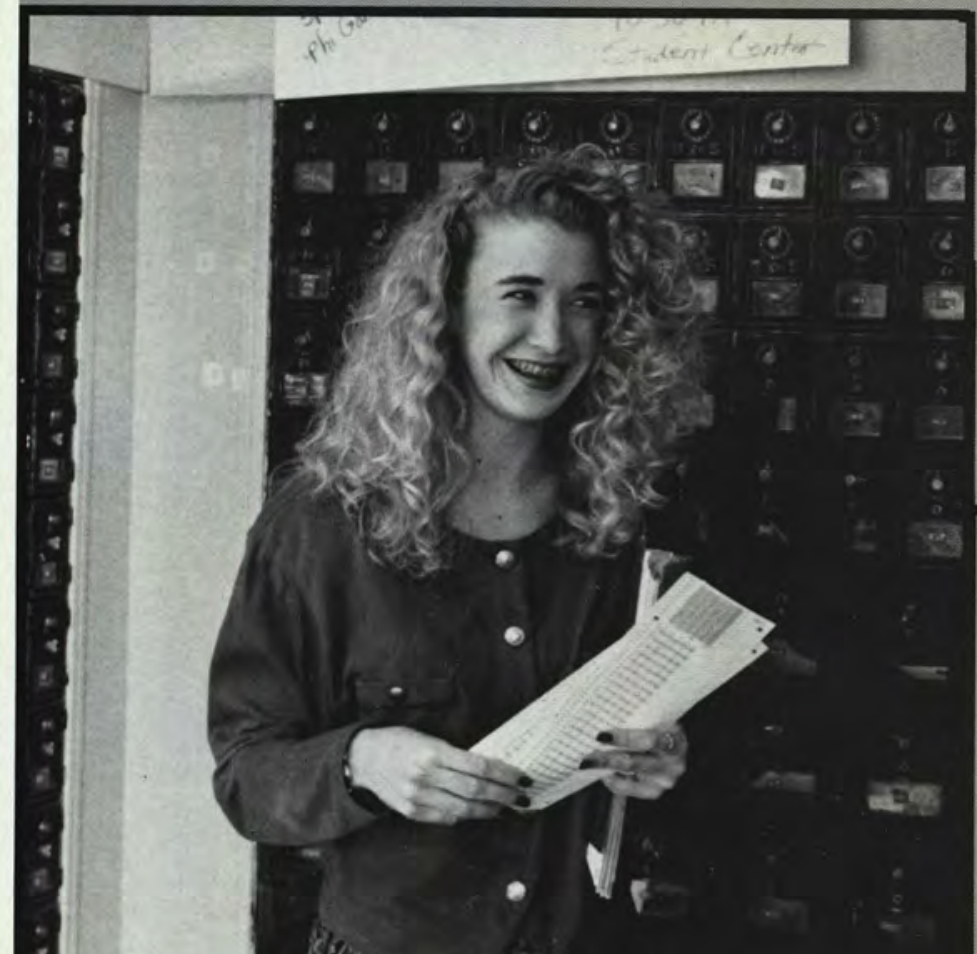

Some Lawlor residents demonstrate their intentions of enjoying the warm weather.
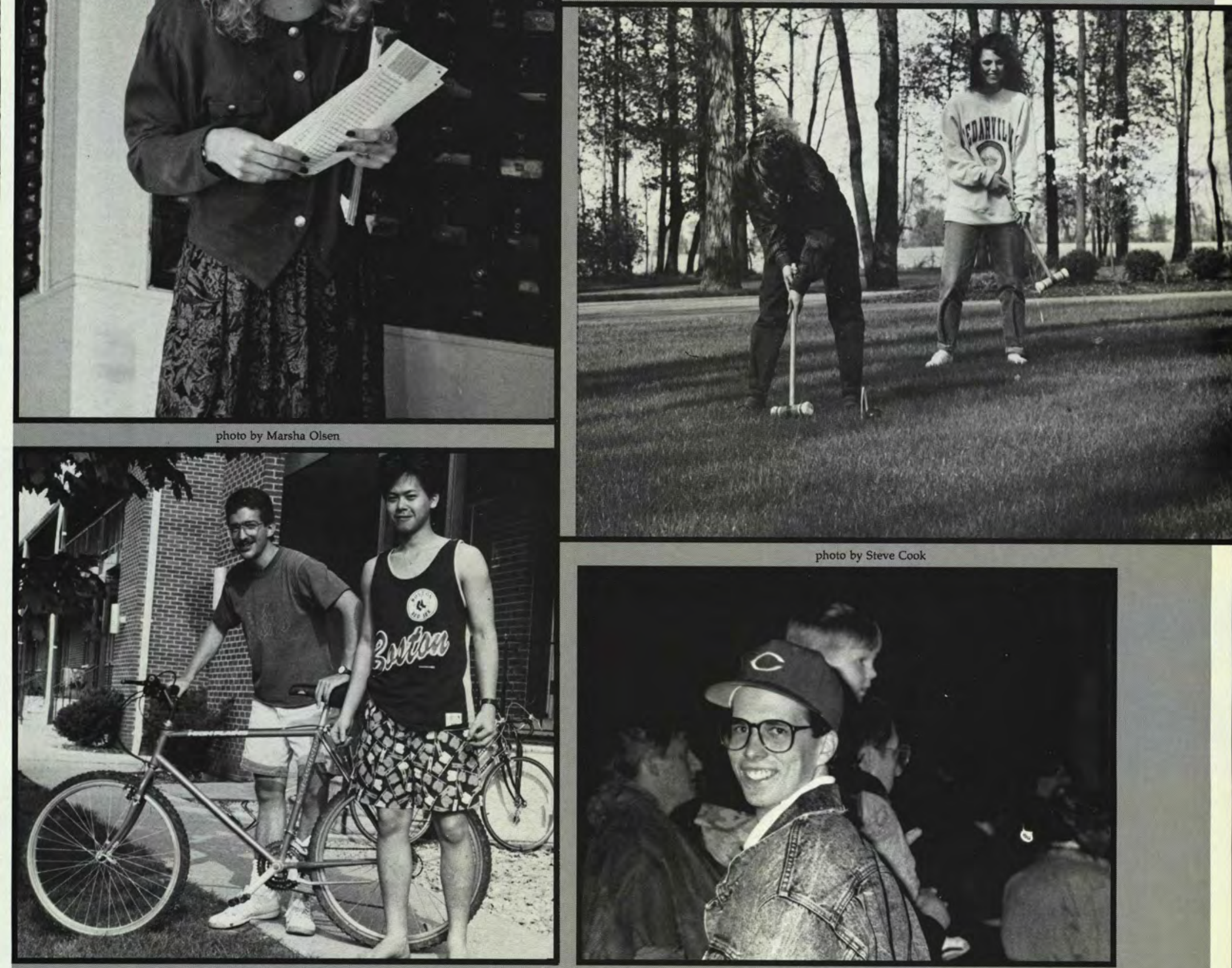

photo by Pat Dixon

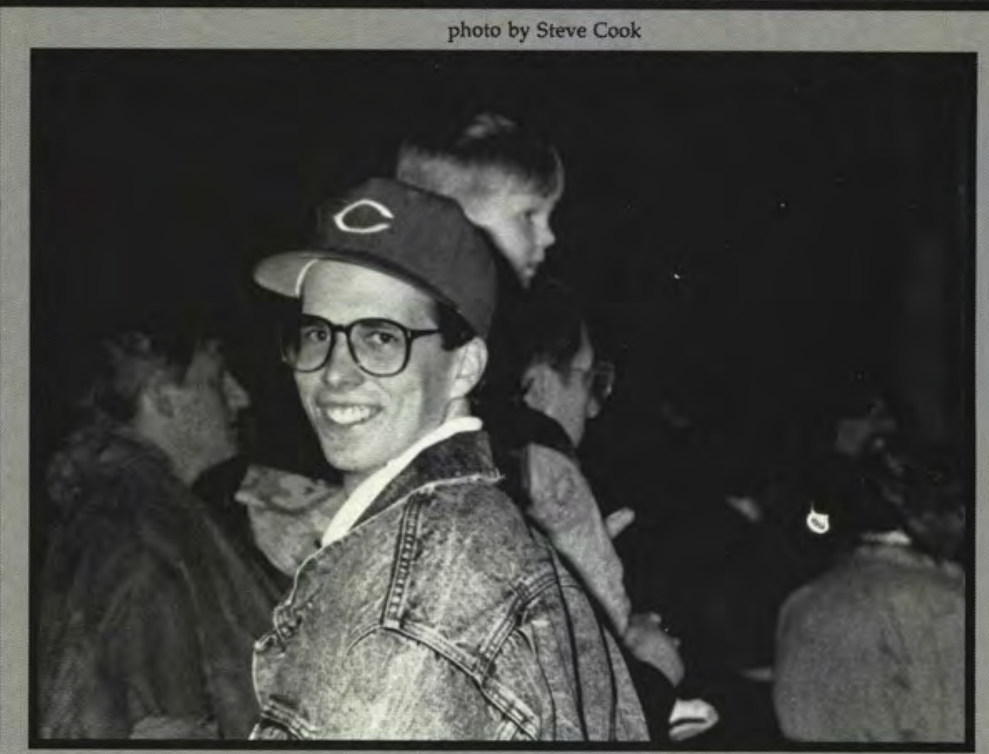

photo by Andy Jamieson 


\section{Blasting the Blues}

It was three weeks before graduation. The campus was quiet except for the dull hum of students diligently working on papers and studying for tests. Then it came....Residence Hall Week!

The campus exploded with an exciting array of colorful activities. First there was oozeball, the zany game of volleyball: vis-a-vis mud wallowing, which left every participant coated with a good time. Then for the slightly more civilized student, the "Brothers One" provided two hours of spirit-lifting Christian music. Finally, di-

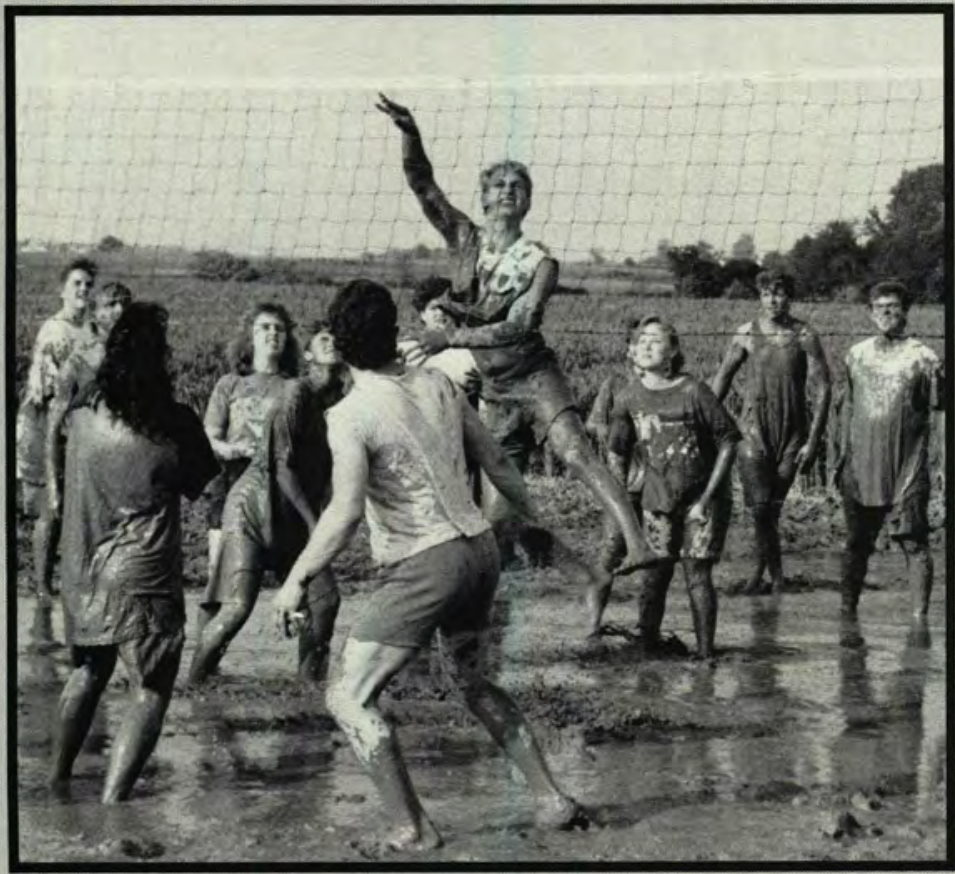

photo by Marsha Olsen rectly following the concert, students searching for adventure and strategy waged the "Battle for the Sahara." This wet version of "Capture the Flag" gave some study-weary students a challenging outlet for their frustrations.

In a time when Cedarville College was tired, frustrated, and surviving only on the thought that soon the year would be over, Residence Hall Week came to the rescue, providing a breath of fresh air and the encouragement to finish the year with a "bang." - Jesse Wesselink

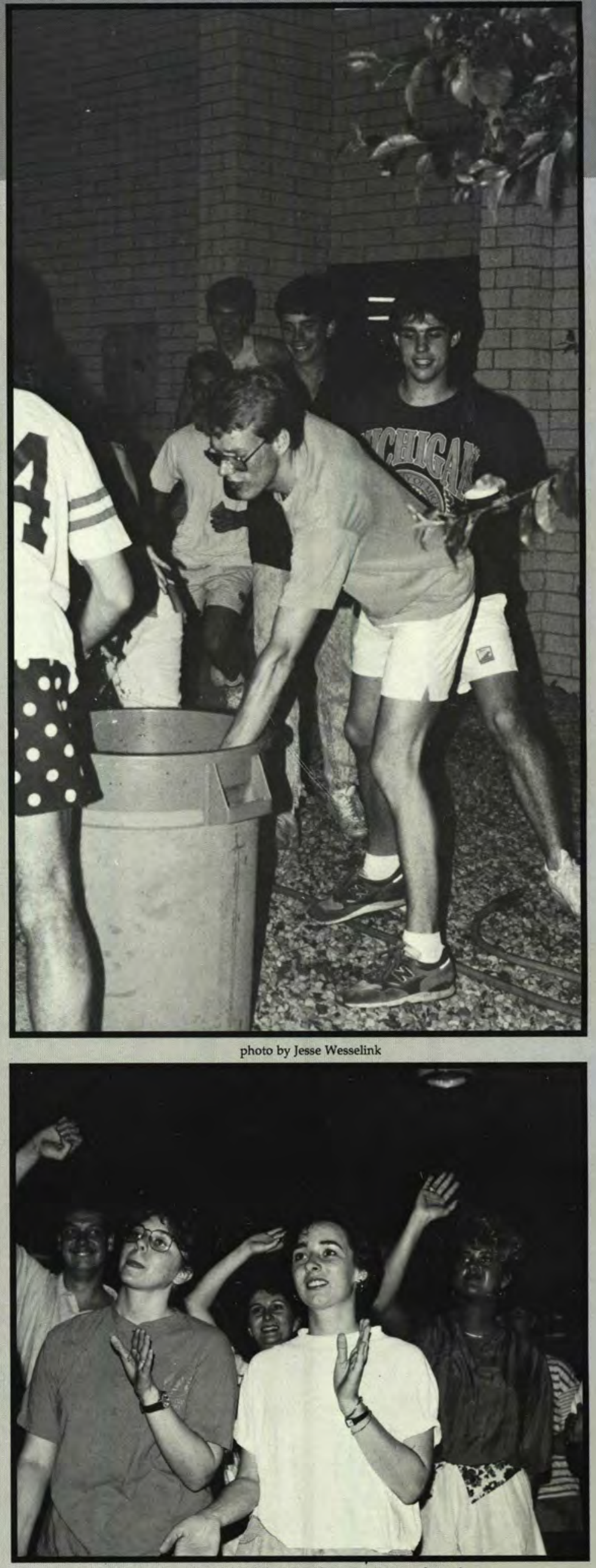

The "Brothers One" uplifts the down spirits of students. 


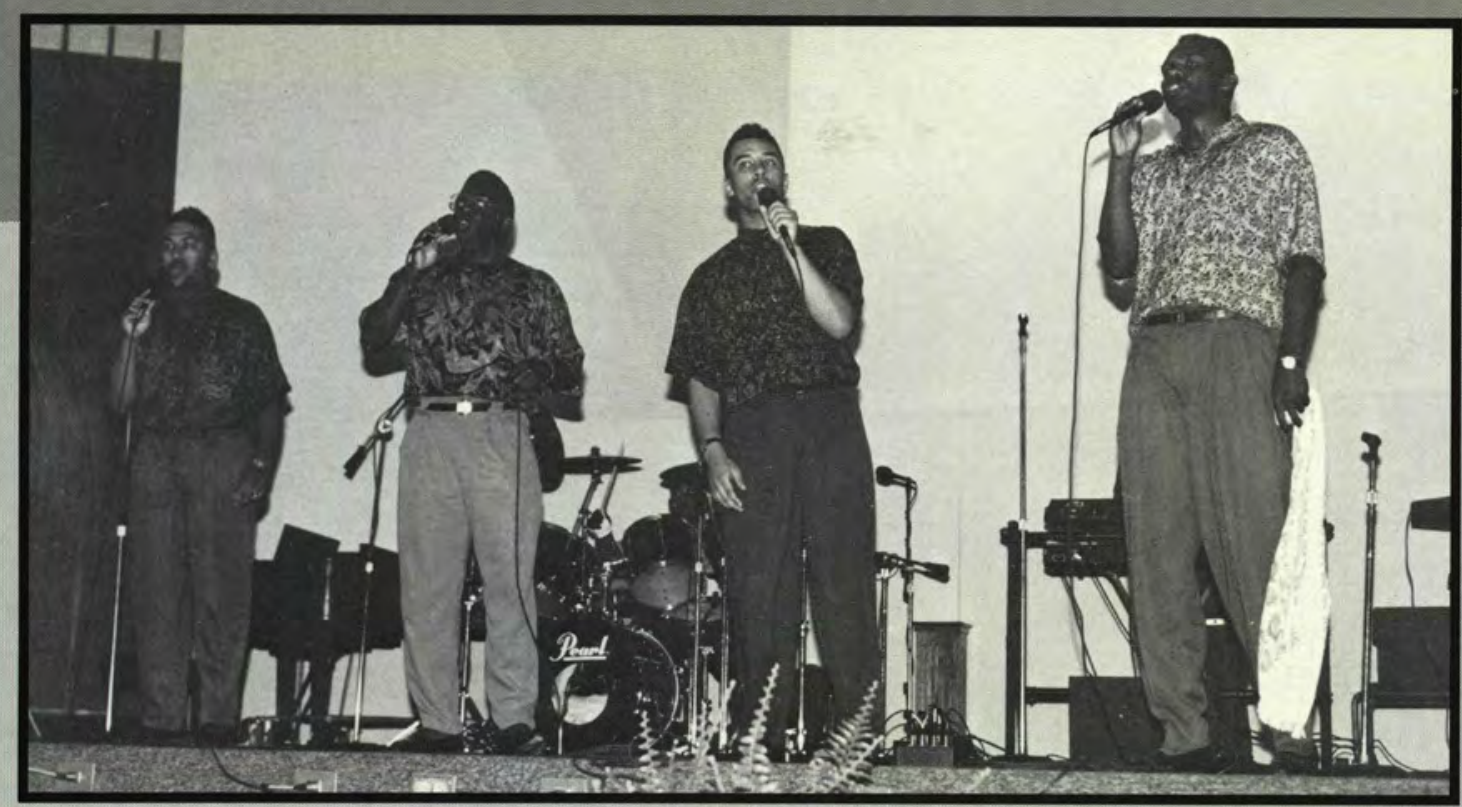

photo by Jesse Wesselink

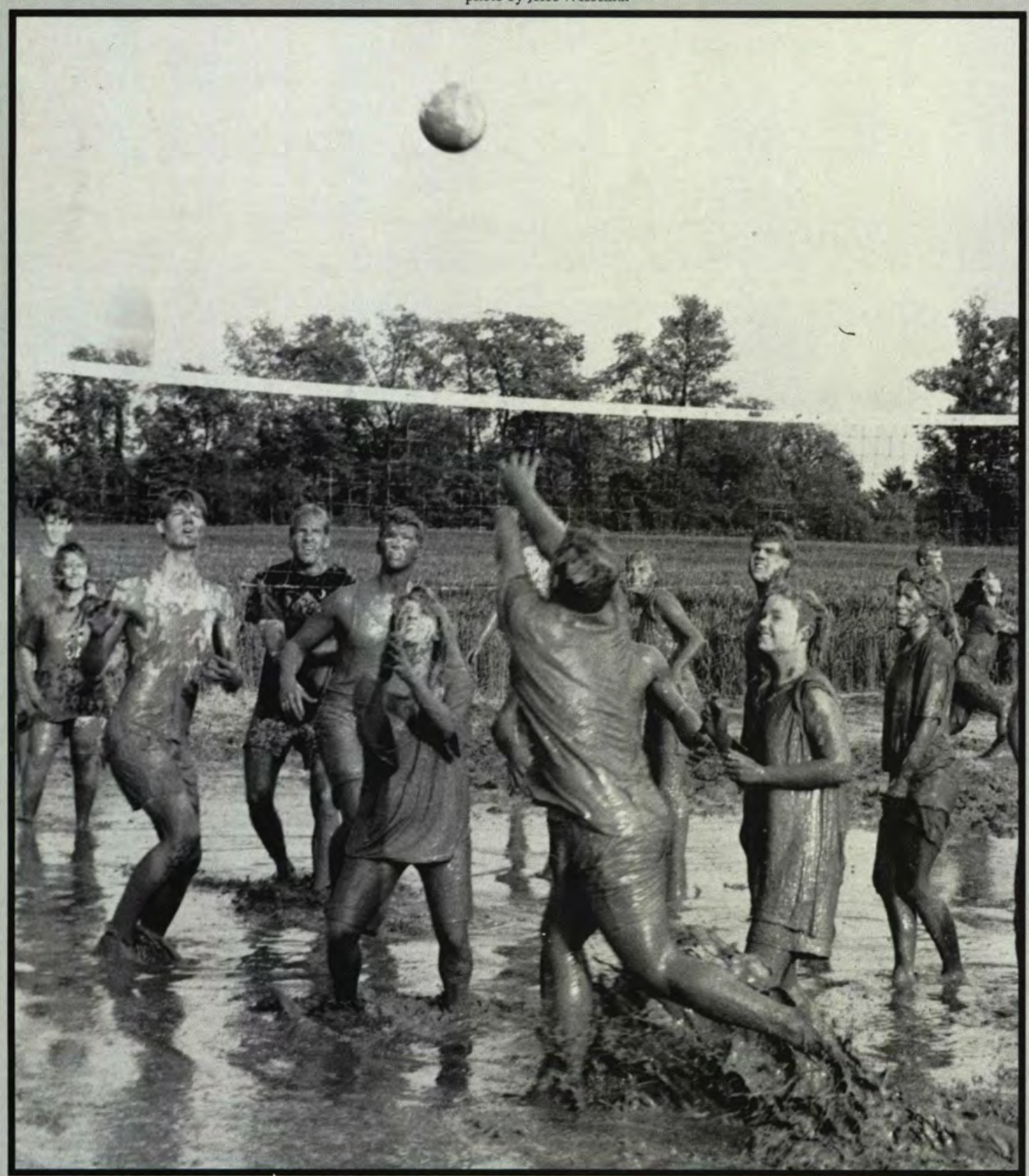

photo by Marsha Olsen
Oozeball tournament

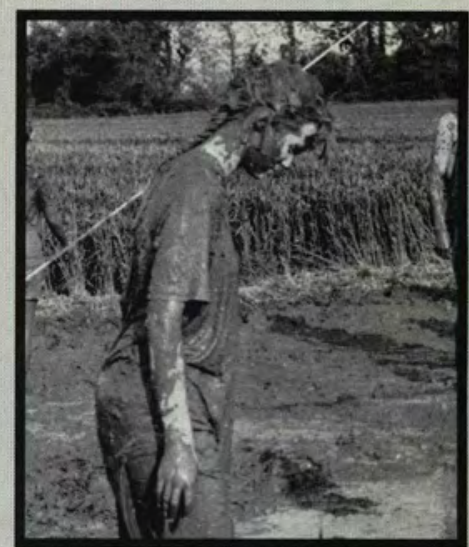

photo by Marsha Olsen

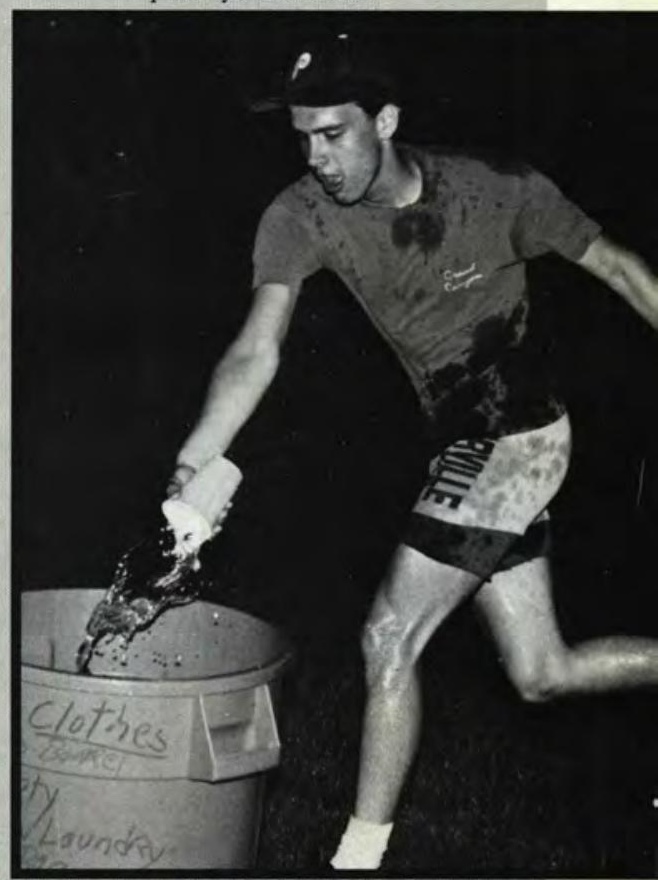

photo by Jesse Wesselink

Student brings home the prize in the "Battle for the Sahara." 


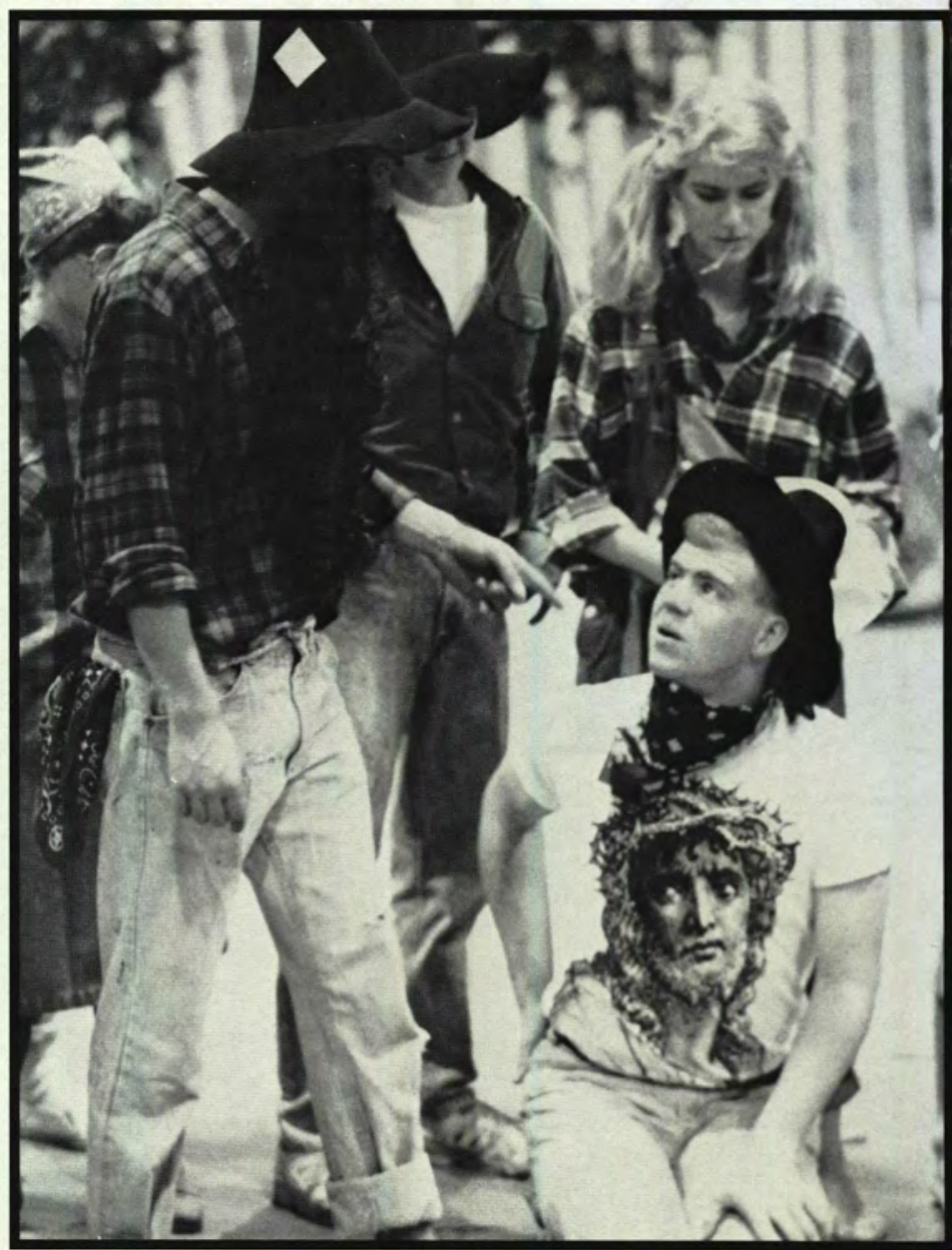

photo by Andy Jamieson

photo by John Bush
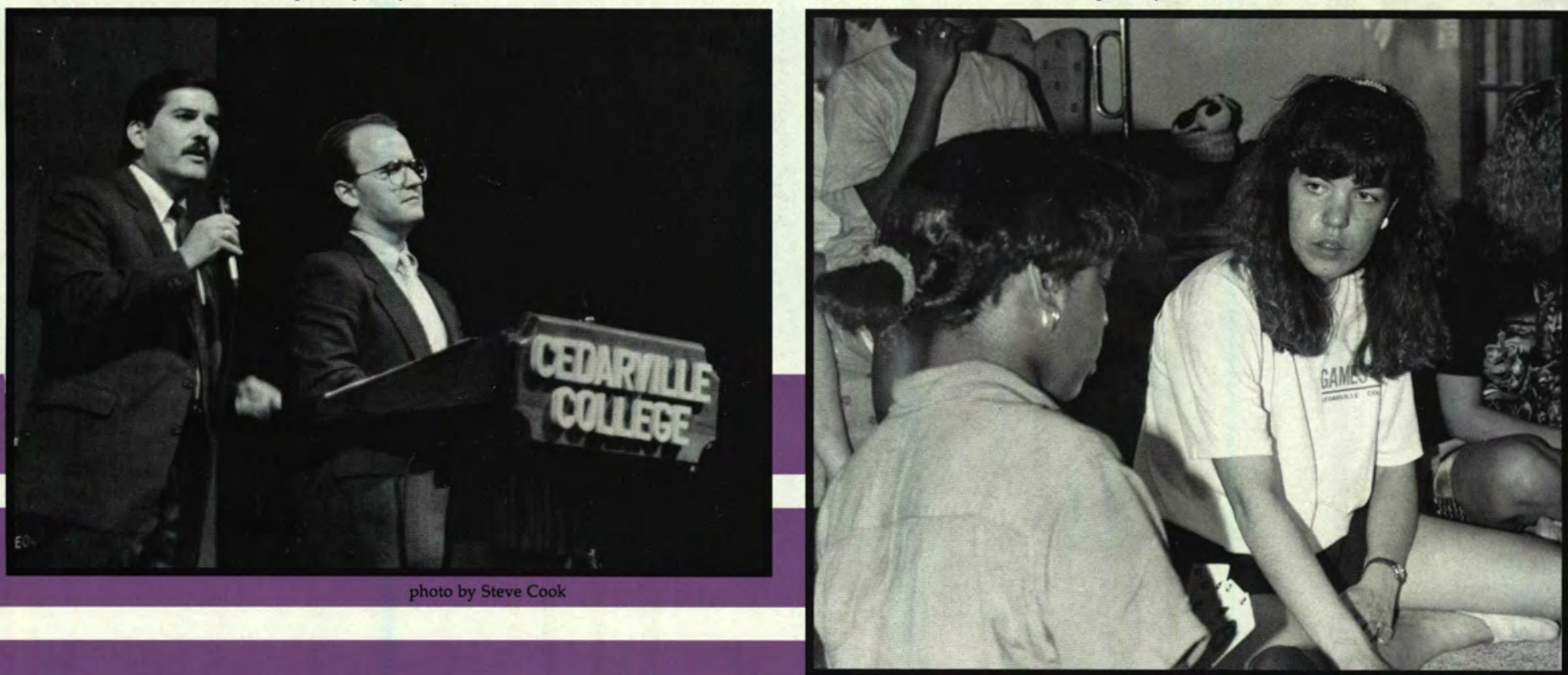

\section{When Miracles Merge. . . They Glorify the Master}




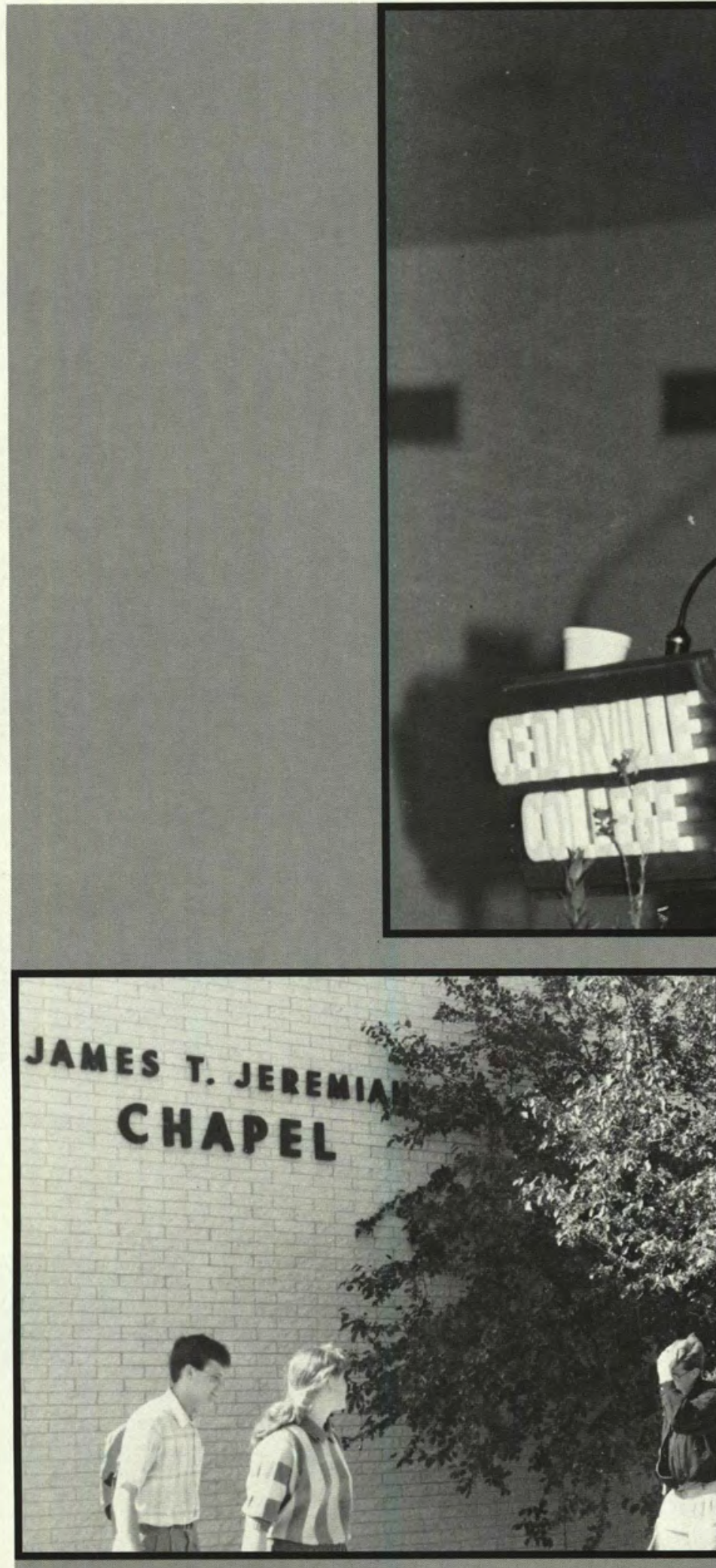

The quarterly handing out of the 4.0 cups is a highlight for the exceptional students. 


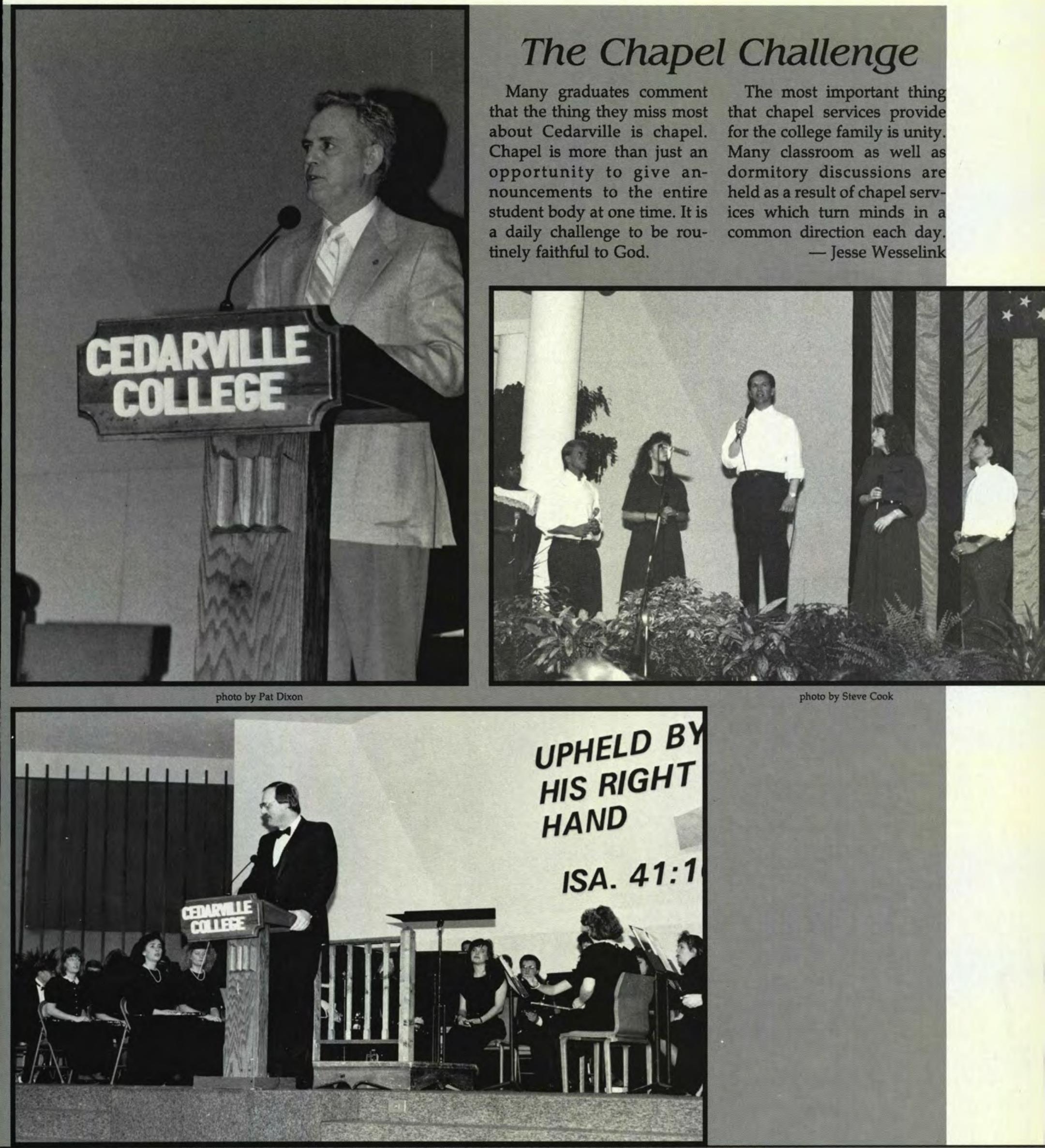




\section{Ready for Lunch. . . \\ With Jesus?}

The 1991 Winter Enrichment Conference left many students with a new desire to serve God and live each day for him. Through four powerful messages, Dr. Jerry Falwell and Dr. Jim Custer challenged the Cedarville Family to be prepared to "have lunch with Jesus."

Dr. Falwell began the annual conference with messages directed at new beginnings. Dr. Jim Custer of the Grace Brethren Church of Worthington, $\mathrm{OH}$, continued the week with messages on the Middle East situation and how it relates to the End Times.

What if Jesus were to come back today? Are we ready to meet Him? Through the conference, God reminded us that $\mathrm{He}$ is in control, and we should live our lives "ready to have lunch with Him."

\section{Conferences}

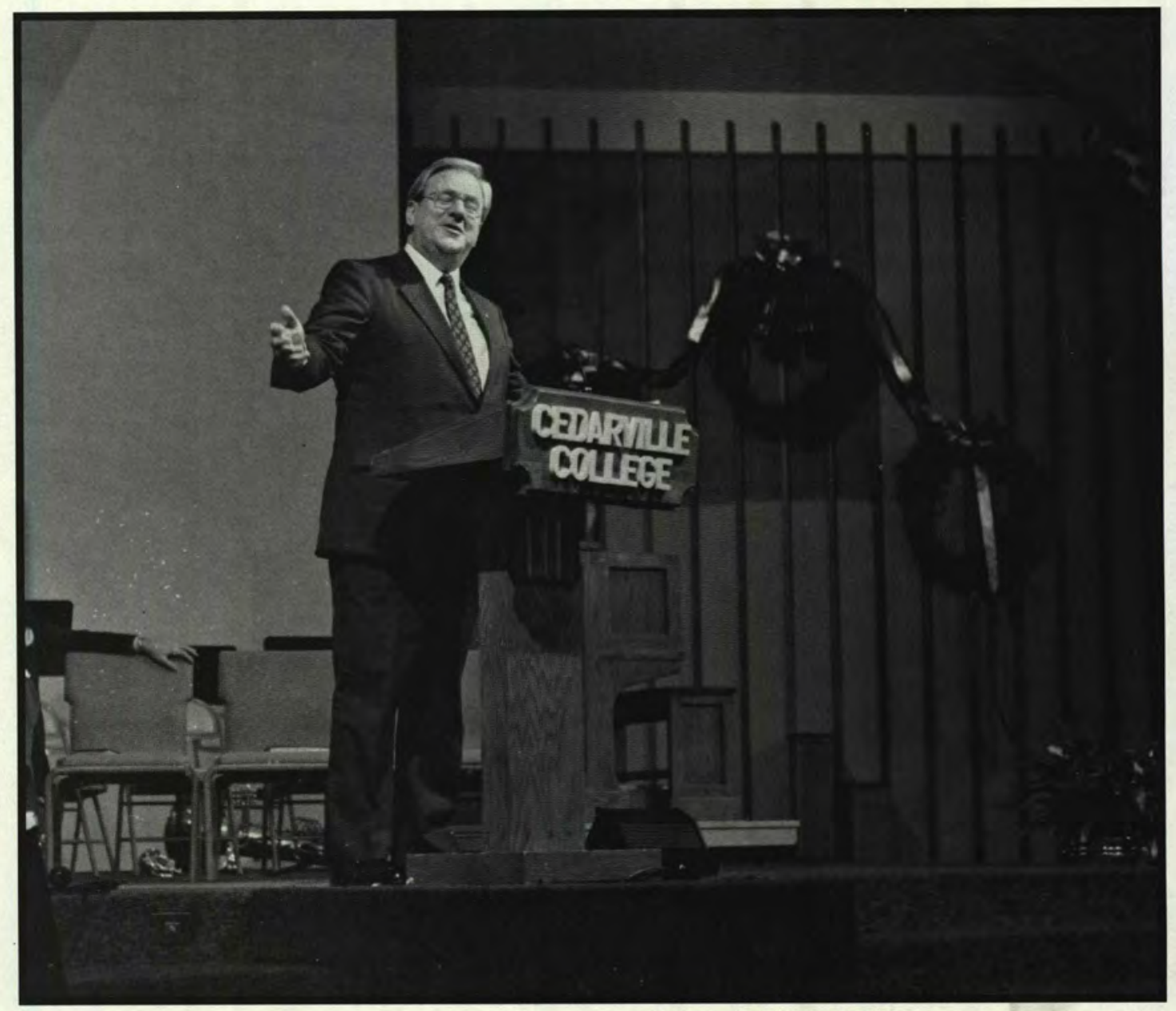

photo by Steve Cook

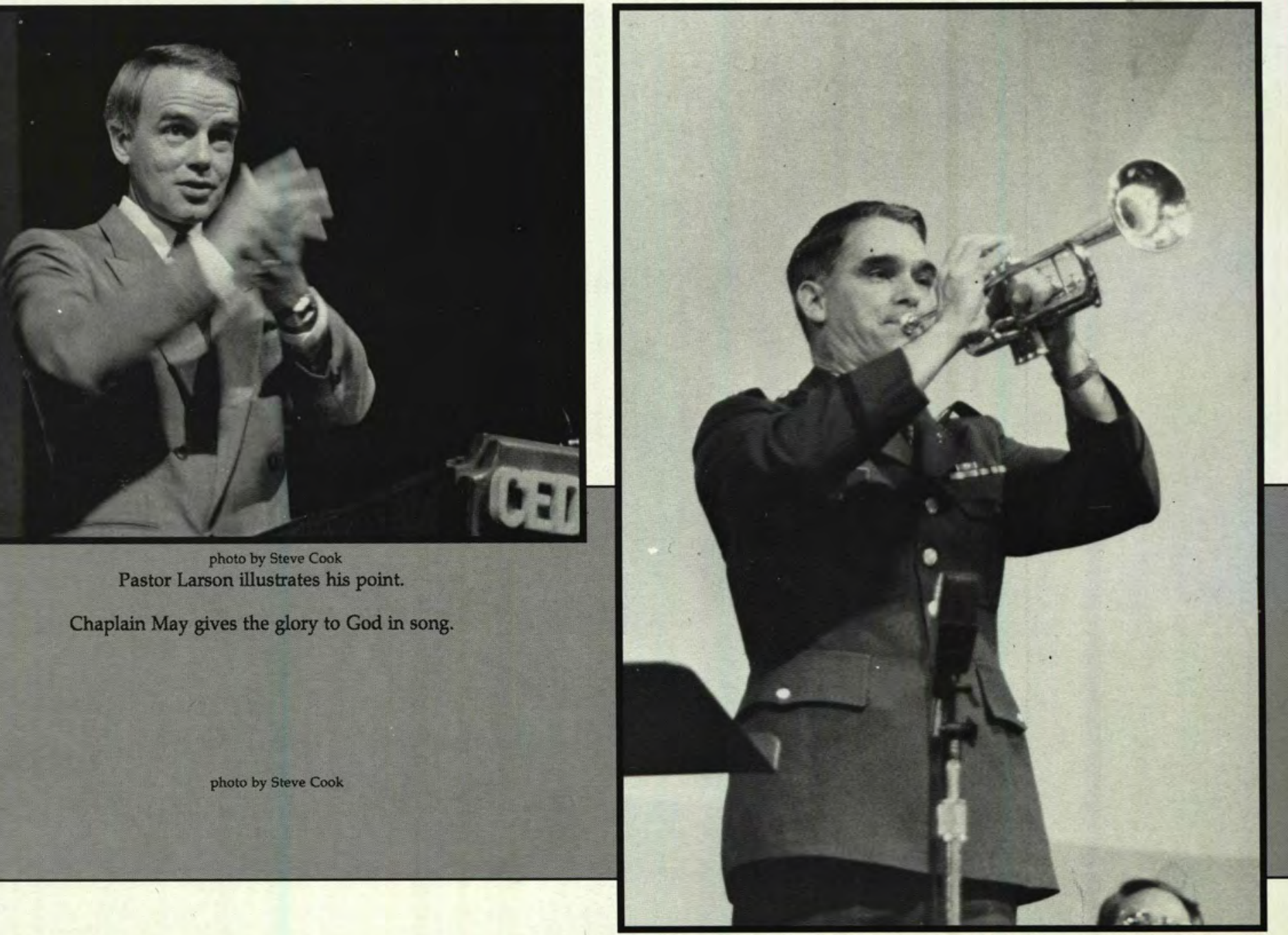




\section{True Worship}

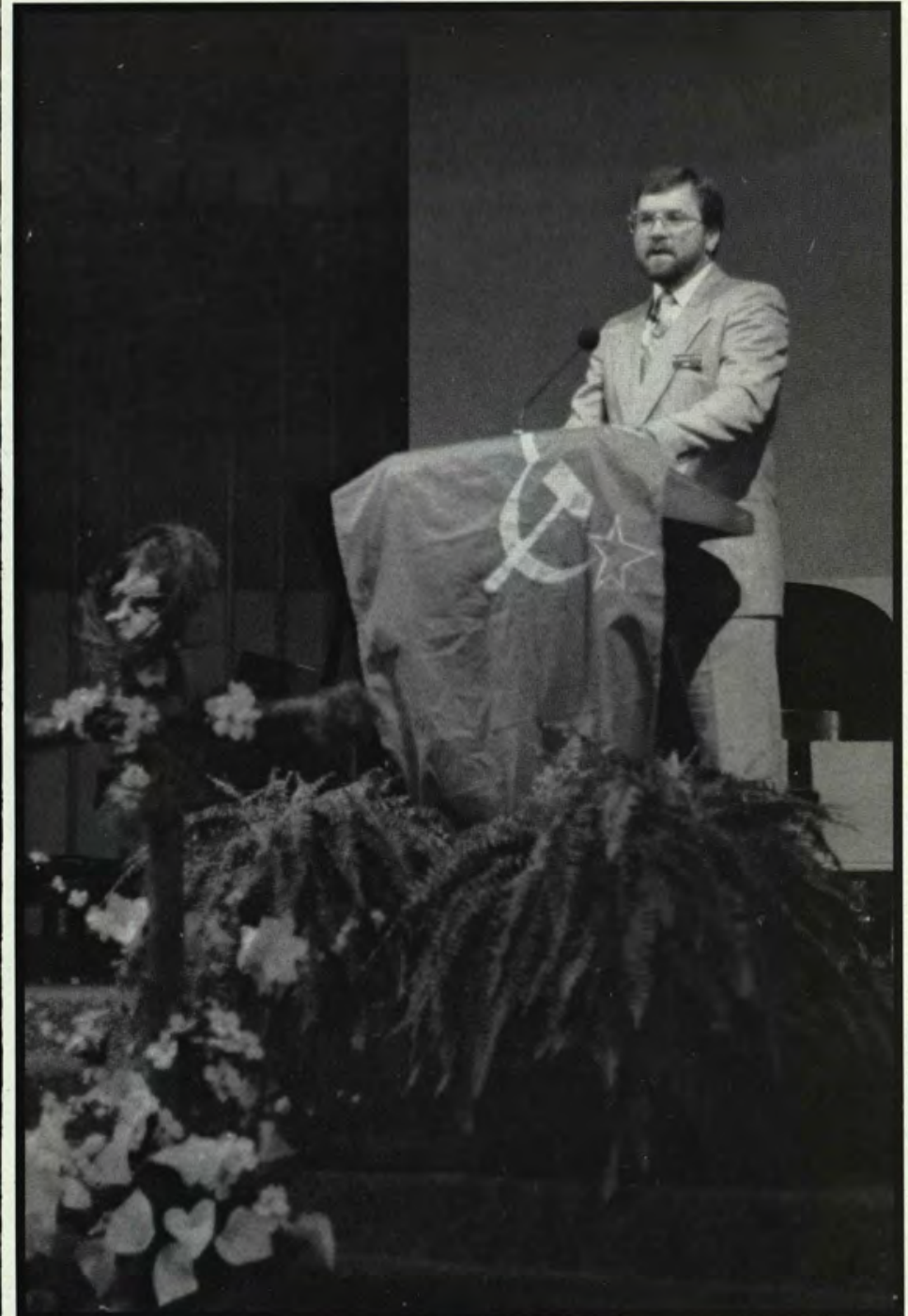

New friends, old friends, fond memories of a summer now ending, room registration and lots of lines. These are some of the thoughts that accompany the beginning of Fall quarter for many students, but the Fall of 1990 brought one more thing to the minds of Cedarville College students - WORSHIP. Rev. Larson, senior pastor of the Chapel in Akron, $\mathrm{OH}$, came for the Fall
Conference and presented the students with a fresh look at the meaning of worship. Pastor Larson, along with the minister of music from the Chapel, not only told students how and why to worship, but also modelled true, sincere, and excellent worship. This was truly a good start to a year of growth at Cedarville.- Jesse Wesselink

photo by Jesse Wesselink
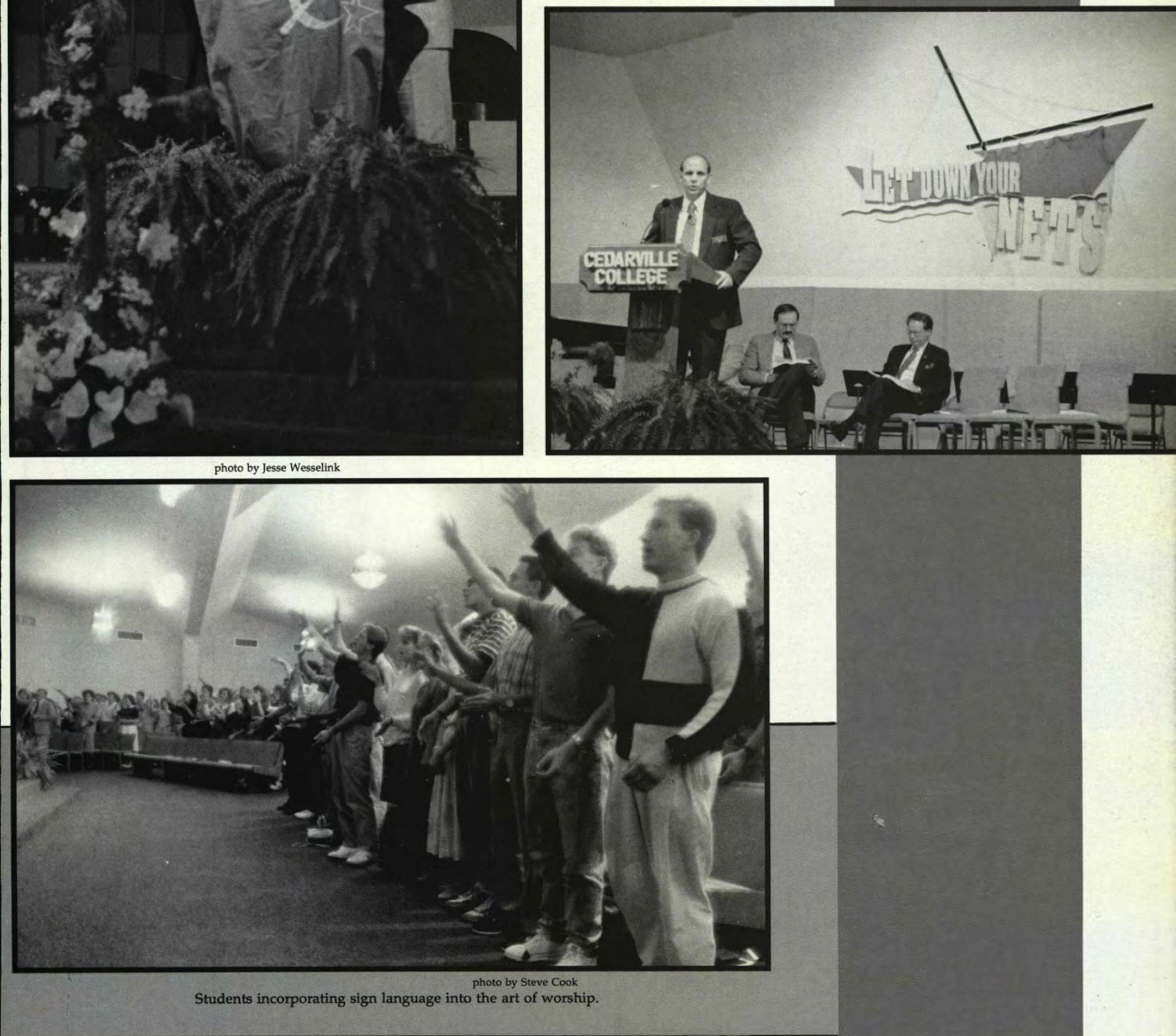


\section{Summer 1990}

\section{Proclaiming Christ. . .}
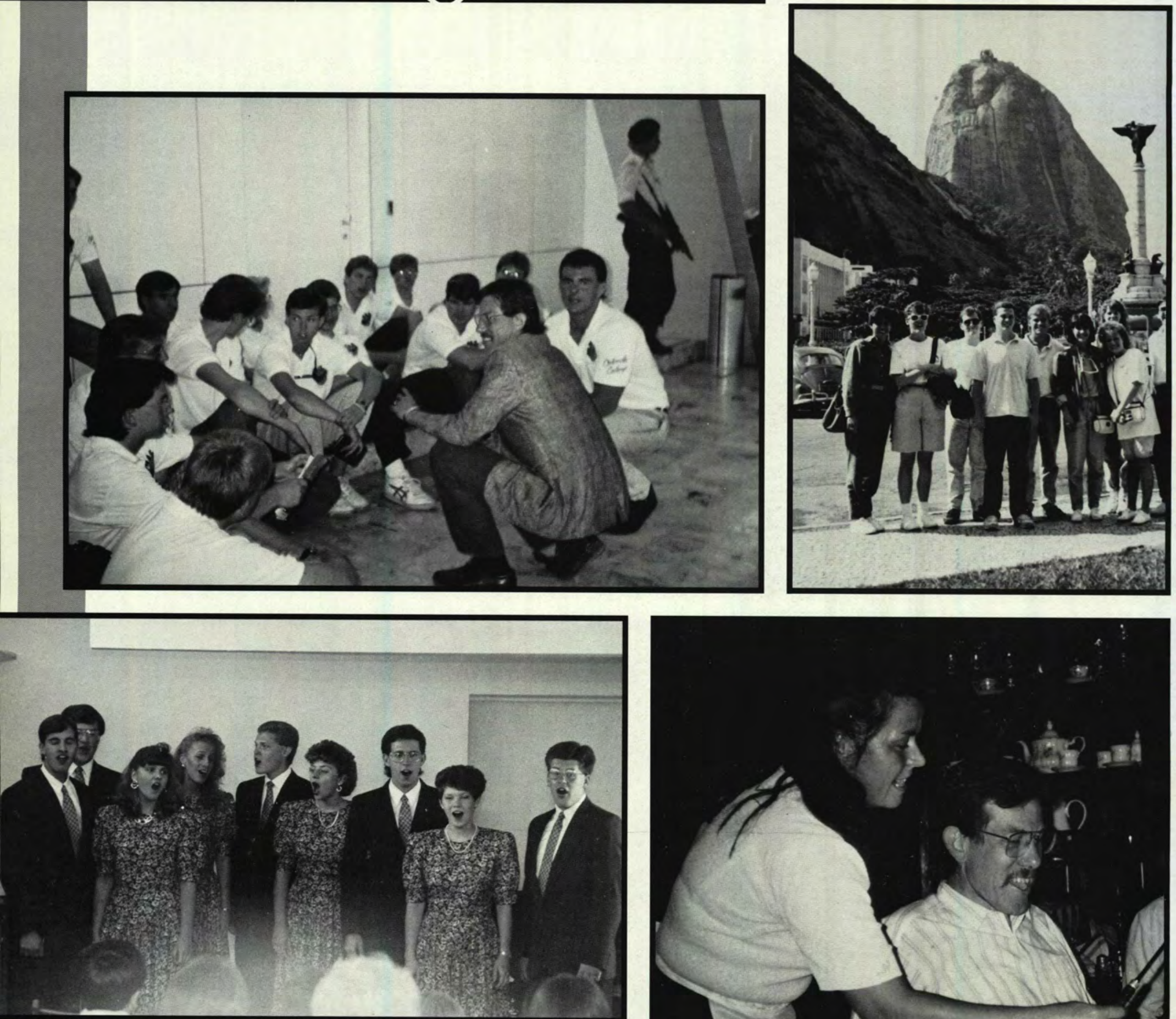


\section{Summer Master's Puppets}

First row: Heidi Westbeld, Maribeth Tramel Second row: Eric Schroll, Reid Gritsavage, Andrew Shearer
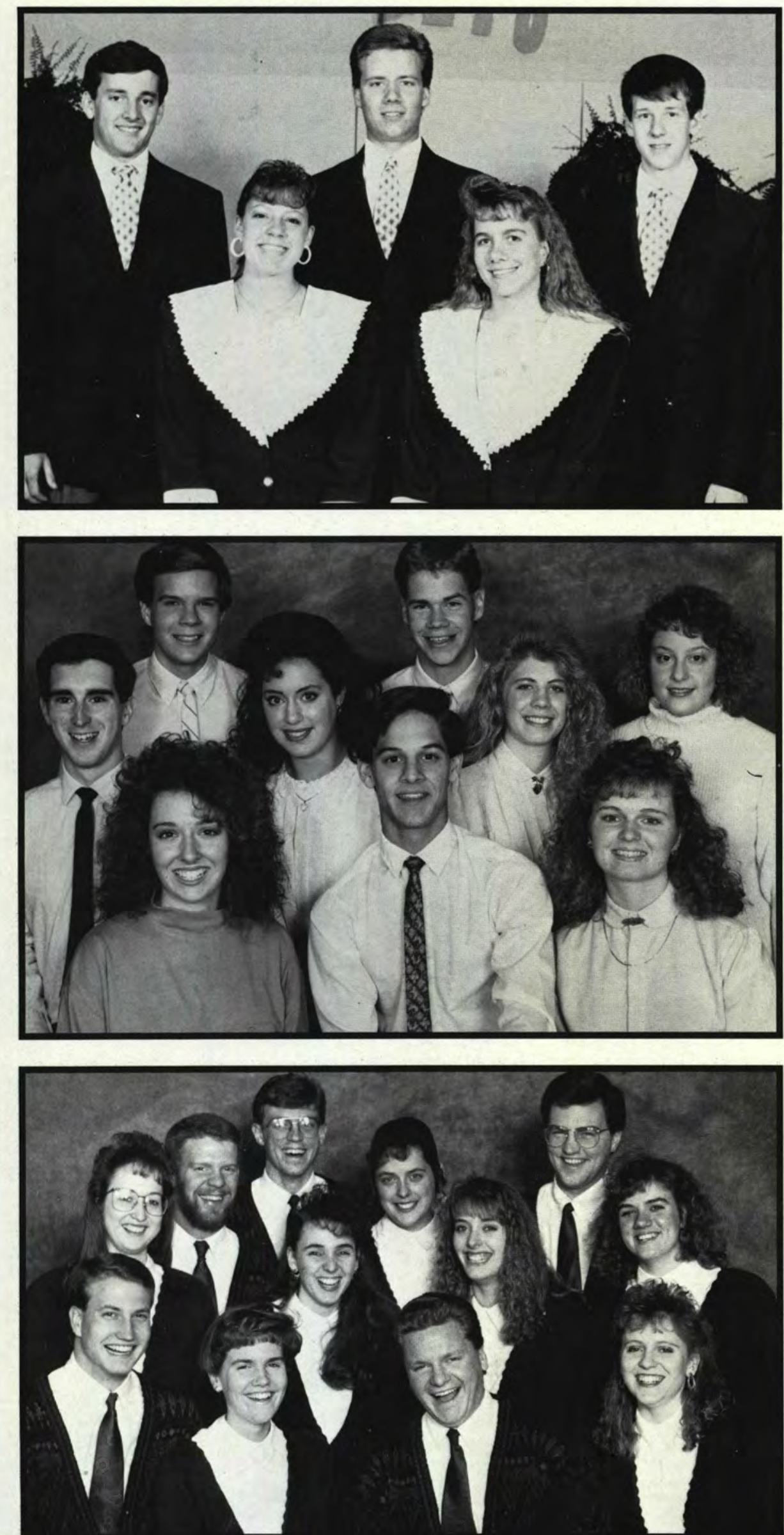

\section{Puppets Writing Team}

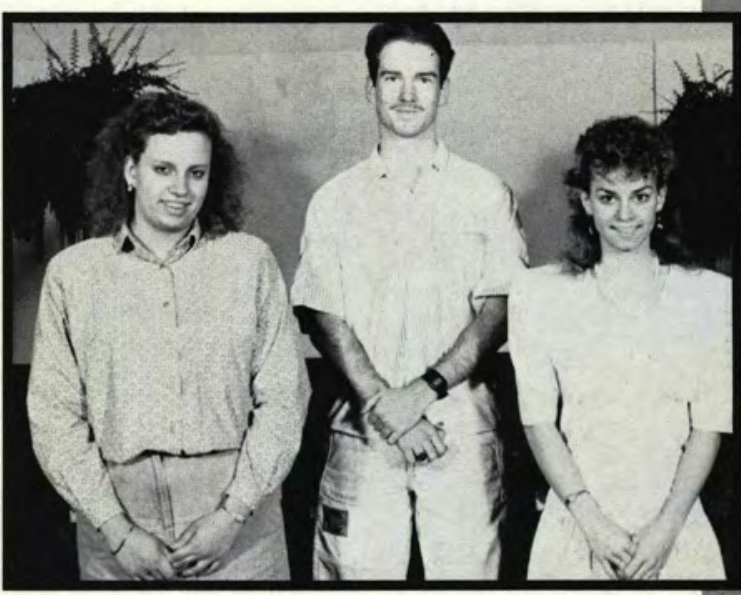

Dawn Ponybtim, Tom Bonifield, Holley Leadbeater Not pictured: Susan Clark, Christine Melvin

\section{Abundant Life Singers}

First row: Dana Gosser, Jeremy Grinnell, Susan Beach Second row: Bruce McKanna, Tracie Dennison, Heidi Krueger Third row: Rob Reed, Doug Schmitt, Heather Rifenberick

\section{Summer}

\section{Swordbearers}

First row: Drue Wolfe, Darcey Blenis, Eric Adnams, Nanci Woodard Second row: Cheryl Steiner, Carmen Bower, Jennifer Libby, Kim Averitt Third row: Curtis Carr, Mark Warnshuis, Lori Jones, Justin Van Eaton

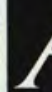




\section{Taking Christ. . .}

\section{Master's Puppets}

Master's Puppets Traveling to various churches throughout the school year, this team shares the gospel through puppets. This ministry is especially aimed at the children with whom the team comes in contact; the children are very receptive to Christ when presented in this manner. The members of Master's Puppets develop close friendships with each other as they work together on a continual basis.

First Row: Joe Lausin, Brian Guinther, Second Row: Shelly McCullough, Amy

Whalen, Lisa Solum, Not Pictured: Phil Graves

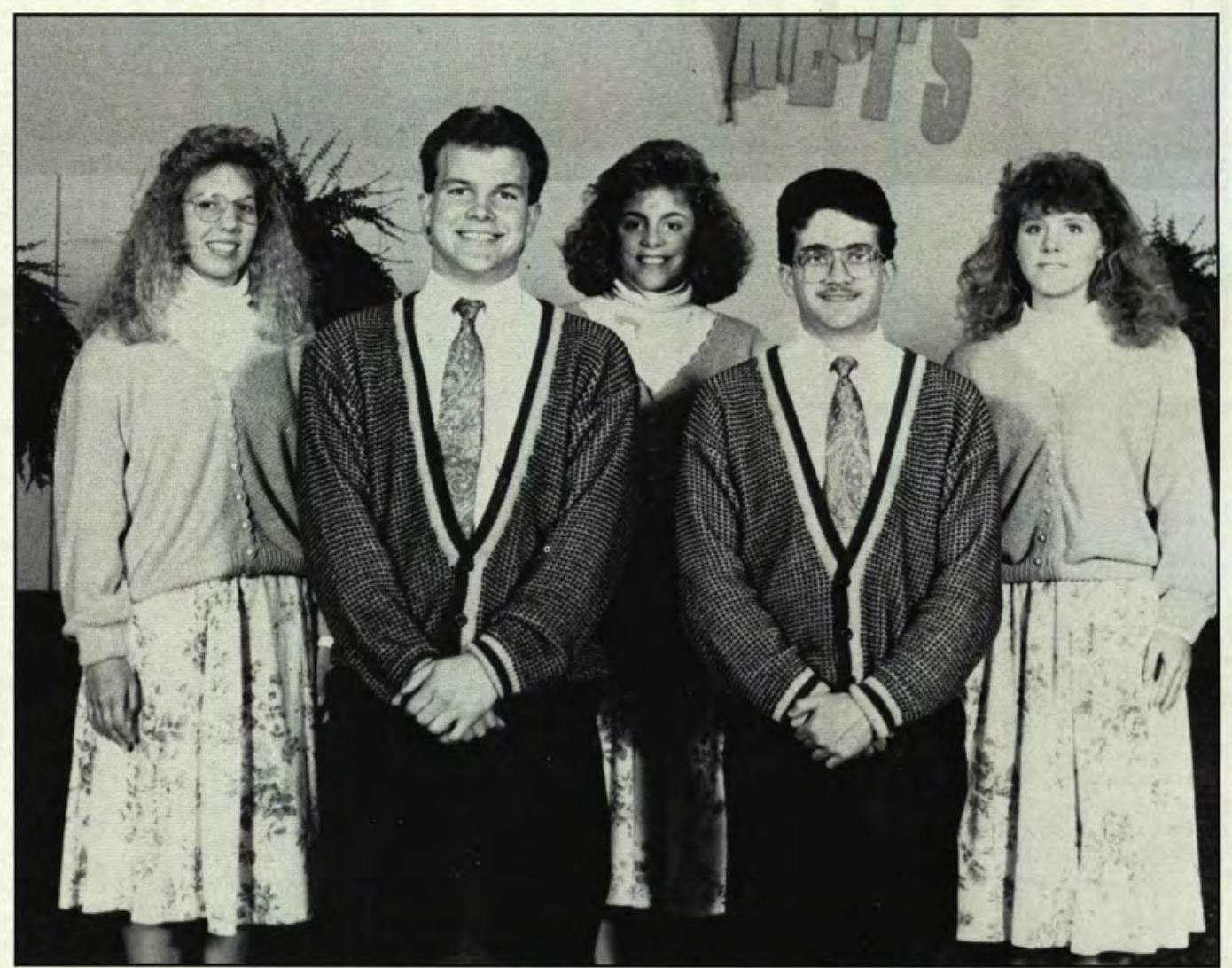

\section{Kingsmen Quartet}

Kingsmen Quartet This group of Cedarville men travels to various churches and youth activities to spread the gospel through song. The close harmony of their music makes it entertaining and enjoyable for all age groups.

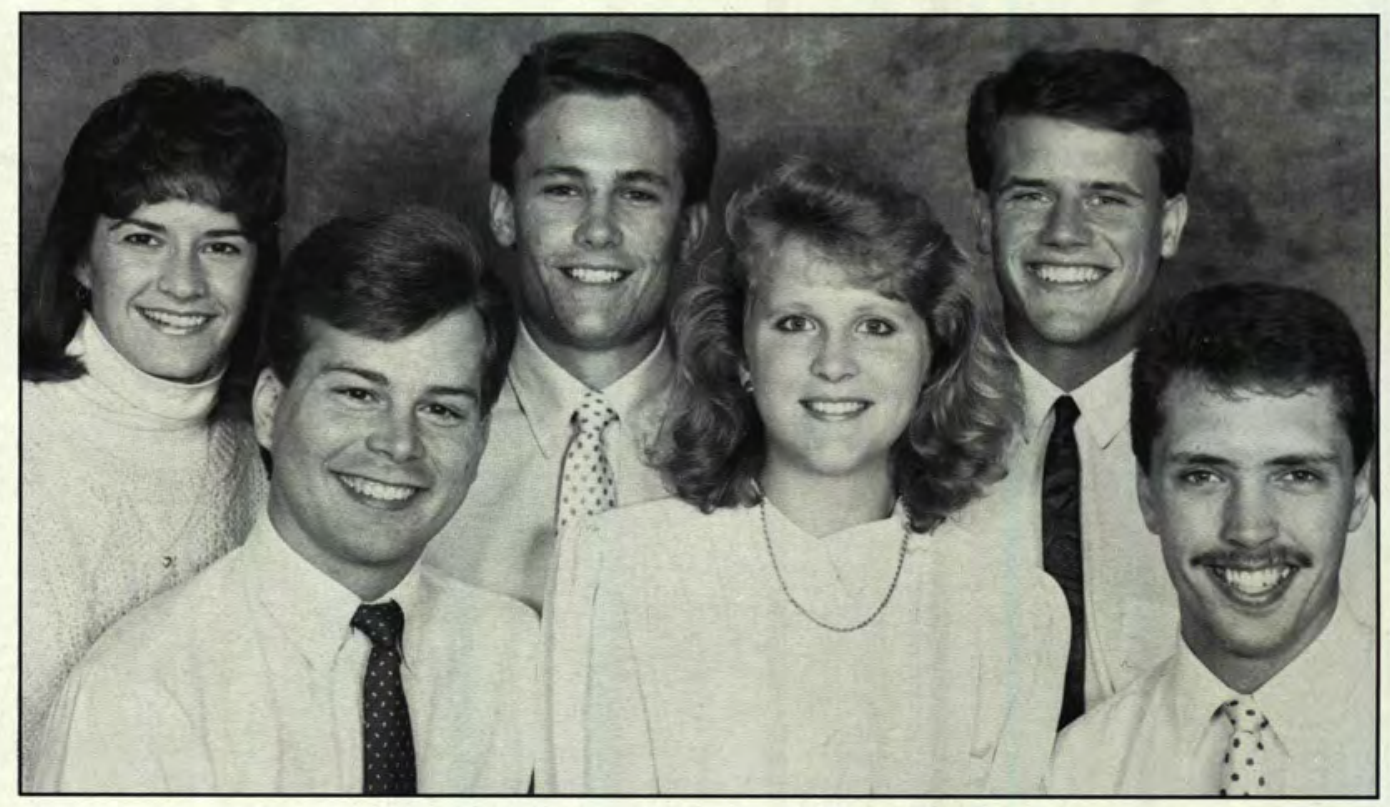

First Row: Tim Walborn, Amanda Dye, Steve Murphy, Second Row: Wendy Le Blanc, Chad Coe

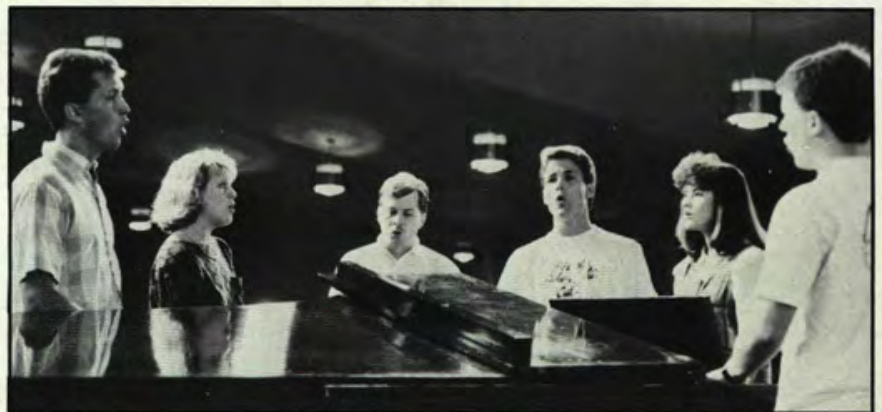



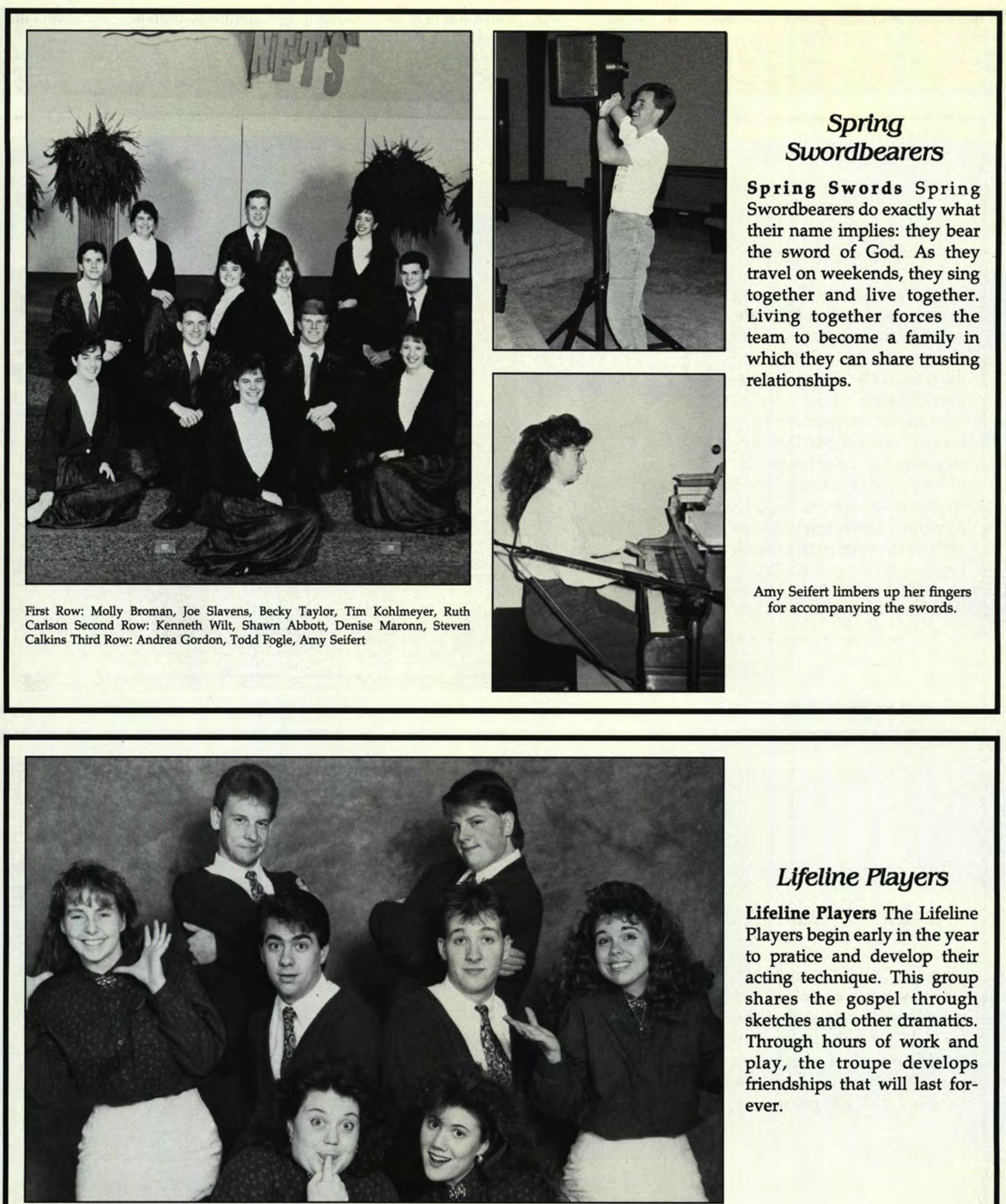

\section{Lifeline Players}

Lifeline Players The Lifeline Players begin early in the year to pratice and develop their acting technique. This group shares the gospel through sketches and other dramatics. Through hours of work and play, the troupe develops friendships that will last forever.

First Row: Elizabeth Sizemore, Debbie Christner,

Second Row: Samantha Doering, Duane Baggerly, Gary Childers, Lori Wright, Third Row: Bill Montgomery, Andy Eastman

\section{.. .On The Road}




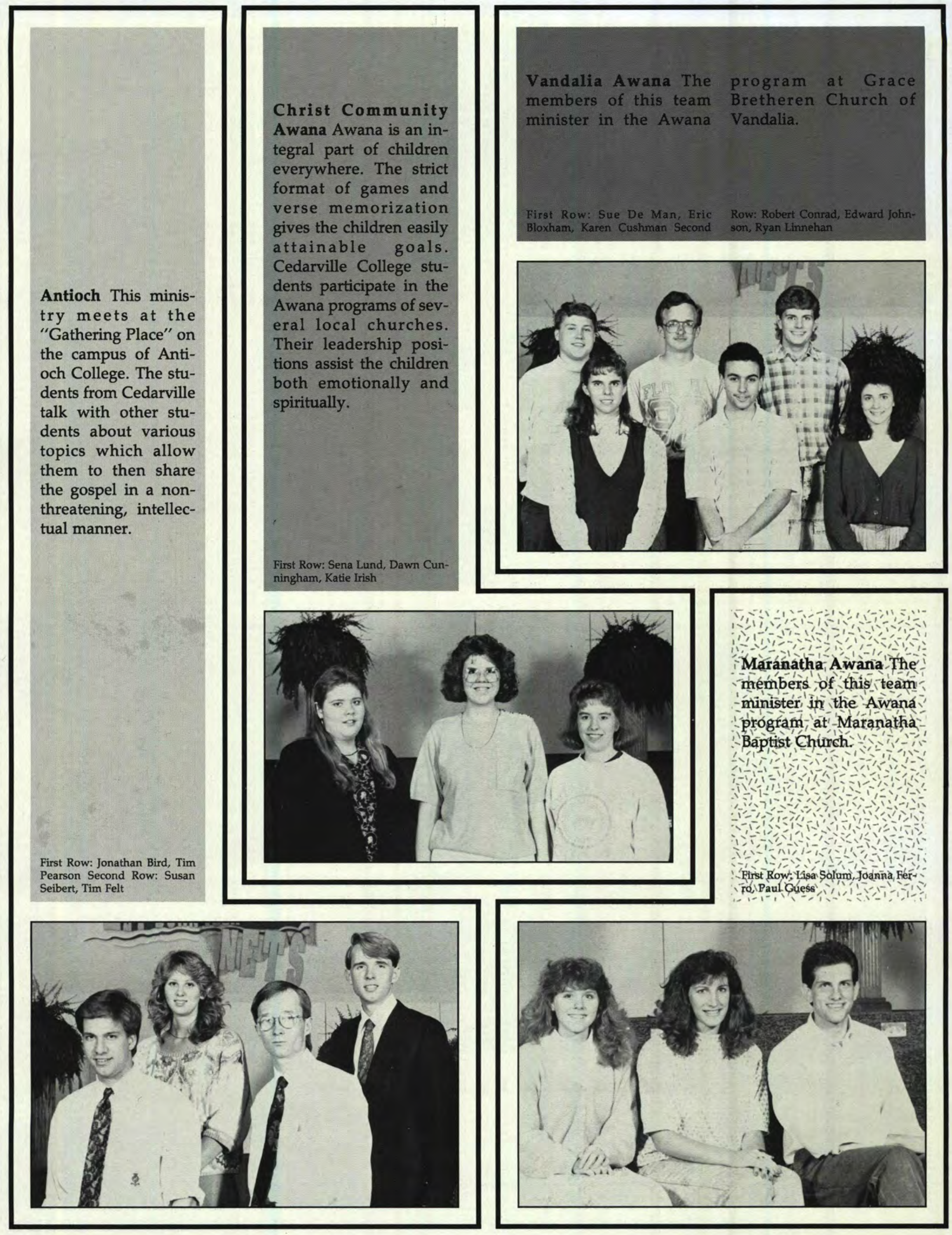




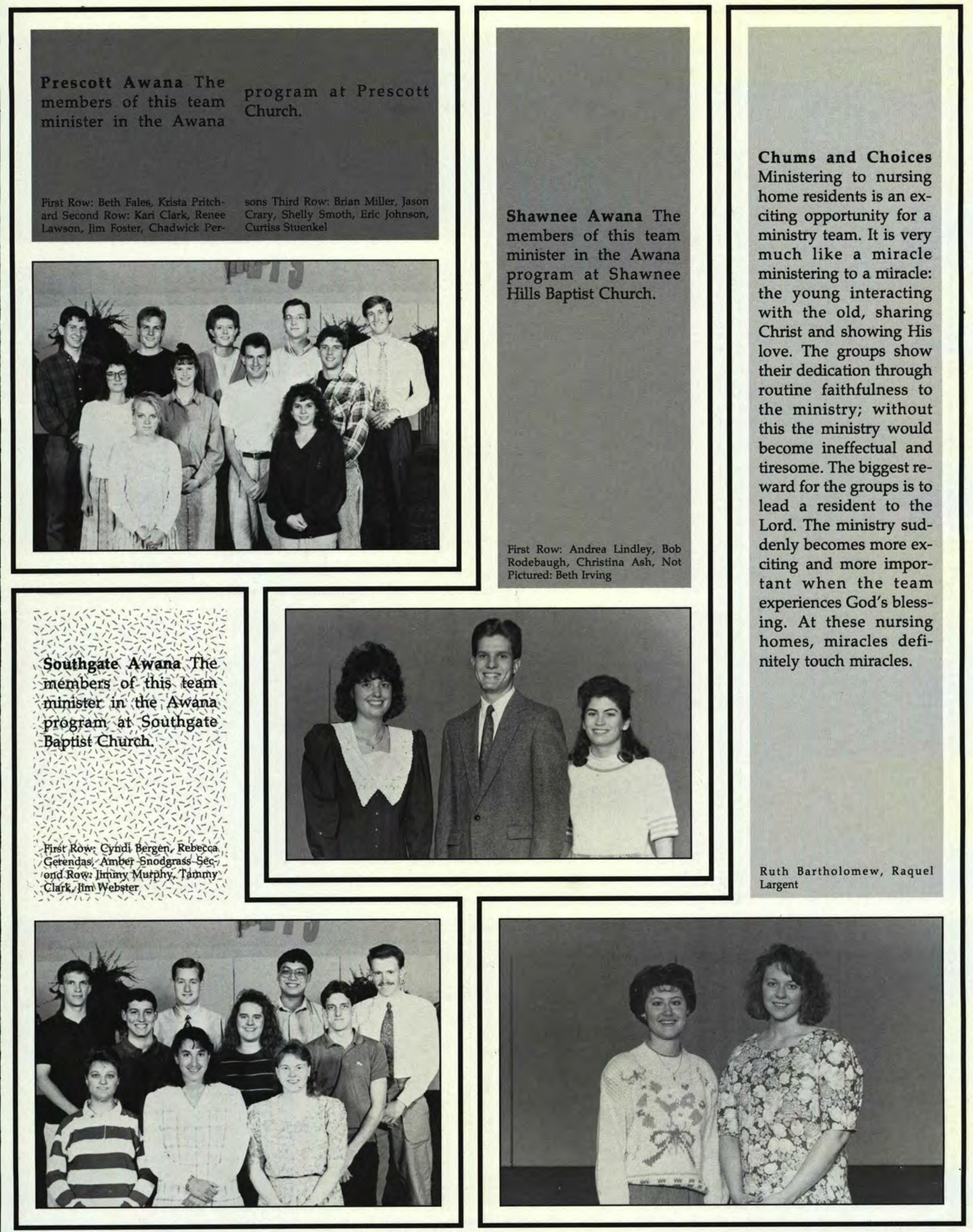


Cedar Cliff Elderly

Housing In this ministry to the elderly of Cedarville, college students are able to develop relationships with the elderly in such a way that they become "adoptive grandparents." Visits to homes, outings and invitations to college functions are all part of the ministry to the elderly of Cedarville.

First Row: Stephanie Hunsaker, Kelly Lucas, Annora Gross, Robin Mills Secon Row: Stephaney Hutchison, Tawna Latham, Steve Ross, Not Pictured: Kristen Nast, Abbe Beach, Stacy Muller

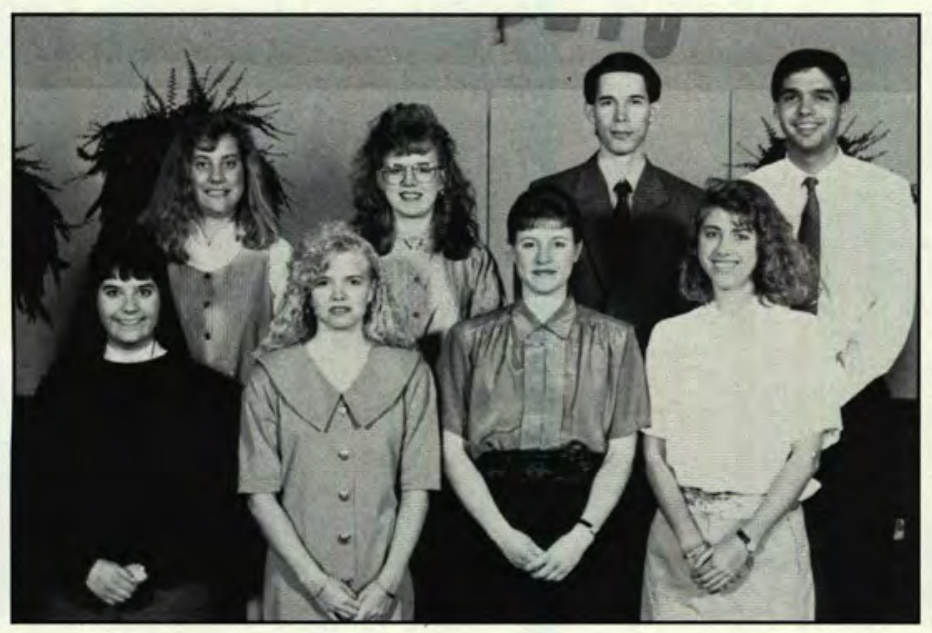

Bristol House This new Christian ministry aims at working with disabled young people as well as the elderly at Bristol House. College students attend on a weekly basis to provide church services for the residents in which they preach, sing and talk to the people in order to build lasting friendships.

First Row: Steve Wolf, Sylvia Faragalla Second Row: Mary Birley, Heather Anderson, Samantha Doering
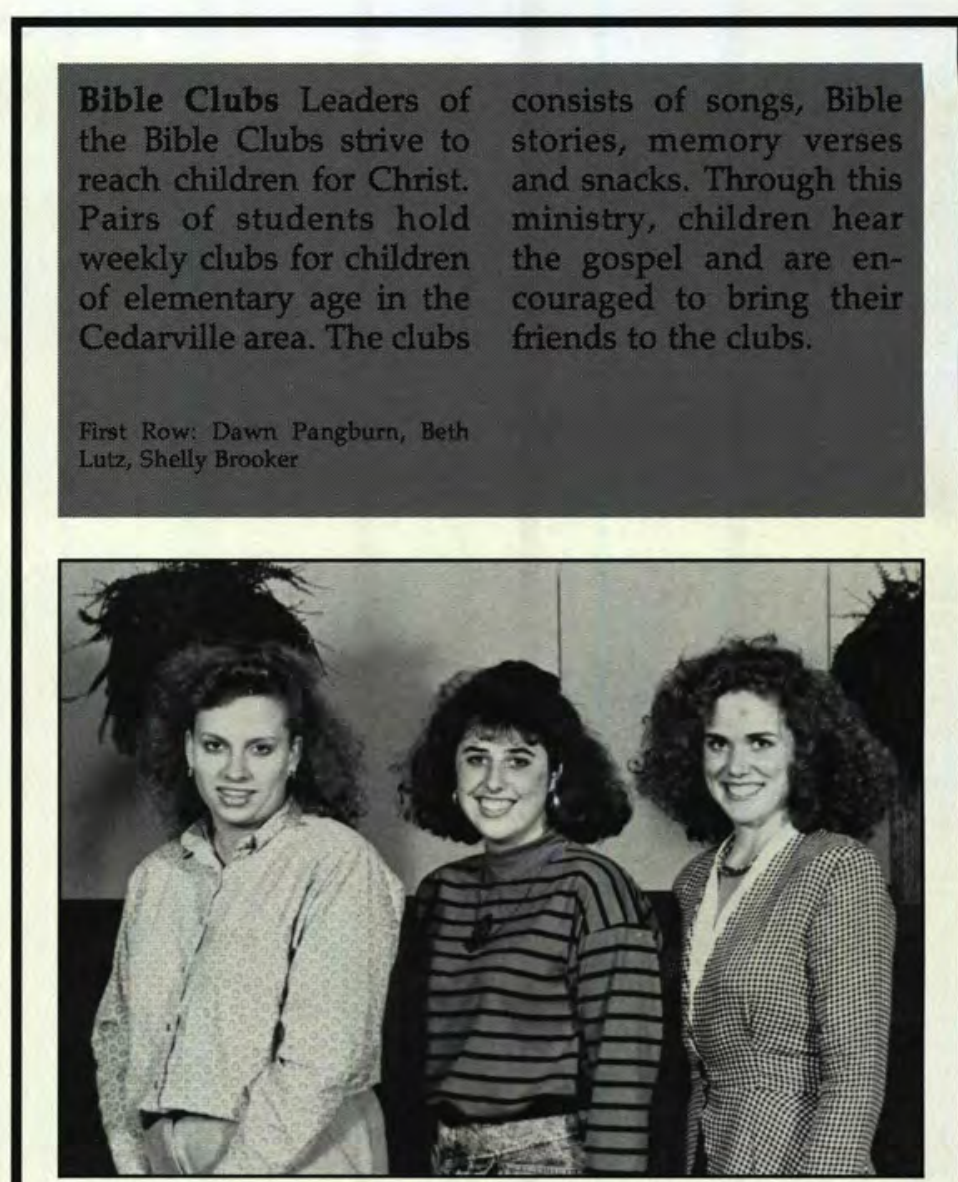

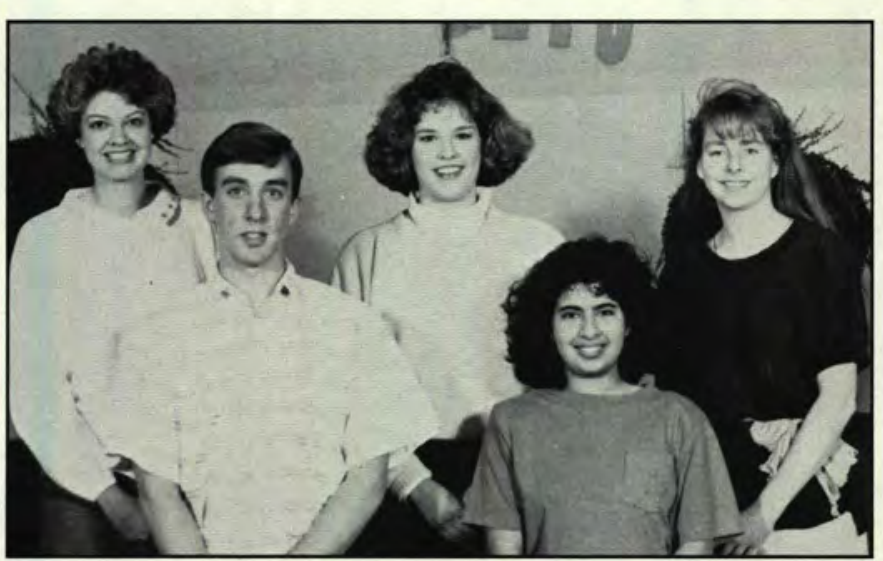

Cedar Kids Cedar Kids ministers to the under privileged children in the Cedar ville area by sharing Bible stories and playing games:

First Row Jullie Young Juendy Io, - Priest, Mary, Edwards Second Row; i, - Jamie-Alexander, Jill Errist, Rebeecea. Gillam Third Row; Erin Ward! "Gedram Third Row Erin Ward, RobbBesusa t

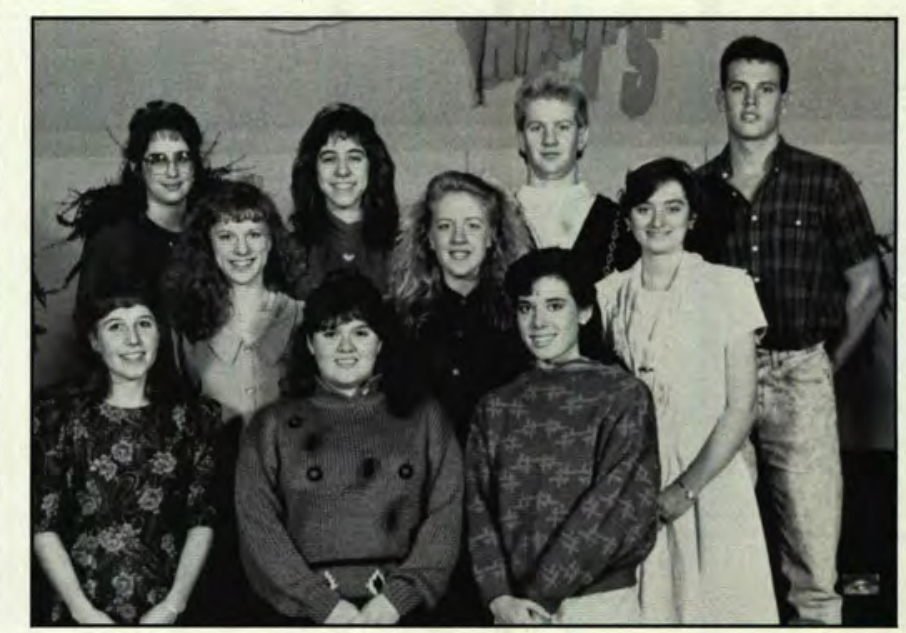



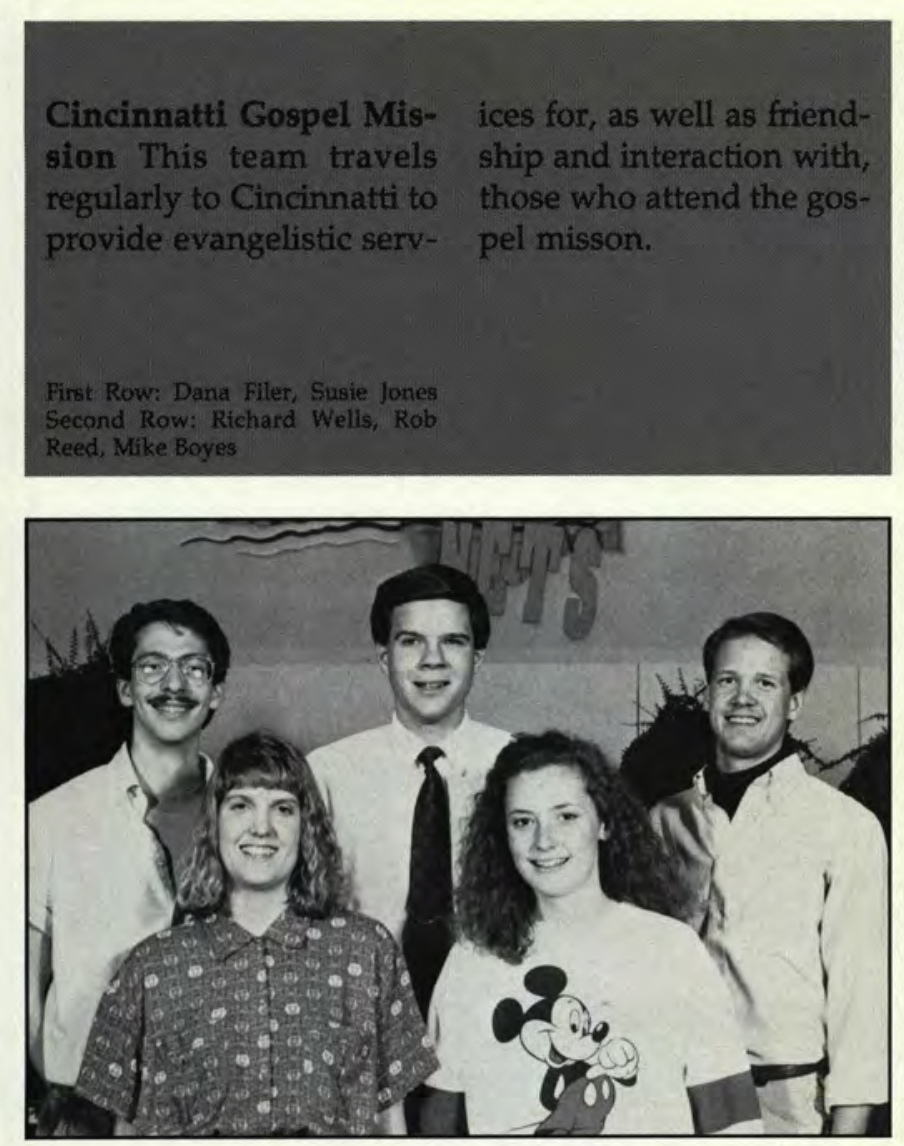

Daýón Detention Home

In this ministry, team members are able tó work with juvenite delinquents who-may have-no one elsé to turn to. Through 'various activities, members are able to share the love of Christ with kids that are so in need.

First Row: Abby Boarte, Allison Knowtes; Kevín Murachanian' Jonathan Varner Secona -Row: Eríc Bloxham, Kayrn Wyman, Beth Lutz, Jonathan Gudeman, Erik-Benson, Jamies Geise- Third, Row. Todd McQueen, Luman Strong. Harbld 'Edington, Michael Gustafson, Kelly
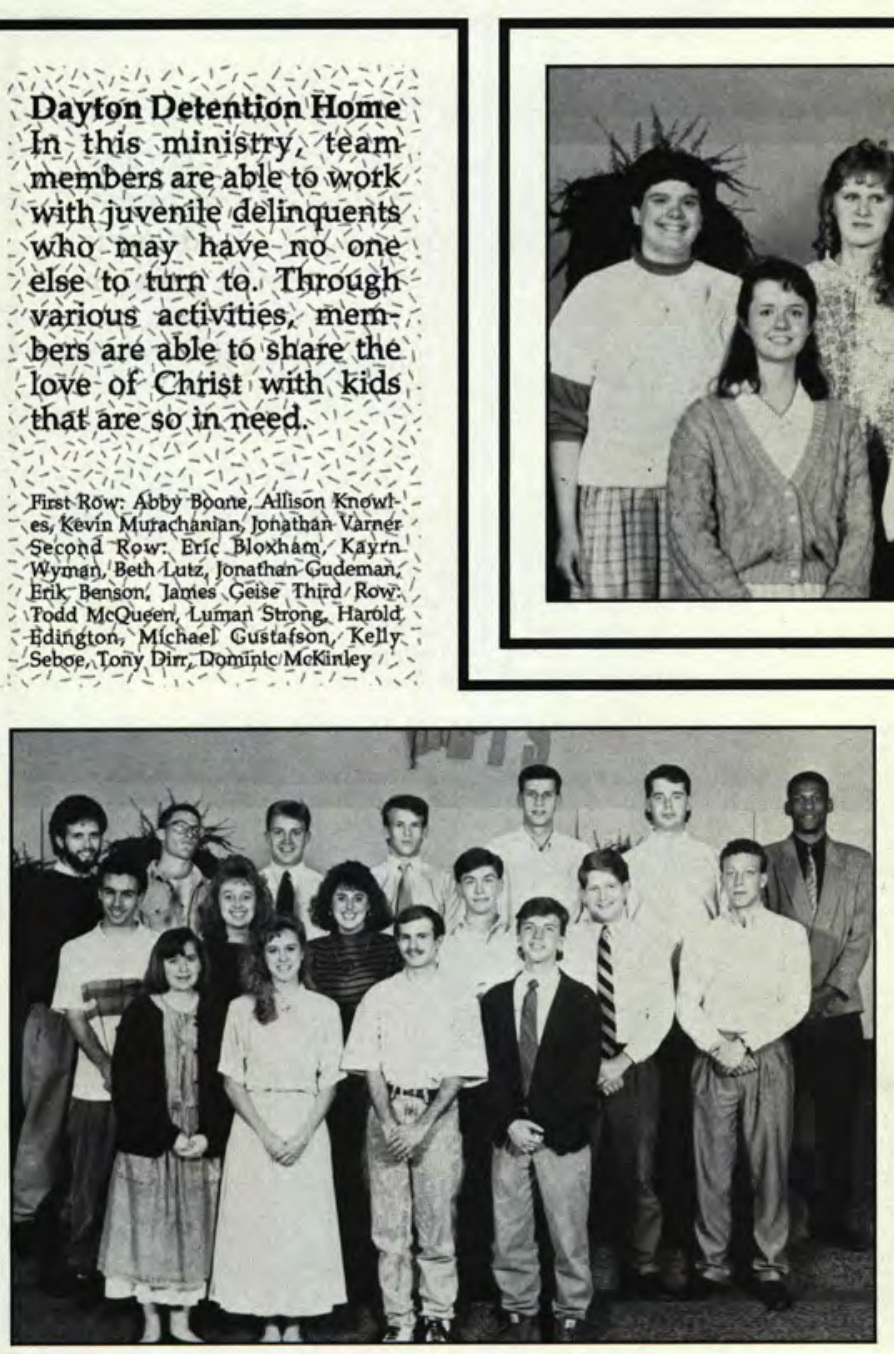

College Partners Students get the opportunity to build friendships with the children of Cedarville as a big brother or big sister. The College Partners spend time with their little brother or sister after school and on weekends; frequently they bring them to various college functions. Once a trusting relationship is established, the student can begin to witness to the child.

First Row: Brenda Killian, Melissa Smith, Maribeth Tramel Second Row: Teresa King, Marcy Johnson, Matt Cutler, Todd Fuchte

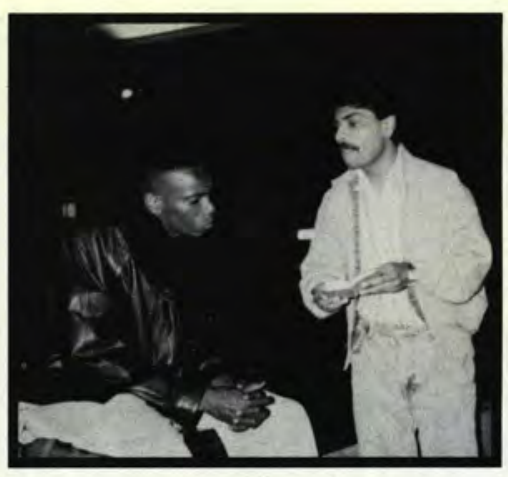

Open Heirs gives students the opportunity to share their faith in the inner city.

Dayton Gospel Mission Implementing the commands of Christ is what students who serve at the Dayton Gospel Mission are doing. Students' duties range from serving food, and leading church services to encouraging people at the mission.

First Row: Kathy Sloan, Kristen Jensen, Rita Swartzentruber, Heather Peters, Mary Bishop, Sylvia Faragalla Second Row: Darla Rudplph, Jody Souza, wland, Susan Comb Third Row: Melissa Wall, Kathleen Coy, Allison Broadhead, Dawn Pangburn, Melinda McDugle, $\mathrm{Pa}$ tricia Allen, Susan Nicholson

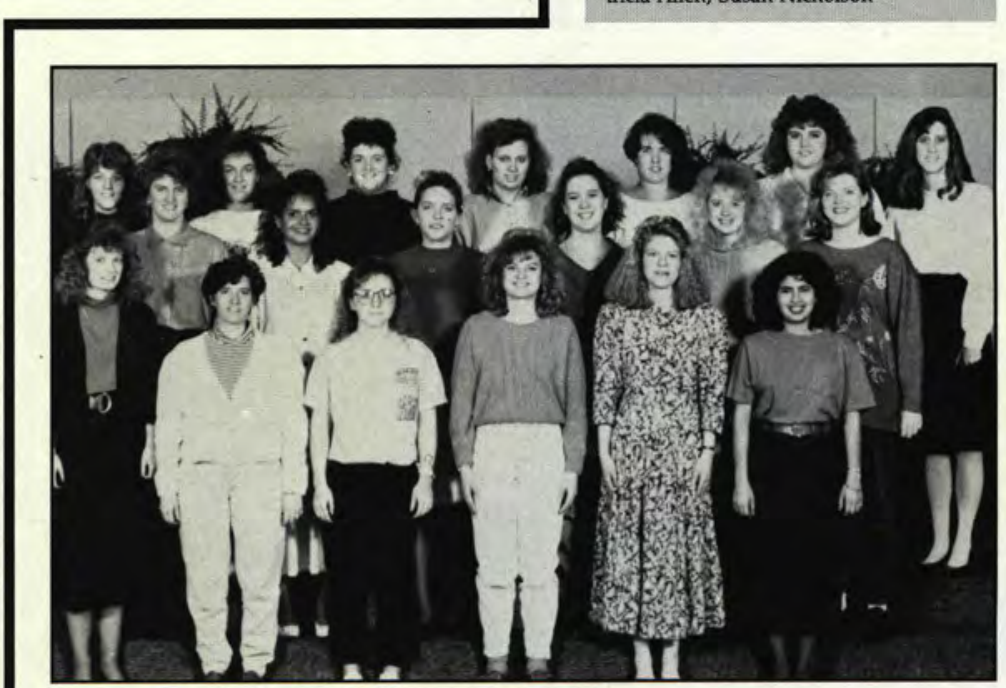



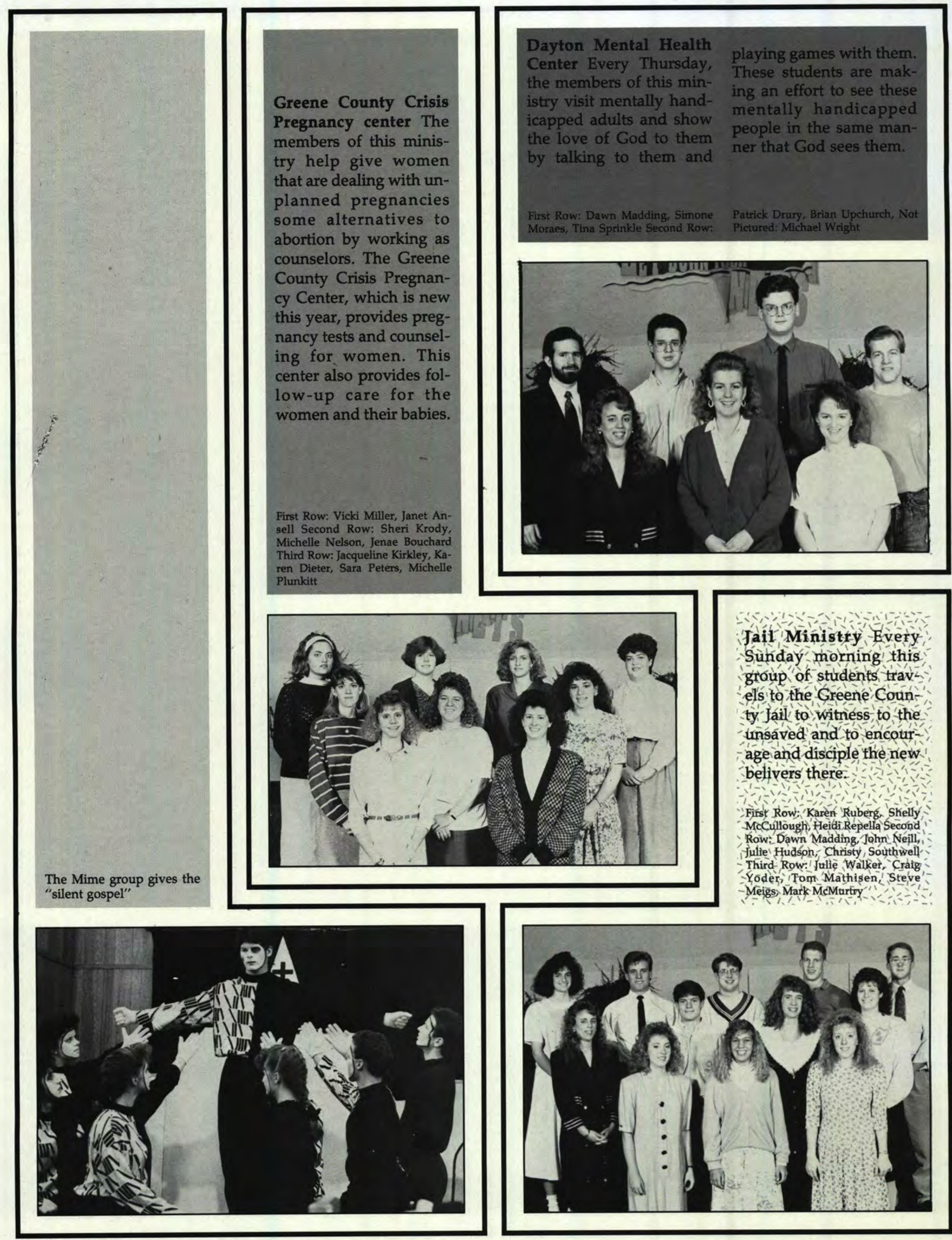

Jail Ministry Every Sunday morning this group of students trav els to the Greene County Jail to Witness to the unsáved and tó éncourage and disciple the new betivers there:

First Row: 'Karén 'Ruberg, Skelly McCullough, Heidr Repella Secónd Row: Dawn Madding, John Nejll, Julie' Hudson, Christy, Southwell Third Row: I Julie 'Walker, ' Craig - Yoder ' Tom 'Mathisen, Steve' - Meigs Mark MclMurtry

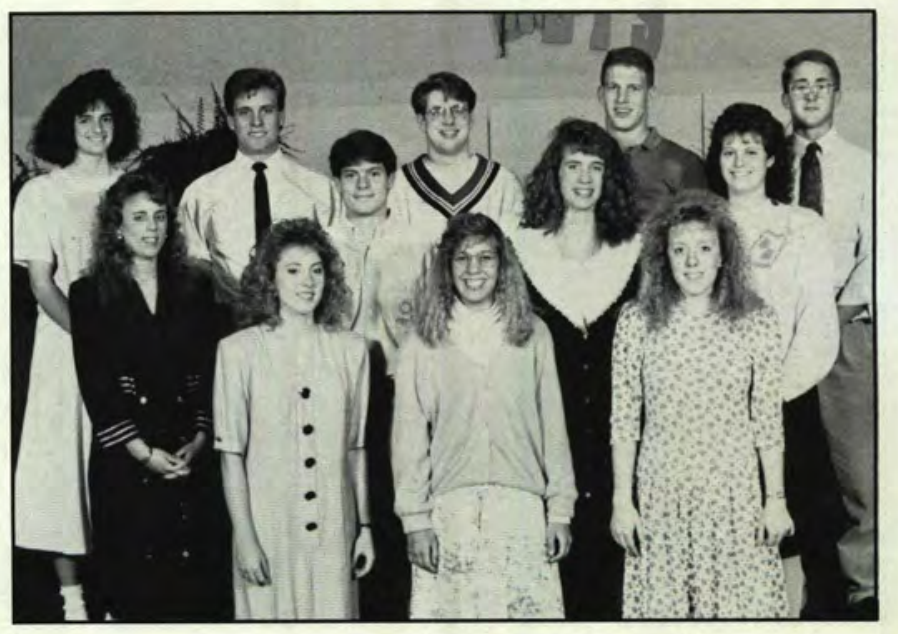




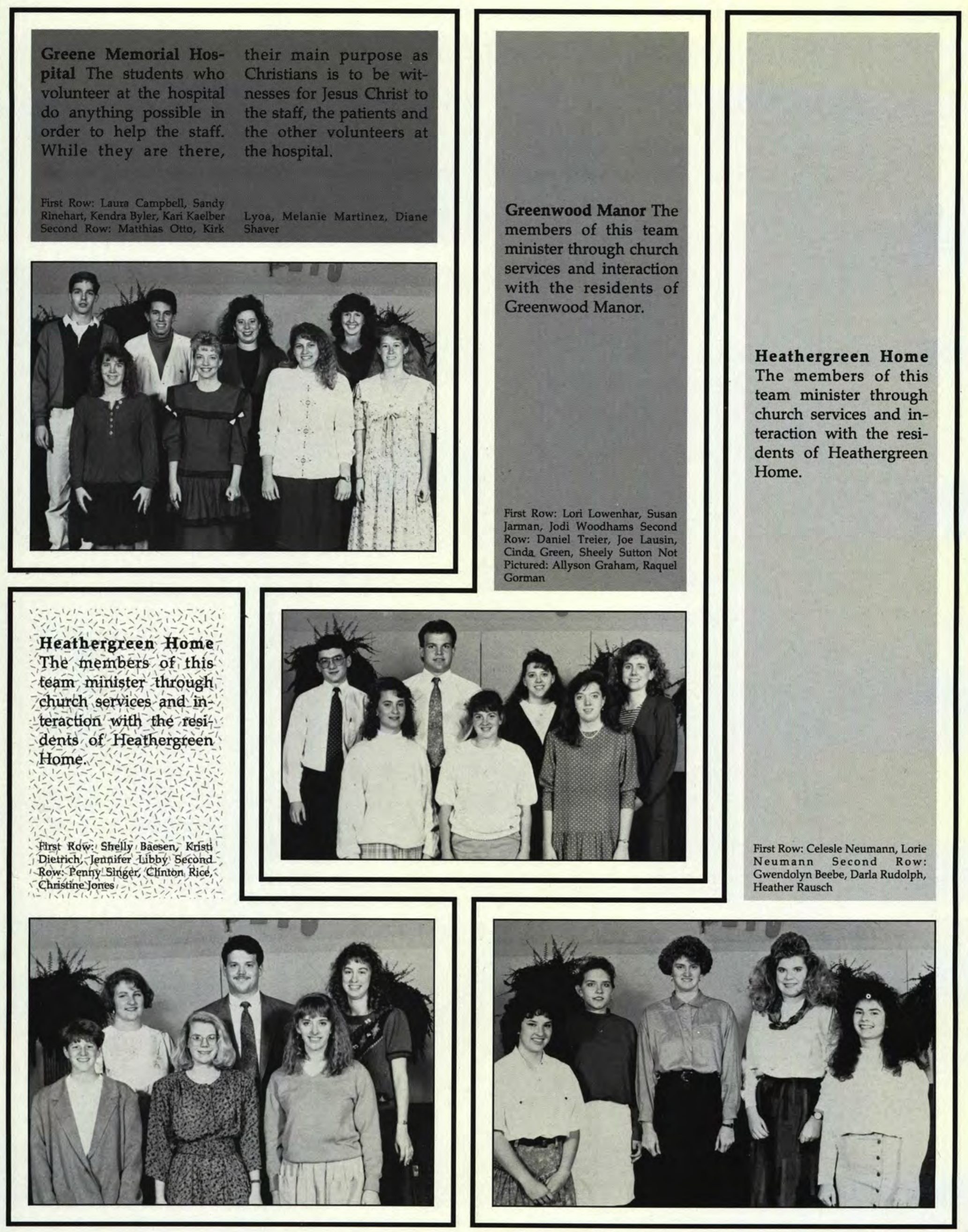


Hospitality Home

The members of this team minister through church services and interaction with the residents of Hospitality Home.
First Row: Heather Hoelscher, Shanda Strayer, Paula Hansen, Gregory Milentrs Second Row: Jennifer Shriver, Teresa King. Jeffrey Johnson, Donald Erickson Not Pictured: Sonja Bartlett, Deborah Olsen, Kevin Shoop, Dan Clifford

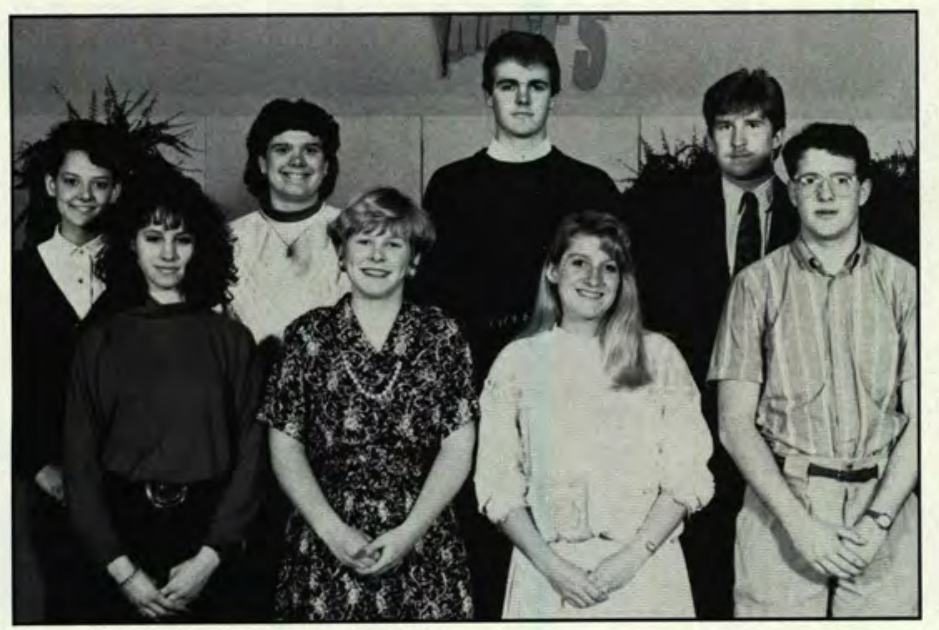

Honors Tutoring Students in the Honors Program experience lifestyle evangelism as they travel to different Greene County schools. These students serve in various ways as some are placed in the classroom setting while others are involved with individual students who require specialized assistance.

First Row: Priscilla Brown, Faith Johnston, Debbie Perkins, Joyce Colangelo, Cynthia Palacios Second Row: Nikki Refior, Tracy Justice, Deborah Richard, Cheryl Pinkerton, Ruth Harton Third Row: Miriam Comegys, Eric Phillips, David Holmes, Jennifer Cornett, Jon Misere, Aaron Harju

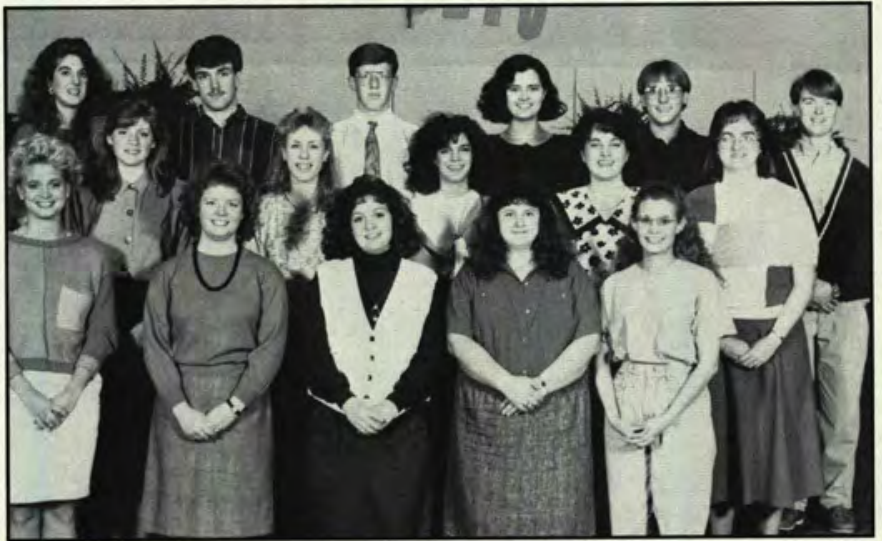

Knights of Pyithias The members of this team minister thróng church services and interaction with the residents of an area retirement home.

Firs't-Rowa 'Kelly Darcy, Tára Rhodes, Ken Vanderwést, Miridy Clappes, Dawn Phillipss, Sharoñ 'Bush Seeona Row wi: Marcy Johnísón. Deborah Richard, David A mibrose, Stefañ Tarapehāk, Matthew Oliven 

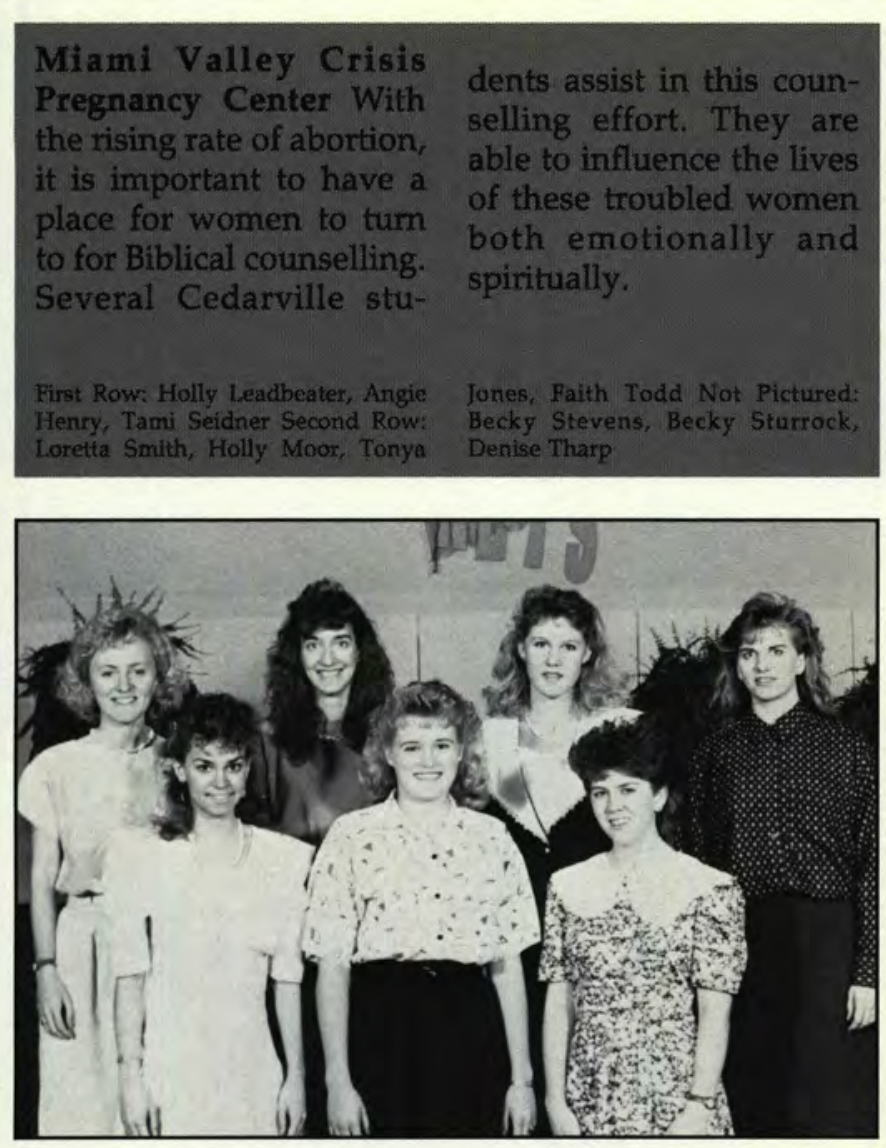

Mime How can one communicate God's love without saying a word? One answer to this question is through mime. This group of students travels to churches, giving encouragement and challenges to Christians, as well as giving the gospel to many unsaved. A gesture and some symbols can many times penetrate further into the soul than the best delivered sermon.
First Row: Mary Jo Brooks, Shelley Fiorito Second Row: Michael Peck, Kenneth Macleod, Jody Oberholtzer Third Row: Tom Bonifield Not Pictured: Chad Parrow, Yolanda Everson

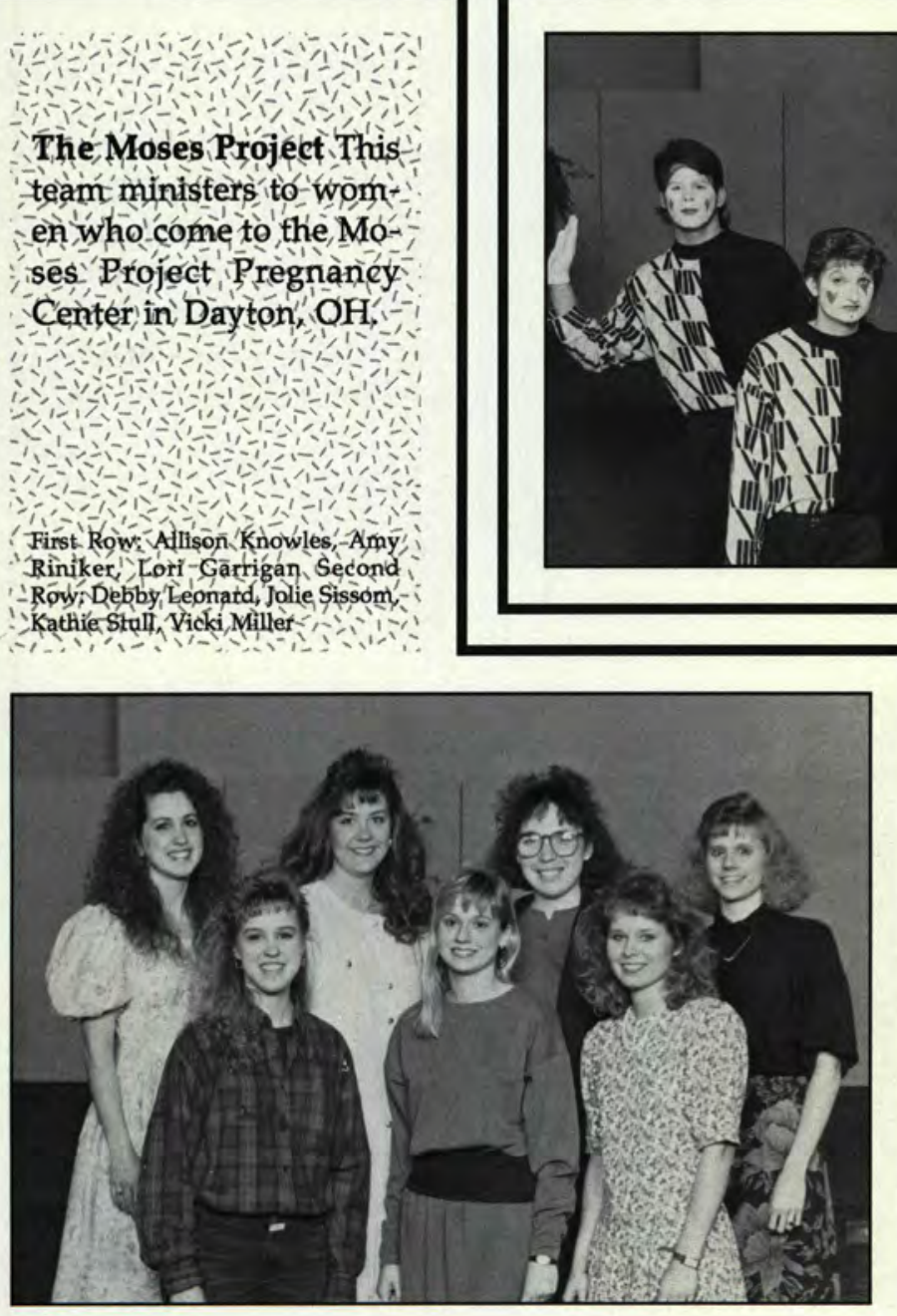

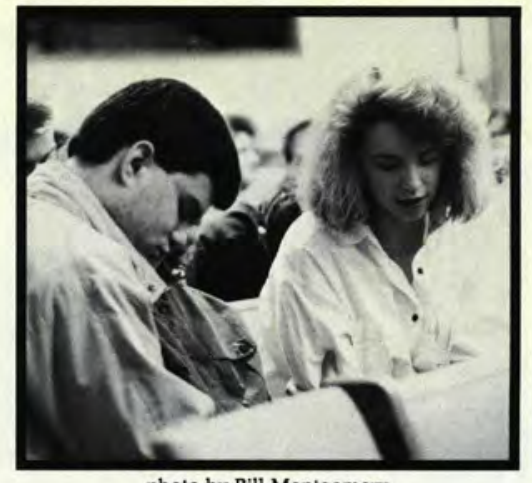

photo by Bill Montgomery

Because of the many ministries and activities at Cedarville, prayer is regularly made a campuswide priority.

Mueller Ministries Each week, these volunteers go to the Mueller Home for the mentally handicapped. In addition to sharing with the residents, the members of this Springfield ministry also spend time participating in basic skill-building activities with these people. The gospel is presented in a simple manner to the residents. Through all these activities, the team members share love with these mentally handicapped people.

First Row: Debbie Wolf, Rebecca Armstrong, Stacey Perler Second Row: Claire Barnhart, Nate Misirian, Edina VanMatre

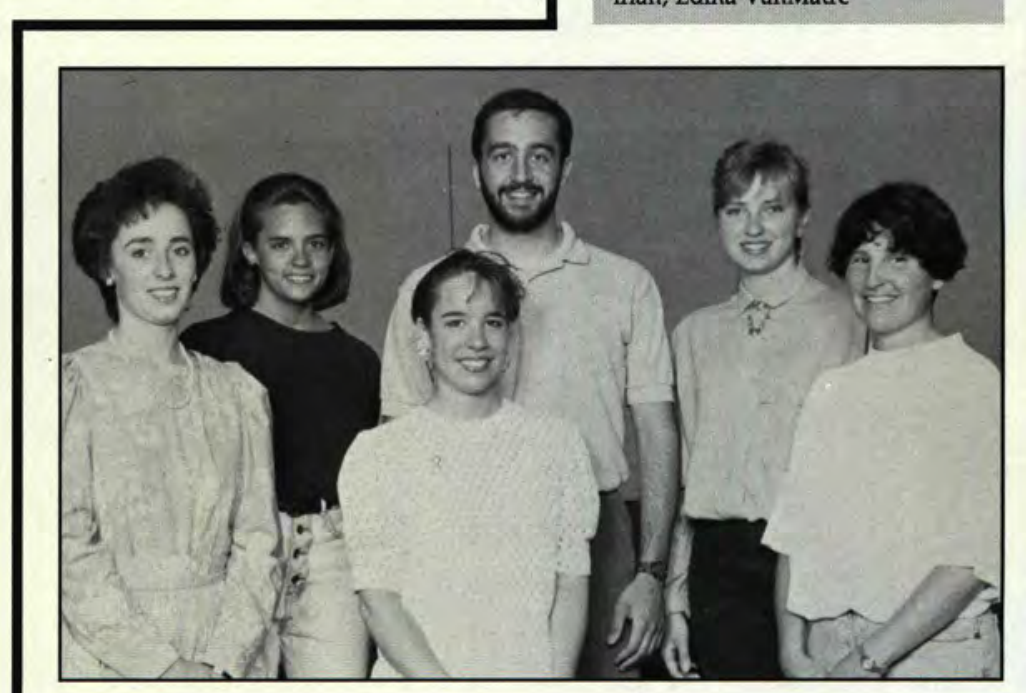


Open Heirs This Christian ministry sends students to the streets of Cincinnati. Each Friday and Saturday evening students head to the city to share the gospel with these spiritually hungry people.

First Row: Amy Geiger, Tami Seidner, Tamara Wymer, Holly Second Row: Janette Rehfeld Allison Stolar, Kristin Cooper, Beth Hess, Diane Jones Third Row: Shawn White, Mark Irving Gregory Milentis, Dan Clifford, Mike Measley, Andrew Rhind

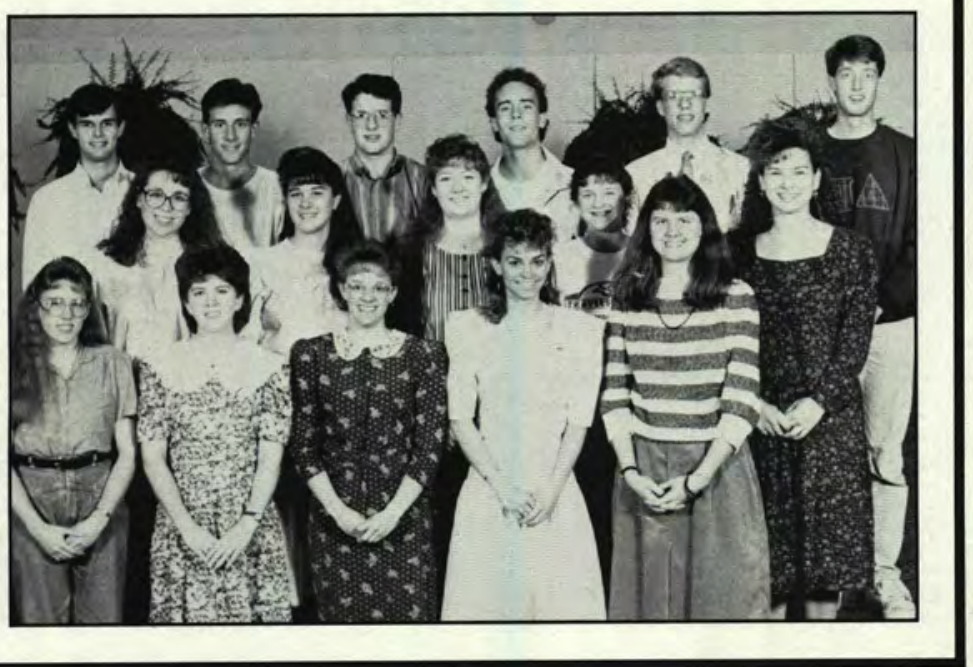
Irwin, Aaron Bishop, Phil Baab Not
Odd Fellows The members of this team minister through church services and interaction with the residents of an area retirement home.

First Row: Renee Randall, Stacy Smith, Aileen Willsie, Pamela Snyder, Renee Beasley Second Row:
Angela Smith, Kimberly Hubbard, JuAngela Smith, Kimberly Hubbard, Julie Bracy, Heather Kenoyer Third
Row: Kelly Miner, Laurie Birch, Peter Row: Kelly Miner, Laurie Birch, Peter Pictured: Lee Randall, Ann Edwards, Julie Bracy, David Crandall, Anna Drew Brandon

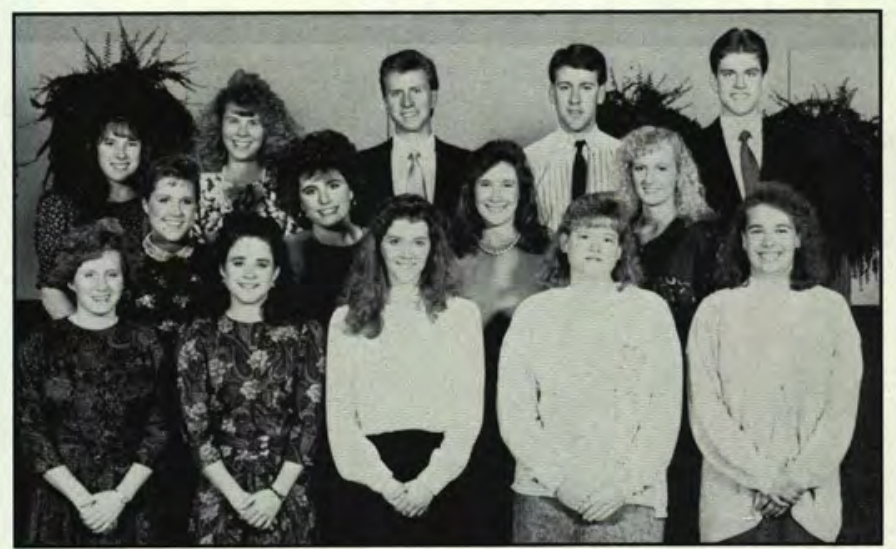

O.V.C.H. This team ministers - on Sunday mornings at the ohio Vetéran's-Childrén.s Home:-This home-alIows Cédarvillé Collégé studénts - to - minister to underpriveledged chil dren.

First Row! Karfa'Warnker, Kim Bailey. Kristá Dayton, Jill' Prickand, Kelly Davis, Jenni-Bond Secónd Row: Peter Casaletto Greg Ridale, is teve Mathwin, Sarah 'Shites, Diane Jones 'Third Row: Jennifer Huxtable, Misty. - Burkholder, Añúrea Beaúlieu', Johnny, - Burkholder, Añórea Beaulieu, Johñny

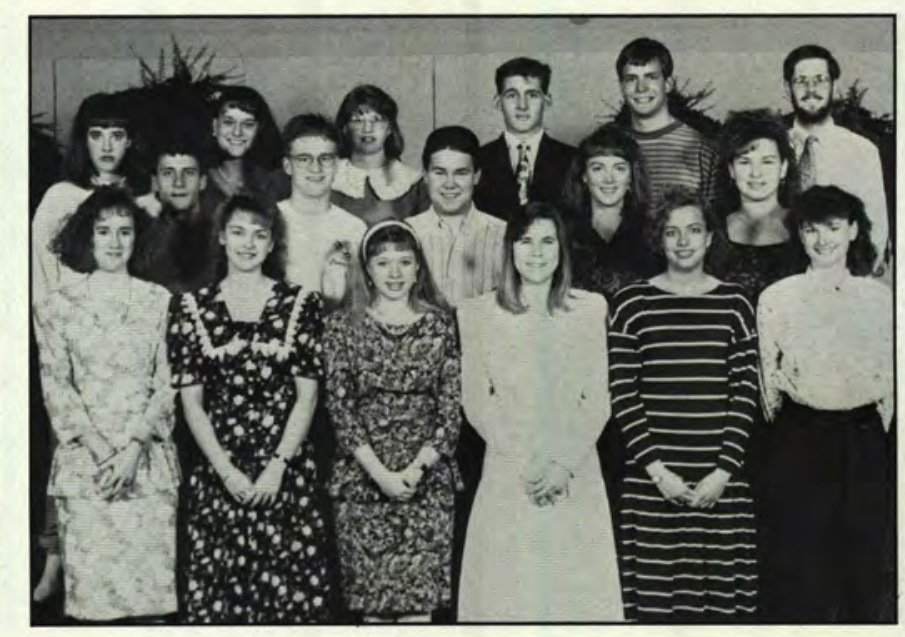



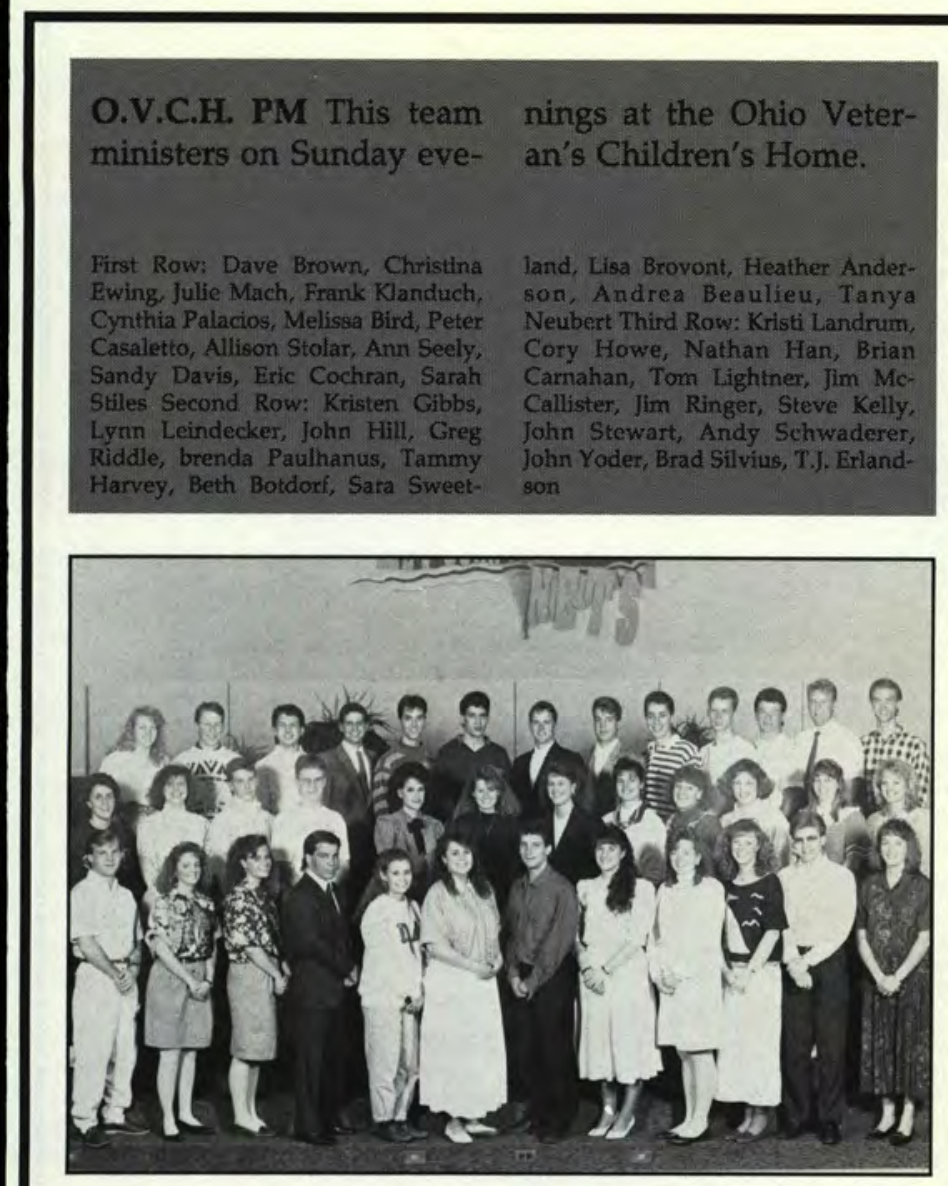

O.V.C.H. Tutoring

These student volunteers work with O.V.C.H. kids on a oneto-one basis. The primary purpose is to assist the kids with their studies, but the volunteers also have the opportunity to develop friendships and share the gospel.

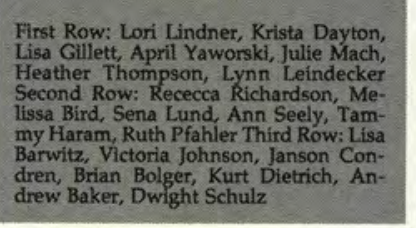

Ronald Mc Donalar House This faeility hou'ses the parents of terminally! it childrén, who are-hospital. ized' The nembers of this group not onty minister to parents emotionally, and spirituálly bat álso-phỳsically as théx cook meals or babysit to enable the parents to yisit the hospitali

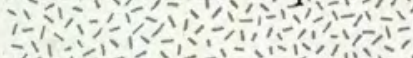

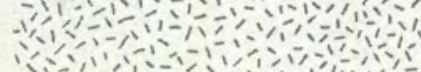

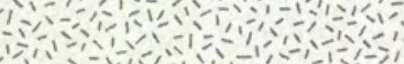

First Row:-Rébecca i Déncé, Beth Kinne, Ann tigrey Darlène Ellis

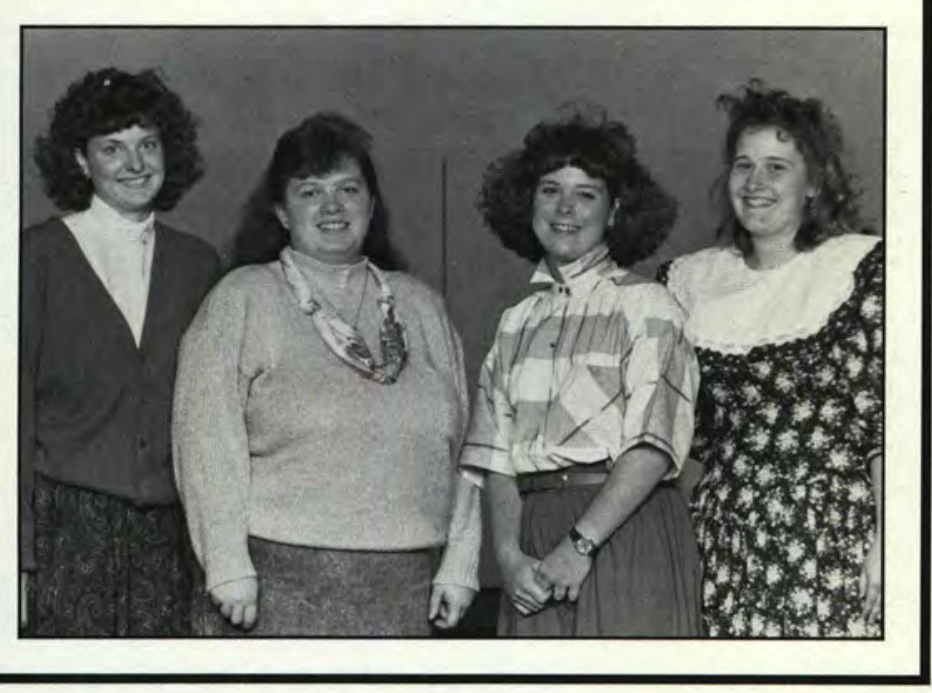

St. John's Center This ministry, under the direction of Dr. Dolph, was started by Psychology majors. Each was assigned a resident to work with and build a friendship. Once this task was accomplished, the student could then begin to share Christ with the resident as well as continue the friendship.
First Row: Jennifer Wilfert, Heather Hoelscher Second Row: Christopher Eckart, Faith Todd

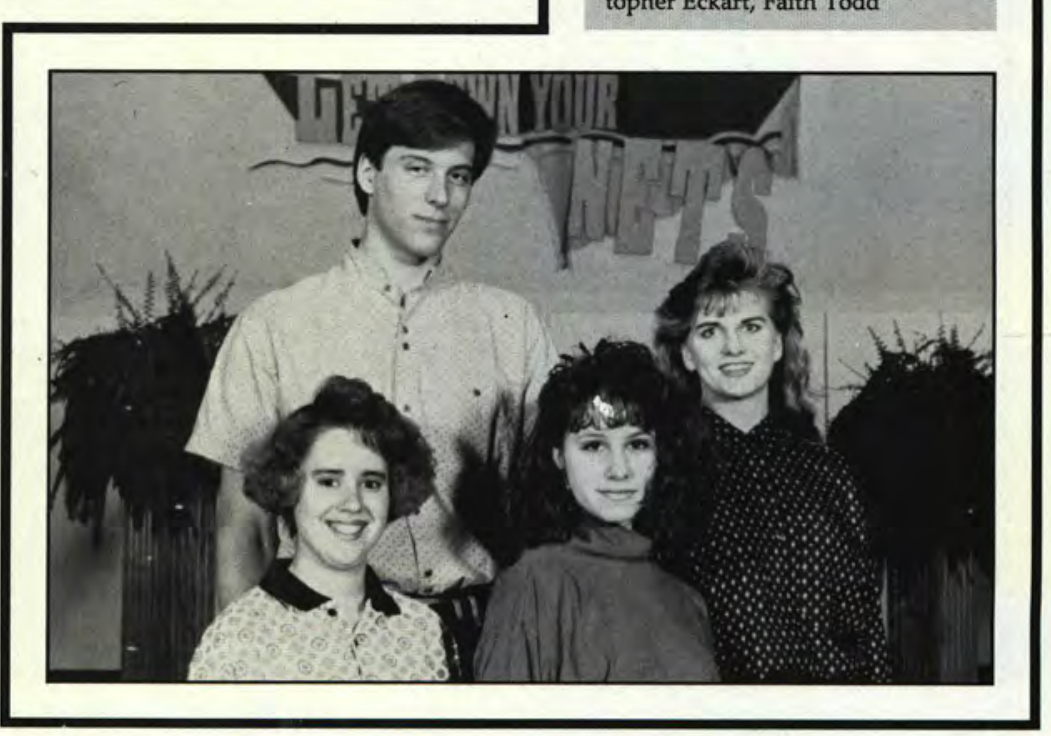


Toward Independence Every week a group of students visits different group homes for the mentally retarded in the community. The members of the group are able to build friendships and share Christ with the residents by talking with them, playing games, making crafts and teaching them basic skills.

Students play cards with the residents of $\mathrm{OVCH}$ in an attempt to build friendships.

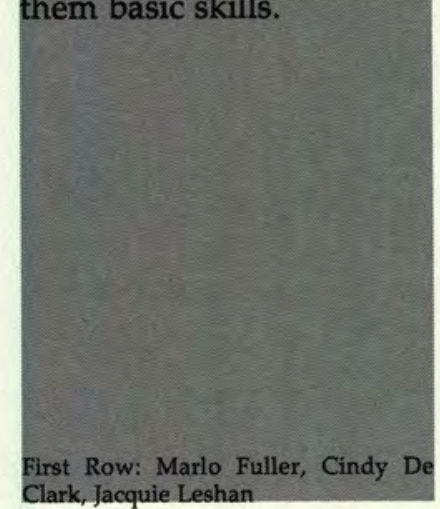

Swordbearer Extension
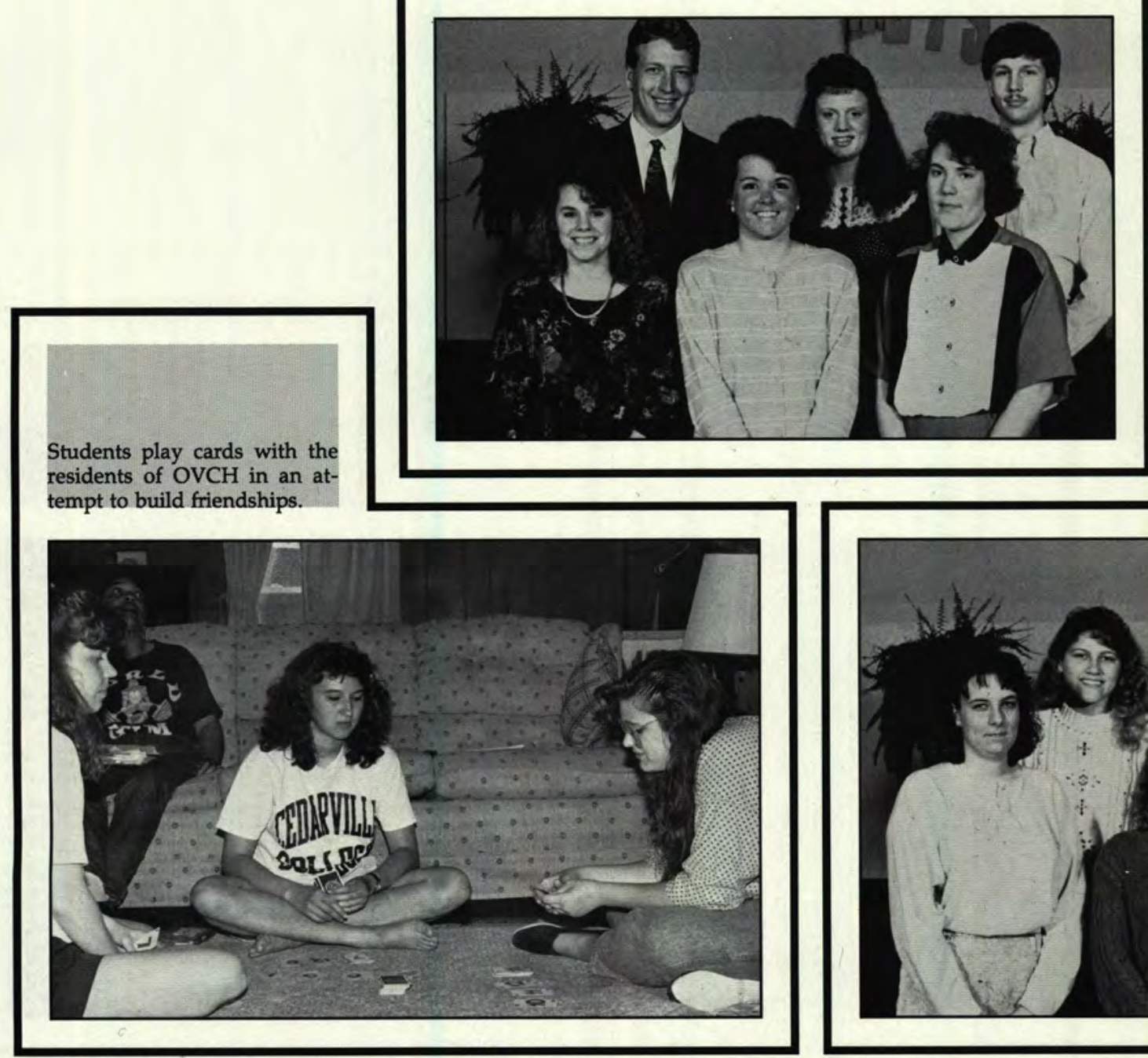

Yetlow Springs Riding

Center 'Every, 'week, ithe mémbers of this team share the Tove of Godito chitdren with 'multiple sclerôsis í or mental Kandicaps by hérping them to

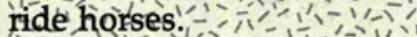
1)

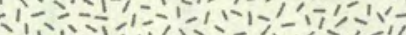

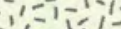

1 - First Row: Tennifer Duak, Launa Camp belt, Amy McClain, Séeond Roww Ken dra Byler,'Tetrianin' Sturenkel, Bue tón

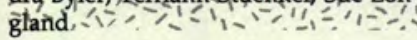

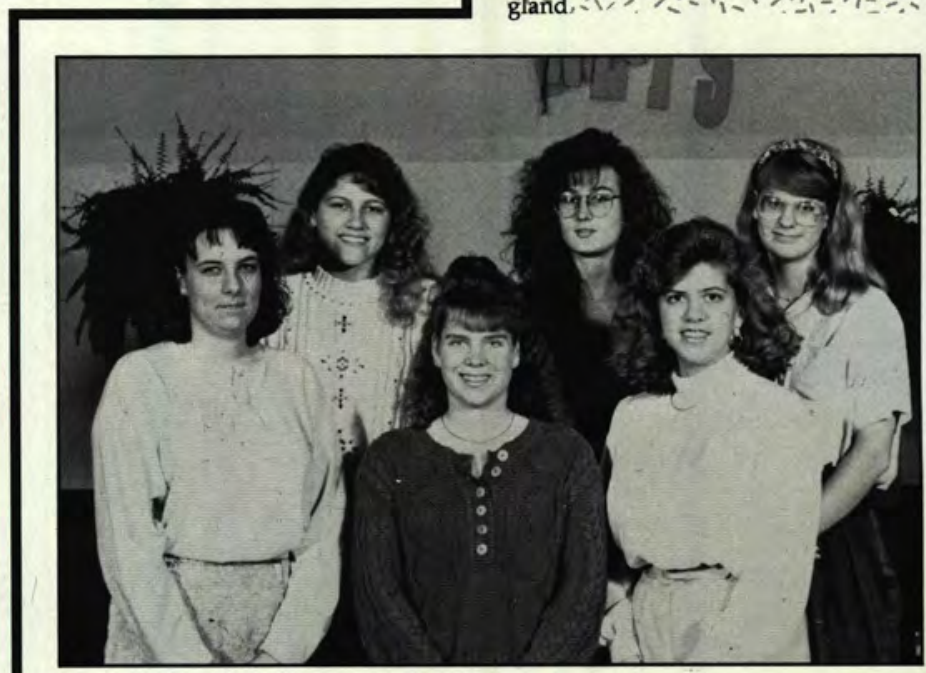




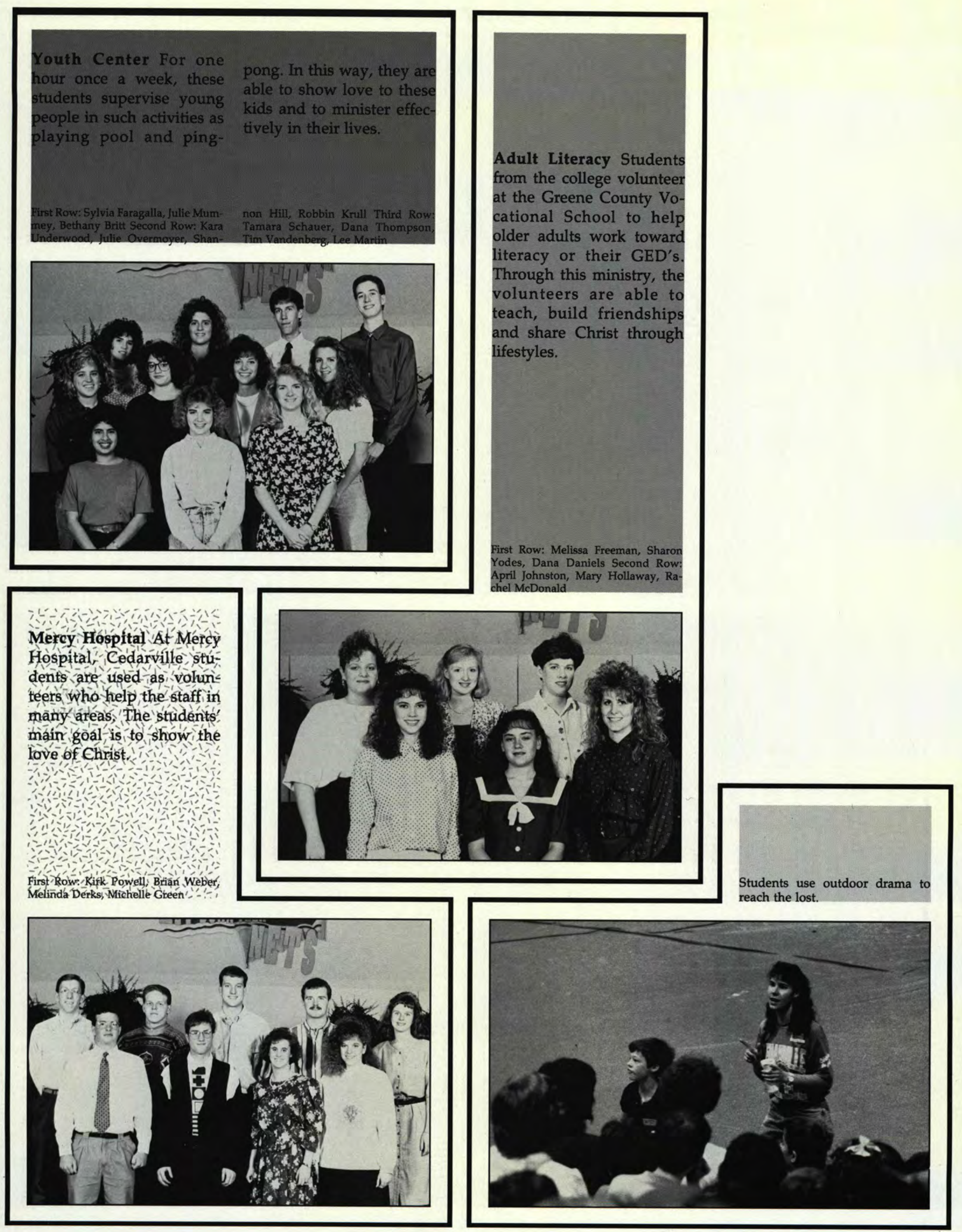




\section{Alternative Ministry}

Todd Yonker proudly puts the finishing touches on the new sign.
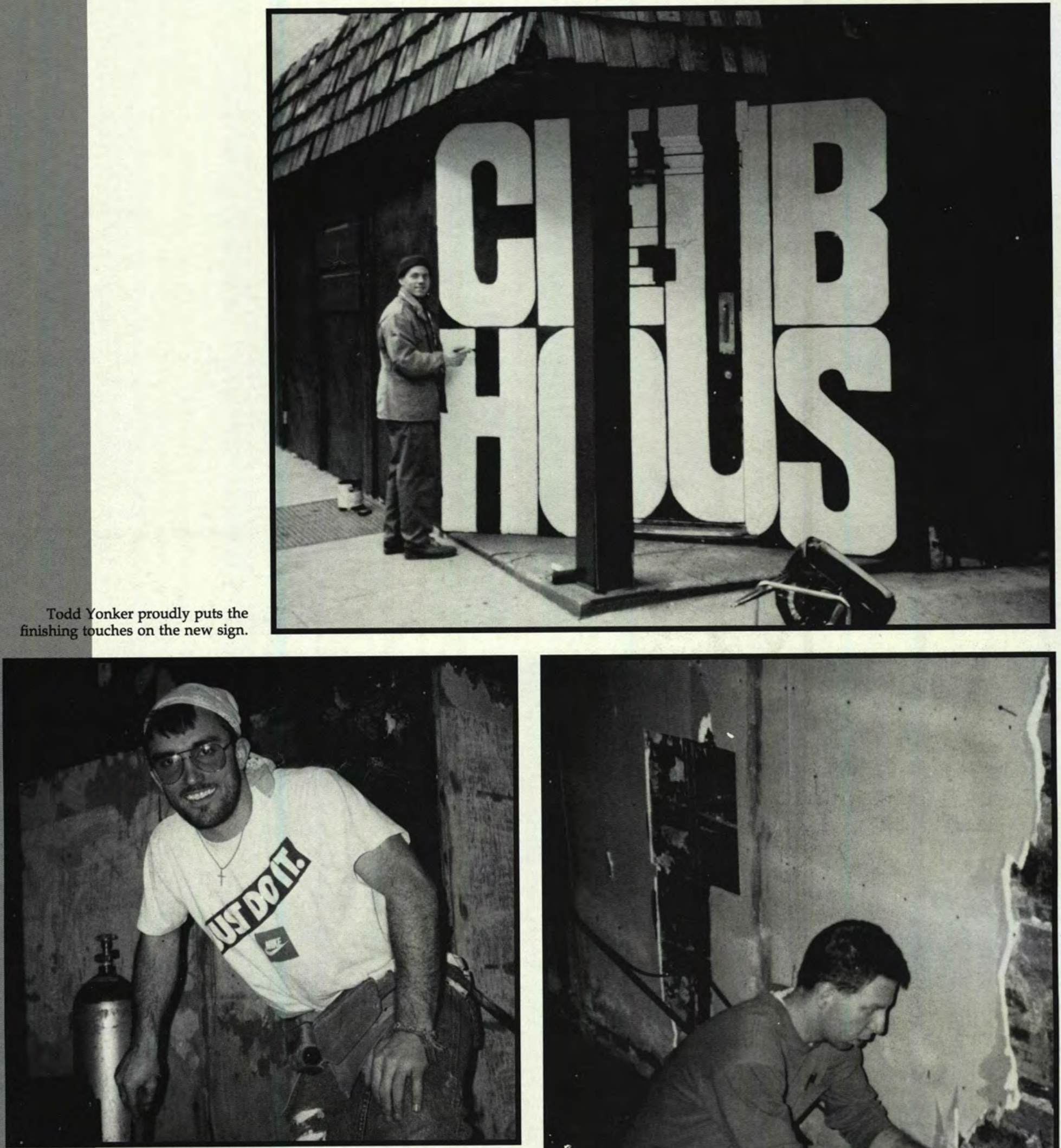

Mike Heft follows the slogan on his shirt as he works at the clubhouse.

Not only looks but also safety had to be considerations in the rennovating of the clubhouse.

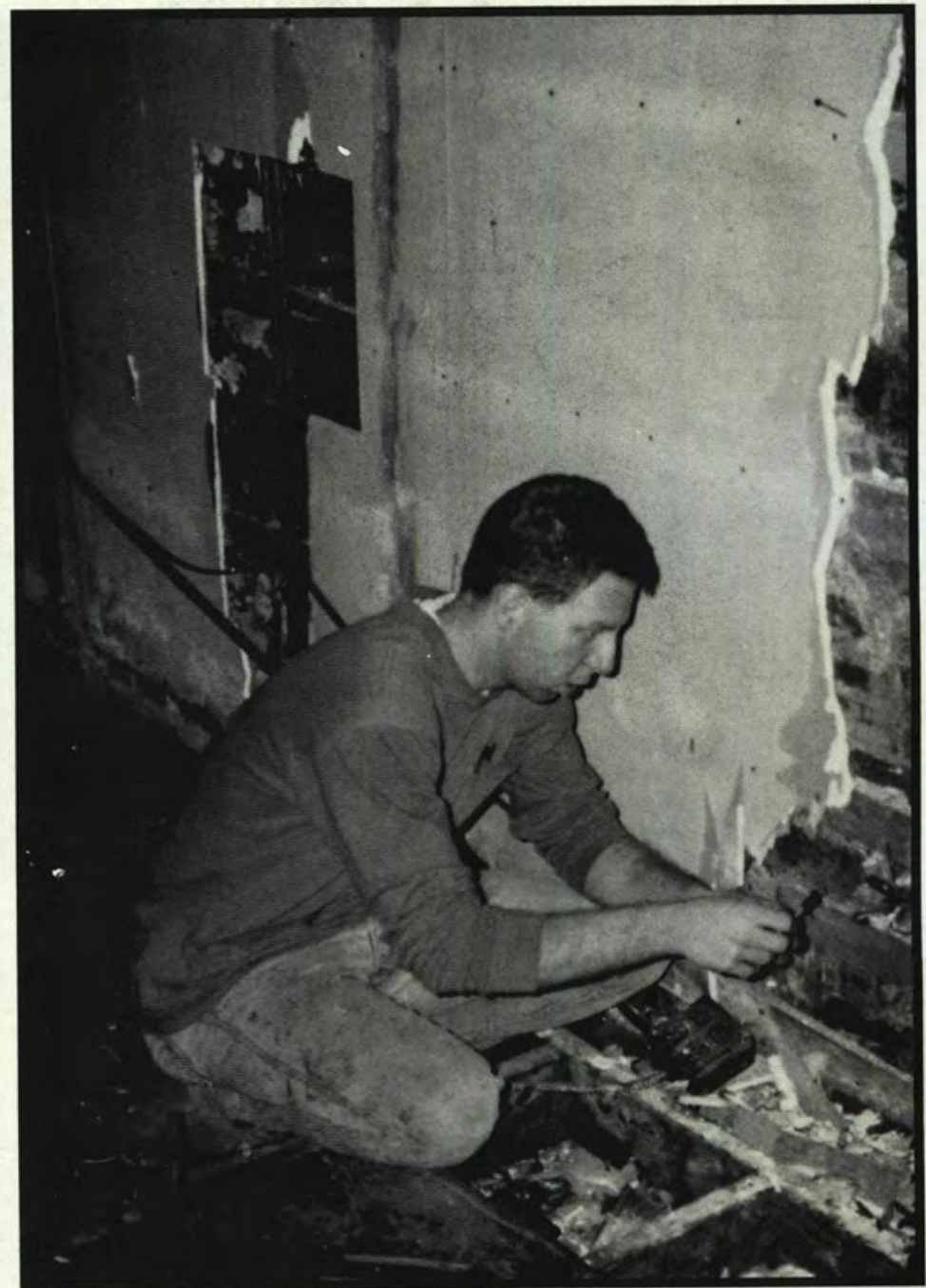


(Lower right) Wayne Ortloff and the rest of the band join in celebration of Homecoming.

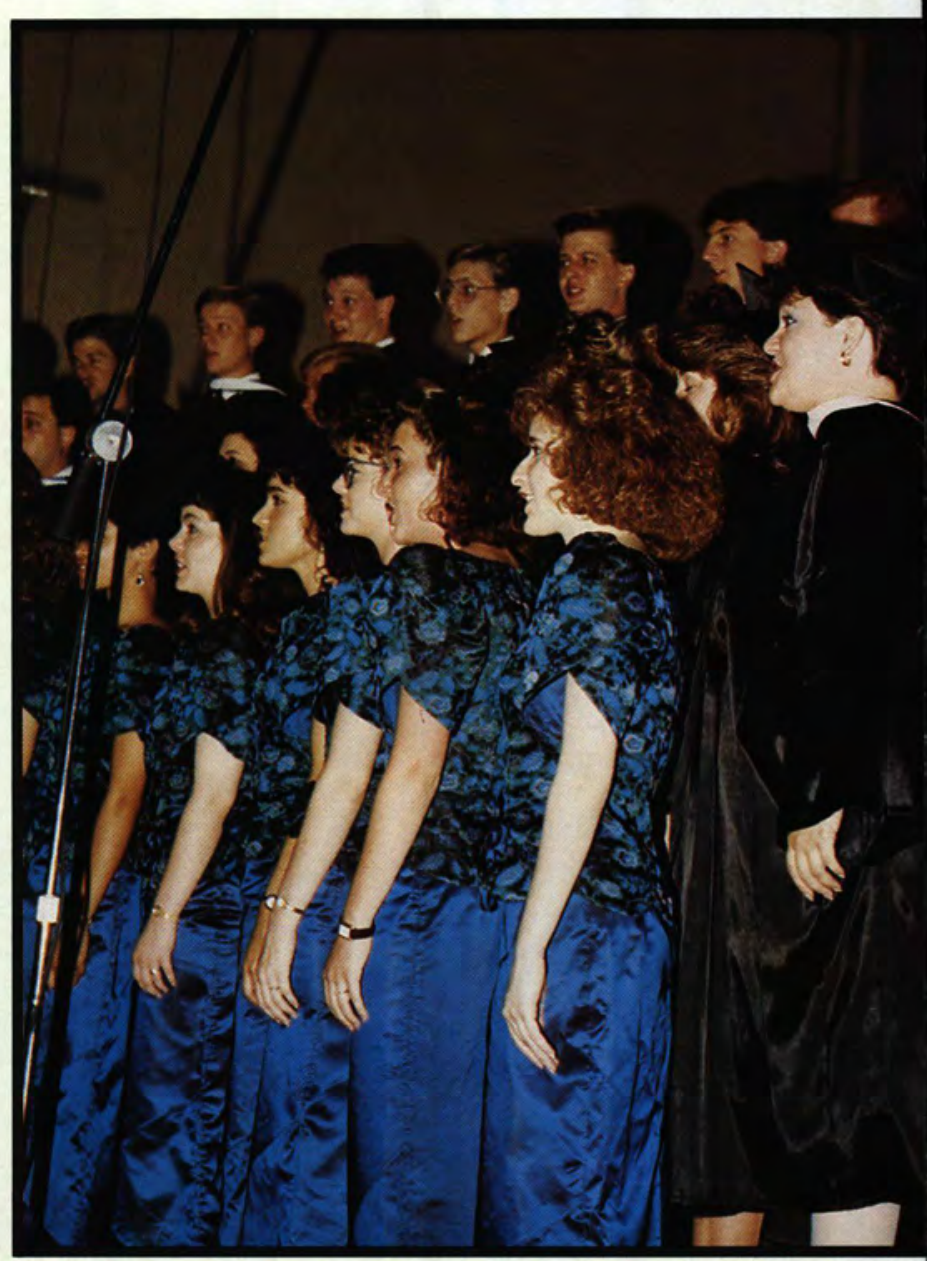

photo by Jesse Wesselink photo by Andy Jamieson

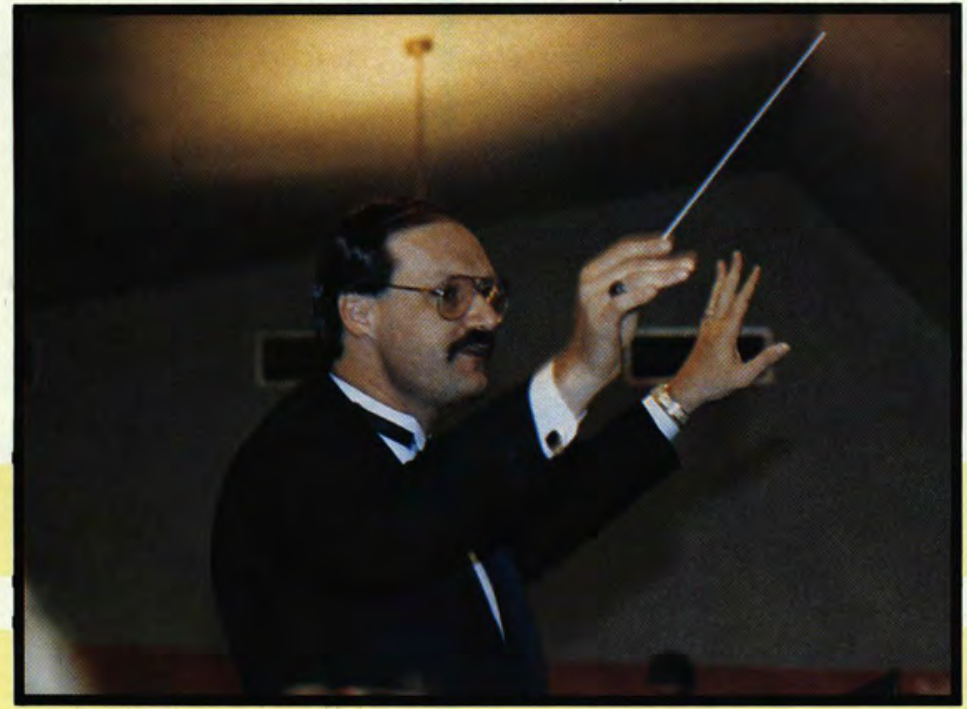

Mr. DiCuirci directs the band during a concert.

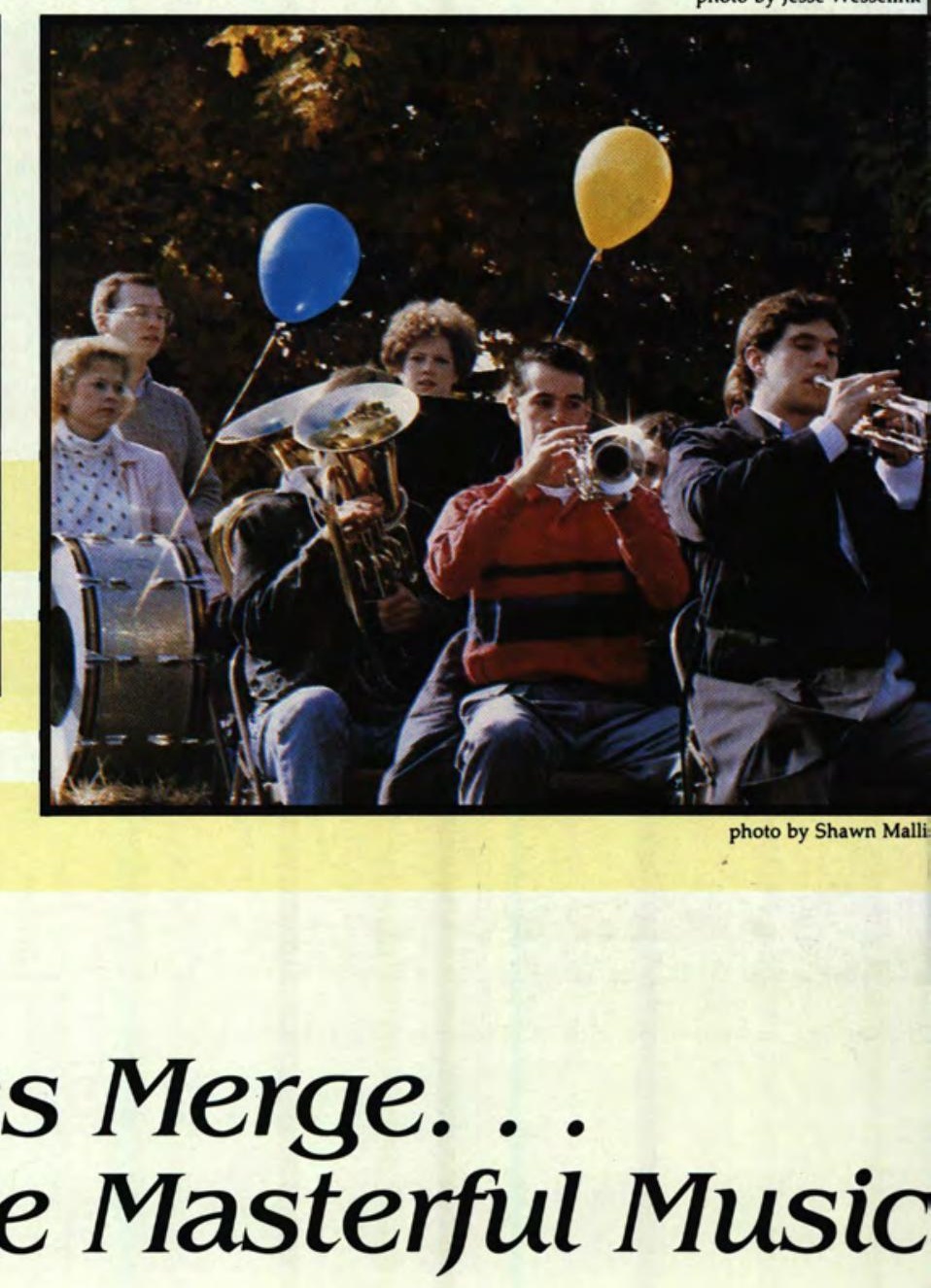

photo by Shawn Malli 
Symphonic Band

Mr. Michael DiCuirci, Director, Debbie Polsdorfer, Becky McDonald Kayley O'Keefe, Jill Prichard, Carol Jariga, Rachel McDonald, Eric Johnson, Chad Davis, Mark Warnshuis, Justin Van Eaton, Andrea Katz, Paula Hansen, David Gardner, Mike Leshan, Joyce Colangelo, Susan Shrimp, Bob Duvall, Robin Sheldahl, Harold Eddington, Kelly Davis, Kevin Murachanian, Rebekah Scott, Curtis Chamberlain, Karen Dieter, Dwight Schulz, Gina Kendig, Charlie Thorsen, Kathy Priddy, Jim Edgerton, Amy Cunningham, Curtis Reno, Vivian Moraes, Matthew Oliver, Joan Saucier, Dave Warren, Deb Wolf, Jon Nisere, Michelle Yates, Alex Kulin, Trish Manning, Brian Megilligan, Carolyn Frisbie, Mark George, Anita Bradley,John

Warnshuis, Molly Whitmer, Aaron Welch, Amy Rayder Matthew Biddinger, Beth Kinne, David Burkley, Gail Currall. Paul Carlson, Tami Haberstich, Keith Watson, Anna Marie Kulin, Paul Currie, Lori Kate Lowenhar, Dave Bishop, Leigh Rogge, Steve Copeland, Theresa Rodgers, Betsy Foster, Jacquie Leshan. Michelle Bendt, Cheryl Pinkerton, lennifer Bork,

Rosemary Pletcher, Susie Jones, Jill Comers, Amy Tapp

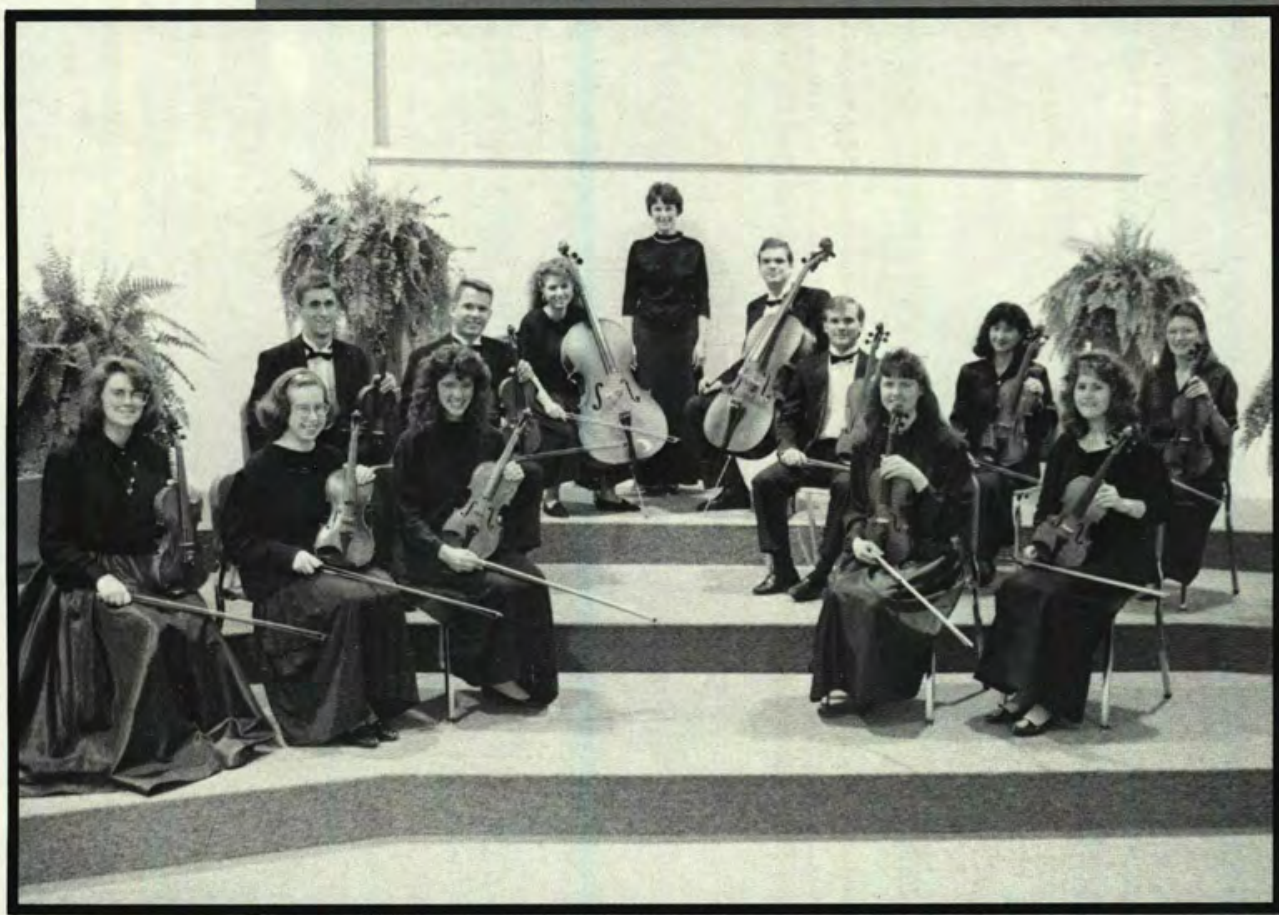

Chamber Orchestra

Violins: Julie Williams, Betsy Carlson, Lori Rodgers, Christina Fishbacher, Linda Thompson, Steven Cook, David Baldwin, Karen Williams, Rachel Chambers Viola: David Brown Cello: Lisa Haaksma, Eric Bletzinger, Professor Kathryn Rodgers (director)
Woodwind

Susan Jones, Tamara Haberstitch, Sheri McPherson, Lori Lowenhar, Jacqueline Leshan, Theresa Rodgers, Susan Shrimp, Stephanie Hunsaker, David Bishop, Michelle Bendt, Curtis Chamberlain, Michelle Yates, Alex Kulin, Maureen Prusinowski, Professor Jerry Rodgers (director)

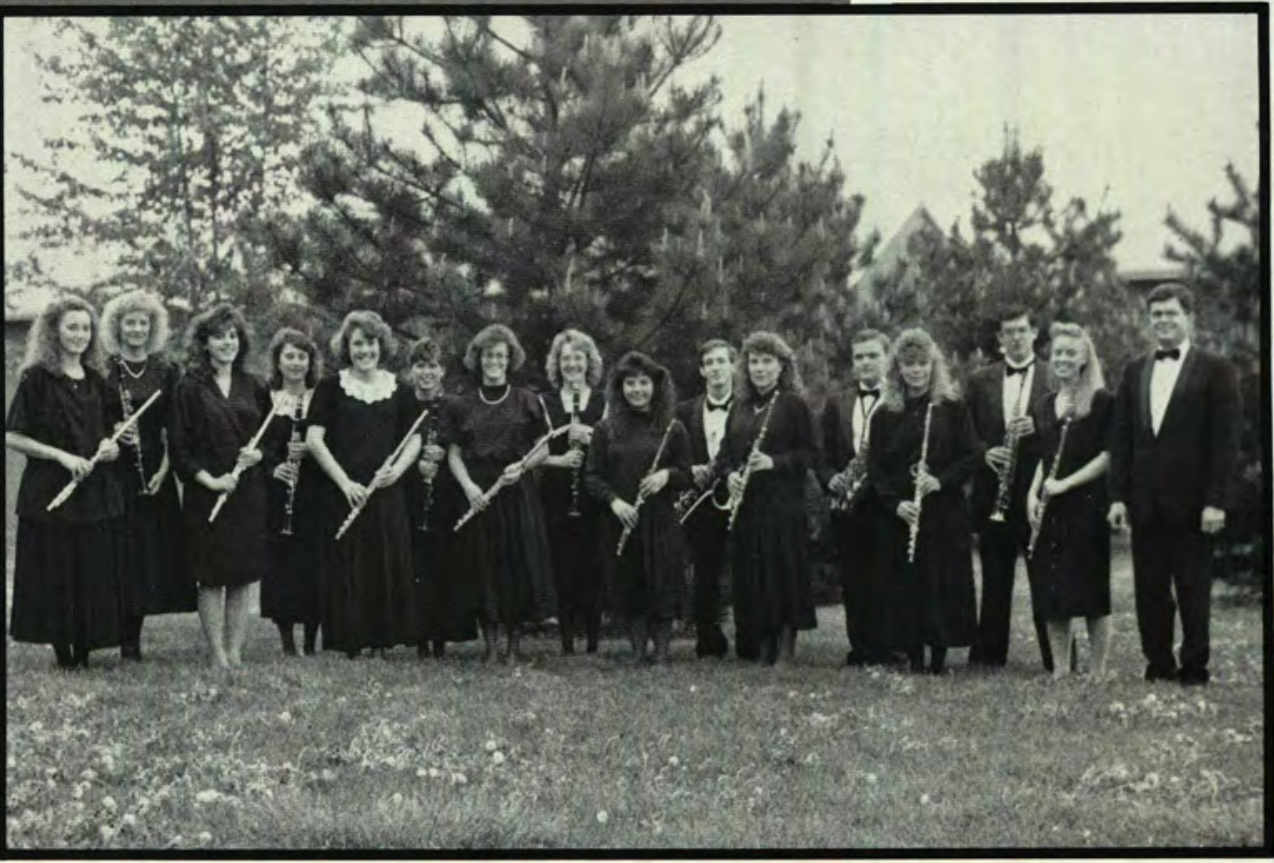




\section{Exploring Musical Expression}

Symphonic Band in concert.
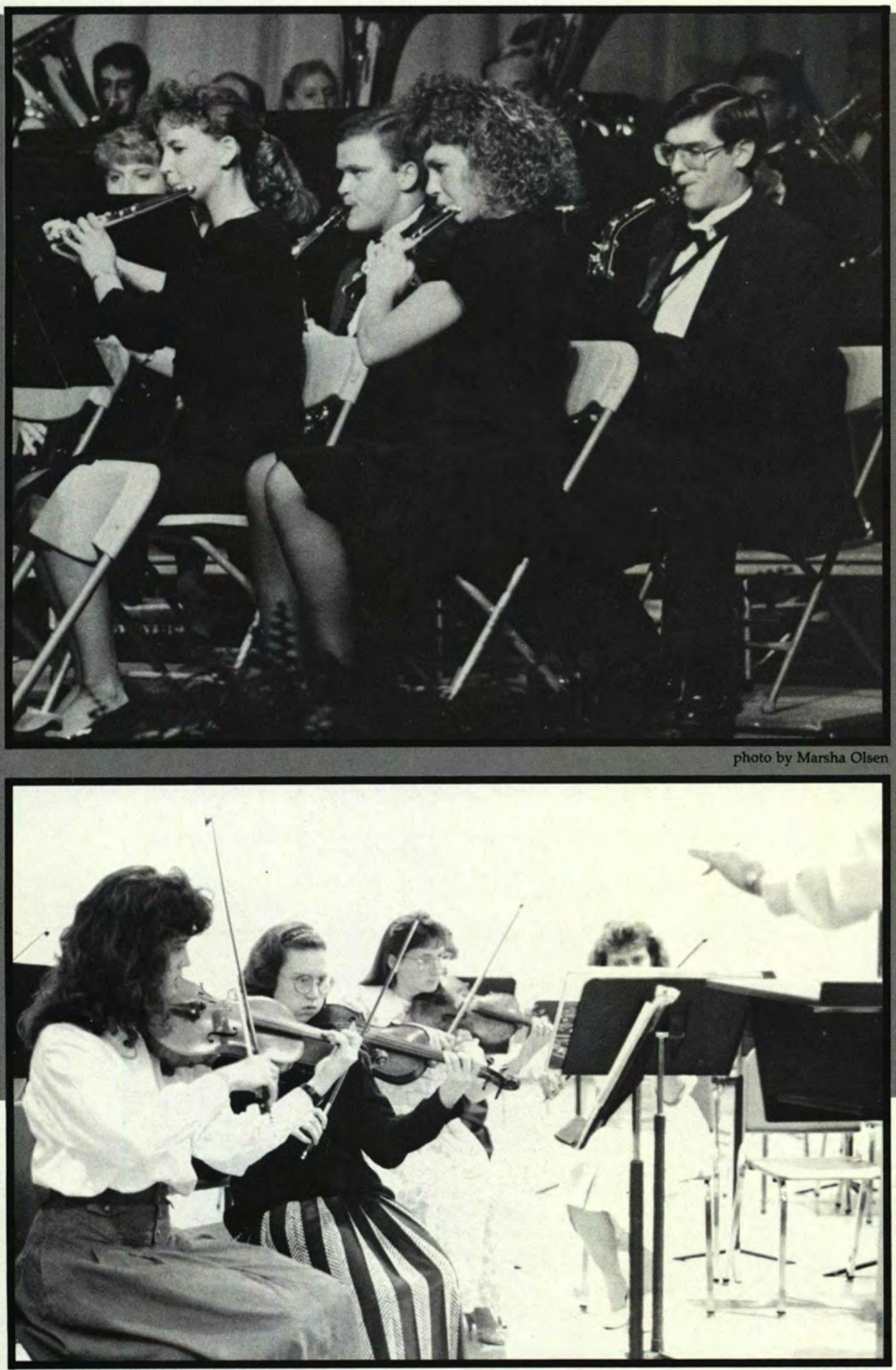

Chamber Orchestra practice.

photo by Jesse Wesselink
Mark Biddinger and the rest of the Band in concert.

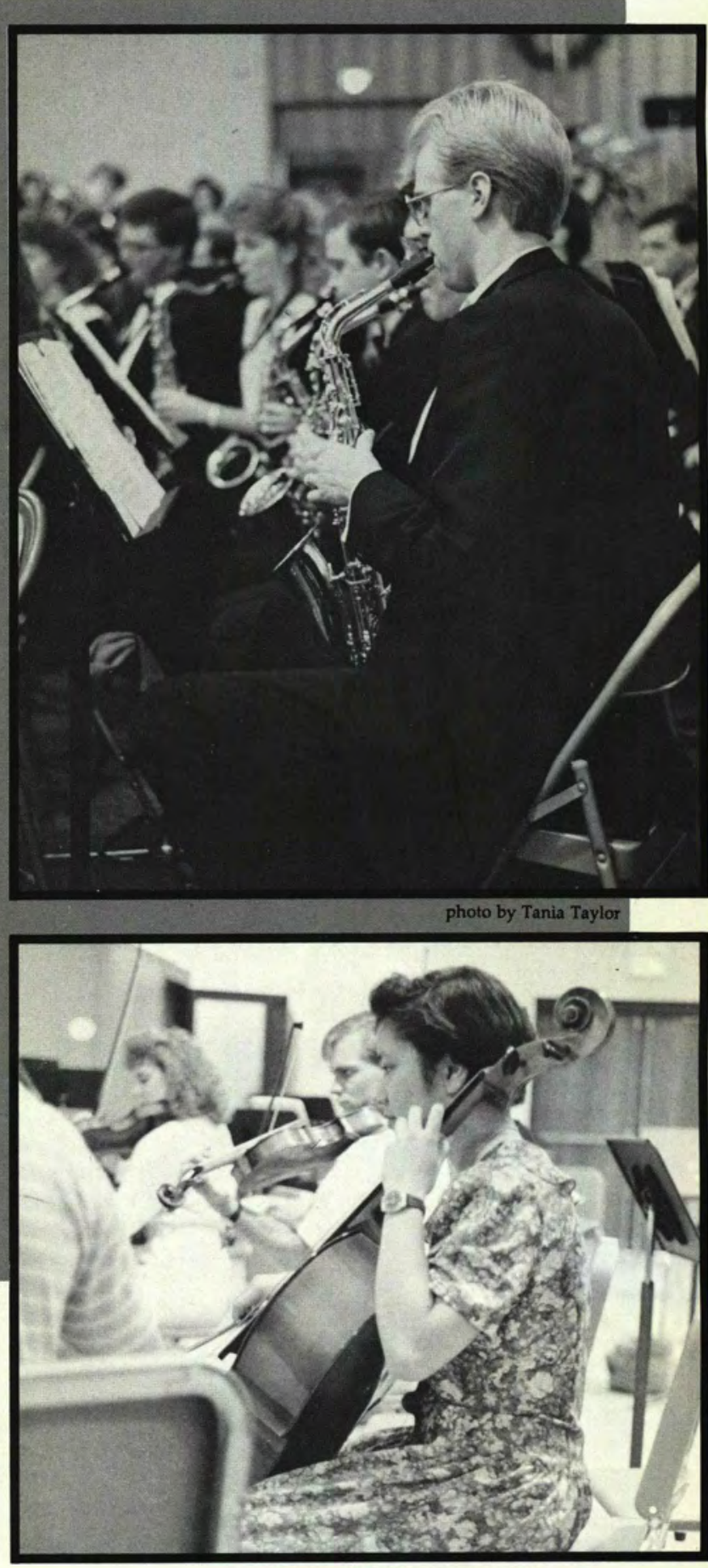

photo by Tania Taylor

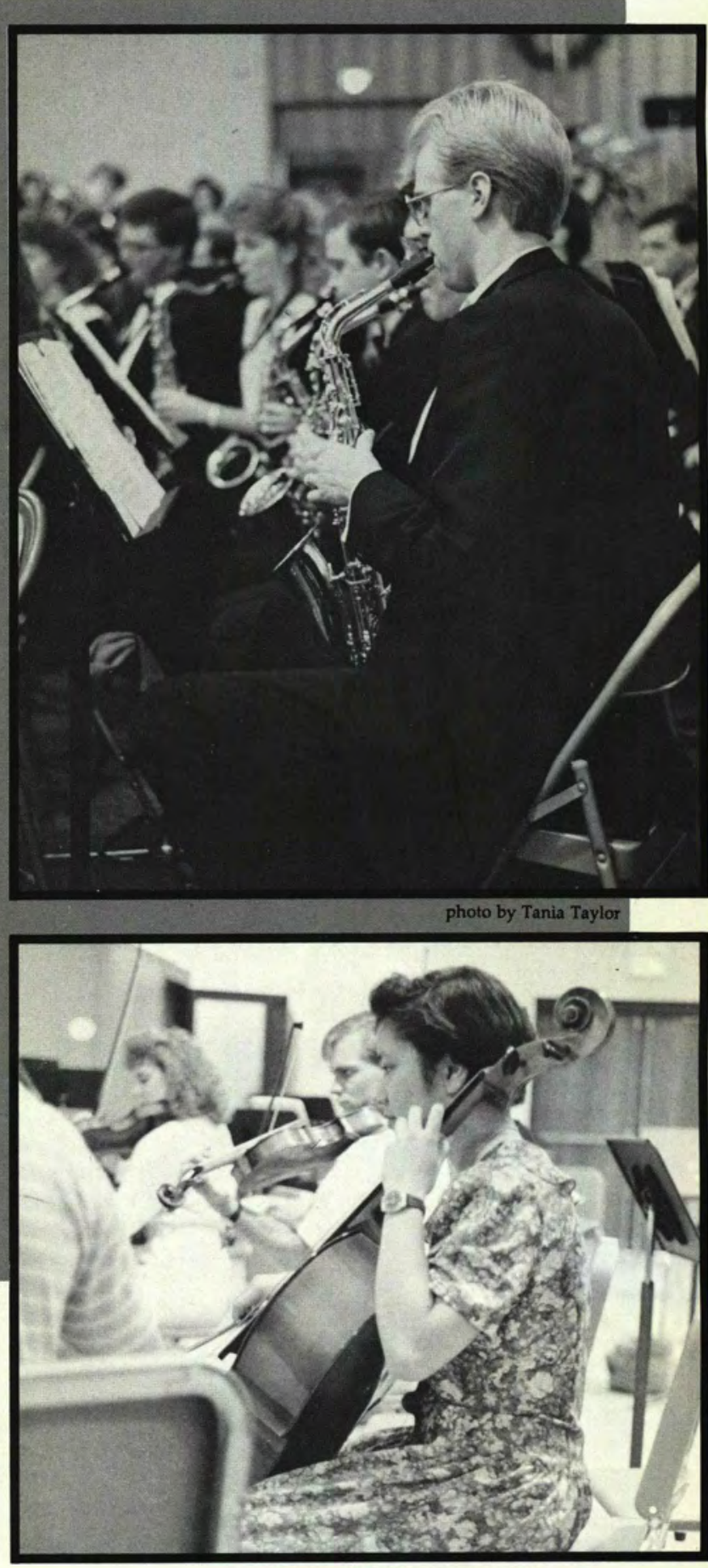

photo by photo by Jesse Wesselink

The Chamber Orchestra practice for an upcoming concert. 


\section{Developing Musical Abilities}

Aaron Welch plays a patriotic tune at the Memorial Day Chapel.
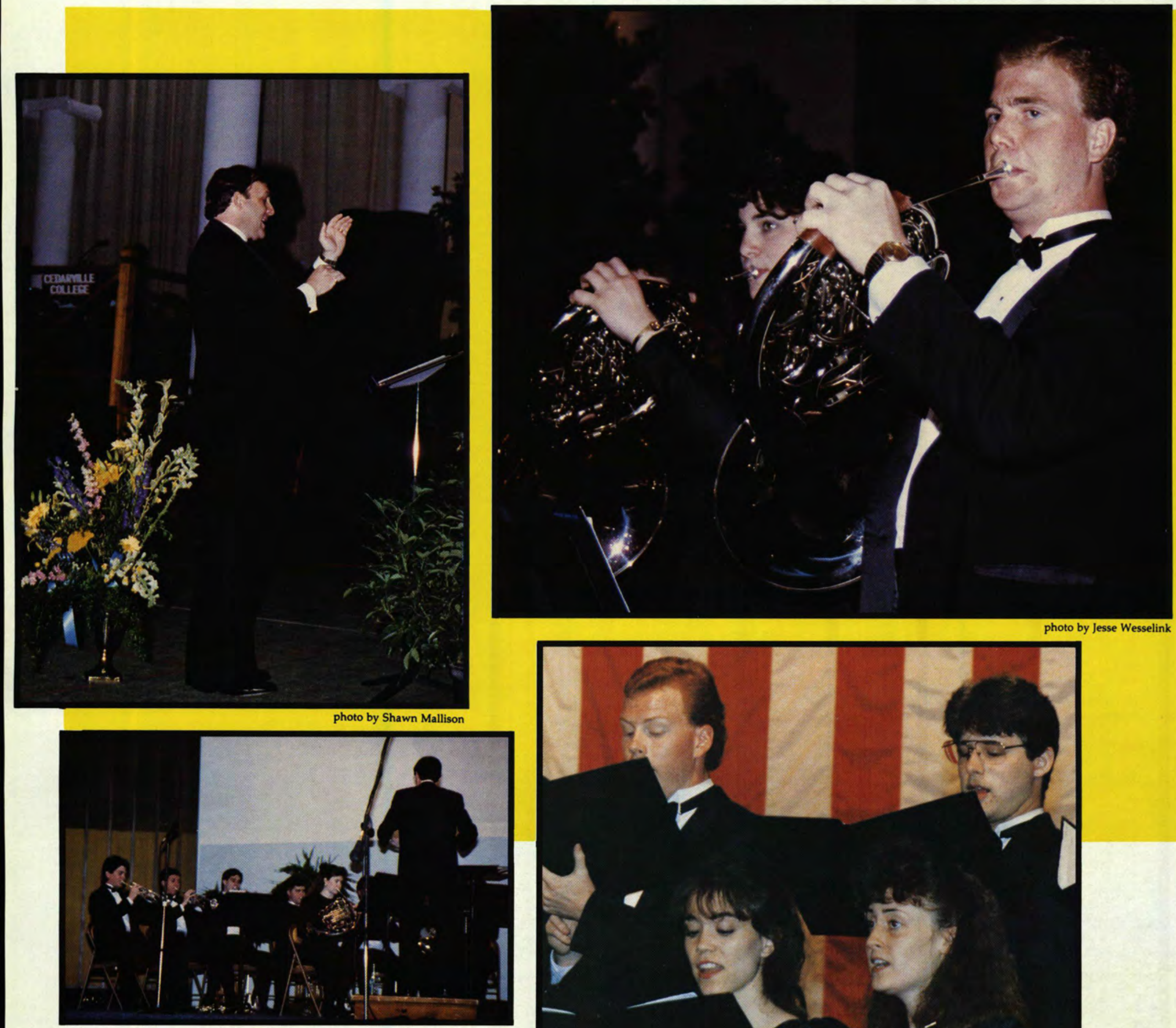

photo by Marsha Olsen

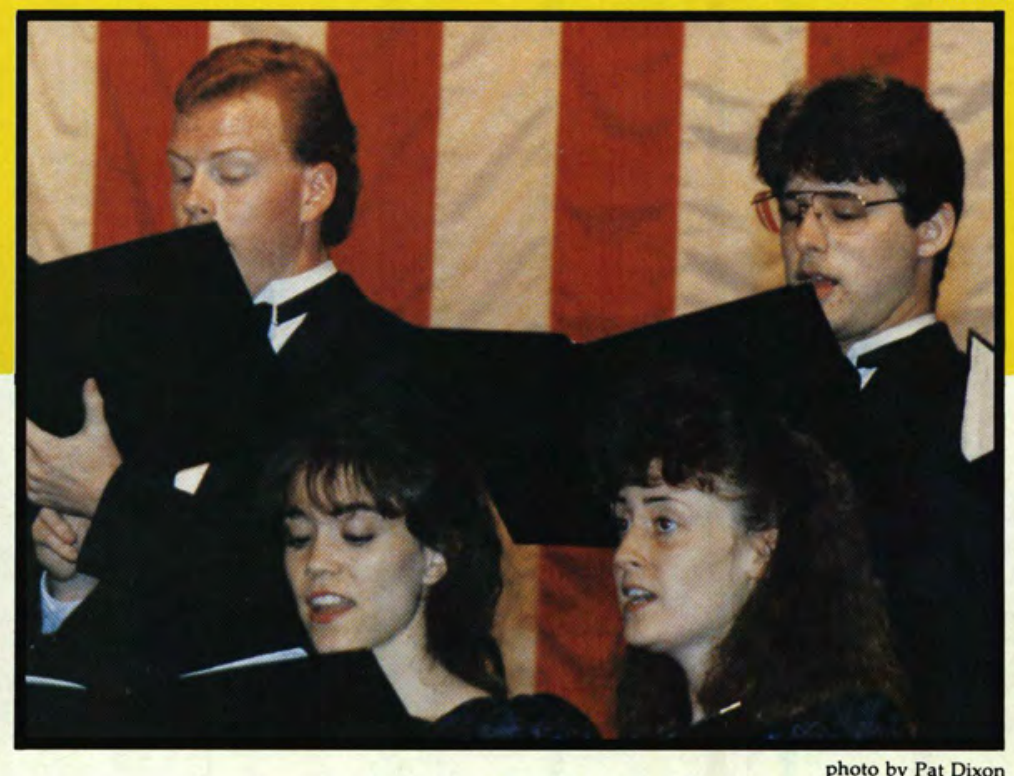

Concert Chorale at Memorial Day Chapel. 


\section{Special Performances}

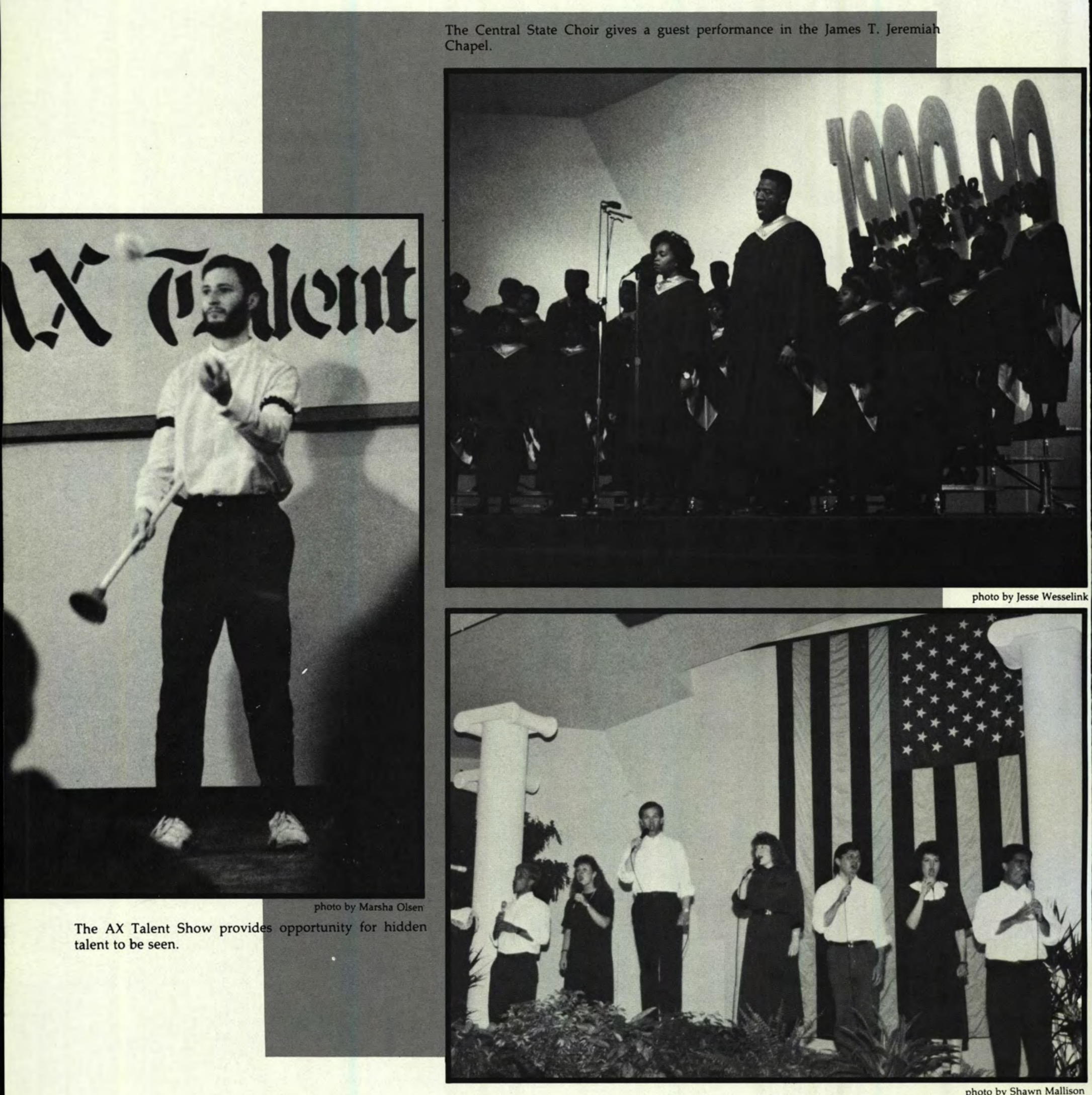

Dr. Robey and company perform in the special Memorial Day Chapel service. 


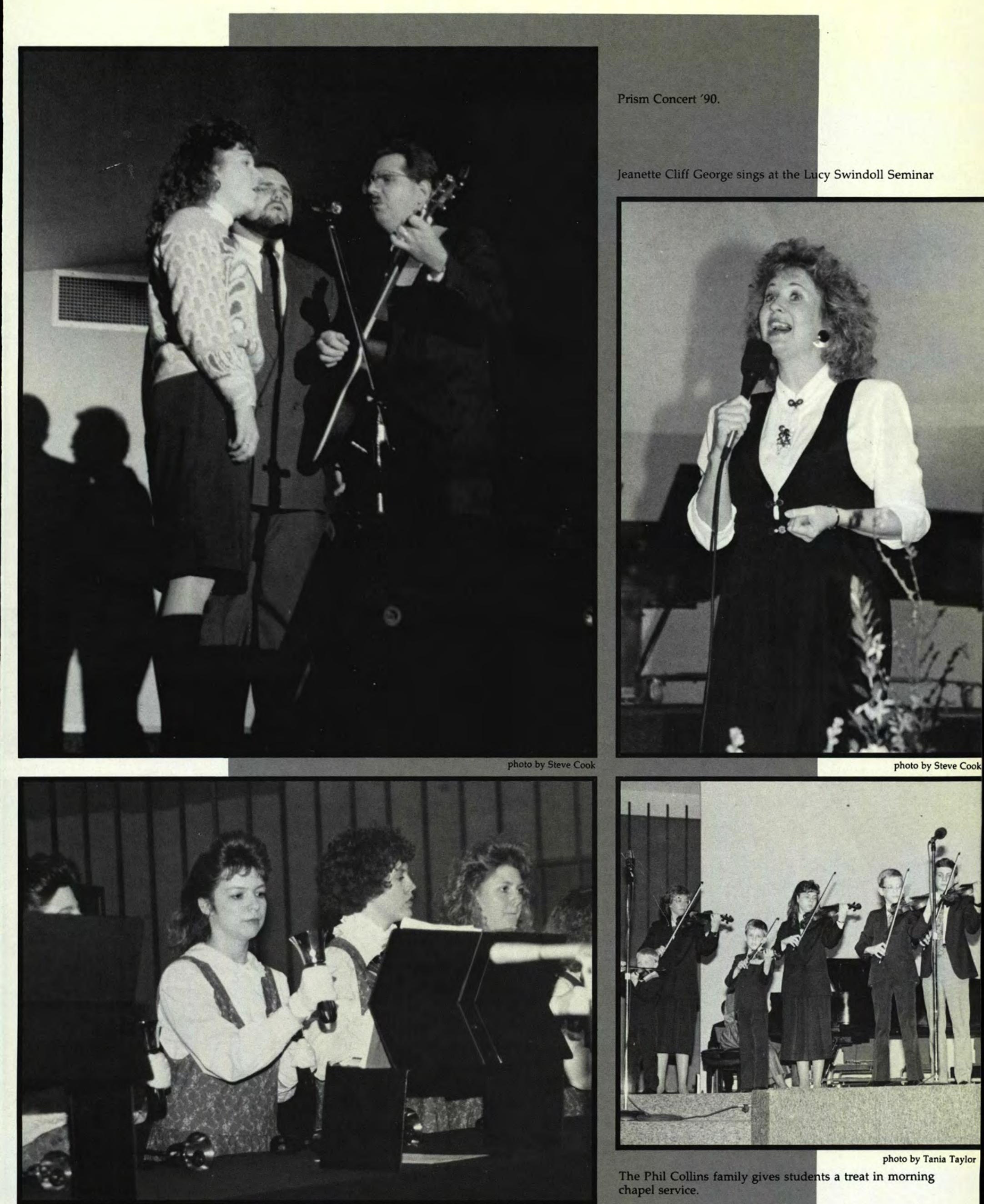




\section{Senior Recitalists}

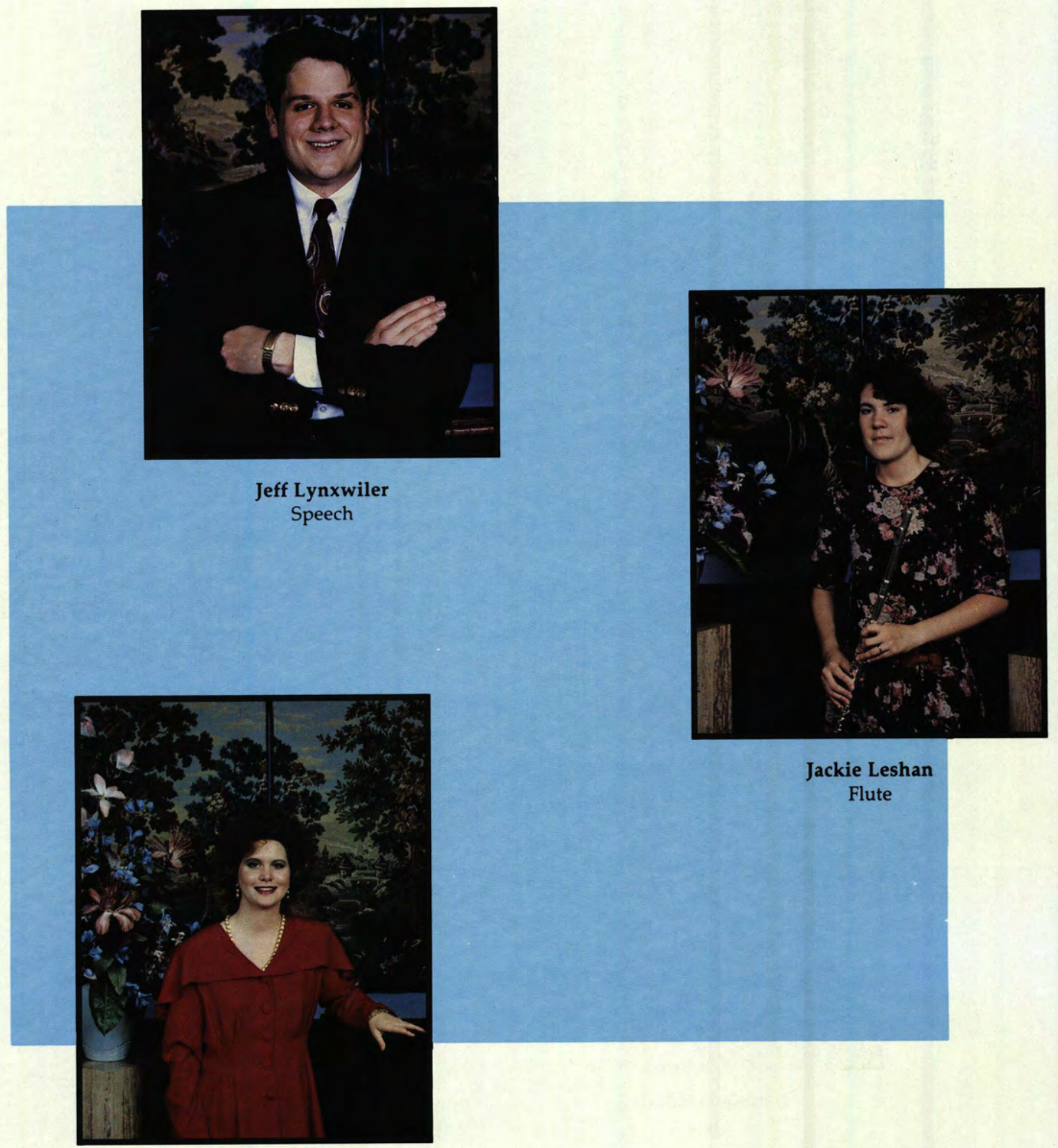

Melodie Holbrook

Speech 


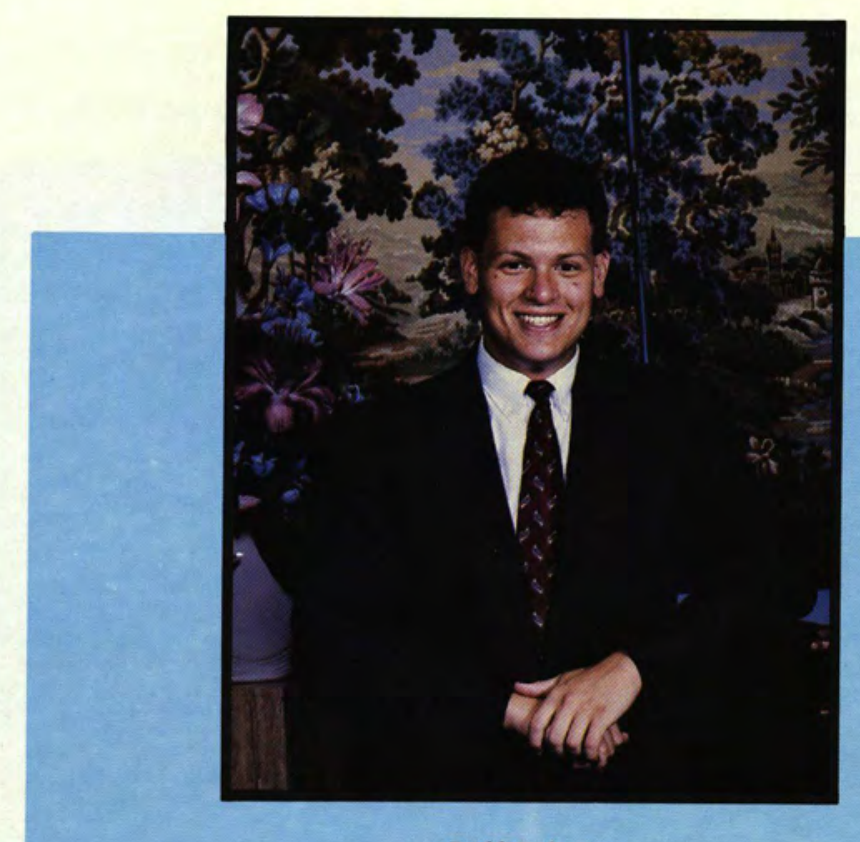

Jeff Joiner

Speech

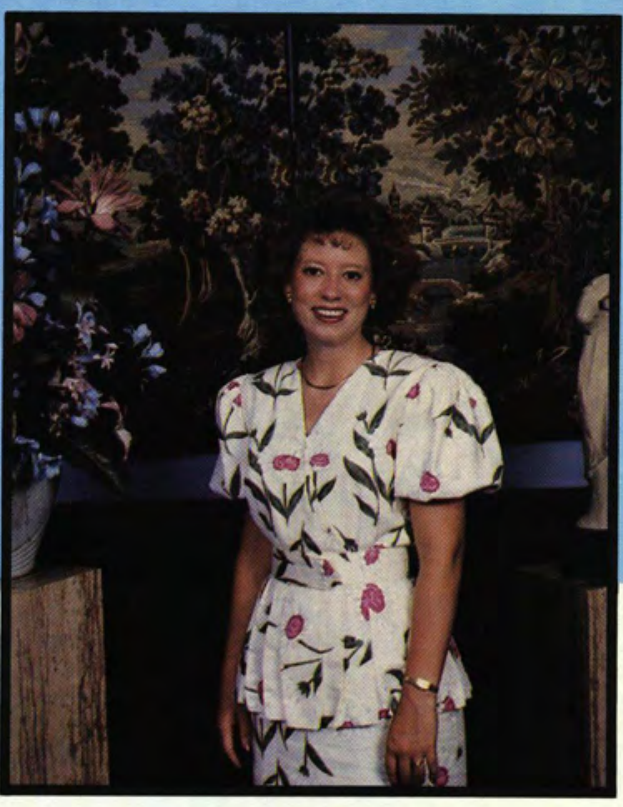

Debbie Polsdorfer Piano

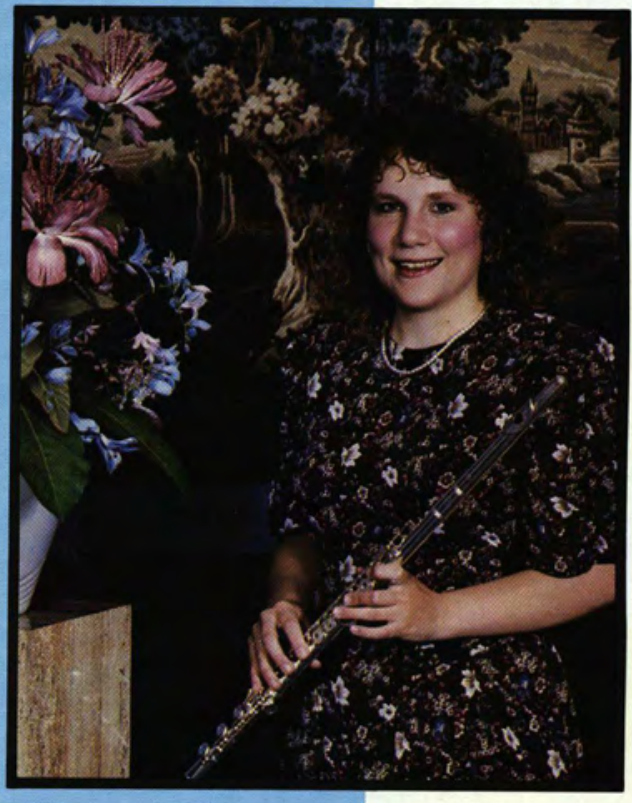

Michelle Bendt Flute

Not Pictured: Alicia Diller, Speech; David Munger, Speech 


\section{C.A.B. Presents. . .}

Greg Buchanan

The Cathedrals
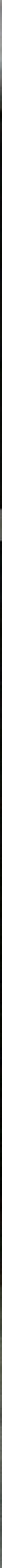

Larnelle Harris

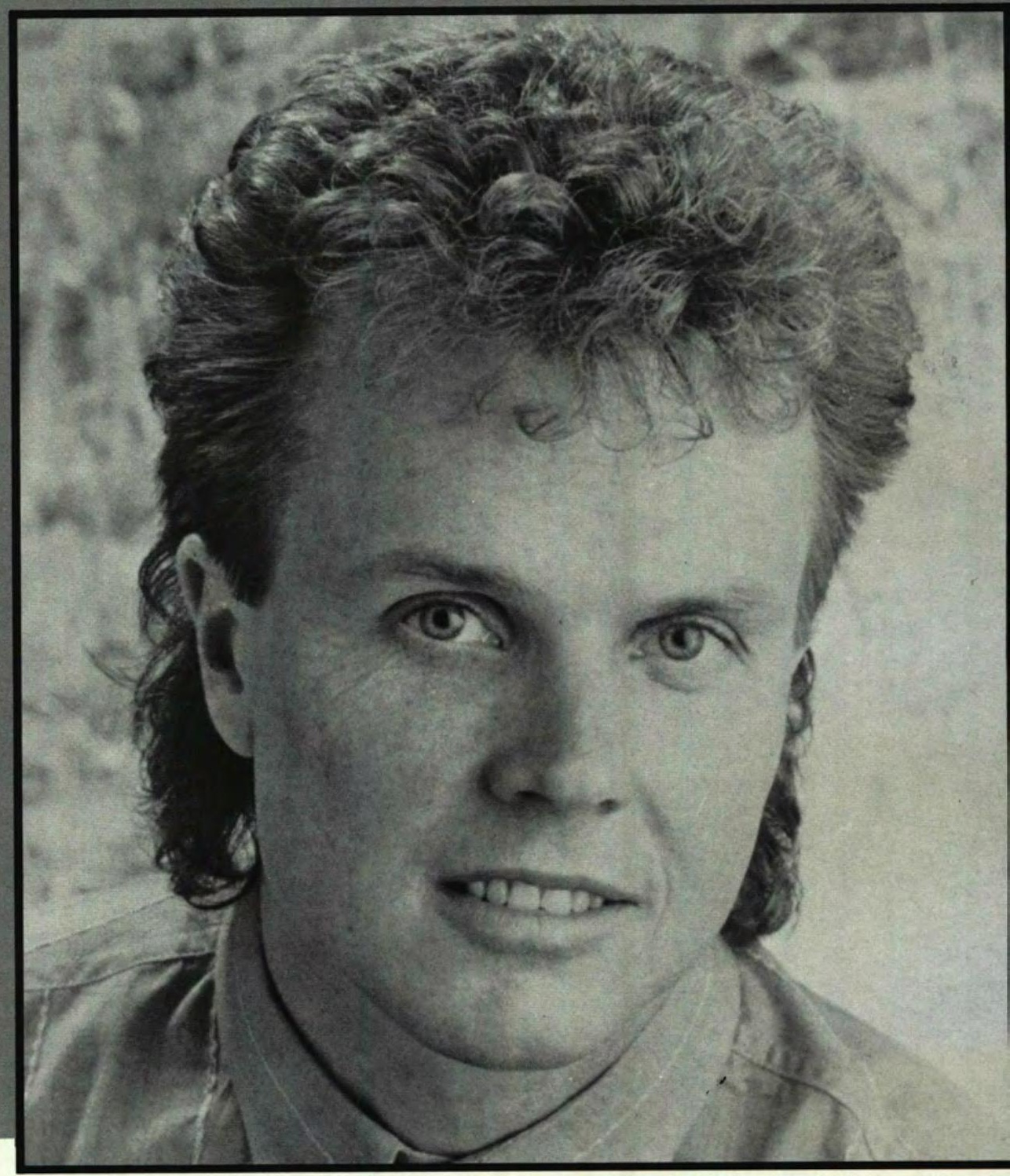

Pete Carlson 


\section{Artist Series}

A.D. Players

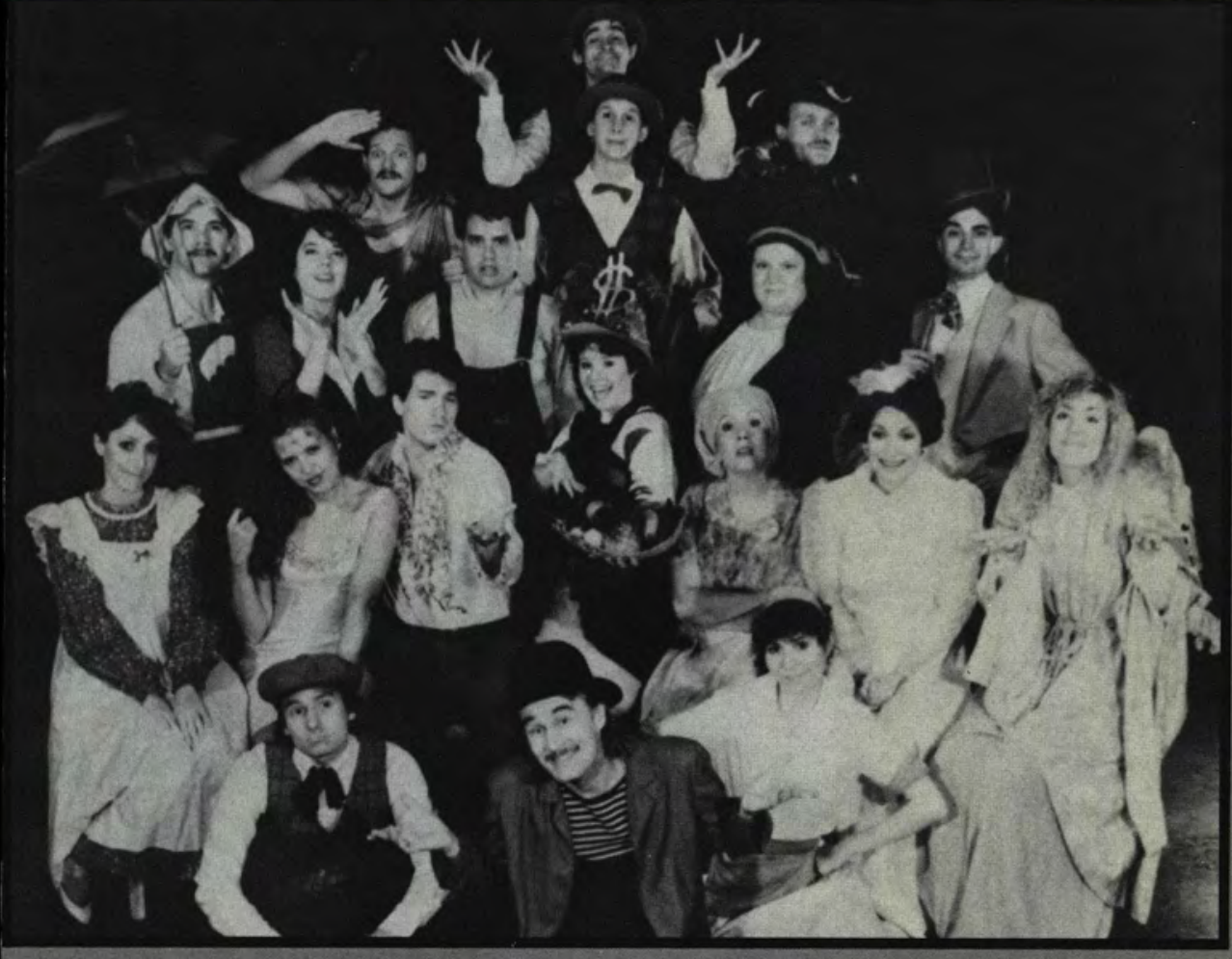

A.D. Players "in the elevator" in the James T.

Jeremiah Chapel.
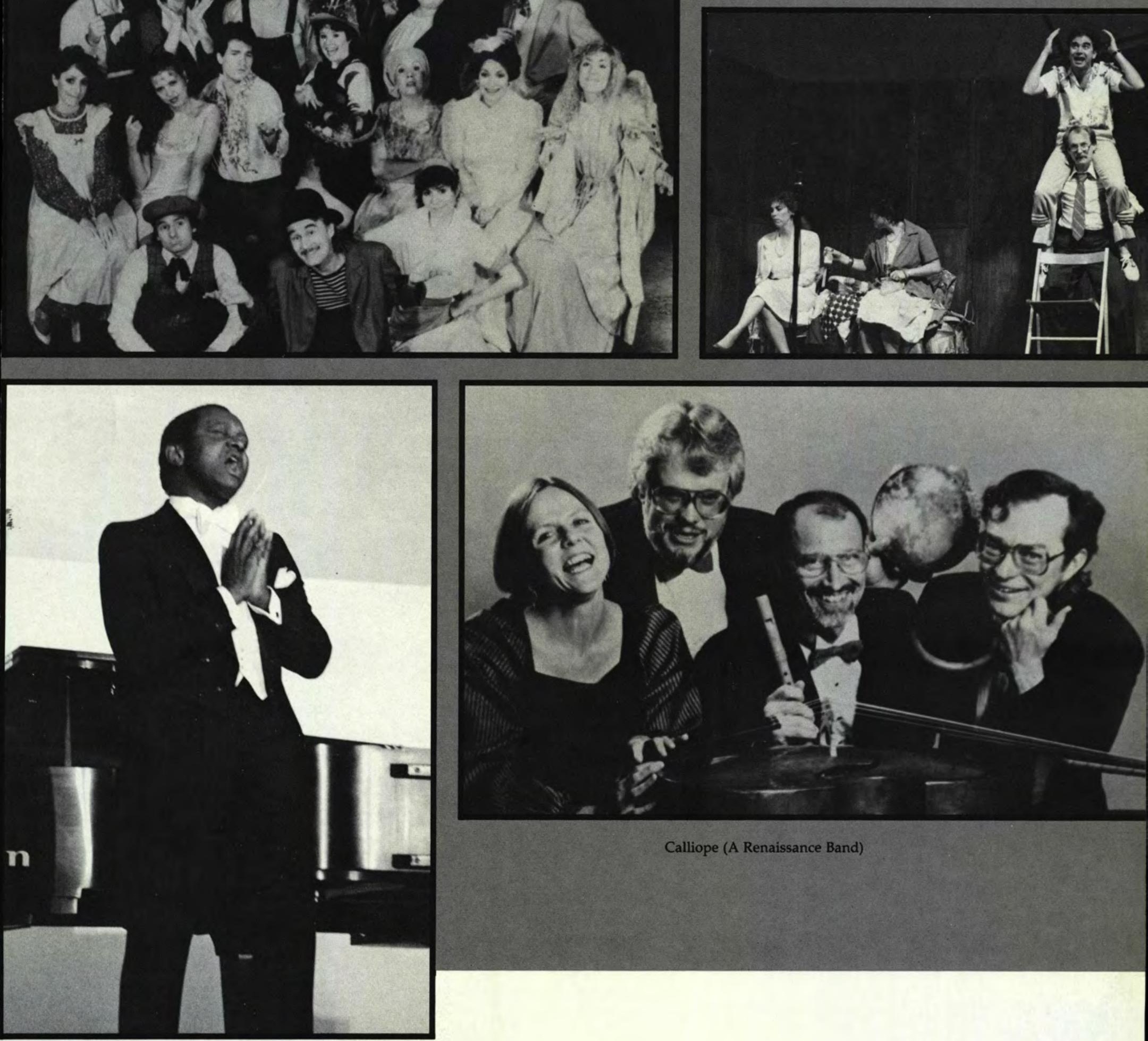

Calliope (A Renaissance Band)

A Festival of Spirituals 
The Cast

The Musician .... Jonathon Edgerton

Peterbono ......... Nathan Dobert

Hector ............. Bruce Quick

Gustave ......... Keith Wiederwax

Lord Edgard ....... Mike Andrews

Lady Hurf . . . . . . . Christine Michael

Juliette ............ Alicia Diller

Eva...$\ldots \ldots \ldots$ Hollee Stover

Dupont-Dufort Sr. . . Matt Stockham

Dupont-Dufort Jr. . . . . . David Moore

Town Crier ........... Brian Bates

Angelica (Nursemaid) ... Lori Linder

Suzette (Little Girl) . . Sylvia Faragalla

Policemen

Steve Brock Jonathon Varner

Women

Carrie Quinn Jerry Cook
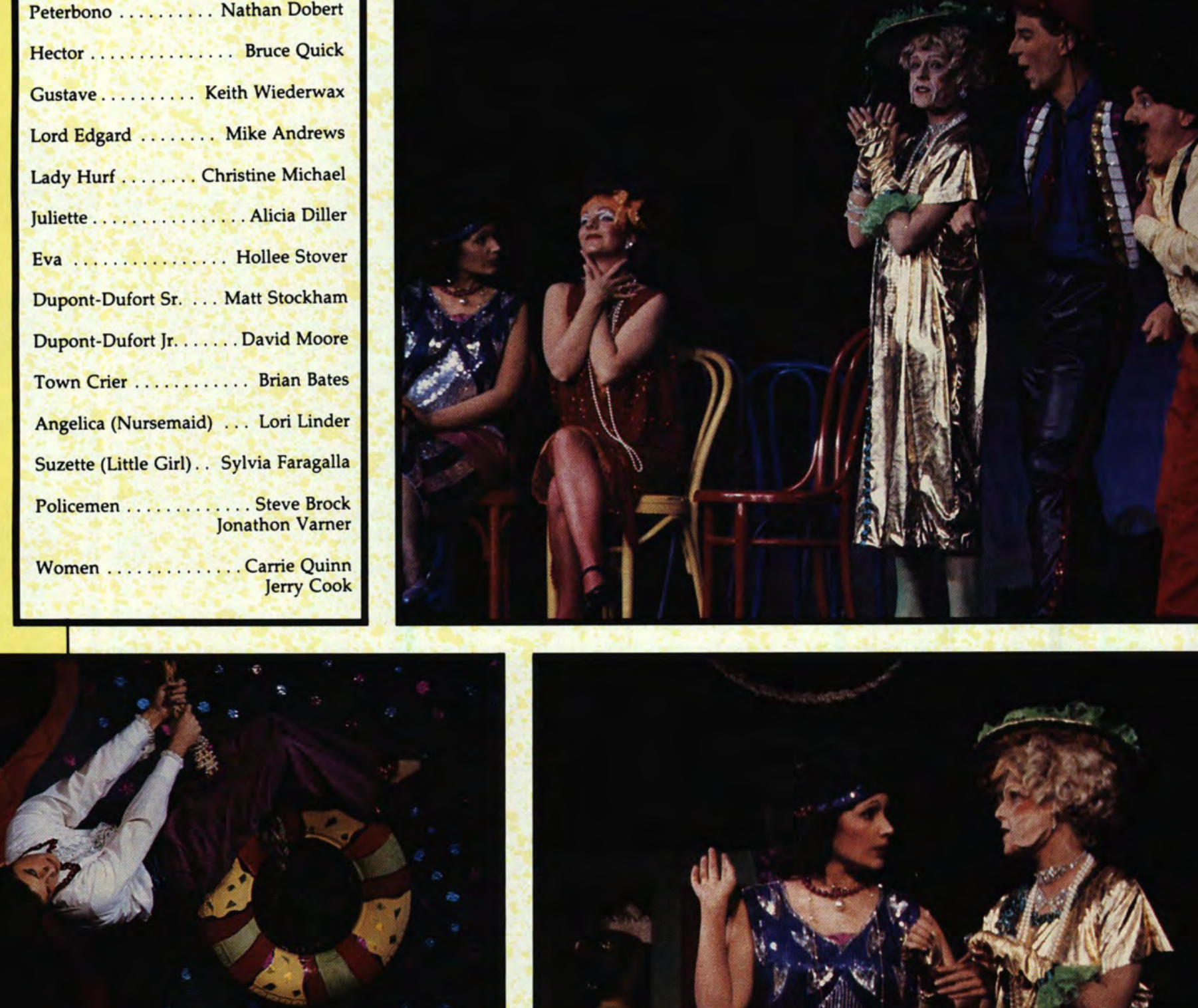

e
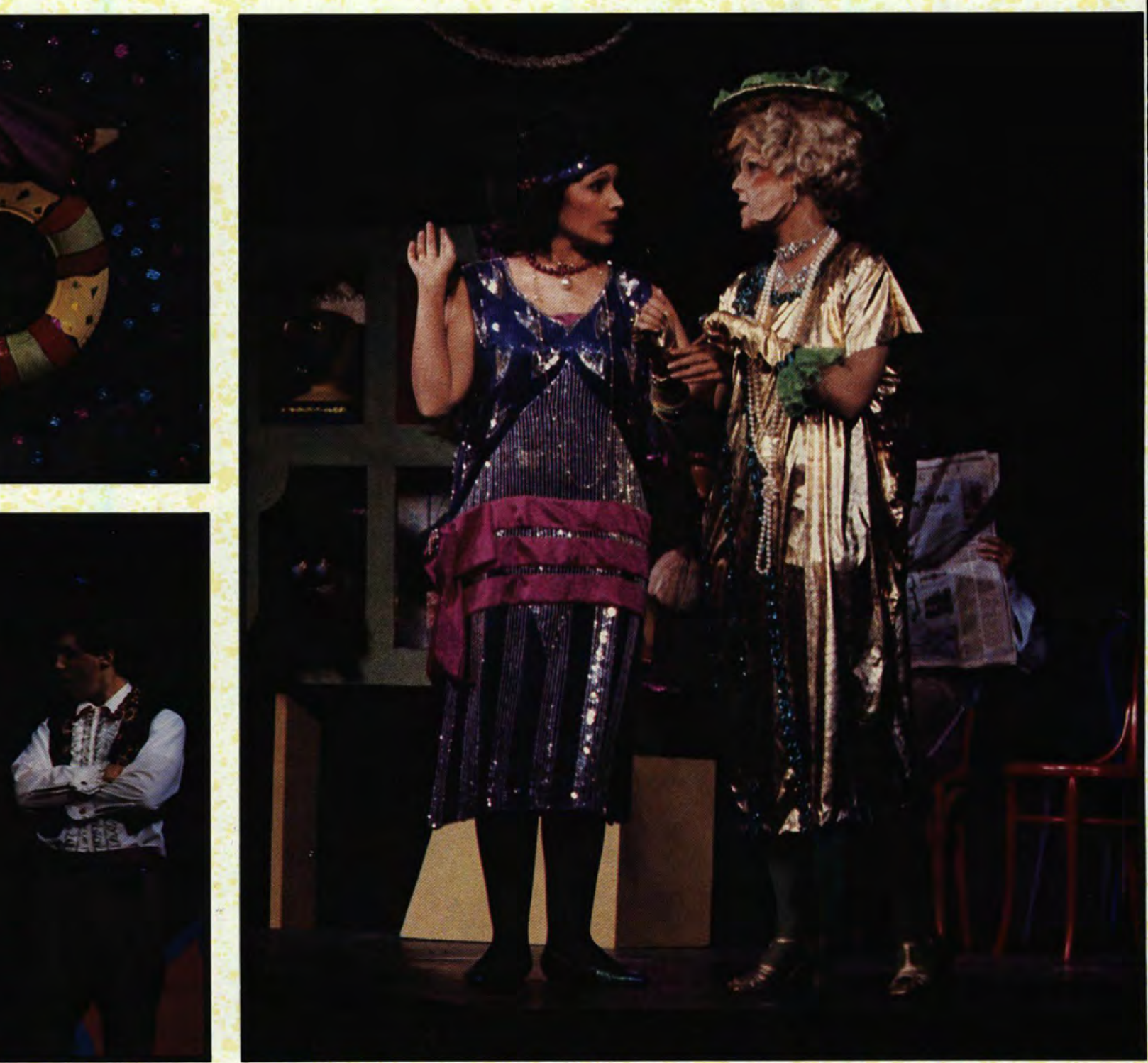


\section{The Miracle Worker}

Few stories capture hearts like The through indulgence, and the Keller's Miracle Worker ${ }^{\prime}$ The Village Players performed this beautiful drama February $14-16$

pain and frustration led them to seek a teacher. In March, the true miracle story

In 1880, in Tuscambia, Alabama, Helof Helen Keller. The cast hoped that in en was born to Captain and Kate Helen troubled times of war, the audience
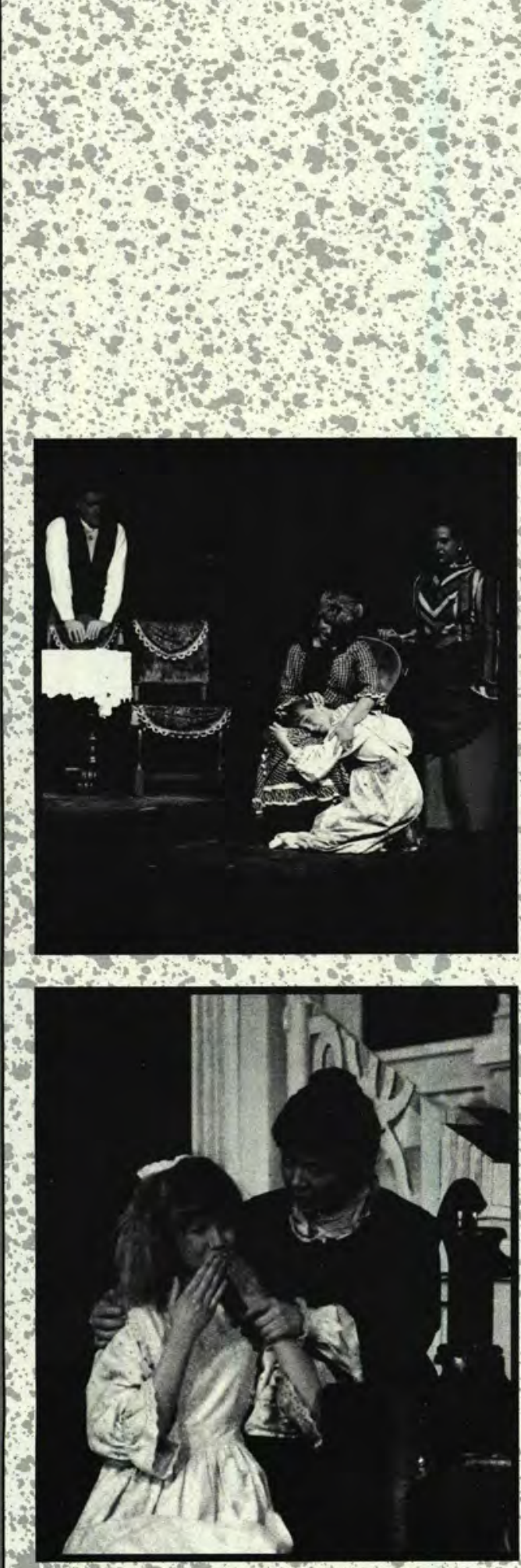
free from her silent prison. Of Helen and Annie, Mark Twain said: "It took the two of you to make a complete and perfect whole."

The committed cast of 23 along with director $\mathrm{Re}$ becca Baker worked to portay

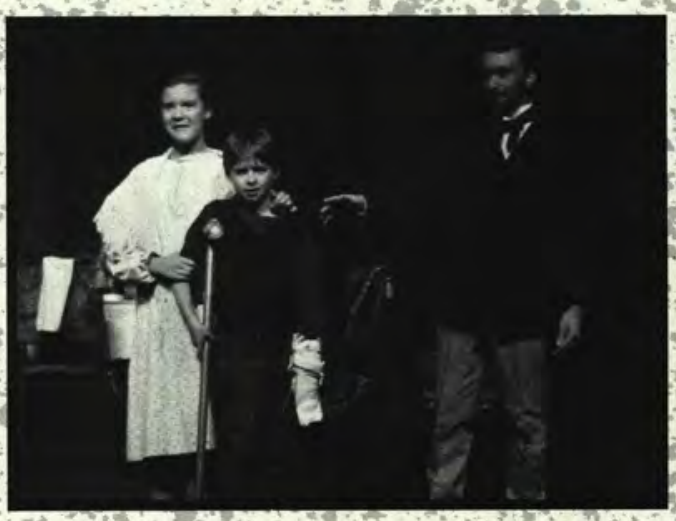
Keller. After being struck with a fever, Hélen became blind, deaf, and mute. Love for the child expressed itself $h$ o p e Amazing grace, how 1887 , Annie Sullivan met a most gifted pupil - Helen Keller.

It was Annie's determination that set sweet the sound :I was blind, but now, Isee.

- Carrie Quinn

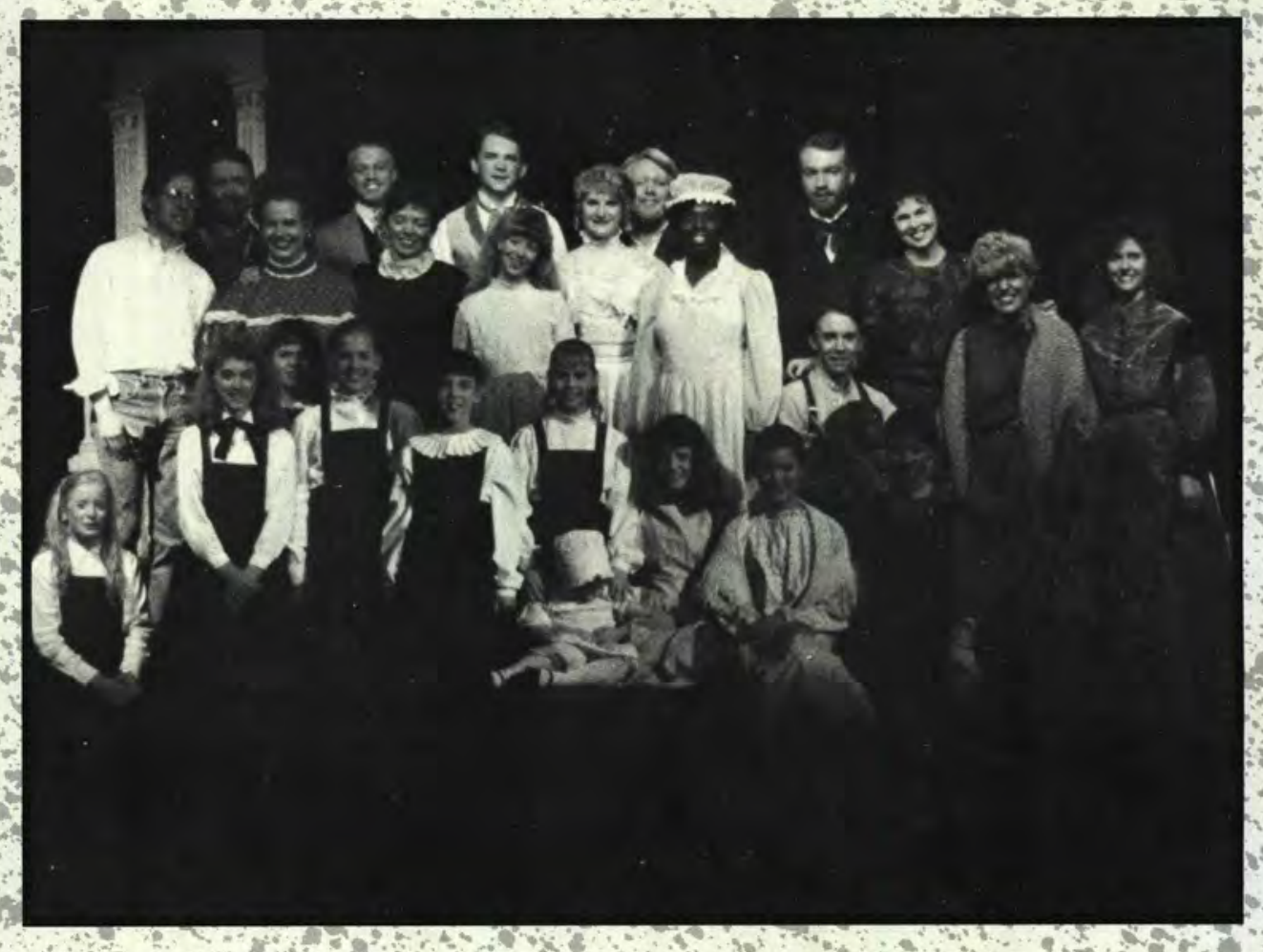




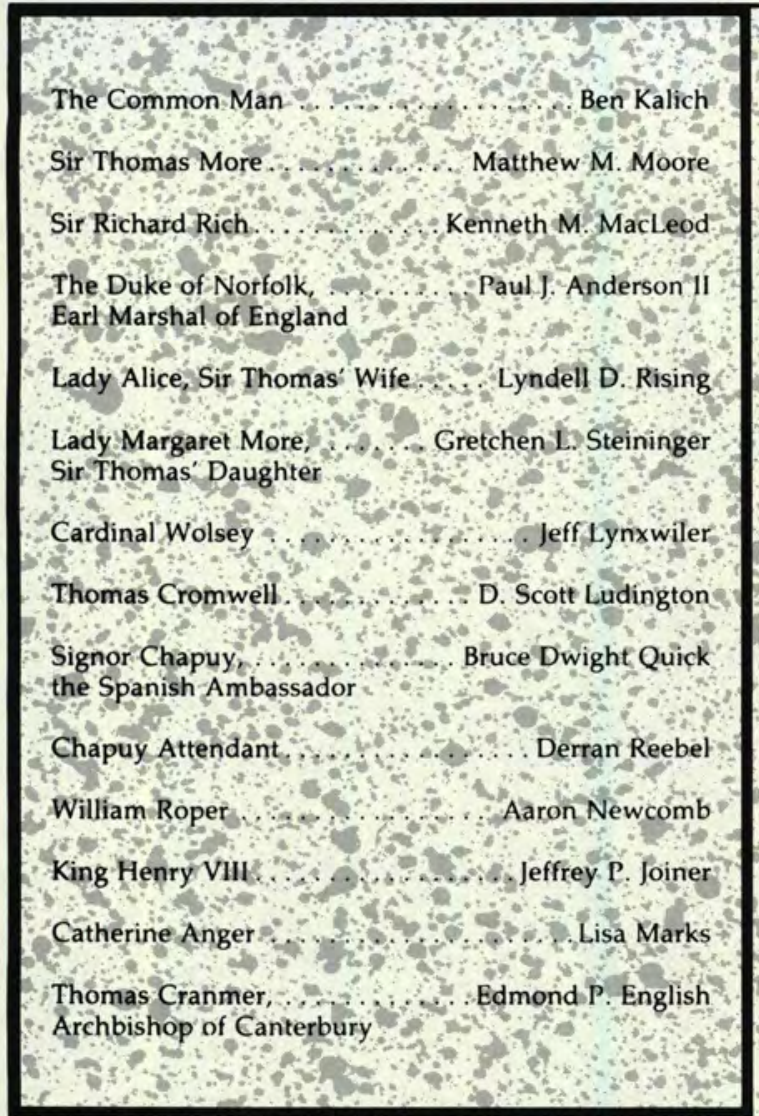

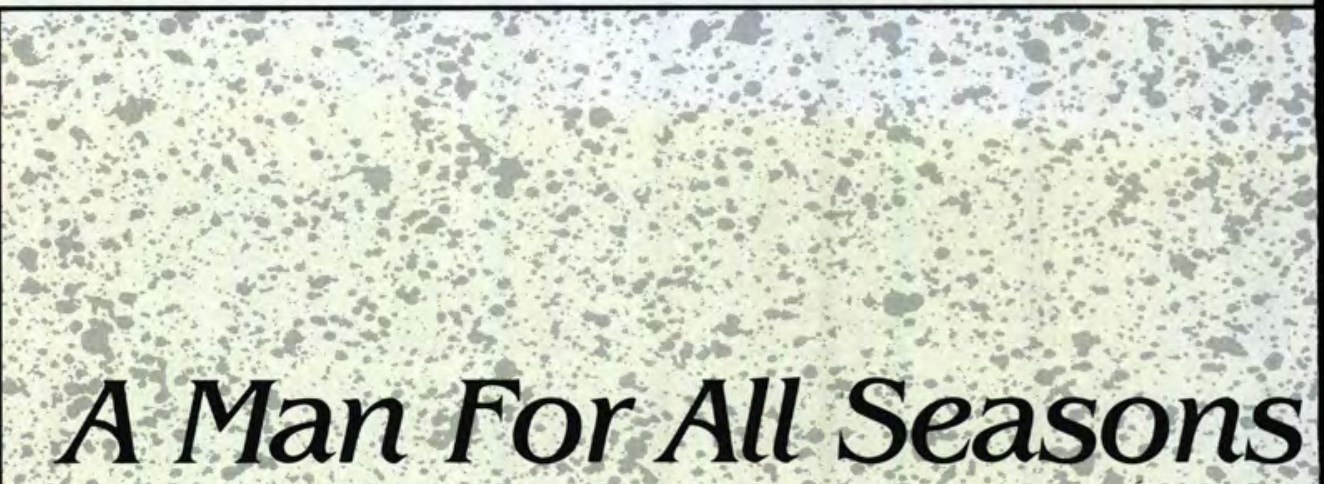

A. Few English kings have had a greater impact on English/American history than Henry the VIII, His quest to father a son prompted his divorce from Catherine and his marriage to Anne Boleyne. The accompanying political upheaval included England's separation from Rome, the establishment of the Church of Eng land, and an attack upon the Lord Chancellor of England, Sir Thomas More.

The Compelling plot of A MAN FOR ALE SEASONS is woven around the classic struggle: God's law vs. Man's law.
Thomas More's dedication to his God led to his removal from office, his imprisonment, the loss of his fortune, and his death a heavy price to pay for personal belief. Author Robert Bolt has done a masterful job of bringing history to life in the colorful and dramatic telling of this story of conscience.

This compelling play was performed by the Cedarville College Spring Production cast and was directed by $\mathrm{Dr}$. David Robey
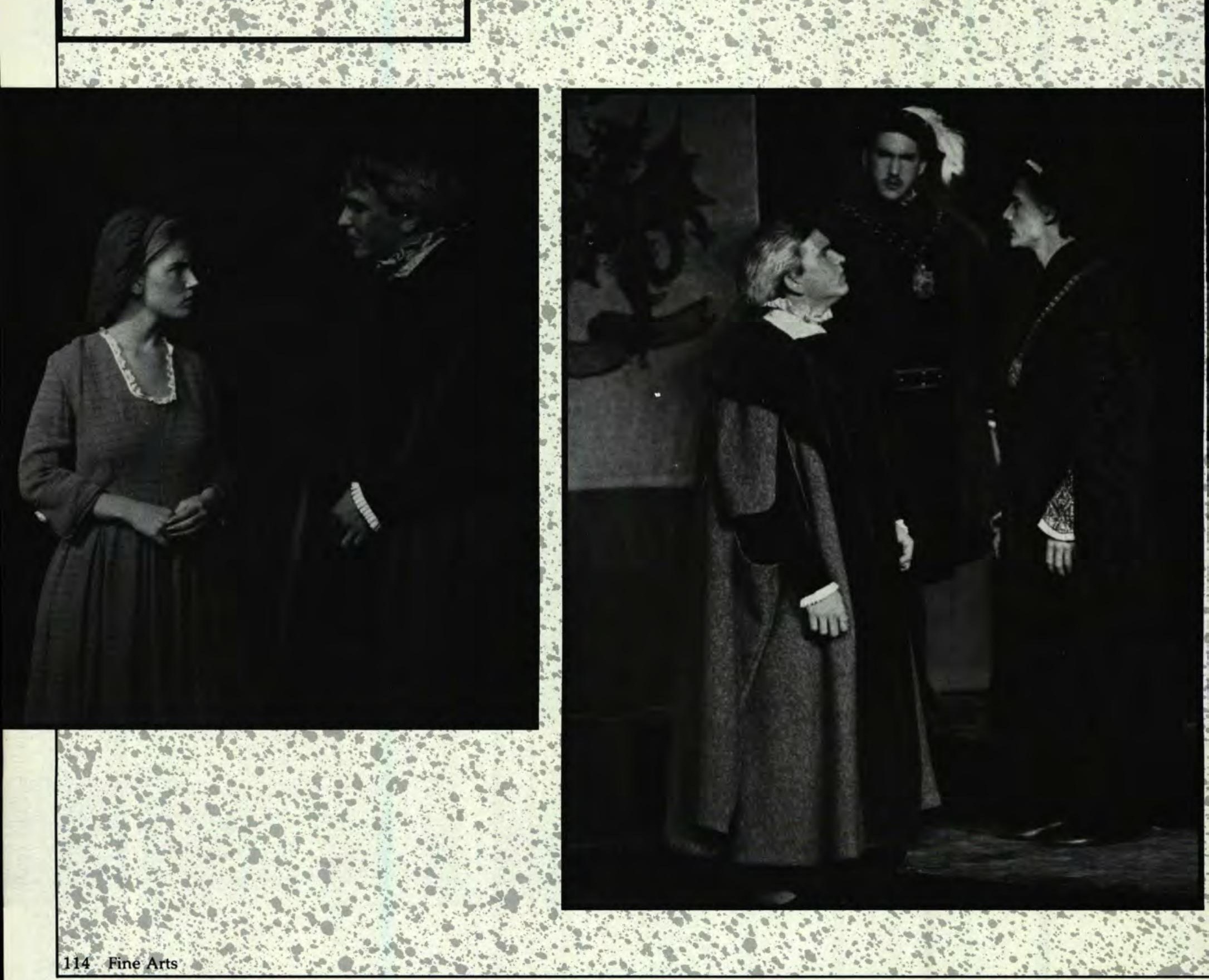


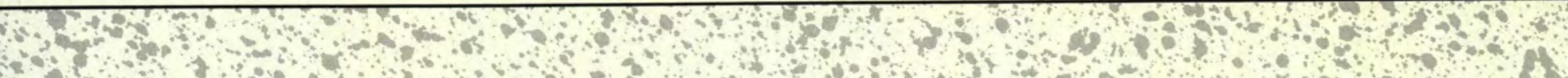

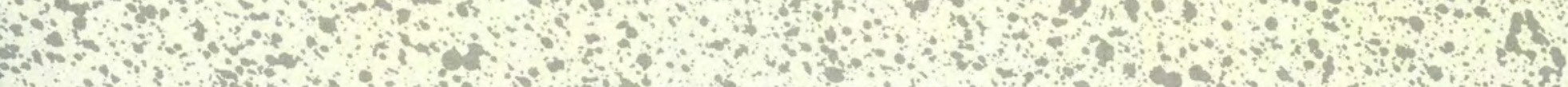

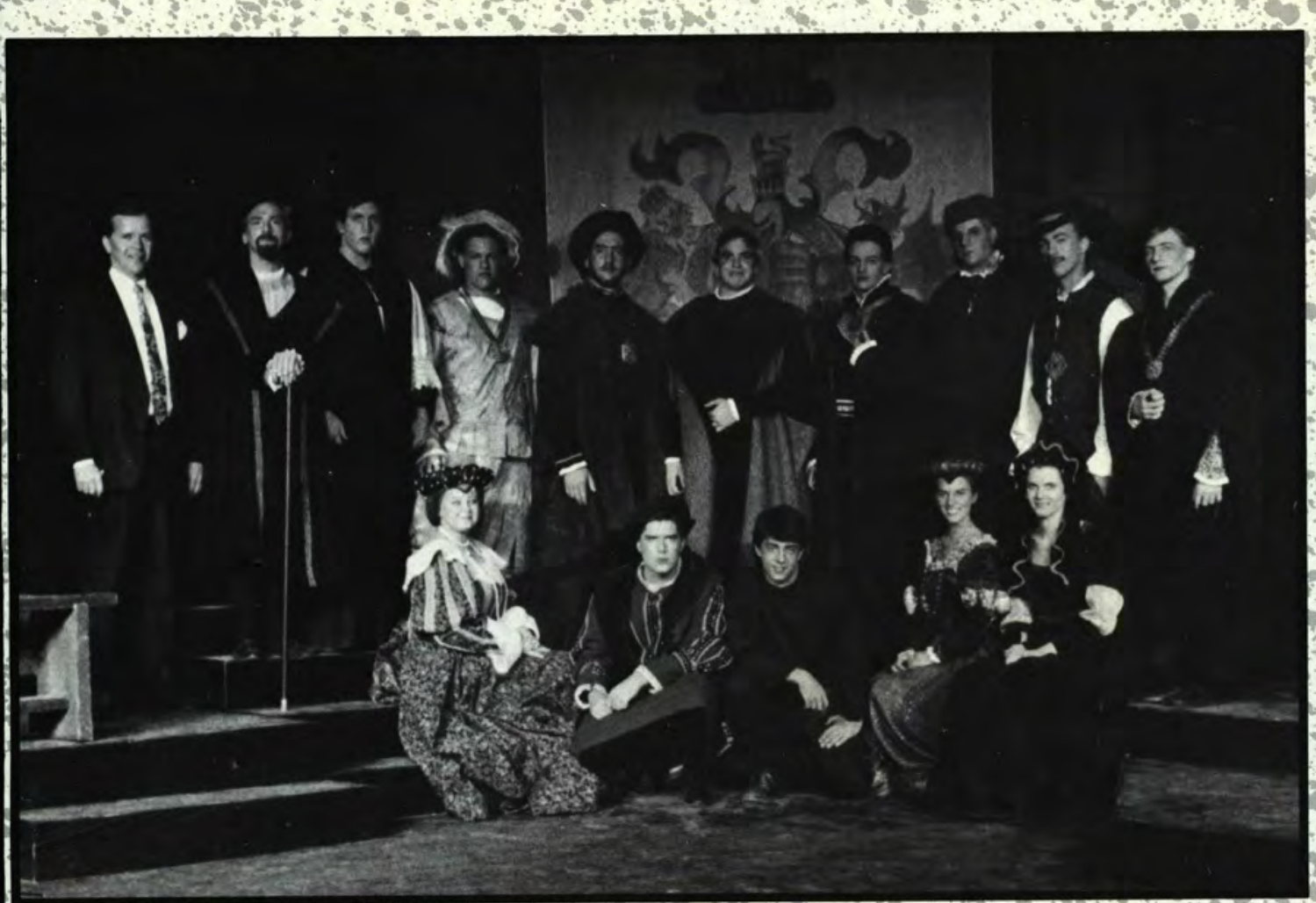
(3)

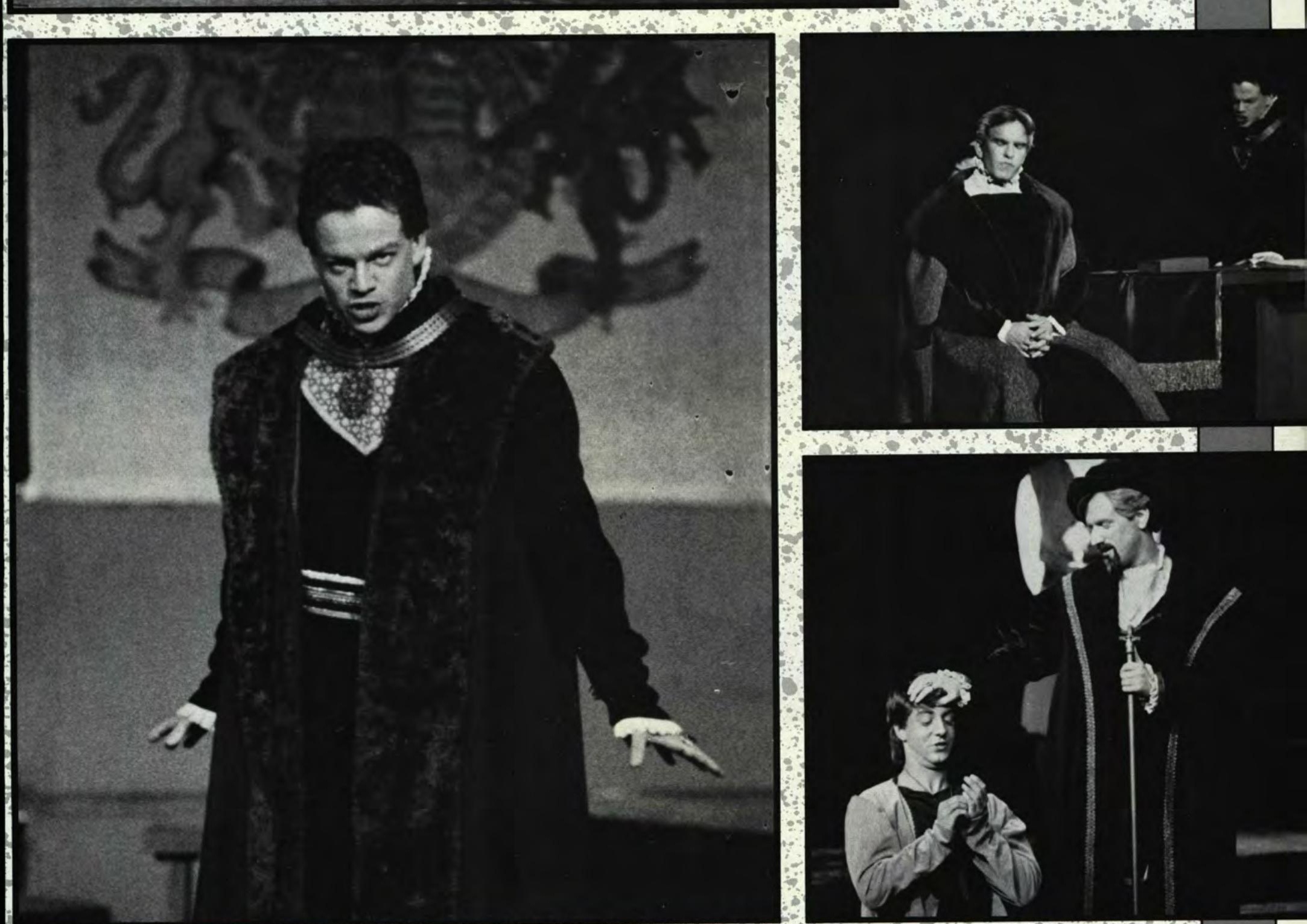

\section{2} 2 
Practice makes perfect for Lori Smith, Gwen Workman and Beth Fales

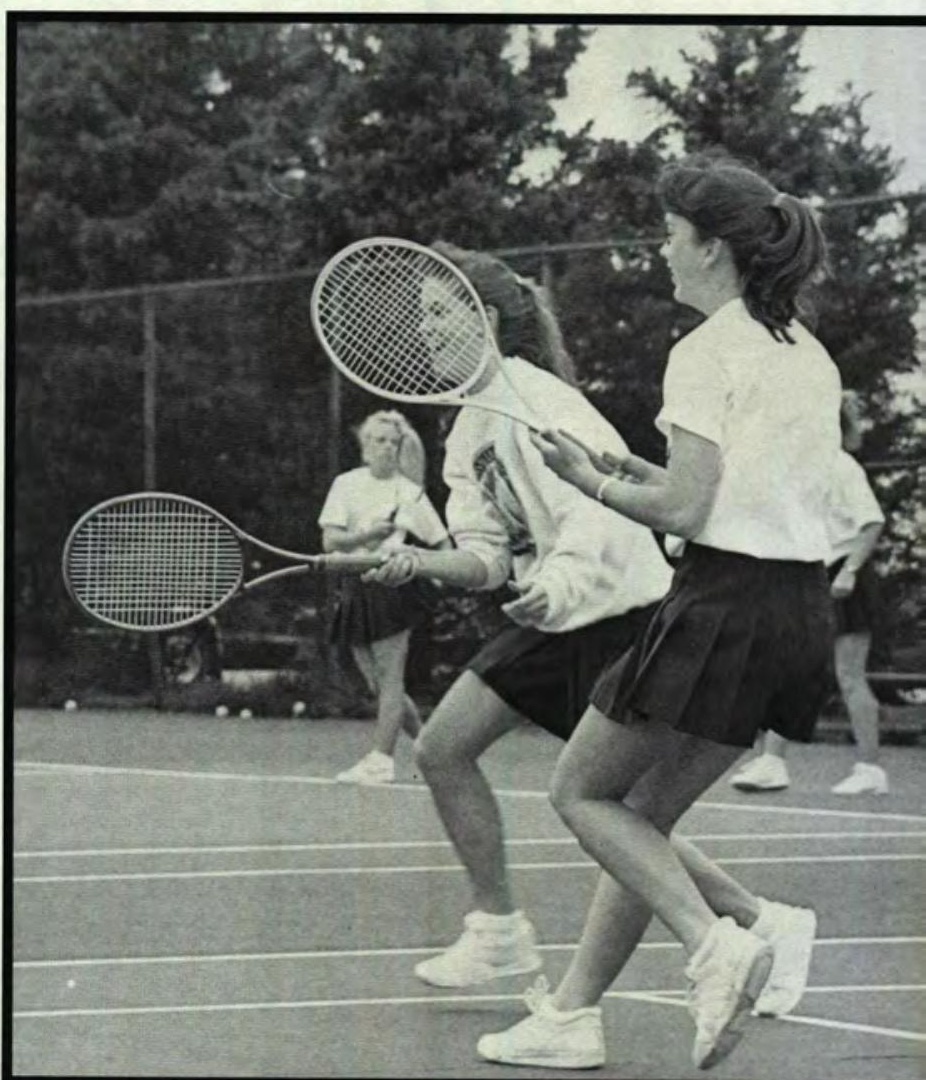

photo by Steve Cook

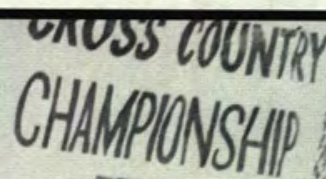

\section{MONGST}

望

$\frac{41}{5}$
-5

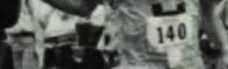

it.

3

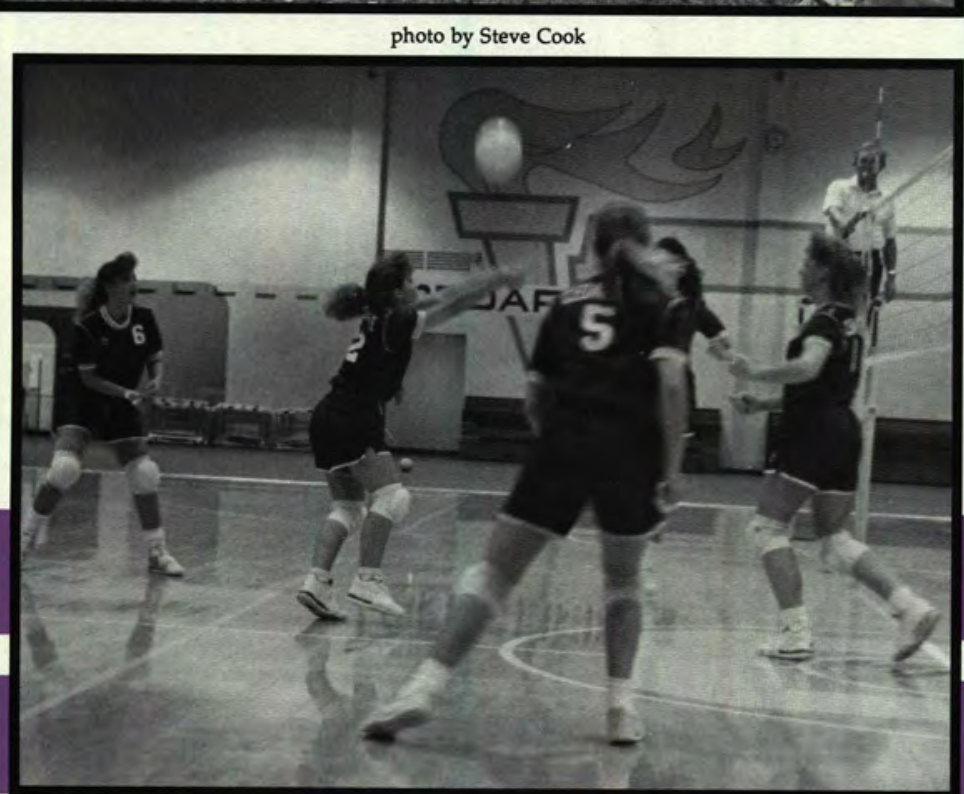

photo by Steve Cook

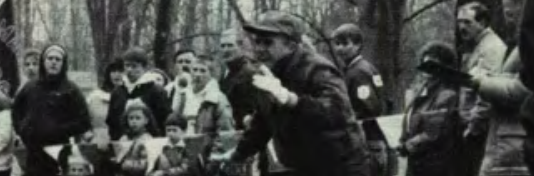

$\because \frac{1}{6}+\frac{1}{2}$
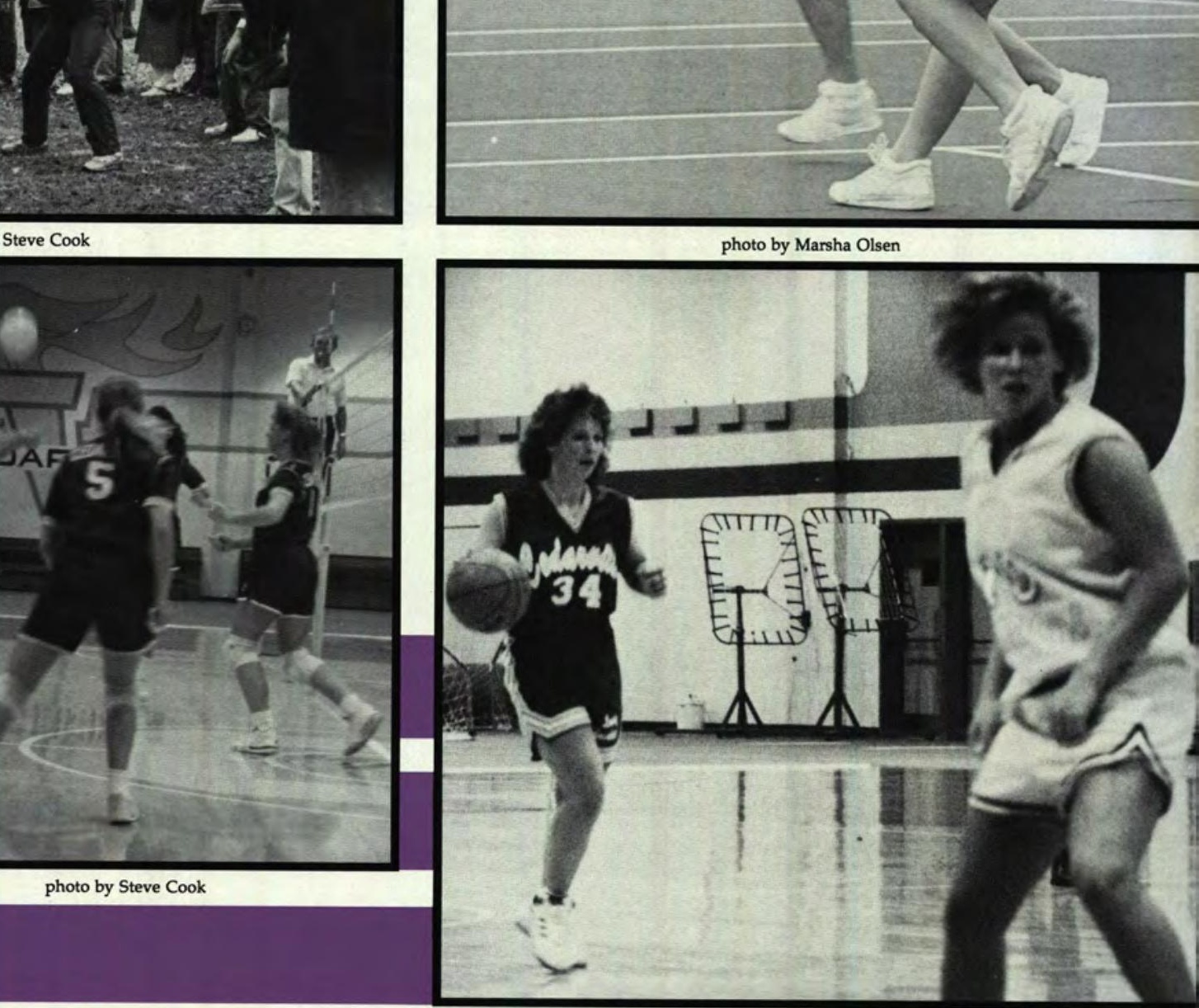

photo by Marsha Olsen

\section{When Miracles Merge. . . They Meet the Challenge}




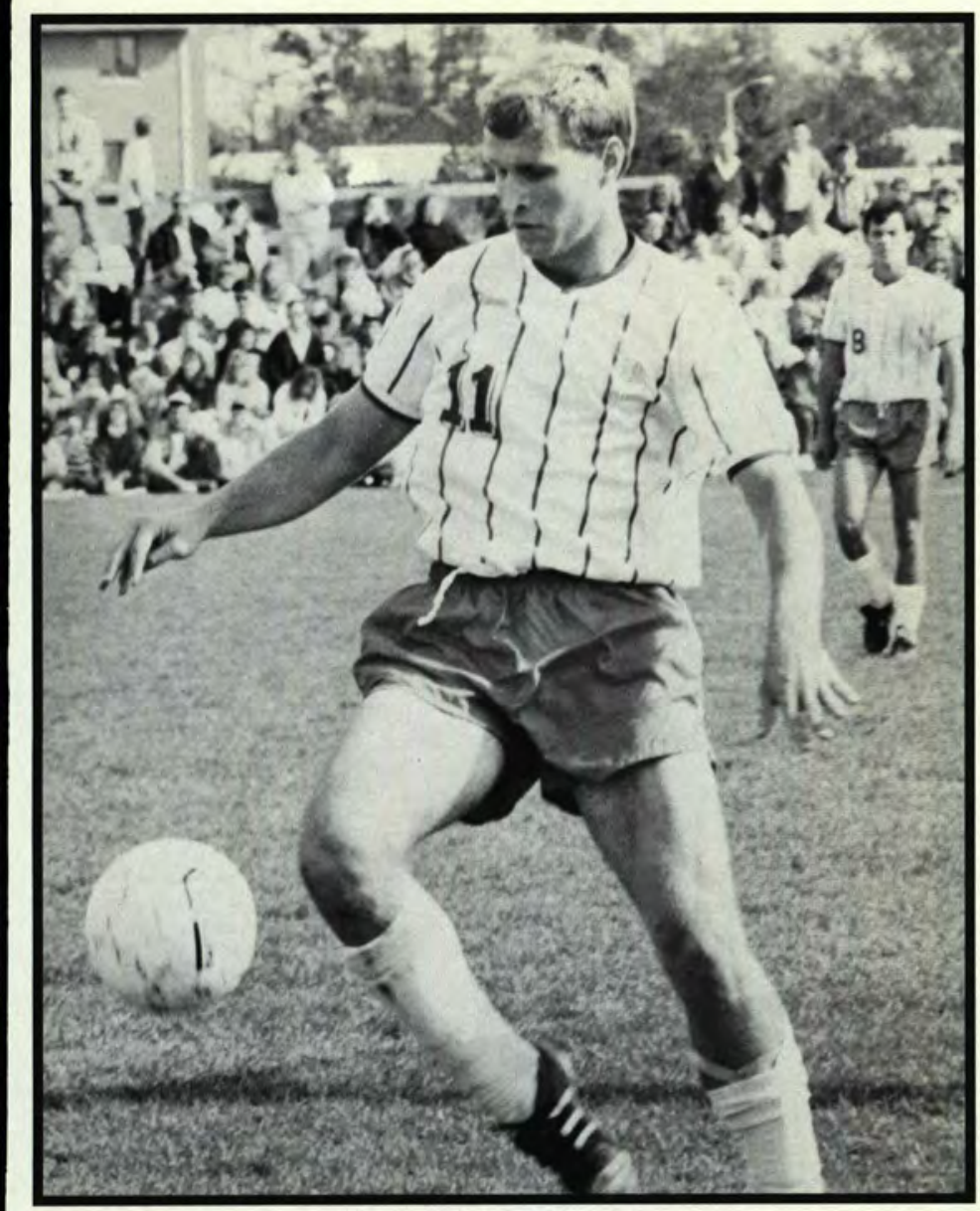

photo by Tania Taylor

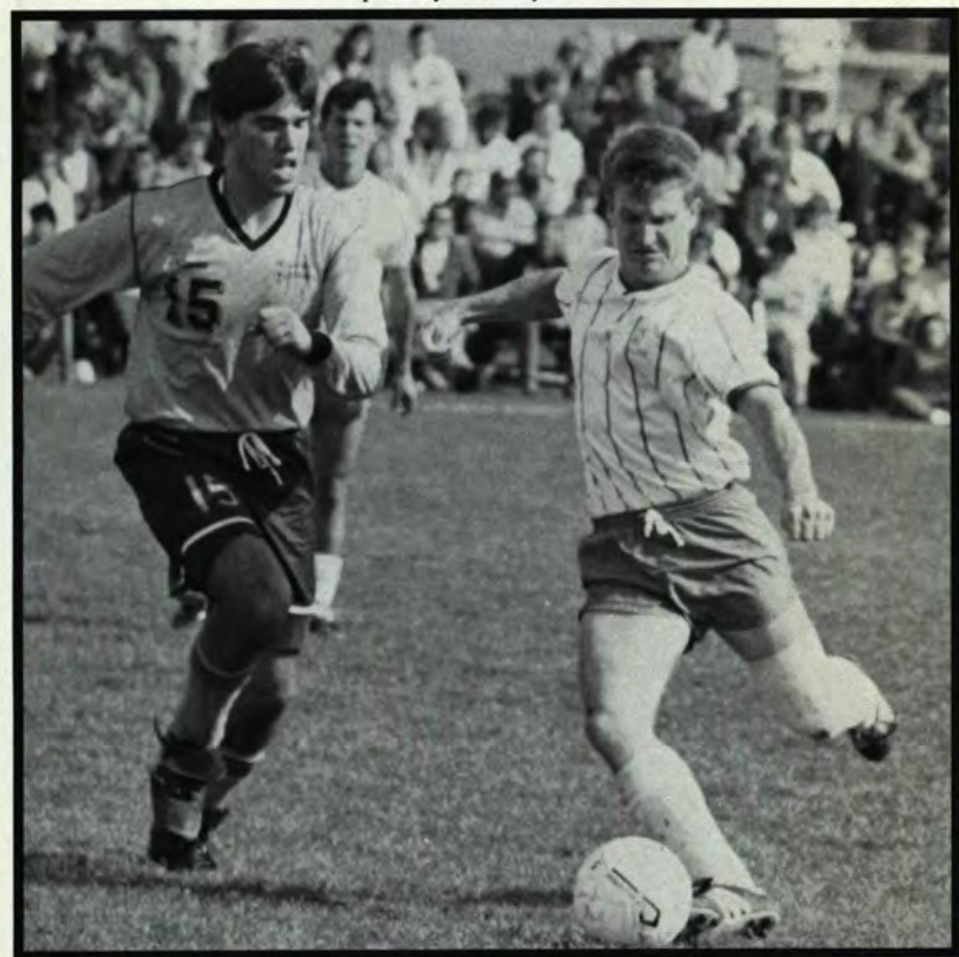

photo by Steve Cook

Dave Kohlmeyer skillfully handles the ball.

Craig Winsor sends the ball flying across the field and away from the other team.

\section{Punting with Power}

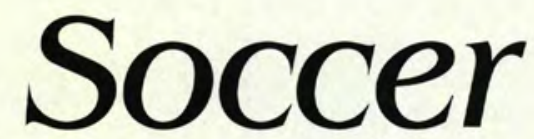

If there were any words to describe the hopes of the 1990-91 soccer team at the beginning of their season, it would be "rebound." The "Season Outlook" published during last summer read,"Senior co-captains Dave Weaver and Brent Davis hope to overcome the injuries that put them on the shelf last fall. Weaver, the team's top goalkeeper, suffered a dislocated elbow in the fourth game and was gone for the year, while Davis, the squad's best ballhandler, played in just eight games because of nagging foot problems."

The team's co-captains did bounce back. Weaver watched the goal in every

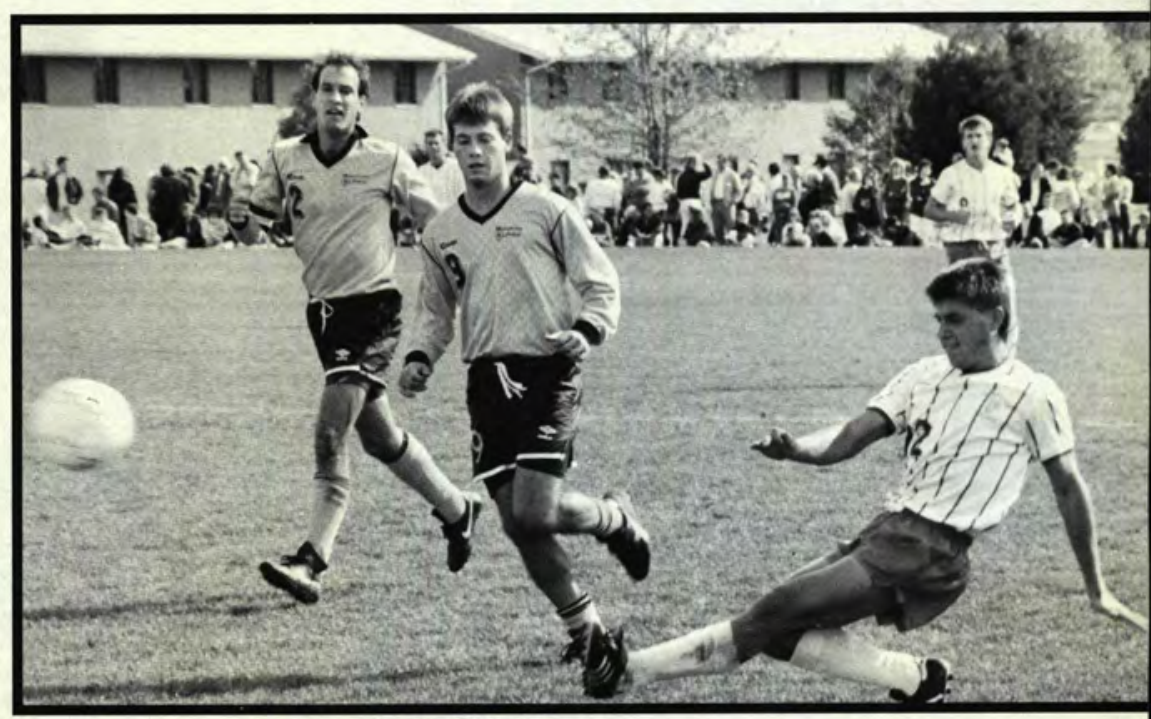

photo by Tania Taylo

Greg Davidson eludes the opposing team with a power kick. game throughout a hardfought season. The team ended the regular season strong with three consecutive wins before going on into the NAIA District 22 Playoffs in Tiffen, Ohio, and then the NCCAA District III playoffs played on the new home field.

Senior back Dan Walsh was named the NAIA District 22 defensive player of the week after firing in a goal and providing an assist in Cedarville's 4-0 victory over Ohio Dominican. Senior foreward Dave Kohlmeyer lead the team in scoring this year for the fourth year in a row 


\section{Racing with Rigor}

\section{Cross-Country}

Imagine running two miles in the freezing cold, for what, for fun? That is exactly what the woman's and men's cross country squads did Saturday November 10, 1990, when they participated in the NCCAA National Cross Country Meet at John Bryan State Park.

I soon realized Cross Country running is much different than any other sport I have been acquainted with. The team comradery and fan participation is something that makes the event extremely interesting to attend. Many times I would see the men's team, who hadn't run yet, running to see where the women runners were and yelling words of encouragement.

For running in the cold, there must be a rewardplacing. The Lady Jackets finished third, behind Malone and Anderson. Individual placings were 4th by Brenda Paulhamus, 6th by Krista Pritchard.

The men from Cedarville hung in to finish strong in the race with a team finish of 5 th and top placings of 11 th, 17 th, and 19th. Even though the day was chilly, the enthusiasm and support of the Jacket fans and team members remained strong.

- Carrie Mann

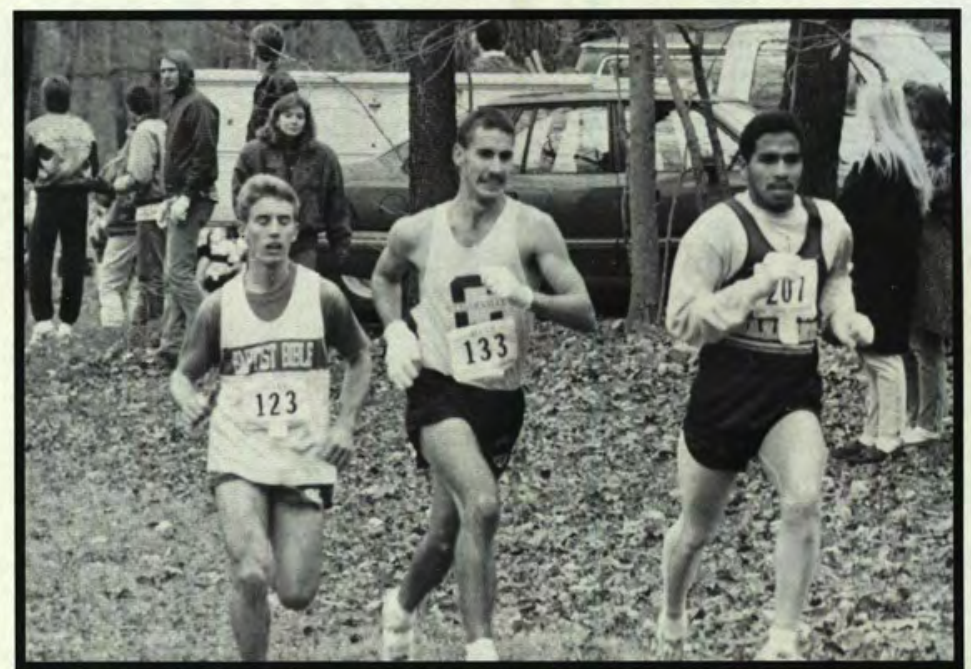

photo by Andy Jamieson

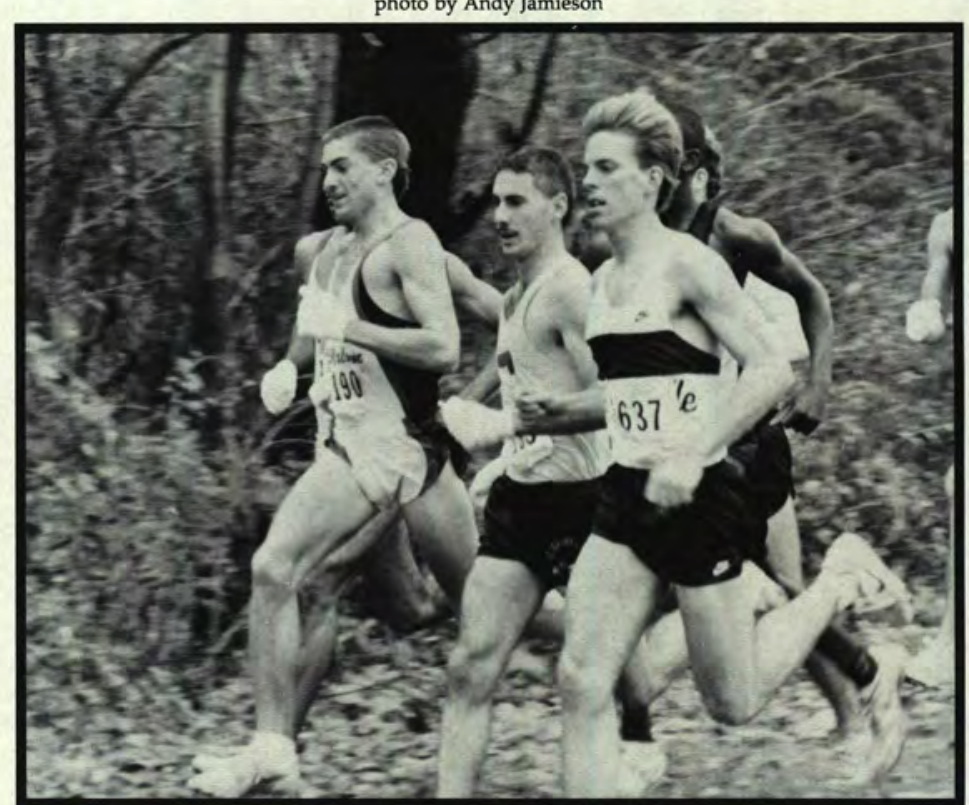

photo by Andy Jamieson

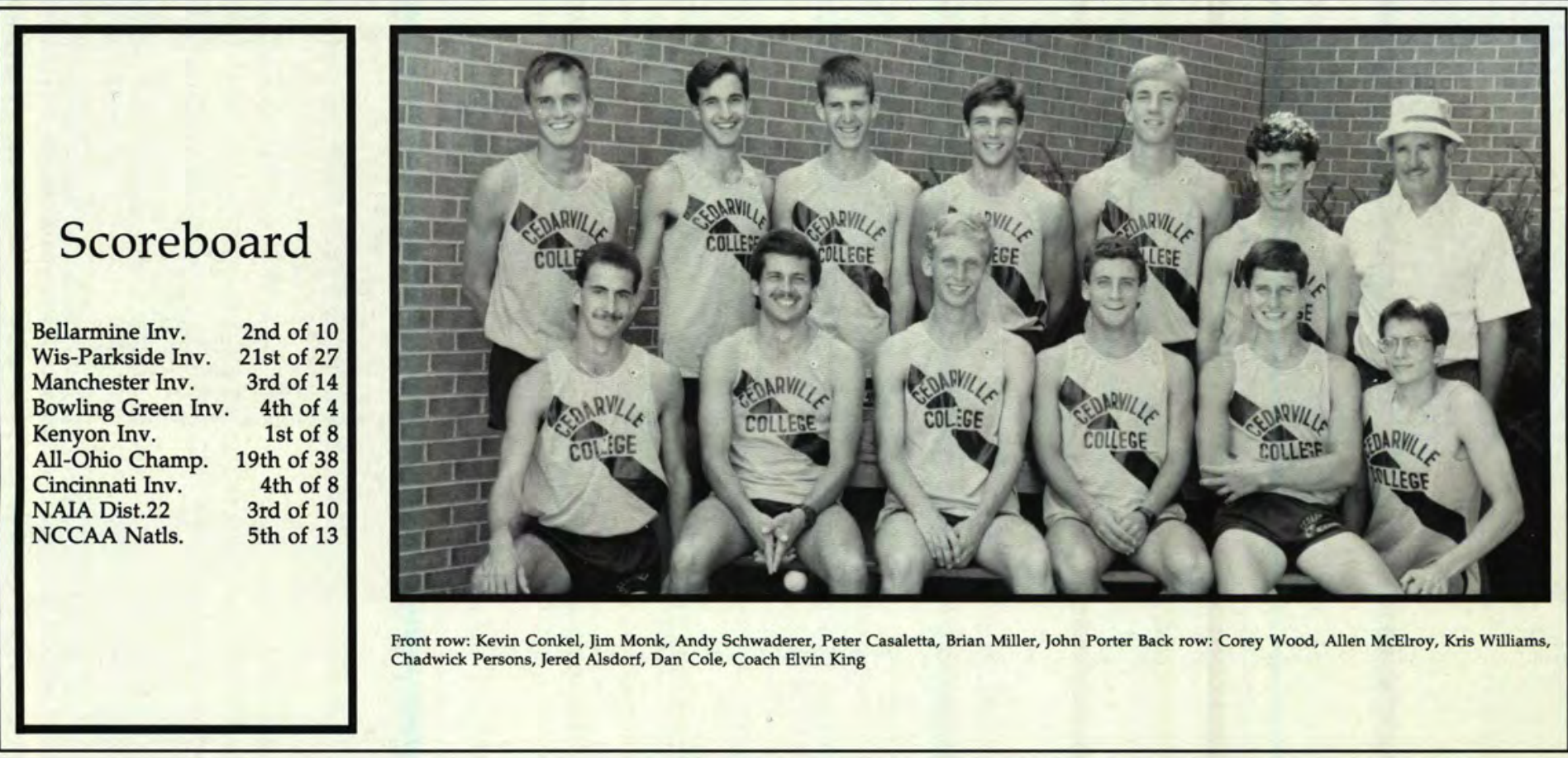




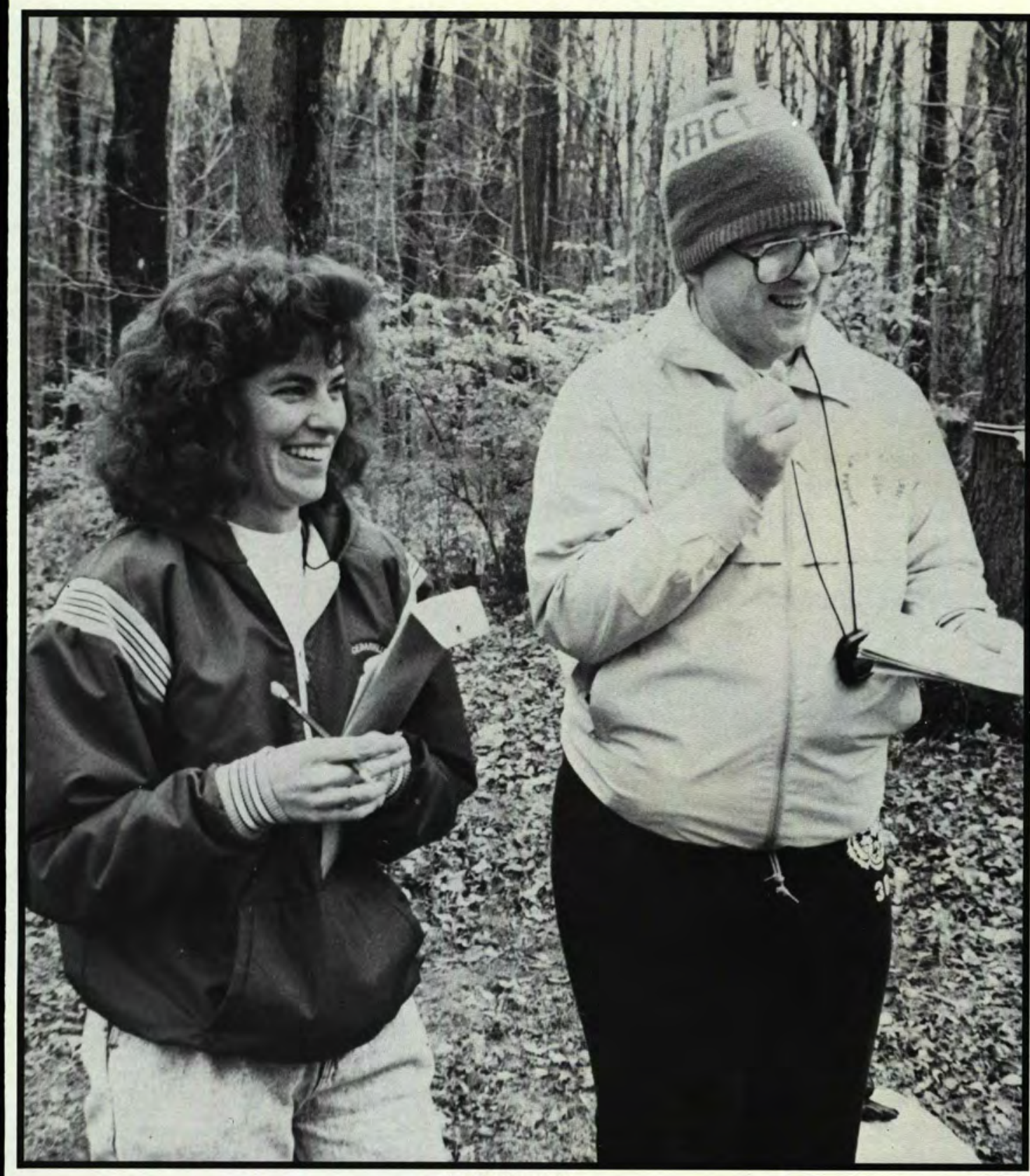

Mindy Schwaderer stretches for the finish.

Brenda Paulhamers leads the pack as she pushes for the finish.

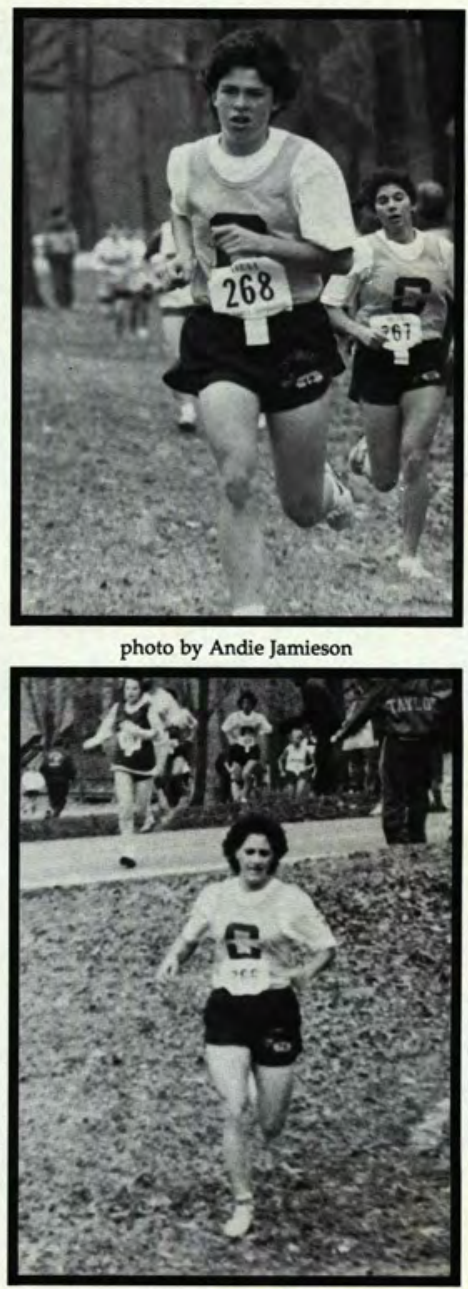

photo by Steve Cook

photo by Steve Cook

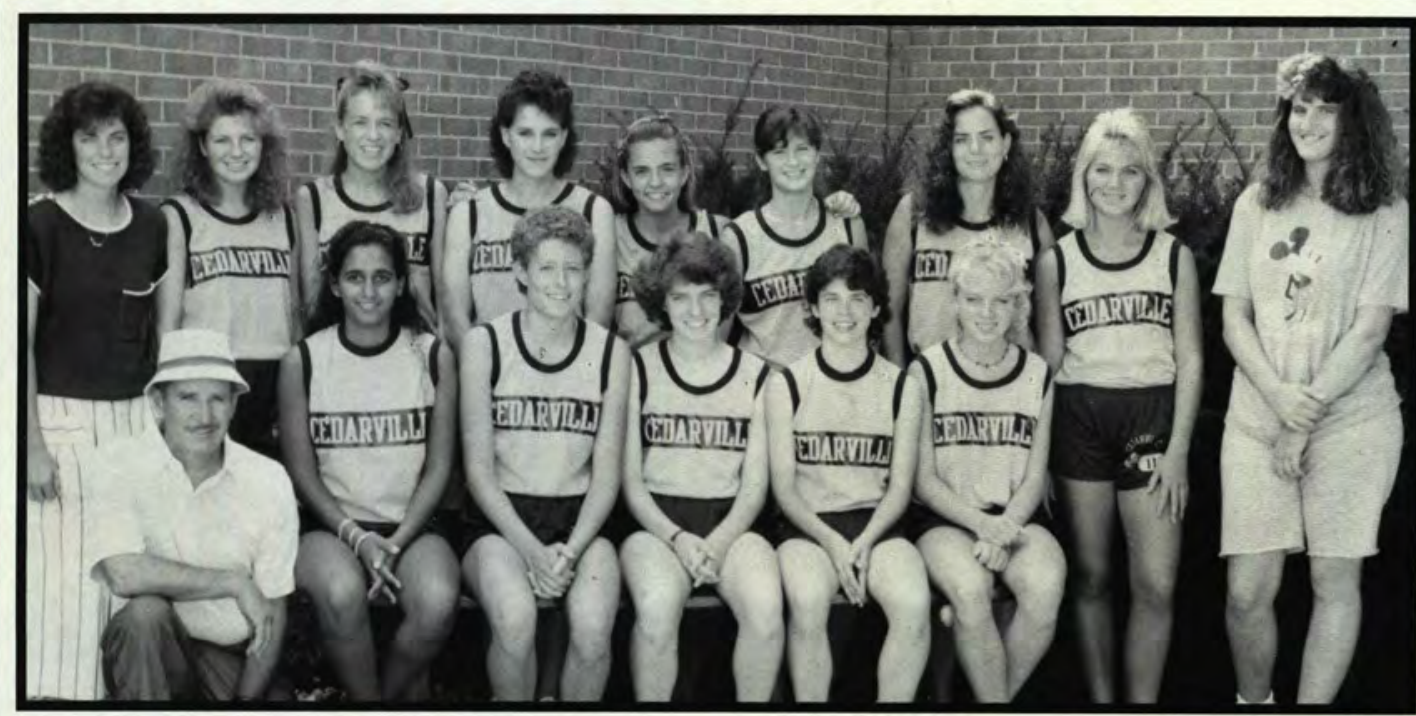

\section{Scoreboard}

Bellarmine Inv. $\quad 1$ st of 8

Wis-Parkside Inv. 12th of 23

Manchester Inv. 3rd of 11

Bowling Green Inv. $\quad 4$ th of 4

Kenyon Inv. $\quad 1$ st of 10

All-Ohio Champ. 10th of 36

Cincinnati Inv. $\quad 4$ th of 8

NAIA Dist22 3rd of 8

NCCAA Natls. $\quad 3$ rd of 8

Front row: Coach Elvin King, Bouchra Sefiane, Shelly Smith, Brenda Woods, Mindy Schwaderer, Beth Tales Back row: Kari Clark, Tammy Harvey, Kerry Unrau, Brenda Paulhamus, Claire Barnhart, Renee Lawson, Sharie Brooker, Marti Day, Heidi Williams 

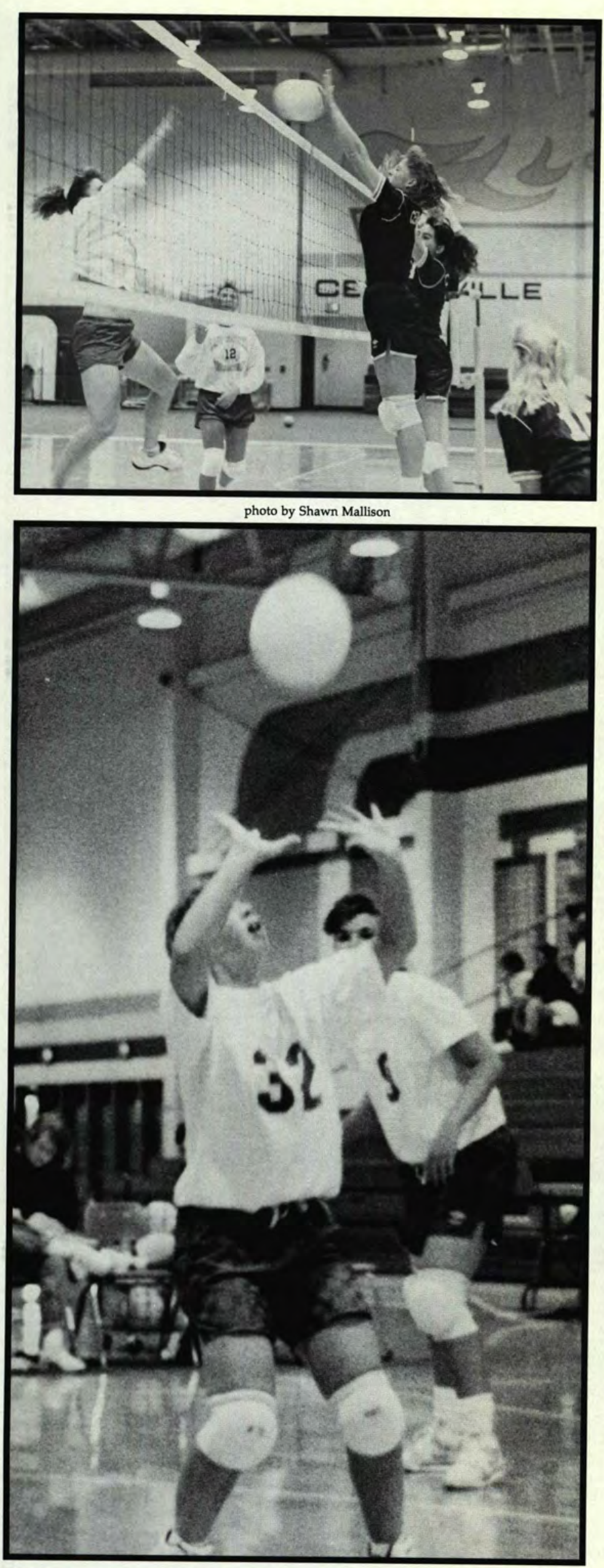

photo by Steve Cook

\section{Spiking with Spunk}

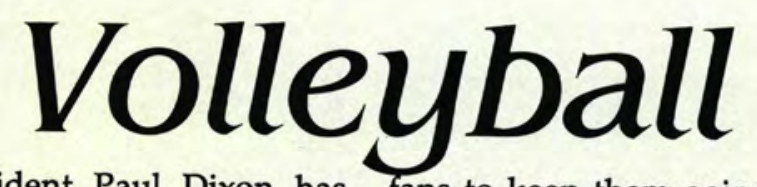

President Paul Dixon has stated many times that life is ten percent what happens to a person and ninety percent how the person reacts to what happens. This was certainly true of the volleyball team this season. As they started slow with tough opponents and low fan support at the games, it was very difficult for the team to keep spirits high through all their hard work and practice. But pulling together and focusing on the games ahead, they fought to show themselves worthy of the student support that they felt they lacked. Many times with only their determination, much practice and only twenty-five to thirty cheering

fans to keep them going, the Yellow Jackets fought through close games to finally emerge as winners.

The volleyball team ended the season strong, winning twelve of their last eighteen matches. Lead by coach Elaine Brown, the team showed that they would not give up under the worst of circumstances, but would react with hard work and determination.

The Yellow Jackets finished second in the WBCC to sixtime champion Bluffton. Sophomore hitter Amy Zehr was named to the All-WBCC first team. She led the team in kills (3.45), blocks (1.18), and service aces $(0.44)$.

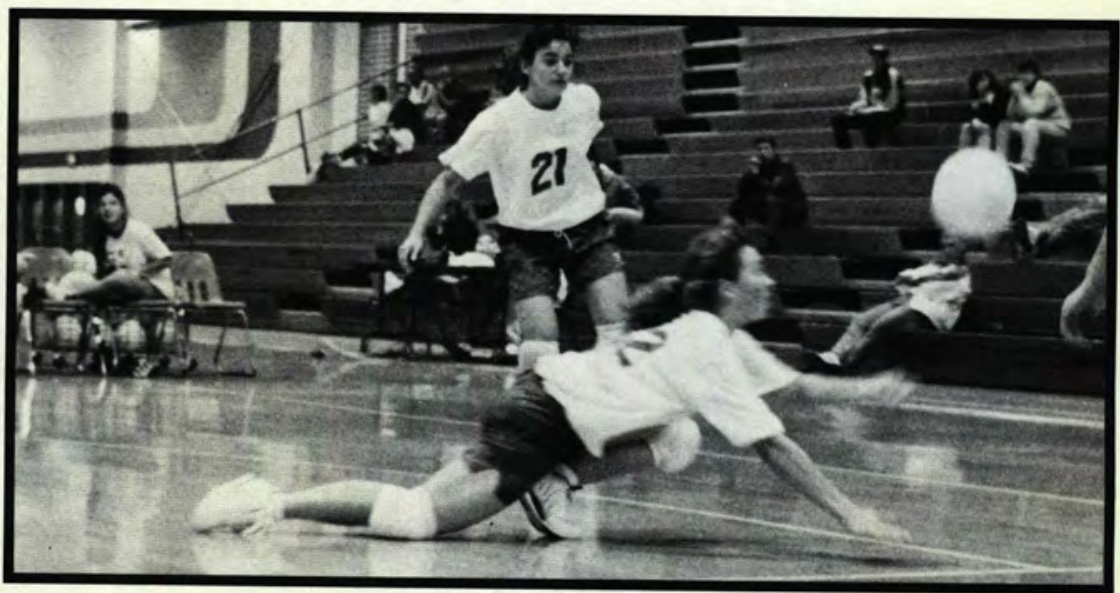

Angela Hartman sets the ball for photo by Steve Cook her teammate.

Dee Houser watches as teammate Angela Hartman dives for a save. 


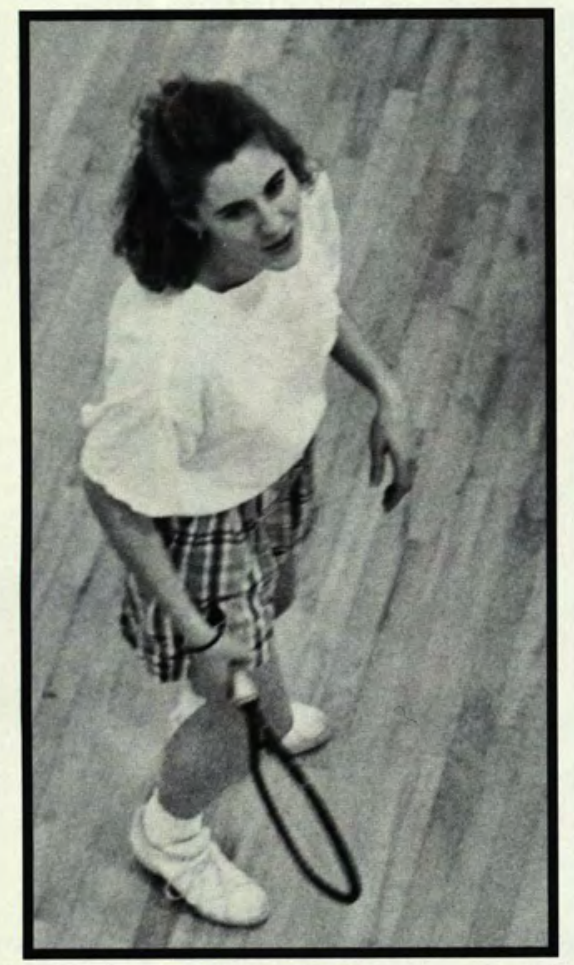

photo by Gwynne Davies Meredith Clements waits for her raquetball game to begin.

Intramurals cause study-laden students to jump into action.

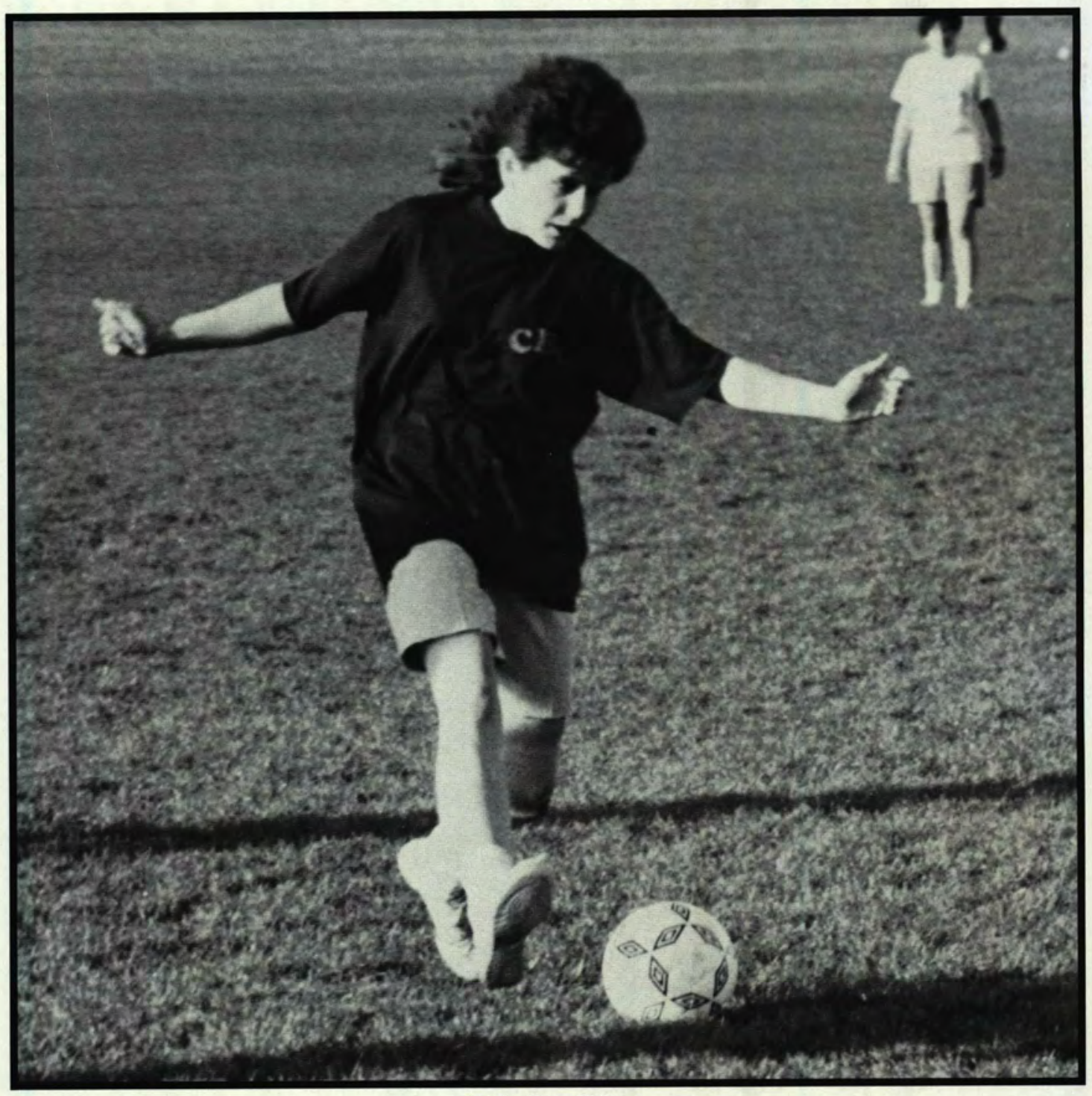

photo by Shawn Mallison

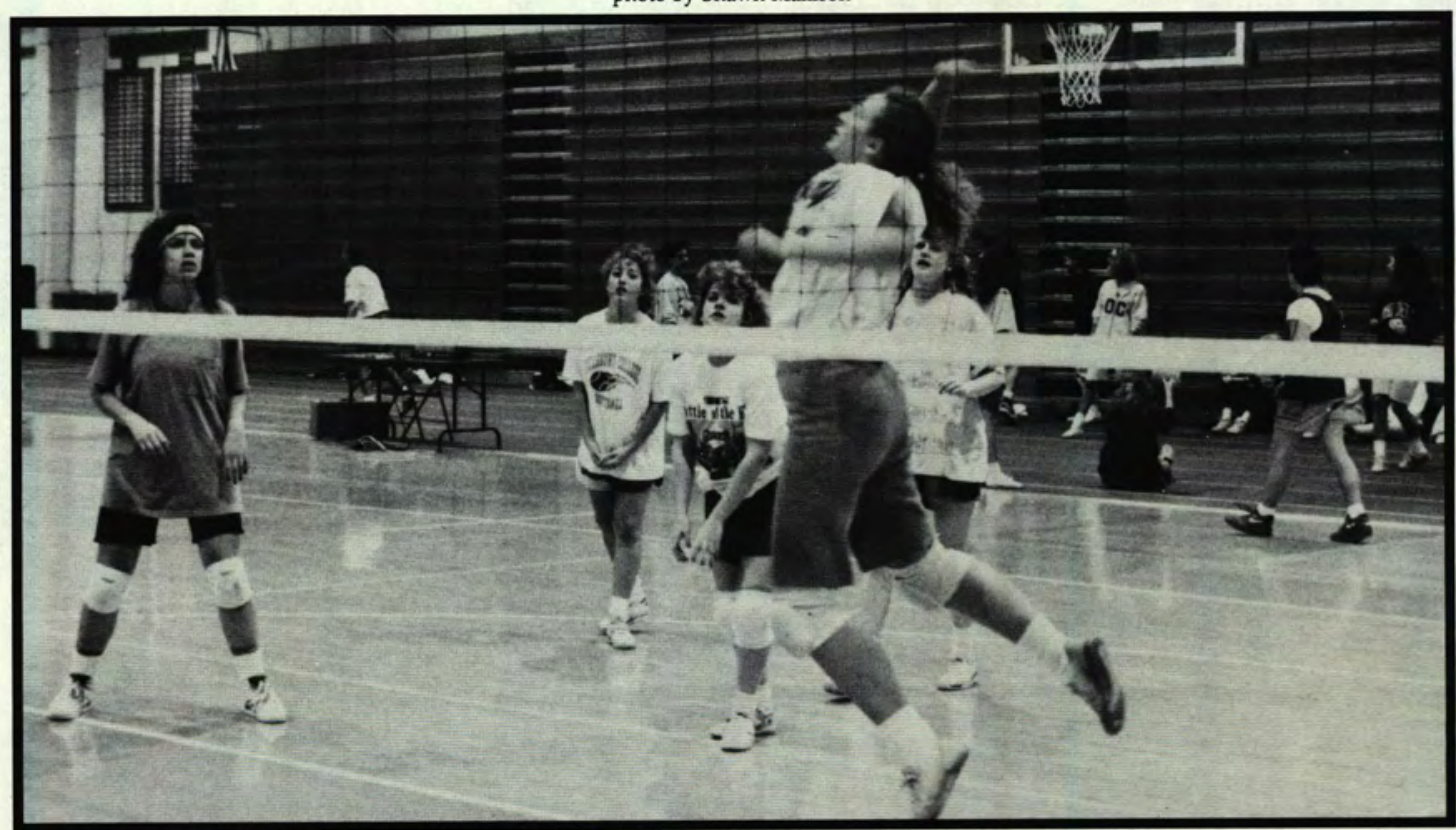

photo by Marsha Olsen 

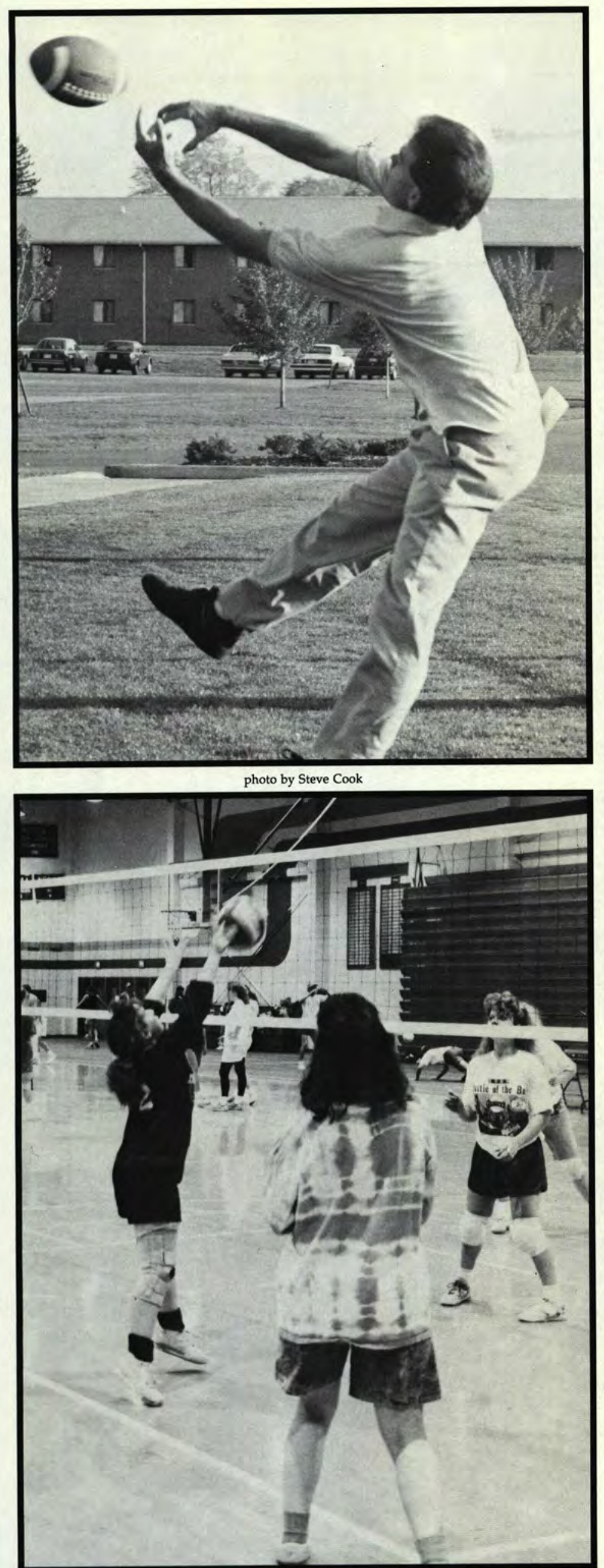

photo by Shawn Mallison

\section{Joining}

\section{the}

Fun

\section{Intramurals}

Every fall quarter Cedarville students undergo a great deal of academic stress resulting from daily classes. To counteract that stress, Cedarville provides a variety of intramural sports in which the student body can get involved. Teams compete for prized $\mathrm{T}$-shirts that scream "CHAMPION" and advertise the college wherever they are worn. As fall quarter winds down, the competition heats up as tournaments are played to determine the following teams as winners of their respective intramural.

FLAG FOOTBALL "A" LEAGUE - DELTA OMEGA EPSILON

FLAG FOOTBALL "B" LEAGUE - CHI

POWDERPUFF FOOT-

BALL - IT'S A MISSION

SOCCER - WOMEN -

THE UMBRO EXPRESS

SOCCER - MEN - FEET

SOFTBALL - MEN DELTA OMEGA EPSILON
SAND VOLLEYBALL "A"

LEAGUE - BEATNESS

SAND VOLLEYBALL "B"

LEAGUE - CURT'S TEAM

3-MAN BASKETBALL "A"

LEAGUE - MAKE OUR DAY

3-MAN BASKETBALL "B"

LEAGUE — ZEP SET

VOLLEYBALL - MEN -

PI SIGMA NU

VOLLEYBALL - WOMEN

"A" LEAGUE - GOTCHA

VOLLEYBALL - WOMEN

"B" LEAGUE - MARCY'S TEAM

SINGLES TENNIS

CHAMPIONSHIP DIVISION - CORY GROVE

INTERMEDIATE DIVISION - MATT BRINCKERHOFF

RACQUETBALL

CHAMPIONSHIP DIVI-

SION - JAMES RINGER

INTERMEDIATE DIVI-

SION - FRANK

KLANDUCH

WOMEN -

CAROL

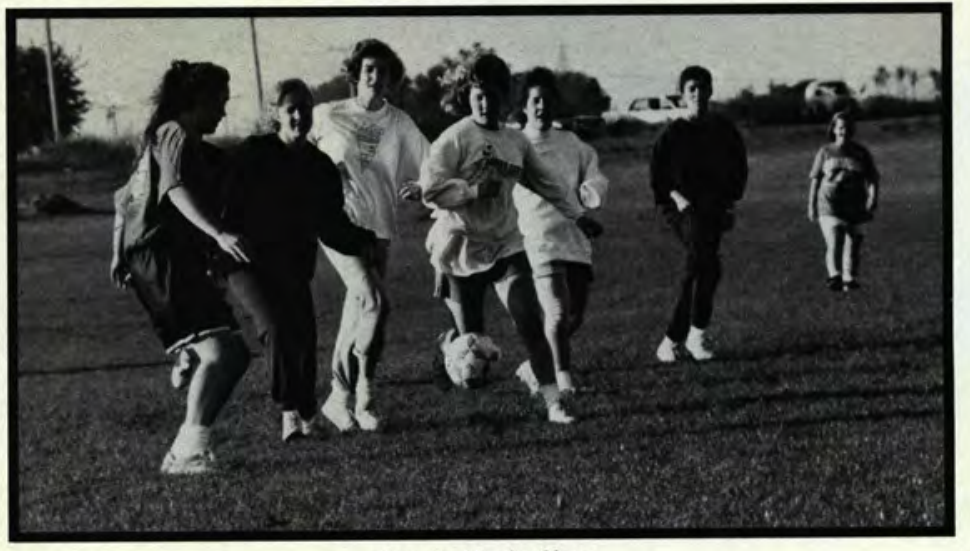

photo by Marsha Olsen

Sara Norder steals the ball from the Students kick out their opposing team. frustrations during intramural soccer. 


\section{Screaming With \\ Excitement}

\section{Spirit}

From anywhere on the campus during the basketball season, the sounds of drum beats and brass can be heard emanating from Stranahan Gymnasium. It's a Friday night at 7:25 p.m., latecomers scan the immense crowd for a seat and the cheerleaders claim the crowd's attention as they prepare the tunnel for the basketball players. Suddenly, the team bursts from the locker room and the gym erupts. The game begins.

Without the Yellow Jacket Pep Band and the cheerleaders, two very important assets, game nights would not be the same. The cheerleaders start practicing early in the fall to develop skills and technique as well as build unity among the squad members. The cheerleaders are also able to minister to the cheerleaders from the opposing team by having devotions with them during home game halftimes. The Pep Band also begins practicing/early in the season to learn new songs and brush up on the old ones such as "Hang on Snoopy." Under the direction of Michael DiCuirci, the Pep Band has become an important part of the basketball season. The band is ultimately responsible for getting the fans excited and involved in the game. Each Cedarville student is proud to be a Yellow Jacket and it shows at every game!Meredith Clements

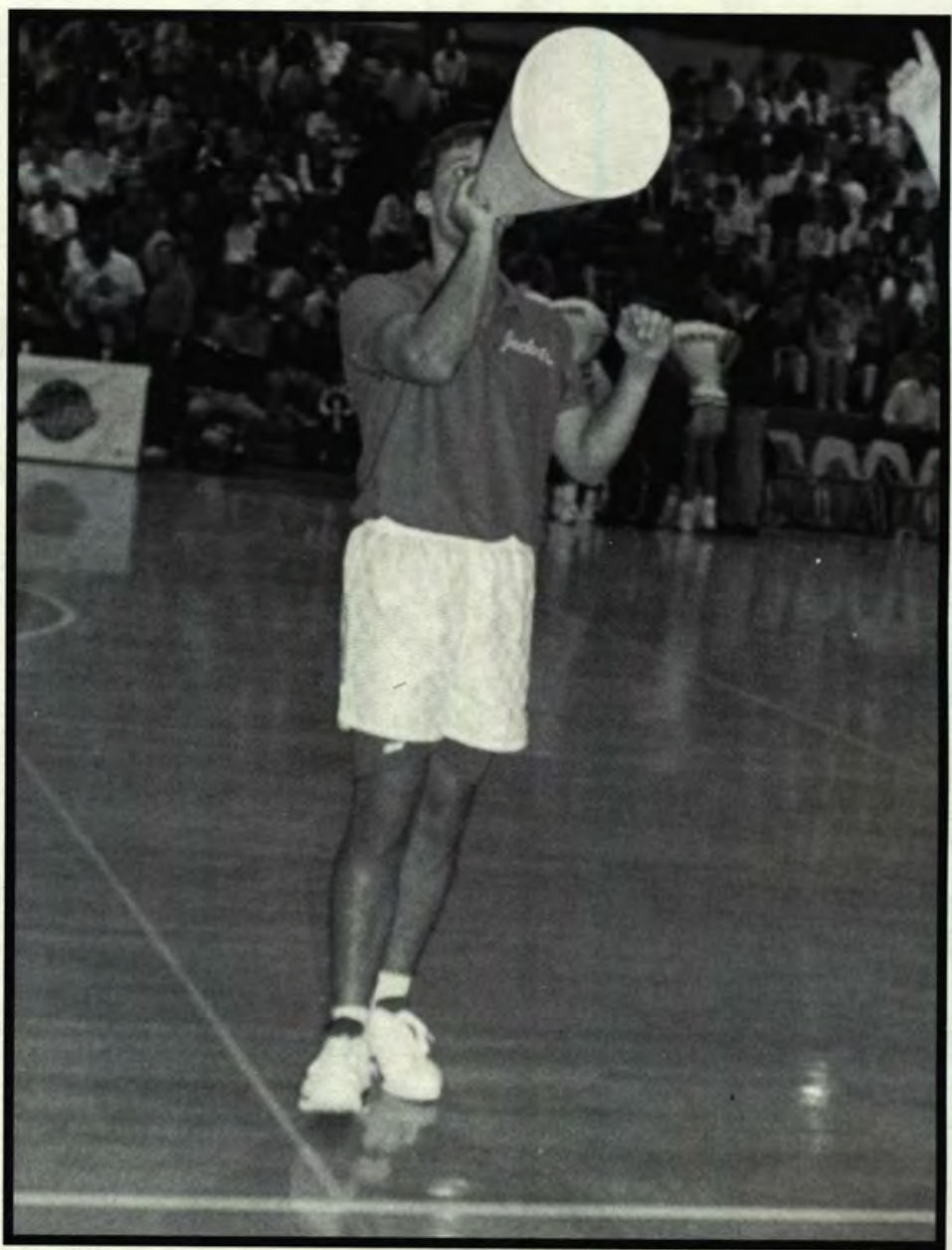

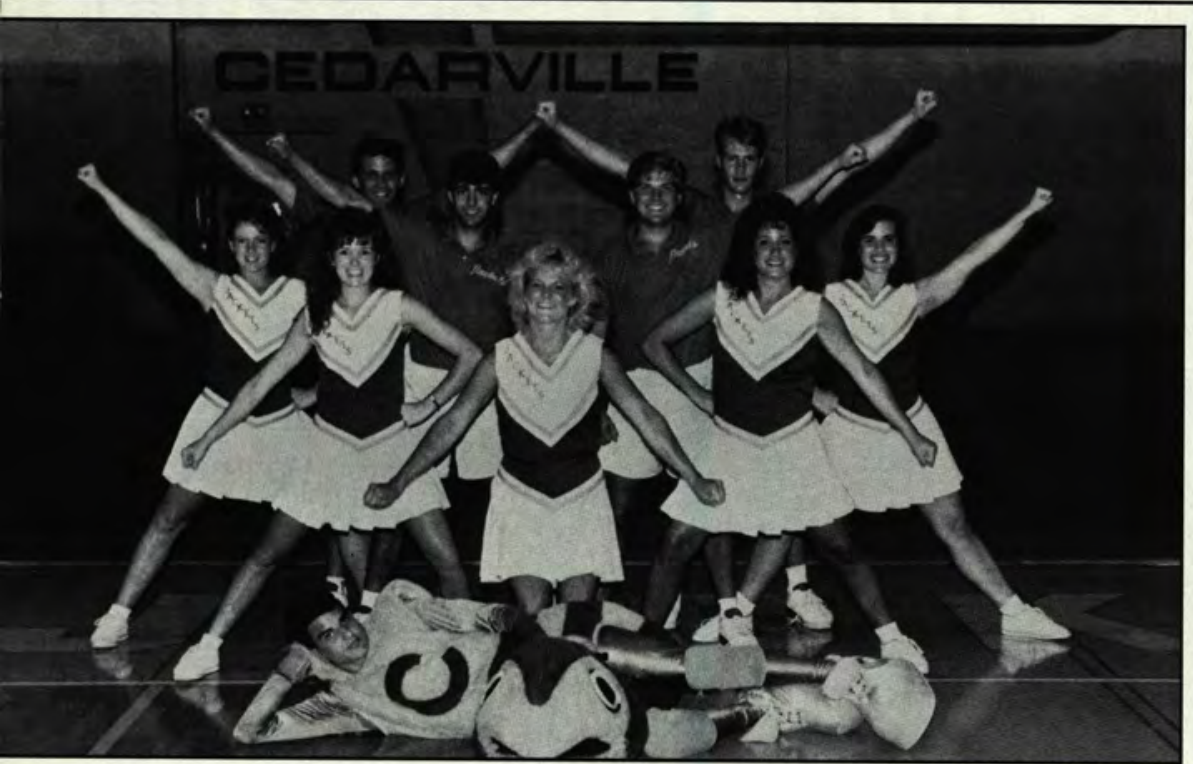

ee: Phillip Powell Front row: Heather Oxford, Sheryn Titus, Kendra Williams, Corinna Williams, my McDonald Back row: Ken Dady, Ben Kalich, Nels Hofert, Eric Sorensen

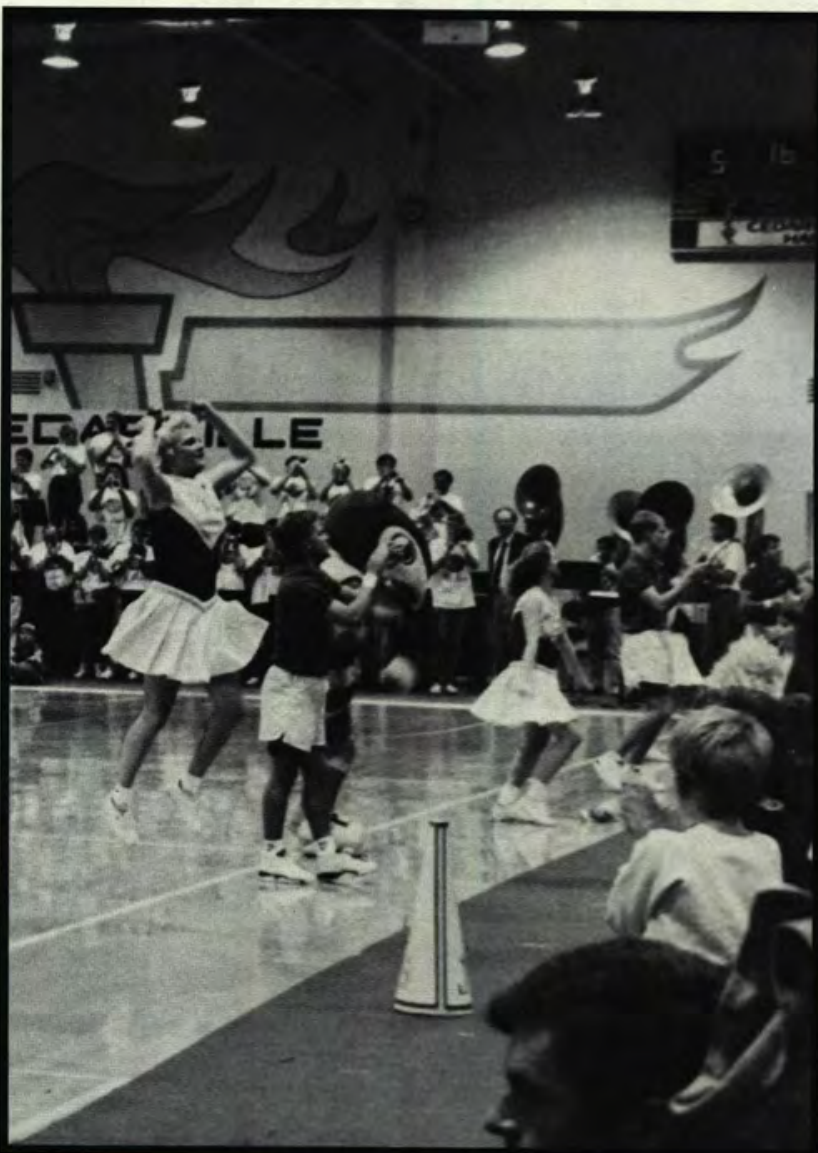



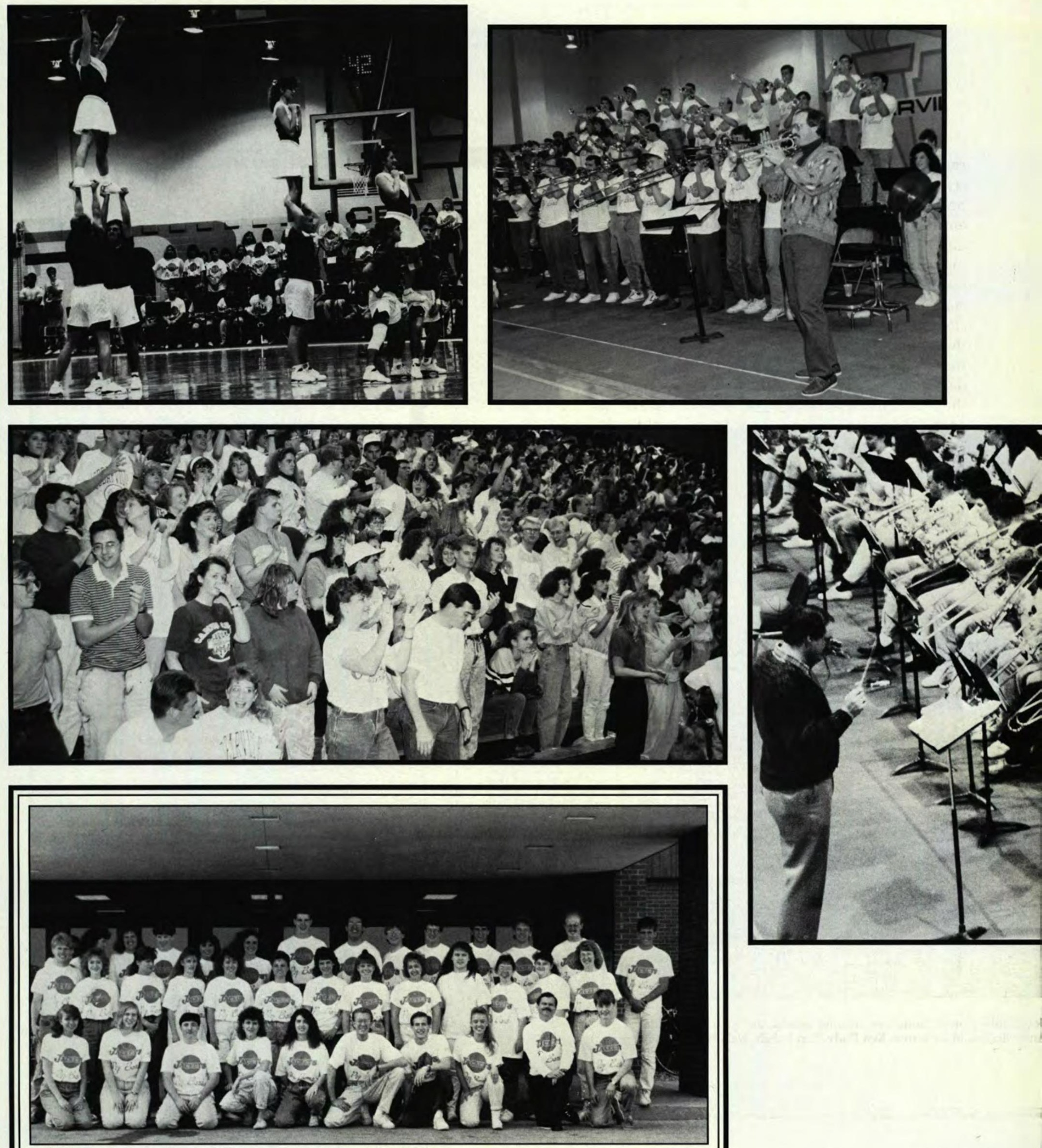

1990-91 Pep Band 


\section{Playing with Pizzazz \\ Basketball}

Take ten elongated guys, as the five fearless fellows in one inflated sphere, and two yellow and blue dominate the metallic hoops with reinforced fishnet hanging from them and what do you have? Hoopla! B-ball! Five-on-five! Or in the koine: basketball, the game that has captivated the hearts of millions, inspired the hope of generations of budding pros, and established itself as a recognized olympic tradition. It has also found a place in the glorious tradition of Cedarville College.

And so the sacred halls of our beloved gymnasium resound with the cries of delight, cheers of encouragement, and shouts of sanctified support,

court. The crowds are dazzled with their slamming, jamming and dunking, their fancy footwork, awesome passing and dynamic dribbling, and their articulate shooting from any spot on their half of the court. Sound unbelievable? No team could be that great, you say. Well, you're right. Still, with a combination of collegiate pride, poetic license, and a hyper-active imagination, we affirm and remember with fondness the Yellow Jacket Hoopsters of '91.

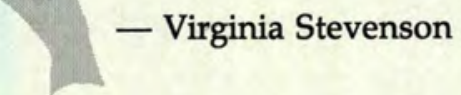

David Barnes jumps to score another point for the Yellow Jackets.

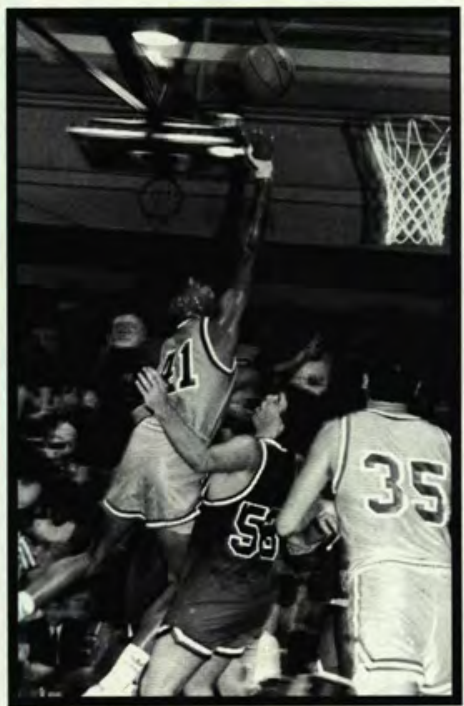

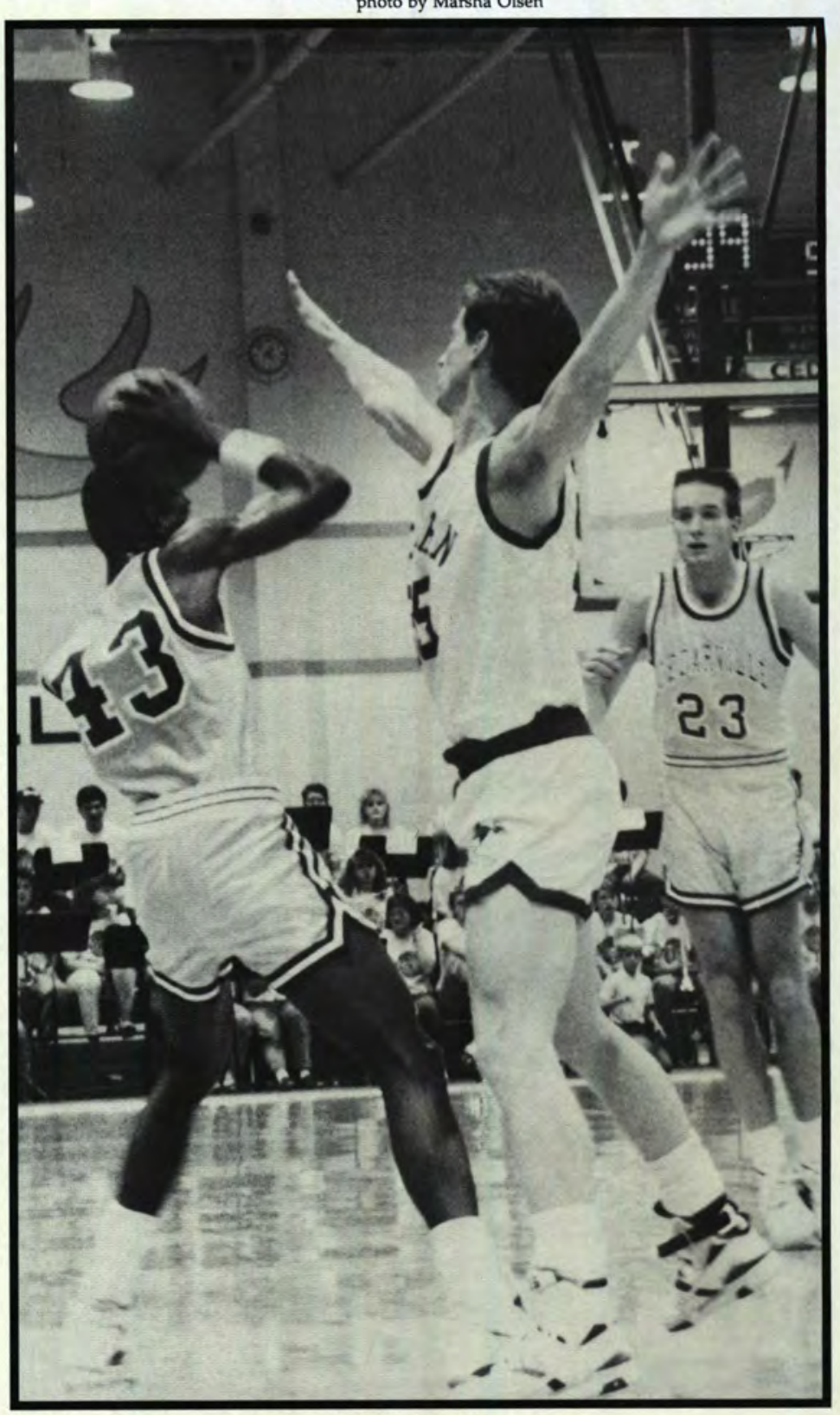

photo by Marsha Olsen

photo by Bill Montgomery

Tracy Stringer outsmarts Western's defense.

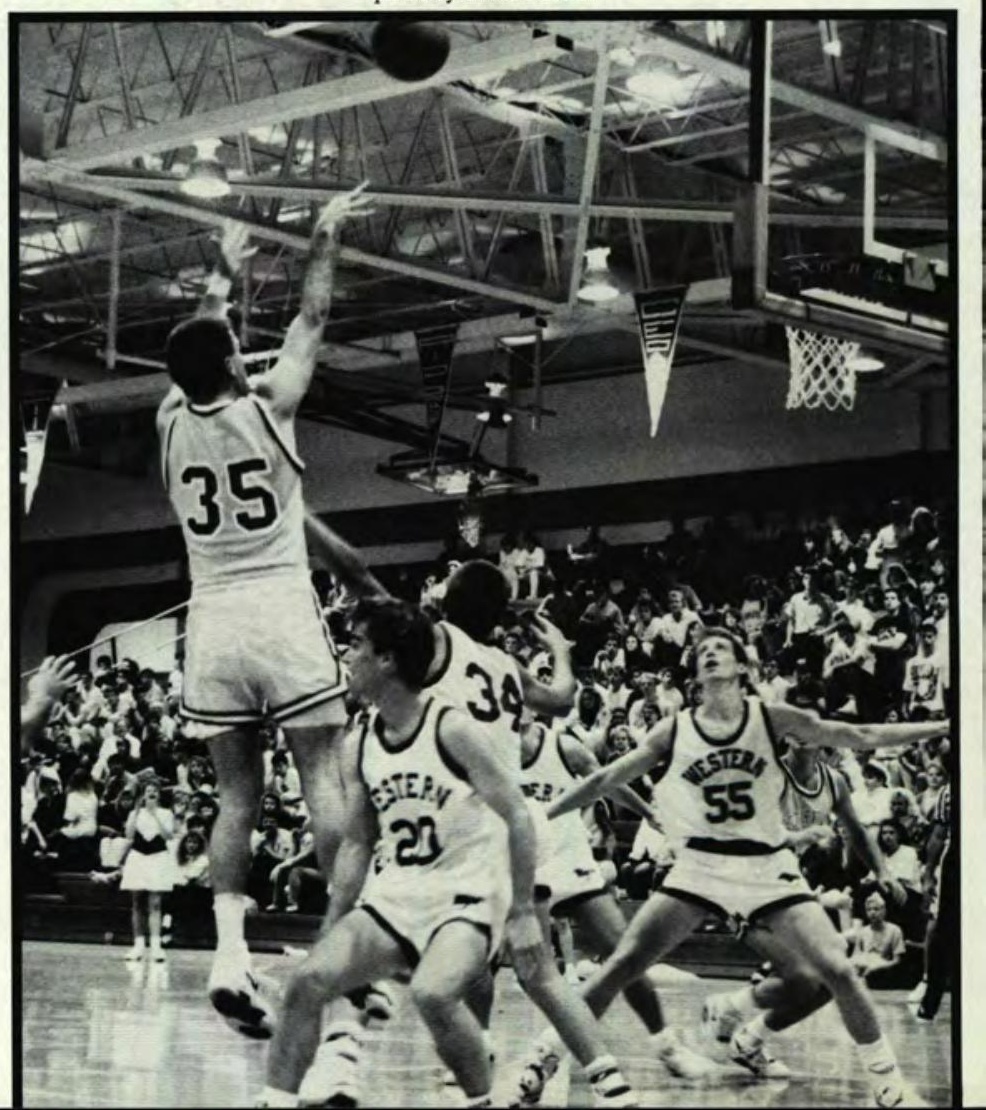




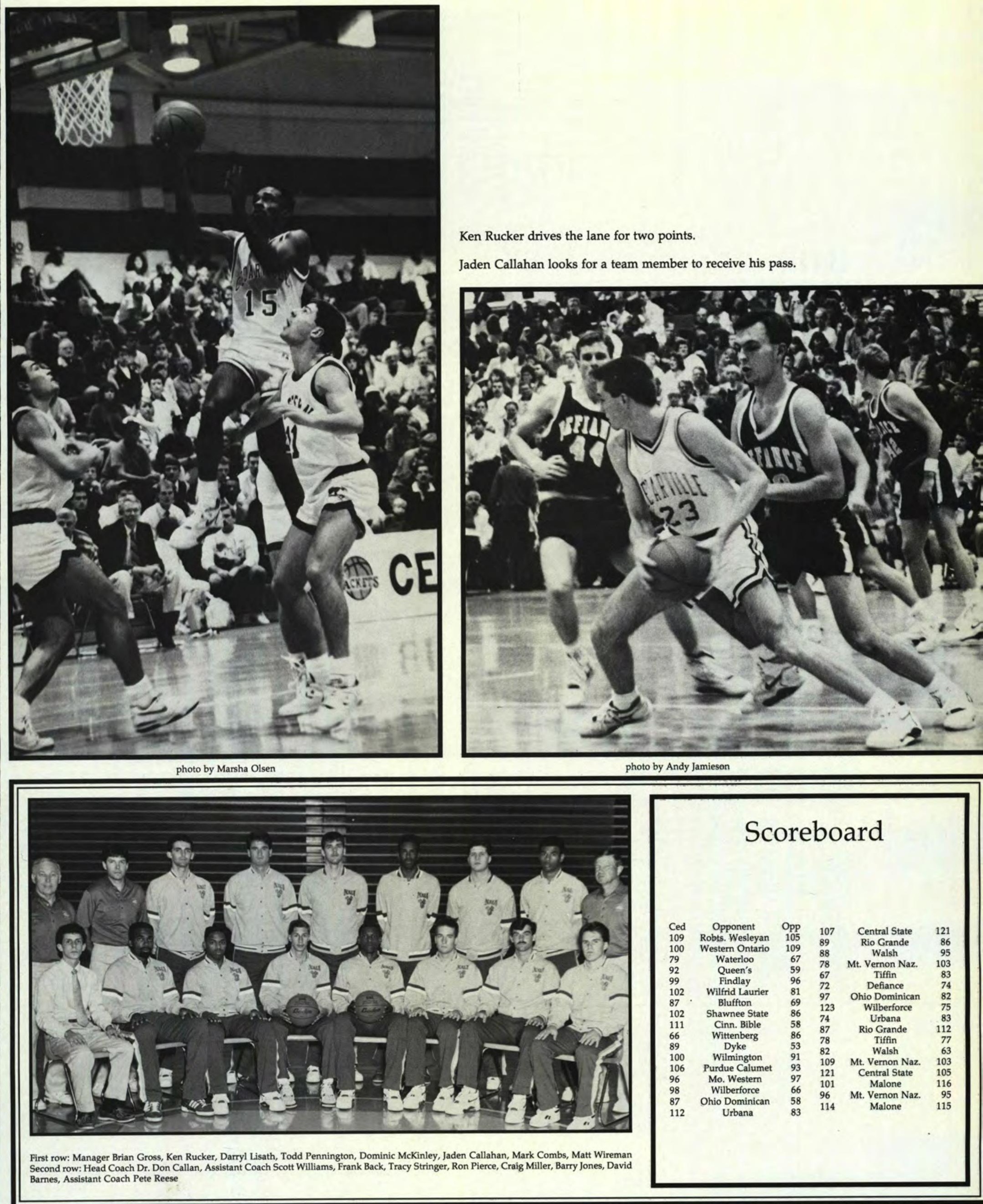




\section{Shooting Sharply}

\section{Women's Basketball}

The main story during the 10-15 Lady Jacket basketball season was the play of junior center Diane Rank and sophomore forward Amy Zehr. Rank averaged 17.3 points and 8.9 rebounds, while Zehr added 15.0 points and 9.0 boards per contest.

Rank became the fifth player in Cedarville women's basketball history to eclipse the 1,000-point barrier for a career. She ended the season as the school's third all-time leading scorer with 1,200 points.

Diane was named to the NAIA All-America ScholarAthlete team, and to the GTE/CoSIDA Academic AllDistrict 4 team. She was se- lected to the NCCAA AllAmerica First Team, the AllNCCAA District III squad, and the All-Western Buckeye Collegiate Conference First Team.

Zehr led NAIA District 22 and the WBCC in field goal accuracy at 60 percent. That mark also ranked 17 th nationally. Zehr's finest moment occurred in the final regular season home game when she pumped in a school-record 41 points in a 112-76 win over Earlham. She added 14 rebounds, nine assists, and eight steals in the game. The 41 points broke the previous standard of 39 set by all-time leading scorer Vicki Butler. Mark Womack
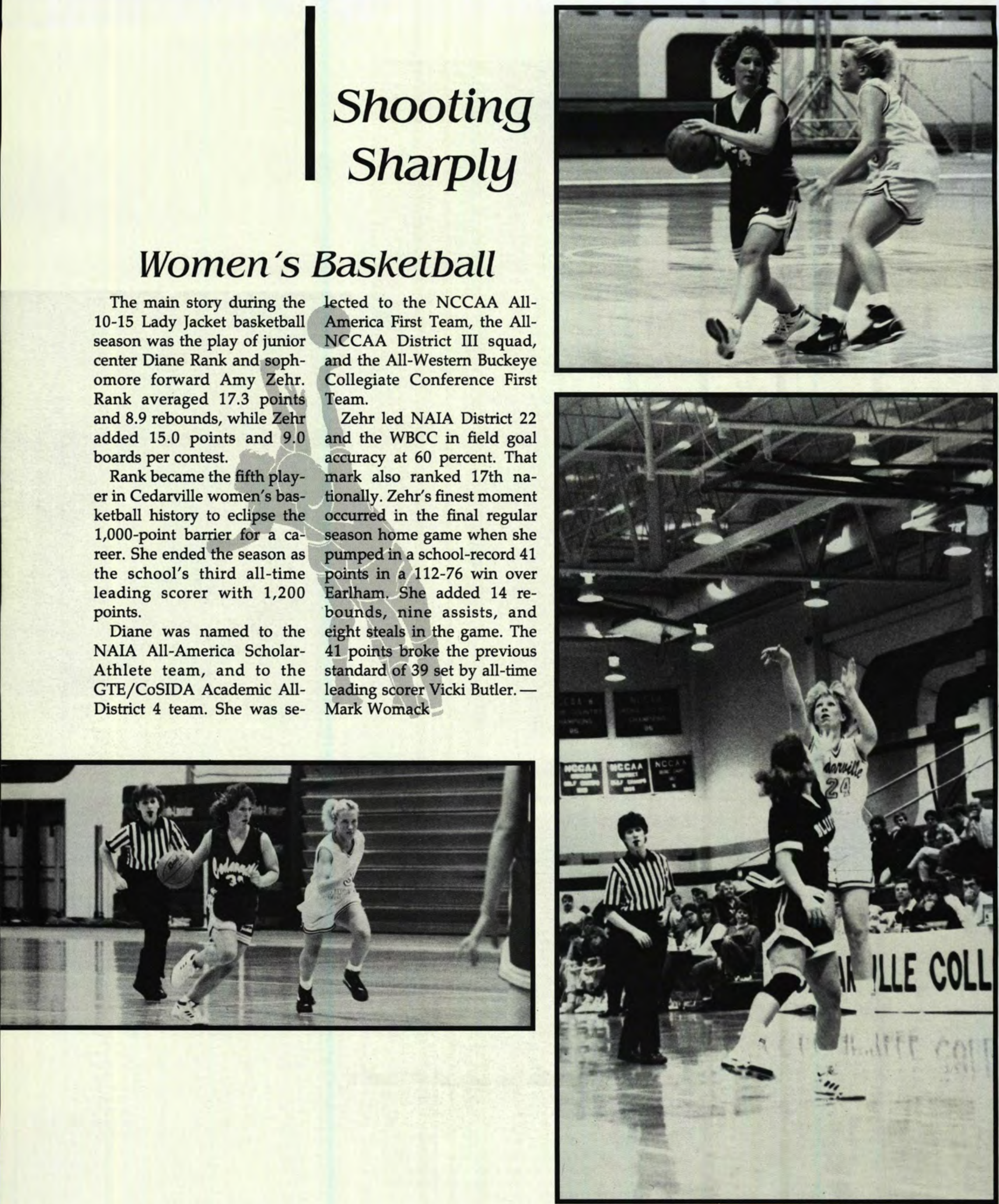

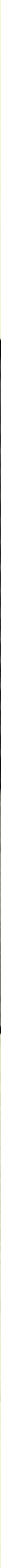

Scoreboard

Front row: Cindy Weibert, Sarah Stiles, Andrea Doctor, Mindy Humble, Carmen Hunt, Trish Manning, Rachel Howard Back row: Manager Ronda Craddock, Asst. Coach Chris Greenwood, Kim McCoy, Cinnamon Brown, Diane Rank, Kristine Deshetsky, Amy Zehr, Denise DeWalt, Dawn Phillips, Coach Bob Fires 

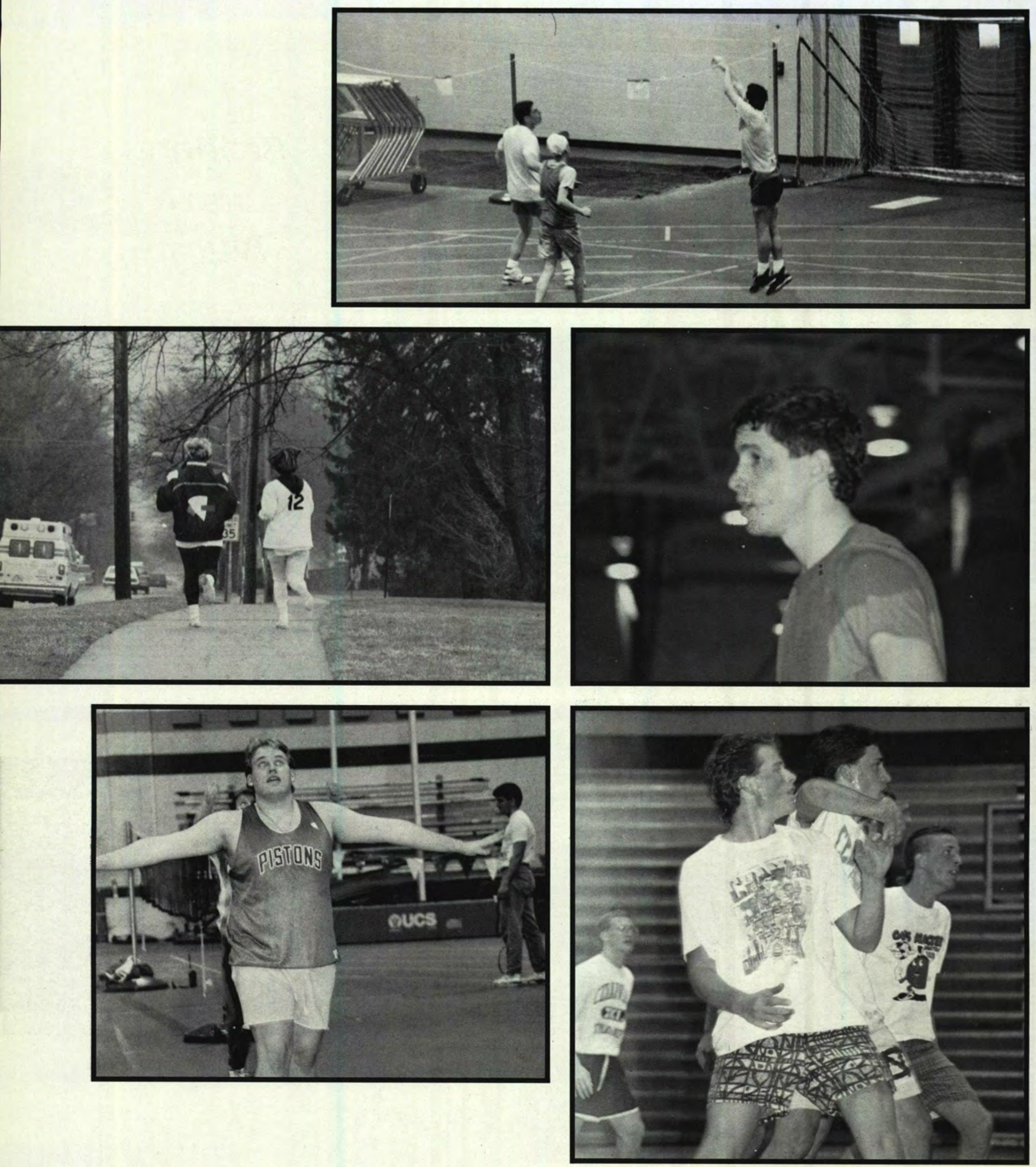


\section{Sliding In Safe \\ Baseball}

A "rebuilding season" was the way Tom Sizer, this year's assistant coach and next year's head coach, described this year's season. Last year Cedarville captured the MidOhio Conference baseball title, but five team starters graduated, leaving a rather young team to take over. This year only three players, Todd Clemens, Jeff Kendra and John Yoder, will graduate. Clemens, who had a .392 batting average, and Yoder, with a .360 batting average, were both outstanding players. The season ended with an overall record of 7-24. At the end of the season the team made a comeback from a losing streak to win a doubleheader against Central State.

Dan Ambrose, a sopho- more, was the first player in Cedarville history to be named the national NAIA hitter of the week. Catcher John Yoder earned a place on the first team in the MOC with Todd Clemens as honorable mention. Yoder also won MVP honors and he made All-NCCAA District III team with Clemens and Ambrose joining him as honorable mentions. All three players: Ambrose, Clemens and Yoder made honorable mention on the All-NAIA District 22 team. The coaches award for the team went to Rusty Russell, and Todd Seljan had the team's lowest ERA.

Next year's team includes only one senior, so according to Coach Sizer, the "rebuilding" will continue.
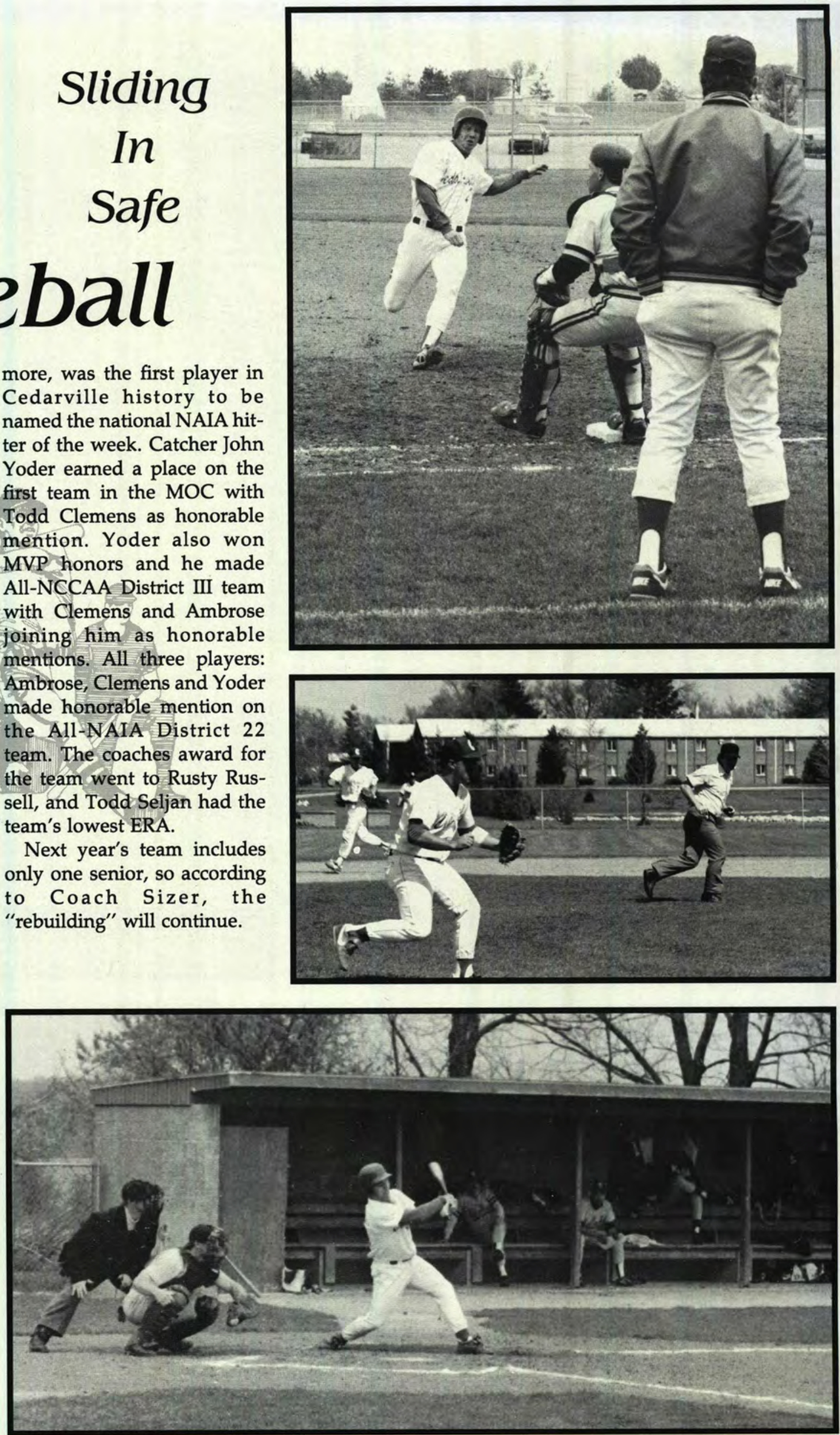

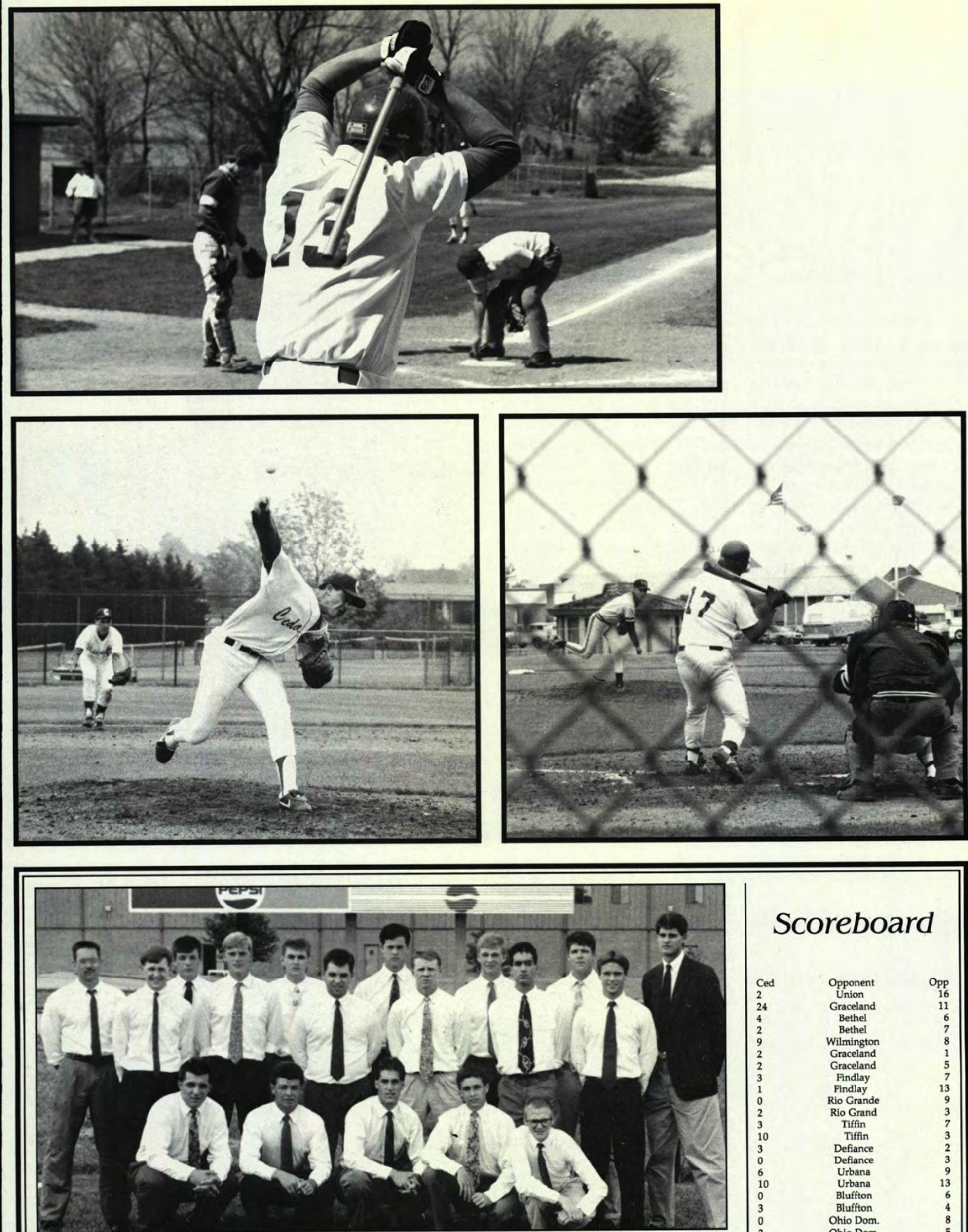

First row: Todd Clemens, John Yoder, Doug Taylor, Jason Allison, Jon Meeder (Man.) Second row: Eric Ashcraft, Scott Cramer, Jeff Kendra, Tom Cadamus, Rich Harrington, Davic Noss Third Row: David Carrick, Tom Bockmann, Craig Sand, Todd Sewan, Curt Pearson, Dan Ambrose, Coach Tom Sizer Not pictured: Rusty Russel, Coach Pete Reese 

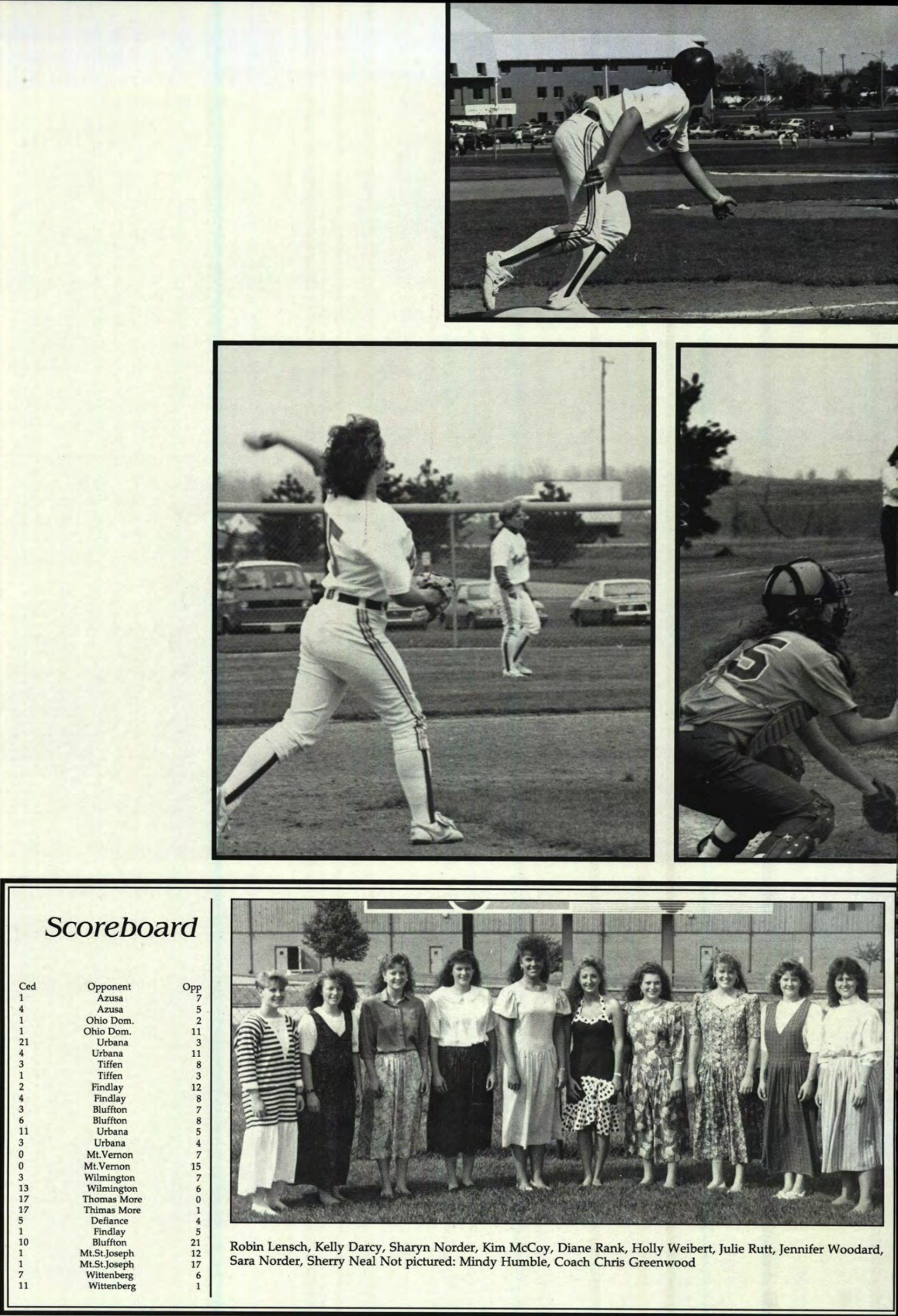


\section{Racing Relentlessly}

\section{Track}

The men's team won Cedarville's first-ever MidOhio Conference track \& field championship in the 42-year history of the conference. Head coach Tim Walters was tabbed MOC Coach of the Year.

Seven Yellow Jackets headed the all-conference team led by Dave Weber, who posted wins in the 100 and 200 meter dashes, plus the 400 meter re lay. He was joined in the 400 meter relay by Ben Biddle, Tim Cole, and Darryl Hammock.

Cedarville finished fourth of 16 schools at the NCCAA Nationals in Huntington, IN. Hammock was the-Jackets' lone All-American by winning the 400 meter dash in 49.14 seconds.

The 400 meter relay unit of Weber, Hammock, Cole, and Ray Anderson set a school record when they turned in a time of 42.47 seconds at the NAIA District 22 meet.
The women's team received All-American performances from Brenda Paulhamus and Sharie Brooker at the NCCAA Nationals. Paulhamus, the Lady Jackets' MVP for the season, set a meet record in winning the 800 meters in $2: 16.2$ breaking the old mark held by former Cedarville standout Jane Brooker. Brooker's sisterin-law, Sharie, won the 1500 meters in 4:52.25. The Jackets placed sixth of 13 teams in the meet.

Cedarville finished fourth of five schools in what was the final WBCC meet because the conference has been dissolved. But the Lady Jackets possessed the best track \& field program in the history of the conference. They captured an unprecedented six consecutive titles from 1984 through 1989.

- Mark Womack
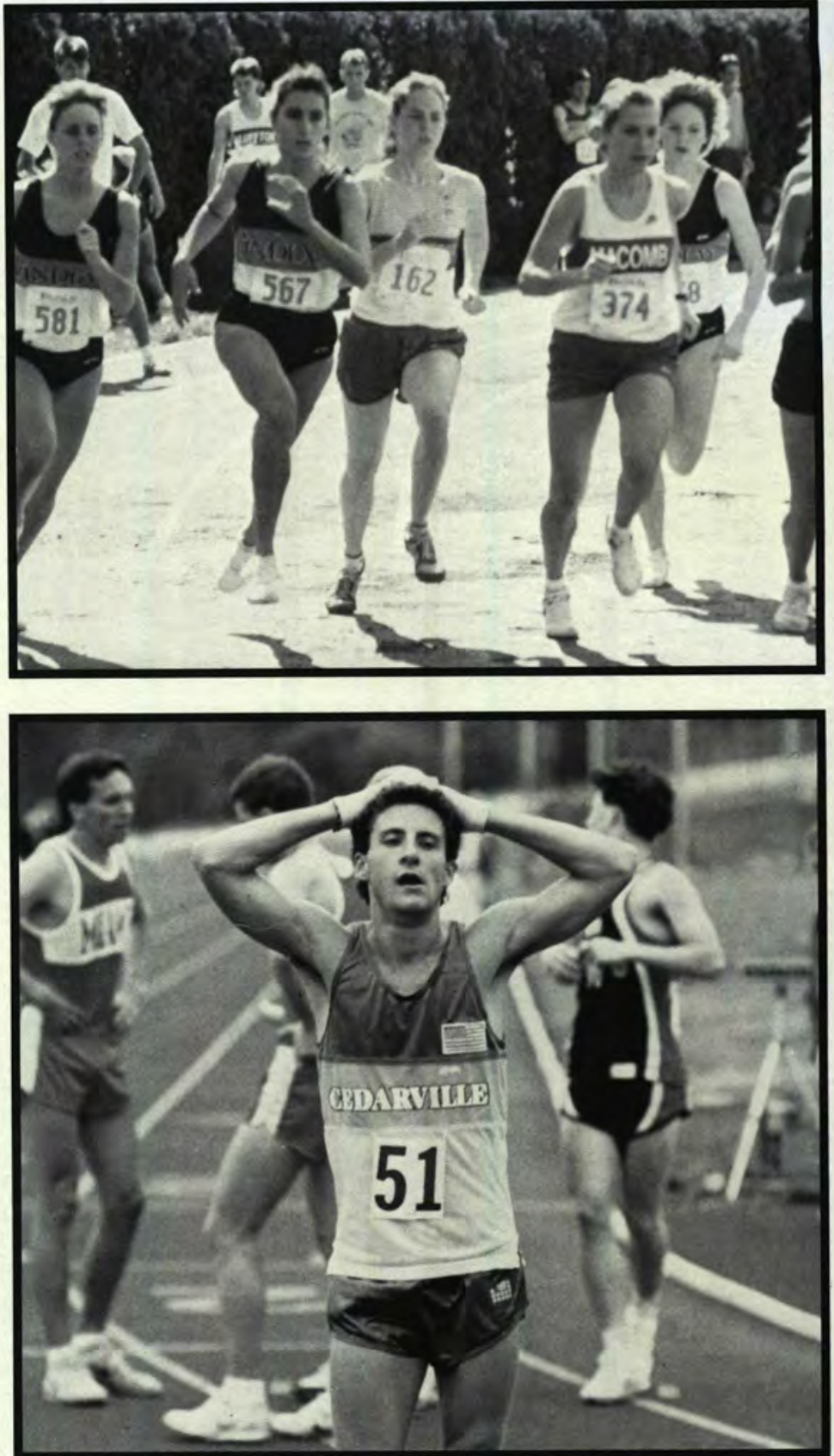

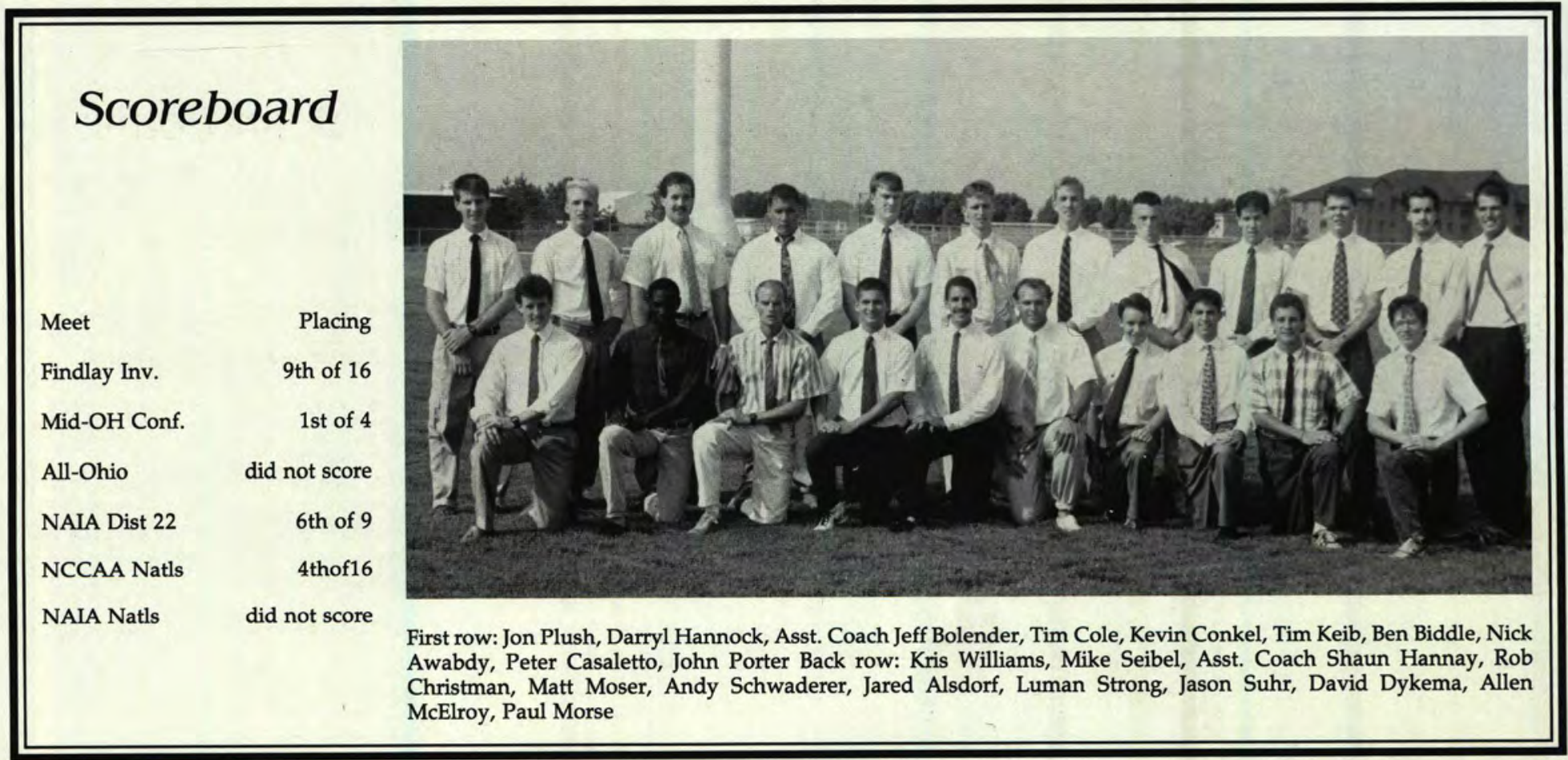



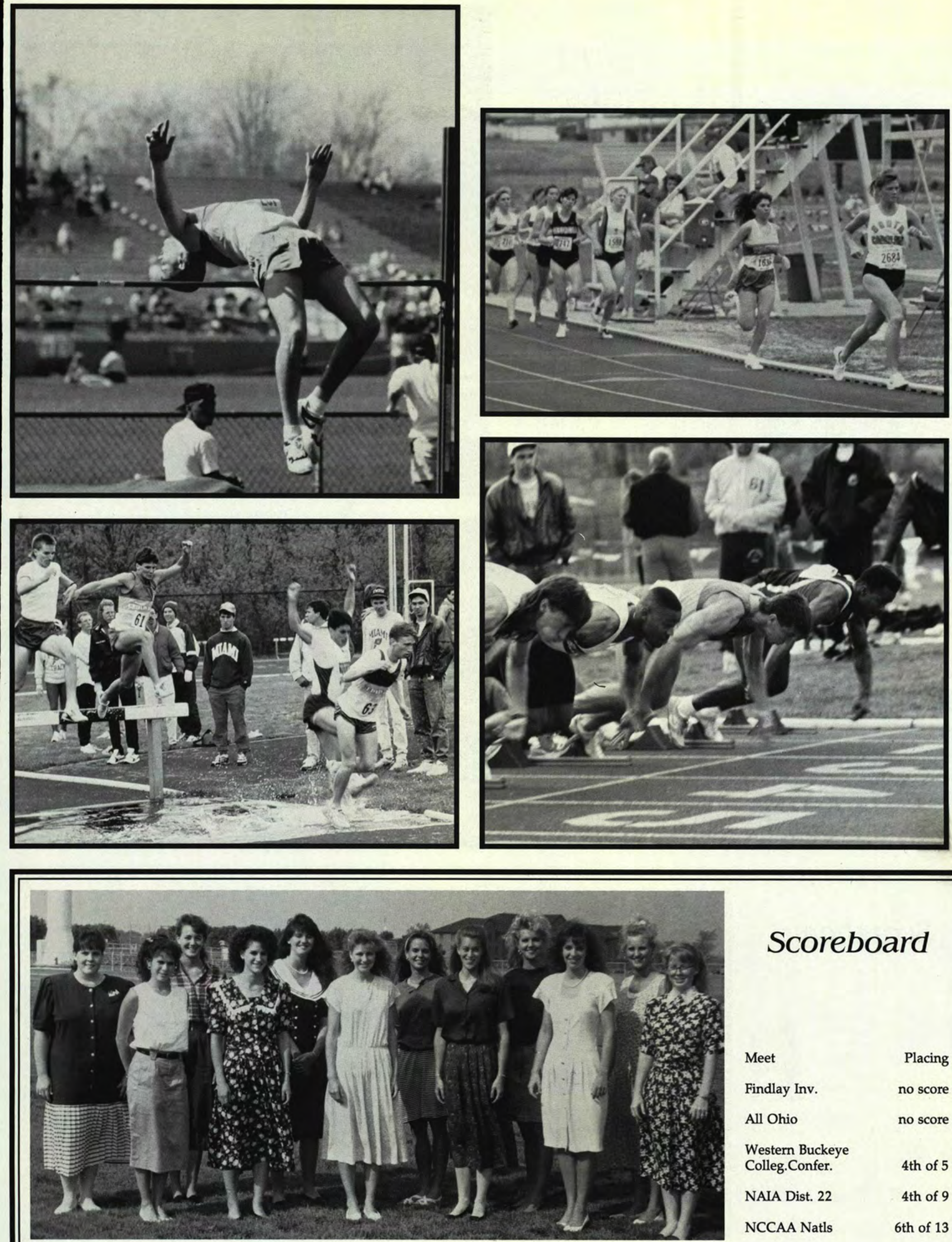

Scoreboard

Amy McLaughlin, Krista Pritchard, Kristi Van Dyke, Brenda Paulhamus, Heidi Williams (Mgr.), Tammy Harvey, Sharie Brooker, Kristin Milner, Nancy Neubert, Shannon Hill, Tonya Neubert, Kim Harbaugh (Mgr.) 


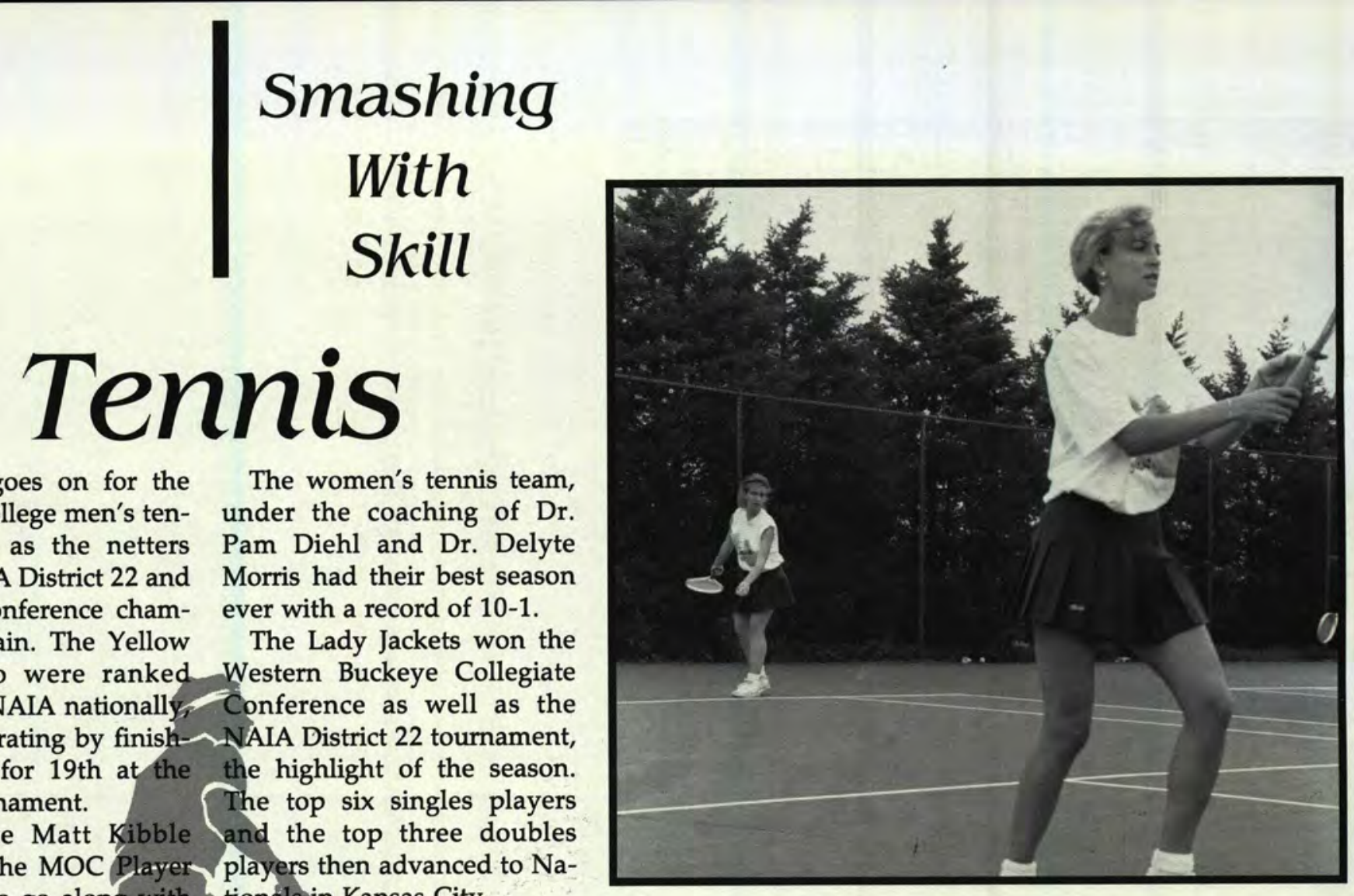

of the Year to go along with tionals in Kansas City.

the NAIA District 22 singles Fulie Switt, a senior and doubles championships Math/English major from He teamed up with classmate Columbus, $\mathrm{OH}$ was named Mike Anthony to win the Most VAluable Player as well doubles crown. Joining Kibble as the NAIA Scholar Athlete. and Anthony on the all- Julie also received the Coachdistrict team were P.J. Kitchen es Award along with her partand Mark Murdoch. Kitchen, ner, Angie Hartman. The who made it to the third Rookie Award was presented round of singles at the NAIA to Angie Hartman and Most Nationals, graduates with a Improved Player went to Car92-14 career record. Murdoch ol Chamberlain. The best sinwas named to the NAIA gles record was held by Scholar-Athlete team, and to Lynette Cruz who was undethe GTE/CoSIDA Academic feated in the regular season.

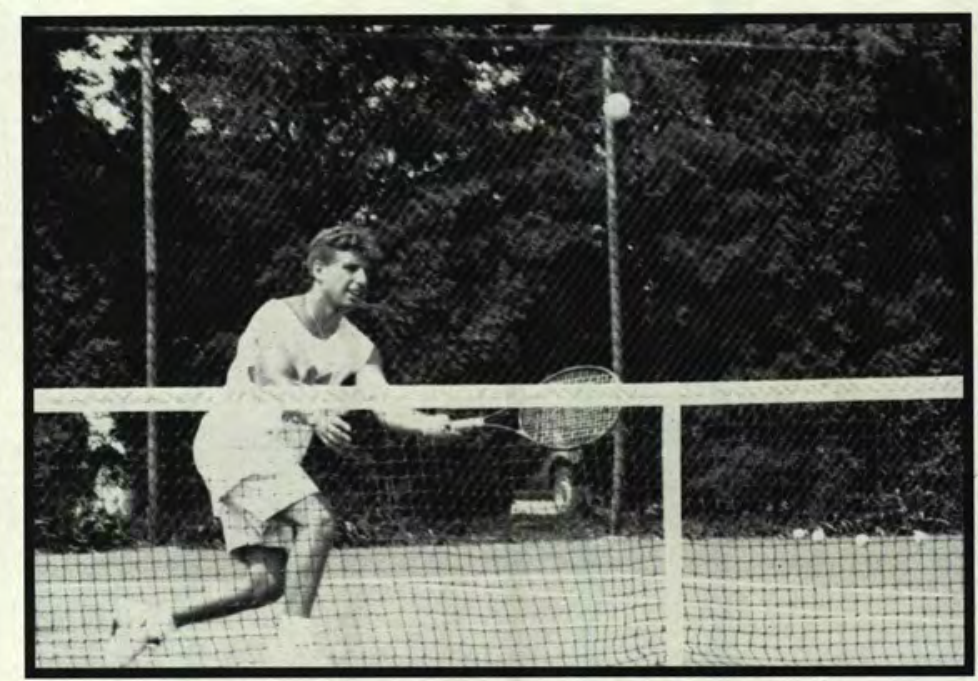
All-District 4 team.

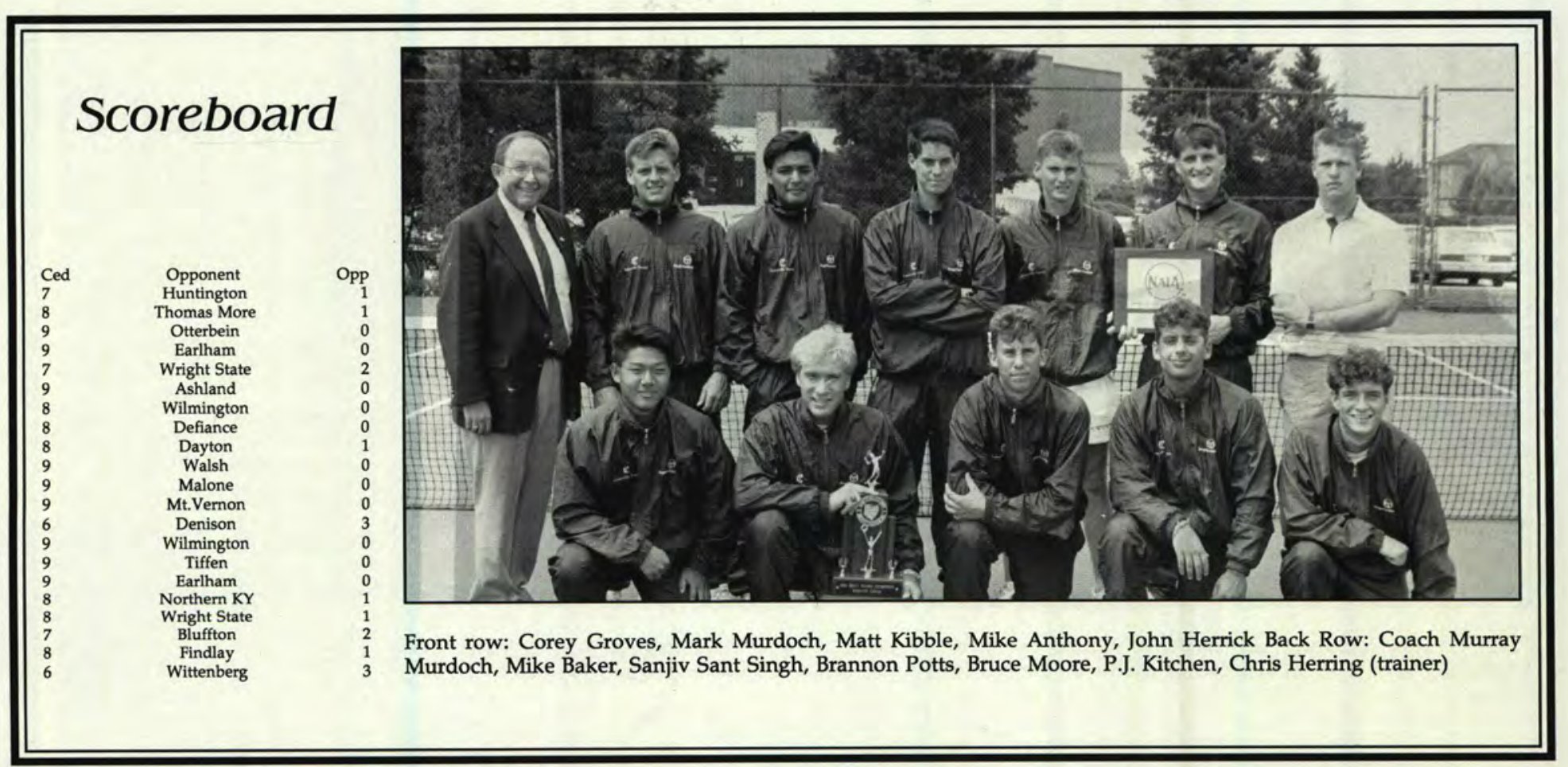




\section{Putting With Precision Golf}

A pair of seniors were the the low round of the year top two golfers once again for - when his 73 won the Clark the Yellow Jacket Linksters. State Invitational.

Ryan Bowen repeated as an Schearer's 82.5 average led All-NAIA District 22 per- the team, plus he averaged former, and Dan Schearer 80.3 in four rounds of MOC earned a spot on the All-Mid- play to earn a position on the Ohio Conference team.

Bowen, last year's district medalist, carded back-to-back rounds of 81 in windy conditions during the district tournament. His 162 total placed him in a five-way tie for third place. He averaged 82.6 strokes per 18 holes, second best on the team, and had

\section{all-conference team.}

Cedarville finished second in both the Miami-Hamilton Invitational and the NCCAA District III. The golfers tied for second in the 10th Annual Cedarville Invitational and were third in the NAIA District 22 tournament.

- Mark Womack
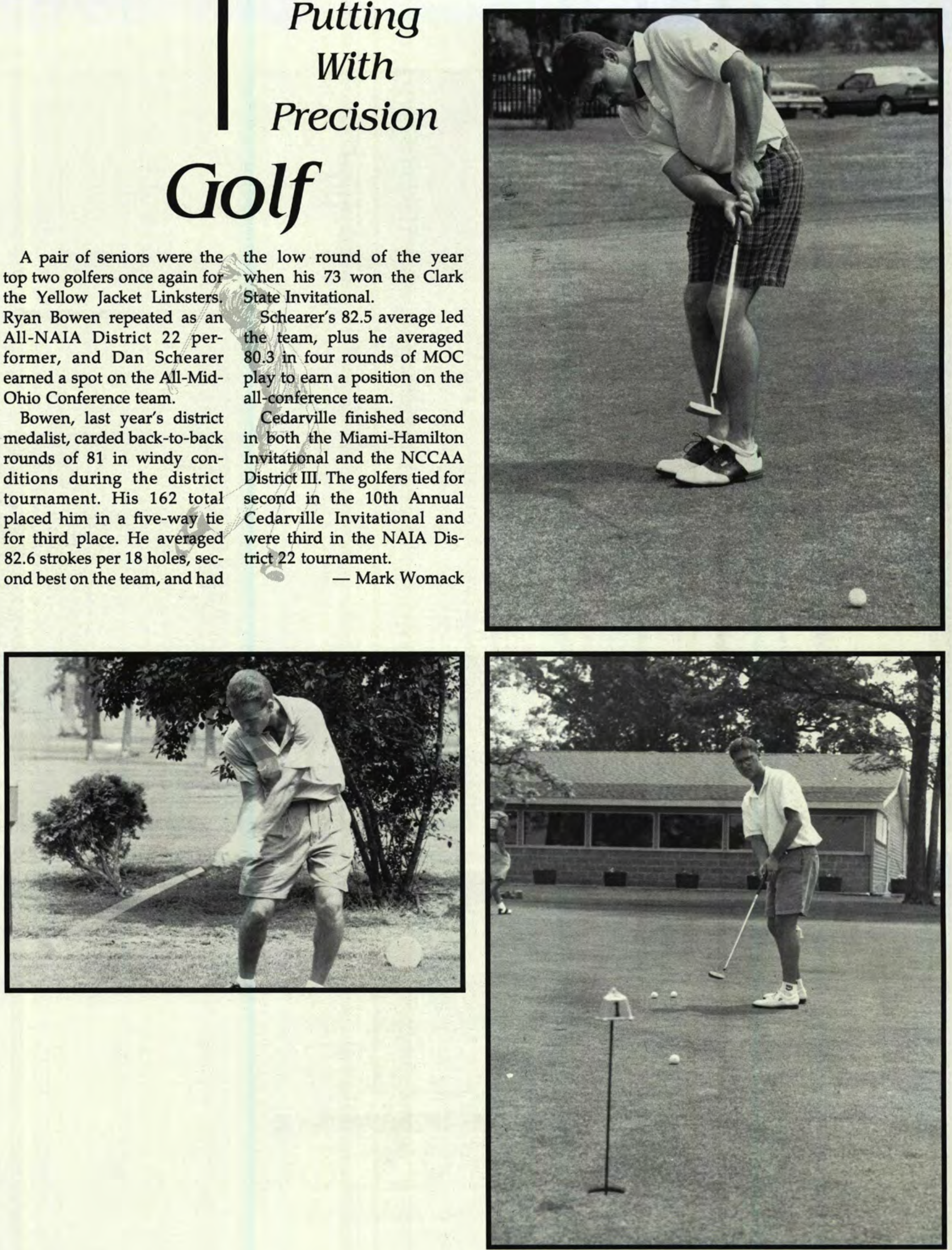

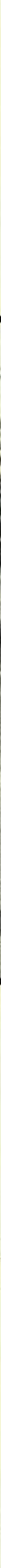

Ryan Bowen, Jeremy Barton, Doug Stanton, Todd Pennington, Dan Schearer, Brian Blackburn, Ted Kruse, Coach Allen Monroe 

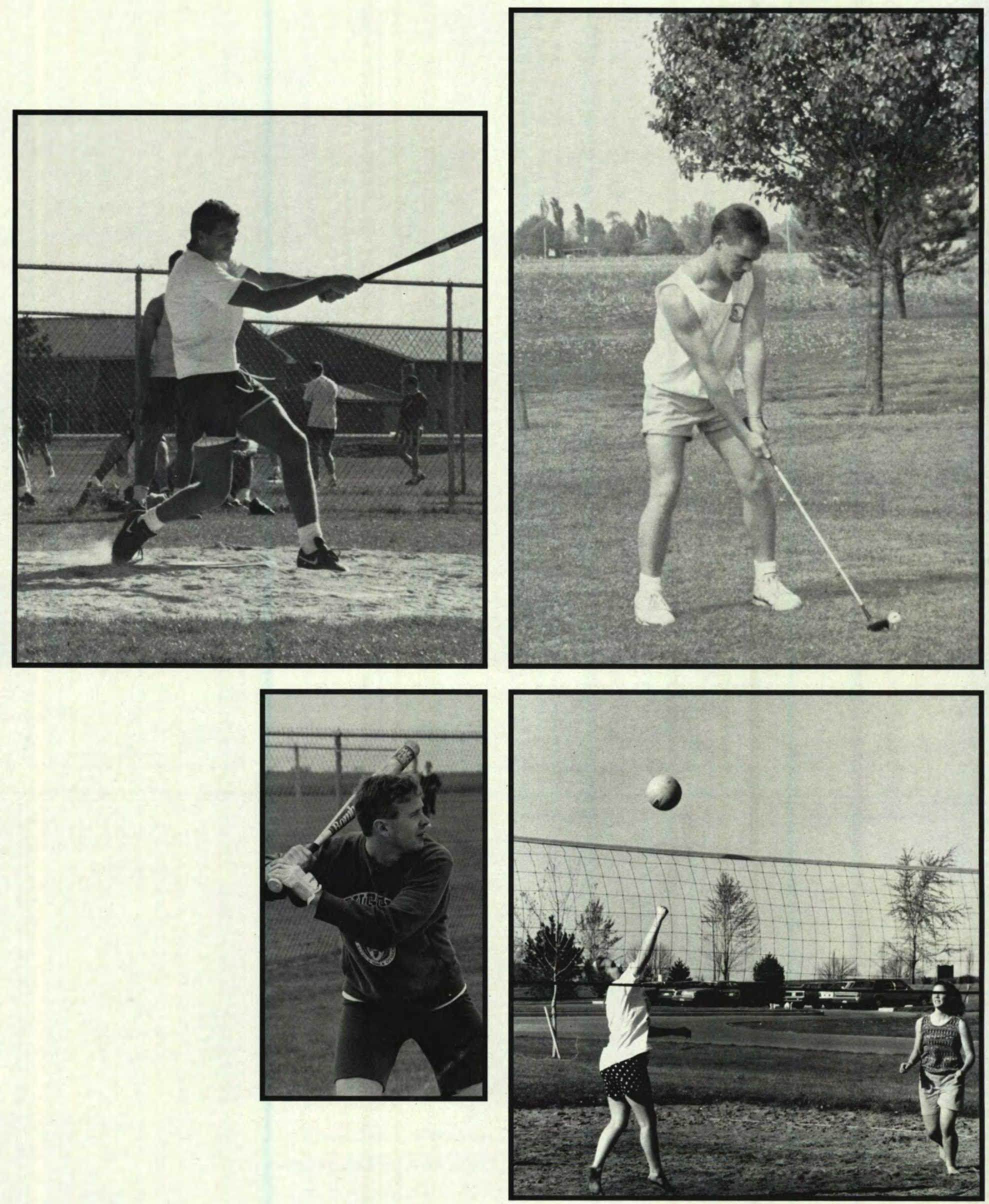


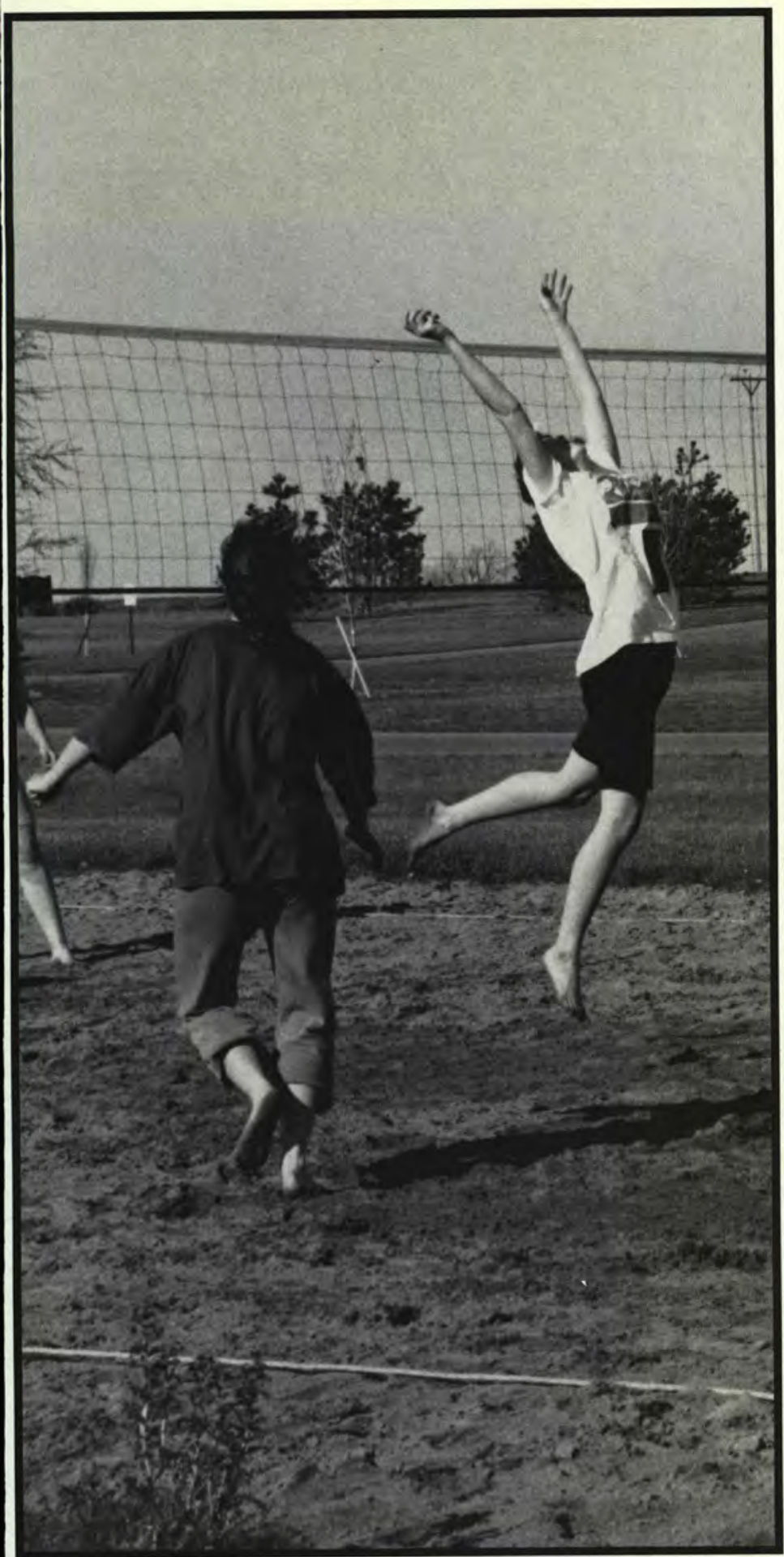

\section{Getting}

\section{Involved}

\section{Intramurals}

\section{Summing UP}

The 1990-91 Cedarville College Sports season was filled with the usual team championships, winning baskets, clutch hits, and fastest times. But it was some special honors that helped to make this Yellow Jacket campaign a little more unique.

Men's tennis player Mark Murdoch and women's basketball standout Diane Rank were hopored as the top scholar-atheletes at Cedarville for the 199091 school year. Murdoch, a senior, (was presented the first-ever Donald E, Callan Award, while Rank, a jut ior, was given the 10m June F. Kearney Award.

Socder coach John McGillivray was the winner of the first-ever Distinguished Merit Award as presented ny the Ohio Collegiate Soccer Officials Association. It honors the coach whose quality character and behavior is also reflected by his own team. Every male and female collegiate soccer coach in Ohio is eligible for the award. McGillivray was also named head coach of the West Team for the NAIA Senior Bowl.

Peter Casaletto was presented the Wheeler Award as the Cross Country Runner of the Year in the National Christian College Athletic Association. It was the third time in the past four years that a Yellow Jacket was selected for the award.

In other highlights, Dave Kohlmeyer (soccer), Diane Rank (women's basketball), Mark Murdoch (men's tennis), and Julie Swift (women's tennis) were named NAIA Scholar-Athletes. Dan Ambrose was tabbed NAIA National Hitter of the Week in baseball in the last week of March. The men's track têam won its first ever Mid-Ofio conference title. Women's tennis coach Pam Diehl and men's coach Murray Murdoch are the NAIA national tournament directors of their respectiye events in Kansas City, MO.

The biggest draw on campus continues to be Yellow Jacket, basketball. Nearly 25,000 fans watched Cedarville achieve its fourth straight 20 -win season with a 22 12 record. The Jackets played in the NCCAA District III title game for the forth straight time losing 115-114 to Malone. Sophomore guard Ken Rucker earned a spot on the NCCAA All-America second team, and head coach Don Callan finished his 31st season just 13 victories shy of the coveted 500-win plateau. - Mark Womack 

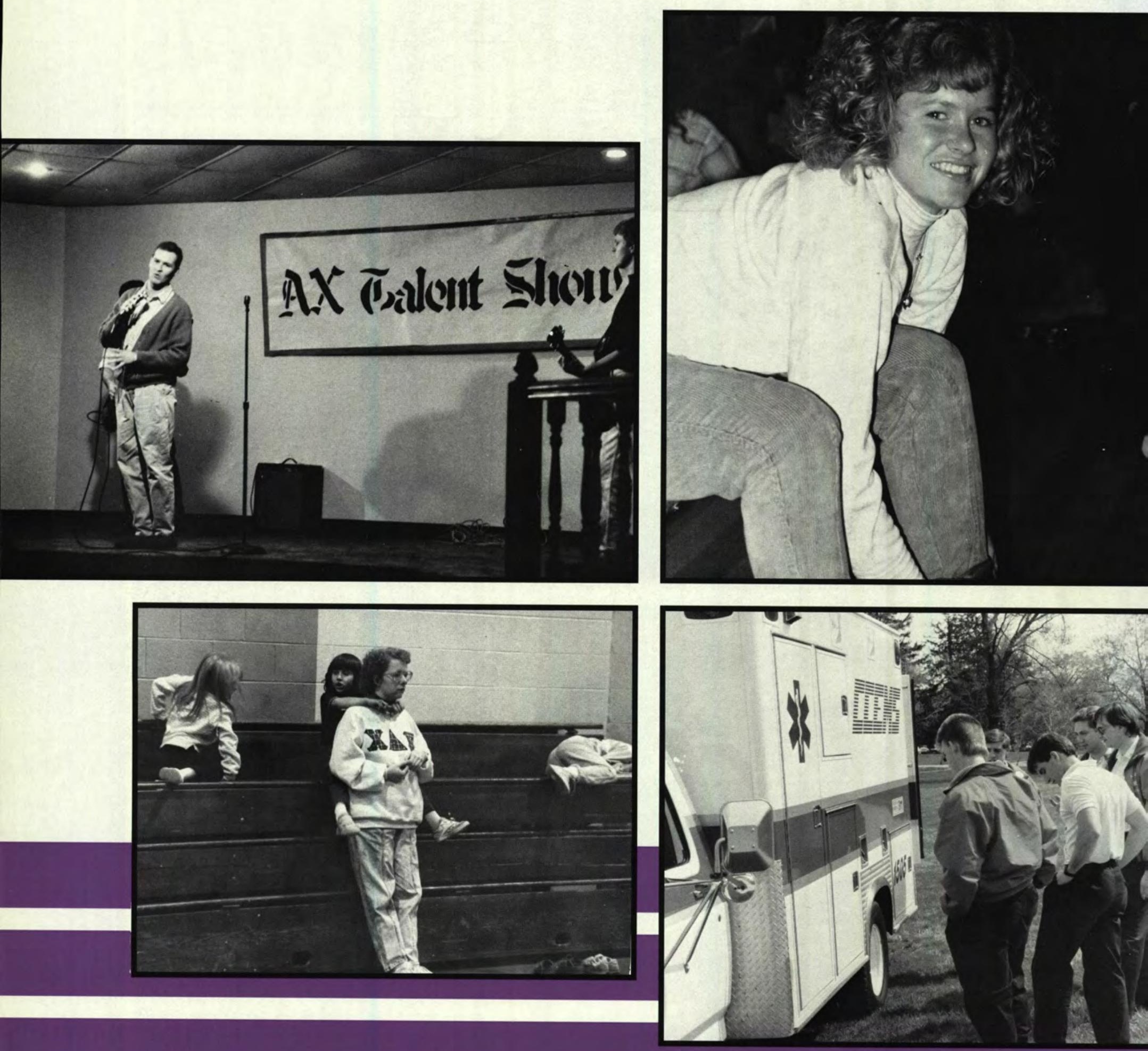

When Miracles Merge. .
They Work With One Another 

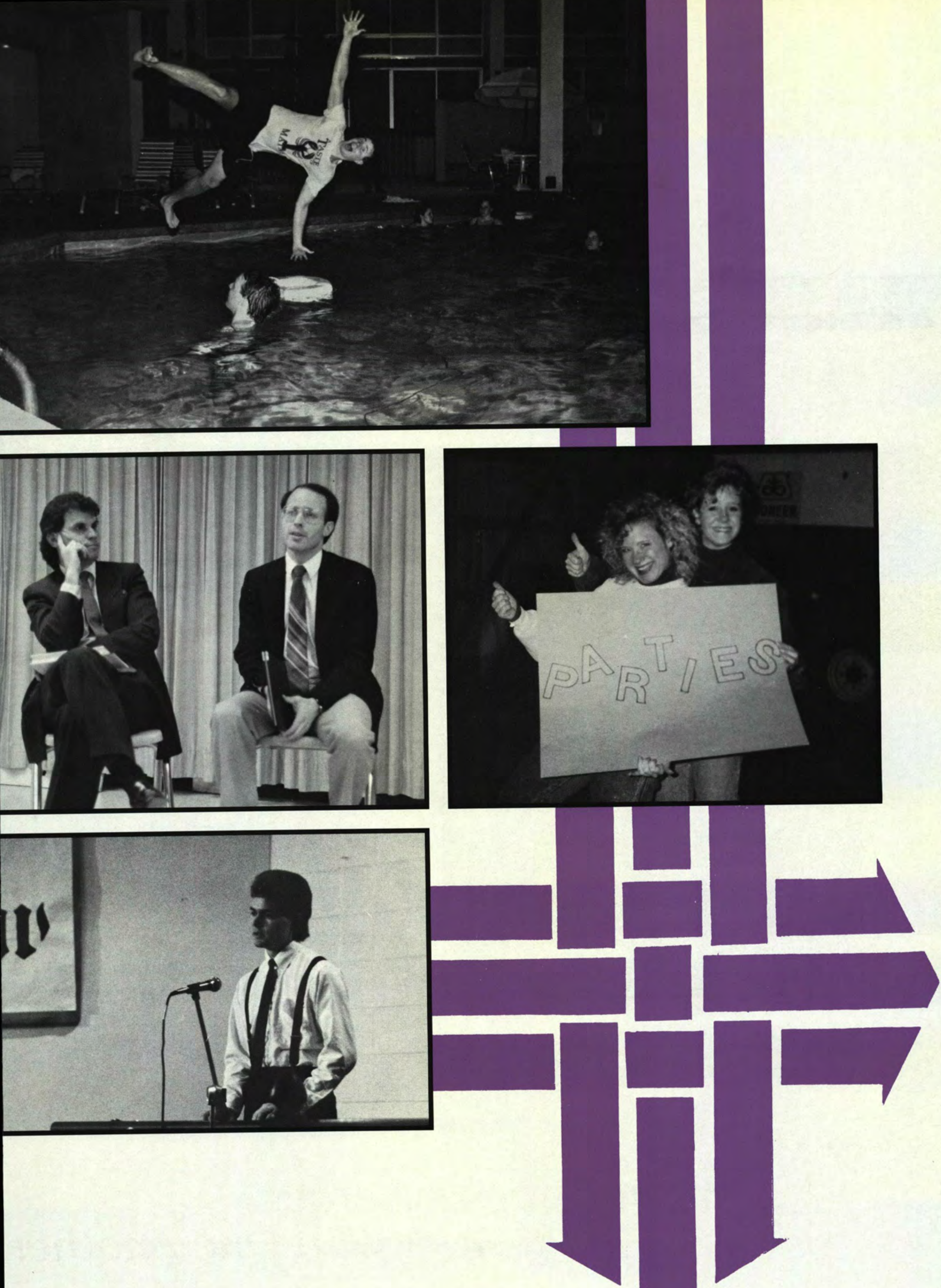


\section{Iota Delta}

First row: Deborah Christner, Heather Hidalgo, Nicole Beecher, Mona Webel Second row: Meredith Clements, Katie Stull, Lisa

$$
\text { Zimmerman }
$$

First row: David Mitchell, Jonathan Gudeman, Jonathan Beach Second row: Troy Deckard, Karen Fuller, Curtis Carr

\section{SIFE}

First row: Michelle Plunkitt, Bethany Britt Second row: Paul Dillon, Stephen Alexander, Patricia Allen
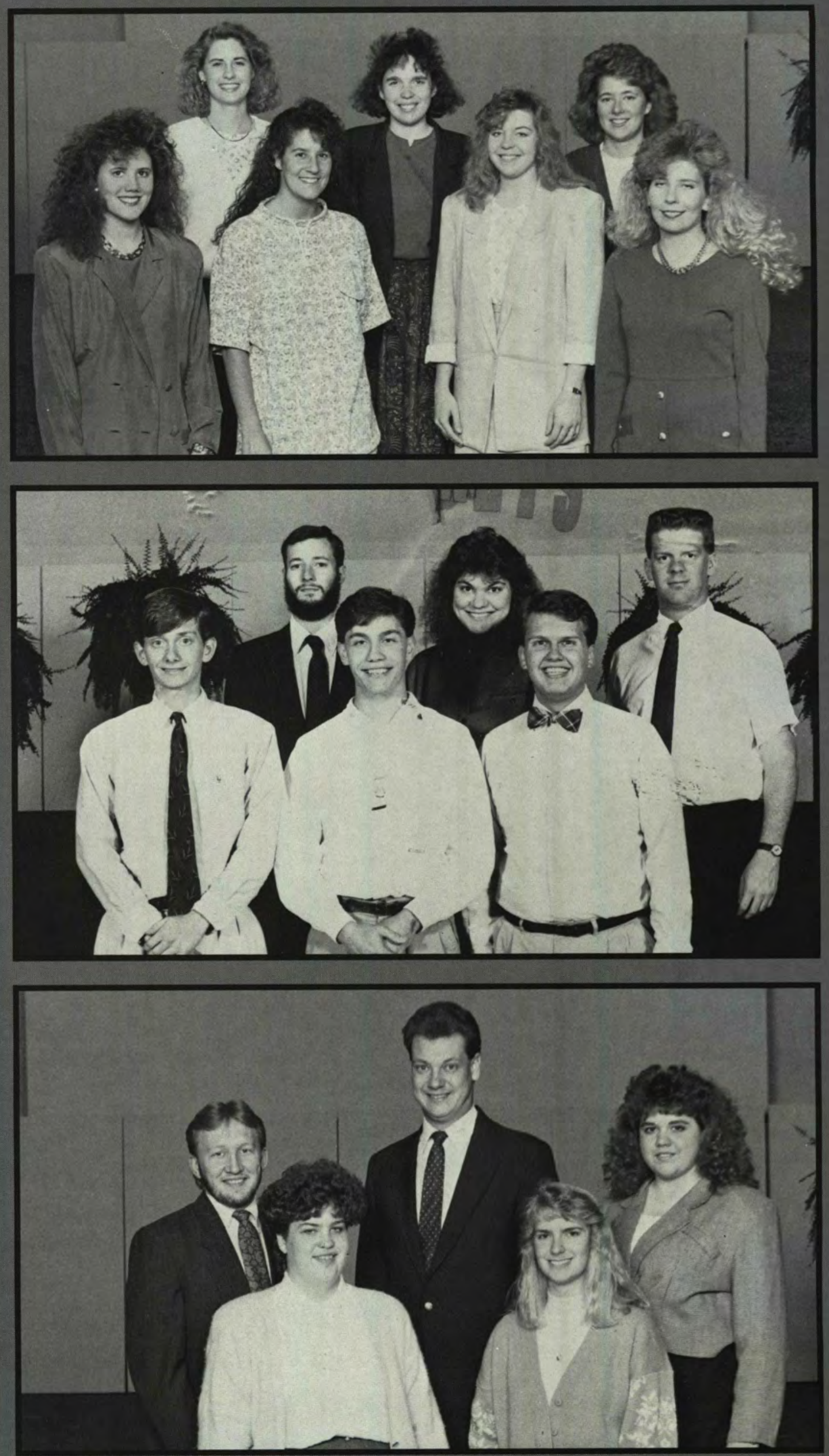

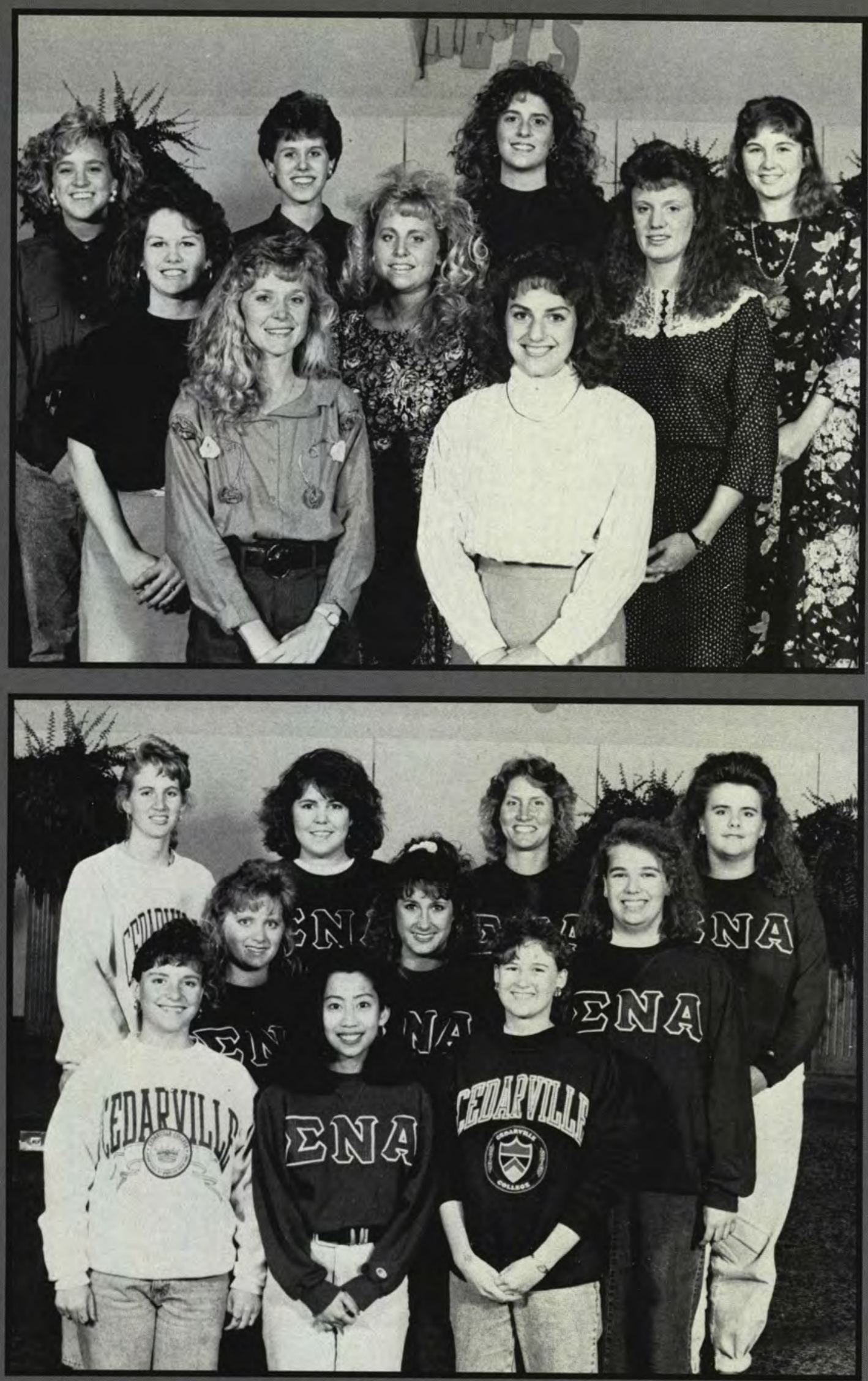

Alpha Delta Omega

First row: Julie Brock, Diane Davison Second row: Zella Sheen, Kathleen Belmont, Kathy Martin Third row: Karen Underwood, Jenine Hyten, Dana Thompson, Kimberly Powelson Not pictured: Lynn Robinson, Cindy Commons, Amy Levacy, Melissa Mott, Kim Harker

Student Nurses

First Row: Elizabeth Foster, Elsa

Estener, Amy Tapp Second row:

Trisha Niccum, Cori Williams,

Renee Beasley Third row: Kathleen

Gasparro, Kimberly Seljan,

Annette Peters, Sara Stoner 


\section{Delta Pi Sigma}

First row: Jane Smith, Sharyn Selby, Sylvia Faragella Second row: Shawn Abbott, Rebecca Scott, Gale Nocella, Tracy Bowersox, Nikki Star,

Renee Randall, Lisa Gillett, Amy Whalen Third row: Amy Fidger, Dayna Sloderbeck, Katrina Parlin, Loretta Smith, Becky Taylor, Amy

Neiser, Lara McGovern, Lee Ann Downing, Kathleen Smith, Shelley Brooker

\section{Delta Omega} Epsilon

First row: Clinton Rice, John Neill, Casey Wood, Stephen McGinnis, Chad Coe, Rob Blenis Second row: Johnny Milligan, Jeff Joiner, Allen

McElroy, William Davis, Todd

Roberts, Mark McMurtry Third row: Dave Dykema, Brendon Cearley, Mark Vroegop, Randy Oswald, Stefan Tarapchak, Dominic McKinley
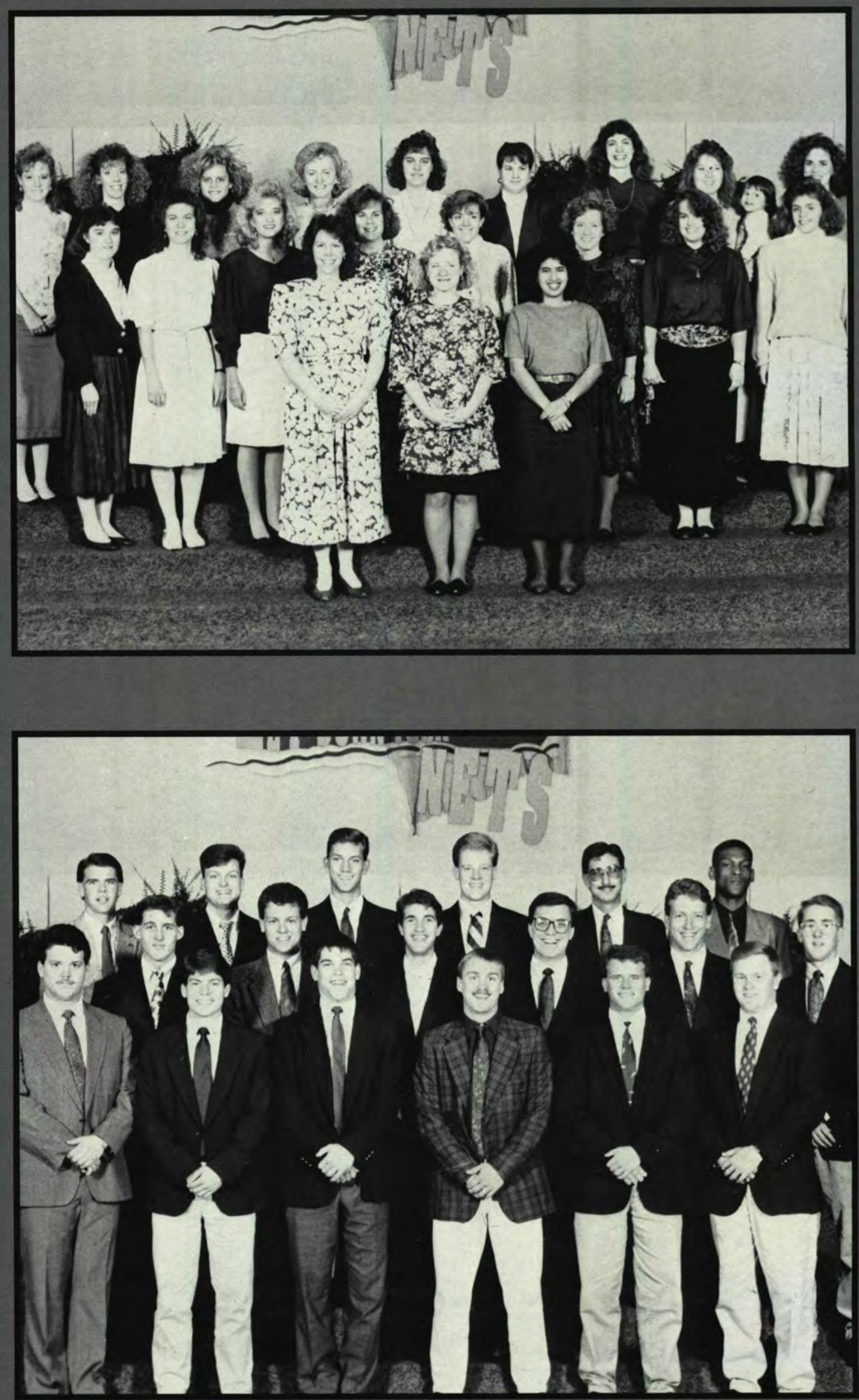


\section{$S T C$}

First row: Nanci Woodard, Holly Leadbeater,

Ruth Bartholomew Second row: Victoria Johnson, Celeste Neumann, Kim Aueritt, Nicole Beecher

\section{E M S}

First row: Katrina Parlin, Gwendolyn Cook Shelley Kincaid Second row: Jonathan Jenks, Jonathan Smith, Brian Blind Third row: Jeff Rinehart, Bill Hauter, Jeff Lindaberry, George Goodwin Not pictured: Beth Hofmann

\section{C.C. \\ Republicans}

Mark Roeder, David Lam, Alex Clow
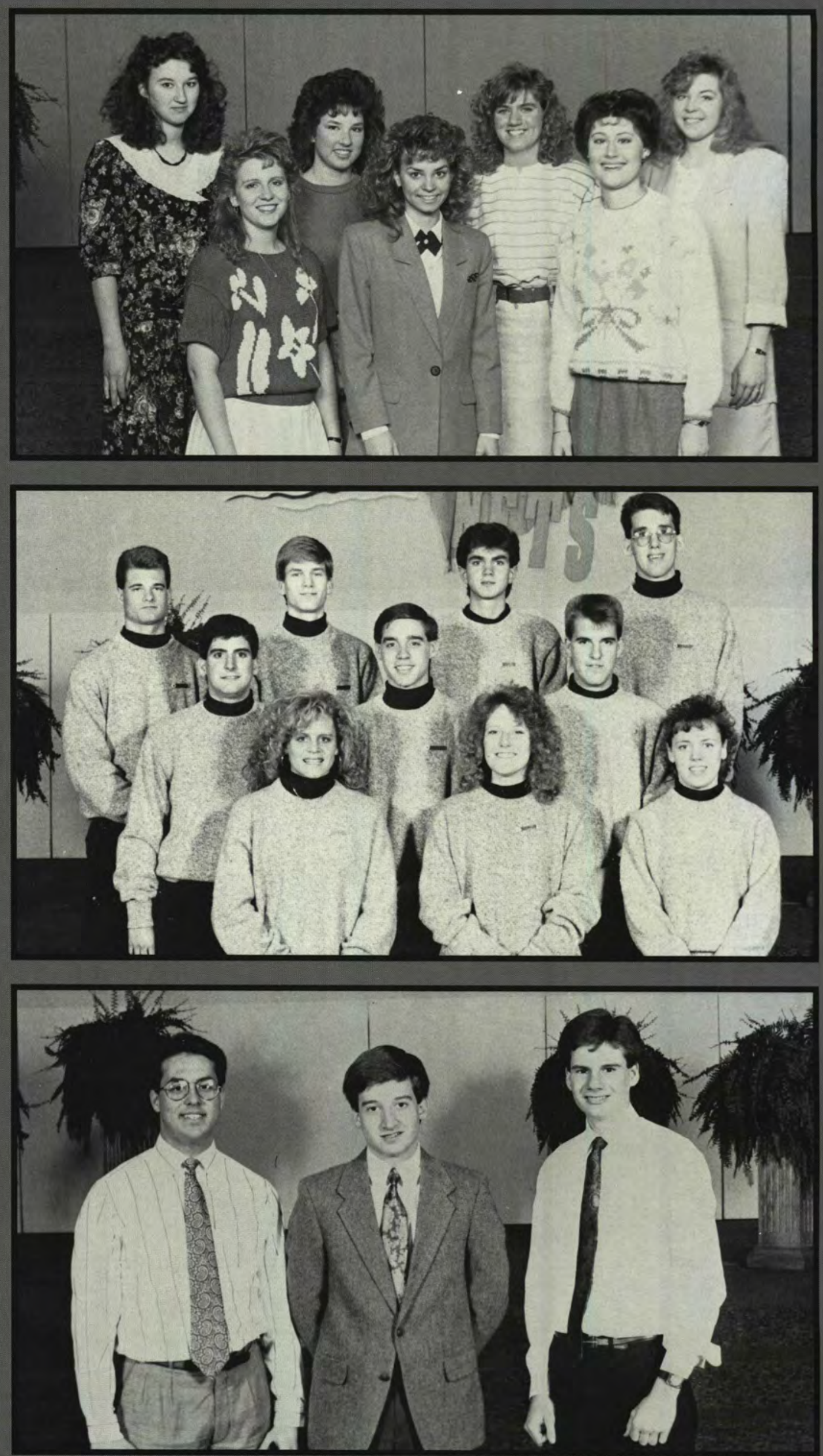

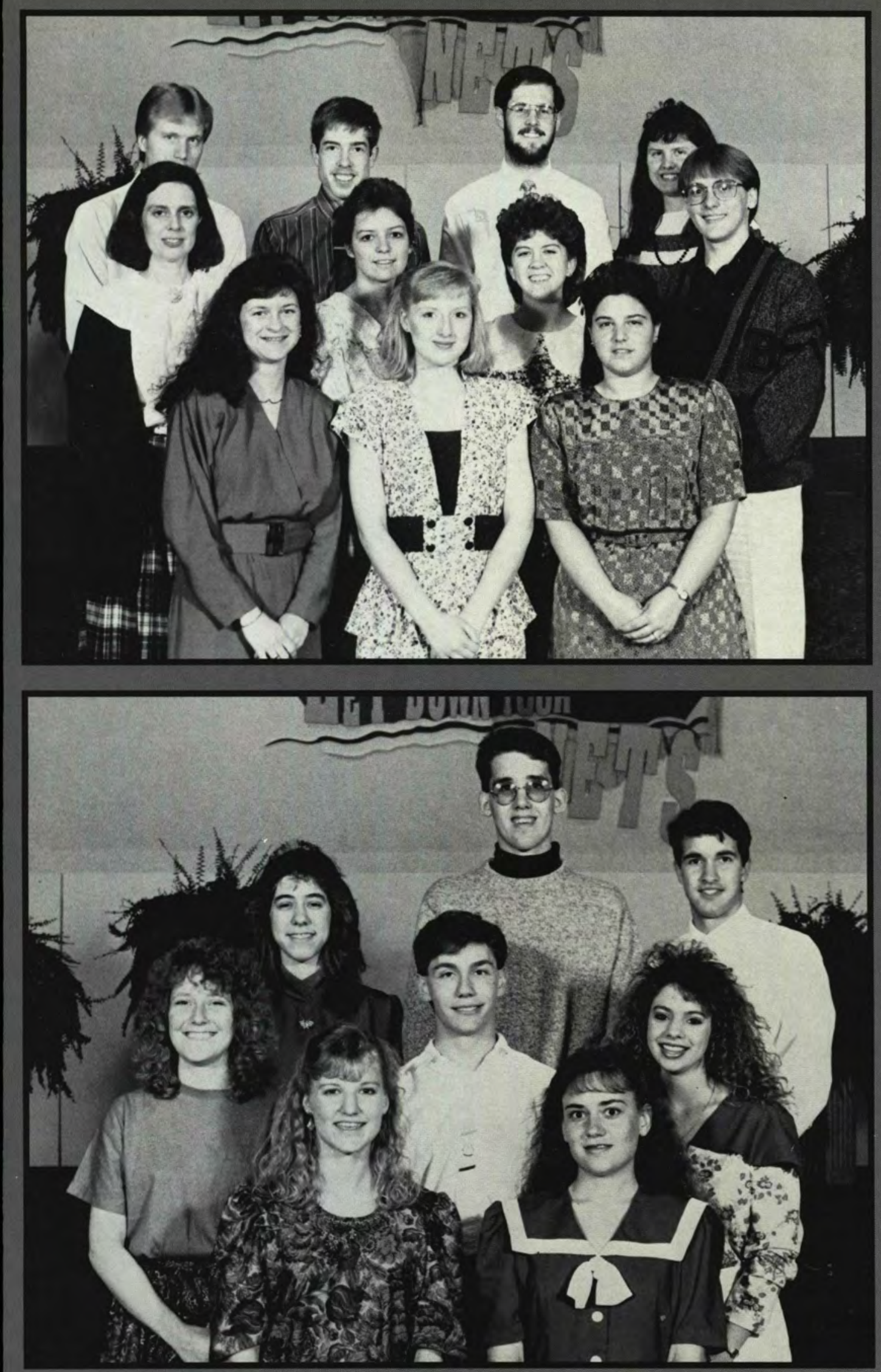

\section{Fellowship for} World Missions

First row: Beth Hess, Mary Hollaway, Traci Starr Second row: Wilhelmina Krugsman, April

Yaworski, Tami Seidner, Jon Misers Third row:

Don Hoover, Robert Jackson, Tim Derks,

Christine Fischbacher

\section{Chi Theta Pi}

First row: Amy Cooper, Sharon Yoder Second row: Gwendolyn Cook, Jonathan Godeman, Tara

Rhodes Third row: Georgia

Hickman, George Goodwin, Allen McElroy 


\section{Data Processing} Management

First row: Brenda Wandell, Lisa Stoltzfus, Marivi Caldejon, Joan Hazen Second row: Daniel Treier, Paul Dettwiler, Chuck Seeley, Edmond English, James Monk Third row: Mark Wong Paul Hicks, Brent Williams, Steve Francisco, Bryan Lykins, Tim Richardson

\section{S H R M}

First row: Dawn Mesnard, Lynn Robinson, Lauralyn Hackacy Second row: Kristy Lough, Dayna Sloderbeck, Kelly Scott, Trent Kaufman, Patrick Drury Third row: Jodi Culp, Michele Abramowitz,

Ruth Carlson, Matthew Perriso,

Timothy Lewis, Kurt Moreland
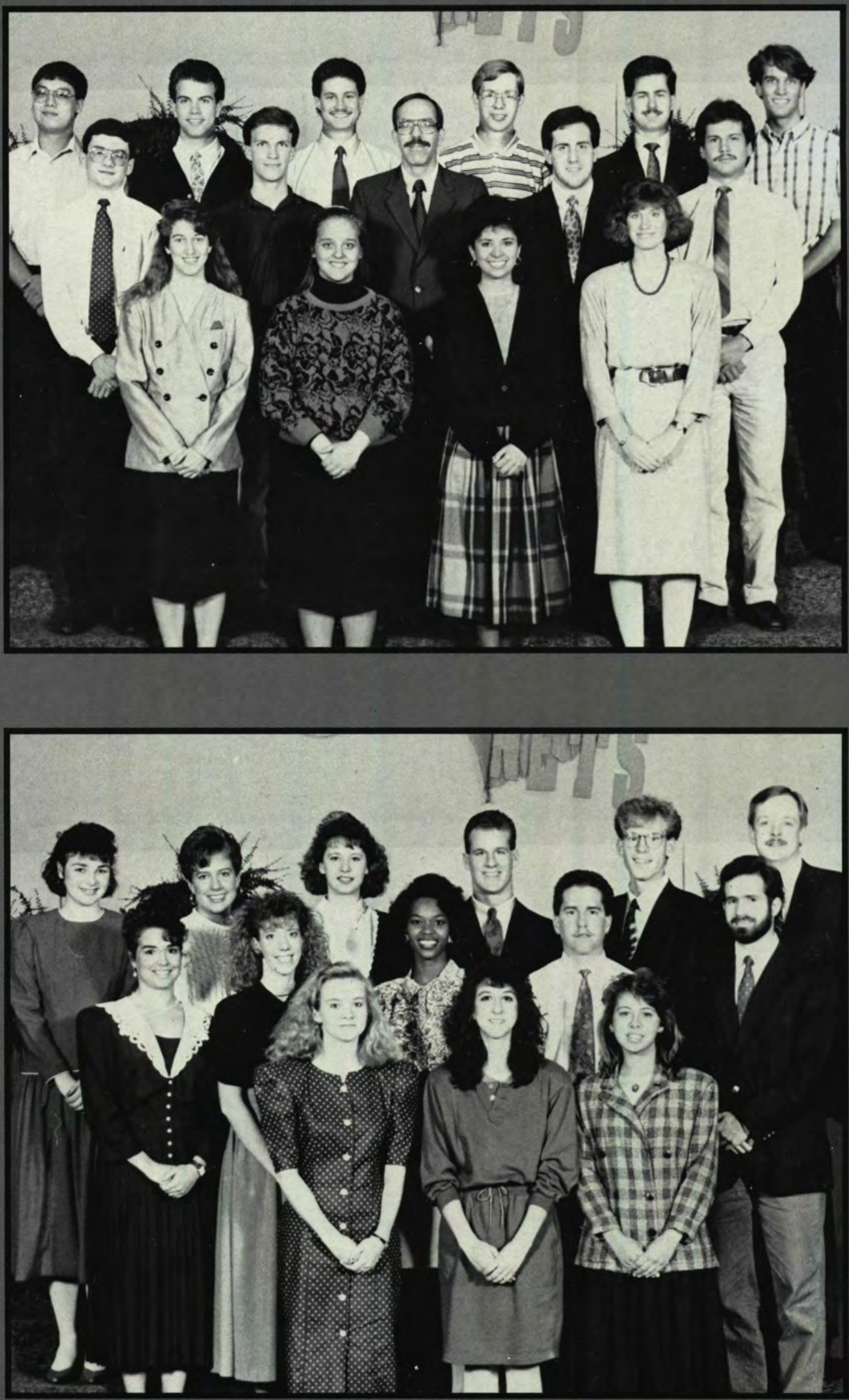


\section{Phi Epsilon Beta}

First row: Lisa Zimmerman, LaDonna Baxter Second row: Kathy House, Heather Hidalgo, Kristy Lough Third row: Michele Gallup, Sue

Rogers, Debbie Bouma, Meredith Clements

First row: Melissa Bethel, Stephanie Hersaken, Brian Megilligan Second row: Lori Jones, Debbie

Reid, Tracie Dennison, Susan Seibert

\section{Alpha Phi Lambda}

First row: Susan Clark, Abby Boone, Karen Miller Second row: Eric Phillips, Kenn Hoffman, Pete Singer
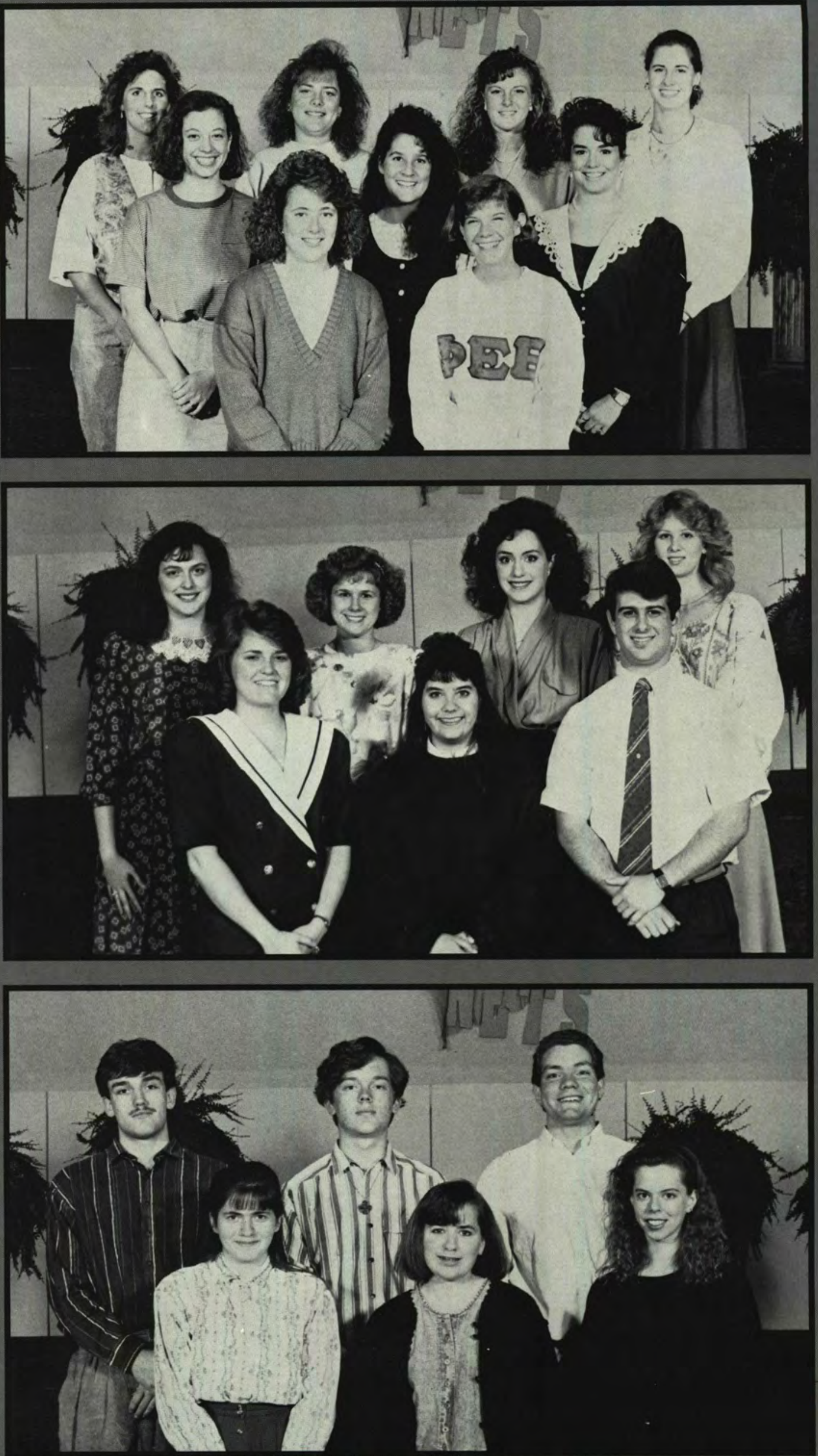

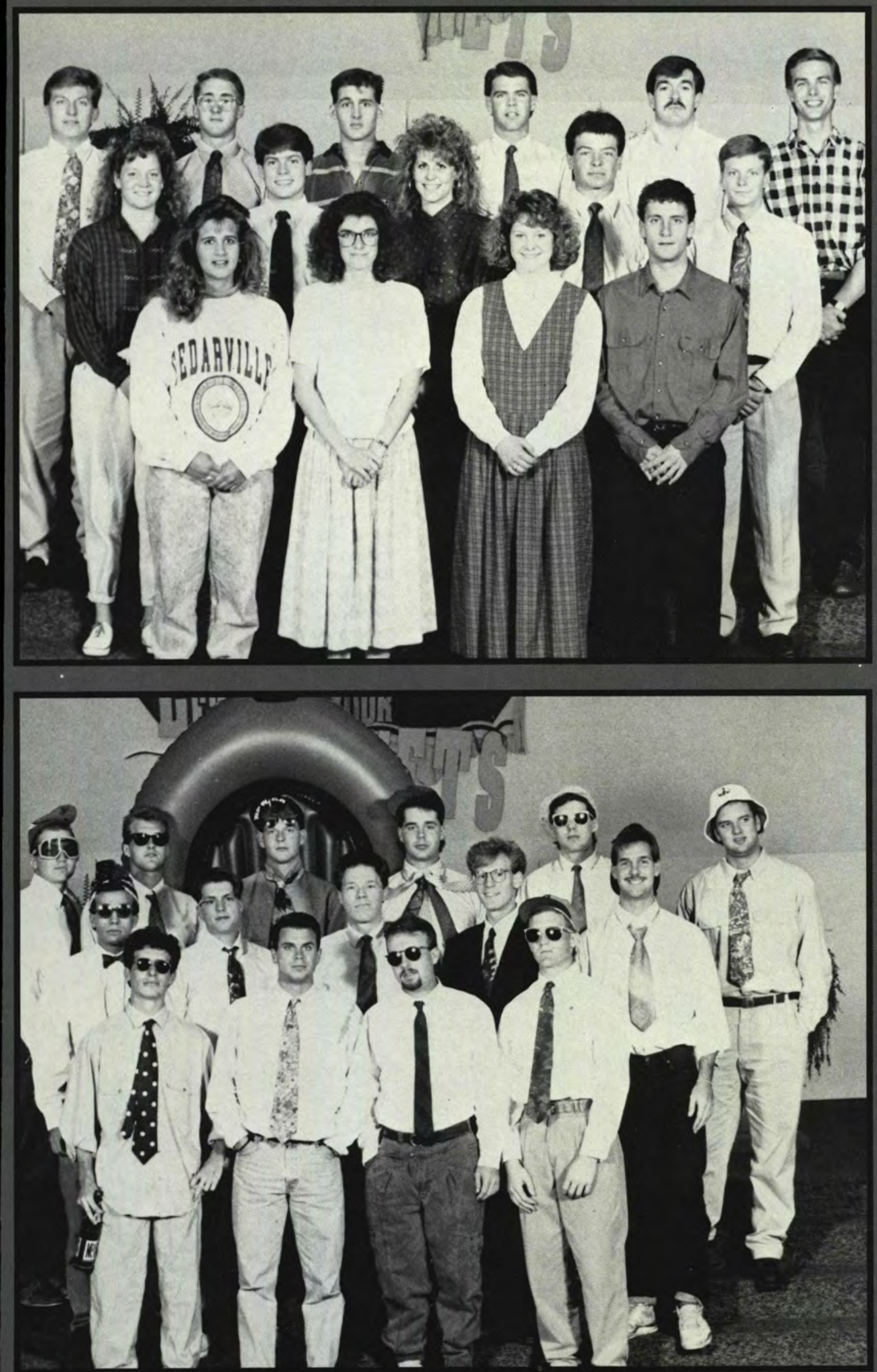

Varsity C

First row: Debbie Henry, Kari Clark, Sara Norder, Peter Casaletto Second row: Sharyn Norder, John Neill, Dana Daniels, John Yoder, Mark Murphy Third row: Dan Walsh, Mark McMurtry, Johnny Milligan, Dave Dykema,

Alan Geist, T.J. Erlandson

\section{Pi Sigma $N u$}

First row: Trigger, Teej,

Moonbeam, Big Dog Second row:

"Purple" Hayes, Jim Hanssen,

Dave Ormsbee, Timothy Lewis,

Padg Third row: Brent Downing,

Tim Neubert, Ed Curry, Tony Dirr,

R.L. Brandmeyer, Mike Bragg Not

pictured: Dan Walsh 


\section{Pi Delta}

First row: Lori Lindner, Jim Breuler, Cynthia Palacios Second row: Debbie Henry, Linda Gagnebin, Faith Linn, Carrie Quinn Third row: Jerri Cook, Matt Moore, Sue Rodgers, Wendy

Miller, Nichole Bouchard Fourth row: Lynn Leindecker, Sara Sweetland, Mark Vroegop, Jeff Halsted, Andrew Rudd, Jim Houser

\section{Kappa Epsilon} Alpha

First row: Wendy Walters, Krista

Dayton, Todd Sechrist, Marcy

Sipe, Relyn St.John, Linda

Bandixon Second row: Carrie

Mann, Michelle Plunkitt, Darcey

Blenis, Stephany Hutchison, Kim Bailey, Sara Peters, Beth DeYoung

Third row: Matthew Martens,

Galyn Nook, Edmond English,

Philip Thompson, James Geise,

Rebecca Gillam, Tamara Schauer

Fourth row: Diane Shaver, Patricia Allen, David Gosman, Paul

Pantzer, Phil Battin, Greg Dail,

Mark Miller, Stephen Alexander
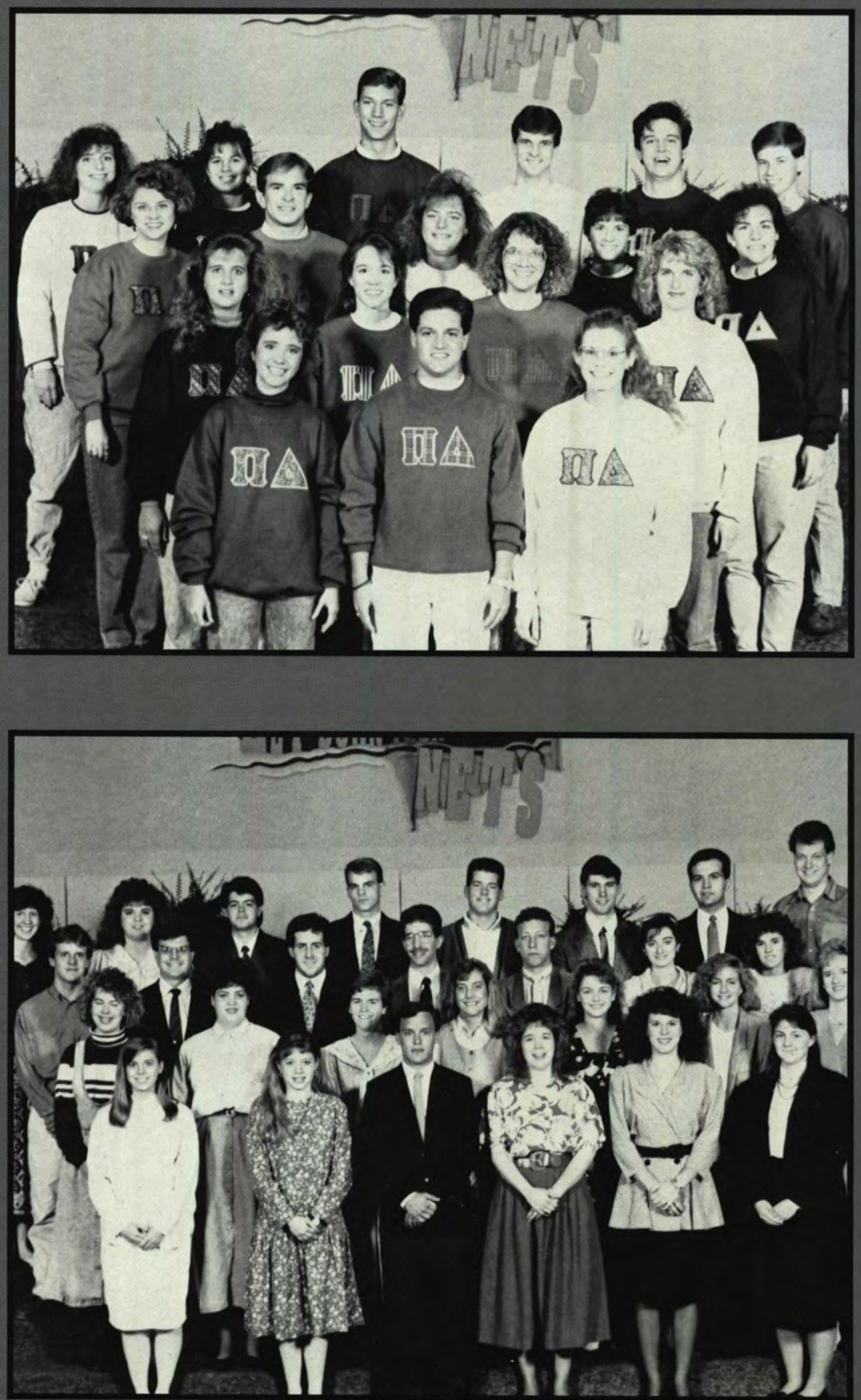
S.T.C.

First row: Holly Leadbeater, Nanci Woodard Second row: Victoria Johnson, Celeste Neumann, Kim Averitt

\section{Students for Social Justice}

First row: Beth Irving, Sylvia Faragalla, Lisa Stoltzfus Second row: Heather Barnard, Jody Souza, Victoria Johnson, Jennifer Shriver Third row: Melinda McDugle, Jonathan Bird, Dave Mills, Mark Irving, Paul Anderson

\section{Forensics Team}

First row: Dr. David Robey, Coach; Brent Apperson, Scott Bowman, Steve Brock, Matt Moore Second row: Sue Terkelsen (judge), Jennifer Lahman, Chantelle Sain, Jennifer Freebourn (judge), Jodi Culp, Carrie Quinn, Erin O'Donnell, Kirsten Gibbs, Priscilla Brown Third row: Ken Vanderwest, Randy Joiner, Jeff Joiner, Mark Vroegop, Paul Anderson, Raul Mosley, Edina Van Matre
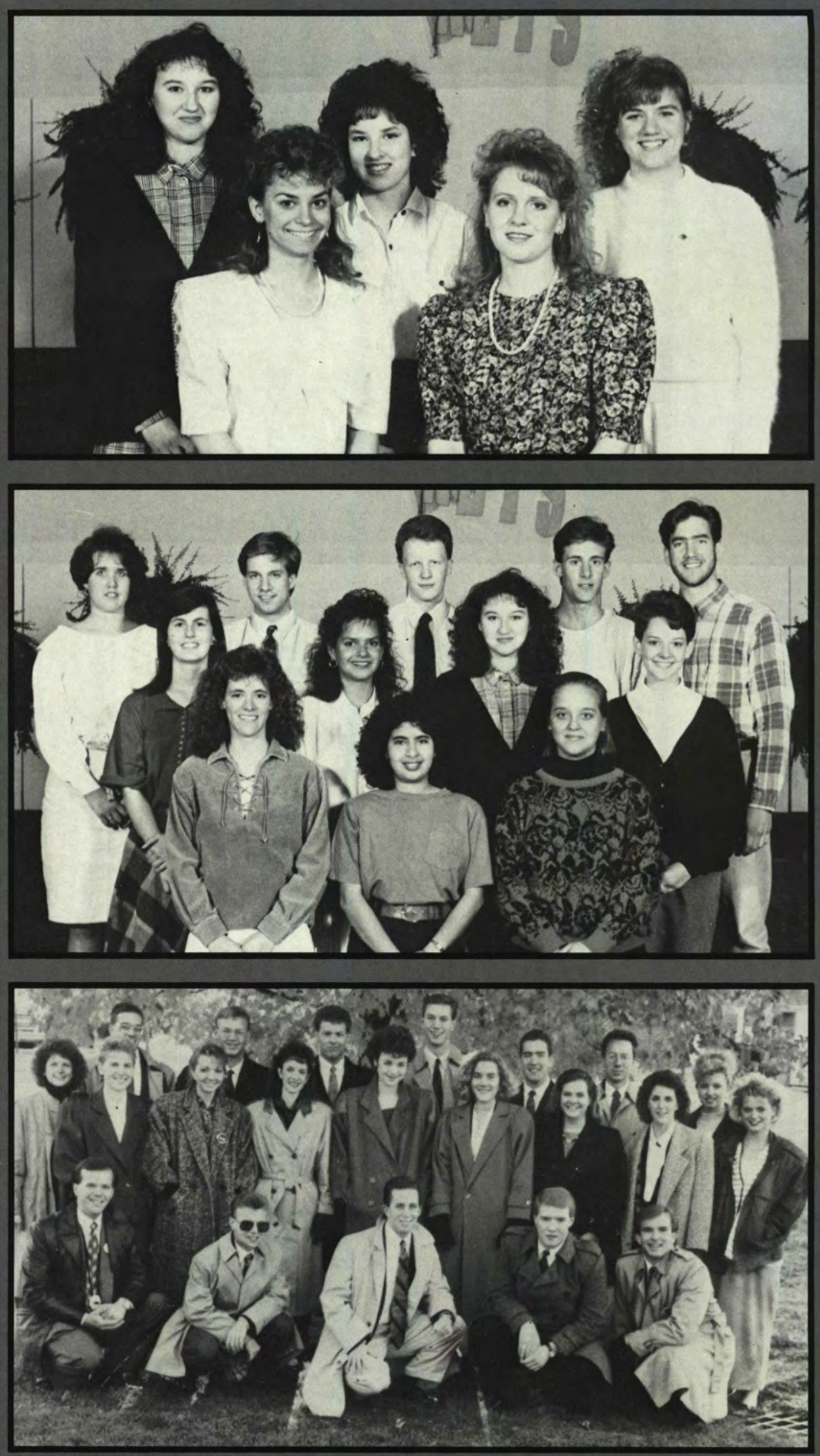


\section{$S G A$}

O

$f$

$f$

$i$

C

e

$r$

$S$
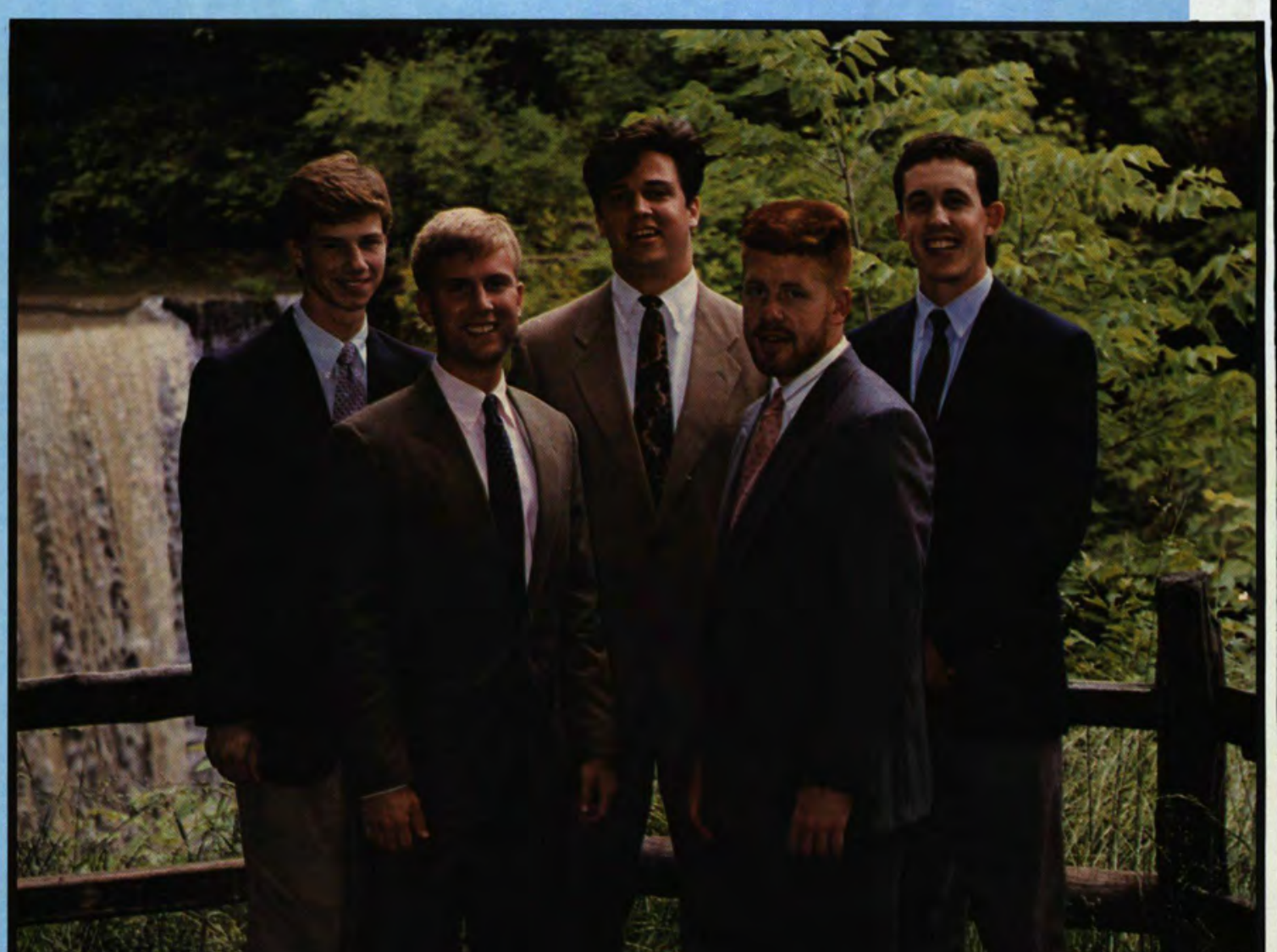

है

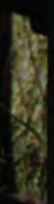

Front row: Mike Koenig, Treasurer, Kelly Fath, President Back row: Jim Houser, Secretary, Andrew Rudd, Vice President, Joṇ McDugle, Chaplain

\section{Freshmen}

Darryl Hammock,

Chaplain, Todd Vande Guchte, SGA Rep., Mark

Moody, President, Tim

Keib, SGA Rep., Karl

Cooper, SGA Rep. Not pictured: Aaron Ray, Vice President, Robin Sheldahl,

Treasurer, Abigail
Worstell, Secretary

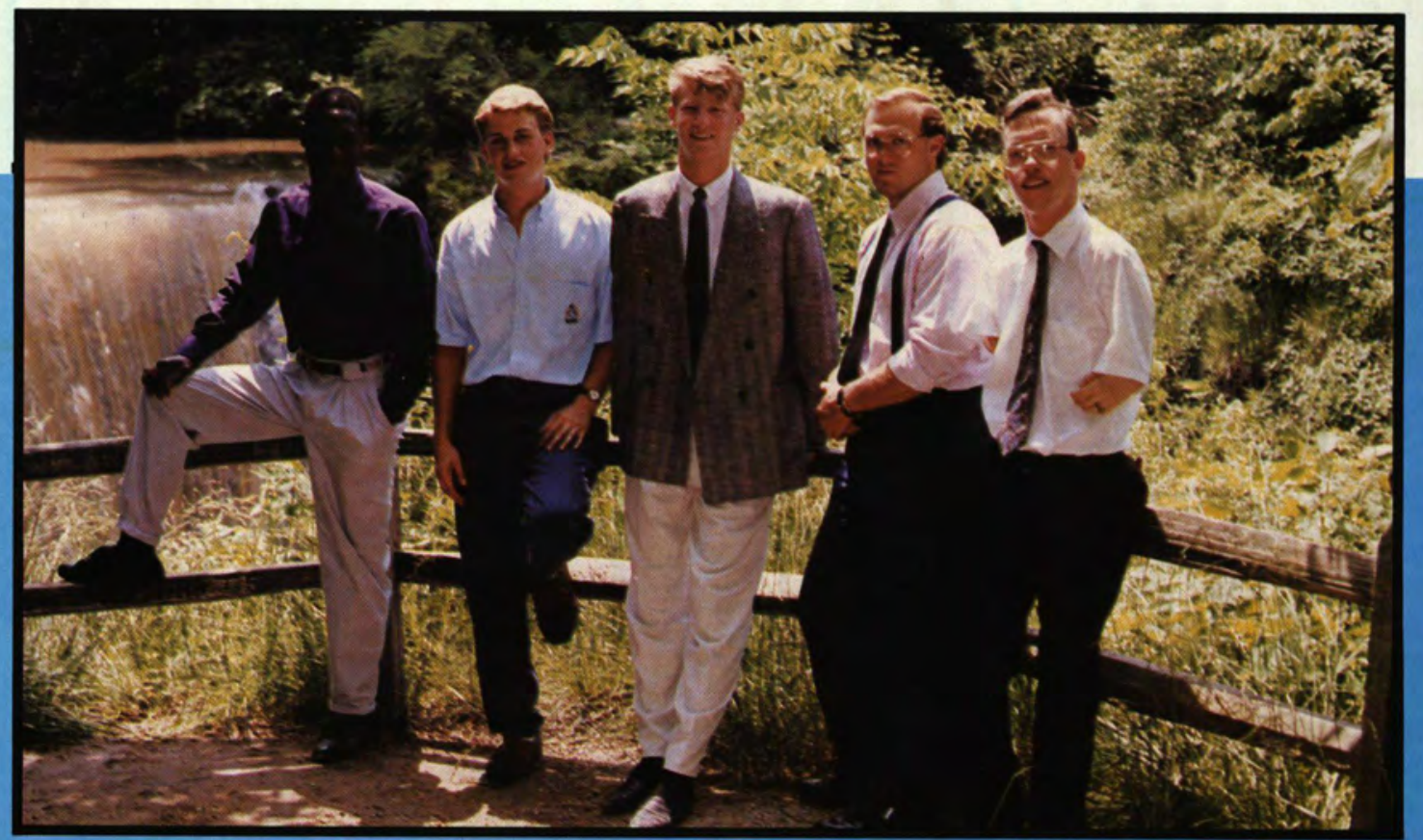



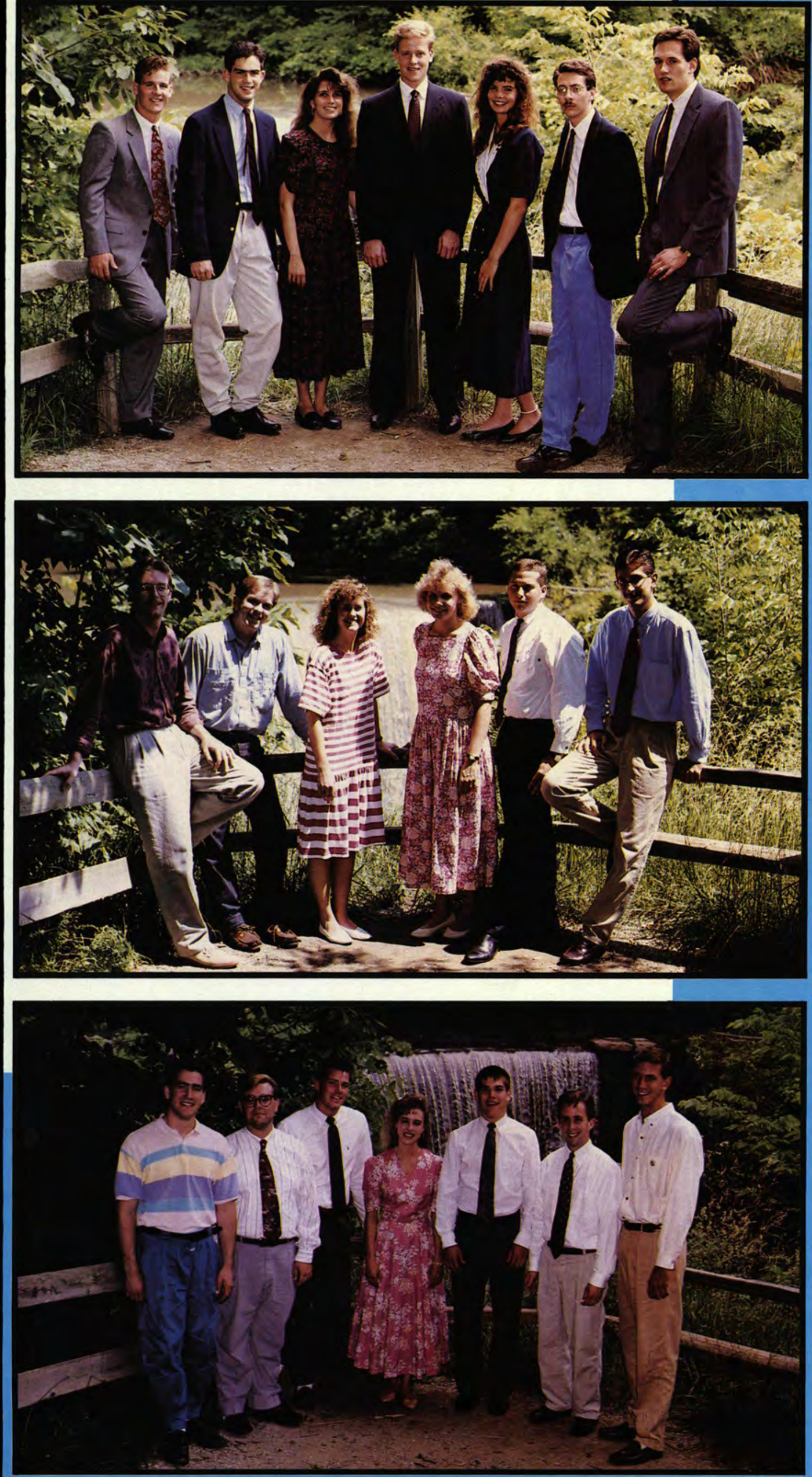

\section{Senior}

Matt Perrigo, Vice

President, Tyler Bragg,

SGA Rep., Kathy

Duhaime, Treasurer,

Randy Oswald, President,

Krista Hill, SGA Rep.,

Richard Wells, Secretary,

Jeff Tague, Chaplain

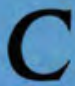

I

2

$S$

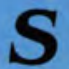

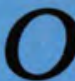

$f$

$f$

i

\section{Junior}

Jim DeVine, SGA Rep.,

Matt Moore, Chaplain,

Michelle Gaffner,

President, Allyson

Graham,

Treasurer/Secretary, Craig

Hamilton, SGA Rep.,

Stefan Tarapchak, Vice

President Not Pictured:

Renee Maxwell, SGA Rep.

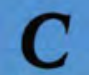

Q

$r$

$S$

\section{Sophomore}

Paul Anderson, SGA Rep.,

Paul McGrady, Vice

President, Phil Battin,

Treasurer, Allison

Knowles, Secretary, Casey

Wood, President, Scott

Bowman, SGA Rep., Mark

Vroegop, Chaplain 


\section{'A Garden}

\section{by the Thames'}

On May 24, 1991, the Junior class presented to the Seniors "A Garden by the Thames." Held at the Omni Netherlands Hotel in downtown Cincinnati, the Junior-Senior Banquet was an elegant affair. The banquet began with a reception during which the guests mingled, had photographs taken, and enjoyed the music provided by Cedarville's String Quartet.

Following the dinner, the comedy duo Hicks and Cohagen provided witty but warm entertainment. Their sketches brought humorous and practical application to living a Christian life.

A slide presentation concluded the evening as a tribute to the Seniors. Captured in each moment of those pictures was a memory that the senior class will cherish always.

Given the privilege of an extended curfew, the guests spent the remainder of the evening touring Cincinnati and taking pictures at Fountain Square.

\section{- Adrienne Butterfield}

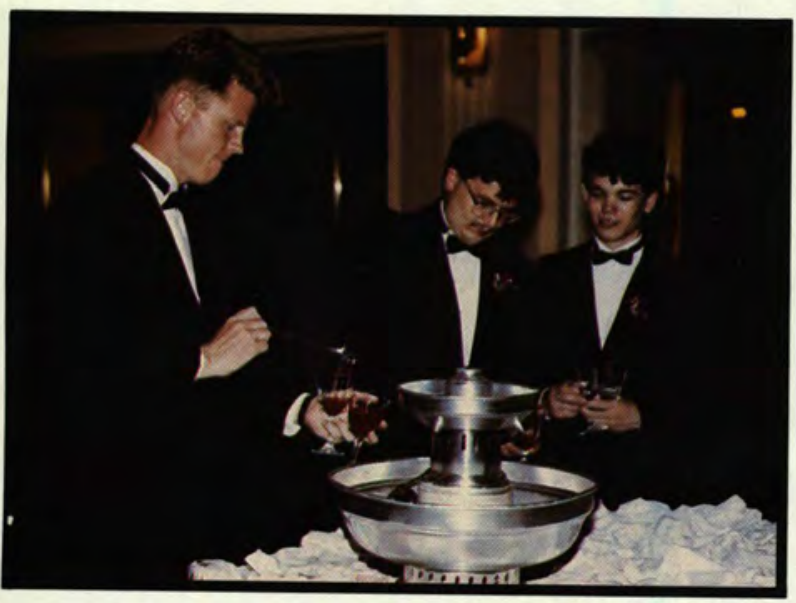

photo by Marsha Olsen The punch fountain provides something for the gentlemen to do while the ladies powder their noses.
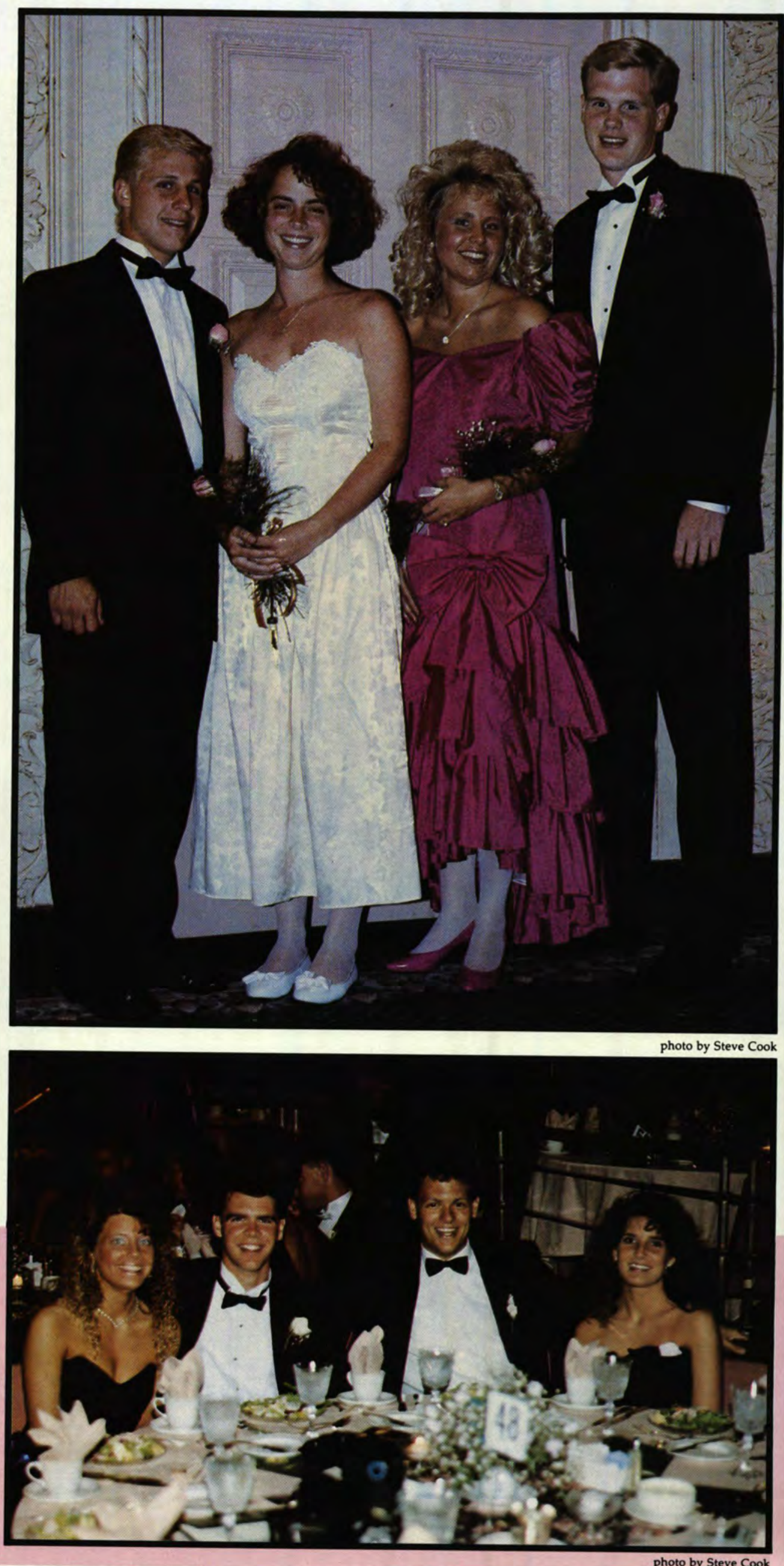

(top) Posing for pictures was a night-long activity at the banquet as students relished this formal affair. 


\section{'Cruising' \\ Toward the Finish}

One beautiful May evening members of the 1991 graduating class embarked on an elegant cruise. Senior Night 1991 featured a dinner cruise on the Cincinnati River.

The evening began with a dinner which was accompanied by a jazz band. This band was composed of members of the Cedarville College faculty. After dinner, the seniors spent time visiting with

classmates and entertaining themselves by immitating their favorite faculty member. When asked what the most memorable aspect of the evening was, Deb Christner replied, "Receiving one free drink coupon."

This evening was just the beginning of the seniors' farewell to Cedarville College.

- Amy Edwards

photo by John Bush

Fellow students provided much of the entertainment for the evening.

(Bottom Right) Faculty members created an atmosphere of class with a live jazz band

The beautiful lights of Cincinnati proved a stunning backdrop for the dinner cruise.
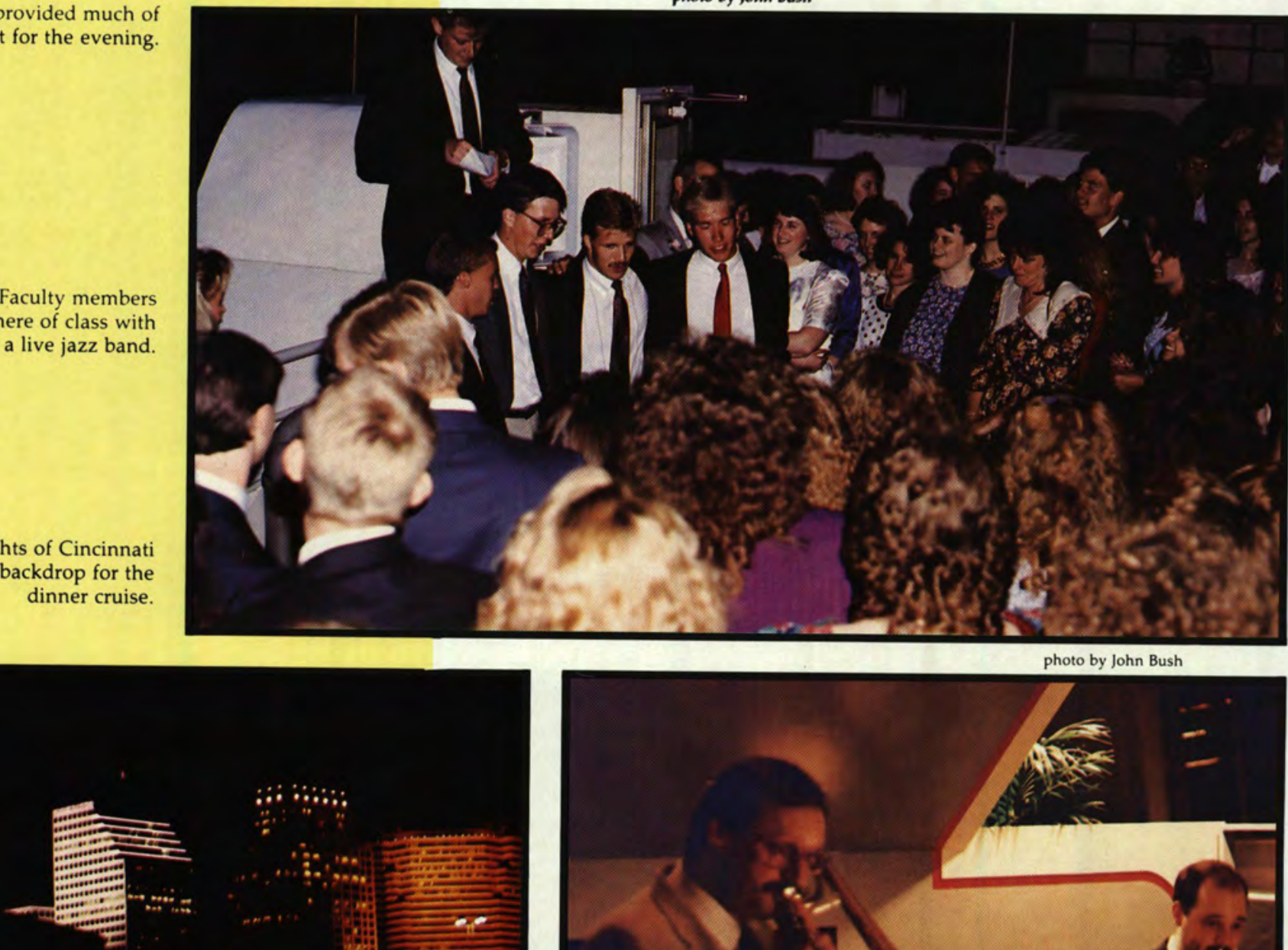
The excitement builds as graduates make their way to the platform to receive their diplomas.

\section{Class of \\ $1991 \ldots$ \\ New}

Beginnings

Mark Murdoch accepts his diploma with honors.

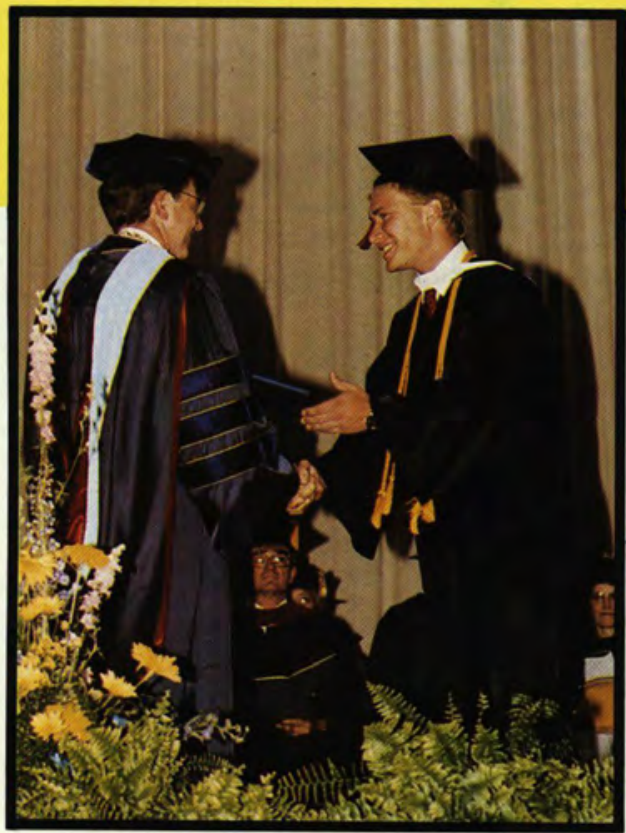

photo by Jesse Wesselink
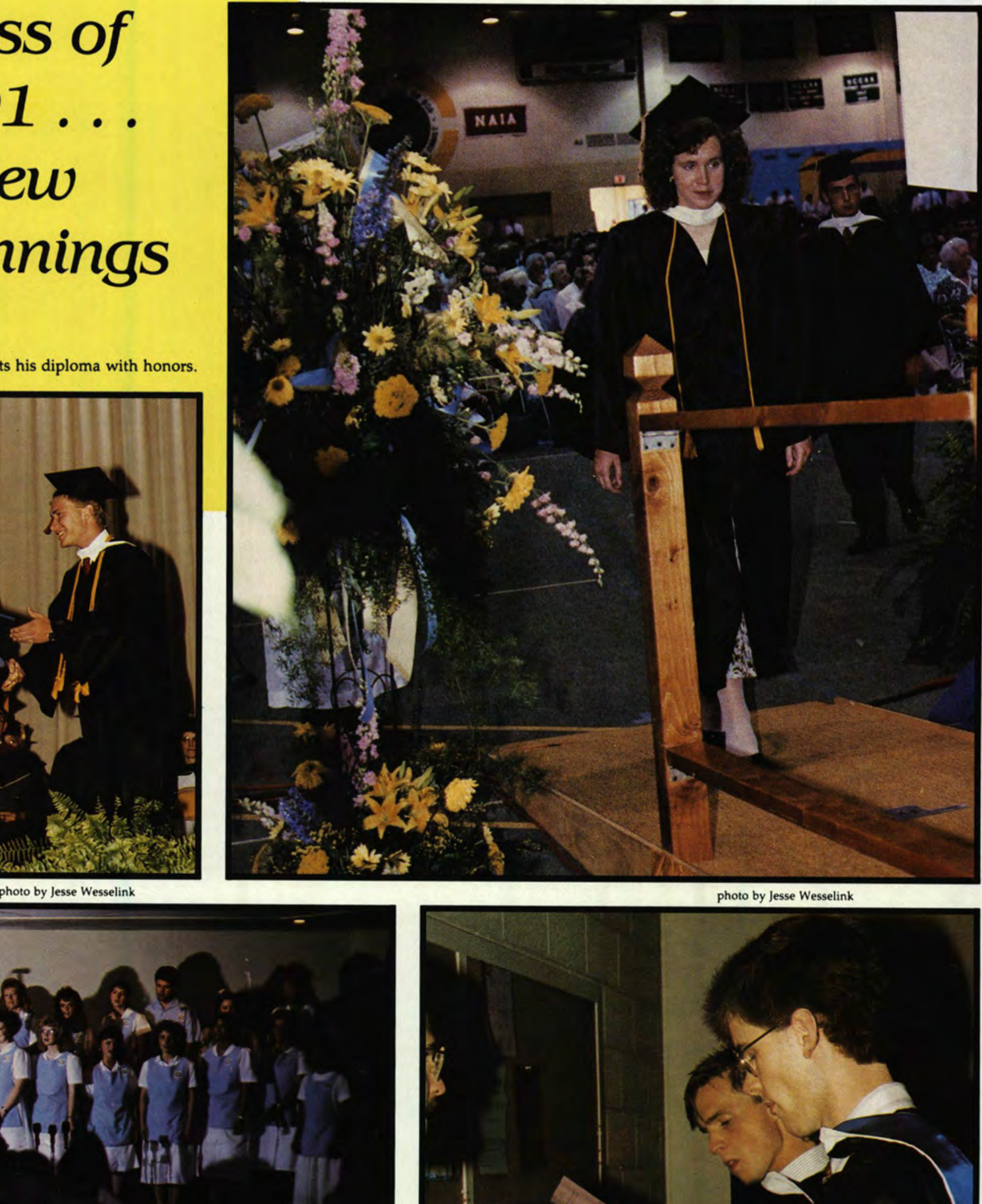

Q. $=$

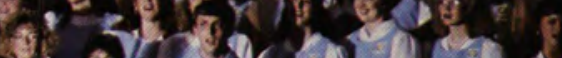
.

,

The concert chorale performs once more for the 1991 graduates.

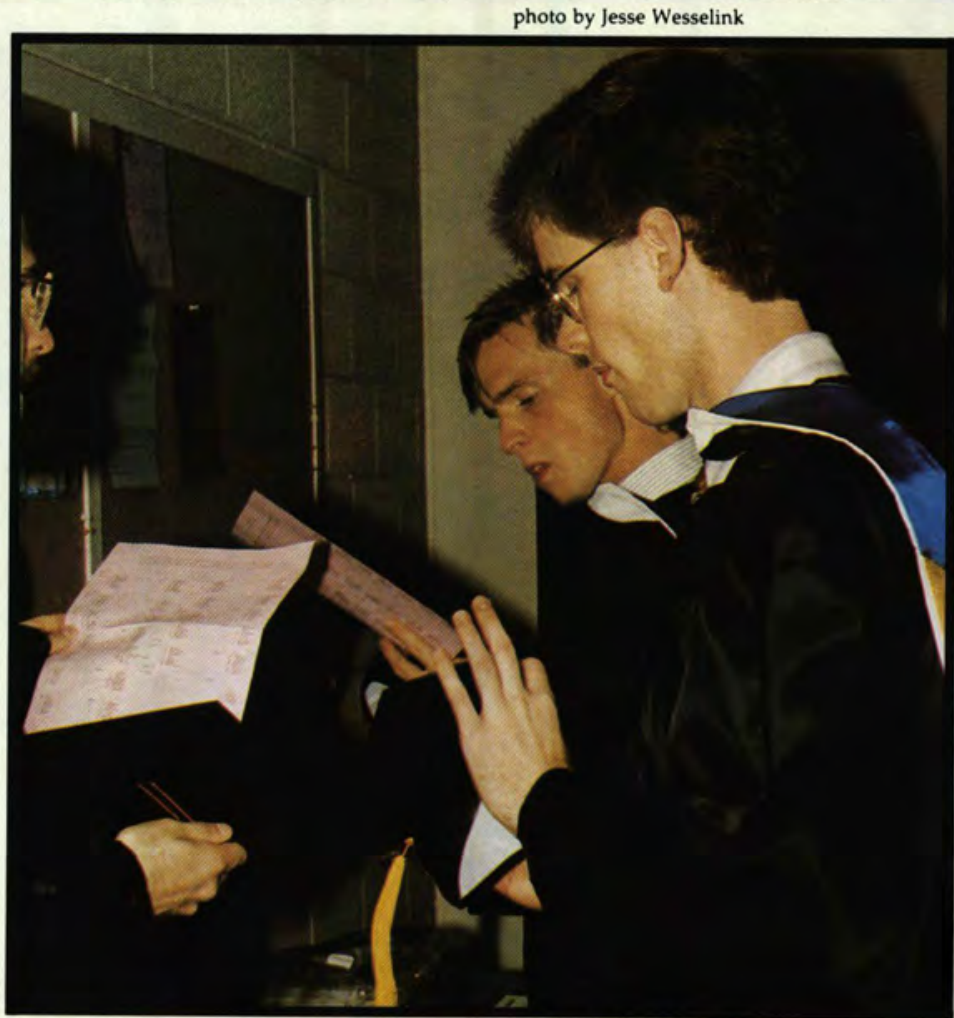


Daniel Cain expresses his feelings about finally graduating.

Graduates pose for pictures with family and friends after the ceremony.

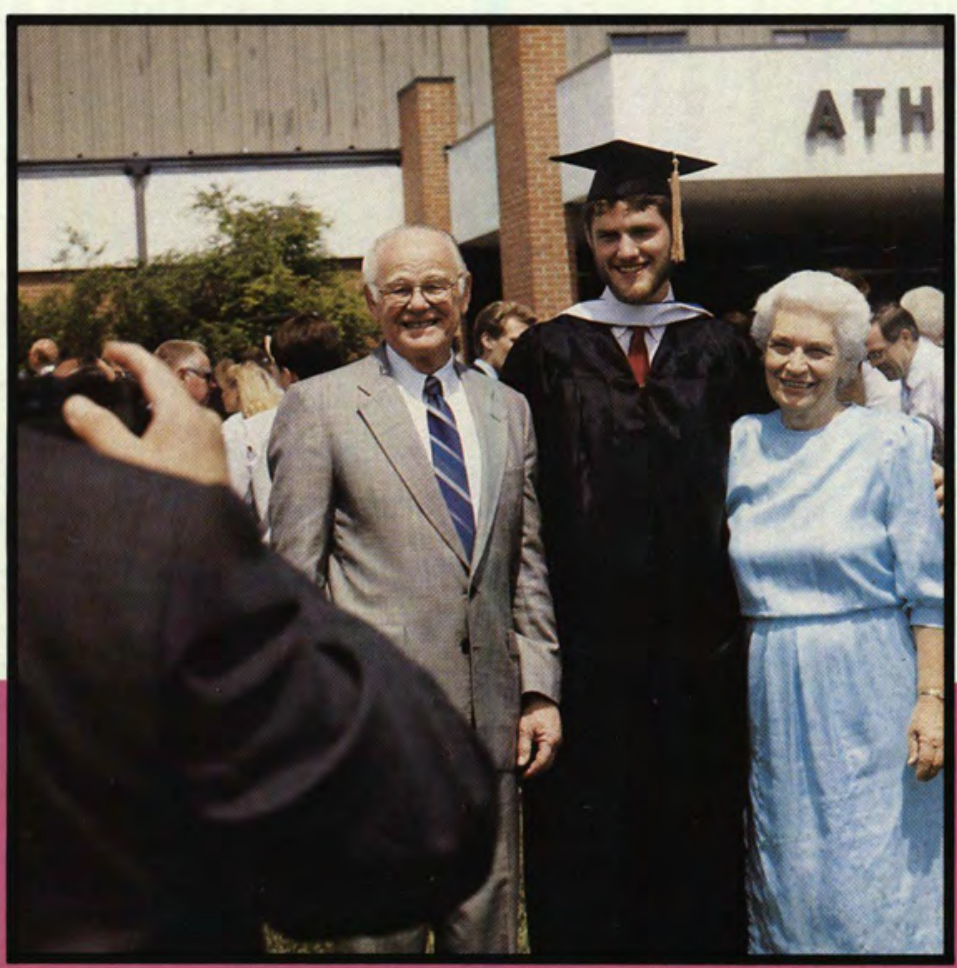

photo by Jesse Wesselink

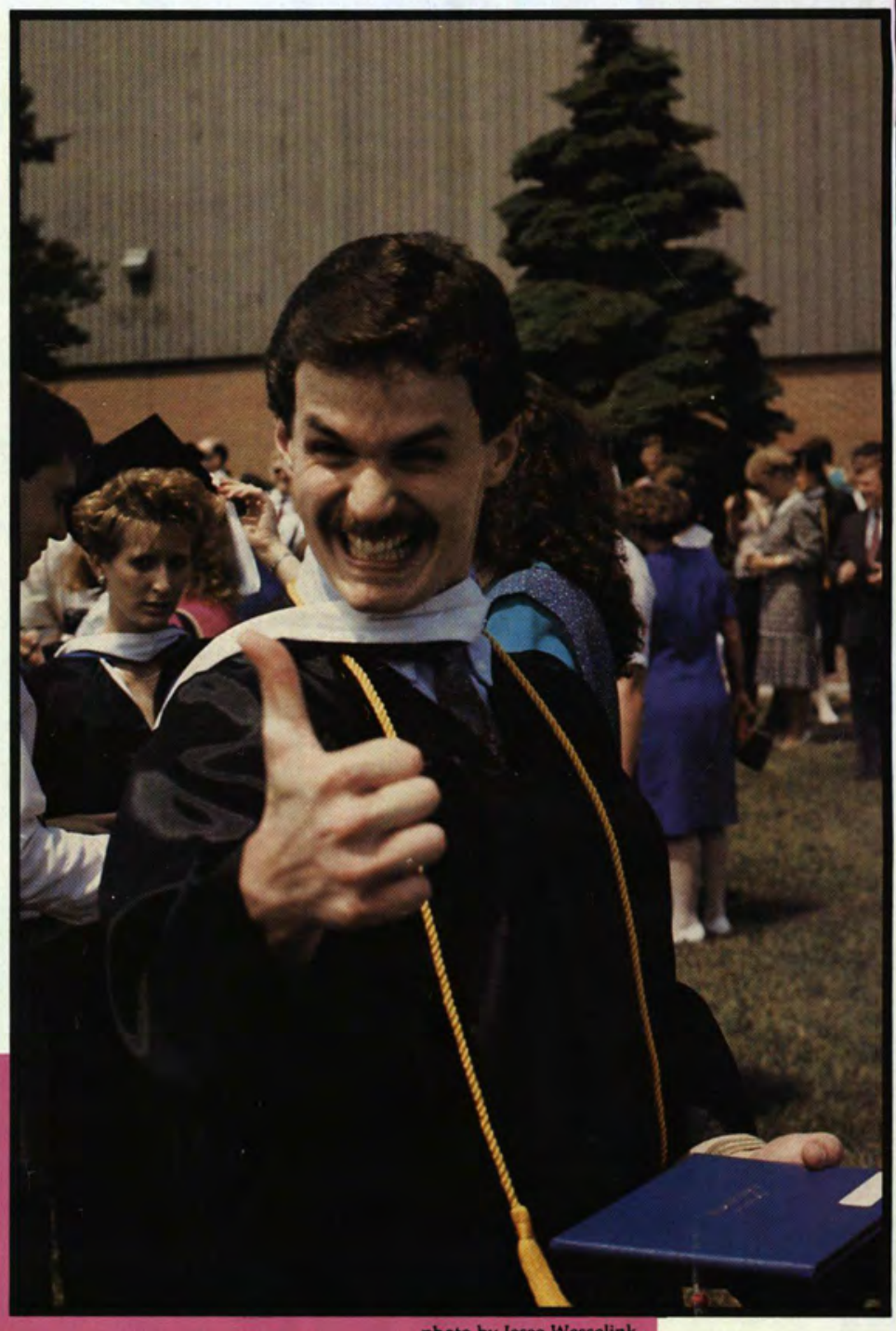

(2)

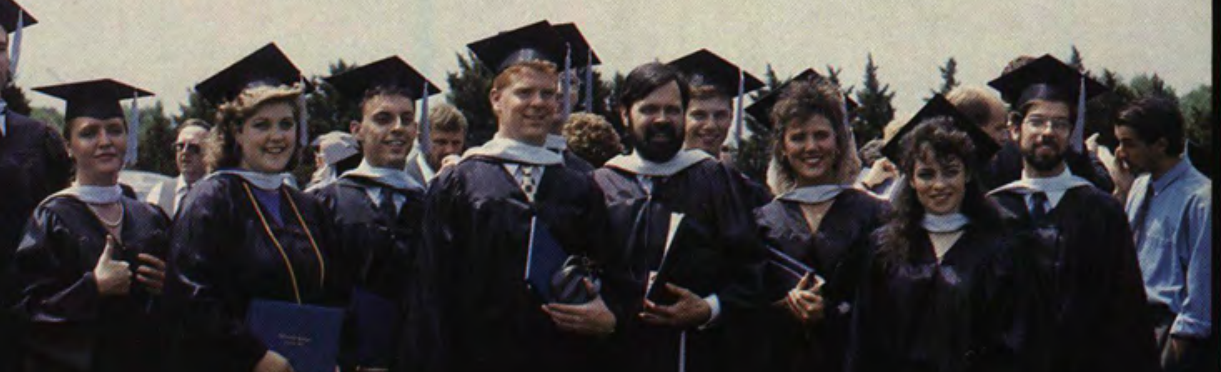

2.

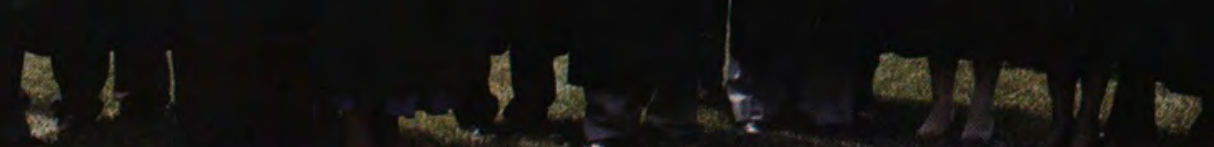

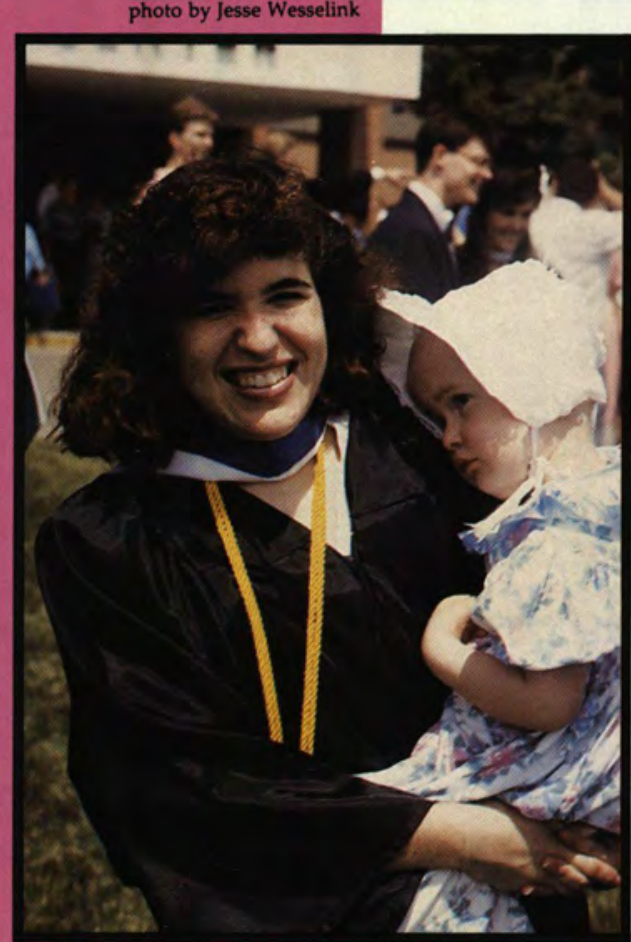

photo by Jesse Wesselink

Monica Bolet enjoys a moment with her baby sister after the graduation ceremony. 


\section{Potraits of a Miracle}

\section{Class of '91}
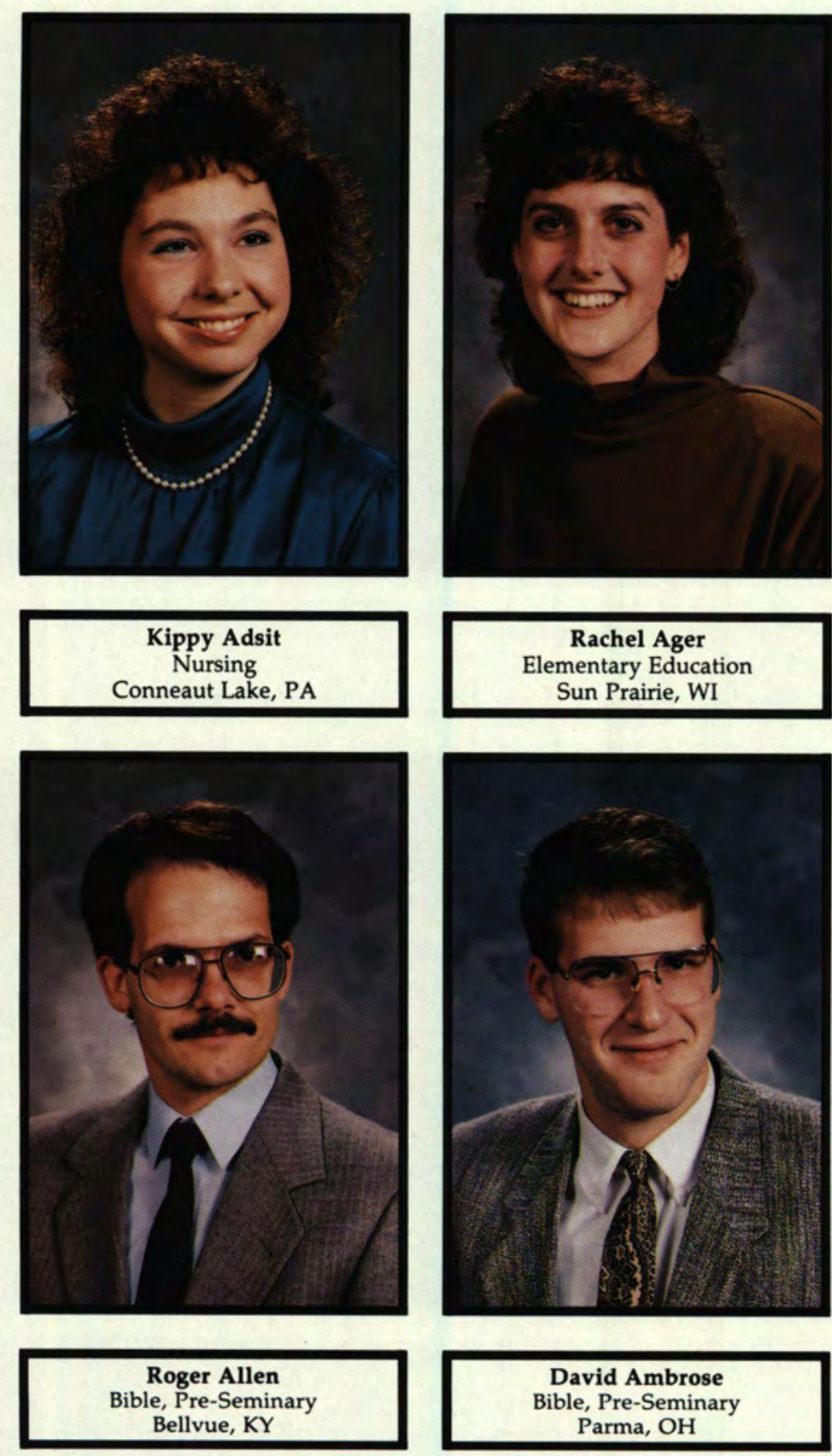
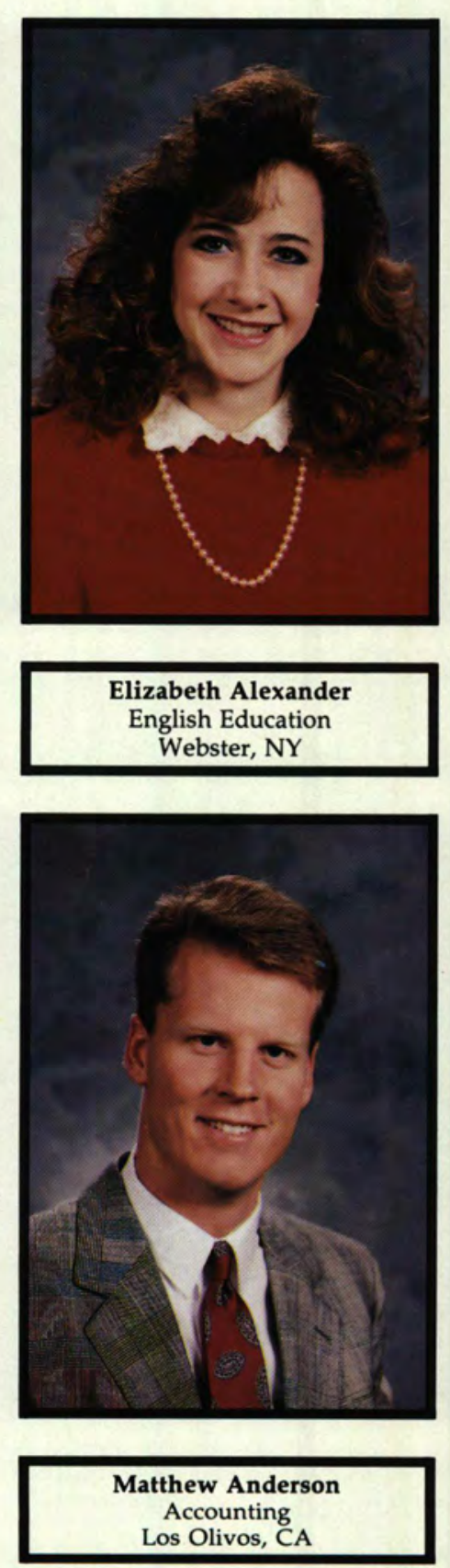

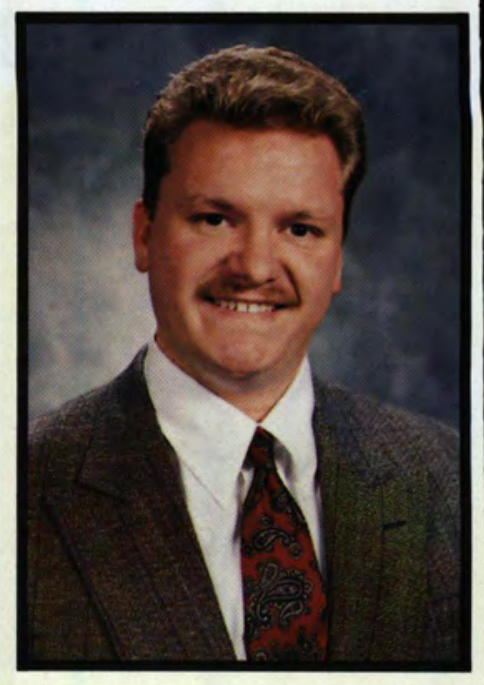

Eric Adnams

Bible Comprehensive Springfield, VT
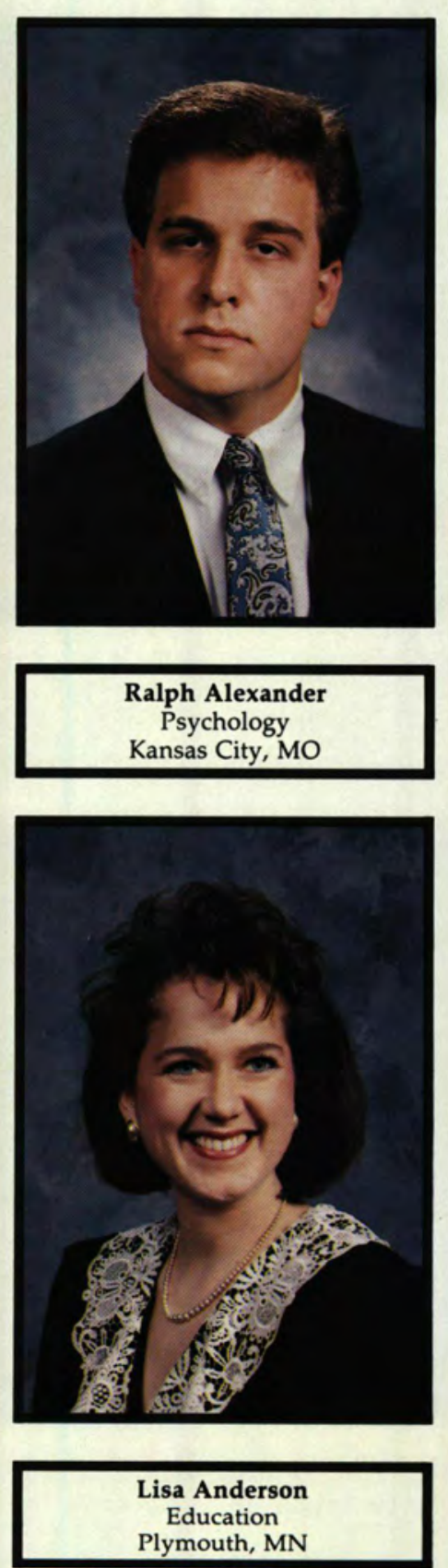

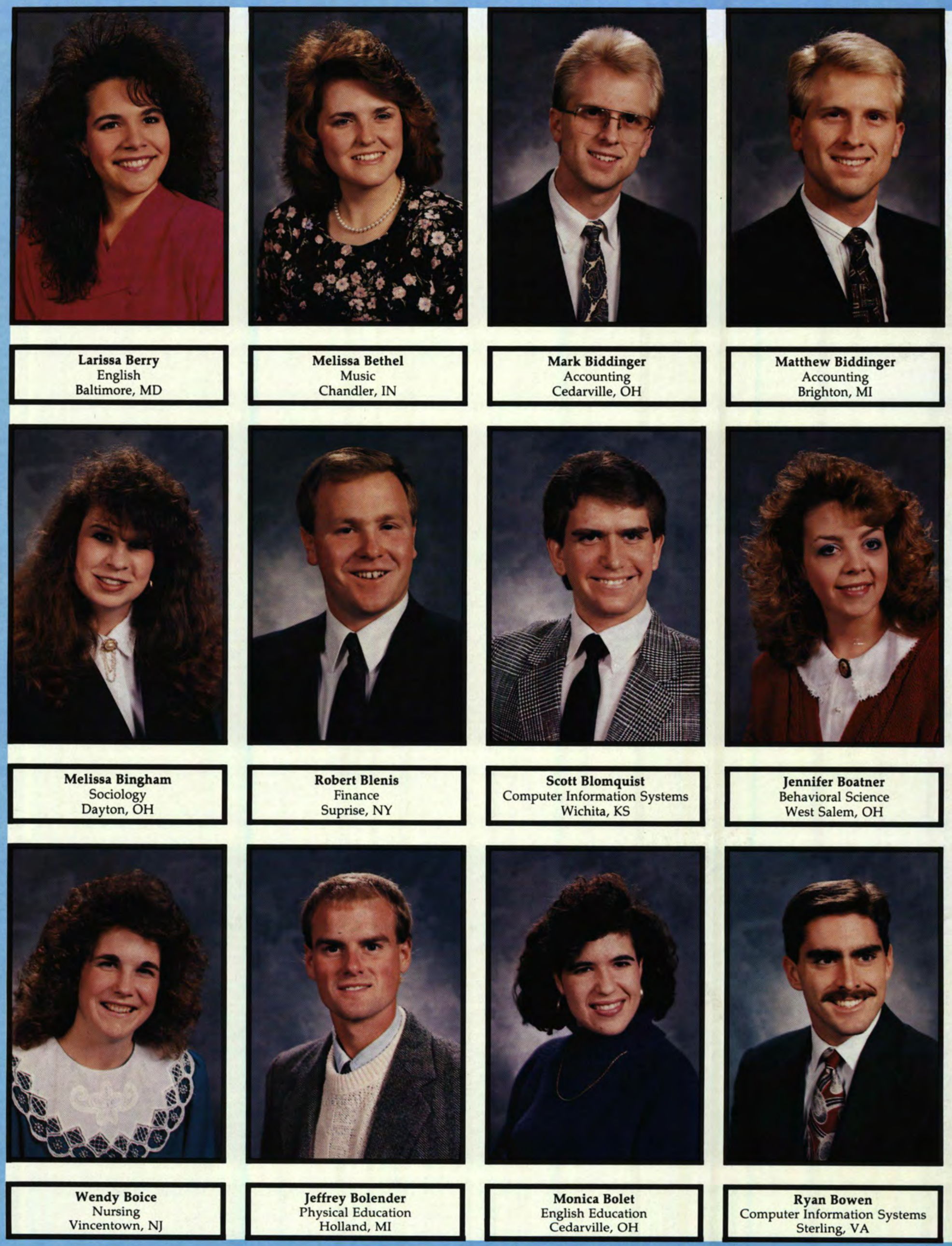

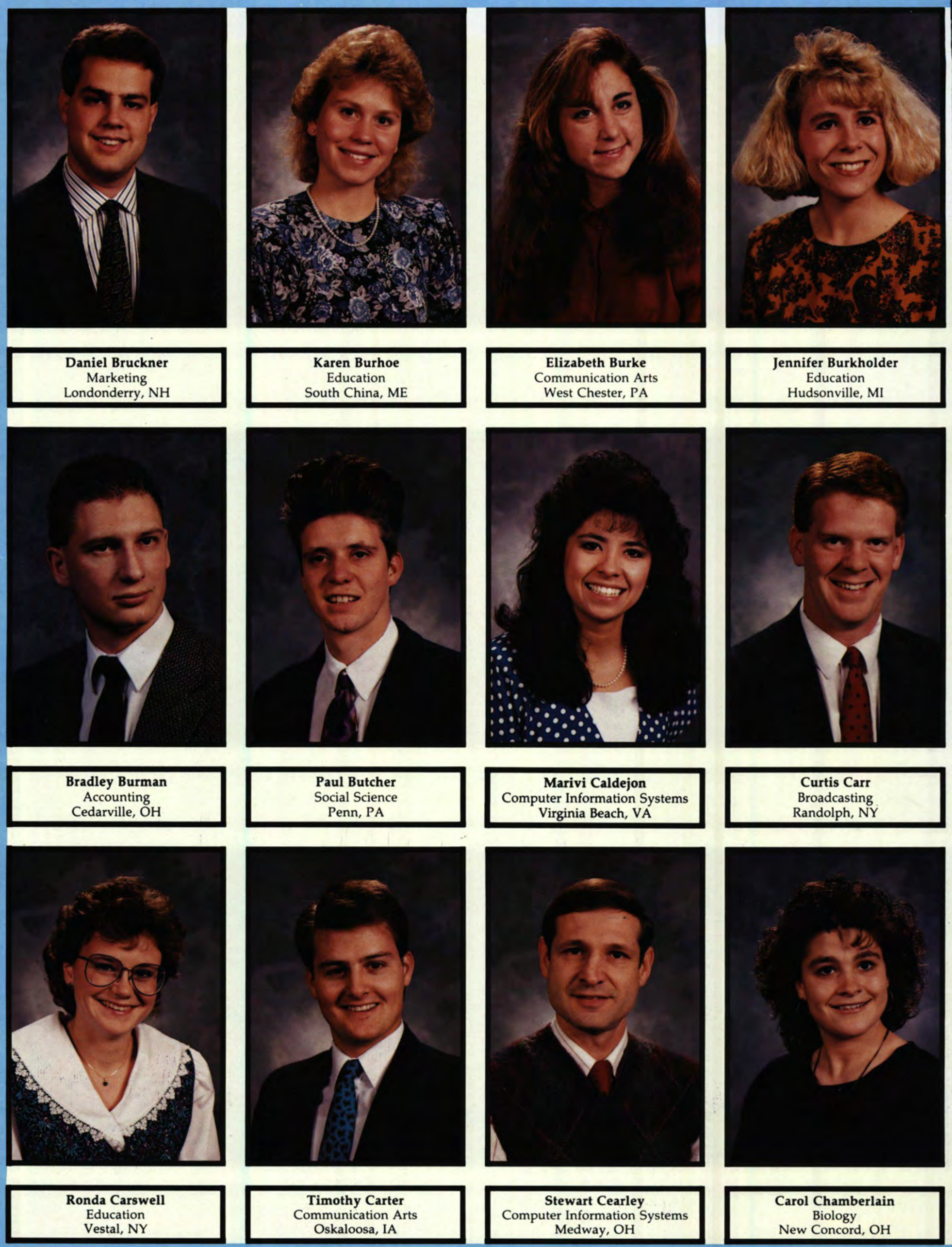

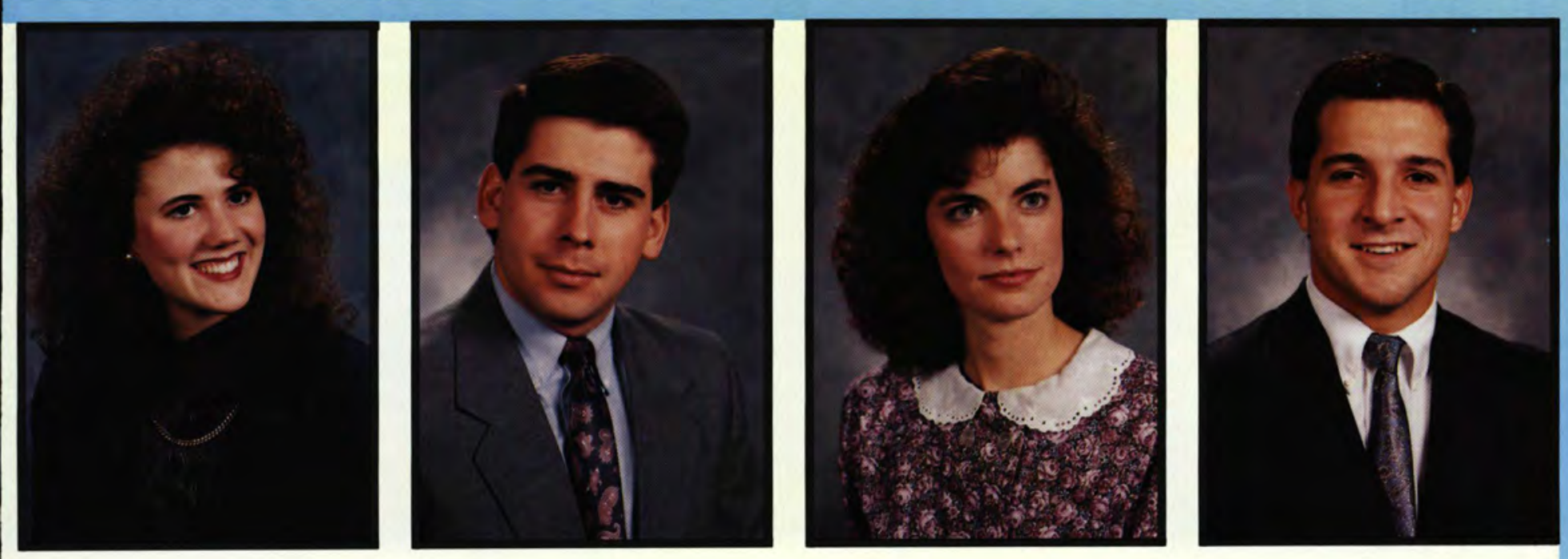

Deborah Christner

Broadcasting

Akron, $\mathrm{OH}$
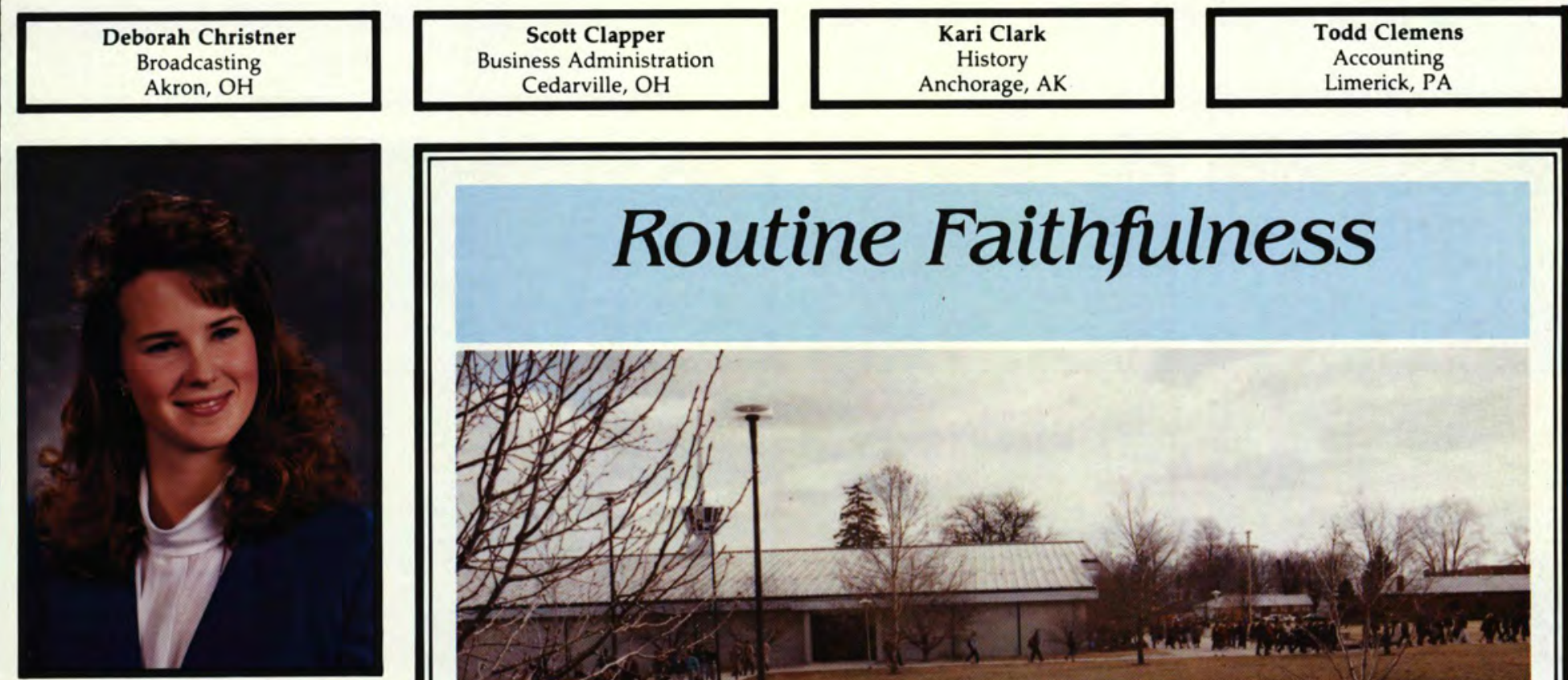

Cynthia Commons

Communication Arts

Cherry Hill, NJ

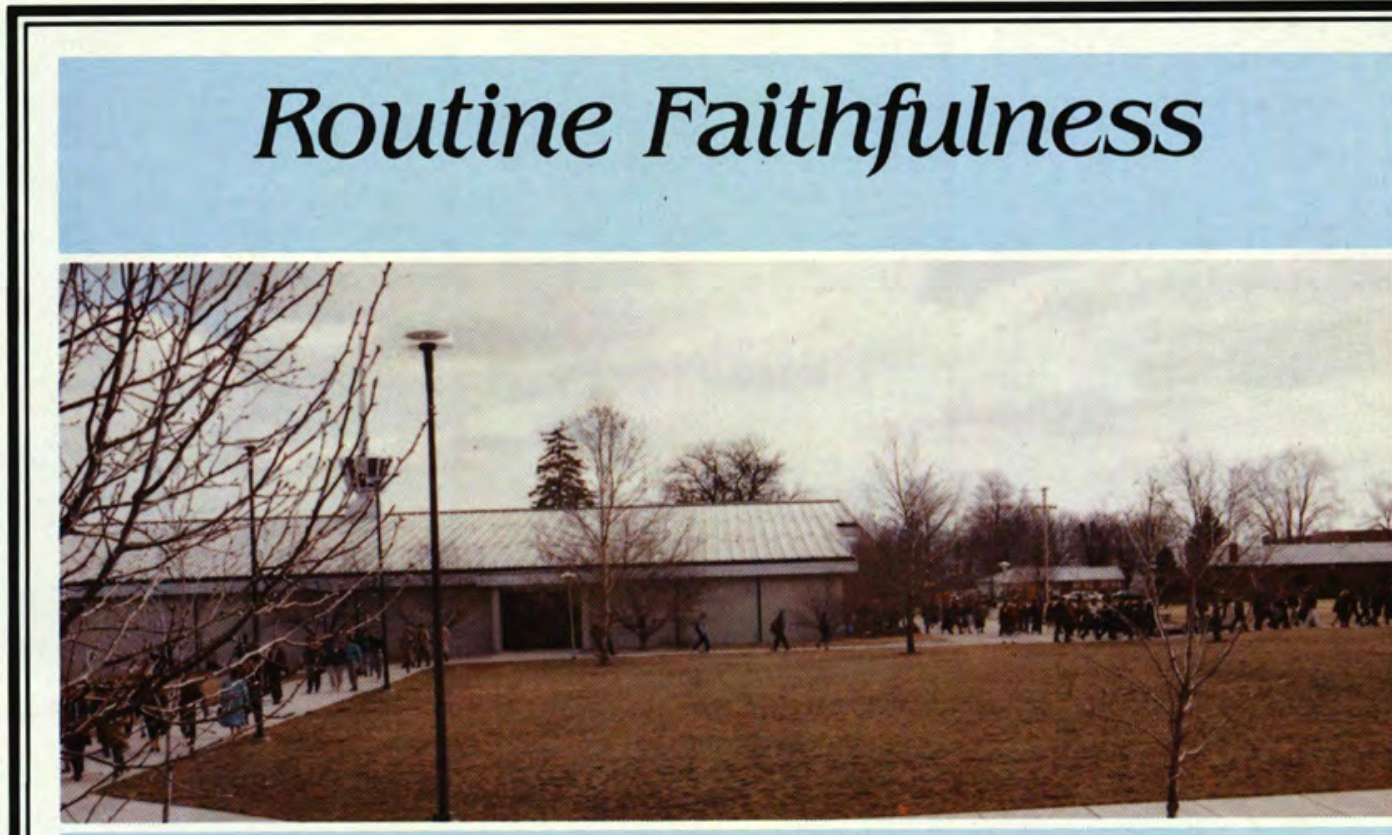

photo by Tania Taylor

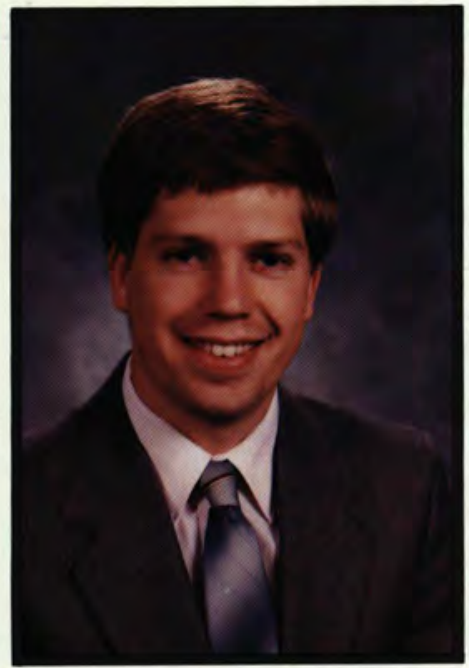

Andrew Cook

Chemistry

Belmont, NY

In the past four years at Cedarville, I've learned that one of the keys to living a godly life is routine faithfulness. It makes such a difference in my walk with God when I am consistently committing my life to Him, learning more about my Lord, and daily striving to please only God. However, the only way these things impact my life is if I am doing it daily whether I feel like it or not.

The balance Cedarville offers and the standards it holds have encouraged consistency in my life. For example, the standards I chose to follow while at Cedarville were primarily on an honor system. This in itself caused me to think through actions and decisions whether they would be consistent with what I am daily striving to achieve. I made the final decision be tween what is right and what is wise.

I am thankful for the challenges to my spiritual life Cedarville has given. However, God is ultimately the one who has stretched and taught me the importance of consistently trusting, committing, and living for Him. Without His hand on my life I am nothing. - Melanie Harty 

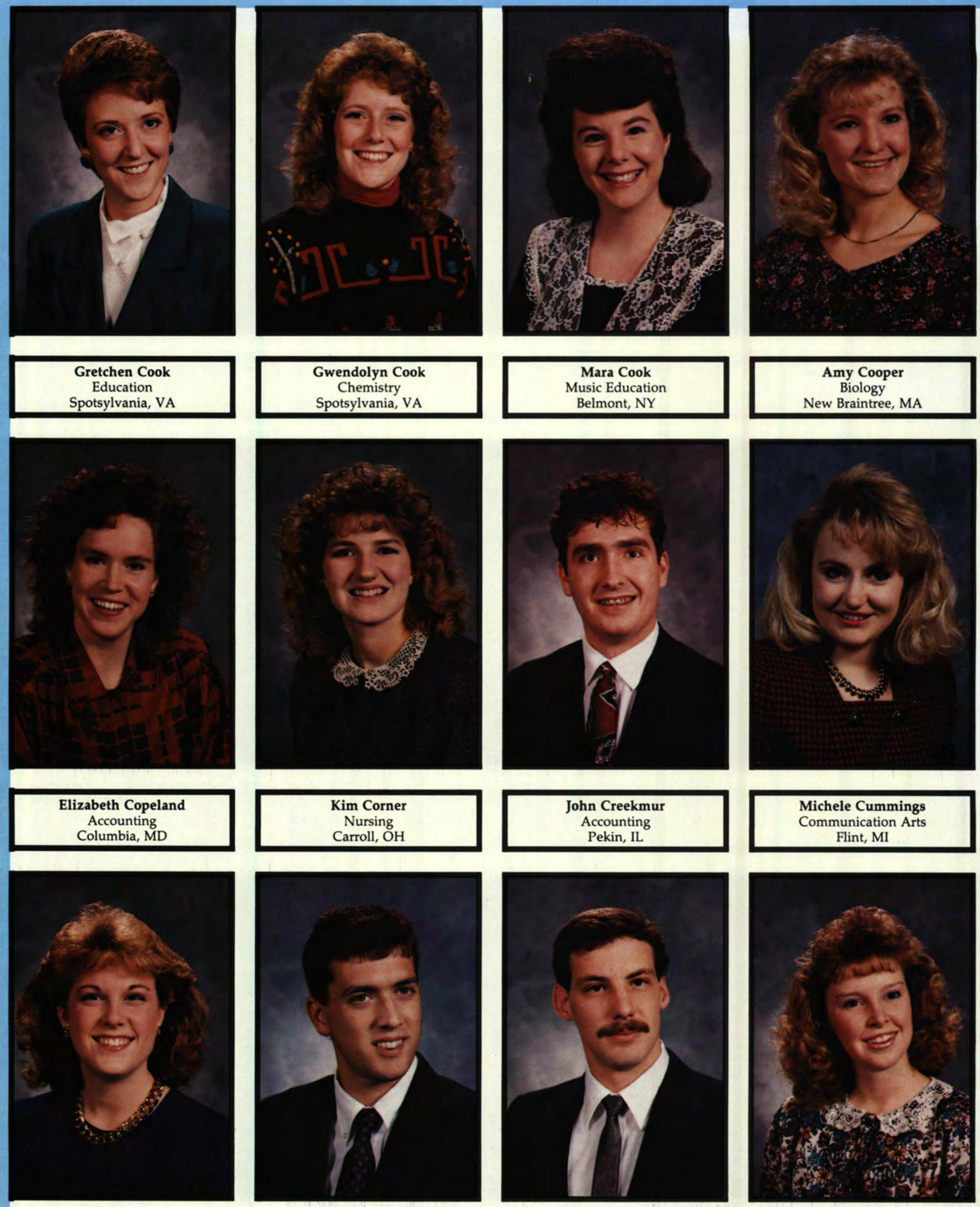

\section{Tricia Cummings Education Waynesville, $\mathrm{OH}$}

Gary Dankworth

Computer Information Systems Troy, $\mathrm{OH}$

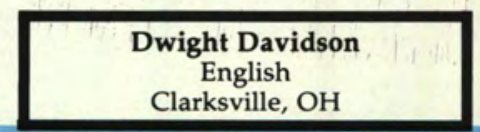

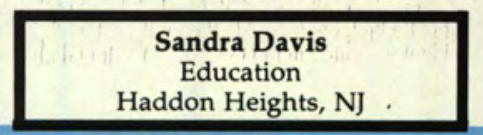



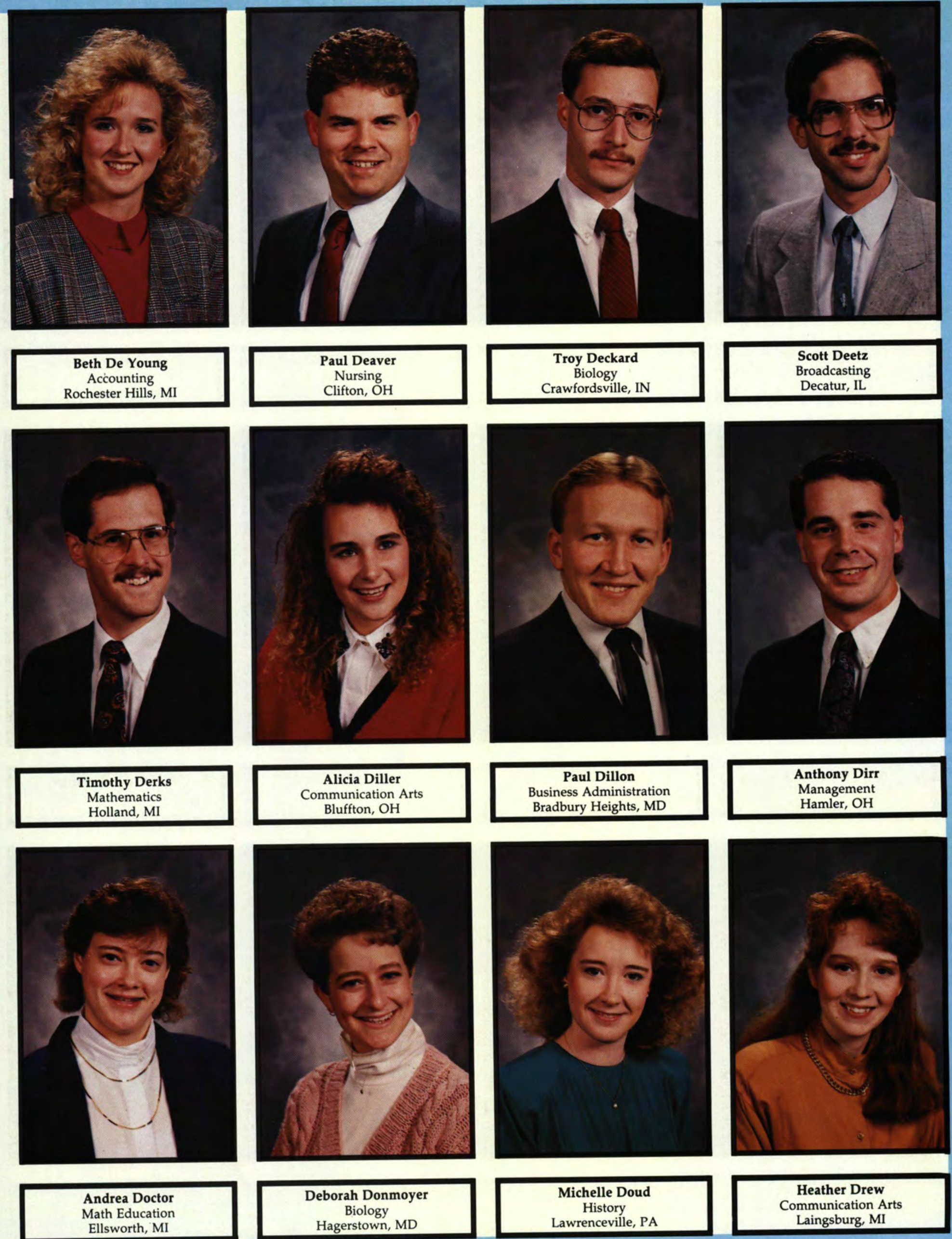

Math Education

Ellsworth, MI

Biology
Hagerstown, MD

Lawrenceville, PA

Laingsburg, MI 

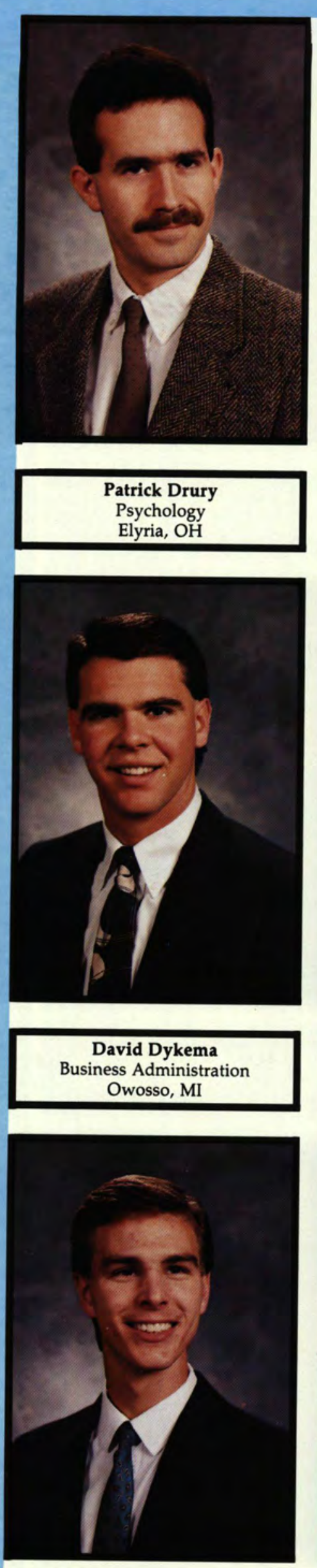

Timothy Erlandson Bible, Pre-Seminary Lombard, IL
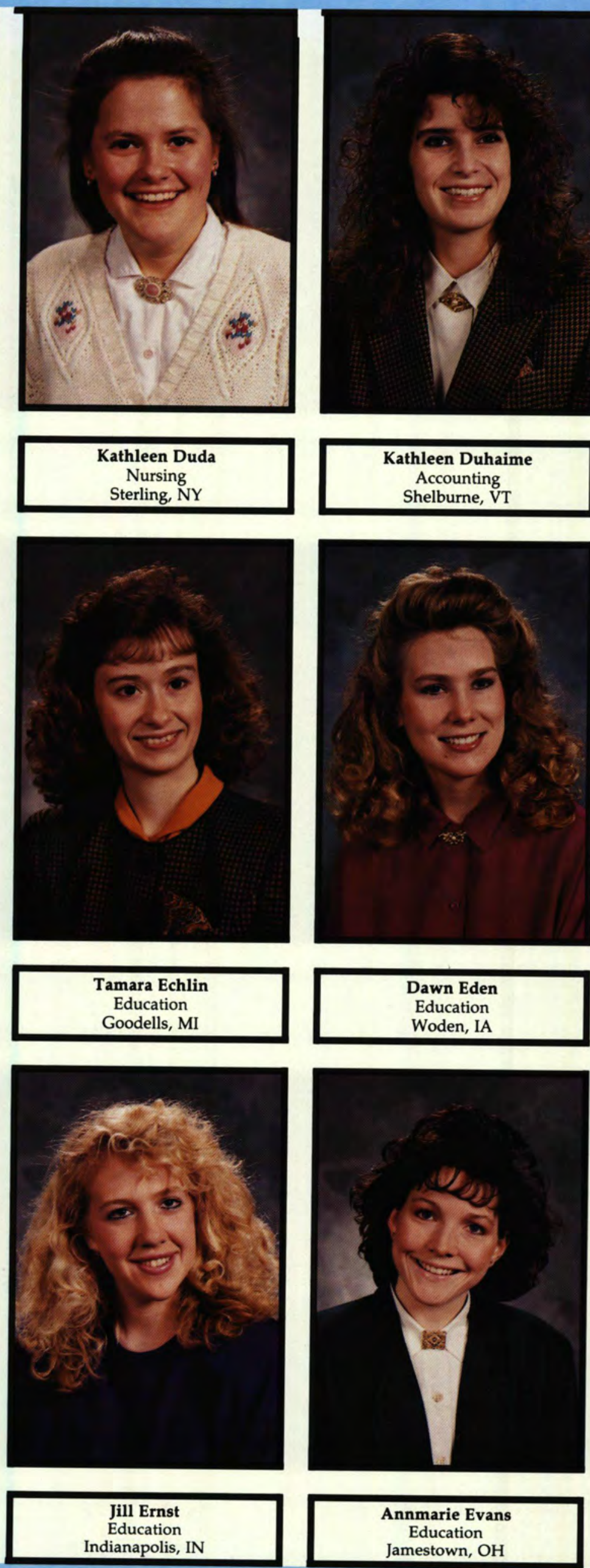
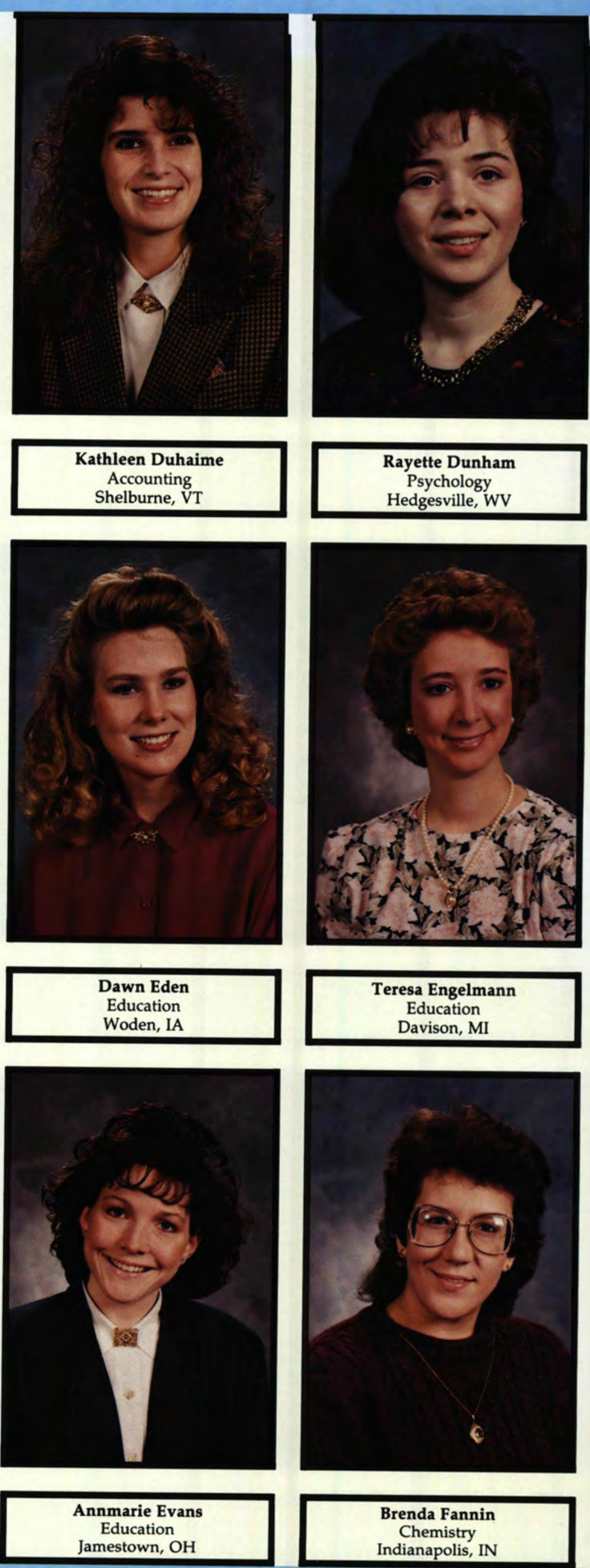


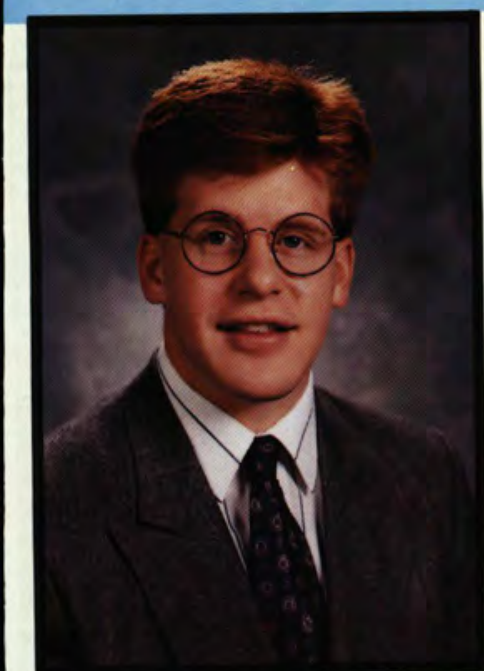

David Fath

Political Science

Annville, PA
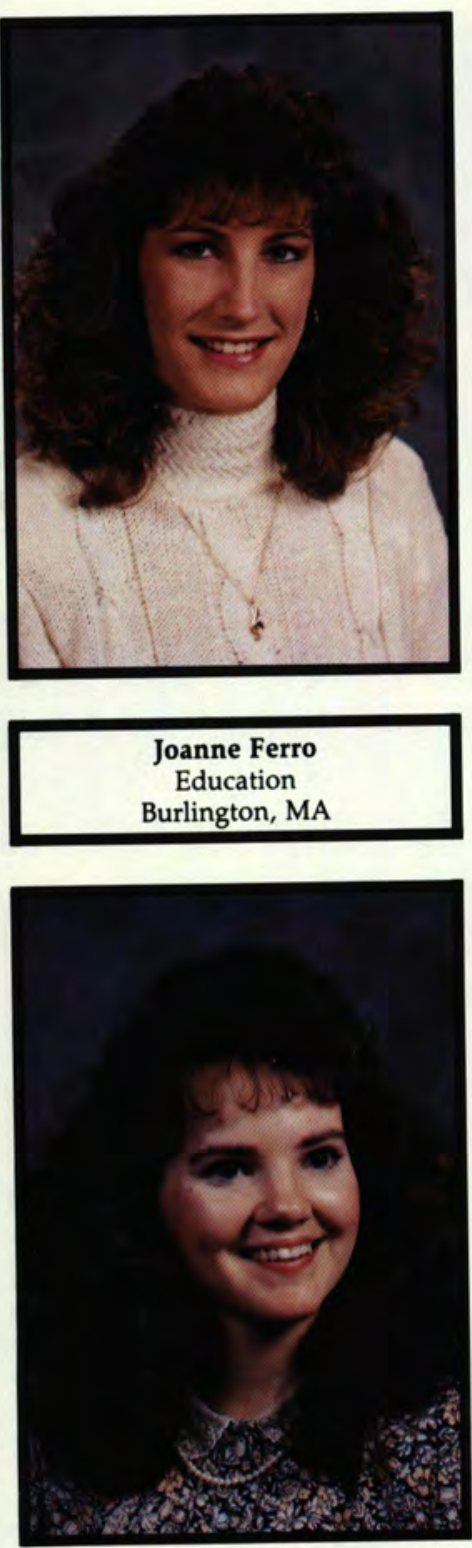

Rhonda Fox

Education

Logan, $\mathrm{OH}$
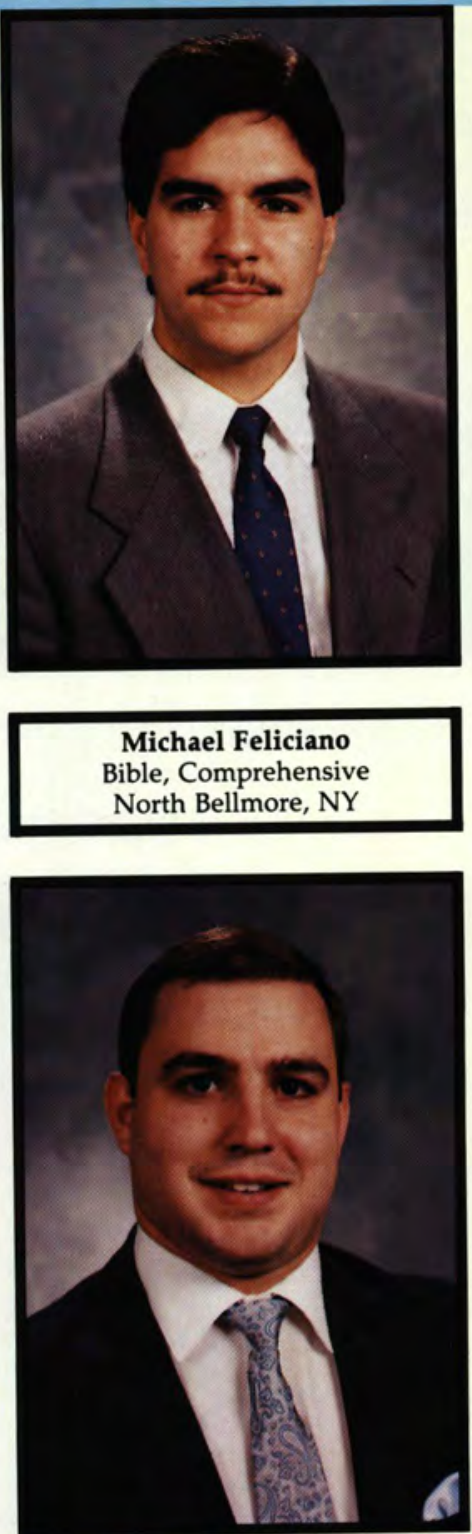

Stephen Fields Bible, Comprehensive Cedarville, $\mathrm{OH}$

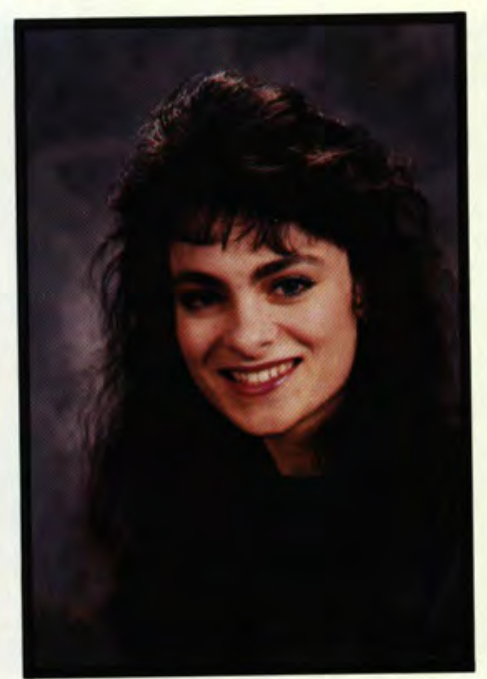

Cynthia Frenkiel

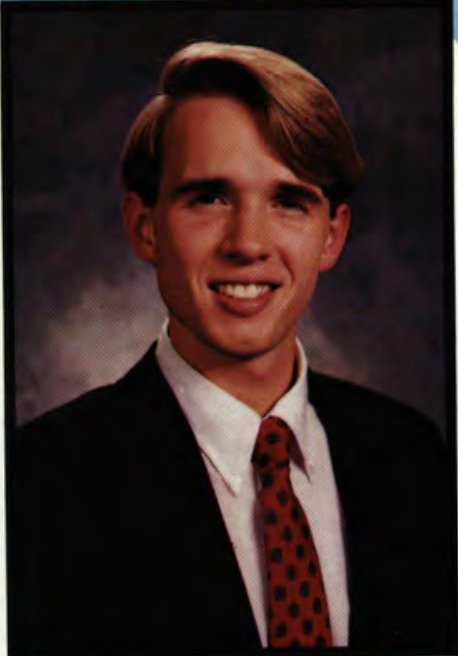

Timothy Felt Political Science

Augusta, ME
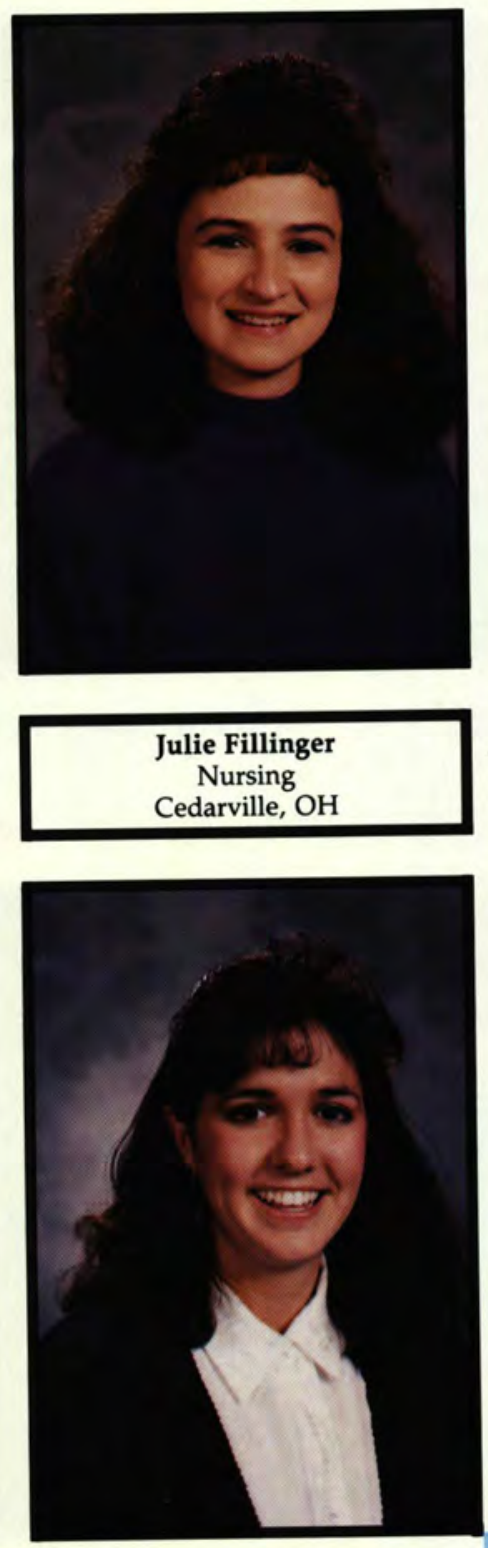

Carolyn Frisbie

Accounting

East Straudsburg, PA

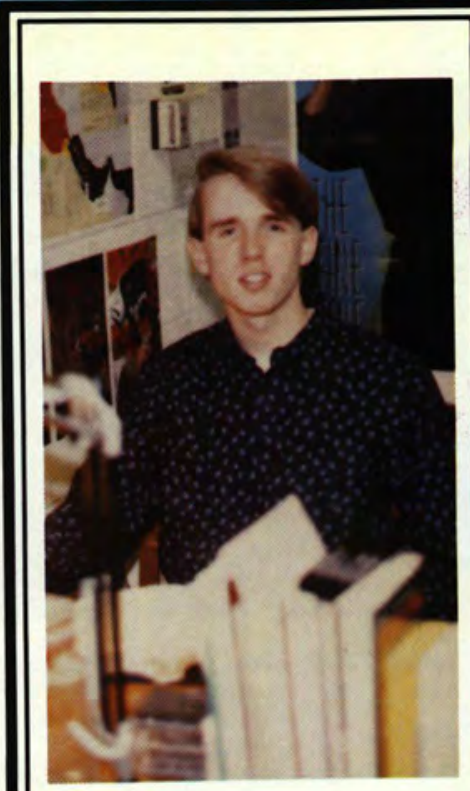

photo by Andrew Jamieson Tim Felt pauses from his studies to pose for a shot.

\section{Historical Foundation}

History is one of the fields which can be best integrated with biblical Christianity. In fact, my faith in Christ and the Bible has been strengthened through my study of the past. The plan of God for man can be clearly seen throughout the annals of history. In biblical prophecy, the coming of Christ is foretold. Since Christ, we can see through the progression of time the repeated failures of mankind and look forward to the ultimate prophecy of the end times. History helps us understand where we have been, who we are, and perhaps where we are going. I believe that the study of history will provide a solid foundation for any career which I choose to pursue. - Tim Felt, Political Science 

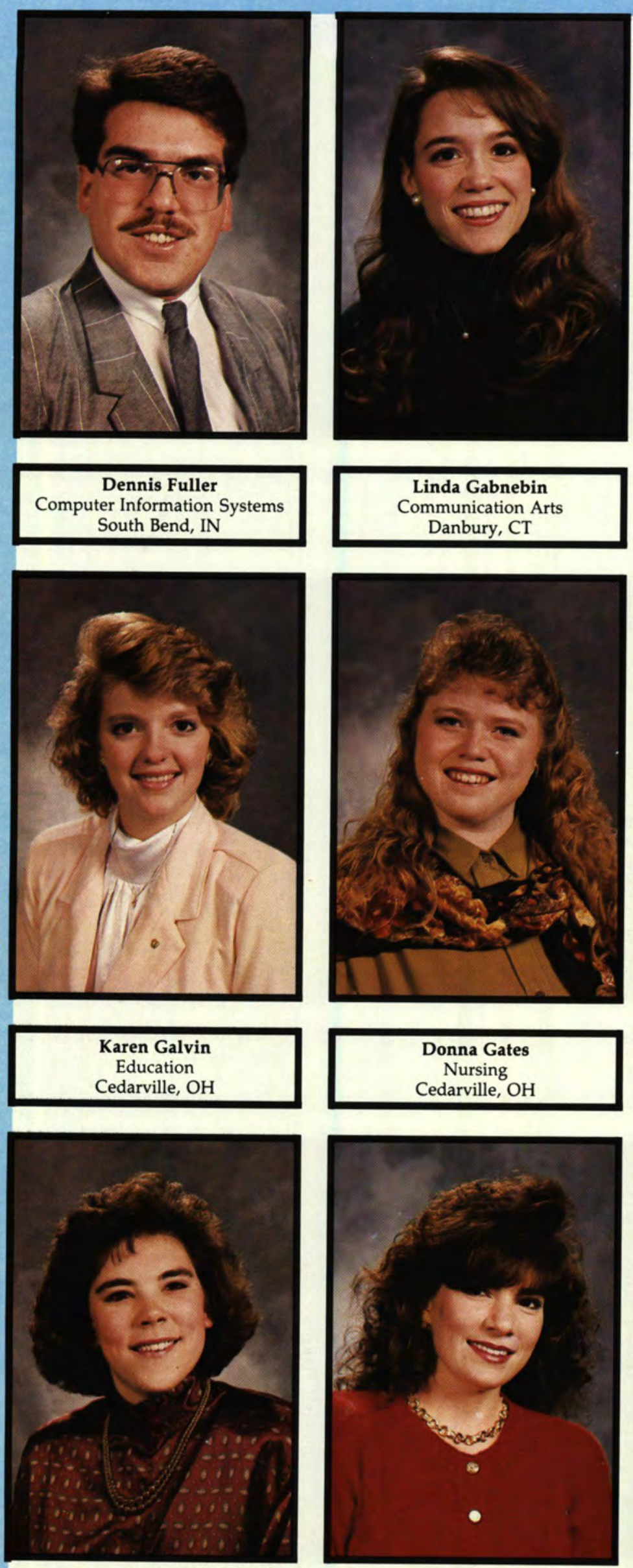

Heidi Gerber

Criminal Justice

Winona Lake, IN

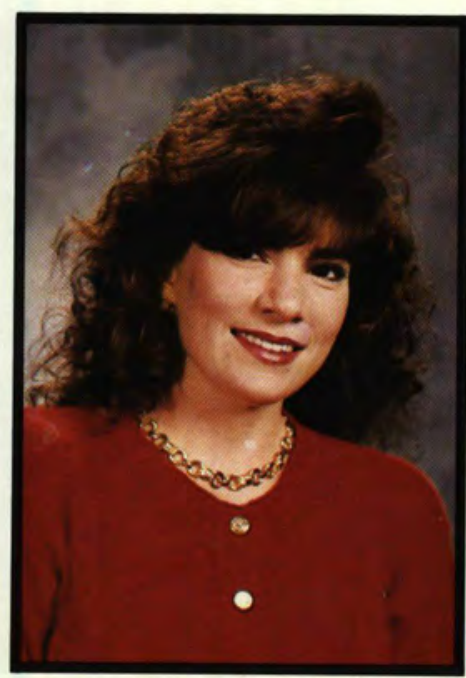

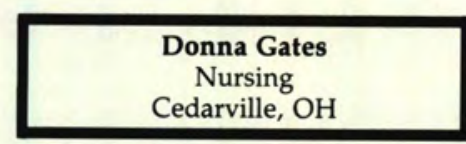
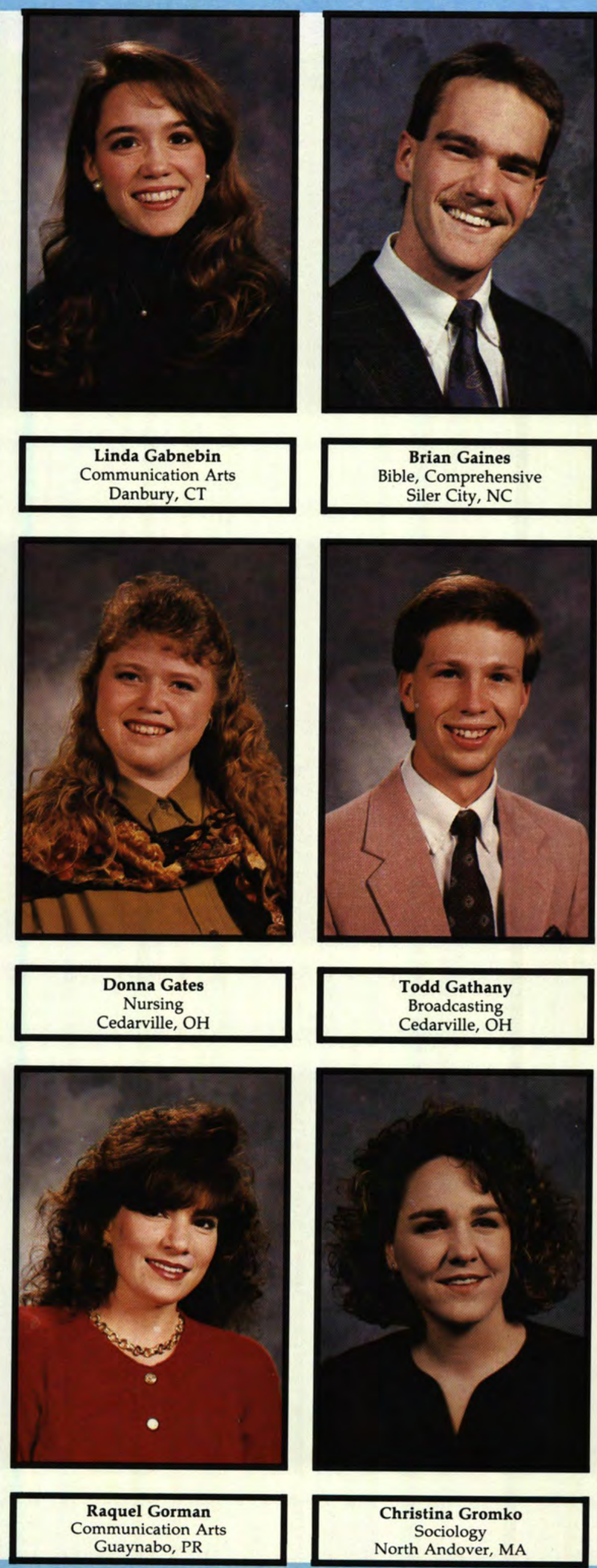
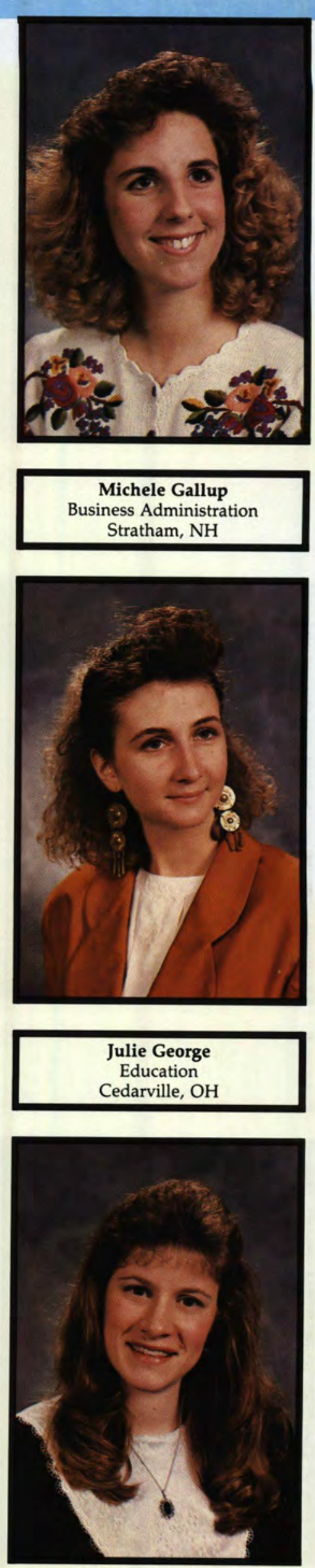

Annora Gross

Education

Midland, $\mathrm{OH}$ 


\section{Senior Panic}

The senior year of college is known for many things. Two words that sum up what the majority of college seniors feel are "Senior Panic."

"Senior Panic" is not the feeling you get when it is the day before graduation and the senior project is not complete. Nor is "Senior Panic" what is felt when the only post-graduation job applied for (you know, the one that offers a company car and a $\$ 40,000$ a year starting salary) falls through and it looks like you will be the only fry station worker with a college degree. "Senior Panic" is the feeling seniors get when they finally realize that they SHOULD have asked out that girl/guy who has been flirting with them since Getting Started.

There are three different stages of senior panic that coincide with the average school year. Here at Cedarville there are three quarters during which the panic progresses.

First, the Fall Frenzy hits. This is the first quarter of the senior year when they realize that they only have one year to find "The Chosen One." Thus begins the mild dating spurt which declines when the senior realizes that he/she has two quarters left.

The second stage, the Winter Wife Watch (so named because here at Cedarville the man is generally the one who does the asking), takes effect. A general dating effort begins again. This dating picks up its pace during T.W.I.R.P. week when the woman takes the initiative - this really gets things moving. The male population finally realizes what it has been missing, and it really is normal for college students to date.

The final phase is the most chaotic. The Spring Search brings with it the resounding chant "Lake, Lake, Lake, ..." and many sparkling diamonds. These two cause much jealousy and thus much more dating which culminates in the Junior/Senior Banquet when many "lucky" ones seal their fate forever.

Marriage is often seen as a dreaded subject for those in college. These are supposed to be our fun years, they say; why wreck that with dating? As the seniors move on to the next phase of their lives, there are those who have resolved their "Senior Panic," and head down the aisle. The rest have entered the world with a bumper sticker on their car reading "Single and Love It!"

- Amy Edwards
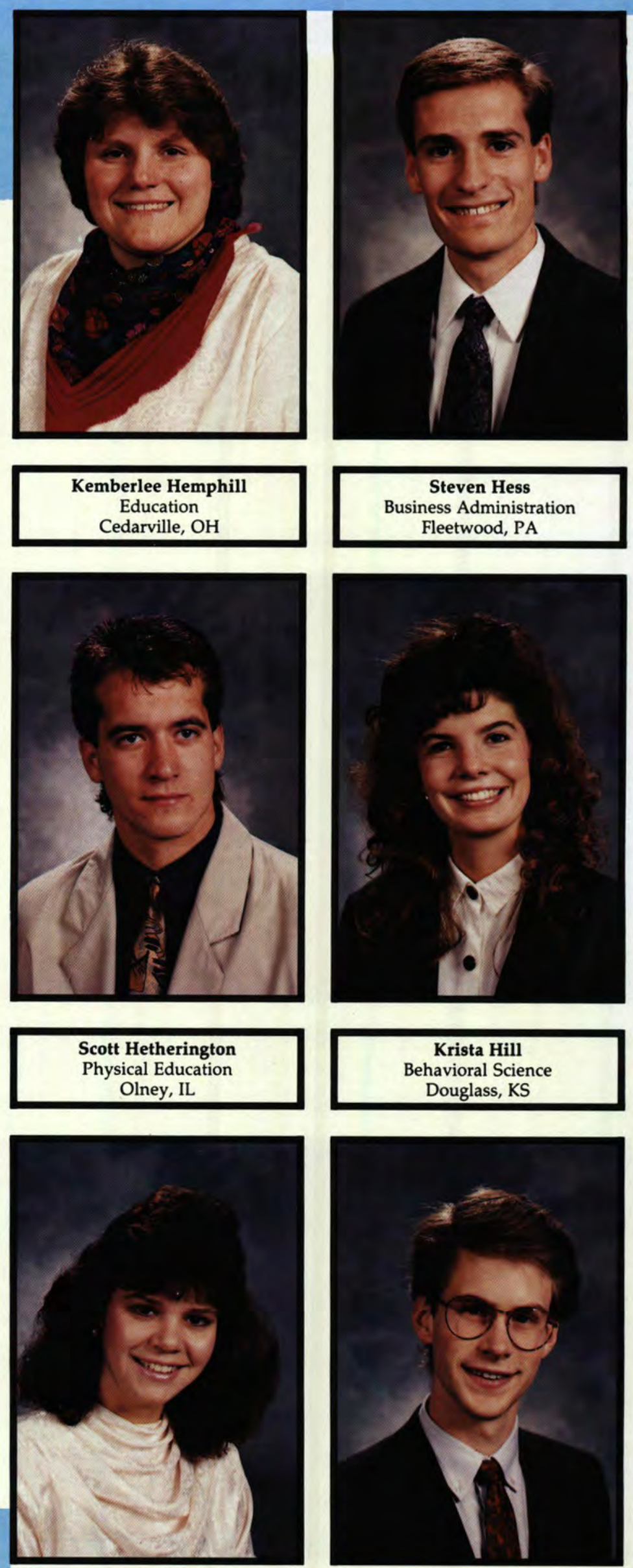

Paula Hines Business Administration Polk, $\mathrm{OH}$
David Hinnergardt Mathematics Newton, CT 

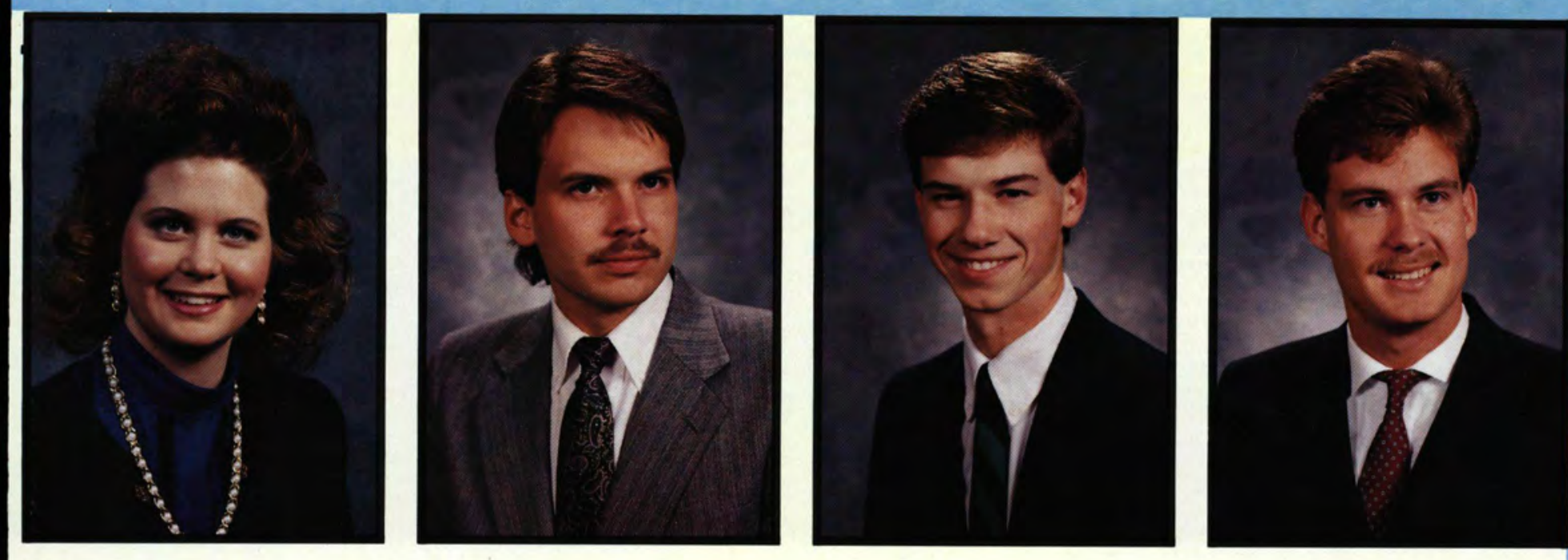

Melody Holbrook

Communication Arts Amherst, $\mathrm{OH}$
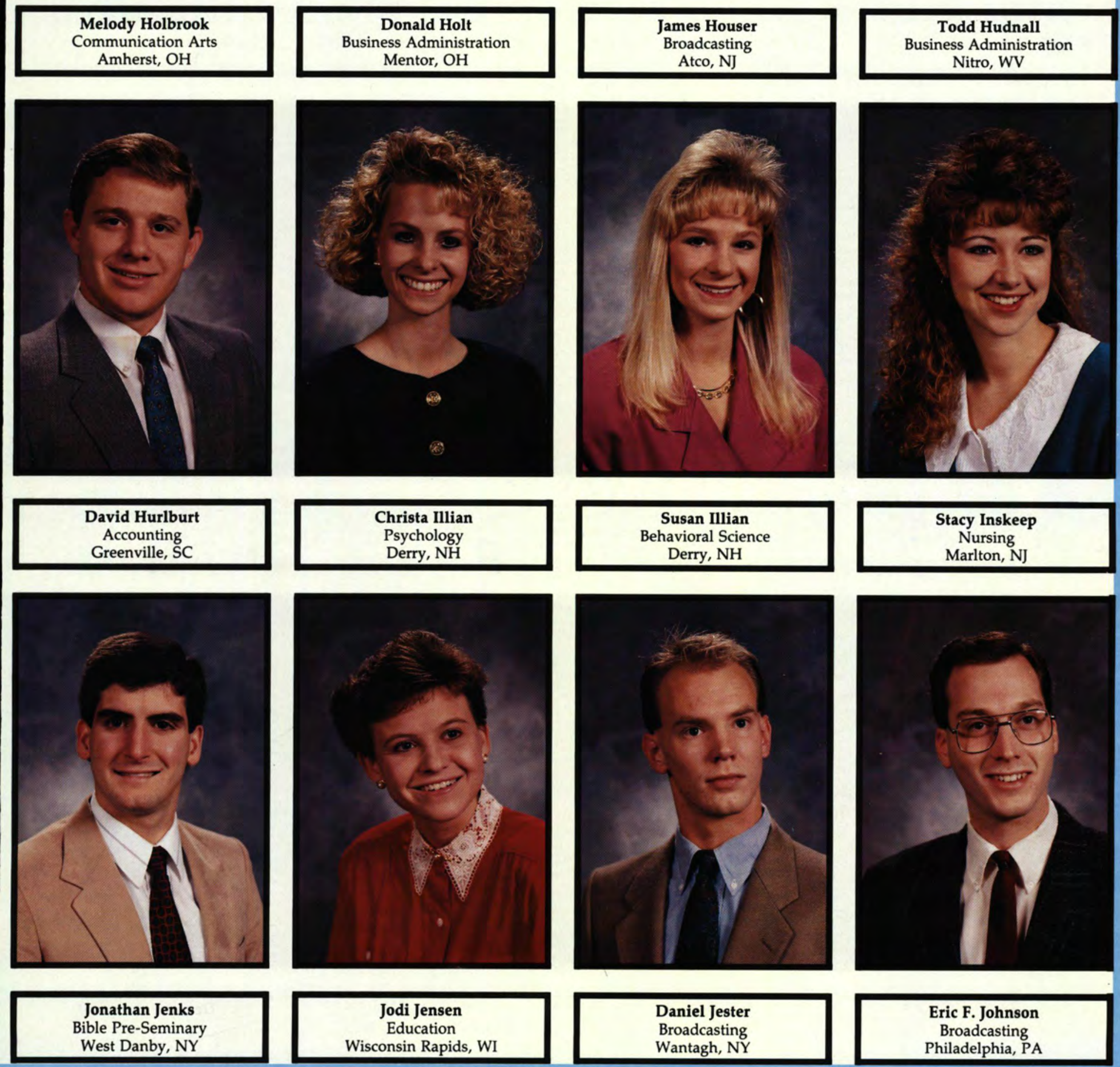

Bible Pre-Seminary

West Danby, NY
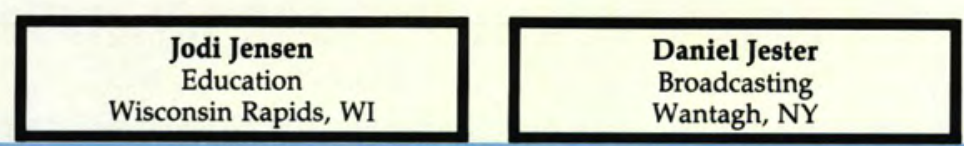

Broadcasting
Philadelphia, PA 

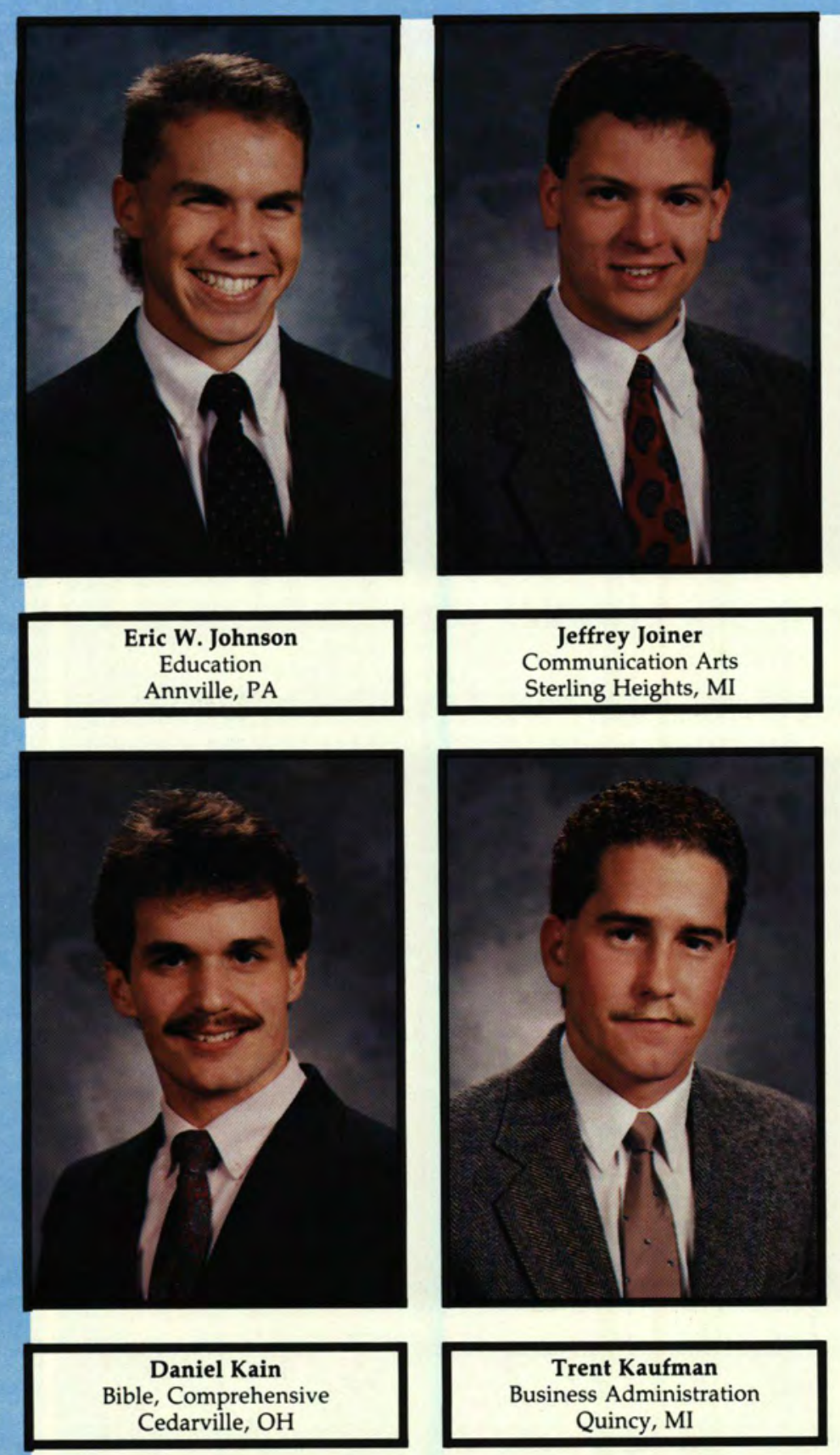

\section{Rochelle Kennedy \\ Accounting}

Grand Rapids, MI
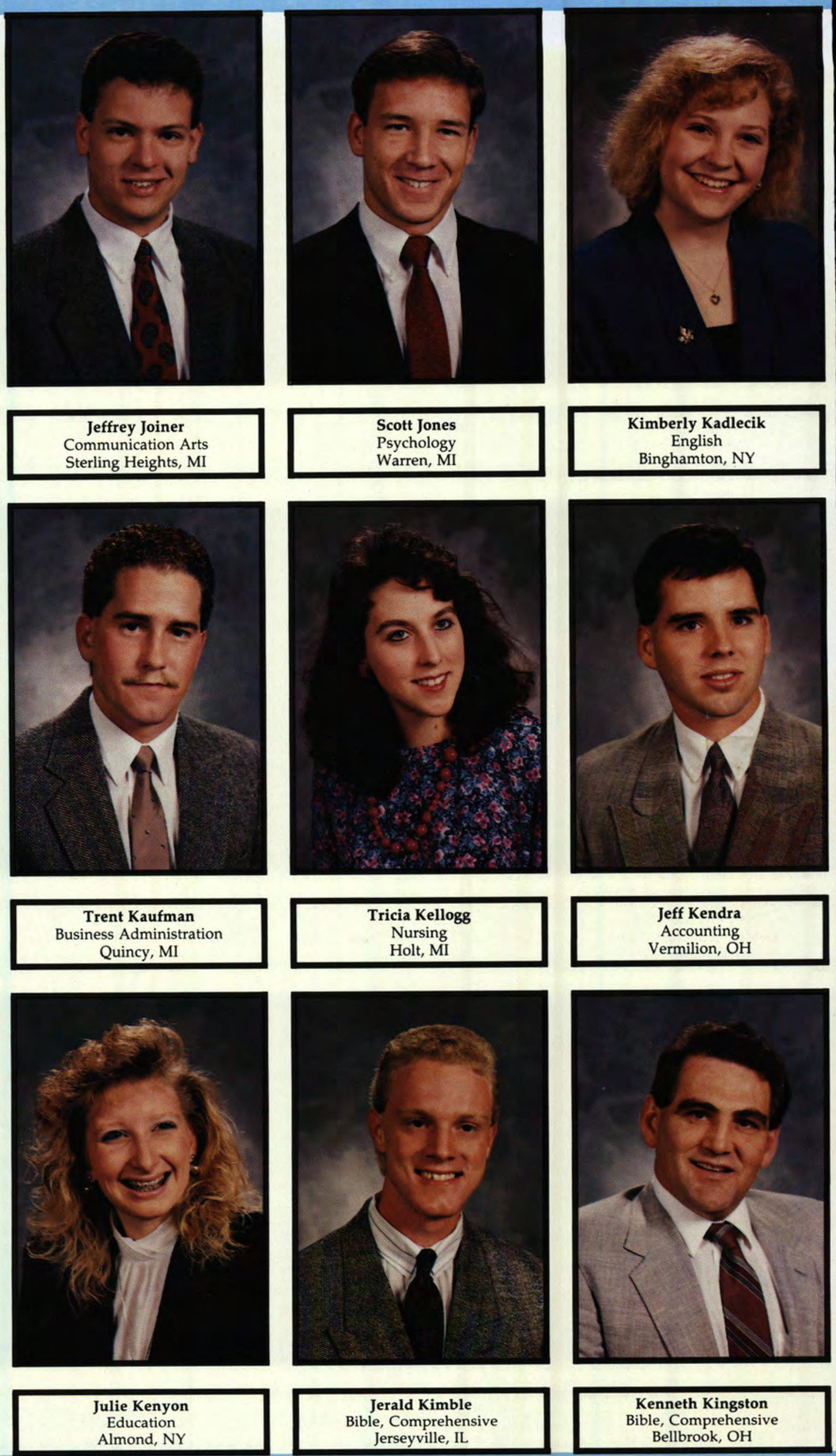

Kenneth Kingston Bellbrook, $\mathrm{OH}$ Bible, Comprehensive 

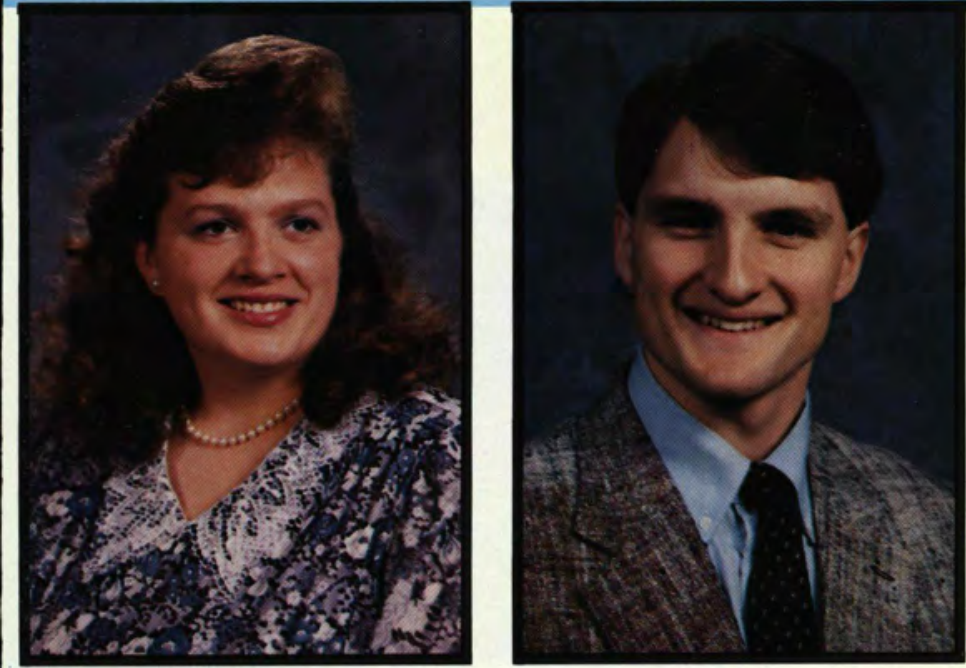

Beth Kinne

Mathematics

Panama, NY

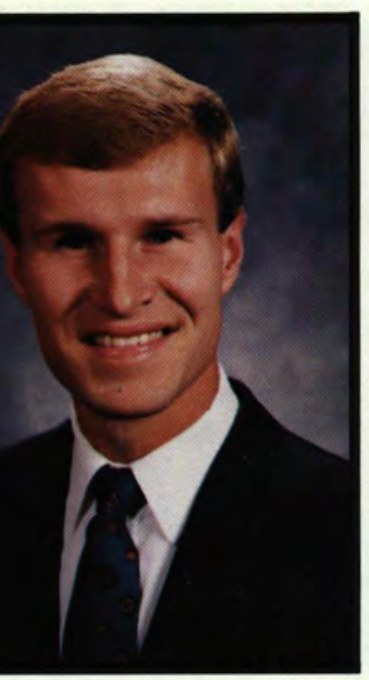

David Kohlmeyer

Business Administration Wheaton, IL
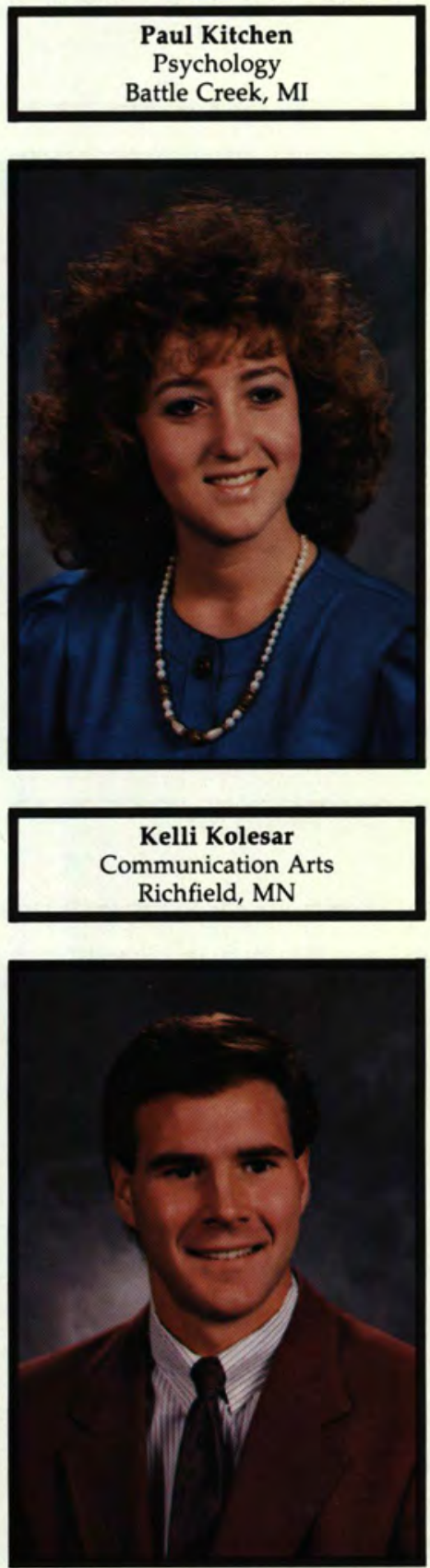

Julie Kurtz

Social Science

Connellsville, PA
Brian Lancenese

Biology

Quakertown, PA
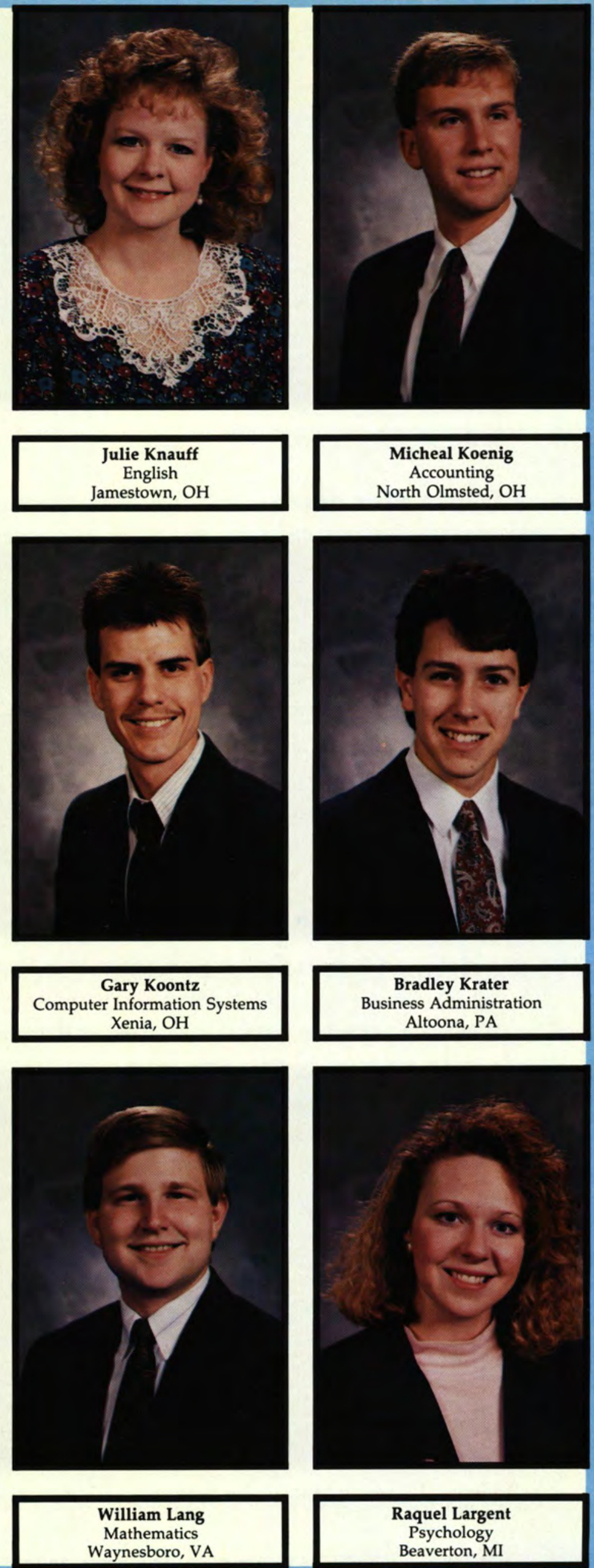

Altoona, PA

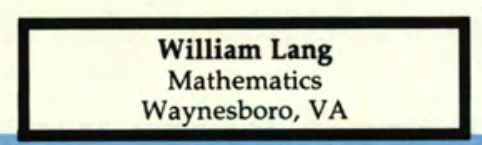

Beaverton, MI 


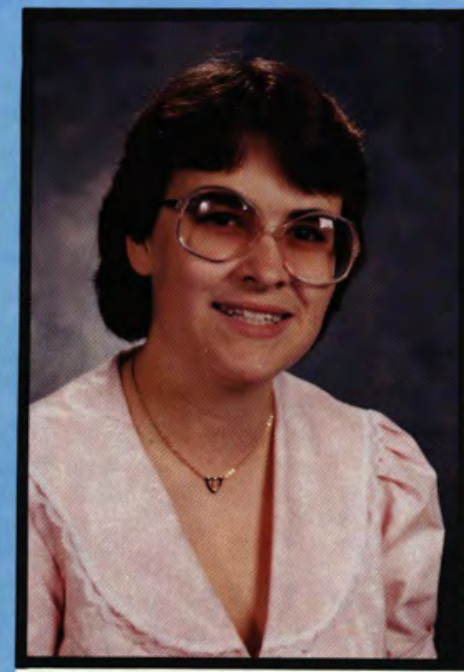

Sheri Larkin

Music Education

Jackson, MI
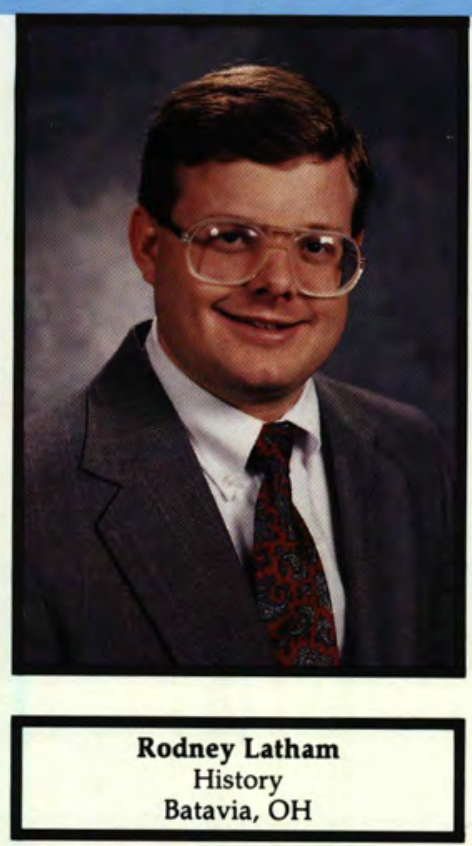

Batavia, $\mathrm{OH}$

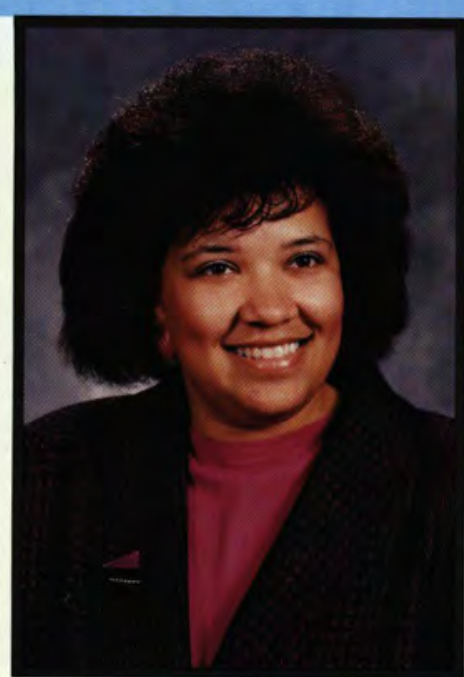

Janet Lawrence

Business Administration Cedarville, $\mathrm{OH}$

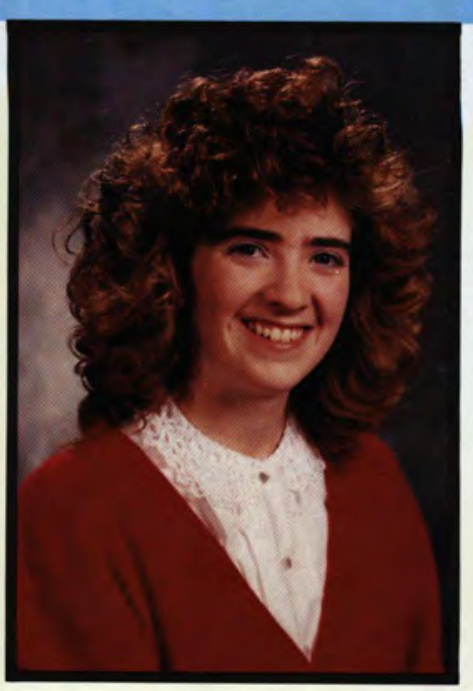

\section{The Family of Cedarville}

When a person from Cedarville mentions the family atmosphere of his or her college to people who aren't familiar with Cedarville, they may laugh. Bolet mentioned that during her freshman year, she thought: "How could college have a family atmosphere?"' But, throughout her four years she realized that Cedarville is more than just a college. Bolet said she came to appreciate the college family when her younger sister was diagnosed with leukemia. She said, "The college family really rallied around me at a time when I really needed support." The Cedarville family has become realistic to this senior who plans to graduate and teach high school English. To people outside Cedarville who haven't experienced the family atmosphere, they are missing a great experience.

- Carrie Mann
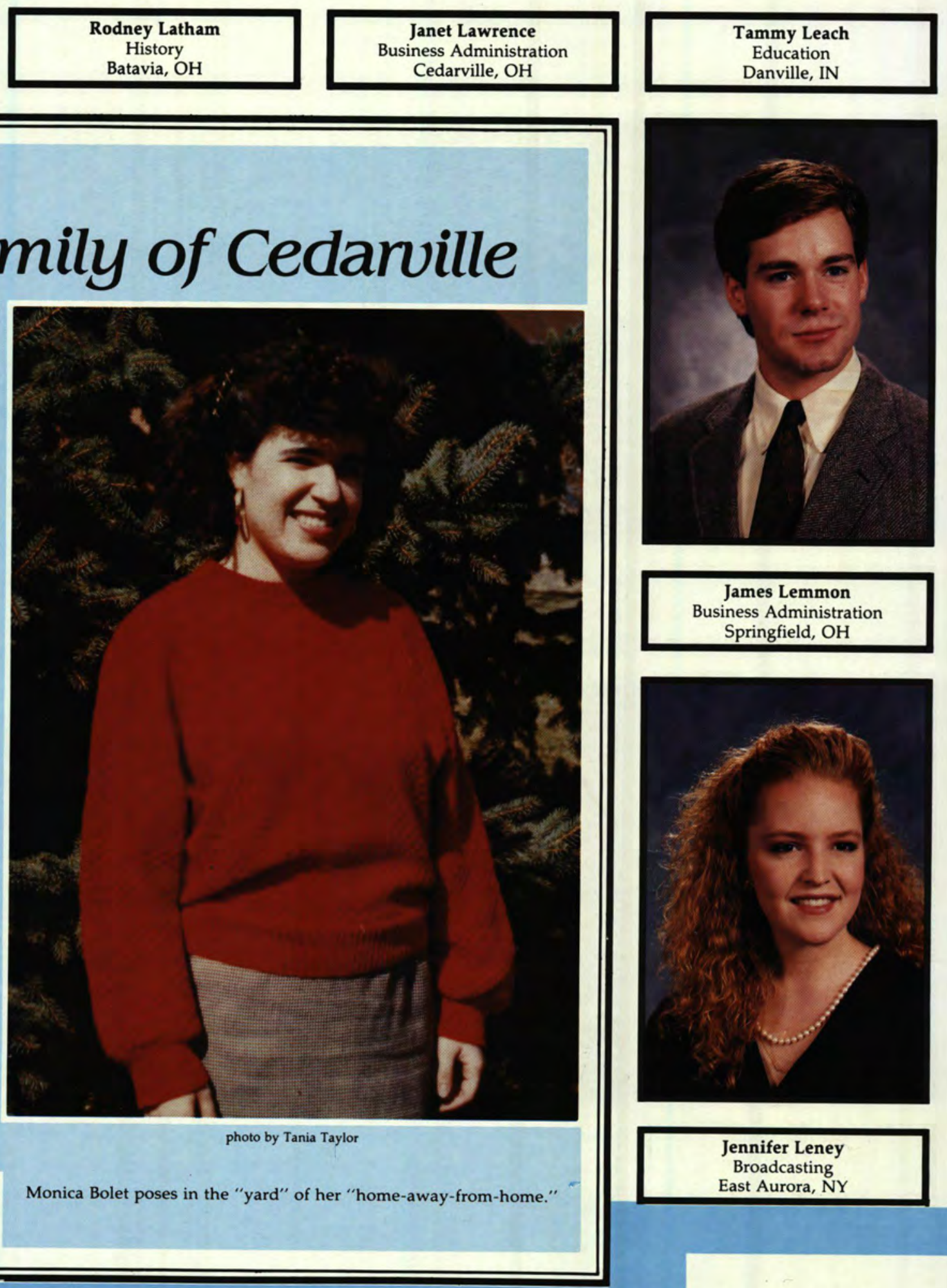

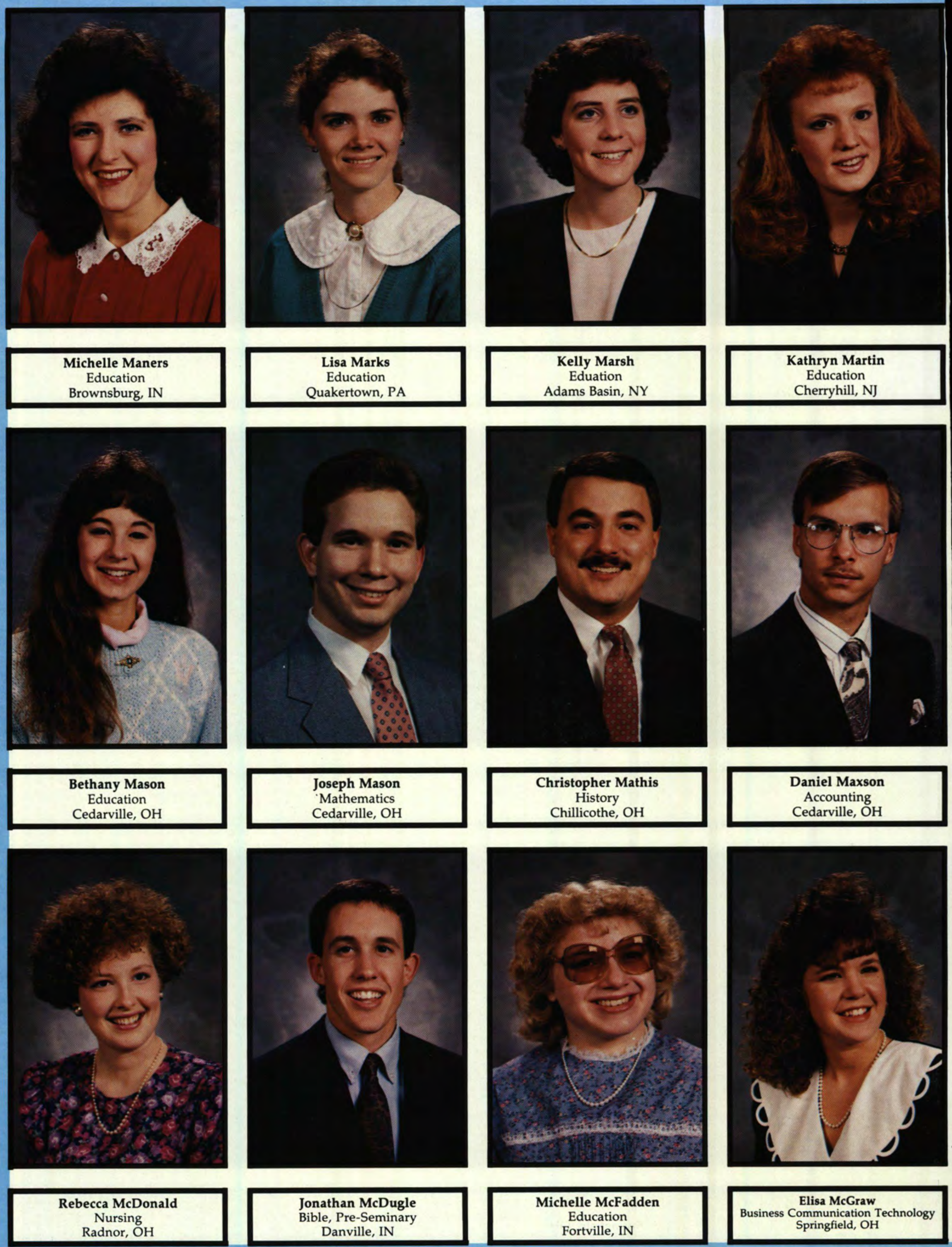

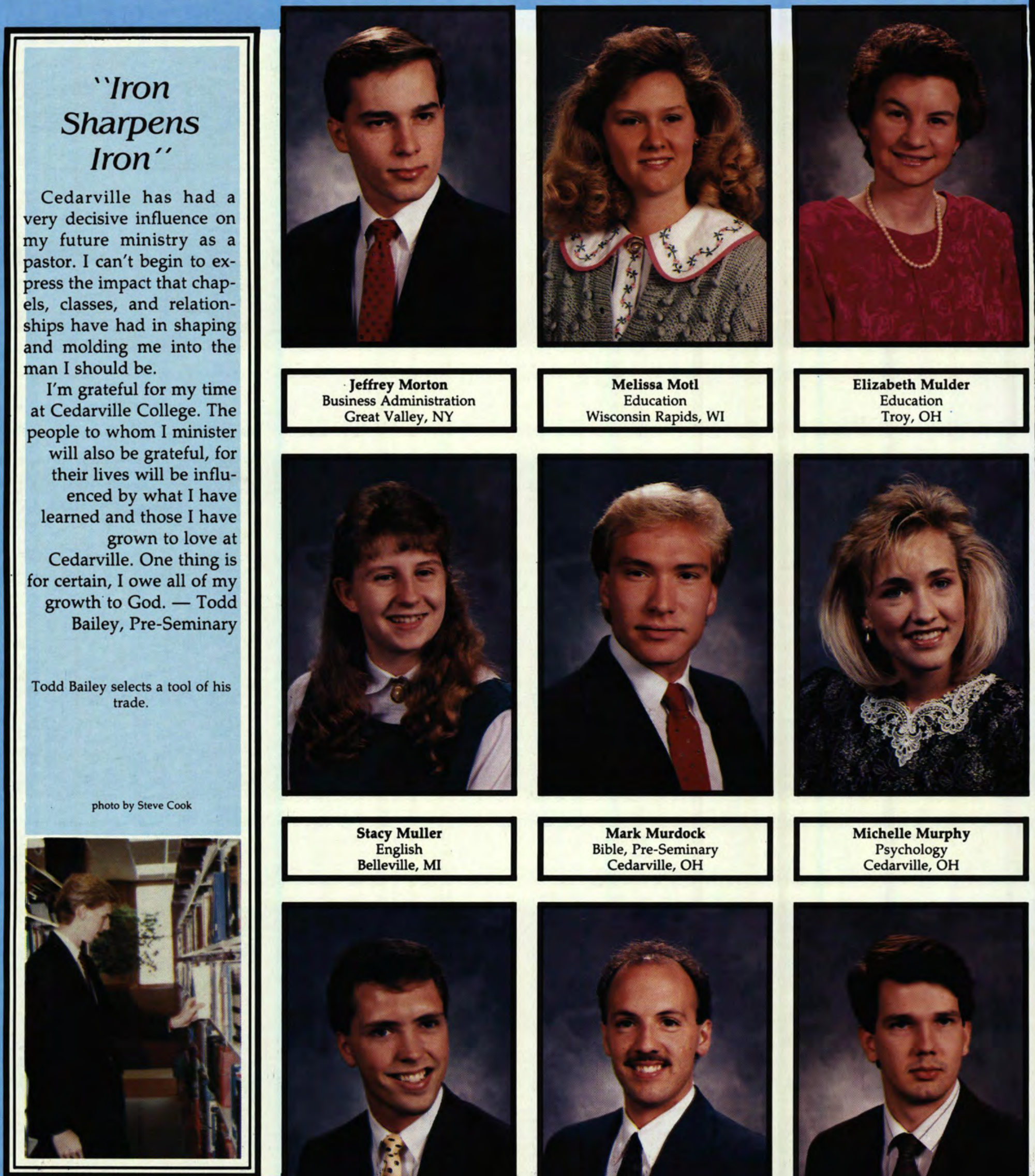

Education
Troy, $\mathrm{OH}$
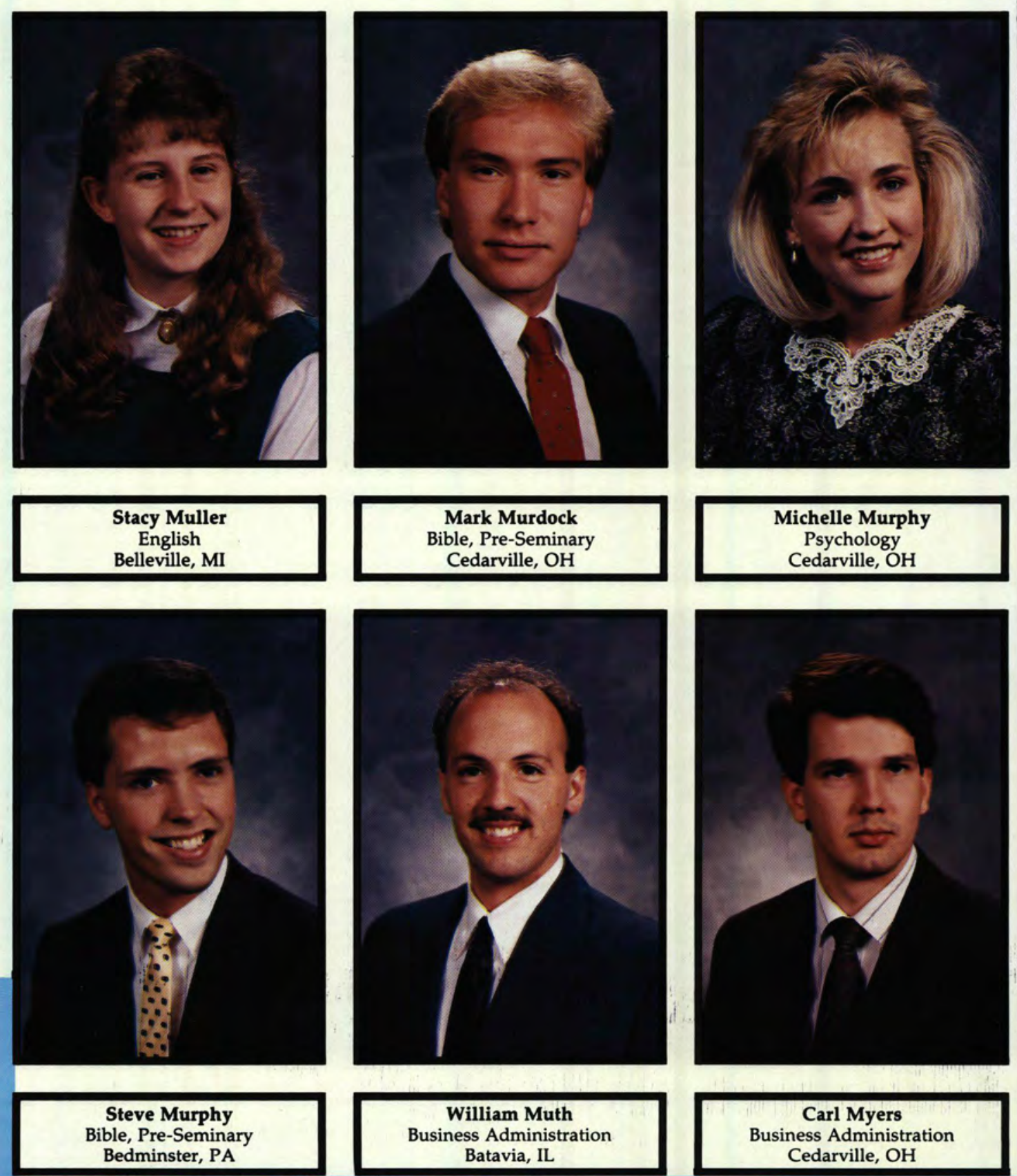

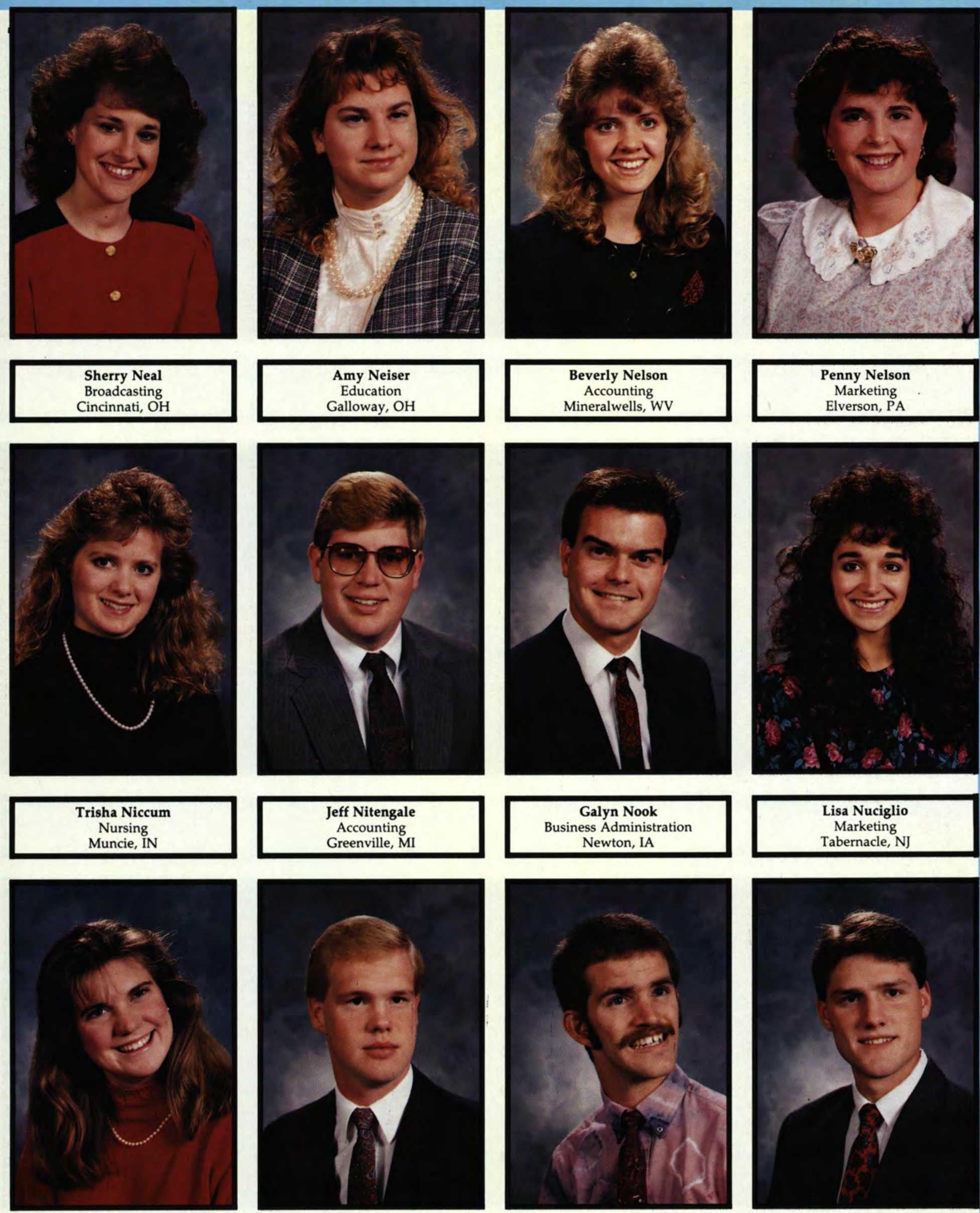

\section{Julie Nyenhuis \\ Education}

Walker, MI

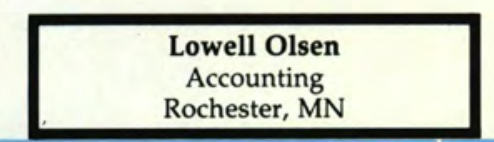

Ken Oster

Bible, Comprehensive

Richland, WA
Daniel Osterhout

Computer Information Systems Oxford, MI 

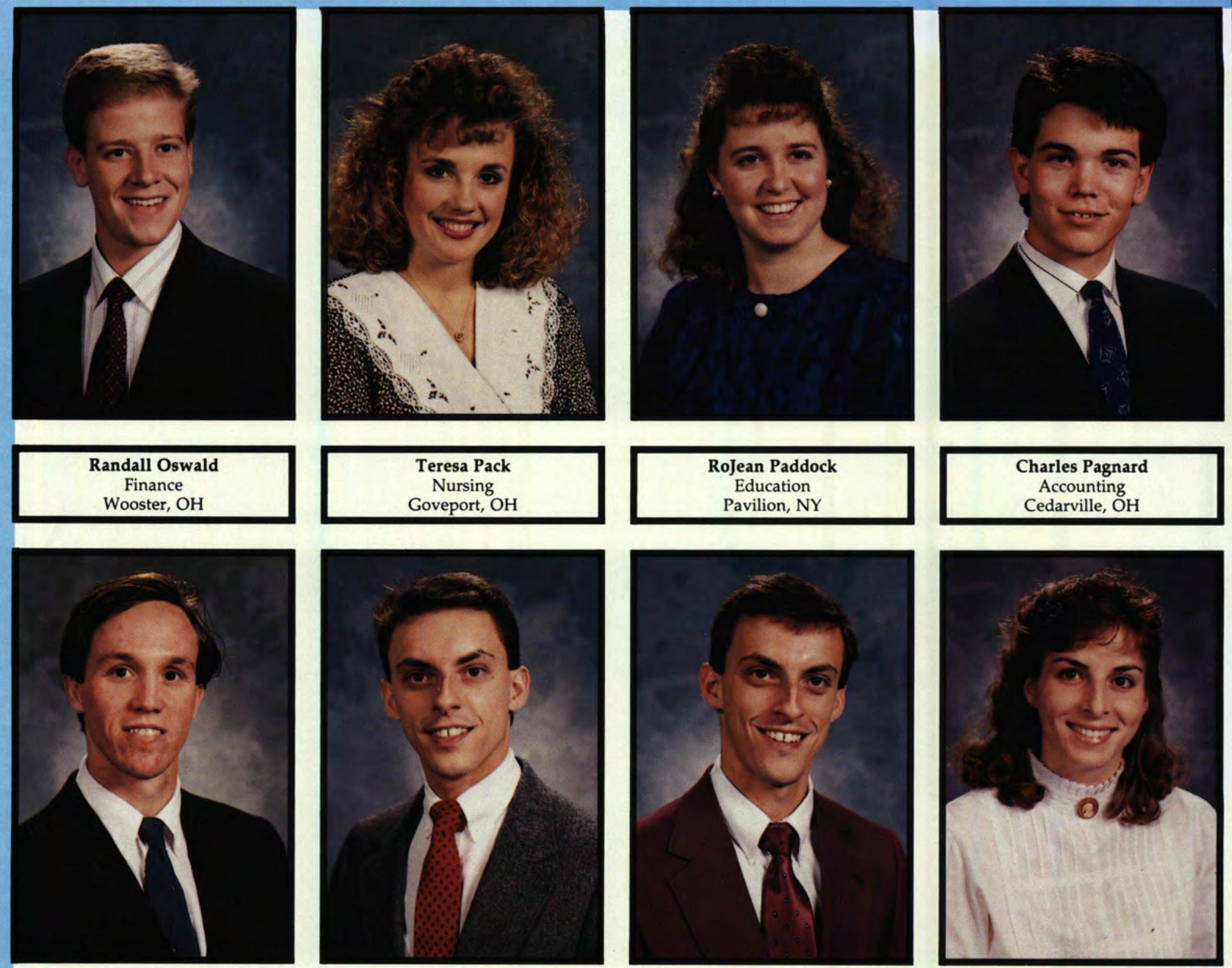

Michael Paradiso Business Administration Hartford, CT
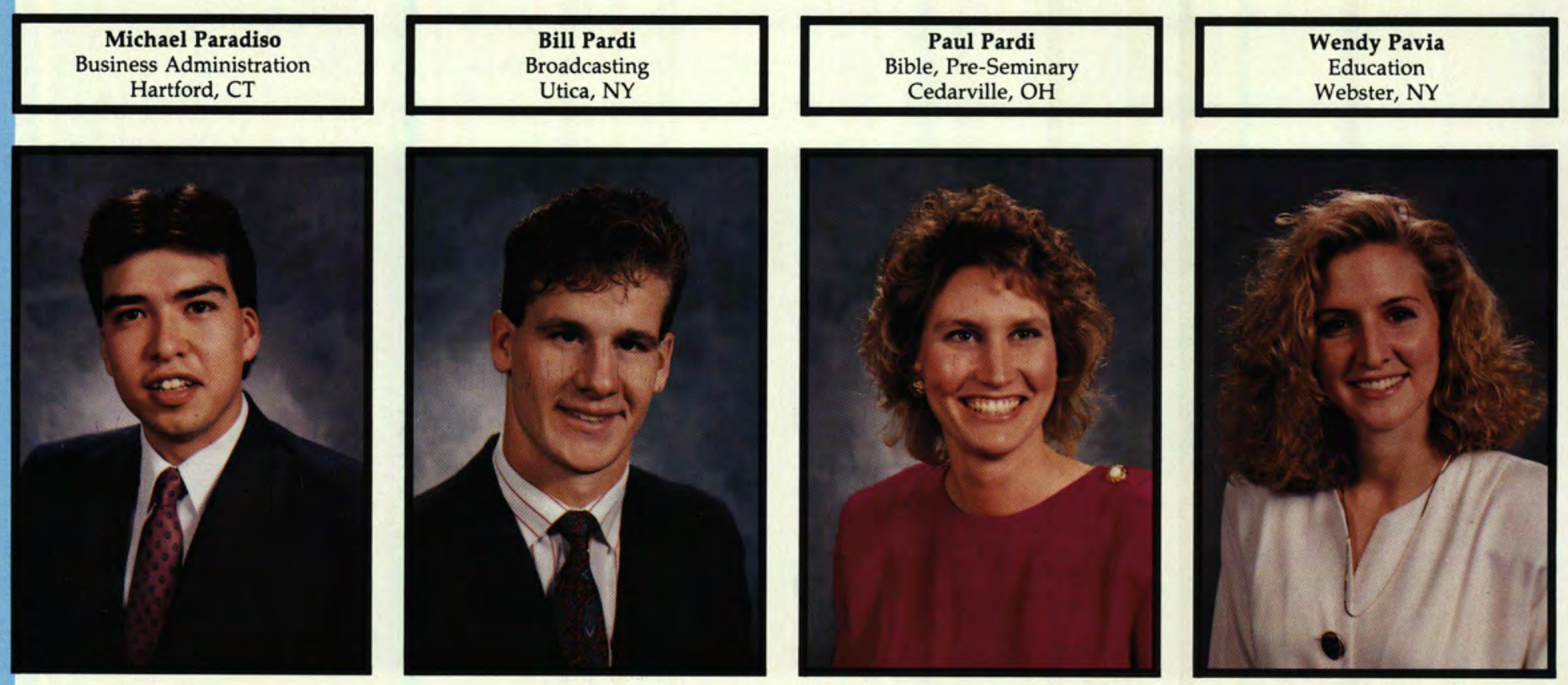

Gregory Perelka Business Administration Sagamore Hills, $\mathrm{OH}$
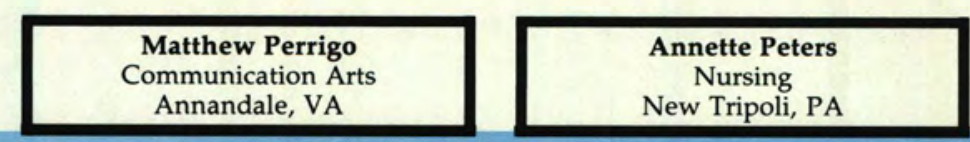

Sara Peters

Business Administration West Branch, MI 

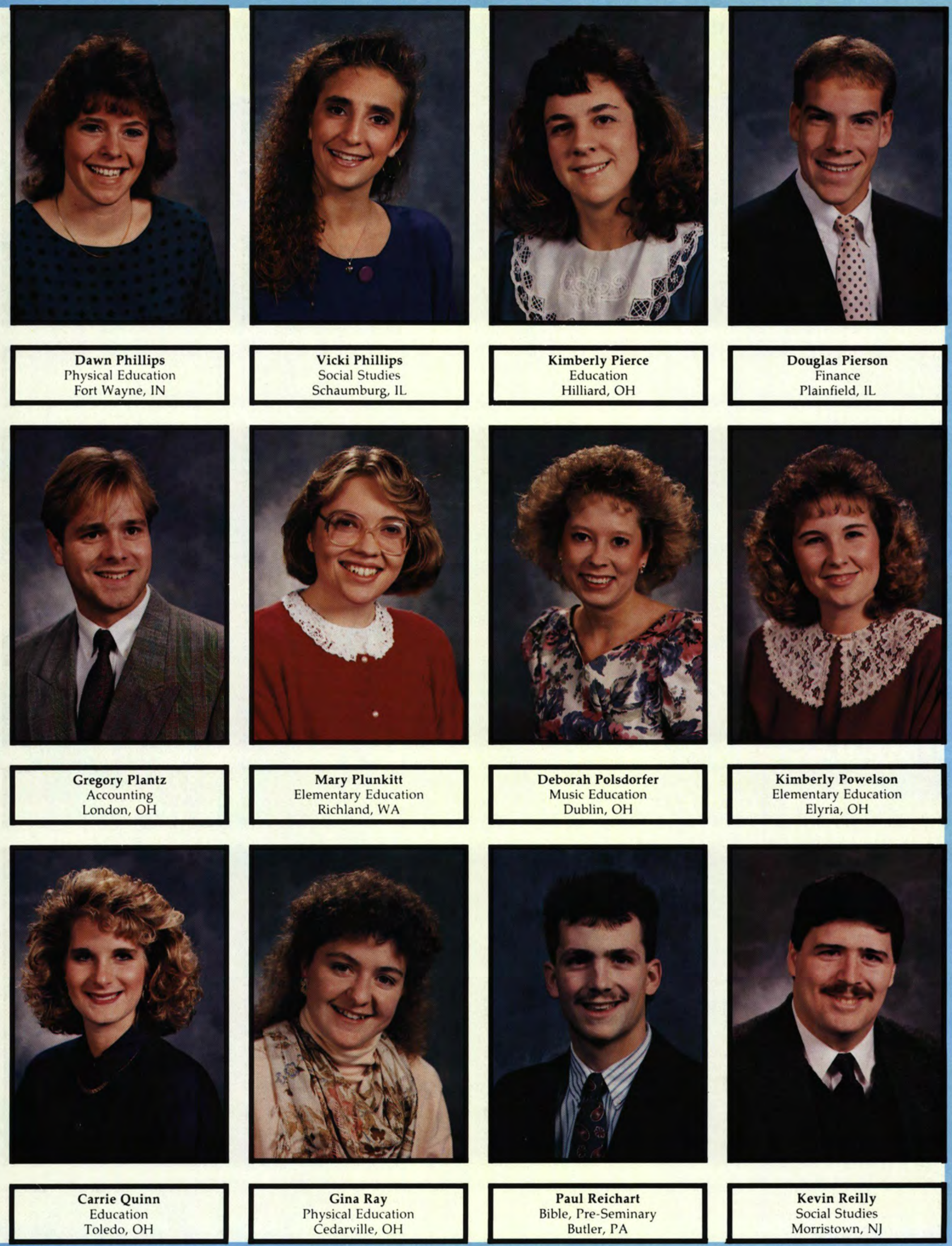

Gina Ray

Physical Education

Cedarville, $\mathrm{OH}$
Paul Reichart

Bible, Pre-Seminary

Butler, PA
Social Studies

Morristown, N] 

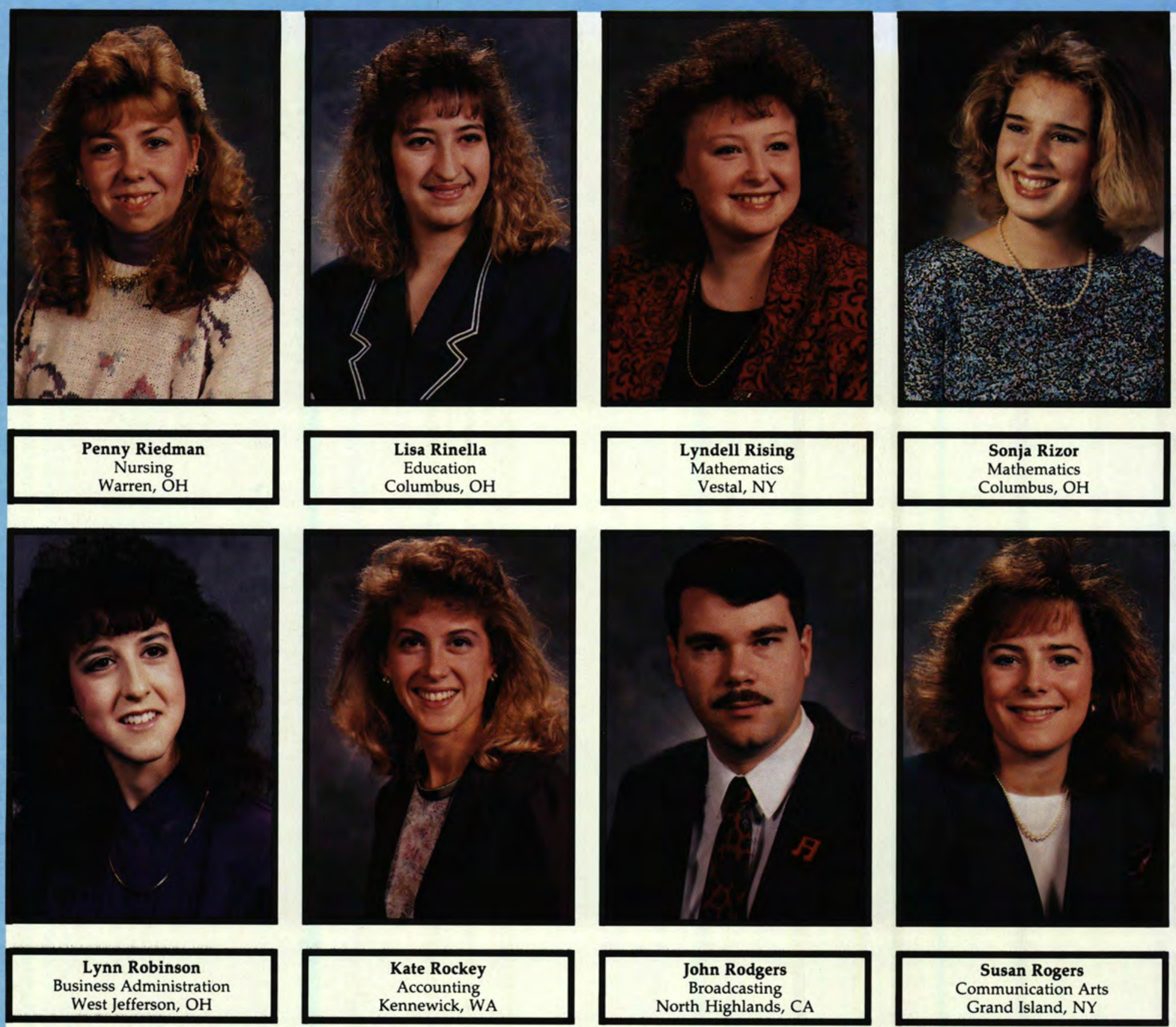

Business Administration

West Jefferson, $\mathrm{OH}$
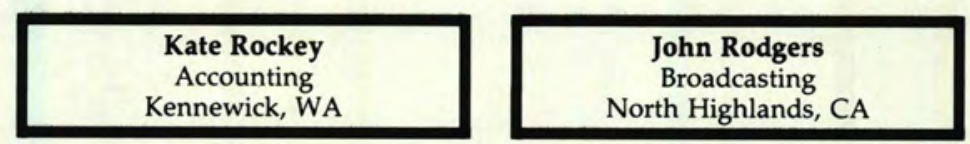

Communication Arts

Grand Island, NY
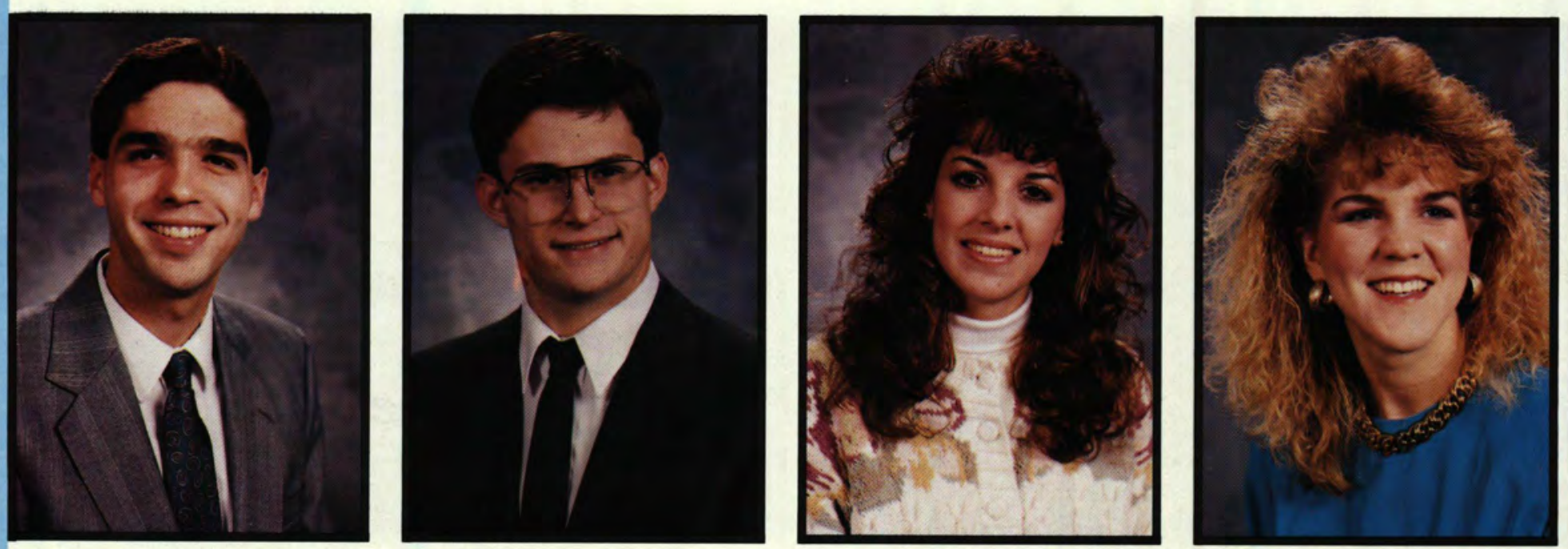

\section{Stephen Ross \\ Accounting}

Greenfield, IN
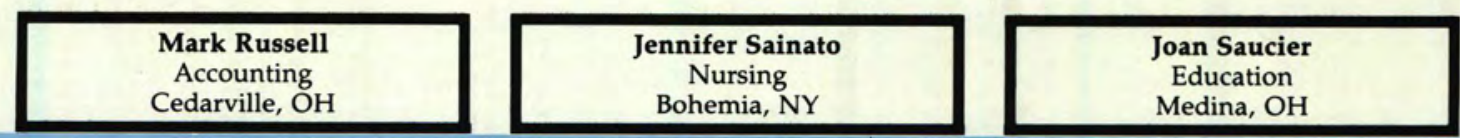


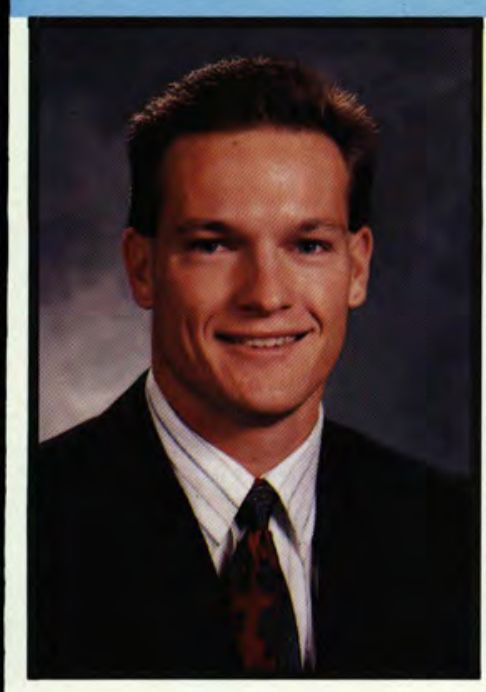

Daniel Schearer

Business Administration Etowah, NC
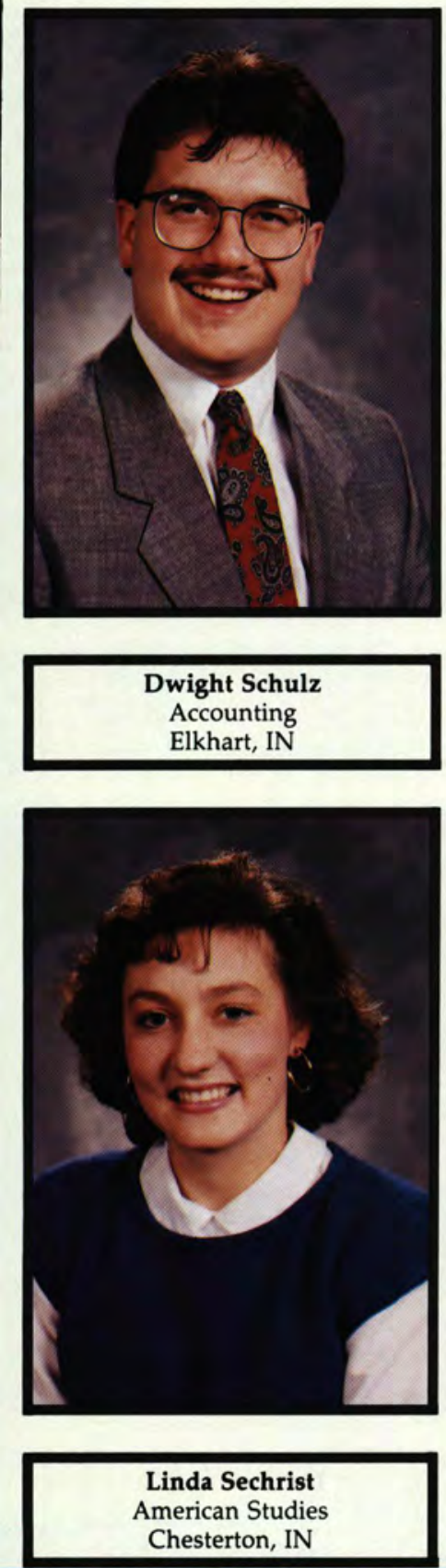

Linda Sechrist

American Studies

Chesterton, IN
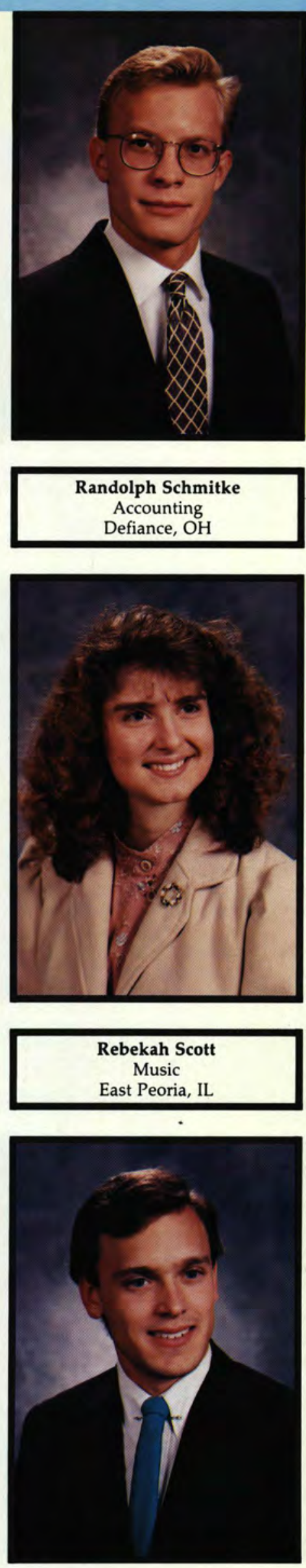

Todd Sechrist

Business Adminstration Douglasville, PA

\section{"...And He Shall Direct Thy Paths"}

Many college students find themselves busy throughout the year. Many think that they are too busy to be involved in a ministry. Senior Mark Murdoch has a different perspective on ministries. Murdoch has been involved with the Southgate Baptist Church youth group since the summer after his sophomore year. Since Southgate was Murdoch's home church, it was only natural for him to be involved there. Before becoming involved with the youth group, Murdoch had been a Business major, but after he became involved, he saw the Lord was leading him to be a full-time youth pastor. From the start of

Mark Murdoch shows that starting in the B.A. doesn't mean God can't guide one elsewhere. his work with the youth group, Murdoch said he was able to build a good relationship with the teenagers. He is a friend but still old enough for them to respect his opinion. After graduation this spring, Murdoch plans to attend Trinity seminary near Chicago and serve as a part-time youth pastor. Mark Murdoch is one Cedarville student who has taken the time to serve God and let Him work in his life.

- Carrie Mann

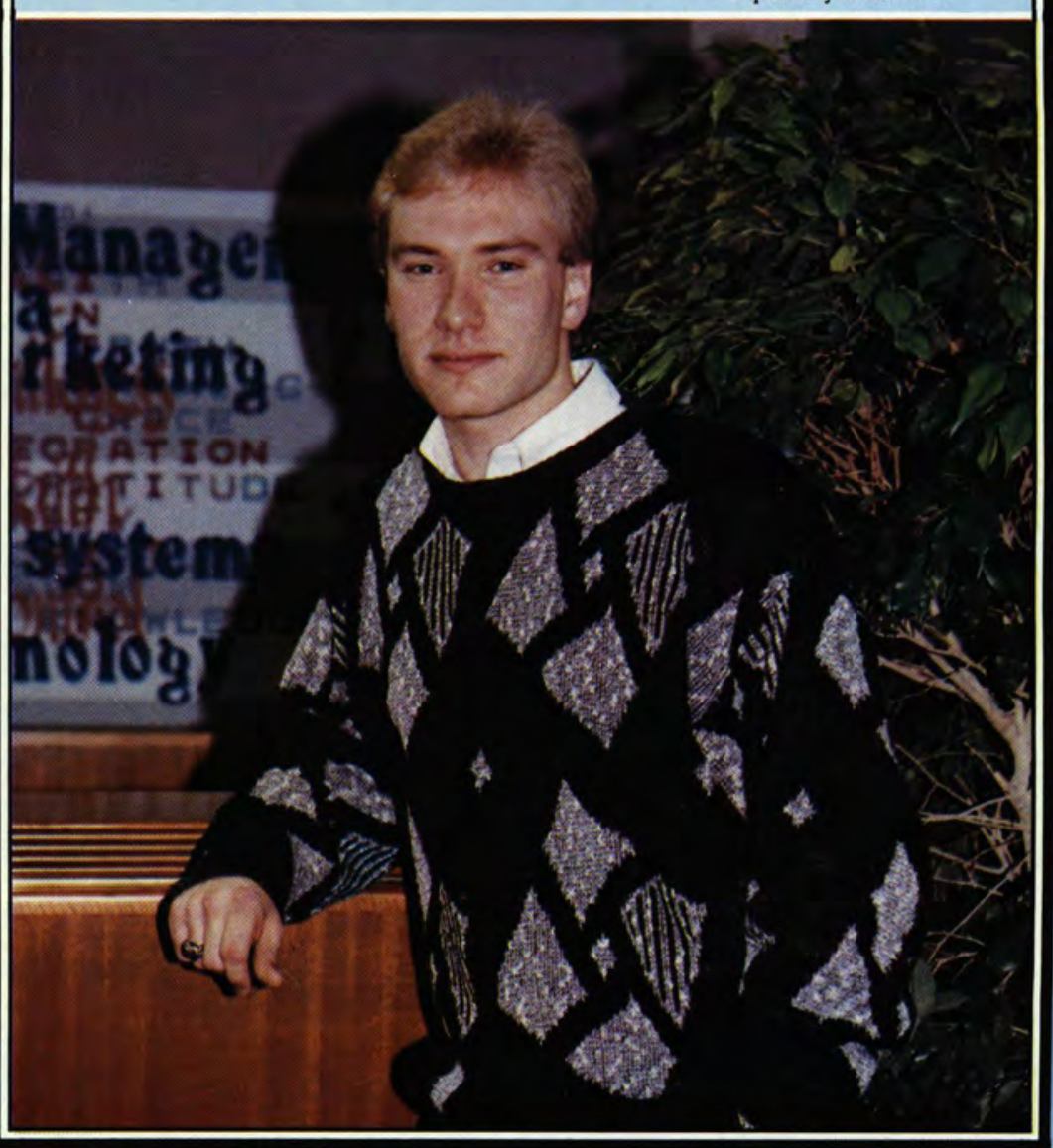



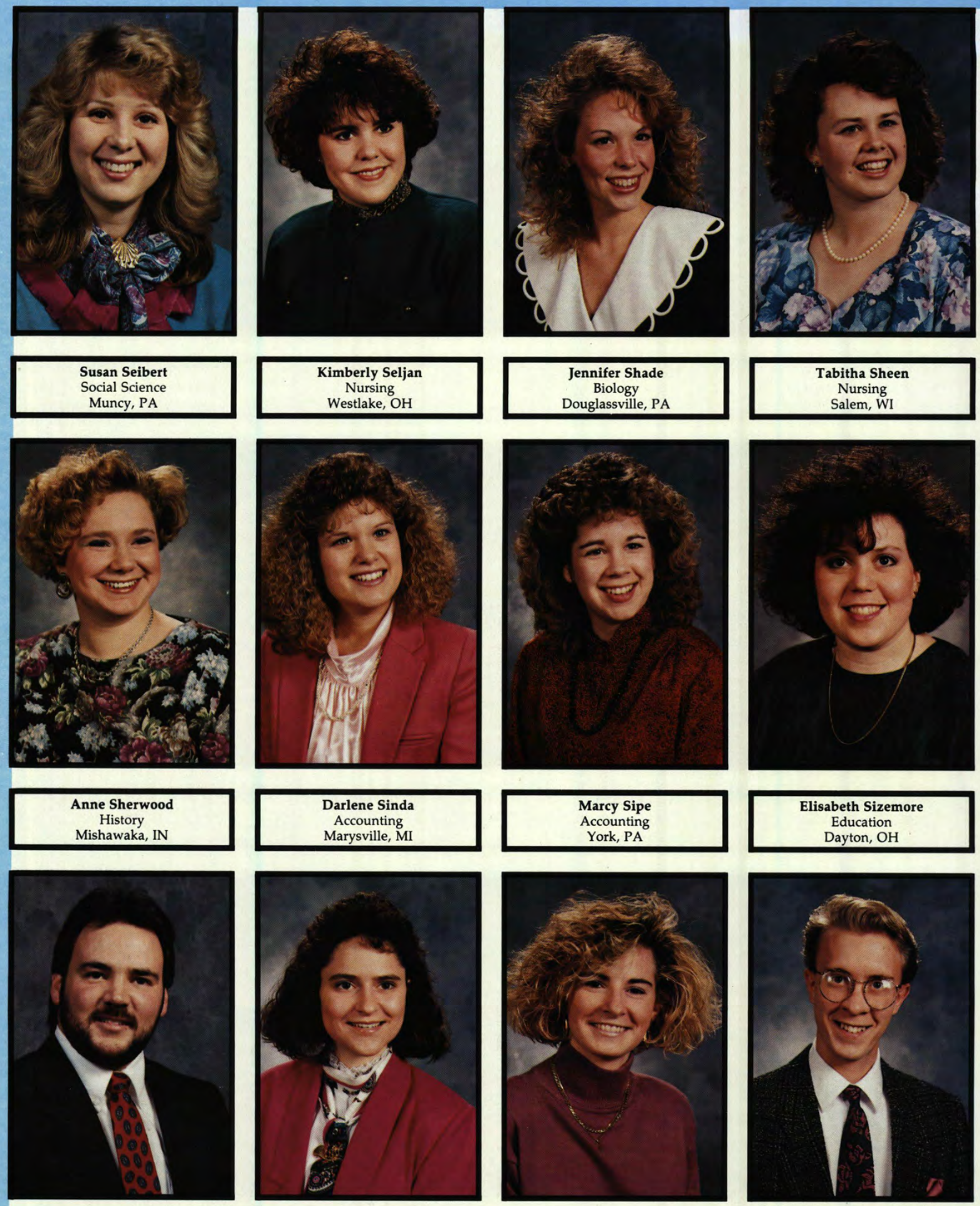

Christopher Smith

Business Administration Cedarville, $\mathrm{OH}$
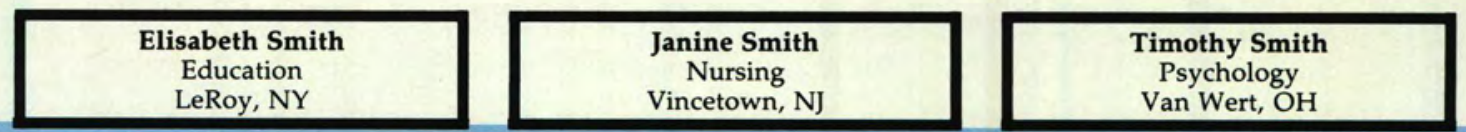

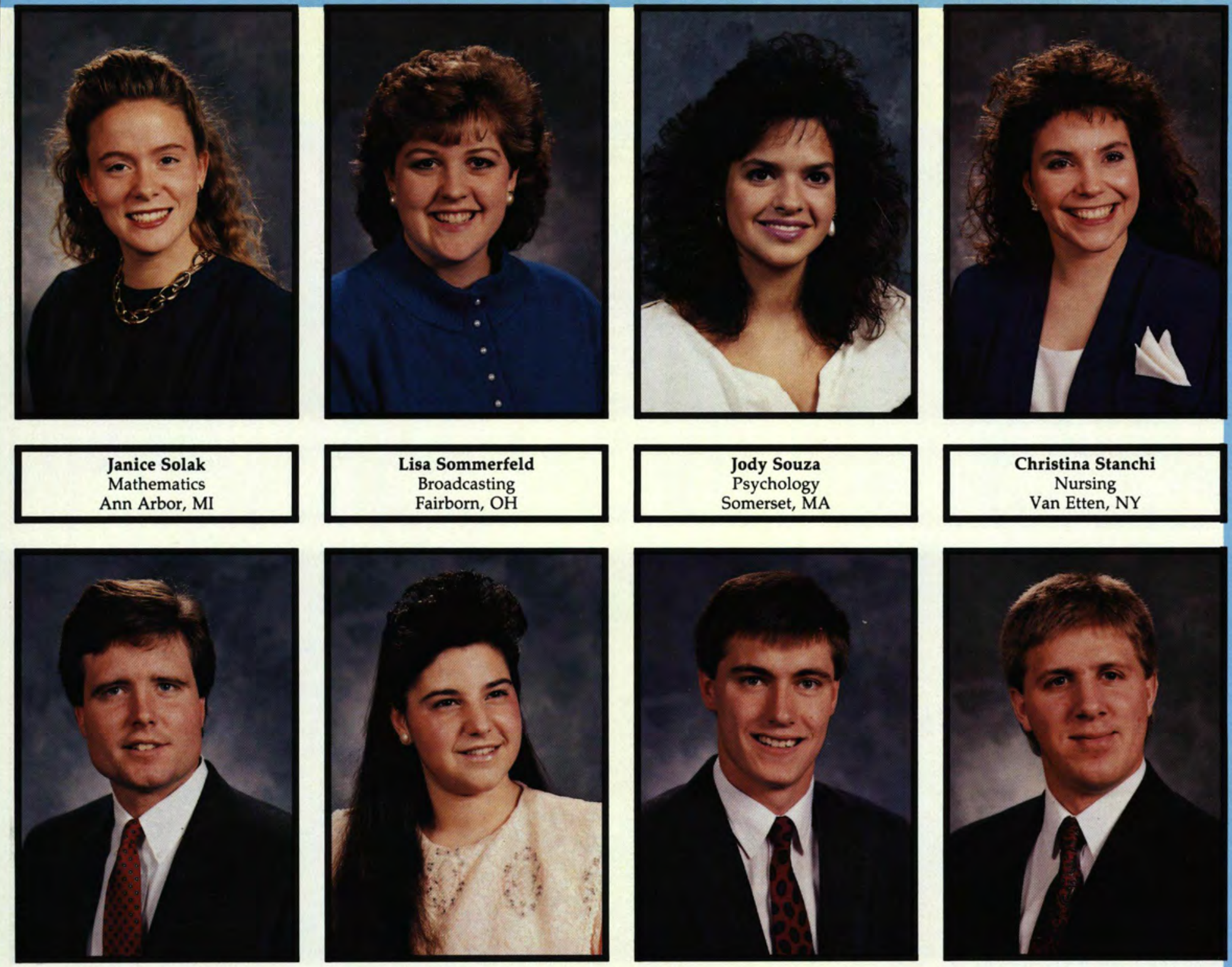

Ronald Stansbury Bible, Pre-Seminary Hagerstown, MD
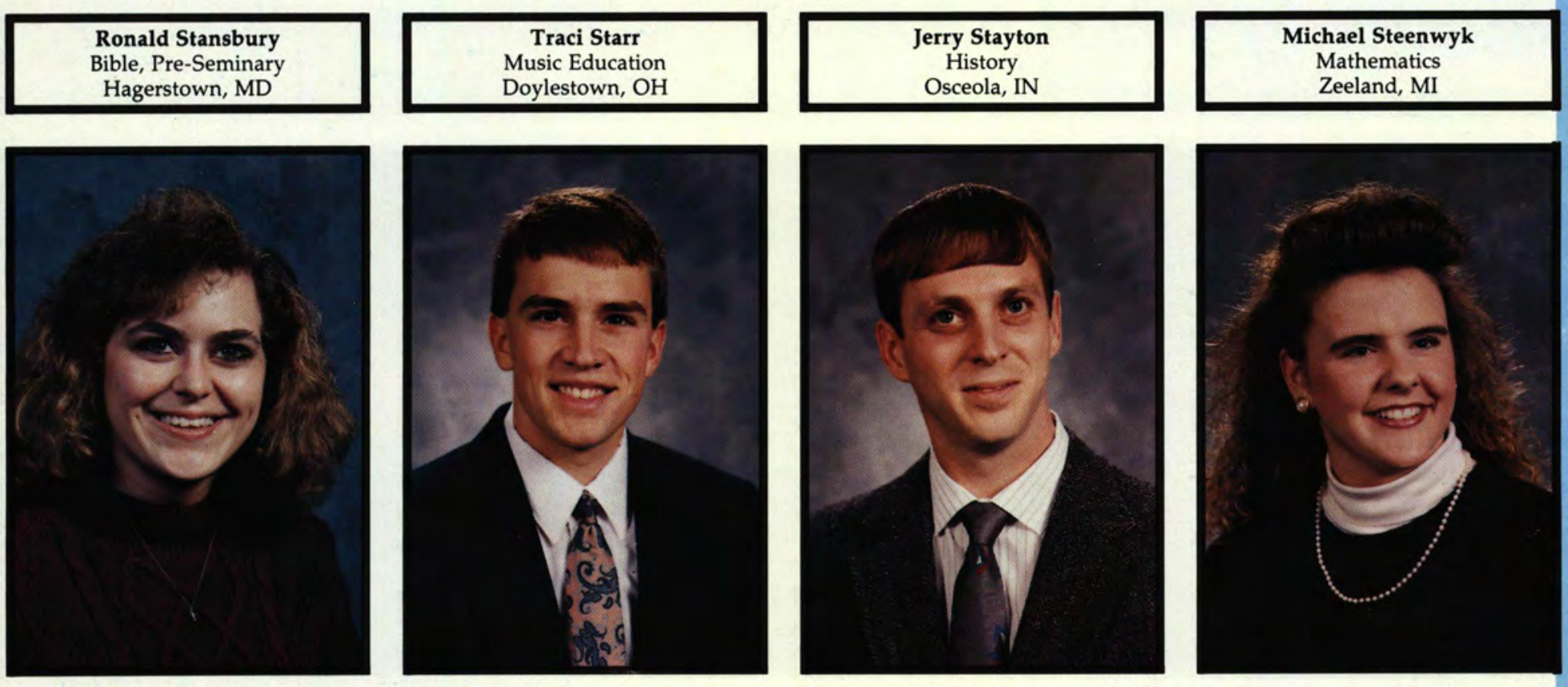

Jennifer Steffy Behavioral Science

Clarion, IA
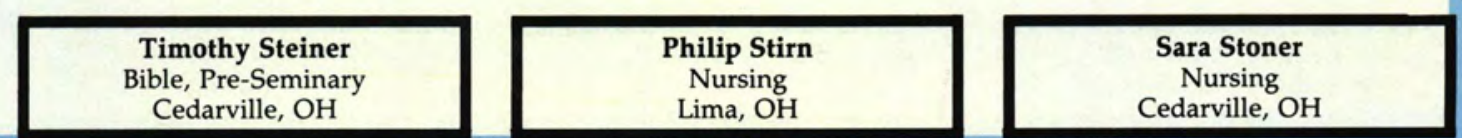

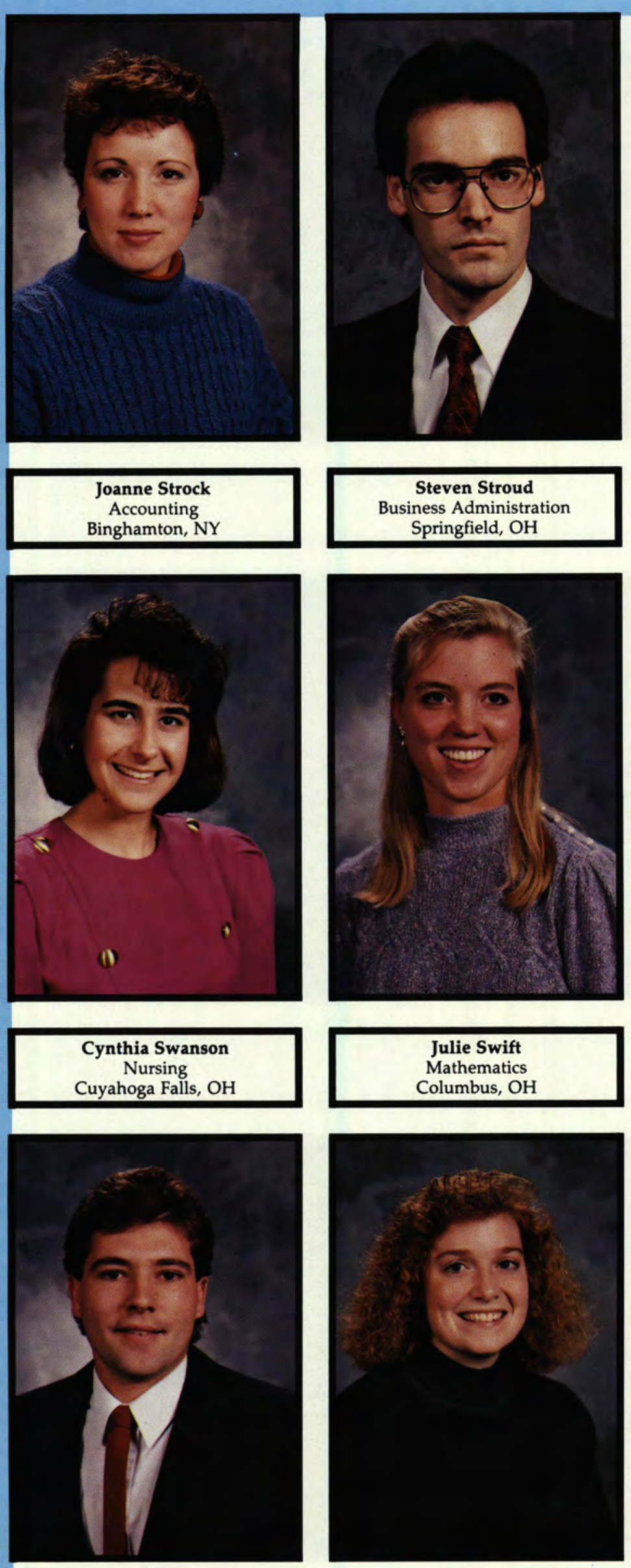

Michael Thomas Business Administration Garrett, PA
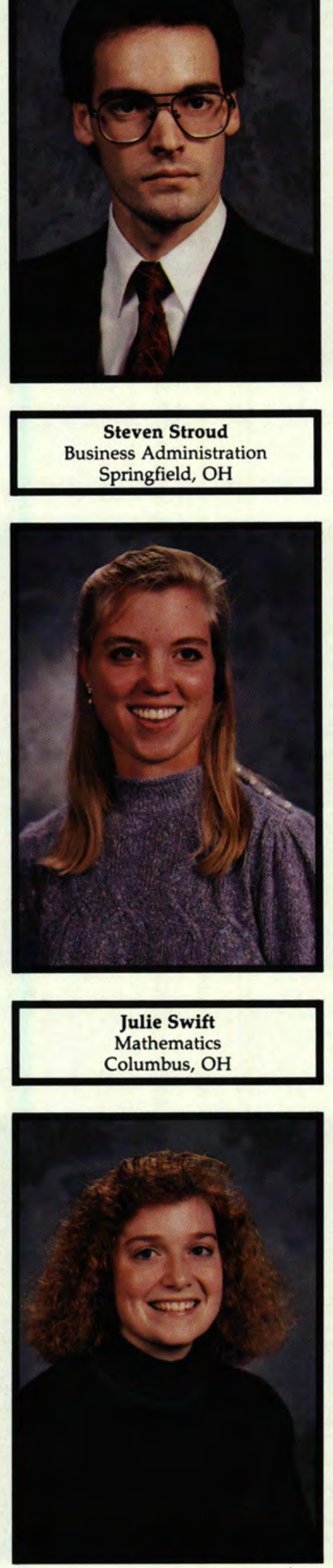
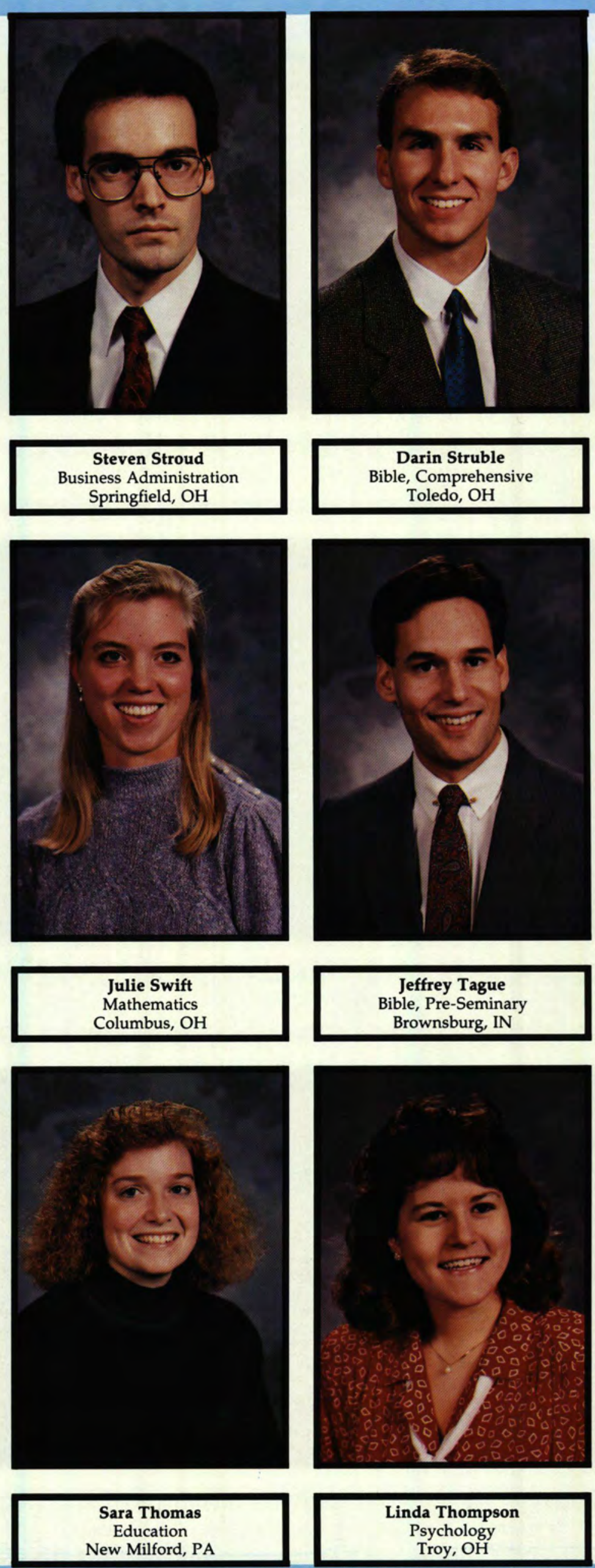
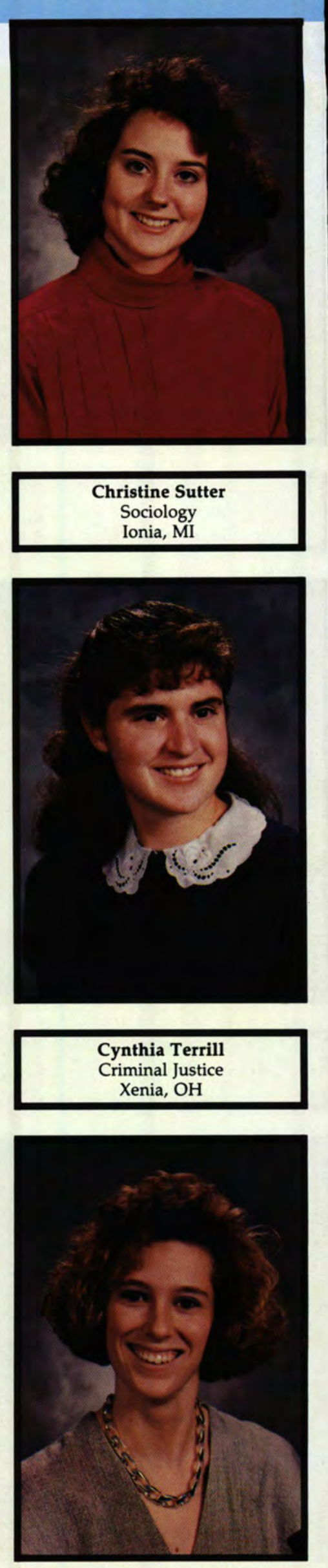

Linda Thompson

Psychology Troy, $\mathrm{OH}$ 

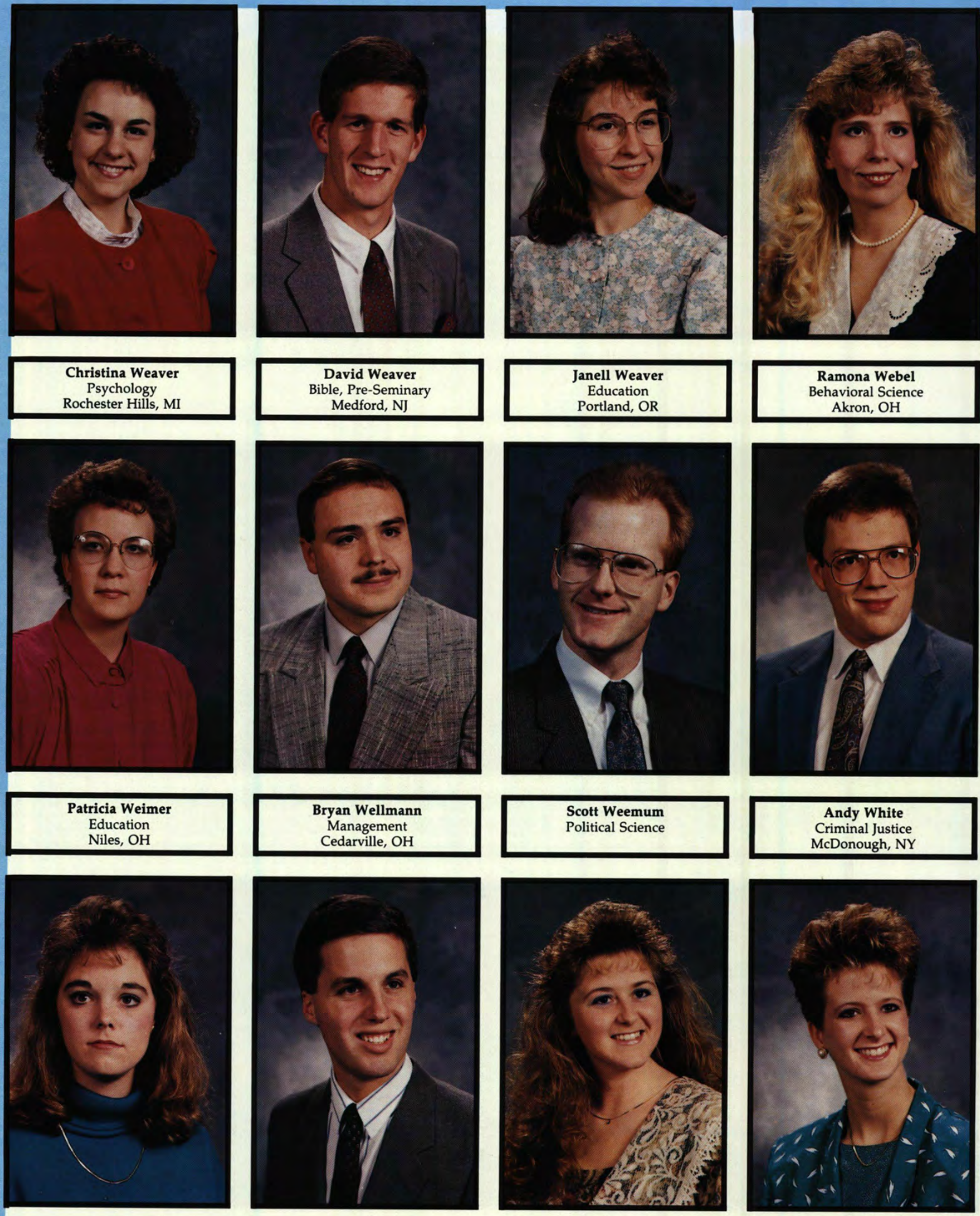

Anita White

Education

Keith Wiederwax

Dayton, OH

Business Administration

Haddon Heights, NJ

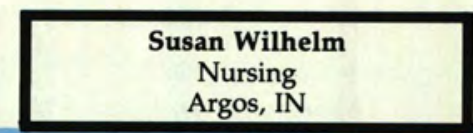

Stephanie Wilkinson

Psychology

Covington, IN 

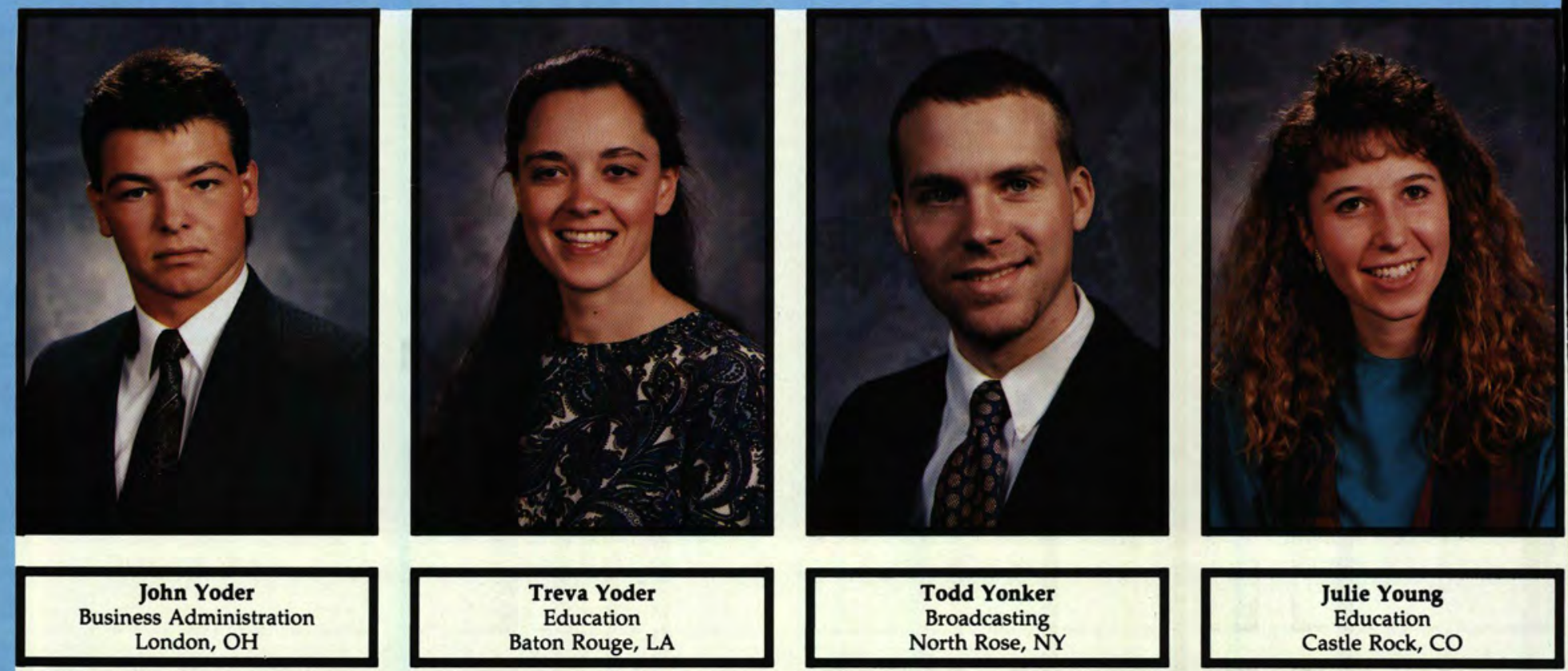

Castle Rock, CO
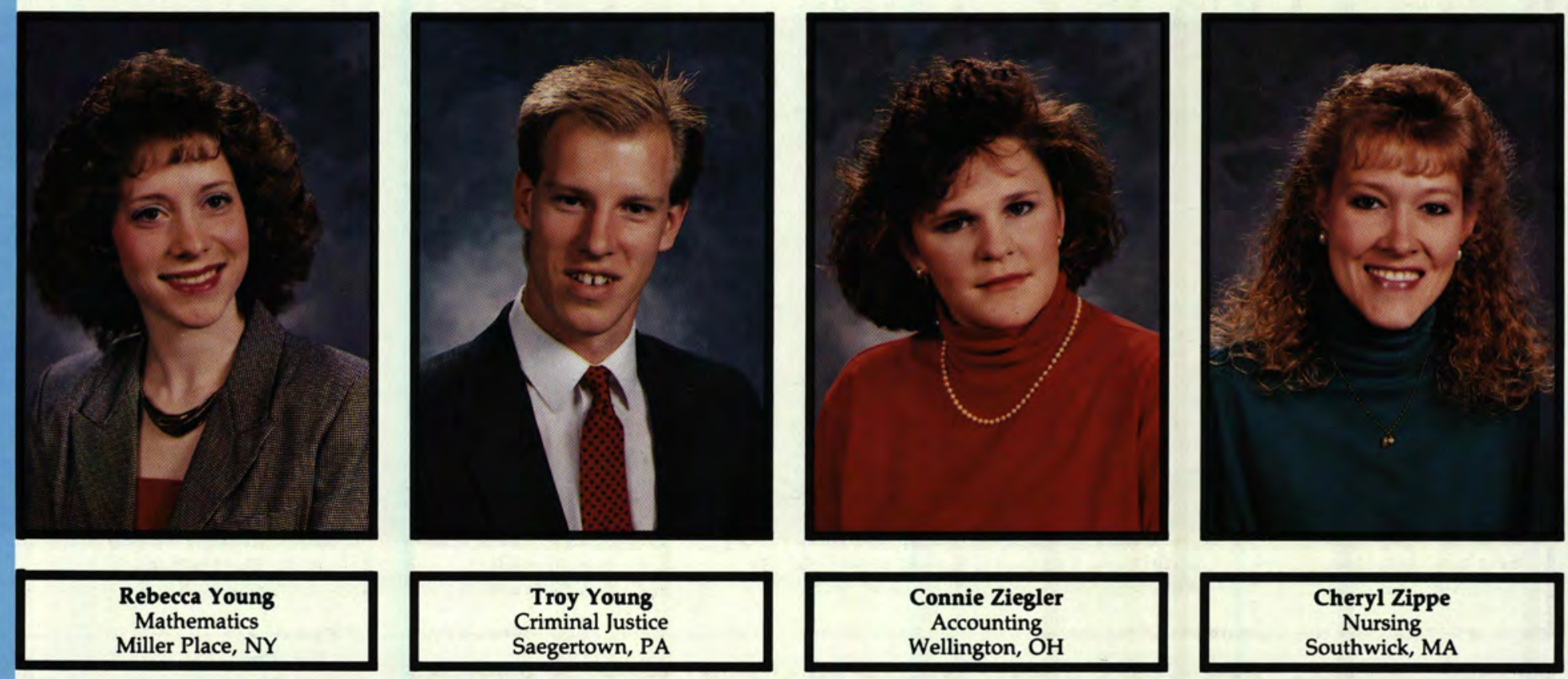

\section{The Extra-Curricular Challenge}

The extra-curricular opportunities at Cedarville College (particularly Forensics, the Village players and the M.I.S. program) have not only stretched my educational experience but have also given me an avenue for glorifying God.

These opportunities encouraged and demanded the development of such spiritual qualities as commitment, discipline, patience, responsibility and courage. But despite all of these challanges, there is the reward of ministry, personal growth, satisfaction and friendship.

The glorification of Christ is the heartbeat of the college and I believe this is exemplified by the faculty and staff and the goals they have in leading the extra-curricular activities. Commitment - to Christ and to excellence - is a key at Cedarville, and one of the ways evidenced is through the variety of opportunities available to every student to use his or her talent for Christ's honor.

- Carrie Quinn

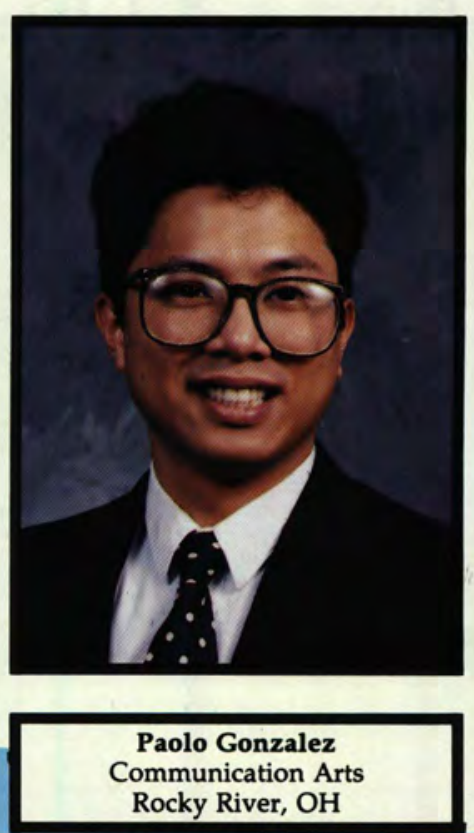




\section{Office Technology}
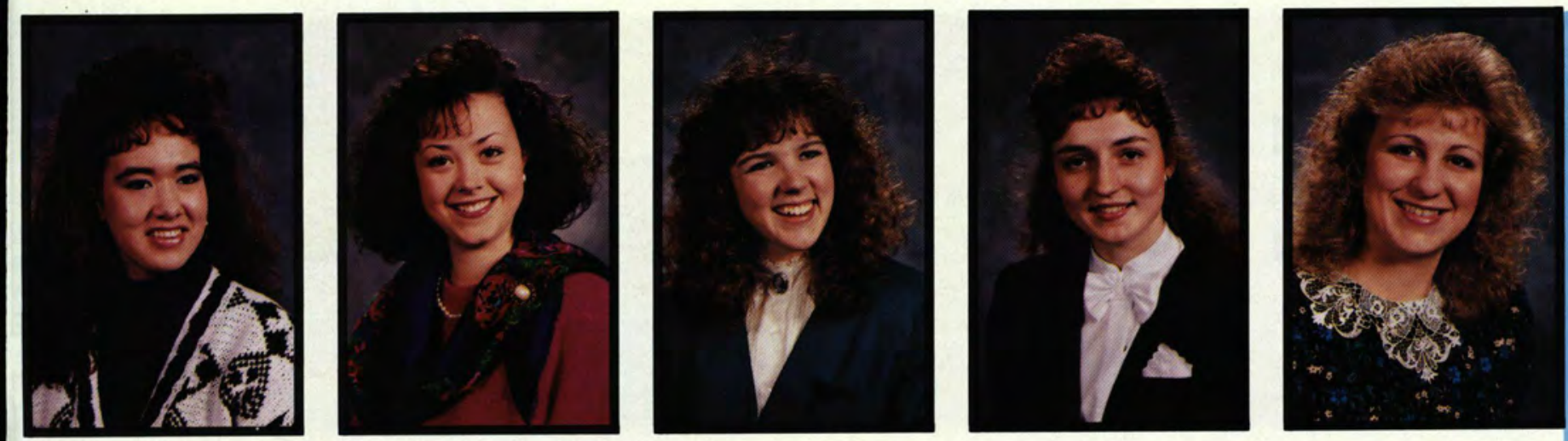

Lori Baker

Fairview Park, OH

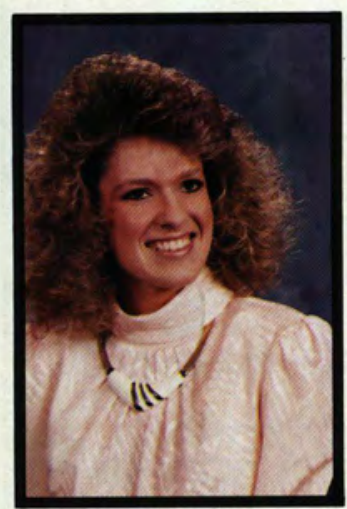

Pamela Constable North York, Ontario

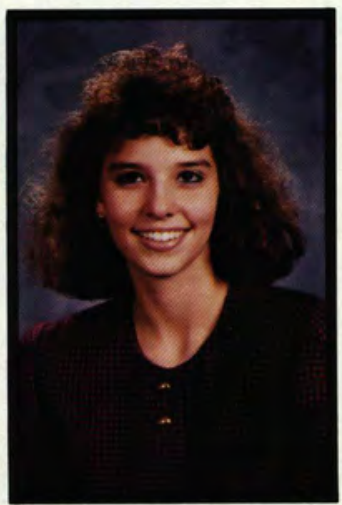

Robin Davis Gallipolis, $\mathrm{OH}$

Cheryl DetricK De Graff, OH
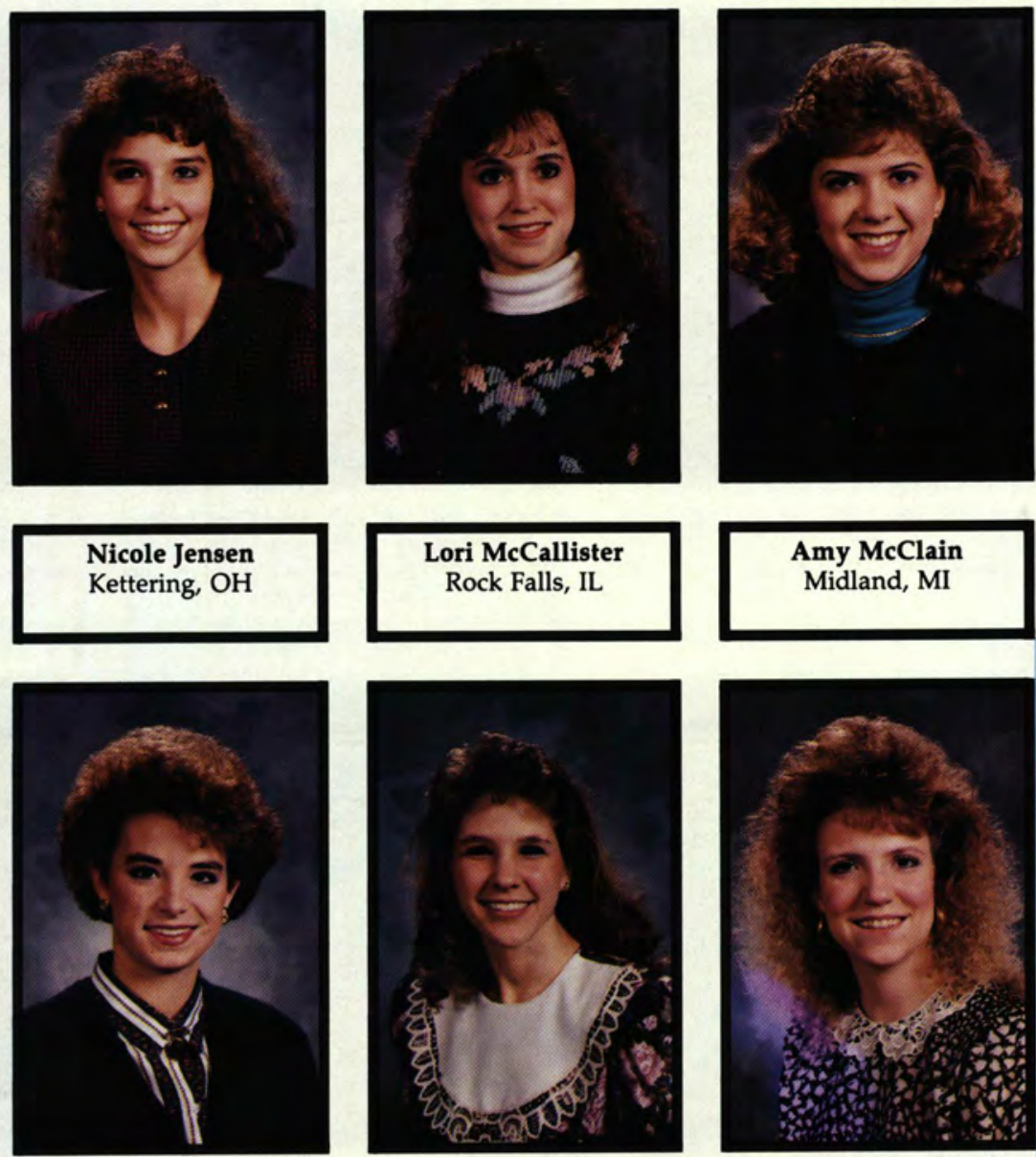

Diana, White Dayton, $\mathrm{OH}$

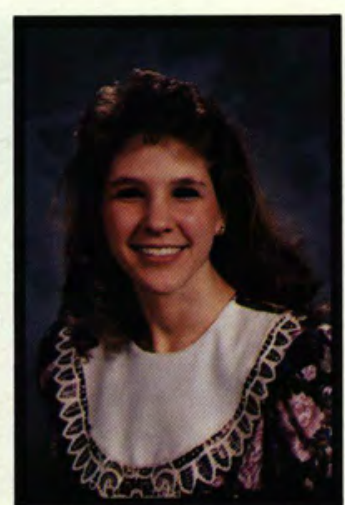

Lisa White Charleston, WV
Sandra, Distler

Warminster, PA

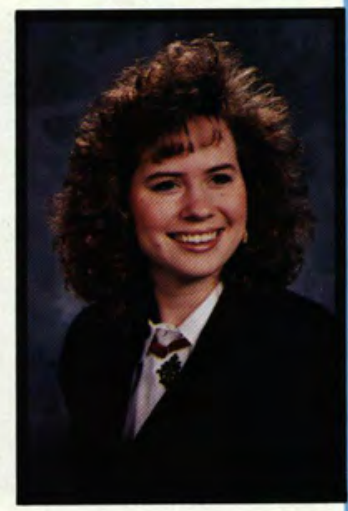

Kathryn Steiner Cedarville, $\mathrm{OH}$
Christen Weiss Dayton, $\mathrm{CH}$ 


\section{I'll Remember. . .}

"The friends I have made who helped make college easier."

Mickey Swich

"Living above the grouchiest unit in

Printy and breaking the zipper on my formal the night before J.S." Deb Christner

"Living in a unit where the sun never set" Kelly Fath

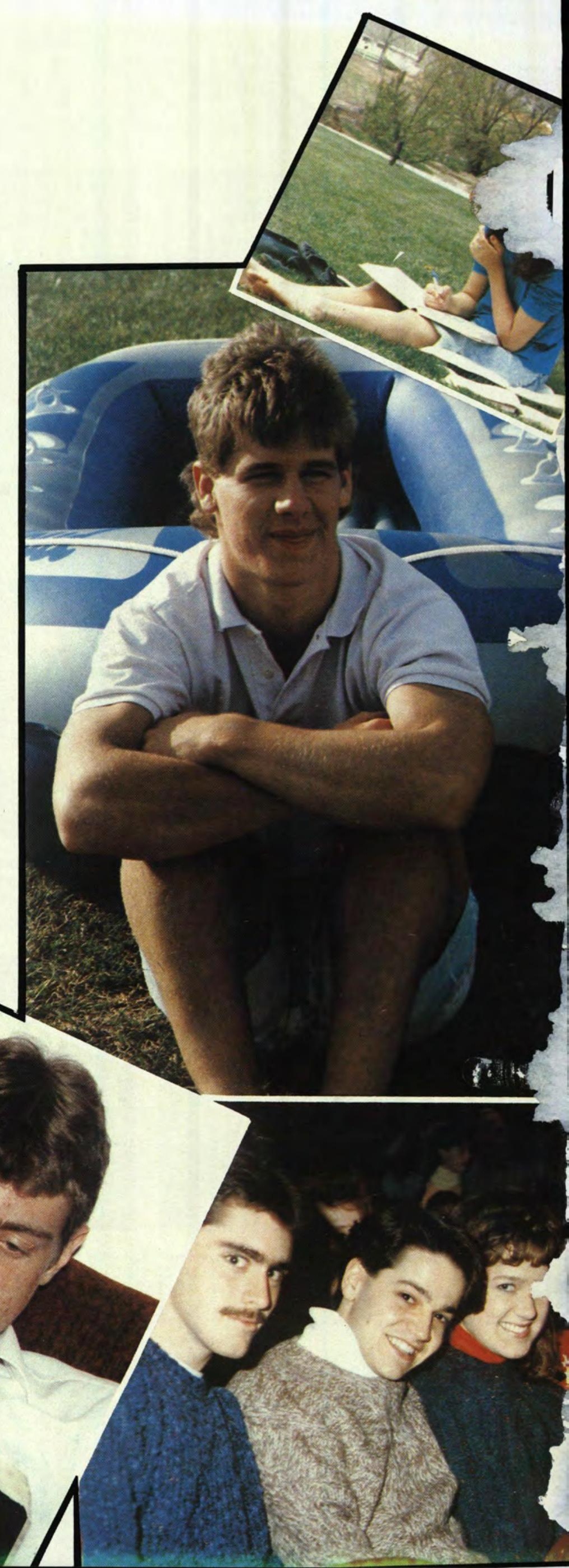




\section{Miracle Staff}

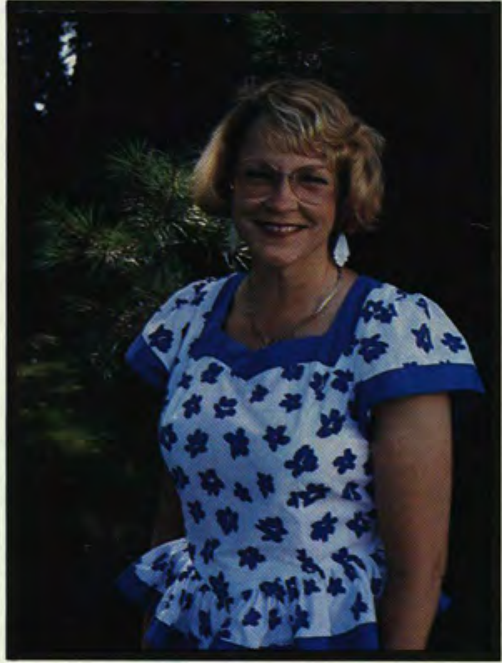

Pat Dixon

Advisor
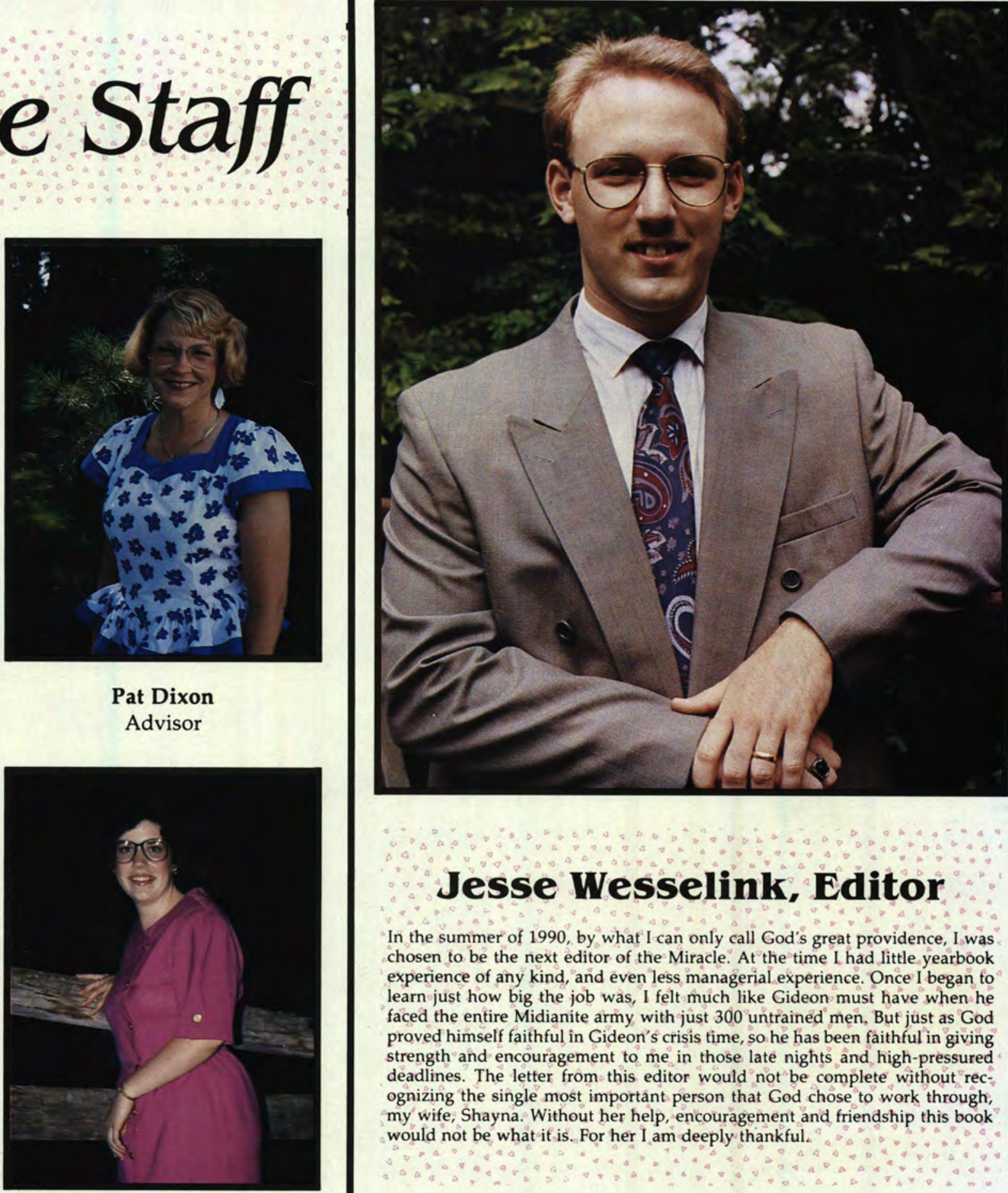

\section{Jesse Wesselink, Editor}

In the summer of 1990 , by what I can only call God's great providence, I was chosen to be the next editor of the Miracle. At the time I had little yearbook experience of any kind, and even less managerial experience. Once I began to learn just how big the job was, I felt much like Gideon must have when he faced the entire Midianite army with just 300 untrained men, But just as God proved himself faithful in Gideon's crisis time, so he has been faithful in giving strength and encouragement to me in those late nights and high-pressured deadlines. The letter from this editor would not be complete without recognizing the single most important person that God chose to work through, my wife, Shayna. Without her help, encouragement and friendship this book would not be what it is. For her I am deeply thankful.

Susan O'Leary

Secretary

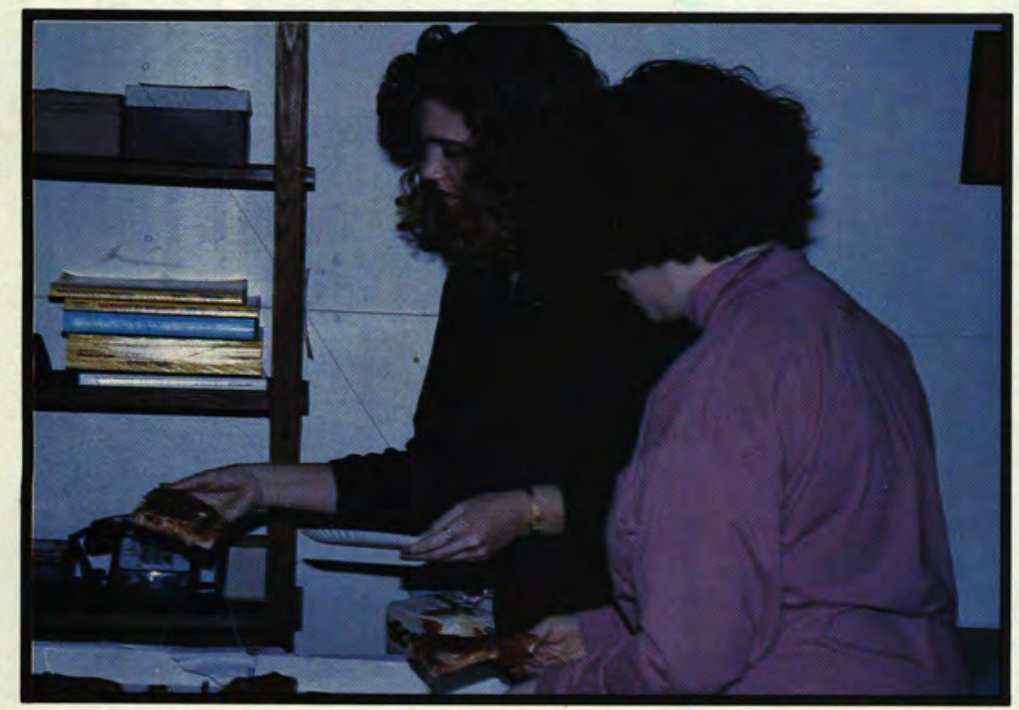

"Miracle Makers" hard at work in the Miracle office.

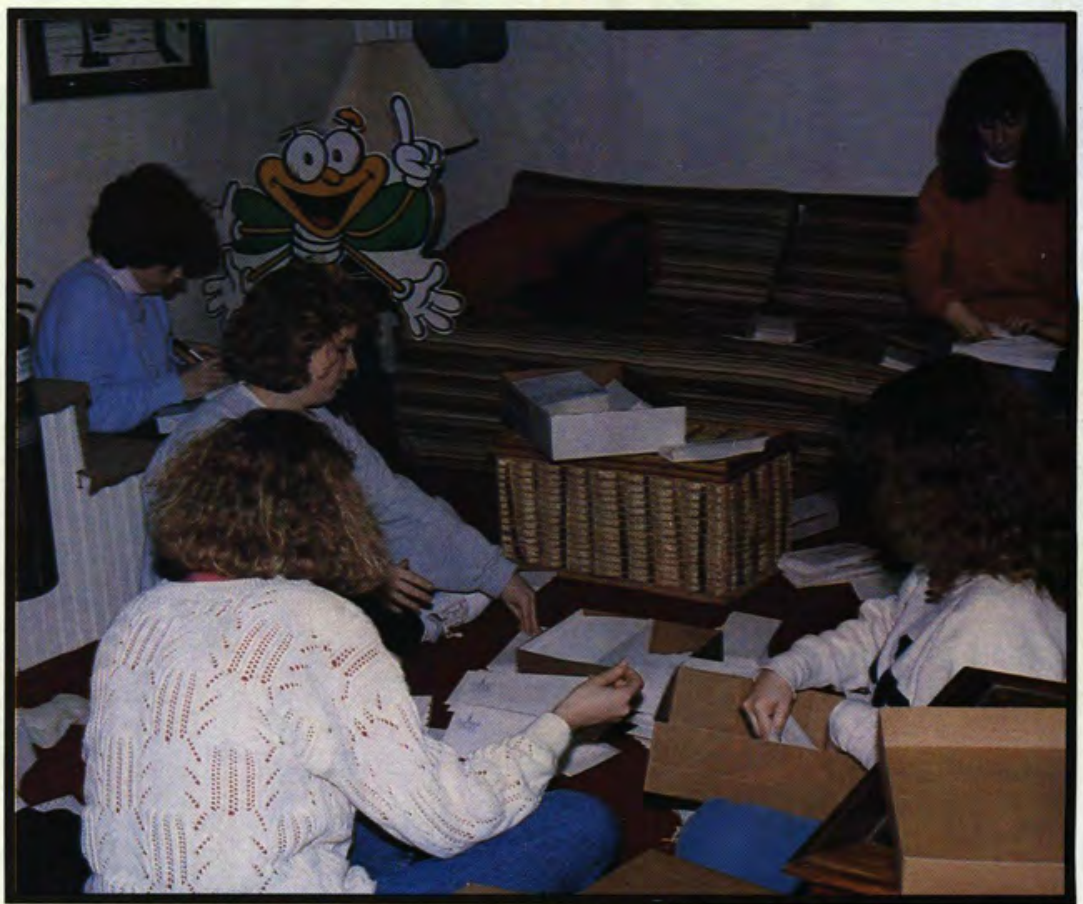




\section{Parent Patrons}

Lionel Marvin Abbott

Rollin W. Ager

Paul Ricky Allen

Michael S. Anthony

Eugene Armour

Abraham Awabdy

Bruce Baker

Robert G. Beach

Raymond N. Beebe

William C. Belh

Eugene Bethel

Wayne F. Blind

Randy M. Bork

James Sheldon Botdorf

Mark A. Brandon

Walter Britt

William E. Broaddus Jr.

Kenneth Lee Broadhead
The Miracle Staff of Cedarville College would like to thank all of the parents, churches and organizations whose patronage made this year's Miracle a success. Without the generosity of these people, the yearbook would lack the color, quality, and capacity which allow it to communicate all of the many aspects of life at Cedarville.

William B. Brooks

David H. Brown

David Ian Brown

Deanna Buckingham

Priscilla Cameron

Marlo H. Carlson

Joyce M. Carr

Paul Casaletto

Lois L. Clark

Larry C. Clemens

James R. Cochran

William T. Commons

Bonnie Cook

John F. Cooper

Thomas N. Cooper
Walter P. Coston

Ralph E. Davis

Glenn R. Deaver

Samuel De Man

Jack O. Derks

James M. Diller

Joe W. Dillon

John Doering

Thomas J. Driskoll

Robert Clayton Duvall

Marvin Eastlund

Robert W. Eckart

Arnold Eden

James W. Edgerton Sr.

Robert G. Engelmann

David K. Fath Sr.

Charles Feldman

Joseph John Ferro Jr. 


\section{Thank You!}

William D. Fulton

Albert W. Garrigan

Eddie Eugene Gill

Donald R. Gilson

David Godden

David D. Gosman

Randal L. Gosser

Janet G. Griffith

Alfred Hahnenstein

Edward A. Harker Jr.

James L. Hartman

James J. Hetherinton

Dennis W. Higley

Kirby Joe Hill

Kenneth C. Hoelscher

Daniel L. Horine

Charles H. Horr

Gerry Horton
Raymond D. Huber

Steven Douglas Hudson

Phillip G. Hughes

Michael D. Humble

Daniel S. Irving

Ismael O. Jamora

Roger C. Jensen

David A. Johnson

Nancy Johnson

Donald D. Jones

Marvin Warren Jones

Michael M. Kadlecik

Robert L. Keiser

Paul Kendra

Charles Jesse Kibble

Paul J. Kitchen Sr.

Earle K. Knowles

John W. Koenig Jr.
Ralph Kuivinen

Michie Lambert

Robert Floyd Landrum

Harry W. Latimer

John K. Le Blanc

Thomas G. Lensch

Philip G. Lindner

John D. Linnehan Jr.

Alexander Lombardo

Herbert Lomelino

Lin F. Lytle

Cort L. Marsh

Philip J. Mc Murtry

John Mc Queen

Donald E. Miller

Russell A. Miller Jr.

Howard W. Miller Sr.

James W. Mills 
Andrew A. Mitchell

Charles David Mitchell

Richard F. Murphy

James G. Nast

Lawrence E. Neal

James Neiser

Earl R. Nickelson

Wayne Nitengale

James P. O'Leary

Bobby G. Oliver

Richard Allen Olsen

J. Wesley Ooms

Gary W. Oswald

Randall W. Patten

Levi E. Pence

Joseph Perkins

Michael F. Phillips Sr.

Ralph A. Pierson

Joe Potts

Linda Ray
Deane G. Riniker

Charles Rizor

Richard M. Rodebaugh

Roger A. Ross

Jerry K. Rotramel

Dale E. Ruth

John Edward Sahl

Richard H. Sand

John Stephen Sandy

John R. Seljan

Robert Shively

Duane Sinda

thomas C. Sizemore

Charles B. Smith Jr.

Dennis Smith

Katherine Smith

Thomas W. Snyder

Roger W. St. John

Alvin Stamper

Gerald Stanton
Leroy Stephenson

Henry Grady Stone

Charles V. Stover

Robert W. Strong

James R. Swanson

Cathey E. Taylor

Dennis Ulery

Gary E. Vandermark

Kenneth C. Vanderwest

Allen G. Waddell

Garth Walters

Clarence L. Wandell Jr.

Paul W. Ward

Galen Weber

Robert Allan Welch

Ronald P. White

David Whitten

John Wayne Wiederwax

David L. Wilcox

Daniel E. Williams 
David M. Williams

Kenneth Williams

Dan Wingate
Clarence I. Wolf III

Douglas M. Woodhams

Ralph W. Wyand
Jon Yarian

Richard D. Yeakey

\section{Church Patrons}

Anthony Baptist Church First Baptist Church

Bible Baptist Church

Calvary Baptist Church

Calvery Baptist Temple

Cedar Hill Baptist Church

Christian and Missionary Alliance

Cornerstone Baptist

Church

Dora Isles Sales

Emmanuel Baptist Church

Faith Baptist Church
First Reformed Church

Grace Baptist Church

Grace Bible Presbyterian

Heritage Baptist Church

Highland Hills Baptist Church

Indianola Regular Baptist

Memorial Baptist Church

Monsanto Fund

Niobe Baptist Church
Northfield Baptist Church

Pleasant Grove

Pleasant Hill Baptist

Church

Pleasant View Bible Church

Regular Baptist Church

Shoaff Park Baptist Church

Southgate Baptist Church

Tabernacle Baptist Church

United Baptist Church

Wheelersburg Baptist Church 


\section{When Miracles Merge. . .}

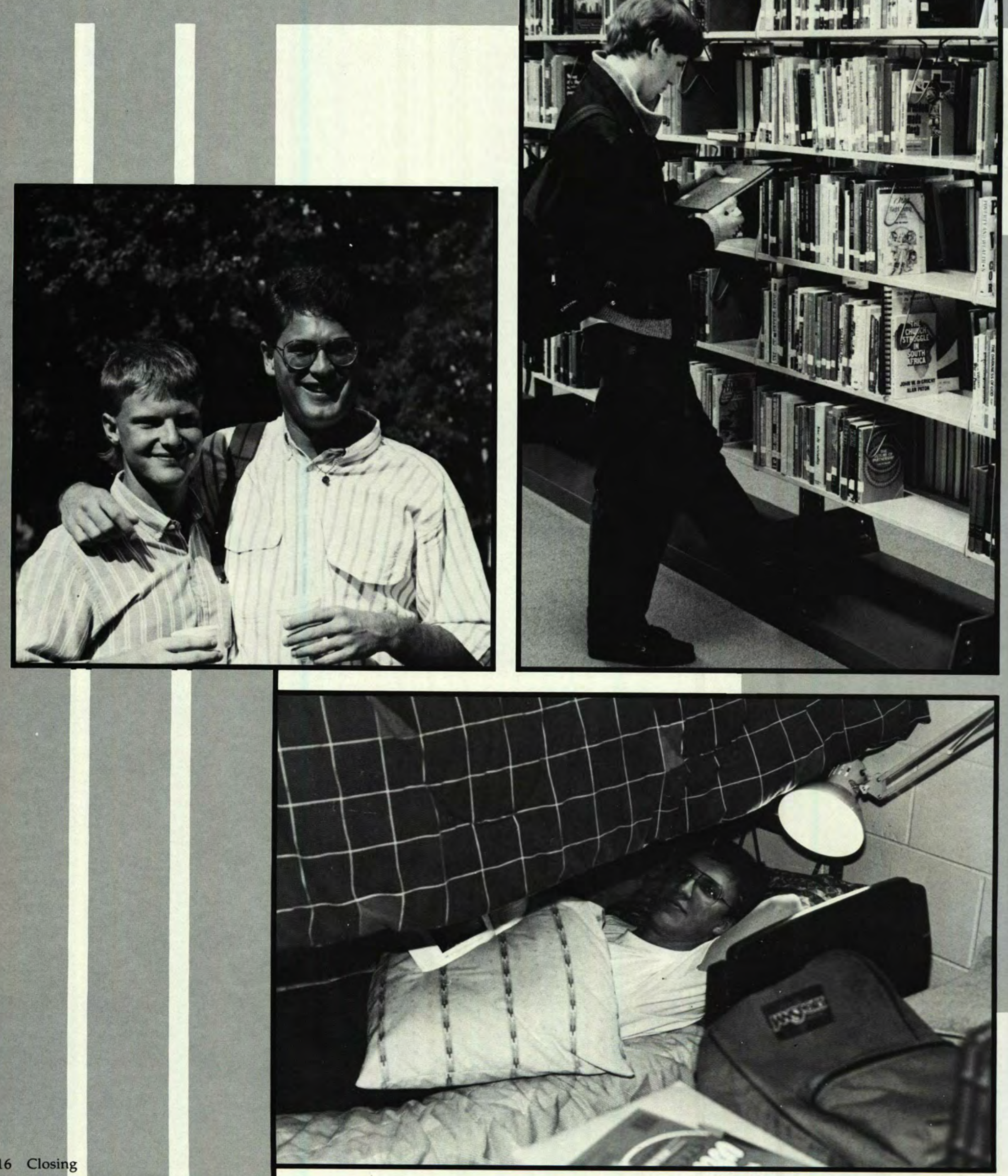



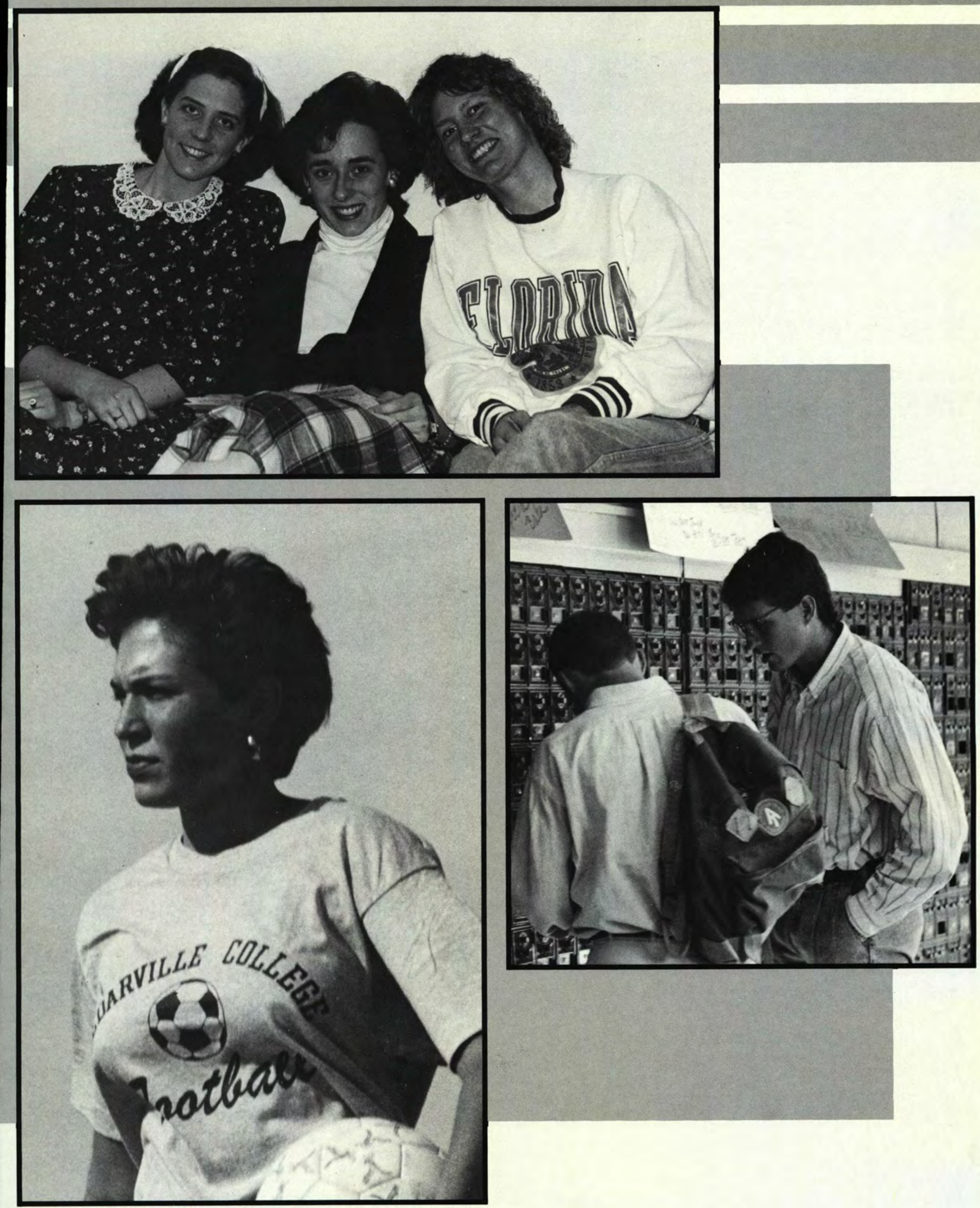

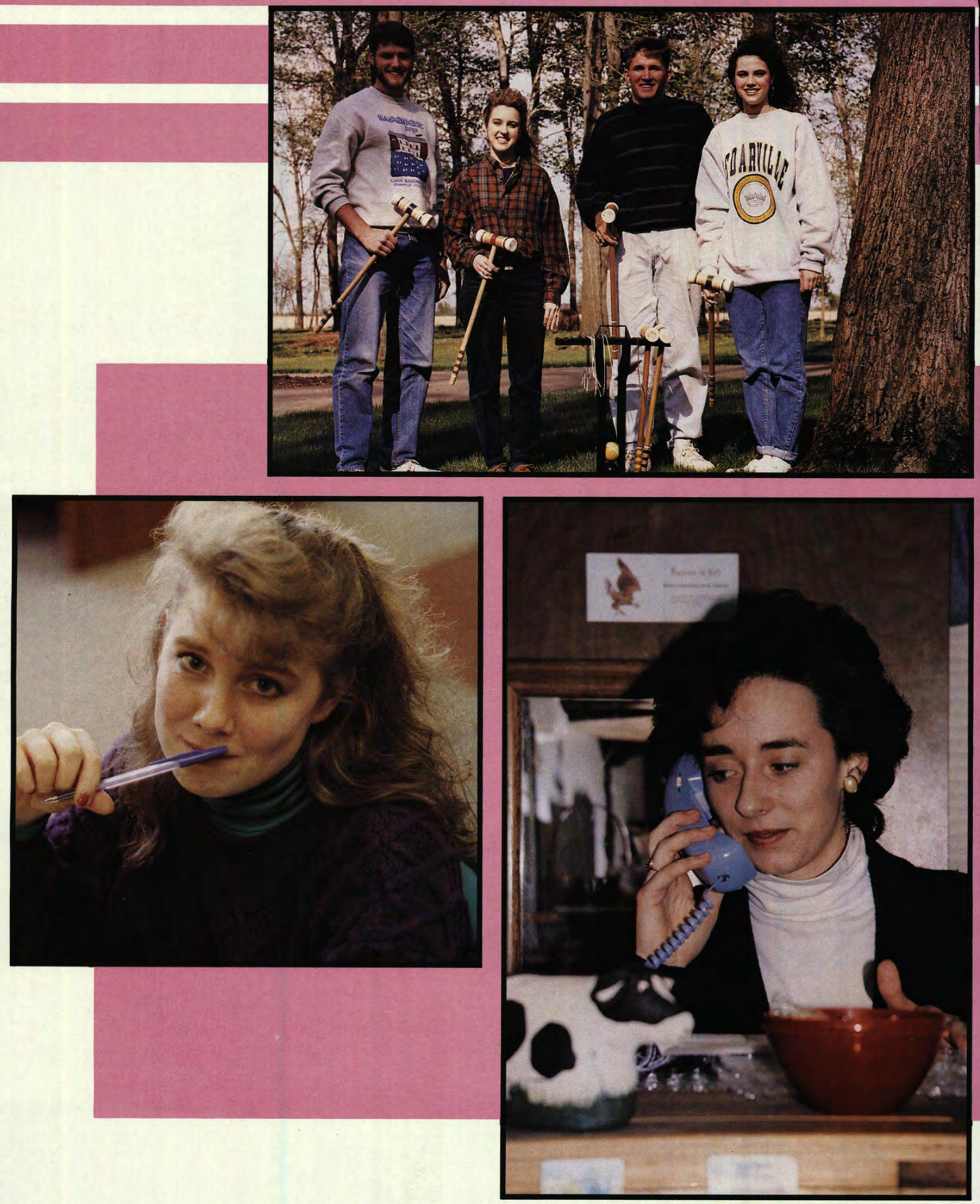


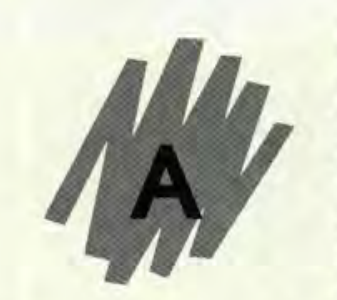

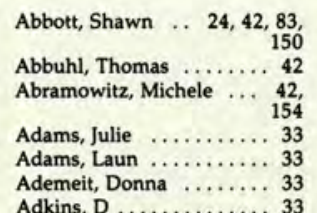

Adkins, D .......... $31,103,17$

Adolph, Cynthia ....... 42

Adsit, Christopher ...... 42

Adsit, Kippy

Ager, Rachel
Ager, Ruth

Agley, Margee .............. 33

Ahlgrim, Kim ............

Alexander, Elizabeth .... 174

Alexander, Jamie .... 33, 86

Alexander, Ralph ....... 174

Alexander, Stephen $\mathbf{4 2 , 1 0 3}$

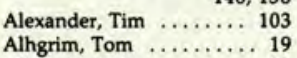

Allen, Anthony $\ldots \ldots \ldots \ldots 24$

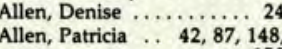

158
Allen, Roger .......... 174

Alley, Beth

Allison, Jason . ..... 24, 135

Ambrose, Dan ....... 33,135

Ambrose, Dawn …. 33, 155

Anderson, David ...... 33

Anderson, Heather .. 42, 86

Anderson, Lisa ..... 12, 174

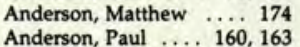

Anderson, Ray . . . . . . 42

Andrews, Michael ...... 24

Ansell, Janet ....... 42, 88

Apperson, Brent ... 33, 160,

Apperson, Lori $\ldots \ldots \ldots .24$

Armstrong, Carrie .... 33, 94

Armstrong, Rebecca .. 24, 91

Ash, Christina ......... 85

Ashbaugh, Sarah .......... 33

Ashcraft, Eric ...... 24, 135

Atkins, Ron $\ldots \ldots \ldots \ldots .175$

Aughinbaugh, Barb ...... 42

Aughinbaugh, David ..... 24

Austin, Melissa ..... 33, 159

Awabdy, Nicholas ... 24, 138

Ayers, Craig

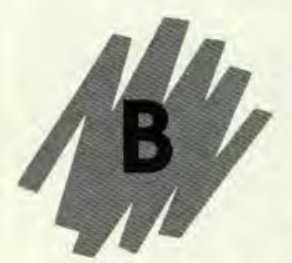

Baab, Phil

42,92

Back, Frank

Back, Harold

Baesen, Shelly .........24, 89

Bailey, Kim .... 42, 92, 158

Bailey, Melissa ......... 19

Bailey, Todd ..... 13, 175, 194

Baise, Barba

Baise, Travis
Baker, Andrew Baker, Lori

Baker, Michael

Baldwin, Martha

Bales, Brian

Ballentine, Janice

Balnton, Steven

Bandixon, Linda

Banfield, Rebecca

Barenscheer, Tara

Barghorn, William

Barkema, Lon

Barker, Traci

Barnard, Shannon

Barnes, Brian

Barnes, David

Barnhart, Claire

Barnitz, Lis

Bartholomew, Ruth ... 33, 85

Bartlett, Sonja ... 33, 90, 103

Barton, Jeremy ...... 33, 143

Barwitz, Lisa

Bass, Marla

Bates, David

...... 33, 103

Phillip ... 33, 45, 158,

Bauer, Marnie $\ldots \ldots .42,97$

Bristen

Bauman, Lawrence ...... 24

Beach, Abbe ..... . 33, 86, 155

Beach, Jonathan ... 103, 148,

Beach, Susan $\ldots \ldots \ldots .33,81$
Bean, Linda $\ldots . .13,122,175$

Bean, Linda . . . 13, 122, 175
Beasley, Renee ... 24, 92, 149

Beasley, Renee ... 24, 92, 149

Beaulieu, Andrea .. 33, 92, 93

Beckelhymer, Kyle ....... 33

Beebe, Gwendolyn ... 33, 89 ,
Beecher, Nicole .... 42, 148,

Beede, Gwendolyn ..... 87

Beikert, Grace ......... 19

Beiler, Jeffery $\ldots \ldots \ldots \ldots \ldots .24$

Bell, Andrew

Bell, James

Belmont, Kathleen .... 42, 149

Belmont, Kevin .... 24, 118

Bender, Lorynda ........

Bendt, Michelle .... 100, 107 ,

Benefiel, Jennifer .... 33, 155

175
175

Benson, Erik ....... 33, 87

Berry, Danette ......... 33

Berry, Larissa

Besosa, Robert

Beste, Jeff

Rethel, Melissa ......... 86

Bice, Leslie ......... 42

Bickel, Nathan ............ 24

Biddinger, Mark .... 101, 176
Biddinger, Matthew .... 100

Biddle, Benjamin ... 24, 138

Biggers, Kristie .......... 24

Bingham, Melissa ....... 176

Binning, Eric $\ldots \ldots \ldots \ldots, 24$

Bird, Jenny ............. 42

Bird, Jonathan .. 42, 84, 155 ,

Bird, Melissa ....... 24, 93

Birley, Mary $\ldots \ldots \ldots .42,86$
Bishop, Aaron $\ldots \ldots \ldots 24,92$

Bishop, Aaron $\ldots \ldots \ldots 24,92$

Bishop, David ........ 33, 100

Bishop, Jason . ....... 42, 92

Bishop, Lori $\ldots \ldots \ldots \ldots \ldots$ 42, 62

Bishop, Mary ... 42, 87, 159

Blackburn, Brian .... 33, 143

Blair, Brian ............. 19

Blake, Robert $\ldots \ldots \ldots \ldots .24$

Blenis, Darcey ... 24, 81, 158

Blenis, Robert $\ldots \ldots 150,176$
Bletzinger, Eric $\ldots . .150$

Bletzinger, Eric $\ldots \ldots \ldots, 100$
Blind, Brian $\ldots \ldots \ldots 24,152$

\begin{tabular}{|c|c|}
\hline \multicolumn{2}{|r|}{ Tara } \\
\hline \multicolumn{2}{|l|}{ nquist, S } \\
\hline Bloxham, Eric & Burrichter, Margaret \\
\hline Blyer, Kendra ...... & Bush, Jonathan .... \\
\hline Boatner, Jennifer . .... & Bush, Sharon \\
\hline Bockmann, Thomas . & Bush, Shawn \\
\hline Boice, Wendy ....... & .. 178 \\
\hline Bolender, Jeffrey $\ldots 138,176$ & Butterfield, Adrienne \\
\hline $\begin{array}{rr}\text { Bolet, Monica } \ldots \quad 12,94,172 \text {, } \\
176,190\end{array}$ & Byers, Norman . \\
\hline 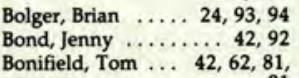 & $\begin{array}{l}\text { Byler, D Clyde } \ldots \ldots \ldots \ldots, 34 \\
\text { Byler, Kendra } \ldots \ldots .24,89,94 \\
\text { Byrom, Mellissa } \ldots \ldots \ldots \ldots 42\end{array}$ \\
\hline
\end{tabular}

Comegys, Miriam

Commons, Cindy ... 55,

Condren, 149, 173, 179, 203

Condren, Jodie .......... 25

Cone, Jeffery $\ldots \ldots \ldots \ldots 25$

Conrad, Robert ..... 25, 84

Constable, Pamela ... 90, 207

Cook, Andrew ......... 179

Cook, Gwendolyn ... 13, 152 ,

Cook, Jerri ....... 43, 158

Boone, Abby $\ldots .24,87,156$

Boone, Melinda $\ldots \ldots \ldots \ldots, 42$

Bork, Jennifer ... 24, 100, 103

Born, Laurel

Botdorf, Nichole

Bouchard, Jenae …...24, 88

Bouchard, Nichole ... 42, 158

Bouma, Deborah ... 33, 156

Bowen, Ryan ...... 143, 176

Bower, Brent ......... 177

Bower, Carmen .. 24, 81, 103

Bowersox, James $\ldots \ldots \ldots .19$

Bowman, Scott ..... 160, 163

Boyes, Michael $\ldots \ldots 42,87$

Bracy, Julie

Bradds, Connie

Bradley, Anita

.. 19

33,100

33,94

Brady, Matthew $\ldots \ldots .33,94$

Bragdon, Mayn

Bragg, Tyler

Brandmeyer, Arlie

Brandmeyer, R L

Brandon, Drew

Bretz, Jonathan

Breuler, James

Breuler, Marjorie 13, 158, 177

Brewer, John

Brewer, William

Britsch, Julie Matthew .... 24

Britt, Bethany .... 42, 95, 148,

Britton, Gary

Broaddus, Brian

Broadhead, Allison ... 33,87

Brock, Julie ...... 19, 149

Brock, Steve

Brokker, Sharon

Broman, Molly ....... 24, 83

Brooker, Sharie . 42, 121, 139

Brooker, Shelley ... 86, 103 ,

Brooks, John

Brooks, Mary

Brovont, Lisa

Brown, Ben

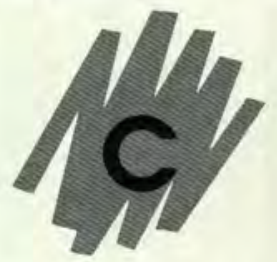

Cadamus, Tom ....... 135

Cain, Daniel ............ 172

Caldejon, Marivi .... 154, 178
Calkins, Steven $\ldots .24,25,83$

Callahan, Jaden .... 34, 128 ,

Callan, Don .......... 129

Calvert, Rebecca $\ldots \ldots \ldots \ldots .25$

Campbell, Fran.$\ldots \ldots \ldots \ldots$. 19

Campbell, Julie ....... 25

Canegrip, Miriam

Canine, Michelle .... 34, 159

Cannon, Tom ........ 19

Carlson, Paul . ....... 100, 103

Carlson, Ruth ...... 42, 154

Carman, Jennifer
Carnahan, Brian $\ldots \ldots .25,25$
C... 93

Carr, Alberta ............. 19

Carr, Curtis .... 60, 81, 148

Carr, Jill ............. 34

Carrick, David ..... 43, 135

Carroll, Michaell, Rhonda .... 159, 178

Carter, Tamara ......... 34

Carter, Timothy

Carteren, Tim $\ldots \ldots \ldots .15$

Casaletto, Peter $120,138,157,161$

Castelow, Tana ......... 25

Cato, Jim

Cearley, Brendon ........... 150

Cearley, Stewart $\ldots \ldots .178$

Chamberlain, Carol .... 141,

Chamberlain, Curtis .... 100

Chambers, Rachel ...... 100

Chase, Margaret $\ldots \ldots \ldots 43$

Cheek, Devin .... 34, 56, 151

Childers, Gary ...........34, 83

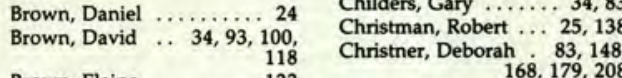

Brown, Elaine …... 122

Brown, Marcy $\ldots \ldots .42,94$
Brown, Matthew $\ldots . .34,94$

Clapper, Melinda ....... 34,90

Brown, Melanie ......... 2

Brown, Philip ......... 34
Brown, Priscilla . 34, 90, 160,

Brown, Stephanie ... 34, 94

Browning, Christine .... 177

Browning, John

Brubaker, Mich

Bruckner, Daniel

Brundage, Holly

Brunton, Susan

Buckingham, Jeffrey

Buckley, Julie

Buent, Marcia

Burhoe, Karen

Burke, Elizabeth

Burkely, David

Burkholder, Jennifer $.55,17$

Burkholder, John .... 24, 25

Burkley, David

Tracie

Burns, Rebecca
Burns, Robert

Burns, Robert

100,103

122
.178

24,25

Cook, Jerri $\ldots \ldots \ldots .43,158$
Cook, Mara $\ldots \ldots \ldots \ldots 1180$

Cook, Steven $\ldots .34,100,211$
Cooper, Amy $\ldots . . .153,180$

Cooper, Jennifer $\ldots \ldots \ldots, 34$

Cooper, Kristen ..... 43, 92

Cope, Paul

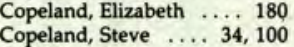

Cordier, Jackie ......... 34

Corner, Kim ............. 180

Cornett, Jennifer . 25, 90, 155

Cornish, Diane

Cossair, Tom

Courtright, Christina 43, 151

Crace, Mike

Craddock, Ronda

Craig, Monti

Cramer, Scott

Crandall, David

Crane, Lori .

Crary, Jason

Crawford, Eric

Creekmer, Rache

Creekmur, John

Creviston

Crouse, Terri $\ldots . . . .34$

Crouthamel, Scott …..... 25

Crow, Jennifer $\ldots \ldots \ldots \ldots 25$

Cruickshank, Mark ..... 34

Cruz, Lynette ... 34, 122, 141

Cudney, Jerilyn

Culp, Jodi .. 43, 154, 160, 161 


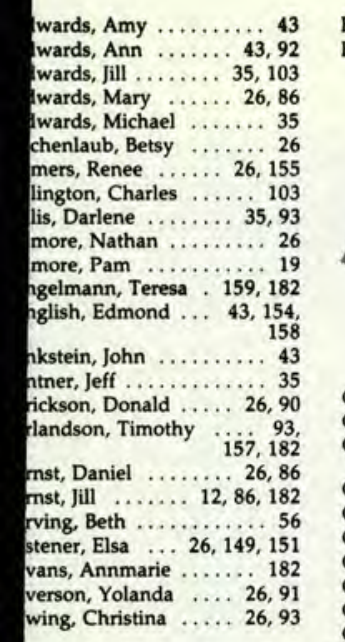

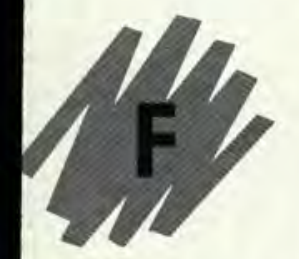

ailor, Samuel $\ldots \ldots \ldots 35$
ales, Elizabeth $\ldots .26,85,116$

ales, Elizabeth . $26,85,116$ Paragalla, Sylvia $45,150,151,160$
, Farkus, Andrew ......... 26 Farnsworth, Laura $\ldots \ldots 43$ Fath, Kelly .. $\begin{array}{r}12,23,60,162 \\ 173,183,208\end{array}$ Faulkner, Susan $\ldots \ldots \ldots \ldots$
feldman, Jocelyn ........ 43 Feliciano, Amy $\ldots \ldots \ldots$.
Feliciano, Michael .... 56, 63, Felt, Timothy .. 84, 151, 173 Ferrigno, Michelle . . 35, 155 Ferro, Joanna …84, 159, 183 Fidger, Amy $\ldots \ldots \ldots 43,150$ Fidler, Kevi Field, Jason ... Filer, Dana $\ldots \ldots \ldots \ldots .43,87$
Fillinger, Julie $\ldots \ldots \ldots \ldots 183$ Finn, Tami ............. 26 Fiorello, Peter …........26 26 Fiorito, Shelley $\ldots \ldots \ldots 35,91$
Fires, Bob $\ldots \ldots \ldots \ldots \ldots .131$ Fires, Bob $\ldots \ldots \ldots \ldots \ldots$.
Fires, Judy ........... 19
Fischbacher, Christine Fischbacher, Christine
$92,100,153$ Fisher, Tim ............. 2020
Fissel, Nancy $\ldots \ldots \ldots \ldots \ldots 20$ Fissel, Nancy
Fletcher, Derek ...............26 26 Floyd, Timothy $\ldots \ldots \ldots \ldots .35$
Foge, Mary Ellen $\ldots \ldots \ldots . .211$ Fogg, Mary Ellen $\ldots \ldots \ldots .211$
Fogle, Kimberly ......... 26 Fogle, Kimberly $\ldots \ldots \ldots \ldots, 26$
Fogle, Todd $\ldots \ldots \ldots, 43,83$ Fol

Fontaine, Scott ........... 35
Ford, Debra ......... 26 Ford, Debra ............ 26
Ford, Timothy .......... 2 Fortner, Jennifer $\ldots \ldots \ldots 26$

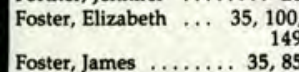
Foster, James $\ldots \ldots \ldots .35,85$
Fox, Rhonda $\ldots \ldots \ldots \ldots .183$ Francis, Bradley ........ 26, 35 Francisco, Steve $\ldots . .35,15$
Frazier, Sylvia $\ldots . .36$ Freebourn, Jennifer ........ 160 Freeman, Melissa .......26, 98

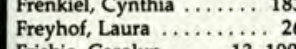
Frisbie, Carolyn ..... 13, 100

Fry, Kassandr: Fuchte, Todd

Fuller, Craig

Fuller, Dennis

Fuller, Karen

Fuller, Marlo $\ldots . .43,94,15$

Fulton, Elizabeth $\ldots \ldots \ldots, 35$
Fulton, Heather $\ldots \ldots \ldots .35$

Fulton, Heather $\ldots \ldots \ldots 35$
Furguson, Jennifer ........ 35

Furman, Brenda .......... 35

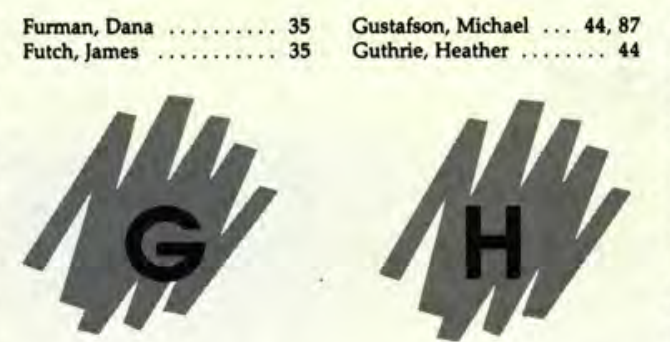

Gabnebin, Linda ... 103, 184 Haaksma, Lisa .... 26, 100

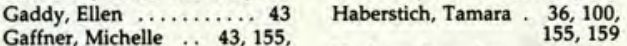
Gaglio, Stephen $\quad 163$ Gagnebin, Linda ..... 12, 158 Gaines, Brian .......... 184 Gallup, Michele .... 156, 184 Gannon, Cynthia ..... 26, 141 Gannon, Cynthia $\ldots \ldots 26,141$ Gardner, David … 26, 100 ,

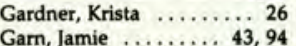
Garn, Jamie $\ldots \ldots \ldots .43,94$ Gasparro, Kathleen . . . 35, 149 Gates, Donna ........... 184 Gathany, Kari ........... 35 Gathany, Todd …......... 184 Gavitt, Sherry $\ldots \ldots \ldots \ldots 26$ Geiger, Amy ....... 35, 92 Geise, James $\ldots .35,87,158$ Geist, Alan ......... 20, 157 George, Mark ............. 100 Gerber, Heidi .......... 184 Gerendas, Rebecca .. 94, 15 Ghere, Eric ........ 35, 57 Gibbs, Kristen .. 35, 93, 155

Gidley, David ......... 20 Gifford, Joshua ........ 35 Gill, Nathan

Gill, Pillip ............ 44 Gillam, Rebecca $\ldots 26,86,158$ Gillett, Lisa ..... 35, 93, 150 Gillies, Leigh ....... 35, 44, 151 Gilson, Matthew ........ 35 Gingerrich, Maria ....... 35 Glauthier, Renee ........ 35

Godden, Sean

Godeman, Jonathan ...... 153 Goding, Matthew ...... 26 \begin{tabular}{lll} 
Goldbourn, Kimberly & $\ldots$ & 26 \\
\hline
\end{tabular} Gollihugh, Karen $\ldots \ldots \ldots .35$ Gonzalez, Paolo ........ 206
Good, Brian .......... 26 Good, Christopher ....... 26 Good, Sarah .......... 35 Goodman, Sara .... 161, 207 Gordon, Andrea ..... 35, 83 Gorman, Raquel .... 89, 184 Gosman, David .... 44, 158 Gosser, Dana .... 26, 81, 155 Gottwals, Dianne ..... 20 Grabbe, Susan $\ldots . . .26,26,161$

Graham, Robert ........ 26 Graver, Michael ….... 26 Graves, Philip ...... 26, 82 Grayson, Carrie $\ldots \ldots \ldots .26$
Green, Cinda $\ldots \ldots \ldots 44,89$ Green, Cinda $\ldots \ldots \ldots .44,89$ Green, Michelle ....... 36, 95
Greenly, Jack ......... 26 Greenly, Jack ..........26, 26 Greenwood, Chris .. 131, 136 Greenwood, Janice $\ldots \ldots .20$ Griffith, Samantha .....26 26 Grinnell, Jeremy $\ldots \ldots .26,81$ Gritsavage, Reid ..... 26, 81 $\begin{array}{lll}\text { Gromko, Christina } & \ldots \ldots & 184 \\ \text { Gromko, Eliza } & \ldots \ldots \ldots & 26\end{array}$ $\begin{array}{llll}\text { Gromko, Eliza } \ldots \ldots \ldots \ldots & 26 \\ \text { Groninger, Andrea } & \ldots \ldots \ldots & 36\end{array}$

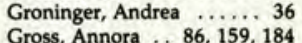
Gross, Annora . . 86, 159, 184 Gross, Brian ......... 129 Gudeman, Jon ...........44 Gudeman, Jonathan . 87, 148 Guess, Paul ........ 36, 84
Guider, Donna ..... 44, 151 Guinther, Brian ..... 44, 82

Heft, Michael ............

Heft, Mike ......... 96, 151

Heiney, Cheryl $\ldots \ldots \ldots \ldots 185$

Heinrich, Tim ........ 44

Heldreth, Shelly ....9.94, 155

Heller, Christopher ..... 185

Hemming, Rosann ...... 36

Henderson, Gail .... 36, 94

Henry, David $\ldots \ldots \ldots \ldots$
Henry, Debbie . 36, 122, 157

Henry, Melissa ........ 36

Heritage, Jennifer .. 44,103
Herring, Chris . . . . . 140

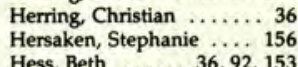
Hess, Beth ..... 36, 92, 153 $\begin{array}{lll}\text { Hess, Steven } \ldots \ldots \ldots \ldots & 186 \\ \text { Hetherington, Scott } & \ldots & 186\end{array}$ Heyd, Ruth . . . . . 27, 103 Heying, Tin

Hibbs, Brian Hickman, Georgia .... 27, 86 Hicks, Paul ....... 36, 154 Hidalgo, Bumper .... 50, 15 Hidalgo, Heather … 44, 148,

Hiebert, Aaron ......... 27 Higginbotham, Kim .. 36, 103 Higley, Ann ........ 27, 93 Hill, Krista ... 13, 55, 163, 186 Hill, Shannon ... 44, 95, 139 Hill, Shannon $\ldots .44,95,139$
Hines, Paula $\ldots . . . . .186$ Hines, Paula $\ldots \ldots \ldots \ldots 186$
Hines Randal $\ldots \ldots \ldots \ldots .36$ Hinman, Kathleen ........ 44 Hinnergardt, David ....... 170 , Hoelscher, Heather ... 90,93 Hoewing, Stephan ....... 36

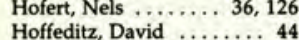

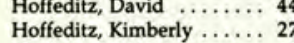
Hoffman, Beth ......... 44 Hoffman, John ......... 27 Hoffmann, Kenneth - 36, 156 Hofheinz, Karl ...... 44, 94 Hofmann, Beth $\ldots \ldots \ldots \ldots$
Hoke, Brian $\ldots \ldots \ldots \ldots$
36 Hoke, Gara $\ldots \ldots \ldots \ldots .27$
Holbrook, Melodie . 106, 187 Holbrook, Melodie $.106,18$
Holcomb, Steven $\ldots \ldots \ldots \ldots 27$ Holden, Steven

Hollander, Laura

Hollaway, Mary .... 36, 35

Holley, Rachel . ....... 27 Holmes, David .. 27, 90, 155

Holsinger, Mark $\ldots \ldots \ldots 36$ Holt, Donald $\ldots \ldots \ldots \cdots$
Holtz, Doug $\ldots \ldots \cdots \cdots$
187 Hoover, Apryl .......... 36 Hoover, Don ........... 153 Hoover, Elaine $\ldots \ldots \ldots \ldots .44$
Horine, Benjamin $\ldots \ldots \ldots .27$ Horine, Benjamin $\ldots \ldots \ldots, 27$
Horst, Vonda $\ldots \ldots \ldots \ldots, 36$ Horst, Vonda $\ldots \ldots \ldots \ldots .36$
Horton, Gerry $\ldots \ldots \ldots 44,151$ Horton, Gerry $\ldots \ldots .44,15$ Houg, G Robert ........ 36 House, Kathy ….. 44, 156 Houser, Dee ........ 122, 123
Houser, James . 12, 158, 162 Howard, Melinda ......2 20 Howard, Patricia ........ 36 Howard, Rachel .... 27, 13 Howder, Scott $\ldots \ldots \ldots \ldots, 20$
Howe, Cory . ....... 27, 93 Howe, Cory $\ldots \ldots \ldots .27,93$
Howell, Tiffany . . . . . Hoy, Timothy ............2 27 Hubbard, Kimberly ... 36, 92 Huber, Nicole $\ldots \ldots \ldots \ldots .27$
Huber, Pearl $\ldots \ldots \ldots \ldots \ldots 27$
Huber, Philip $\ldots \ldots \ldots \ldots .27$ Huber, Trish Hudnall, Todd Hudson, Julie ........ 36,8 Hughes, Lisa .......... 44 Humble, Mindy .... 131, 136 Hunsaker, Stephanie $\ldots \ldots 0,86$ Hunsberger, Heather ..... 44 Hunt, Carmen ...... 27, 131 Hunt, Leigh $\ldots \ldots \ldots \ldots \ldots,{ }^{20}$
Hurlburt, David ......... 187 Hurlburt, David $\ldots \ldots \ldots \ldots$
Hurst, Amy $\ldots \ldots \ldots \ldots$
Husaker, Stephanie $\ldots \ldots \ldots$ Husaker, Stephanie $\ldots \ldots \ldots$
Hutchison, Stephaney $\ldots . .27$ Huxtable, Jennifer .... $86,158,92$ Hyten, Jenine ...... 36, 149

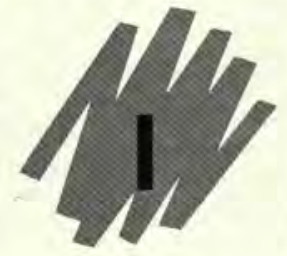

Illian, Christa Illian, Susan
Irish, Kathleen

Irish, Katie

rving, Beth $\ldots \ldots \ldots \ldots .84$ Irving, Elisabeth ....... 36 Irving, Mark .... 27, 92, 155 Irwin, Peter ....... 44, 92 Iten, Bradford

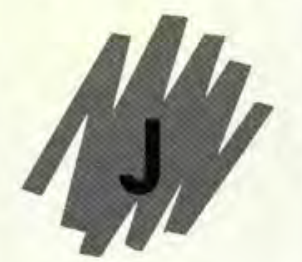

Jackson, Robert Jacobs, William

Jamera, Gina

Jamieson, Andrew

Jamieson, Andy

Jamora, Gina

ariga, Bill

Jarman, Susan

Jefson, Jill

Jenks, Jonath

Jensen, Jodi

Jensen, Kristen

Jensen, Nicole

Jester, Daniel

John, Relyn S

John, St Robyn

Johnson, Edward

Johnson, Eric F

ohnson, Jennifer

Johnson, Jonatho

Johnson, Judy

Johnson, Marcy

Johnson, Martha

Johnson, Shirley

ohnson, Victoria

Johnston, April

....27,95 Joiner, Jeff ... 107, 150, 160

Joiner, Randall 161, 164, 18

Joiner, Randy . . . . . . . . 160

Jones, Barry ........ 27, 129

Jones, Christian ........ 27

Jones, Christine ...44, 89, 103

Jones, Jason . ............. 36

Jones, Jennifer . . . . . 81, 103, 156

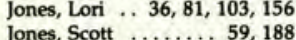

Jones, Steve ........... 44

Jones, Susan ..... 27, 87, 100

Jones, Tom ........ 44, 118

Justice, Susanne ........ 36

Justice, Tracy .... $90,94,155$

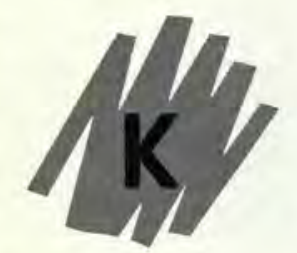

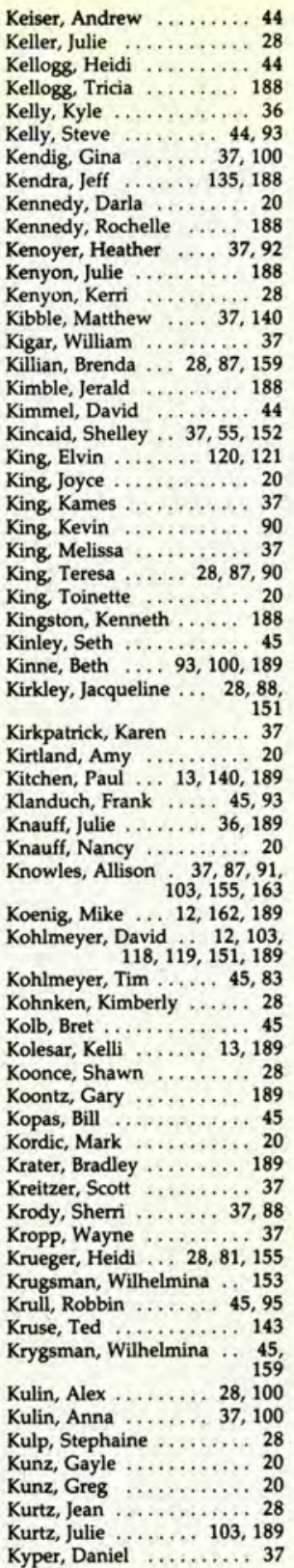

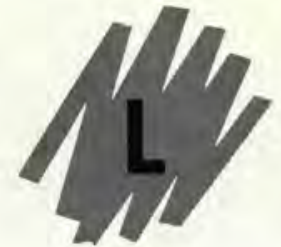

Ladenburger, Melissa .... 37

Lahman, Jennifer .... 37, 160

Lam, David ....... 45, 152

Lambert, Jennifer $\ldots \ldots \ldots \ldots$
Lancaster, Susan $\ldots \ldots \ldots \ldots 37$

Lancenese, Brian ...... 189

Landrum, Kristi ..... 28, 93

Lane, Beth $\ldots \ldots \ldots 155,159$

Lang, Craig …........ 28

Lang, William ..... 103, 189

LaPine, Jeremy $\ldots \ldots \ldots . .37$

Larkin, Sheri ...... 85,190

Latham, Rodney ..... 13, 190

Latham, Tawna ..... 37, 86

Lauener, Matthew . . $28,82,89$

Lausin, Joe ...... 28, 82, 89

Law, Jill ............... 20

Lawrence, Janet ...... 190

Lawson, Renee .. 37, 85, 121

Leadbeater, Holly ...45, 81 , 


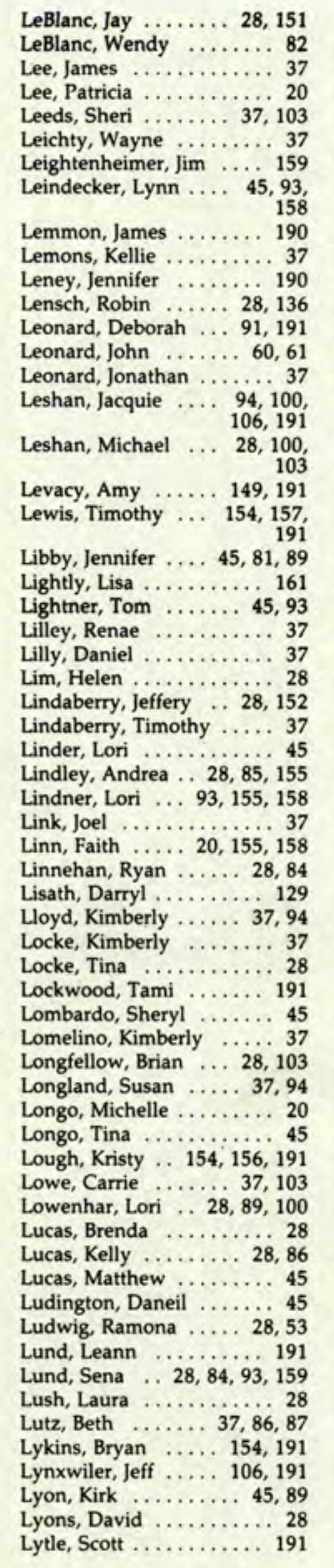

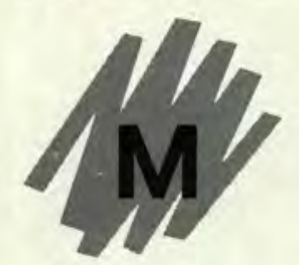

Mach, Julie

Mackenzie ........ 28, 93

Mackenzie, Heidi ...94, 19

Macomber, Carl .......... 91

Madding, Dawn …. 88, 191

Madsen, Tracy $\ldots \ldots \ldots \ldots$
Malone, David $\ldots \ldots \ldots \ldots 45$
Maners, Michelle .... 159, 192

Maners, Michelle .... 159, 192
Mann, Carrie ...... 28, 158

Mann, Chandra ....... 45, 94

Manning, Trish $\ldots \ldots r$
Marks, Carrol $\ldots \ldots \ldots \ldots$
131
100

Marks, Lisa .......... 192

Marsh, Kelly …....... 192

Marshall, Laura ....... 37

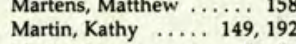

Martin, Kathy $\ldots \ldots .149,192$
Martin, Lee $\ldots \ldots \ldots .37,95$

Martinez, Melanie ..... 45, 89

Marzano, Dennis ..... 37, 118

Mascari, Jason

Mascari, Tonya

Mason, Bethan

Mason, Joseph

Mathews, Mark
Mathis, Christopher ... 192 Mathisen, Tom . . 37, 88, 159
Mathwin, Steve ..... 37, 92 Mathwin, Steve ...... 37, 92 Matthwin, Steve .... 151, 211 Maust, Audrey Maust, Audrey Maxie, Wayne Maxon, Anna . Maxson, Cynthia Maxson, Daniel Maxwell, Renee McCallister, Jim McCallister, Lori ...... 207 McCarthy, Christiane .... 37 McClain, Amy .. 94, 161, 207 McClish, Michelle ...... 28 McComb-Davies, Beverly ... 28

McCormick, Sherrie .... 28 McCoy, Kim .... 37, 131, 136
McCoy, Molly .......... 37 McCullough, Shelly ... 82, 88 McCullough, Sherrie ..... 28 McDonald, Amy .... 37, 45, McDonald, Amy … 37, 45 , McDonald, Rachel ‥ 95, 100 McDonald, Rebecca ..... 192 McDonald, Tricia ........ 45 McDugle, Jonathan $\begin{array}{r}13,162 \\ 173,192\end{array}$ McDugle, Melinda ... 37, 87 , McElroy, Allen ... 120, 138 , McElroy, James ....... 45 McFadden, Michelle . ‥ 94 McGillivray, John ...... 118 McGillvary, Suzanne ..... 28 McGinnis, Steve ....... 45

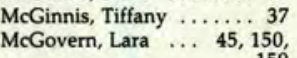
MCGovern, Lara ... 45, 150 ,

McGrady, Paul .... 37, 163 McGraw, Elisa .... 161, 192 McGuire, Dwight ....... 103
McKanna, Bruce . 37, 81, 155 McKinley, Craig ......... 28 McKinley, Dominic 87,128

McKinley, Jamia …... 193 McLatchy, Melissa ........ 37

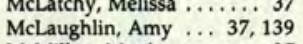
McMurtry, Mark ... 88, 150 , McMurtry, Mark … $\quad 88,150$, McNabney, Lara ... 159, 193 McNabney, Melina ..... 37 McNeal, Kezia ..... 103, 151
McPherson, Sheri ... 37, 94 McQueen, Todd ..... 37, 87 Measley, Michael ...... 94 Meeder, Jon .... 28, 94, 135 , Meek, Gregory ......... 28 Megilligan, Brian ... 28, 100, Meigs, Steve $\ldots \ldots \ldots 37,88$ Melvin, Christina .... 28, 81 Menendez, Anthony . . 45, 61 Mesnard, Dawn ..... 154, 193
Meyer, Ben .......... 45 Meyer, Ben Michael, Christine .... 12, 193 Michael, Lynda ........ 28 Milentis, Gregory $\quad$ 28, 90, 92 Miller, Andrea Miller, Brian ..... 28, 85, 120 Miller, Charlene $\ldots \ldots \ldots .45$ Miller, Cheryl

Miller, Cindy Miller, Craig ….... 28 Miller, Karen $\quad 45,156$ Miller, Mark ........ 45, 158 Miller, Rhonda Miller, Ron . Miller, Vicki ...... 45, 88, 91 Miller, Wendy .... 103, 158 , Milligan, Johnny $\begin{array}{r}46,59,92 \\ 118,150,157\end{array}$ Mills, Dave ... 46, 155, 160 Mills, Deborah ........ 46 Mills, Robin ....... 28, 86
Mills, Scott .... 46, 103, 151 , Milner, Kristin . .... 28, 139 Miner, Kelly …..... 29, 92 Misere, Jon $\ldots 29,90,153,155$
Misirian, Nate $\ldots \ldots .37,91$

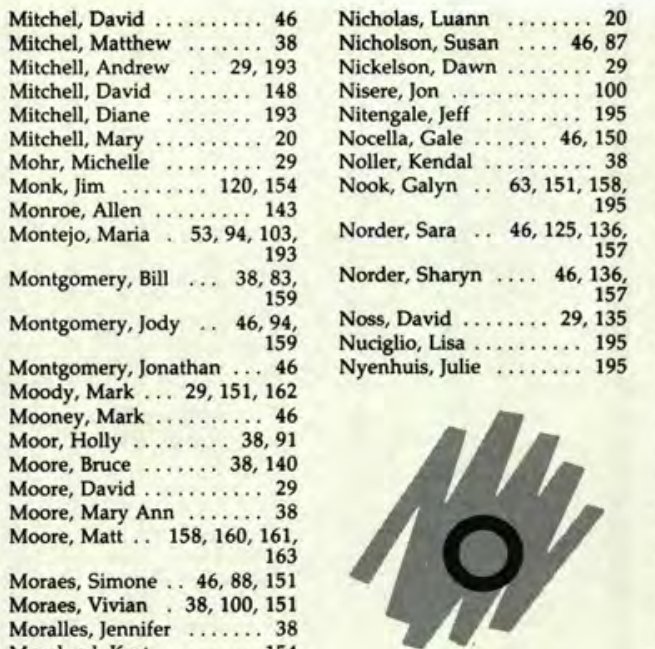

Moralles, Jennifer $\ldots \ldots \ldots, 38$

Morgan, Jeffery ......... 38

Morgan, Kristine $\ldots \ldots \ldots .29$

Morris, Dale

Morris, George

Morse, Hope

Morton, Jeffrey $\ldots \ldots \ldots .194$

Moser, Matt ..... 46, 56, 138

Mosley, Raul ... 46, 160, 161

Motl, Christopher ........ 38

Mott, Melissa ...... 149, 194

Mouser, Angie ..... 46, 103

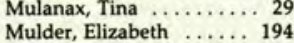

Muller, Stacy ….... 86, 194

Mullins, Loren ........ 29

Mummey, Julie $\ldots 38,95,159$
Munger, David ....... 107

Murachanian, Kevin . $\begin{array}{r}38,87 \text {, } \\ 100\end{array}$

Murdoch, Mark _. 13, 140,

Murdoch, Murray …. 140

Murphy, James ... 29,85, 94

Murphy, Mark .. 46, 118, 157

Murphy, Michelle ....... 194

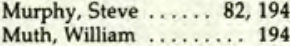

Myers, Buffie

Myles, Melinda ......... 194

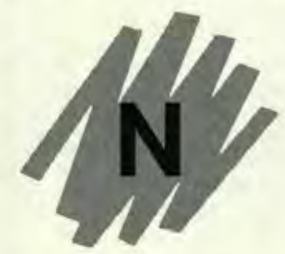

Nagel, Shannon ..... 38, 103

Naman, Melisa $\ldots \ldots \ldots .159$
Nast, Kristen ....... 46, 86

Nast, Kristen $\ldots \ldots \ldots .46,86$
Nauman, Melissa $\ldots \ldots \ldots .29$

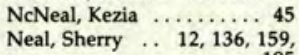

Neal, Sherry .. 12, 136, 159 ,
195
Nearmyer, Lisa

Nearmyer, Lisa $\ldots \ldots \ldots \ldots .46$
Neil, Daniel ....... 29,155

Neil, Daniel . $4 \ldots \ldots 29,155$
Neill, John . 46, 88, 118, 150 ,

Neiser, Amy ‥ 150, 159, 195

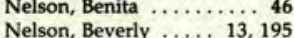

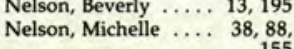

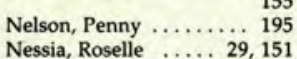

Nessia, Roselle ..... 29, 151
Nettleingham, Brian . . ... 38

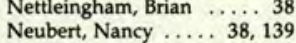

Neubert, Tanya ….. 29, 93

Neubert, Tim

Neubert, Tonya

157
139

Neudeck, Jennifer $\ldots \ldots \ldots 29$
Neumann, Celeste ... 89, 152

Neumann, Lorie ....... 89

Newcomb, Aaron ........ 29 Pennington, Todd ... 129, 143

Newell, Lori

Newmann, Celeste ....... 46 46 Perelka, Gregory .......... 196

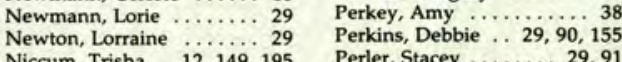

Newton, Lorraine
Niccum, Trisha $.12,149,195$
O'Donnell, Erin .... 38, 160 O'Keefe, Kayley ..... 38, 100 O'Neal, Christine ..... 29, 38,94 Oberholtzer, Jody .... 29, 91 Oliver, Matthew .......... Olsen, Deborah ..... 29, 90 Olsen, Marsha ........ 38, 211 Ooms, Brad ........ 29, 103 Ortlieb, Michael .......... 46 Ortloff, Wayne .... 46, 98, 103
Osborn, Deanna ........ 29

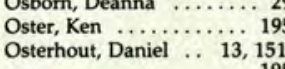
Oswald, Randy $163,131,150$ Otto, Matthias ...... 38, 89 Overmoyer, Julie ..... 38, 95

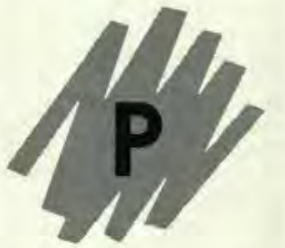

Pachard, Christan

Pack, Teresa .......

Paddock, RoJean

Padgett, Steve

Pagnard, Charles

159,196

... 99, 103

$93,155,158$

Palmer, Brad ...... 29, 103

Pangburn, Dawn .. 29, 86, 87

Paradiso, Michael $\ldots$...... 196

Pardi, Bill ............. 196
Pardi, Paul . . . . . . . . 196

Park, Tressa .......... 46

Parrow, Chad ........ 29, 91

Patrick, Mee

Paulhamus, Brenda ... 46, 93

Pavia, Wendy

Pawluk, Laurie

Payne, Rose

Pearson, Curt ...... 38, 135

Pearson, Jennifer .... 38, 103

Pearson, Rob $\ldots \ldots \ldots \ldots \ldots .68$

Peary, Darryl ........... 46
Perrigo, Matthew .. 154, 163 ,

Perry, Georgia ......... 46

Persons, Chadwick .. 29, 85

Petek, Greg . ......... 38

Peters, Annette …....149, 196

Peters, Heather …....29, 29,87

Peters, Sara .... 88, 158, 196

Peura, Karen ......... 29

Prahler, Ruth ........ 38, 93

Phillips, Cheryl .......... 29

Phillips, Dawn .. 90, 131, 197

Phillips, Doug . ........ 20

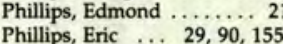

Phillips, Michael .... 46,94

Phillips, Vicki ........ 197

Phipps, Heather $\ldots \ldots \ldots, 29$

Pierce, Kimberly . ...... 197

Pierson, Douglas ......... 197

Pike, Gretchen

Pincket, Chris

Pinkerton, Cheryl $\ldots 00,103,15$

Plantz, Gregory ......... 197

Pletcher, Rosemary . . 38, 100

Plunkitt, Mary .... 39, 94, 197

Plunkitt, Michelle .. 88, 148

Plush, Jonathan $\ldots \ldots 29,138$ Poiesz, Mildred ......... 29 Polsdorfer, Debbie ‥ 12, 100

Ponyburn, Dawn ...... 8 Pope, Jim ........ 46, 94 Pope, Michelle $\ldots \ldots \ldots \ldots, 46$
Porter, John $\ldots .29,120,138$ Porter, Susan ........... 46 Potter, Susan $\ldots \ldots \ldots \ldots \ldots .21$ Potts, Brannon ....... 29, 140 Potts, Matthew .......... 39 Potts, Matthew Kirk ............ 39, 95 Powell, Phillip ...... 29, 12 Powelson, Kimberly ... 149

Powers, Tracy ..... 46, 97 Prall, Michael

Precise, Mark

Prich Mu .......... 46

Priddy, Kathy .....4 46, 100

Priest, Wendy …..2 29, 86

Pritchard, Krista ..... 85, 139

Prusinowski, Maureen 94,29 ,

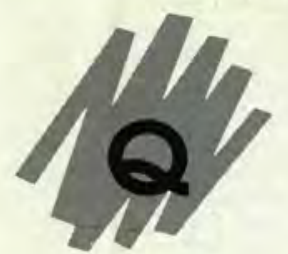

Quick, Bruce

Quinn, Carrie .. 13, 155, 158

Quinn, Tracy ....... 160, 15

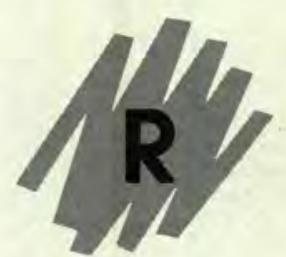

Radcliff, Beth

Radcliff, June

Radclift, Dale

Rains, Kevin

Randall, Rene

Ranger, Nan

Rank, Diane

Rathbun, April

Ratliff, David

Ray, Aaron

Ray, Aaron $\ldots \ldots \ldots \ldots 29,16$
Ray, Gina $\ldots \ldots \ldots \ldots \ldots, 197$
Rayder, Amy $\ldots \ldots \ldots$ 46, 100

Rebecca, Gerendas

Reed, Dan

Reed, Rebecca

Reed, Rob ... 39, 81, 87,

Reese, Joyce

Reese, Pete ..... 21, 129,

Rehfeld, Janette ...... 46,

Reich, Betsy

Reichart, Beth

Reilly, Kevin

Reno, Curtis

Reno, Lloyd .

Ressler, Don

Reynolds, Nathan

Rhind, Andrew

Rhodes, Tara $\ldots . .46,90,15$
Rice, Clinton $\ldots . .46,89,15$
Rich, Matthew ..........

Rhodes, Tara ..... 46, 90, 15
Rice, Clinton .... 46, 89, 15
Rich, Matthew ..........

Richard, Deborah ........

Richards, Amy

Richardson, Karla

Richardson, Rebecca

Richardson, Timothy 


\section{$\mathrm{s}_{1}^{7}$}

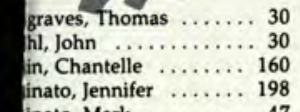

inato, Jennifer $\ldots \ldots \ldots$
inato, Mark $\ldots \ldots \ldots$

lomon, Mark ... 39, 94, 155

zman, Lyan

nd, Craig

ucier, Joan ......... 100, 198

e, Warren

ffer, Brian ........... 39

hauer, Tamara … 47, 95 ,

hearer, Daniel ... 143, 199

effel, Sherry $\ldots \ldots \ldots .39$
39,159

layer, Carol ...... 30, 94

hmitke, Randolph . 13, 199

fimitke, Roberta ...... 30

hroll, Eric $\ldots \ldots \ldots \ldots .81$

hroll, Steve ........... 30

hulz, Dwight . 93, 100, 199

chwaderer, Andy ... 47, 93 ,

hwaderer, Mindy .. 47, 121 hwanz, Paul ......... 39

chwartz, Amy ........ 39

cott, Kelly ....... 15i, 154

tt, Rebekah ....... 100, 199

ott, Sandy $\ldots \ldots \ldots \ldots 30$

boe, Kelly ........ 47, 87

thrist, Linda ........ 199

christ, Todd ...... 158, 199

ey, Chuck ........... 154

fiane, Bouchra .... 39, 121,

ibel, Mike ........ 39, 138

idner, Tami ... 47, 91, 92 ,

ffer, Amy . ........... 30

ifert, Amy .......... 83

lby, Sharyn .......... 150

ljan, Kimberly $\ldots . \quad 149,200$

llers, Rachel $\ldots \ldots \ldots 39,122$
wan, Todd ........ 135
.

pade, Jennifer . 13, 103, 200

haffer, Laura $\ldots \ldots \ldots \ldots .3$
haner, Brian $\ldots \ldots \ldots \ldots .39$
$39,89,158$

Shaver, Diane $\ldots .39,89,158$
Shaw, Lori $\ldots \ldots \ldots \ldots$.
39
...........

Shaw, Timothy $\ldots \ldots \ldots 39.39$

heen, Fred ........... 30

Sheen, Zella ....... 47, 149

Sheldahl, Robin .... 30, 100 , 162

hiles, Sarah ........... 92

thimp, Susan

hively, Paul ......... 39

Shoop, Kevin ...... 30, 9

Short, Tonya ........... 47

Shrader, Denise ...... 47, 94

Shreve, Matthew . . . . . . 30
Shrimp, Susan . . . . . 100

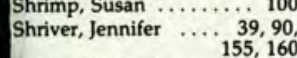

Shuler, Kimberly $\ldots \ldots \ldots 39$
Shumaker, David $\ldots .330,151$

Shumaker, David ... 30, 151
Shupp, Dan ........... 39

Shustrick, Celeste ....... 39

Silaghi, Marcie

Silber, Shell

Simmens, Joe

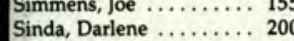

Singer, Penelope $\ldots \ldots \ldots 47$
Singer, Penny

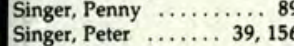

Singh, Sanjiv Sant ...... 140

Sininger, Heather $\ldots \ldots . .30$
Sipe, Marcy $\ldots . .13,158,200$

Sipe, Marcy $\ldots \ldots 13,158,200$
Sissom, Jolie $\ldots \ldots \ldots 39,91$

Sissom, Joy . . . . . . . . 103
Sizemore, Elisabeth ... 83, 200
Sizer, Tom .......... 135
Skiles, Jenifer $\ldots \ldots \ldots \ldots \ldots$
Skillman, John $\ldots \ldots \ldots \ldots .21$

Skillman, Sylvia $\ldots \ldots \ldots \ldots 21$

Slavens, Joseph $\ldots \ldots \ldots 30,83$

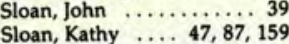

Sloderbeck, Dayna . 47, 150 ,

Smith, Alison .......... 39

Smith, Angela ....... 47, 92

Smith, Ben $\ldots \ldots \ldots \ldots \ldots, 21$

Smith, Brock .............. 30

Smith, Christopher ......200

Smith, Dee ............ 30

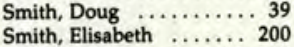

Smith, Jane Adams .. 21, 150

Smith, Janine ......... 200

Smith, Jennifer ........ 47

Smith, Kathleen ........ 150

Smith, Laura ......... 39

Smith, Lori -.....

Smith, Maria .... 39, 45, 151

Smith, Melissa ....... 47,87

Smith, Michael ......... 30

Smith, Michelle ..... 21, 47

Smith, Shawna $\ldots \ldots \ldots \ldots .47$

Smith, Shelly $\ldots \ldots \ldots \ldots .121$

Smith, Timothy ....... 200

Smoot, Joan $\ldots \ldots \ldots \ldots \ldots .21$

Snodgrass, Amber .... 30, 94

Snook, Linda ........... 30

Snow, Kevin $\ldots \ldots \ldots \ldots .39$
Snyder, Pamela ....... 39, 92

Solak, Janice $\ldots \ldots \ldots \ldots, 201$

Solum, Lisa _. 47, 82, 84, 103

Sommerfeld, Scott ...... 47

Sorensen, Eric .....40, 126

Sorg, Pamela ........... 30

Southwell, Christy .. 30, 88

Southwell, Randy ... 40,118

Souza, Jody .... 47, 87, 160

Souza, Shelly ....... 30, 55

Sprinkle, Tina ….... 47, 88

Spurr, Jonathan ........ 47

Stach, Todd ........... 30

Stackhouse, Sherry $\ldots \ldots \ldots .47$

Stamper, Cynthia .... 40, 155

Stanchi, Christina …...201

Stansbury, Ronald .... 12, 201
Stanton, Doug . ..... 40,143

Starr, Nikki ….. 40,94, 150 Starr, Nikki ..... 403, 153, 201 Starr, Tracy..$\ldots \ldots \ldots .103$ Stayton, Jerry $\ldots \ldots \ldots \ldots$
Steenwyk, Michael $\ldots \ldots . .201$

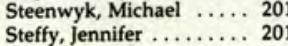

Steiner, Cheryl ..... 47, 81

$\begin{array}{llll}\text { Steiner, Kathryn } & \ldots \ldots \ldots & 207 \\ \text { Steiner, Timothy } & \ldots \ldots \ldots & 201\end{array}$

Steininger, Gretchen ...... 30

Stephen, Deana ........ 40

Stephens, Gail ......... 30
Stephens, J] .... 47, 159, 211

Stephenson, Martin ...... 40

Stevens, Becky

Stevens, Rebekah ....... 30

Stevenson, Virginia …....

Stewart, John .... 32, 47, 93

Stiles, Sarah .... 31, 93, 131

Stirn, Philip $\ldots \ldots \ldots \ldots .201$

Stitchman, Michele ..... 47

Stockham, Matt ........
Stolar, Allison .... 31, 92,93

Stoll, Lisa ........ 40, 155

Stoltzfus, Lisa . . . 47, 154, 160

Stone, Stephen $\ldots \ldots \ldots . .31$

Stonehouse, Hans ......
Stoner, Sara ....... 149, 201

Stover, Hollee ........ 47

Stover, Ryan $\ldots \ldots \ldots \ldots, 40$

Stringer, Tracy ... 47, 128, 129

Strock, Joanne ....... 202

Strong, Luman ... 40, 87, 138

Stroud, Steven .......... 202

Struble, Darin . 103, 118, 202

Stuenkel, Curtiss . . . 4 47,85

Stuenkel, Teresa ........ 31

Stull, Katherine .. 31, 91, 148
Stumbo, Gary $\ldots \ldots \ldots \ldots, 40$

Sturrock, Rebecca ..... 31, 91

Stutes, Patty ........... 21

uhr, Jason ........ 31, 138

Sutter, Christine $\ldots \ldots \ldots 202$

Sutton, Shelly $\ldots 40,89,159$

$\begin{array}{llll}\text { Swackhamer, Teresa } & . \ldots & 31 \\ \text { Swackhamer, Tonya } & . . & 47\end{array}$

Swackhamer, Tracy ..... 92

Swanson, Angelia ......

Swanson, Cynthia $\ldots .13,202$

wartzentruber, Rita .. 31, 87

Sweetland, Sara ..... 47, 158

Swensen, Brent ........ 47

Swich, Mickey ........ 208

Swigart, Lora ............ 141, 202$$
\text { Swinehart, Kristal ....... } 40
$$

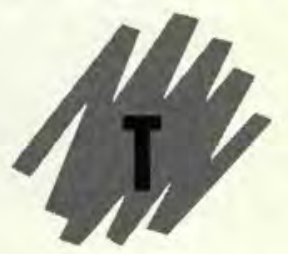

Tackett, Laura

Tague, Amy $\ldots \ldots \ldots \ldots, 40$
Tague, Jeffrey $\ldots \ldots .163,202$

Tait, Elizabeth ........47

Tales, Beth ........50, 121

Talyor, Douglas .......... 40

Talyor, Tania ........... 40

$\begin{array}{ll}\text { Tapp, Amy } \ldots \ldots & 31,100,149 \\ \text { Tarapchak, Stefan } \ldots .47,90\end{array}$

Taylor, Becky ...... 83, 150

Taylor, Doug ........ 135

Taylor, Eleanor $\ldots \ldots 21,141$

Taylor, Sara ............. 3

Taylor, Tania $\ldots \ldots \ldots \ldots .211$

Tennant, Cindy $\ldots \ldots \ldots, 40$

Terkelsen, Susan .... 21, 160

Terpstra, John $\ldots \ldots \ldots \ldots$
Terrill, Cynthia $\ldots \ldots \ldots \ldots 2$

Tharp, Denise ….. 47, 91

Thomas, Mike ............ 118, 202

Thomas, Sara ...... 159, 202

Thompson, Dana .... 40, 95 , 149

155
Thompson, jill

Thompson, Linda ......... 13, 10

Thompson, Philip . . 47, 158 Thompson, Steven ..... 21

Thorsen, Charlie ... 40, 100 ,

Tilleman, Catherine .... 31

Tipton, Brett $\ldots \ldots \ldots \ldots \ldots 40$

Tober, Susanne $\ldots \ldots \ldots 31$

Tock, James $\ldots \ldots \ldots \ldots \ldots$ 31

Todd, Faith ….4.47, 91, 93

Todd, Seljan ......... 30

Tramel, Maribeth .... 40, 81,

Traucht, Andra ........ 31

Treier, Dan ............40

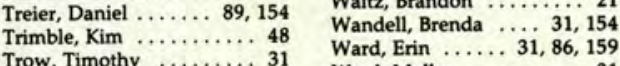

Tucker, Barar

Tuorinsky, Laura....... 2

Turner, Cooley ...........

Turner, Layne $\ldots \ldots \ldots \ldots .6 .118$

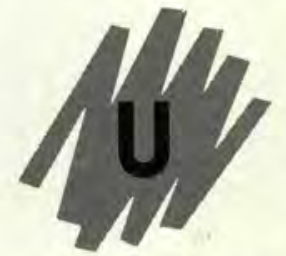

Valentine, Jason ......... 31

VandeGuchte, Todd ...... 31

VandeGutche, Tim $\ldots \ldots .151$

Vandenburg, Timothy .... 40 ,

Vanderwest, Ken .... 40, 90 ,

VanDyke, Kristi … 31, 122 ,

VanEaton, Justin .... 81, 100

VanMatre, Edina .... 48, 91 ,

Vannest, Steve ........ 40

VanWert, Sonja $\ldots \ldots \ldots 31$
Varner, Jonathan $\ldots \ldots$
31,87,

Veelman, Bill .........4 40

$\begin{array}{lll}\text { Veith, Doran } \ldots \ldots \ldots \ldots & 118 \\ \text { Velazco, Ivo } \ldots \ldots \ldots \ldots & 203\end{array}$

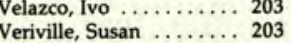

Vibbert, Karen ......... 48

Vickman, Bonnie ........ 21
Vickman, Jeff ......... 21

Vickman, Kenneth .......... 21

Viera, Pablo .......... 151

Vine, Allan

Vine, Kitty ............... 21

Vroegop, Mark $158,160,161,163$

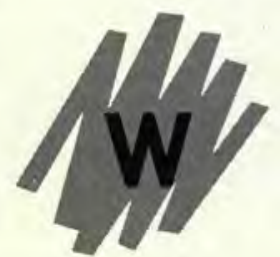

Waddell, Janice ....... 203

Waddell, Sandra ... 48, 103 ,

Wafford, Gary ......... 103

Wagner, Trudee ......... 21

Wakefield, Mike ....... 48

Walborn, Josette $\ldots \ldots \ldots 31$
Walborn, Tim $\ldots .48,82,103$

Walker, Bryan $\ldots \ldots \ldots \ldots 40$

Walker, Julie $\ldots \ldots \ldots$
Wall, Melissa $\ldots \ldots \ldots$
.....

Wallace, Melinda ....... 48

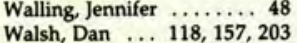

Walter, Melanie ........ 31

Walters, Wendy ....... 158

Wandell, Brenda $\ldots . .31,154$

Ward, Molly $\ldots \ldots \ldots \ldots \ldots 31$

Ware, Paul .......... ${ }^{21}$

Warnshuis, John ....40, 100

Warnshuis, Mark ... 81, 100 ,

Warren, David .. 40, 100, 103 Waters, Cassandra ... 40, 159 Watson, Keith .. 48, 100, 103 Weaver, David ....... 118, 204

Weaver, Doris $\ldots \ldots \ldots \ldots 40$

Weavel, Ramona ..... 148, 204

Webel, Ramona $\ldots \ldots .148,204$
Weber, Brian $\ldots \ldots \ldots \ldots .95$

Weber, David $\ldots \ldots \ldots \ldots \ldots 48$
Weber, Paula .......... 48

Weber, Paula $\ldots \ldots \ldots \ldots .48$

Webster, Douglas $\ldots \ldots \ldots 31$
Webster, Jim ..... $31,85,94$
Webster, Steven $\ldots \ldots \ldots 31$

Webster, Theresa ....... 48 $\begin{array}{lll}\text { Weelmann, Bryan } \ldots \ldots \ldots & 204 \\ \text { Weemum, Scott } \ldots \ldots \ldots . & 204\end{array}$ Weibert, Cindy

Weibert, Holly

Weigle, David

Weimer, Patricia ......... 204

Weiss, Christen …...... 207

Welch, Aaron .. 48, 100, 102,

Wells, Richard .. 87, 163, 171

Wendy, Walters .......... 31

Wesselink, Jesse ........ 48

Westlake, Leanne ........ 31

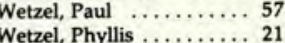

Wetzel, Phyllis $\ldots \ldots \ldots \ldots$
Wetzel, Tonya $\ldots \ldots \ldots \ldots$

Weyand, Wendy $\ldots \ldots \ldots, 31$

Weyhe, Jill ........ 31, 87
Whalen, Amy ... 48, 82, 150

Whetstone, Steven $\ldots \ldots .31$

White, Andy …... 92, 204

White, Angela $\ldots \ldots \ldots \ldots$
White, Anita

White, Anita $\ldots \ldots \ldots .204$

White, Laurel . ........... 31

White, Lisa ........ 207

White, Shawn ....... 40, 92

White, Wendy $\ldots \ldots \ldots .49$

Whitmer, Molly .... 40, 100 ,

Whitten, Scott ......... 31

Whittenburg, Jori ........ 204

Wilcox, Deanna ........... 49

Wilfert, Jennifer ..... 31, 93

Wilhelm, Susan ....... 204

Wilkinson, Stephanie ... 103 .

Wilks, Christine ....... 40

Williams, Brent ..... 154, 205

Williams, Cori ..... 90, 149

Williams, Corinna ... 40, 126

Williams, Dan $\ldots \ldots \ldots \ldots$
Williams, Heidi .... 121, 139

Williams, Jon .......... 40 
"For where two

or three come

together in my

name, there am I

\author{
with them."
}

(Matthew 18:20) 


$\therefore \quad-2+2=0$

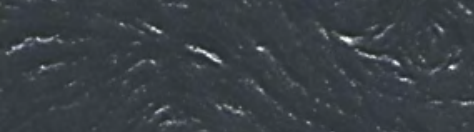

